Adriana Antunes Lopes

\title{
Estudo da gestão integrada dos resíduos sólidos urbanos na bacia Tietê-Jacaré (UGRHI-13)
}

Tese apresentada à Escola de Engenharia de São Carlos da Universidade de São Paulo para obtenção do Título de Doutor em Ciências da Engenharia Ambiental.

Orientador: Prof. Assoc. Valdir Schalch 
AUTORIZO A REPRODUÇÃO E DIVULGAÇÃO TOTAL OU PARCIAL DESTE TRABALHO, POR QUALQUER MEIO CONVENCIONAL OU ELETROONICO, PARA FINS DE ESTUDO E PESQUISA, DESDE QUE CITADA A FONTE.

Ficha catalográfica preparada pela Seção de Tratamento da Informação do Serviço de Biblioteca - EESC/USP

Lopes, Adriana Antunes

Estudo da gestão integrada dos resíduos sólidos

L864e Estudo da gestăo urbanos na bacia Tietê-Jacaré (UGRHI-13) / Adriana Antunes Lopes; orientador Valdir Schalch. -- São Carlos, 2007 .

Tese (Doutorado-Programa de Pós-Graduação e Área de Concentraçăo em Ciências da Engenharia Ambiental) -Escola de Engenharia de Săo Carlos da Universidade de São Paulo, 2007.

1. Residuos sólidos - gestão integrada. 2. Agua superficial. 3. Água subterrânea. 4. Lixiviação. 5. Aterros sanitários. 6. Bacia Hidrográfica Tietê Jacaré. 7. UGRHI. 8. Monitoramento de água. I. Título. 
iii

FOLHA DE JULGAMENTO

Candidata: Arquiteta Urbanista ADRIANA ANTUNES LOPES

Tese defendida e julgada em 01/11/2007 perante a Comissão Julgadora:

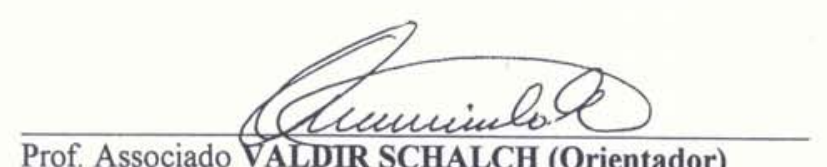

(Escola de Engenharia de São Carlos/USP)

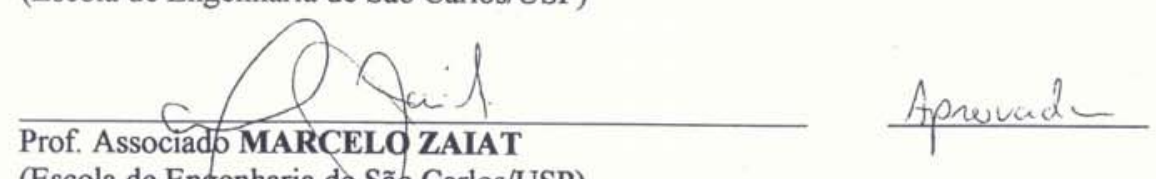

(Escola de Engenharia de São Carlos/USP)

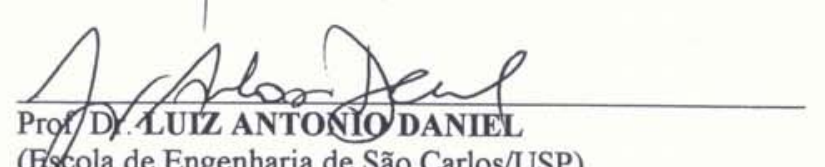

APROVDDA

(E)cola de Engenharia de São Carlos/USP)

APRoVADA

Prof. Dr. JORGE HAMADA

APRONADA

(Universidade Estadual Paulista "Julio de Mesquita Filho"/UNESP-Campus de Bauru)

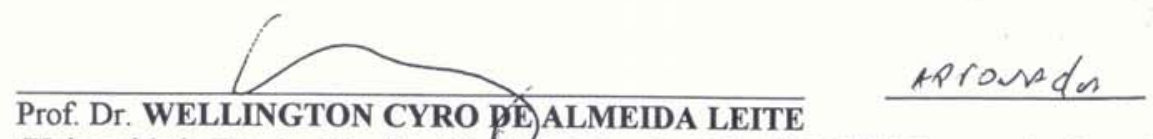

(Universidade Estadual Paulista "Julio de Mesquita Filho"/UNESP-Campus de Guaratinguetá)
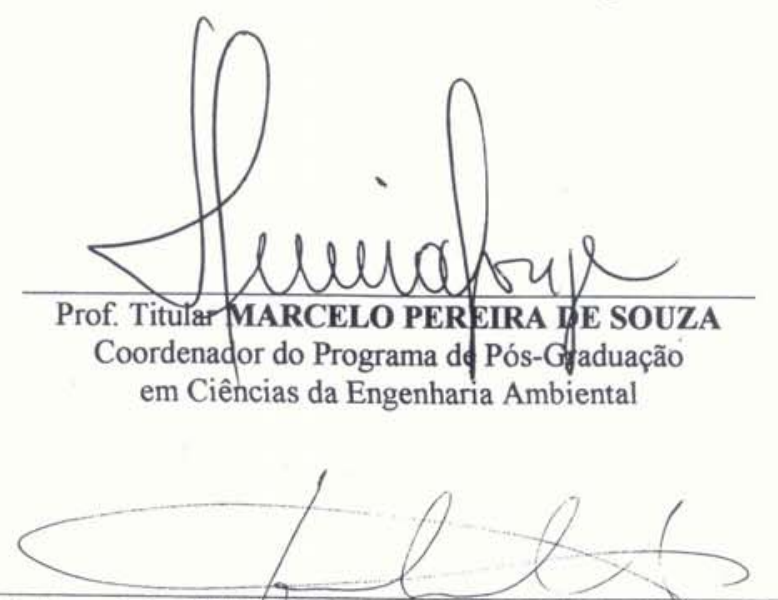

Prof. Associado GERALDO ROBERTO MARTINS DA COSTA Presidente dąComissão da Pós-Graduação da EESC 


\section{AGRADECIMENTOS}

A Deus, por tudo, principalmente por me iluminar a seguir os caminhos do ensino e da pesquisa, que me trouxeram muitos amigos, alegrias, aprendizado e realizações.

Ao meu "mestre do lixo", Professor Valdir Schalch, pela orientação, paciência, empréstimo de materiais e equipamentos, por todo apoio durante nossa convivência.

À Fundação de Amparo à Pesquisa do Estado de São Paulo (FAPESP), pelo financiamento do estudo.

Aos Professores Luiz Antonio Daniel e Wellington Cyro de Almeida Leite, pelas contribuições durante o Exame de Qualificação.

Aos Professores Eduardo Mario Mendiondo, Evaldo Luiz Gaeta Espíndola, Frederico Fábio Mauad e Maria Olímpia de Oliveira Rezende da EESC/USP, pelo apoio fundamental para o desenvolvimento da pesquisa.

Ao Professor Marcelo Zaiat da EESC/USP, pelo incentivo, apoio e ensinamentos durante o Programa de Aperfeiçoamento ao Ensino (PAE).

À Professora Marisa Spirandeli Crespi da UNESP de Araraquara, pelo apoio na realização das análises de solo.

Ao secretário-executivo do Comitê da Bacia Hidrográfica Tietê-Jacaré, Braz Aureliano Biagioni Passalacqua, pela atenção especial.

À Prefeitura Municipal e ao Departamento Autônomo de Água e Esgotos de Araraquara, em especial ao engenheiro Roma, Agamemnon Brunetti Junior (Gerente de Operação do Sistema de Resíduos Sólidos), Marcos, Chico e Cristiane. À Coordenadoria do Meio Ambiente, especialmente a Almir Zancul e José Francisco.

À Prefeitura Municipal de Bauru, em especial ao Sr. João Firmino (Chefe da Coleta Seletiva) e João Roberto, membros da Secretaria Municipal de Meio Ambiente e a Empresa Municipal de Desenvolvimento Urbano e Rural de Bauru, em especial ao Sr. Duarte, Roberta Oliveira Lança, Solange Fernandes de Souza Gabriel (Agente de Administração - Diretoria de Limpeza Pública) e Mario Martins (Chefe do setor de resíduos sólidos - aterro sanitário).

À Estância Turística de Barra Bonita, em especial a Ademir Negrini (Chefe do Setor de Limpeza Pública do Departamento de Obras e Serviços).

À Prefeitura Municipal de Bariri, em especial ao Setor de Meio Ambiente.

À Prefeitura Municipal de Brotas, em especial a Angelo Roberto Lazari Junior (Diretor de Meio Ambiente), pelas informações, ajuda e atenção.

À Prefeitura Municipal de Dois Córregos, em especial a Lidiane Maria Nai (Diretora de Meio Ambiente e Desenvolvimento Sustentável).À Prefeitura Municipal de Itirapina, em especial a José Maria Candido, a Nilson Bernardi Ferreira (Coordenador de Capacitação Ambiental) e José Roberto Manduca (Secretário de Serviços Públicos). 
À Prefeitura Municipal de Jaú, em especial ao Sr. José Izidro Toledo Bergamin (Secretário de Serviços Municipais), Hugo Monerato Neto, Deubles e José Roberto Pegoretti (Diretor da Secretaria de Serviços Municipais, Seção de coleta de lixo).

À Prefeitura Municipal de Ribeirão Bonito, em especial a Eraldo Cezar Vanalli Polez (Departamento de Obras) e Lucy.

À Prefeitura Municipal de São Carlos, em especial ao Sr. Emerson Leal, Paulo Mancini (Diretor de Política Ambiental), Paulo Shiroma, Marcos Gonçalves e Ismael Feliciano Ferreira, membros da Secretaria Municipal de Desenvolvimento Sustentável Ciência e Tecnologia; à Flavia Thiemann da Secretaria de Educação; ao Professor Ricardo Martucci, Heloísa e Fabrício, membros da Secretaria de Planejamento Urbano e Habitação.

Ao engenheiro Samir Fagury da PROHAB de São Carlos.

À Casa da Agricultura de São Carlos, em especial ao Sr. Bordini.

À Empresa Vega Engenharia Ambiental de São Carlos, em especial ao engenheiro Marcelo Cicconi (Supervisor da Unidade São Carlos), Osmar de Febo (Assistente de Suprimentos) e Miguel, pelas informações e por autorizarem visitas e coletas de água no aterro.

Ao geólogo Rogério Malagoli Bassam, pela atenção e interesse na pesquisa, principalmente durante as visitas aos aterros e construção dos poços de monitoramento.

A Abimael Cereda Junior, membro do Núcleo de Geoprocessamento da UFSCar, pela ajuda na elaboração dos mapas.

Aos membros da CETESB (São Paulo), Claudio Luiz Dias (setor de solos e águas subterrâneas) e Carlos Ferreira de Souza (setor de resíduos sólidos) pelas informações.

Ao Sr. Mario da CETESB (Agência Ambiental de Bauru), pelas orientações.

Aos técnicos dos laboratórios da EESC/USP: Cidinha, Diva, Juliana, Júlio Trofino, Paulo Fragiácomo, por todo apoio e orientações durante a realização das análises.

Aos funcionários do Centro de Recursos Hídricos e Ecologia Aplicada (CRHEA): Achilles, Claudete, Mara, Sr. Maurício, Paulo de Luccas, Nelson, Regina, Sonia e Wellington, por todo apoio e atenção. Agradeço especialmente a Waldomiro Antonio Filho, que me auxiliou nas coletas.

Aos funcionários do Departamento de Hidráulica e Saneamento (SHS): Bruno, Cecília, Fabio, Flavia, Fernanda, Jaqueline, Márcia, Pavi, Rose, Sá, Valdecir e Valderes, pelo excelente atendimento!

Ao Sr. Paulo Romano do setor de transportes da EESC/USP, pelo apoio no agendamento de veículos para as visitas a campo.

Aos moradores do Sítio Santa Madalena de São Carlos, Sr. Álvaro Rizolli, Ailton e Sandra Regina Lucatti, pelas informações e auxílio durante as coletas. 
Ao Sr. Romeu e Toninha, por autorizarem a perfuração dos poços de monitoramento em suas propriedades, onde está localizado o lixão de Jaú.

Aos amigos Andréia Márcia Cassiano, Carla Polaz, Clarice Botta Paschoal, Janete Brigante, Evaneide Lima, Fernanda Marciano, Giulliana Mondelli, Luana Marelli, Nilo André Bernardi Filho, Walter Décio de Andrade e Wellington Fernando Antonio, que de alguma forma contribuíram com o trabalho. Obrigada pelo carinho e ajuda!

Especialmente aos amigos Marcelo, Pedro Caballero, Ronan Cleber Contrera, Rosane Battistelle, Sonia de Almeida e Tania Leme de Almeida, pelo acompanhamento e ajuda durante algumas visitas.

A todos os amigos do PPG-SEA, em especial a Adeildo, Alessandro, Andréia Novelli, Maria Edna Tenório, Evelyn, Fortunato, Ozelito, Mara Pagliuso, Ricardo Braga, Ricardo Minotti, Ricardo Reis, Rita e Suze.

Aos amigos do Núcleo de Estudo e Pesquisa em Resíduos Sólidos (NEPER) e SHS.

Às amigas Ana Maria Baião, Edna Kunieda, Maira Buonadio e Márcia Capelini, pelo incentivo.

A toda minha família, especialmente pelo apoio e carinho. 
O contato com a natureza é sempre uma ruptura. Sentir medo do horizonte, da altura, da profundidade, do vento, do frio, do sol escaldante, do mato fechado, do barulho dos insetos, da precariedade e do desconforto remete-nos a rompimentos com nossos comportamentos mais "assentados".

E essas rupturas abrem "brechas" para a introdução/construção de novas leituras/discursos sobre o que somos, o que gostamos, o que acreditamos. Romper com formas consagradas de falar, ver e sentır é um camınho saudável de construir o novo. E o novo só aparece quando se dá espaço. Forçar rupturas enfrentando voluntariamente sıtuações inesperadas gera mudanças. 


\section{RESUMO}

LOPES, A. A. Estudo da gestão integrada dos resíduos sólidos urbanos na Bacia Tietê-Jacaré (UGRHI-13). 2007. 370 f. Tese (Doutorado) - Escola de Engenharia de São Carlos, Universidade de São Paulo, São Carlos, 2007.

Os resíduos sólidos podem poluir e contaminar as águas superficiais e subterrâneas, pela migração de lixiviado gerado em aterros e lixões, o que pode colocar em risco a saúde pública e o ambiente. Assim, o objetivo deste estudo foi analisar a gestão dos resíduos sólidos urbanos na Bacia Hidrográfica Tietê-Jacaré, pertencente a $13^{a}$ Unidade de Gerenciamento dos Recursos Hídricos (UGRHI-13) do Estado de São Paulo, bem como verificar a sua influência na qualidade dos recursos hídricos da região, por meio de coletas de água superficial (14 pontos) e subterrânea (20 pontos), localizados nos municípios de Araraquara, Bauru, Brotas, Jaú, Ribeirão Bonito e São Carlos. Para a realização deste trabalho foram coletadas quatro amostras de água subterrânea em quatro poços de monitoramento, um a montante e três a jusante, de cinco aterros. Também foram coletadas quatro amostras de água em dois pontos de sete córregos na área de influência de aterros e lixões. As coletas foram realizadas durante 2004 e 2005. As amostras foram submetidas a análises físico-química, microbiológica e ecotoxicológica. O nível d’água, bem como os parâmetros $\mathrm{pH}$, condutividade elétrica, salinidade, oxigênio dissolvido e temperatura foram obtidos in situ. Durante o monitoramento realizado foi constatado alteração das características naturais dos recursos hídricos, indicando poluição e contaminação em alguns pontos. Com base nas visitas realizadas e nas informações obtidas, o estudo permitiu concluir que não há gestão integrada dos resíduos sólidos na Bacia Tietê-Jacaré, salvo avanços em alguns municípios. Os aterros municipais estão melhorando gradativamente, a fim de atenderem às exigências dos órgãos ambientais, porém constatou-se que as medidas são emergenciais e corretivas. Falta investimento da administração pública no que se refere à prevenção dos impactos negativos.

Palavras-chave: gestão integrada de resíduos sólidos; água superficial; água subterrânea; lixiviado; aterros sanitários; Bacia Hidrográfica Tietê-Jacaré; UGRHI-13; monitoramento. 


\begin{abstract}
LOPES, A. A. Study of the integrated management of urban solid waste at the TietêJacaré Basin (UGRHI-13). 2007. 370 f. Thesis (Doctoral) - Escola de Engenharia de São Carlos, Universidade de São Paulo, São Carlos, 2007.

Solid waste can pollute and contaminate superficial and groundwater, through the migration of sanitary landfills and dumps leachate, which can endangers the public health and the environment. Therefore, this work aimed to analyze the urban solid waste management at Tietê-Jacaré Basin, which belongs to the São Paulo State $13^{\text {th }}$ Water Resources Management Unit (UGRHI-13), and to verify its influence to the regional water resources quality by sampling superficial water (14 points) and groundwater (20 points) at Araraquara, Bauru, Brotas, Jaú, Ribeirão Bonito and São Carlos. Four groundwater samples were collected at four wells, one upstream and three downstream, at five landfills. Four water samples were also collected at two points from seven streamlets of the landfills influence area. The sampling occurred on 2004 and 2005. The samples were submitted to physicchemical, microbiological and ecotoxicologycal analysis. Water table, $\mathrm{pH}$, electrical conductivity, salinity, dissolved oxygen and temperature were achieved in situ. During the monitoring, alteration of the natural characteristics of the water resources was verified, indicating pollution and contamination at some points. Based on the surveys and the information, this study could conclude that there is not an integrated management of solid wastes at Tietê-Jacaré Basin, excepting improvements at some municipalities. The municipal landfills are being improved gradually, following environmental agencies requests, but the measures are emergent and correctives. There is lack of investment from governments for negative impacts prevention.
\end{abstract}

Key-words: integrated management of solid wastes; superficial water; groundwater; leachate; sanitary landfill; Tietê-Jacaré Basin, UGRHI-13; monitoring. 


\section{LISTA DE FIGURAS}

Figura $\quad 1$ - Resíduos sólidos urbanos gerados em países europeus............................................. 15

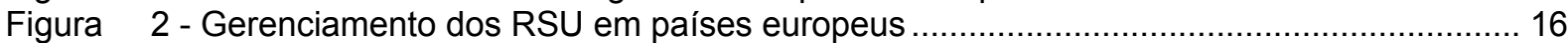

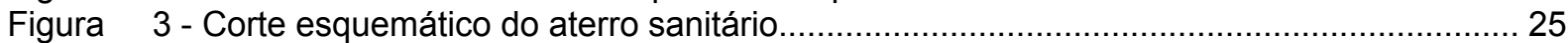

Figura 4 - Número de áreas contaminadas no Estado de São Paulo conforme a atividade ............... 36

Figura 5 - Esquema da técnica para contenção de contaminantes............................................. 38

Figura $\quad 6$ - Esquema de técnicas para remoção de contaminantes............................................... 38

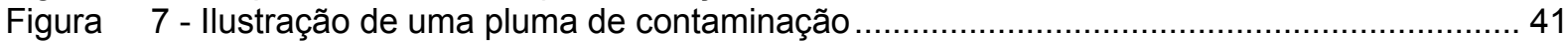

Figura 8 - Localização da UGRHI - 13 no Estado de São Paulo .................................................. 52

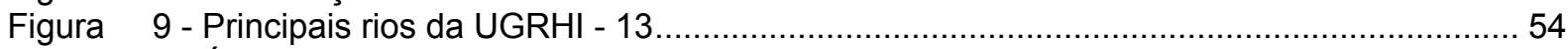

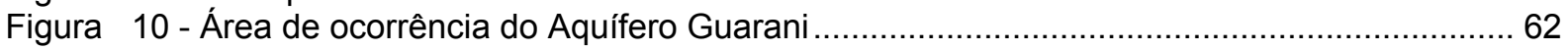

Figura 11 - Localização das áreas monitoradas na UGRHI-13 ................................................... 74

Figura 12 - Mapa pedológico da UGRHI-13 com a localização das áreas monitoradas .................... 76

Figura 13 - Mapa geológico da UGRHI-13 com a localização das áreas monitoradas ....................... 80

Figura 14 - Esvaziamento de poço no aterro de Araraquara ......................................................... 82

Figura 15 - Detalhe do coletor de água subterrânea utilizado nos poços de 4" ................................ 82

Figura 16 - Coleta da amostra de água subterrânea em Jaú ........................................................... 83

Figura 17 - Detalhe do coletor de água subterrânea utilizado nos poços de 2" ............................... 83

Figura 18 - Amostras de solo do PM e do PJ3 do lixão de Jaú ....................................................... 93

Figura 19 - Quantidade de recicláveis provenientes da coleta seletiva de Araraquara.................... 100

Figura 20 - Central de Triagem de recicláveis no aterro de Araraquara, 04/11/2003 ..................... 101

Figura 21 - Central de Triagem de recicláveis no aterro de Araraquara, 10/05/2007 .................... 101

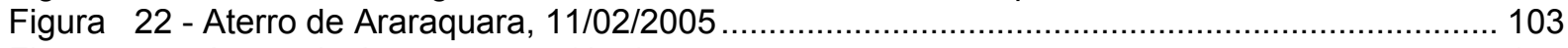

Figura 23 - Aterro de Araraquara, 31/05/2007 ................................................................... 103

Figura 24 - Estação de Tratamento de Resíduos Sólidos de Araraquara ...................................... 104

Figura 25 - Catadores no aterro de Araraquara 02/07/2004 ................................................. 105

Figura 26 - Presença de catadores no aterro de Araraquara, 31/05/2007 ................................... 105

Figura 27 - Compactação de terra no aterro de Araraquara em 02/07/2004 …............................ 106

Figura 28 - Cobertura de resíduos no aterro de Araraquara em 09/11/2004 ............................... 106

Figura 29 - Lagoa de lixiviado do aterro de Araraquara, 10/05/2007 ......................................... 106

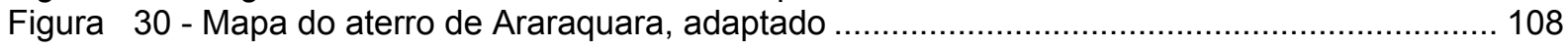

Figura 31 - Incinerador do aterro de Araraquara, 10/05/2007 .............................................. 110

Figura 32 - Vista interna do incinerador do aterro de Araraquara, 10/05/2007 ............................ 110

Figura 33 - Identificação da ATT de RCC de Araraquara, 31/05/2007 ........................................ 111

Figura 34 - ATT de RCC de Araraquara, 31/05/2007 .......................................................... 111

Figura 35 - Pneus armazenados na ETRS de Araraquara, 31/05/2007 …................................ 112

Figura 36 - Central de Recebimento de Embalagens Agrotóxicos, 31/05/2007 ........................... 113

Figura 37 - Armazenamento de embalagens de agrotóxicos, 04/11/2003 …............................... 113

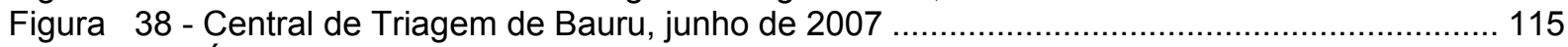

Figura 39 - Área externa da Central de Triagem de Bauru........................................................ 115

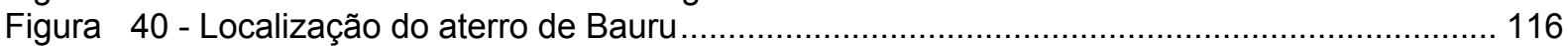

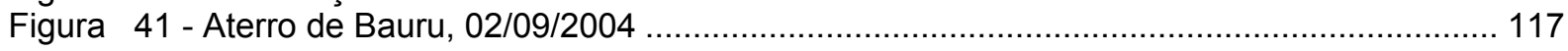

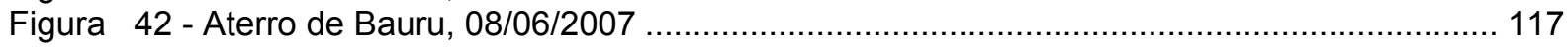

Figura 43 - Impermeabilização de base no aterro de Bauru, 25/09/2003 …................................. 118

Figura 44 - Coletor de gás no aterro de Bauru, 25/09/2003 ................................................. 118

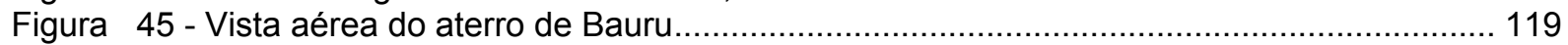

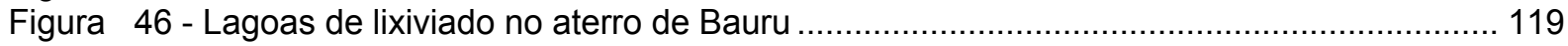

Figura 47 - Vista da parte superior do aterro de Bauru, 08/06/2007 ....................................... 119

Figura 48 - Lagoa de lixiviado no aterro de Bauru, 08/06/2007 ...................................................... 119

Figura 49 - Construção de lagoas para o armazenamento de lixiviado no aterro de Bauru ............. 120

Figura 50 - Lagoas para o armazenamento de lixiviado no aterro de Bauru, 08/06/2007 .............. 120

Figura 51 - Poços de monitoramento a jusante no aterro de Bauru, 25/09/2003 ........................... 120

Figura 52 - Poço de monitoramento (PJ1) no aterro de Bauru, 02/09/2004 ........................................ 120

Figura 53 - Localização dos poços de monitoramento no aterro de Bauru ..................................... 122

Figura 54 - Identificação de "substância infectante" nos sacos e caixas com RSS em

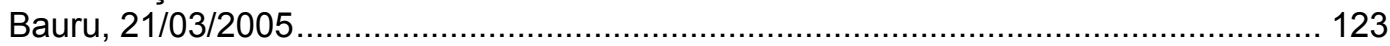

Figura 55 - Veículo de coleta dos RSS em Bauru, 08/06/2007 ......................................................... 123

Figura 56 - Manejo dos RSS no aterro de Bauru, 08/06/2007 ................................................... 124 
Figura 57 - Manejo dos RSS no aterro de Bauru, 25/09/2003 ............................................... 124

Figura 58 - Disposição de RCC em Bauru, 08/06/2007 ……................................................ 125

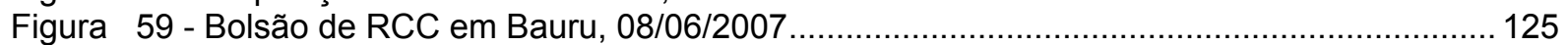

Figura 60 - Armazenamento de pneus no aterro de Bauru, 25/09/2003.................................... 126

Figura 61 - Pneus armazenados no aterro de Bauru, 08/06/2007 ........................................... 126

Figura 62 - Coleta seletiva realizada pela APAE de Brotas .................................................... 128

Figura 63 - Barracão onde é realizada a triagem de materiais em Brotas....................................... 128

Figura 64 - Separação dos recicláveis no barracão da APAE de Brotas....................................... 128

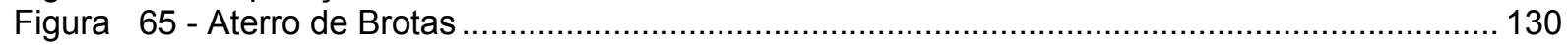

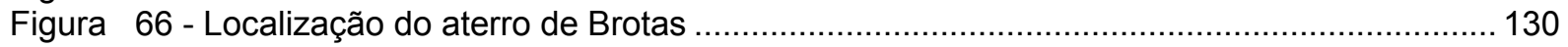

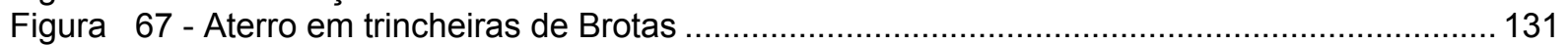

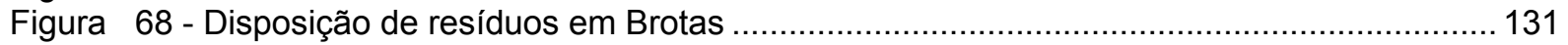

Figura 69 - Preparação de trincheira no aterro de Brotas........................................................ 132

Figura 70 - Impermeabilização de vala no aterro de Brotas ..................................................... 132

Figura 71 - Sondagem realizada no ponto a montante do aterro de Brotas .................................. 133

Figura 72 - Sondagem realizada no ponto a jusante do aterro de Brotas ..................................... 133

Figura 73 - Amostras de solo do aterro de Brotas armazenadas, 06/08/2004 ............................... 133

Figura 74 - Amostras de solo do aterro de Brotas, 06/08/2004 ............................................... 133

Figura 75 - Disposição de RSS no aterro de Brotas, 14/07/2004 ............................................... 134

Figura 76 - Disposição de RSS no aterro de Brotas, 14/07/2004 ….......................................... 134

Figura 77 - Embalagens de agrotóxicos nas margens do córrego da Cachoeira Grande em

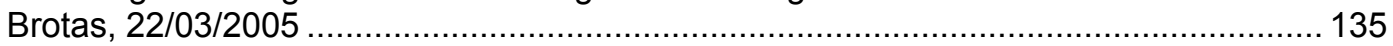

Figura 78 - Lixão de Jaú, 18/08/2005

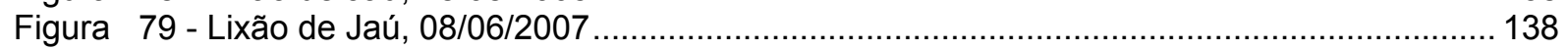

Figura 80 - Presença de catador, disposição de resíduo volumoso e animais de grande porte

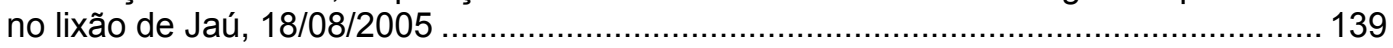

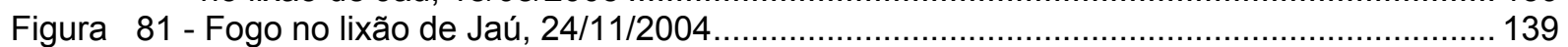

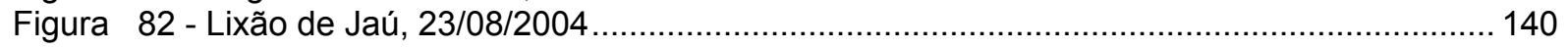

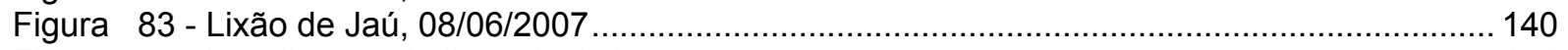

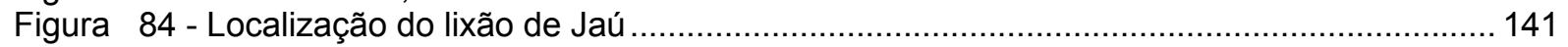

Figura 85 - Disposição de resíduos no lixão de Jaú, 25/01/2007 ............................................... 141

Figura 86 - Disposição de resíduos no lixão de Jaú, 08/06/2007 ................................................ 141

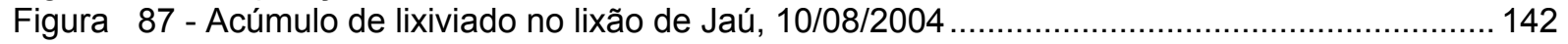

Figura 88 - Formação de lixiviado no lixão de Jaú, 22/03/2005 ......................................................... 142

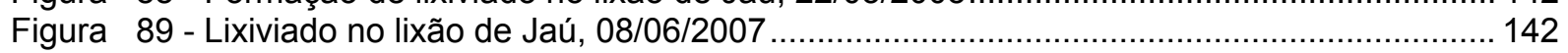

Figura 90 - Resíduos carreados para o ribeirão do Matão em Jaú, 24/11/2004 .................................. 143

Figura 91 - Resíduos acumulados no lixão de Jaú devido às chuvas, 08/06/2007 .......................... 143

Figura 92 - Resíduos carreados para o ribeirão do Matão em Jaú, 22/03/2005 ............................ 143

Figura 93 - Erosão próxima ao ribeirão do Matão em Jaú, 08/06/2007 ........................................ 144

Figura 94 - Formação de erosão no entorno do lixão de Jaú, 22/03/2005 ........................................... 144

Figura 95 - Erosão próxima ao poço de monitoramento no lixão de Jaú, 08/06/2007 ...................... 144

Figura 96 - Poço a jusante do lixão de Jaú (PJ3), 27/08/2004 .................................................. 145

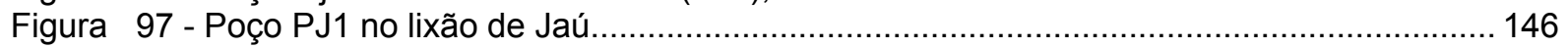

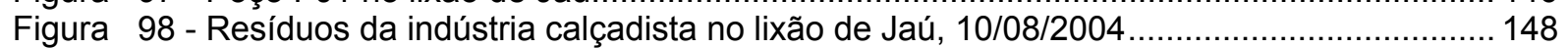

Figura 99 - Disposição de resíduos de artefatos de couro no lixão de Jaú ...................................... 148

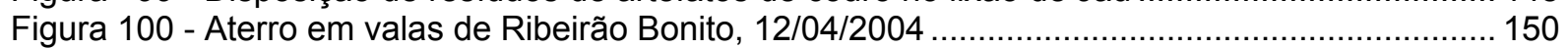

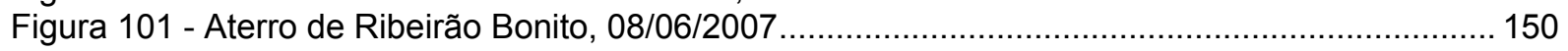

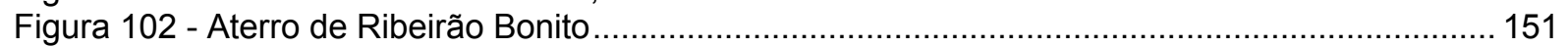

Figura 103 - Materiais vendidos pelas cooperativas de São Carlos em 2007 .................................. 157

Figura 104 - Resíduos dispostos no antigo lixão de São Carlos, 10/02/2005 ................................... 160

Figura 105 - Vista da área onde o antigo lixão de São Carlos era operado, 09/03/2004 ....................... 161

Figura 106 - Pastagem de animais na área do antigo lixão de São Carlos, 01/07/2004 ..................... 161

Figura 107 - Levantamento planialtimétrico da região do lixão de São Carlos - SP............................. 162

Figura 108 - Localização do antigo lixão de São Carlos ..................................................................... 162

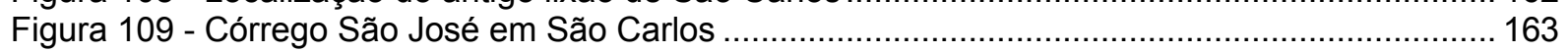

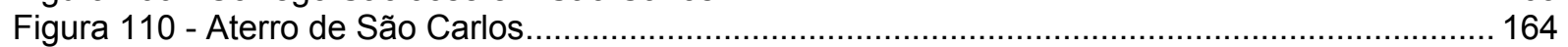

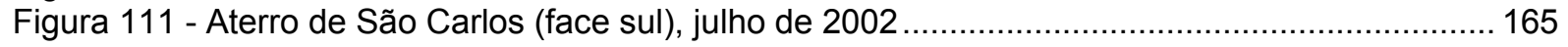

Figura 112 - Aterro de São Carlos (face sul), maio de 2007 ............................................................. 165

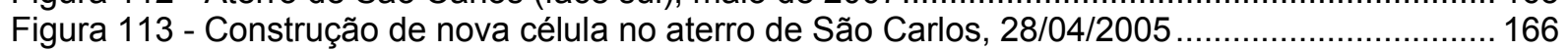

Figura 114 - Impermeabilização de nova célula no aterro São Carlos, 28/04/2005 ............................. 166 
Figura 115 - Coletor de gás no aterro de São Carlos, julho de 2002 .......................................... 166

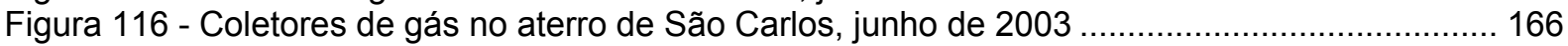

Figura 117 - Localização das lagoas e poços de monitoramento no aterro de São Carlos ................. 168

Figura 118 - Lagoas de lixiviado no aterro de São Carlos, 17/05/2007 ........................................ 169

Figura 119 - Poços de monitoramento a jusante do aterro de São Carlos, 08/03/2004.................... 170

Figura 120 - Armazenamento de RSS no aterro de São Carlos................................................ 173

Figura 121 - Entrada da Fábrica de Artefatos de Cimento de São Carlos, 13/01/2004 ..................... 174

Figura 122 - Cura de blocos na Fábrica de Artefatos de Cimento de São Carlos.............................. 174

Figura 123 - Córrego Água Quente em São Carlos, 07/01/2004 ............................................... 175

Figura 124 - Local de implantação do aterro de RCC de São Carlos............................................. 176

Figura 125 - Valores médios de pH na água subterrânea ........................................................... 235

Figura 126 - Valores médios de Nitrogênio Amoniacal na água subterrânea .................................. 235

Figura 127 - Valores médios de Oxigênio Dissolvido na água subterrânea ..................................... 235

Figura 128 - Valores médios de Sulfato na água subterrânea ................................................... 235

Figura 129 - Valores médios de Cor Aparente na água subterrânea ............................................. 235

Figura 130 - Valores médios de Turbidez na água subterrânea.................................................. 235

Figura 131 - Valores médios de Demanda Bioquímica de Oxigênio na água subterrânea................ 236

Figura 132 - Valores médios de Demanda Química de Oxigênio na água subterrânea ..................... 236

Figura 133 - Valores médios de Condutividade Elétrica na água subterrânea ................................. 236

Figura 134 - Valores médios de Cloreto na água subterrânea ................................................... 236

Figura 135 - Valores médios de Carbono Orgânico Total na água subterrânea ................................. 236

Figura 136 - Valores médios de Sólidos Totais Dissolvidos na água subterrânea............................ 236

Figura 137 - Valores médios de Zinco na água subterrânea ...................................................... 237

Figura 138 - Valores médios de Cromo Total na água subterrânea............................................... 237

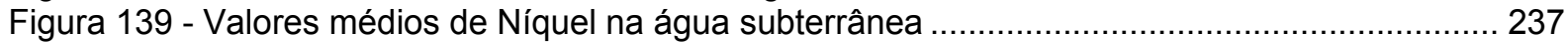

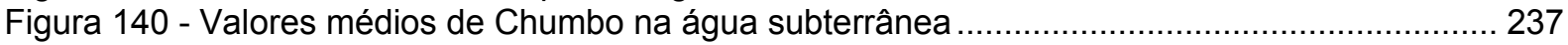

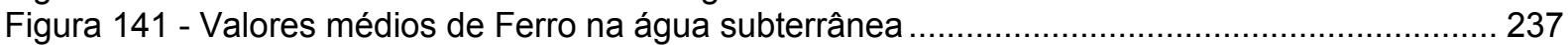

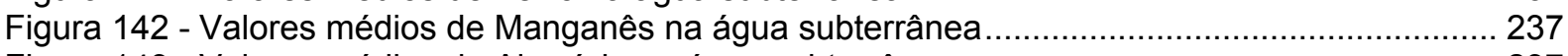

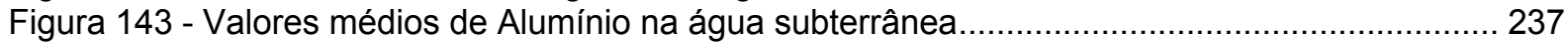

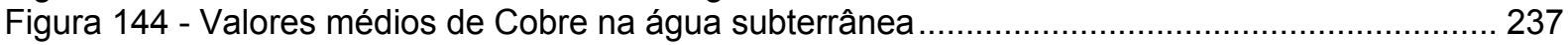

Figura 145 - Valores médios de Cor Aparente na água superficial ........................................... 241

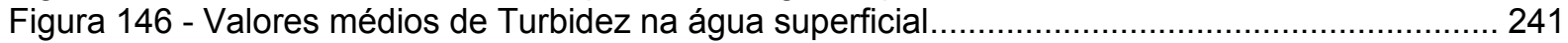

Figura 147 - Valores médios de Demanda Bioquímica de Oxigênio na água superficial.................... 241

Figura 148 - Valores médios de Demanda Química de Oxigênio na água superficial ........................ 241

Figura 149 - Valores médios de Carbono Orgânico Total na água superficial .................................. 241

Figura 150 - Valores médios de Fósforo Total na água superficial ............................................ 241

Figura 151 - Valores médios de Oxigênio Dissolvido na água superficial ........................................ 242

Figura 152 - Valores médios de Sólidos Totais Dissolvidos na água superficial............................... 242

Figura 153 - Valores médios de Condutividade Elétrica na água superficial ................................. 242

Figura 154 - Valores médios de Cloreto na água superficial ................................................... 242

Figura 155 - Valores médios de Nitrogênio Nitrato na água superficial........................................... 242

Figura 156 - Valores médios de Nitrogênio Nitrito na água superficial....................................... 242

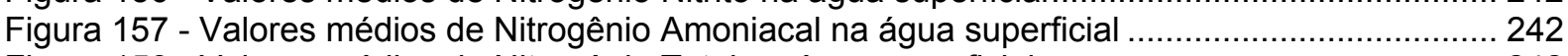

Figura 158 - Valores médios de Nitrogênio Total na água superficial ............................................ 242

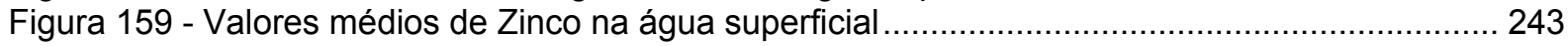

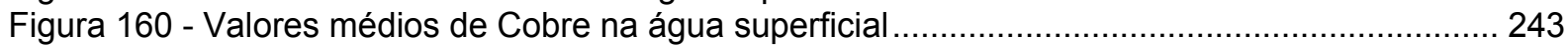

Figura 161 - Valores médios de Ferro Solúvel na água superficial ............................................. 243

Figura 162 - Valores médios de Manganês Solúvel na água superficial ......................................... 243

Figura 163 - Valores médios de Cromo Total na água superficial................................................. 243

Figura 164 - Valores médios de Alumínio na água superficial.................................................. 243

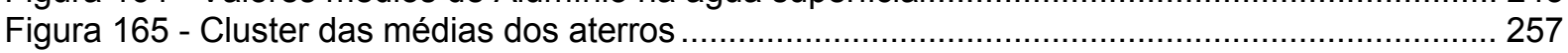

Figura 166 - Cluster das médias dos córregos .................................................................... 259

Figura 167 - Cluster das médias dos metais dos aterros ............................................................. 268

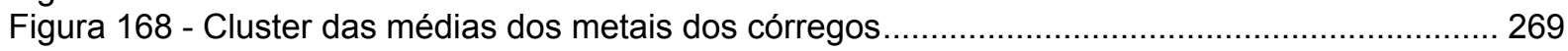




\section{LISTA DE QUADROS}

Quadro 1 - Destino do lixo no Brasil....

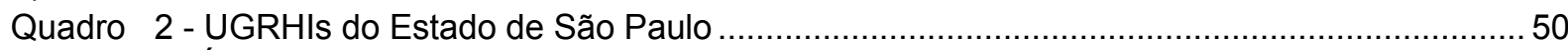

Quadro 3 - Índice de vulnerabilidade do empreendimento no Estado de São Paulo .......................60

Quadro 4 - Destino dos RSD e tipos de disposição nas bacias hidrográficas paulistas..................60

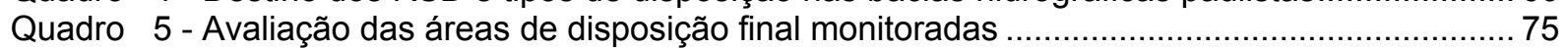

Quadro 6 - Unidades litoestratigráficas das áreas de disposição final monitoradas ...................... 79

Quadro 7 - Metodologia analítica dos parâmetros analisados ................................................ 87

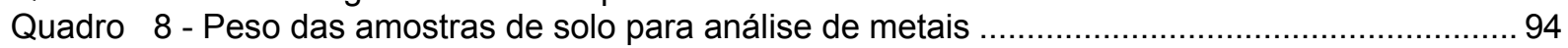

Quadro 9 - Padrões de qualidade de água, segundo as legislações vigentes .............................99

Quadro 10 - Distribuição da coleta seletiva em Araraquara.................................................... 101

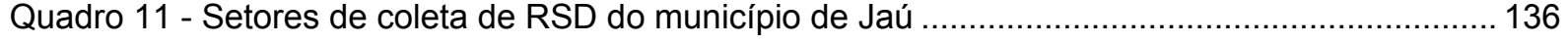

Quadro 12 - Distribuição da coleta seletiva em São Carlos.................................................. 155

Quadro 13 - Aspectos relacionados aos resíduos sólidos nos municípios monitorados ..................274 


\section{LISTA DE TABELAS}

Tabela 1 - Índices de produção per capita de RSD em função da população urbana ......................12

Tabela 2 - Disposição final e tratamento de resíduos sólidos nos distritos brasileiros e no Estado de São Paulo................................................................................... 13

Tabela 3 - Valores médios nas águas subterrâneas de três locais de disposição final ......................29

Tabela 4 - Valores de nitrogênio amoniacal em lixiviado de aterros da Alemanha ......................... 30

Tabela 5 - Número de áreas contaminadas no Estado de São Paulo......................................... 36

Tabela 6 - Número de áreas contaminadas confirmadas no Estado de São Paulo ......................... 37

Tabela 7 - Classificação dos municípios por número de habitantes......................................55

Tabela 8 - Condições das áreas de disposição final de resíduos sólidos na UGRHI-13 em 2006 .........56

Tabela 9 - Principais doenças de veiculação hídrica ...........................................................6 65

Tabela 10 - Coordenadas e distâncias aproximadas entre os pontos monitorados ..........................78

Tabela 11 - Locais de coleta das amostras de água superficial ................................................ 84

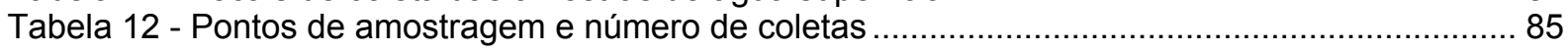

Tabela 13 - Coletas de amostras de água superficial e subterrânea ........................................... 85

Tabela 14 - Dados físico-químicos da água de cultivo de Ceriodaphnia silvestrii ..............................89

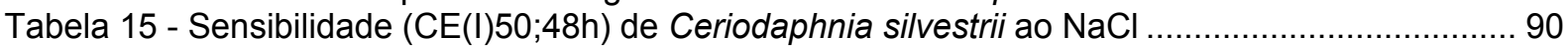

Tabela 16 - Profundidade e nível d'água dos poços do aterro de Araraquara.............................. 107

Tabela 17 - Quantidade e destino das embalagens de agrotóxicos recebidas em Araraquara ........ 113

Tabela 18 - Custos dos serviços com os resíduos sólidos em Araraquara .................................... 114

Tabela 19 - Profundidade e nível d'água dos poços monitorados no aterro de Bauru .................... 121

Tabela 20 - Custos dos serviços com os resíduos sólidos em Bauru ....................................... 126

Tabela 21 - Custos dos serviços com os resíduos sólidos em Brotas......................................... 135

Tabela 22 - Nível d’água inicial dos poços do aterro de Jaú .................................................. 145

Tabela 23 - Custos dos serviços com os resíduos sólidos em Jaú ............................................ 149

Tabela 24 - Custos dos serviços com os resíduos sólidos em Ribeirão Bonito .............................. 154

Tabela 25 - Centrais de Triagem de recicláveis de São Carlos............................................ 156

Tabela 26 - Composição gravimétrica dos RSU destinados às áreas de disposição final de

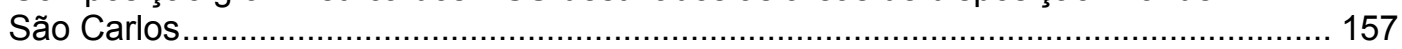

Tabela 27 - Profundidade e nível d'água dos poços do aterro de São Carlos............................... 170

Tabela 28 - Estimativa da geração de RSS em São Carlos .................................................. 172

Tabela 29 - Custos dos serviços com os resíduos sólidos em São Carlos ................................... 179

Tabela 30 - Valores obtidos na água subterrânea e no lixiviado do aterro de Bauru...................... 193

Tabela 31 - Determinação de metais em amostras de solo de São Carlos .................................... 217

Tabela 32 - Monitoramento da água subterrânea no antigo lixão de São Carlos ...........................225

Tabela 33 - Monitoramento do córrego São José na área do antigo lixão de São Carlos ................ 231

Tabela 34 - Valores médios obtidos nos poços de monitoramento ............................................... 233

Tabela 35 - Valores médios obtidos nos córregos ........................................................... 239

Tabela 36 - Análise de metais com amostras de solo do lixão de Jaú ........................................244

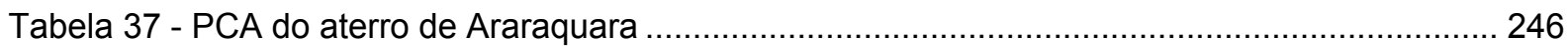

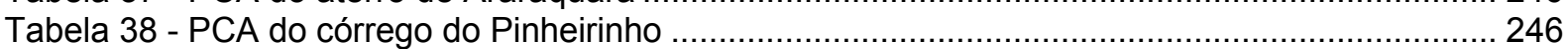

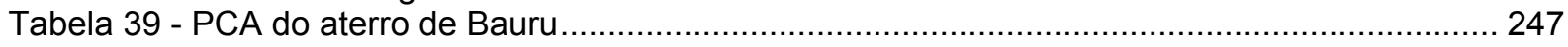

Tabela 40 - PCA do córrego da Gabiroba................................................................... 248

Tabela 41 - PCA do córrego da Cachoeira Grande .......................................................... 249

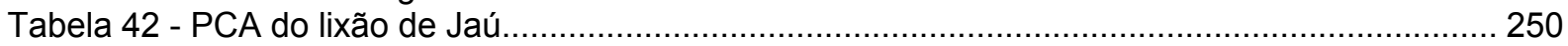

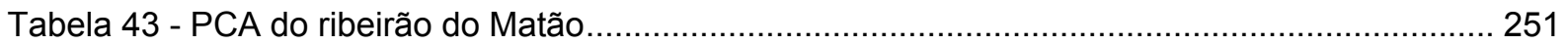

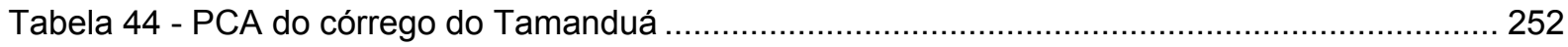

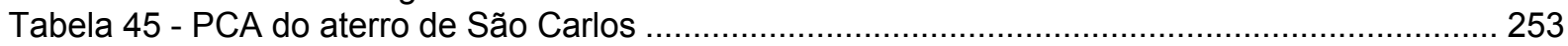

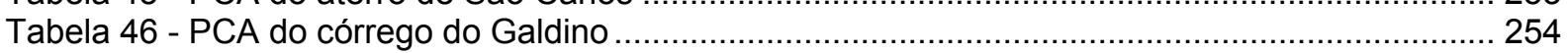

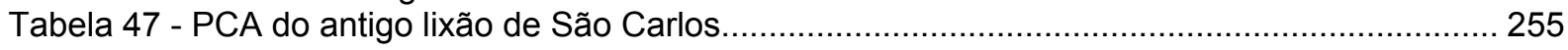

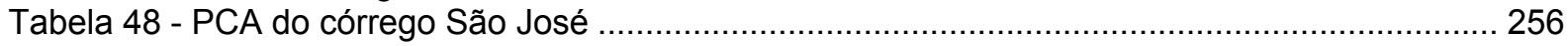

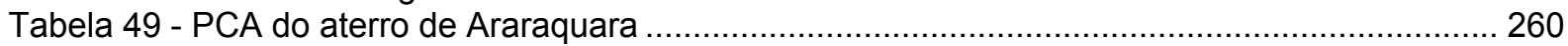

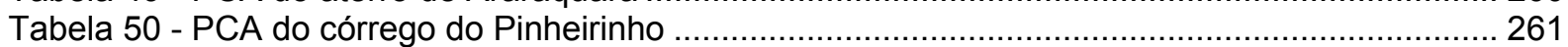

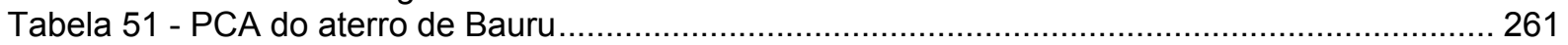

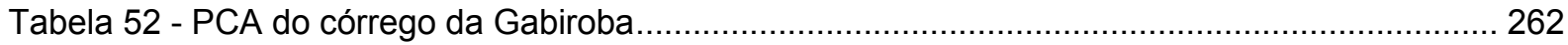

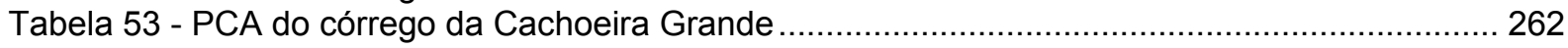

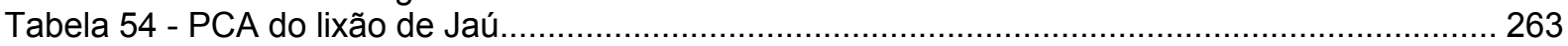

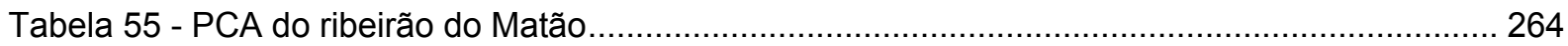


Tabela 56 - PCA do córrego do Tamanduá

Tabela 57 - PCA do aterro de São Carlos.

Tabela 58 - PCA do córrego do Galdino

Tabela 59 - PCA do antigo lixão de São Carlos

Tabela 60 - PCA do córrego São José. 


\section{LISTA DE ABREVIATURAS E SIGLAS}

\begin{tabular}{|c|c|}
\hline $2,4-D$ & Diclorofenol \\
\hline 2,4,5-T & Triclorofenoxiacético \\
\hline 3Rs & Reduzir, Reutilizar e Reciclar \\
\hline ABNT & Associação Brasileira de Normas Técnicas \\
\hline ABRELPE & $\begin{array}{l}\text { Associação Brasileira de Empresas de Limpeza Pública e Resíduos } \\
\text { Especiais }\end{array}$ \\
\hline AESAS & $\begin{array}{l}\text { Associação Brasileira das Empresas de Diagnóstico e Remediação de Solo } \\
\text { e Águas Subterrâneas }\end{array}$ \\
\hline ACAP & Associação dos Catadores de Papel de Jaú \\
\hline ANIP & Associação Nacional da Indústria de Pneumáticos \\
\hline ANVISA & Agência Nacional de Vigilância Sanitária \\
\hline APA & Área de Proteção Ambiental \\
\hline APAE & Associação de Pais e Amigos dos Excepcionais \\
\hline APASC & Associação de Proteção Ambiental de São Carlos \\
\hline ASTEN & Associação dos Transportadores de Entulhos e Agregados de Bauru \\
\hline ATT & Área de Transbordo e Triagem \\
\hline BHTJ & Bacia Hidrográfica Tietê-Jacaré \\
\hline BTEX & Benzeno-Tolueno-Etilbenzeno-Xileno \\
\hline CADRI & Certificado de Autorização e Destinação de Resíduos Industriais \\
\hline $\mathrm{CBH}-\mathrm{TJ}$ & Comitê de Bacia Hidrográfica do Tietê-Jacaré \\
\hline CDCC & Centro de Divulgação Científica e Cultural de São Carlos \\
\hline CE & Condutividade Elétrica \\
\hline CEET & Comissão de Estudo Especial Temporária \\
\hline CEPROM & Centro de Produção Municipal de Jaú \\
\hline CETESB & Companhia de Tecnologia de Saneamento Ambiental \\
\hline $\mathrm{CH}_{4}$ & Metano \\
\hline $\mathrm{CL}$ & Cloreto \\
\hline CMPP & Ácido 2-metil-4-clorofenossipropanóico \\
\hline CNEN & Comissão Nacional de Energia Nuclear \\
\hline $\mathrm{CO}_{2}$ & Dióxido de Carbono \\
\hline CONAMA & Conselho Nacional de Meio Ambiente \\
\hline CONSEMA & Conselho Estadual do Meio Ambiente \\
\hline COOTRAMAT & Cooperativa dos Trabalhadores de Materiais Recicláveis de Bauru \\
\hline COR & Cor Aparente \\
\hline COT & Carbono Orgânico Total \\
\hline CPRN & $\begin{array}{l}\text { Coordenadoria de Licenciamento Ambiental e de Proteção dos Recursos } \\
\text { Naturais }\end{array}$ \\
\hline CRHEA & Centro de Recursos Hídricos e Ecologia Aplicada \\
\hline DAAE & Departamento Autônomo de Água e Esgotos de Araraquara \\
\hline DAE & Departamento de Água e Esgoto de Bauru \\
\hline DAIA & Departamento de Avaliação de Impacto Ambiental \\
\hline DBO & Demanda Bioquímica de Oxigênio \\
\hline DDT & Dicloro-Difenil-Tricloroetano \\
\hline DEPRN & Departamento Estadual de Proteção dos Recursos Naturais \\
\hline DQO & Demanda Química de Oxigênio \\
\hline DSMA & Dissódio Metanoarsenato \\
\hline EESC & Escola de Engenharia de São Carlos \\
\hline EIA & Estudo de Impacto Ambiental \\
\hline EMBRAPA & Empresa Brasileira de Pesquisa Agropecuária \\
\hline EMDURB & Empresa Municipal de Desenvolvimento Urbano e Rural de Bauru \\
\hline EPI & Equipamento de Proteção Individual \\
\hline ETE & Estação de Tratamento de Esgoto \\
\hline
\end{tabular}




\begin{tabular}{|c|c|}
\hline ETRS & $\begin{array}{l}\text { Estação de Tratamento de Resíduos Sólidos de Araraquara } \\
\text { Fluoreto }\end{array}$ \\
\hline & Fluoreto \\
\hline FAFQ & Fundação de Apoio à Física e à Química da EESC/USP \\
\hline FAPESP & Fundação de Amparo à Pesquisa do Estado de São Paulo \\
\hline FECOP & Fundo Estadual de Prevenção e Controle da Poluição \\
\hline FIESP & Federação das Indústrias do Estado de São Paulo \\
\hline FIPAI & Fundação para o Incremento a Pesquisa e Aperfeiçoamento Industrial \\
\hline FUNPEC & Fundação Norte Rio-Grandense de Pesquisa e Cultura \\
\hline GPS & Sistema de Posicionamento Global \\
\hline $\mathrm{H}_{2} \mathrm{O}_{2}$ & Água oxigenada \\
\hline $\mathrm{HNO}_{3}$ & Ácido nítrico \\
\hline IAP & Índice de Qualidade das Águas para fins de Abastecimento Público \\
\hline IBGE & Instituto Brasileiro de Geografia e Estatística \\
\hline IGC & Instituto Geográfico e Cartográfico \\
\hline INPE & Instituto Nacional de Pesquisa Espacial \\
\hline IPT & Instituto de Pesquisas Tecnológicas \\
\hline IQA & Índice de Qualidade das Águas \\
\hline IQR & Índice de Qualidade de Aterro de Resíduos \\
\hline IVA & Índice de Qualidade das Águas para Proteção da Vida Aquática \\
\hline LI & Licença de Instalação \\
\hline LO & Licença de Operação \\
\hline LP & Licença Prévia \\
\hline LRF & Lei de Responsabilidade Fiscal \\
\hline MANOVA & Análise Multivariada \\
\hline MCPA & Ácido Ariloxialcanóico \\
\hline MSMA & Monosódio Metanoarsenato \\
\hline NBR & Norma Brasileira Registrada \\
\hline NCMF & Número de Colônias na Membrana Filtrante \\
\hline NEPER & Núcleo de Estudo e Pesquisa em Resíduos Sólidos \\
\hline $\mathrm{NNH}_{3}$ & Nitrogênio Amoniacal \\
\hline $\mathrm{NNO}_{2}$ & Nitrogênio Nitrito \\
\hline $\mathrm{NNO}_{3}$ & Nitrogênio Nitrato \\
\hline NT & Nitrogênio Total \\
\hline OCA & Órgão de Controle Ambiental \\
\hline OD & Oxigênio Dissolvido \\
\hline ONG & Organização Não Governamental \\
\hline $\mathrm{P}$ & Fósforo \\
\hline PARA & Programa de Análise de Resíduos de Agrotóxicos em Alimentos \\
\hline PAS & Posto de Atendimento Sanitário \\
\hline PCA & Análise de Componentes Principais \\
\hline PCB & Bifenilas Policloradas \\
\hline PEAD & Polietileno de Alta Densidade \\
\hline PERH & Plano Estadual de Recursos Hídricos \\
\hline PET & Politereftalato de Etila \\
\hline PEVs & Pontos de Entrega Voluntária \\
\hline PVC & Cloreto de Polivinila \\
\hline $\mathrm{pH}$ & potencial Hidrogeniônico \\
\hline PJ & Ponto a Jusante \\
\hline PM & Ponto a Montante \\
\hline PMSC & Prefeitura Municipal de São Carlos \\
\hline PNRS & Política Nacional de Resíduos Sólidos \\
\hline PNMA & Política Nacional do Meio Ambiente \\
\hline
\end{tabular}




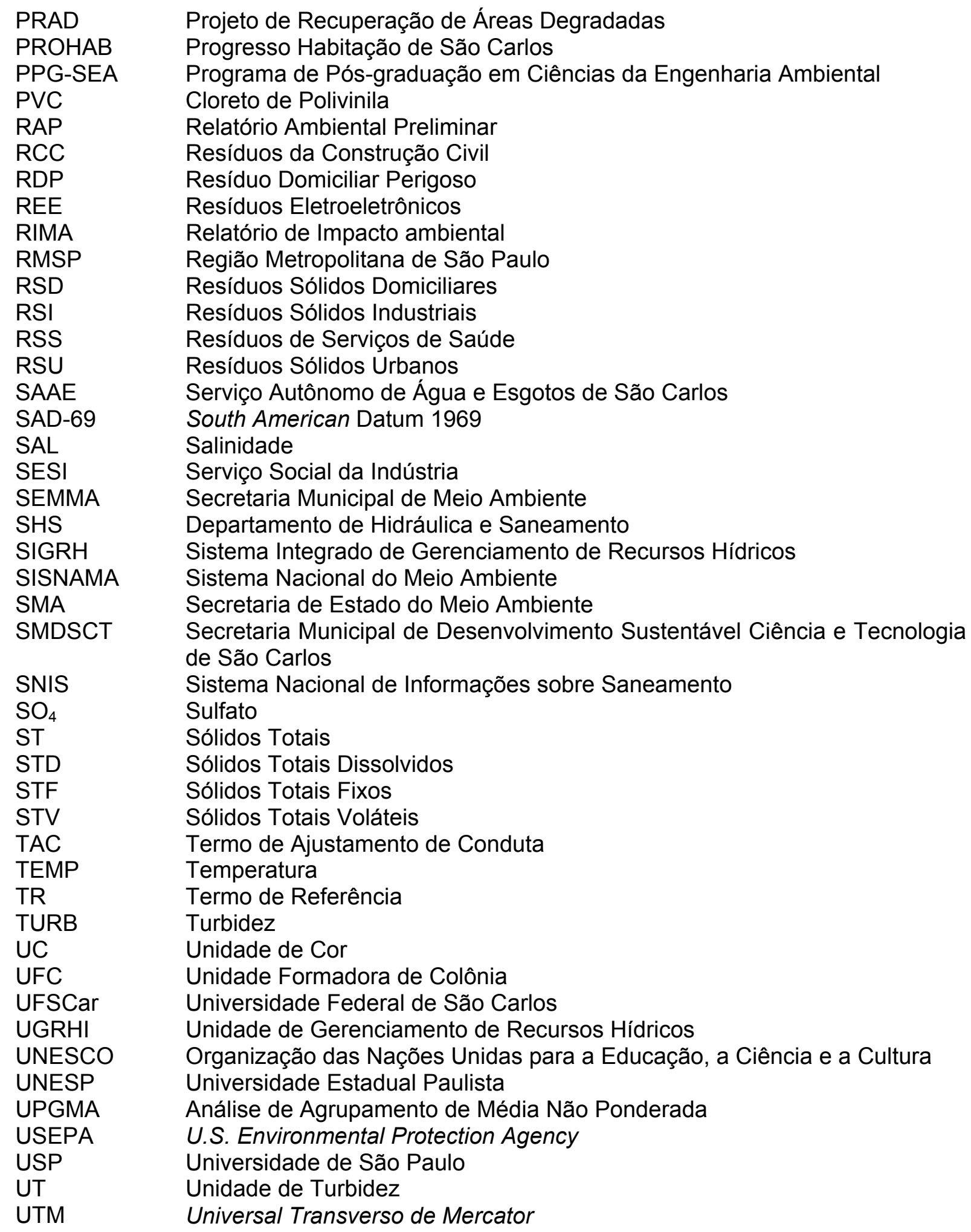




\section{SUMÁRIO}

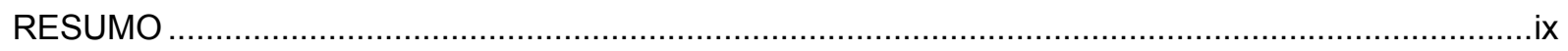

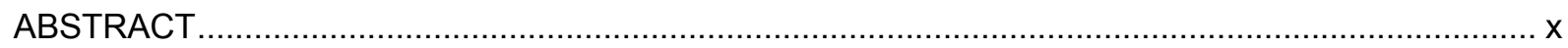

1 INTRODUÇÃO

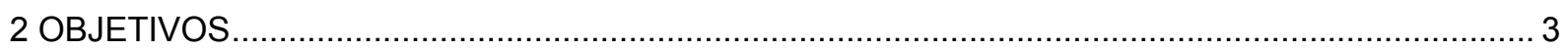

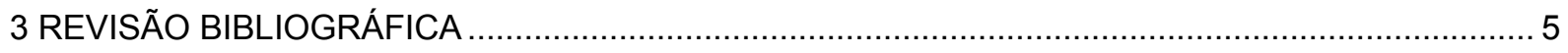

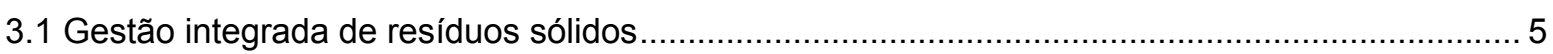

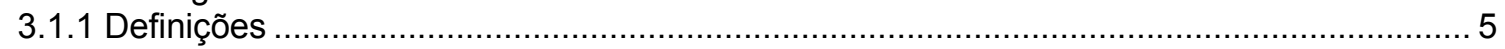

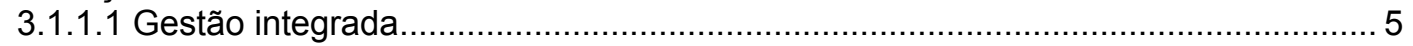

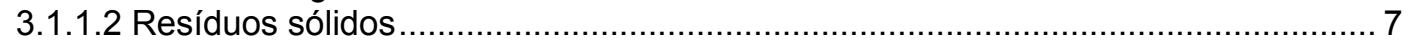

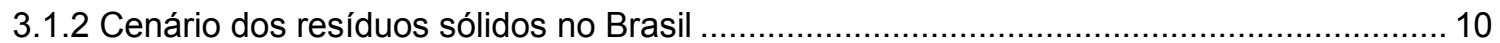

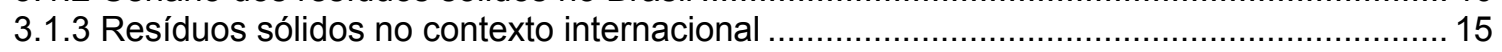

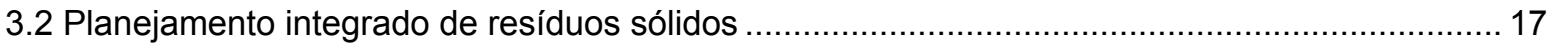

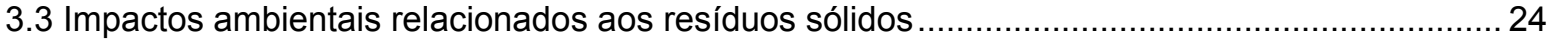

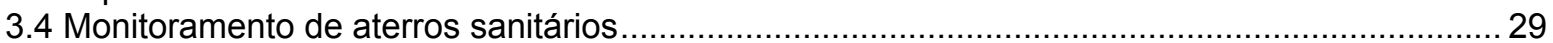

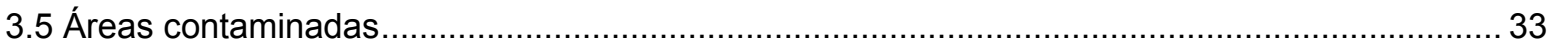

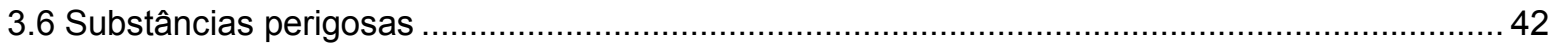

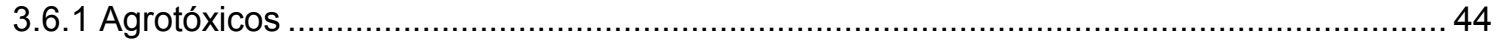

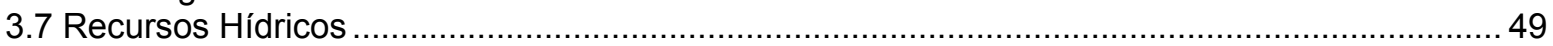

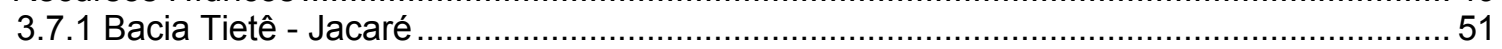

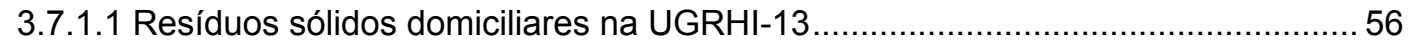

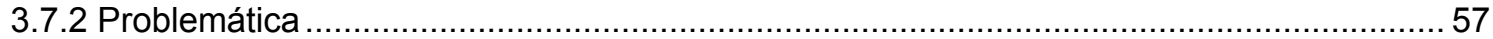

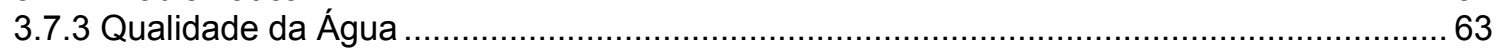

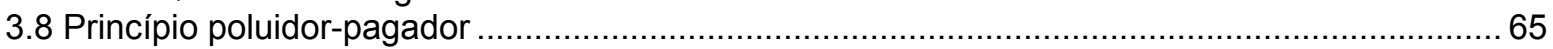

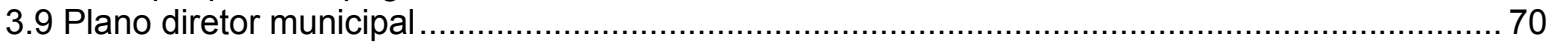

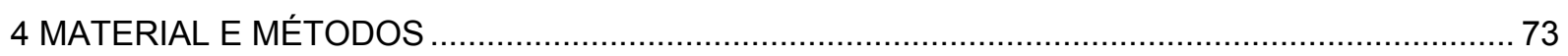

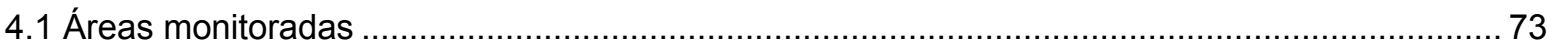

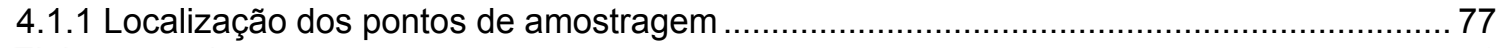

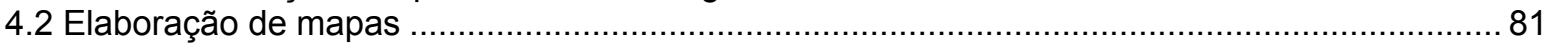

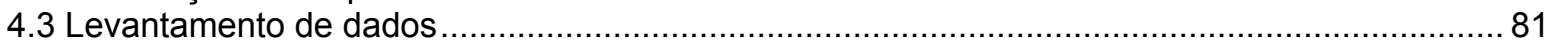

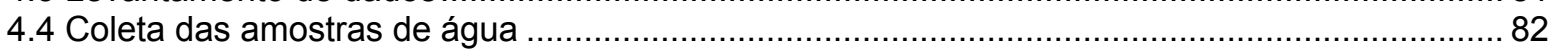

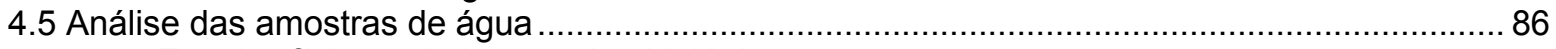

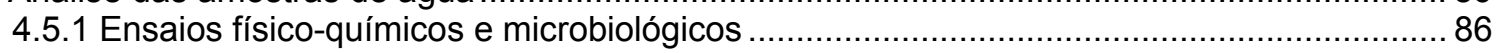

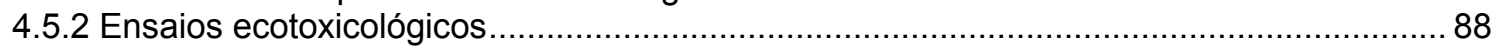

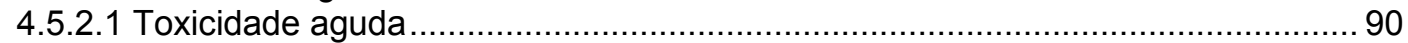

4.5.2.2 Toxicidade crônica .................................................................................... 91

4.5.3 Ensaios de extração e quantificação de substâncias orgânicas ....................................... 92

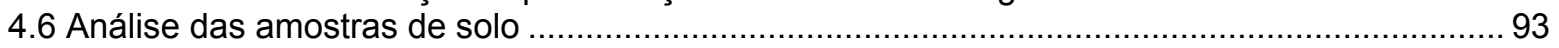

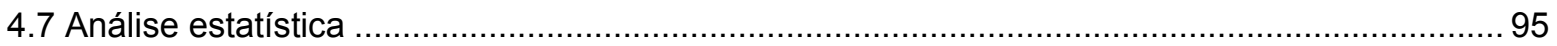

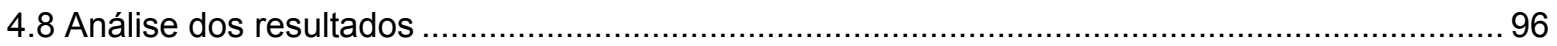


5.1 Caracterização dos municípios monitorados quanto aos resíduos sólidos.................................99

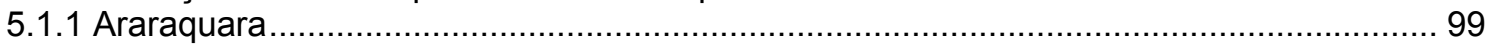

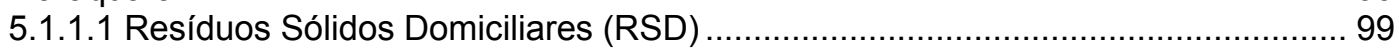

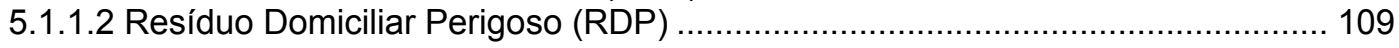

5.1.1.3 Resíduos de Serviços de Saúde (RSS) ..................................................... 109

5.1.1.4 Resíduos da Construção Civil (RCC) ............................................................. 110

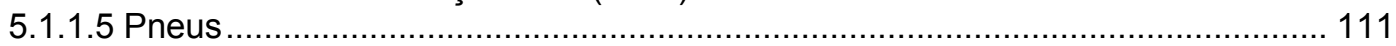

5.1.1.6 Embalagens de Agrotóxicos ................................................................... 112

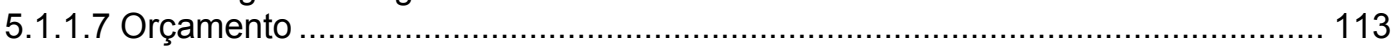

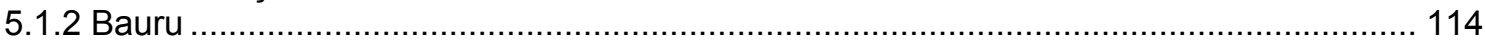

5.1.2.1 Resíduos Sólidos Domiciliares (RSD) …….............................................. 114

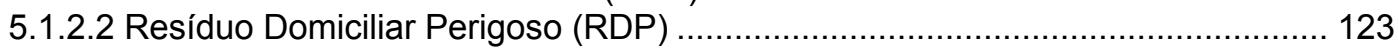

5.1.2.3 Resíduos de Serviços de Saúde (RSS) ….................................................. 123

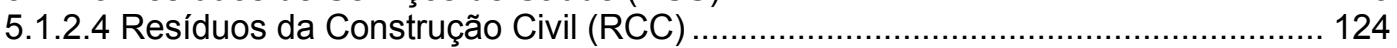

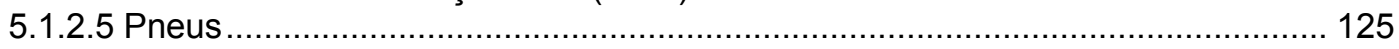

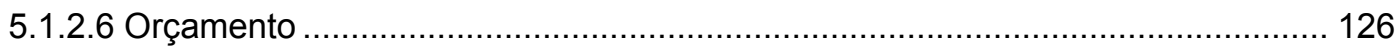

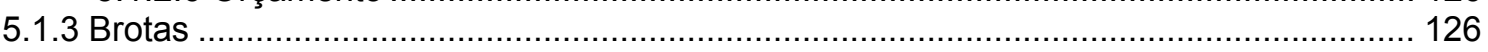

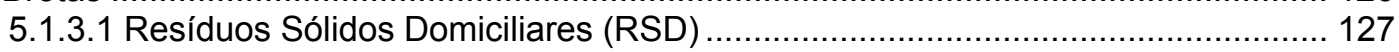

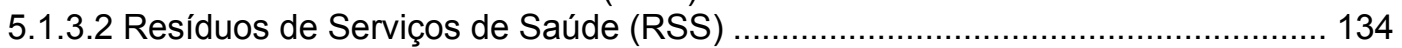

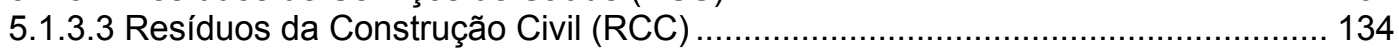

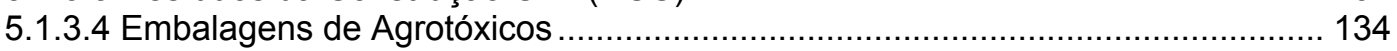

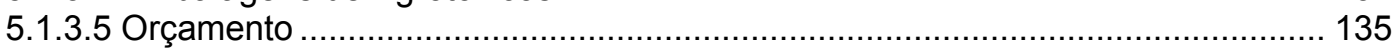

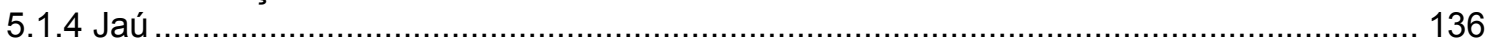

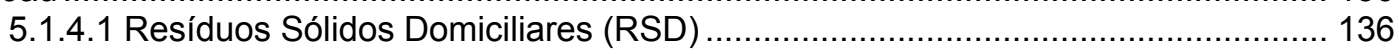

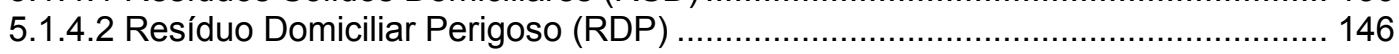

5.1.4.3 Resíduos de Serviços de Saúde (RSS) ...................................................... 146

5.1.4.4 Resíduos da Construção Civil (RCC) .......................................................... 147

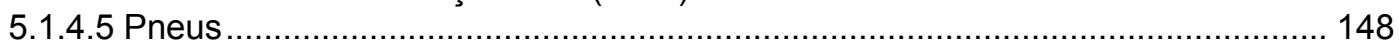

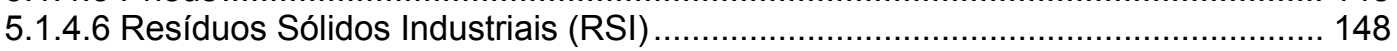

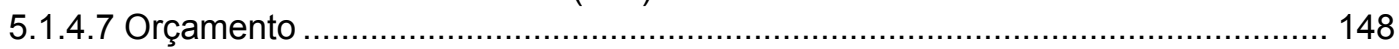

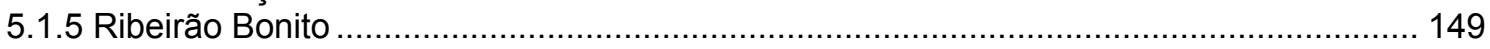

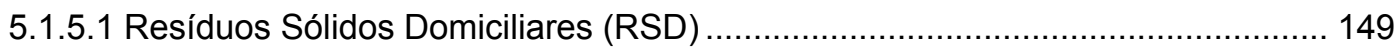

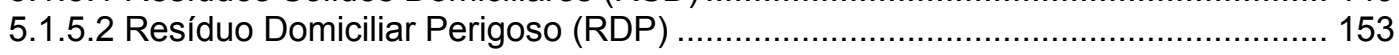

5.1.5.3 Resíduos de Serviços de Saúde (RSS) ….................................................. 153

5.1.5.4 Resíduos da Construção Civil (RCC) ........................................................... 153

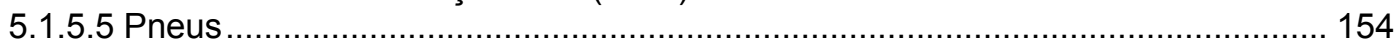

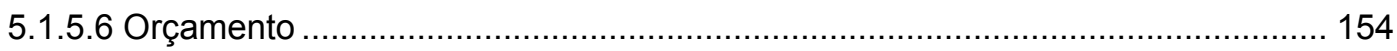

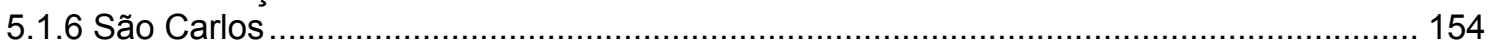

5.1.6.1 Resíduos Sólidos Domiciliares (RSD) ...................................................... 154

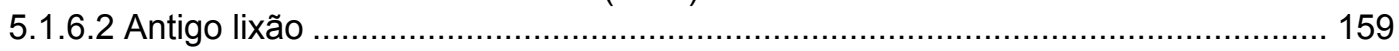

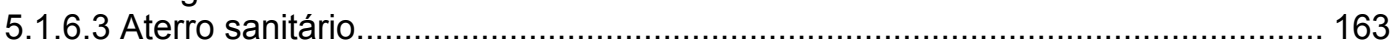

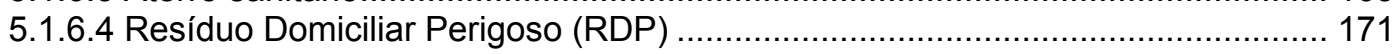

5.1.6.5 Resíduos de Serviços de Saúde (RSS) ..................................................... 172

5.1.6.6 Resíduos da Construção Civil (RCC) ......................................................... 174

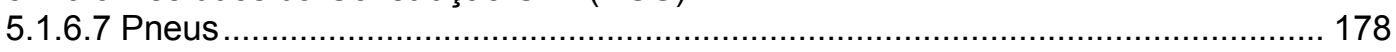

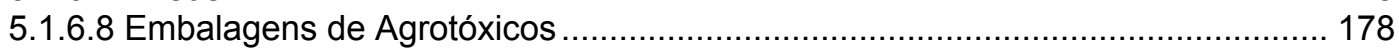

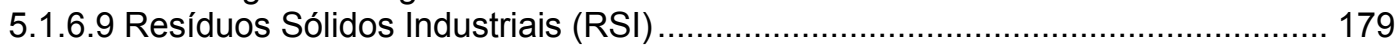

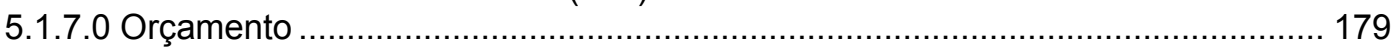

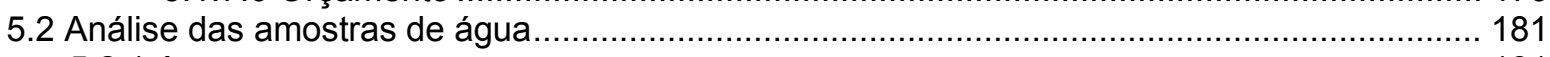

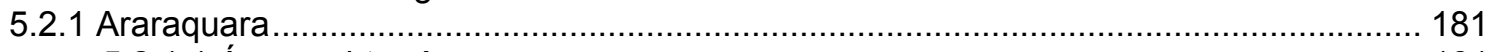

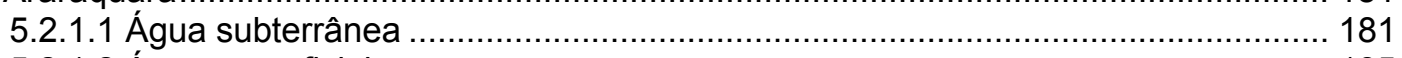

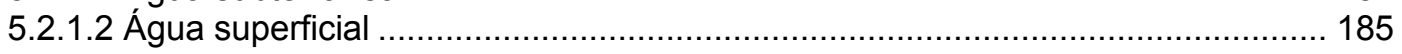

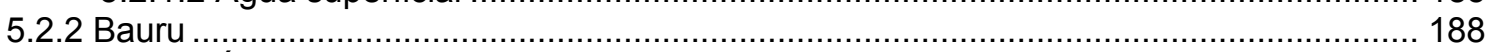

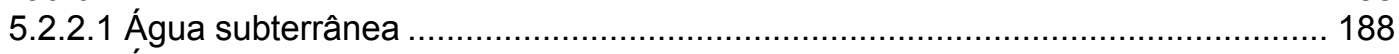

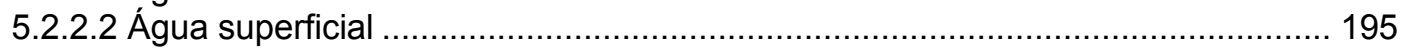

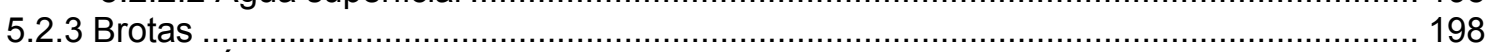

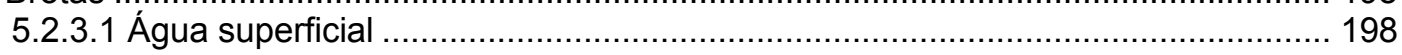

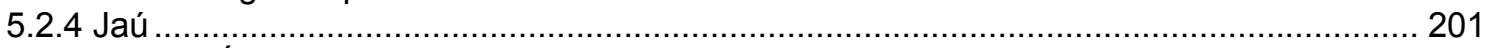

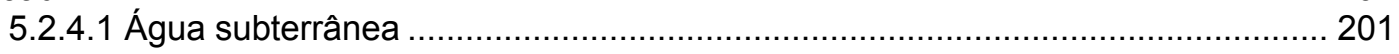




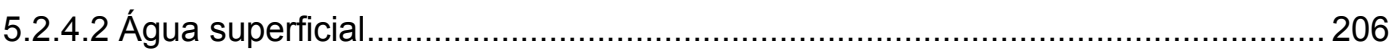

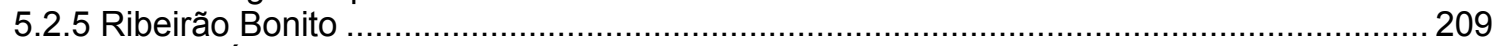

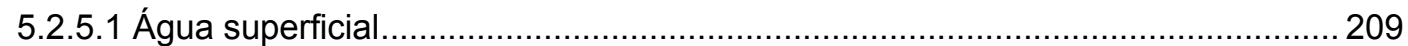

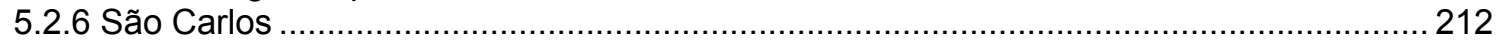

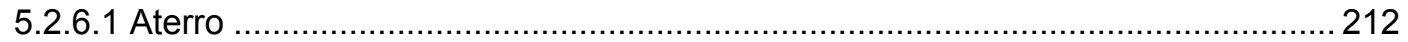

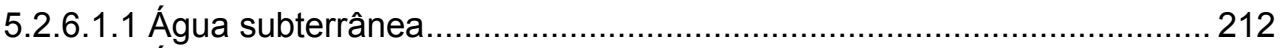

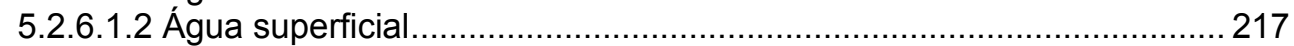

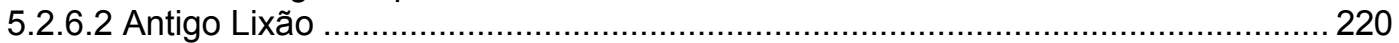

5.2.6.2.1 Água subterrânea............................................................. 220

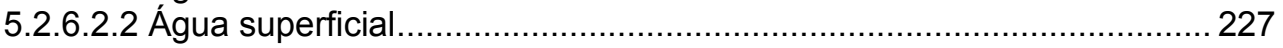

5.3 Comparação entre os valores médios obtidos nos poços de monitoramento ........................232

5.4 Comparação entre os valores médios obtidos nos córregos .......................................238

5.5 Análise das amostras de solo do lixão de Jaú ........................................................ 244

5.6 Análise estatística dos parâmetros físico-químicos ................................................ 245

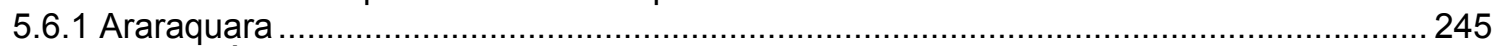

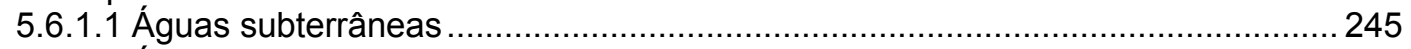

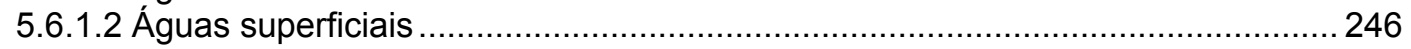

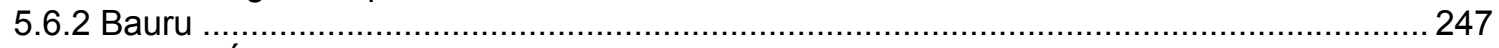

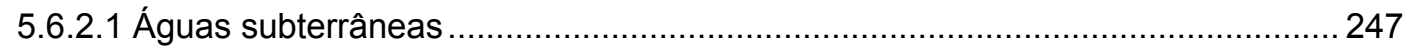

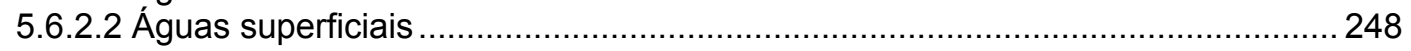

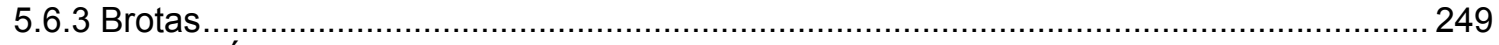

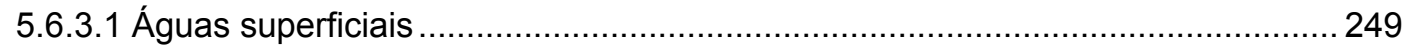

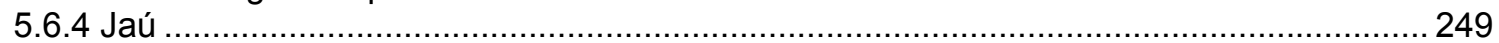

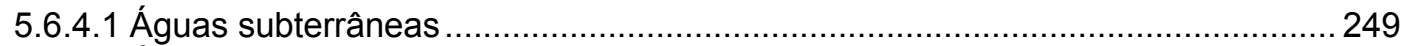

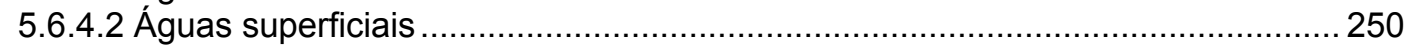

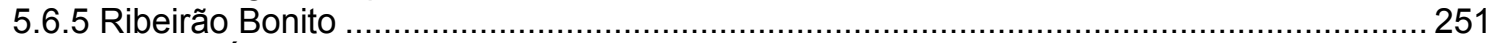

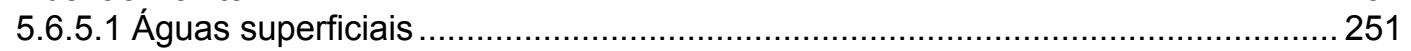

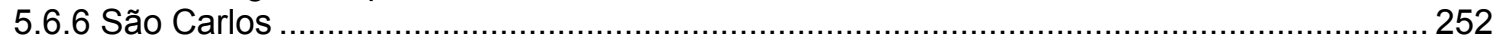

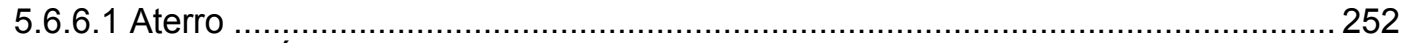

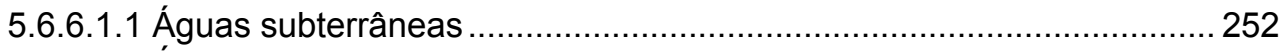

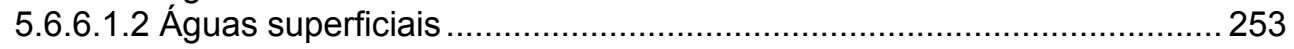

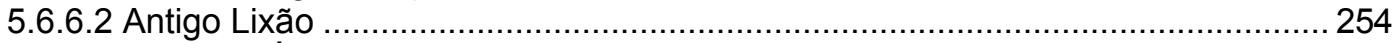

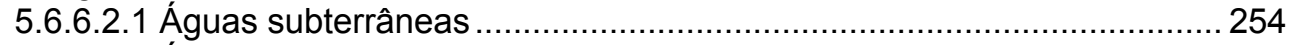

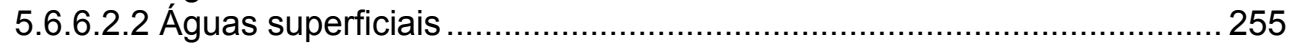

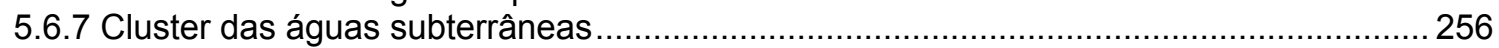

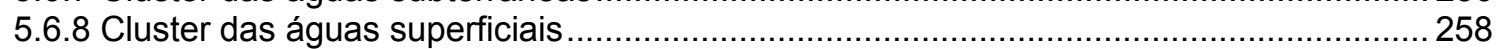

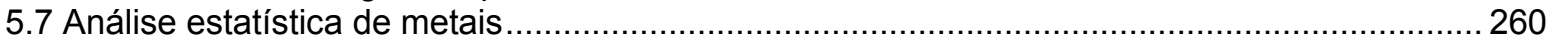

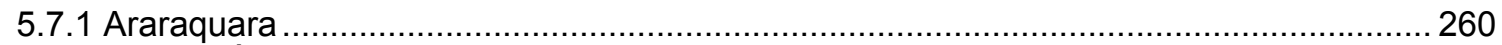

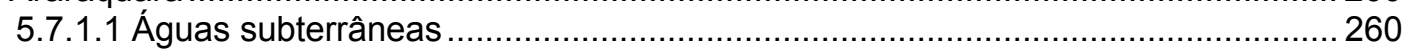

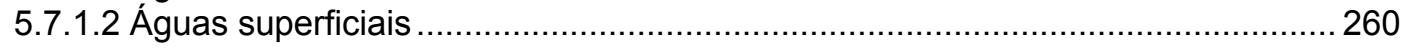

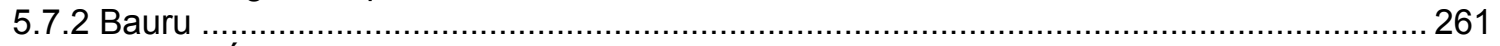

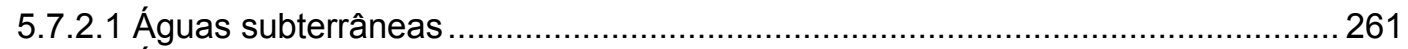

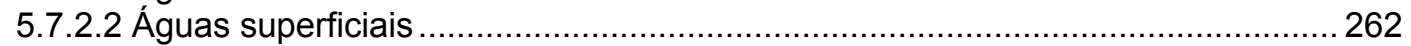

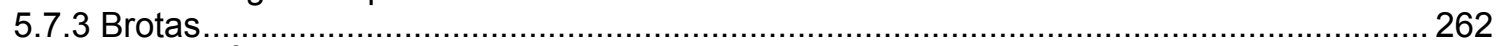

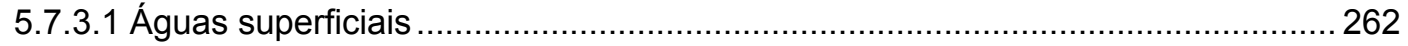

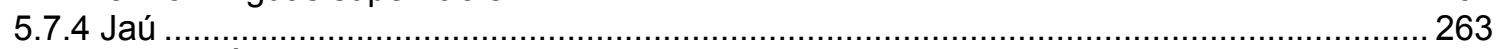

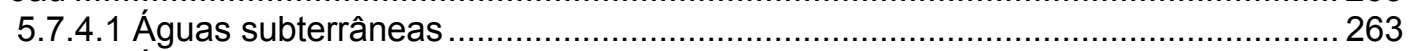

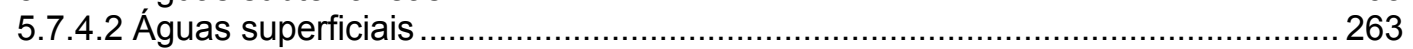

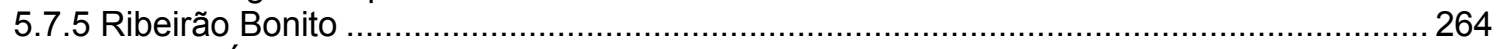

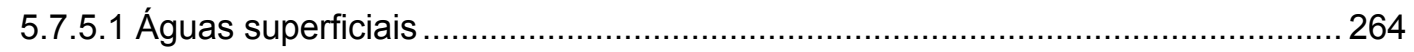

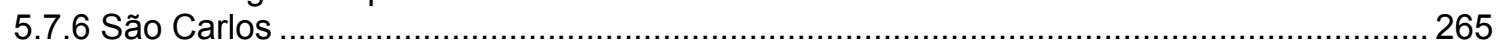

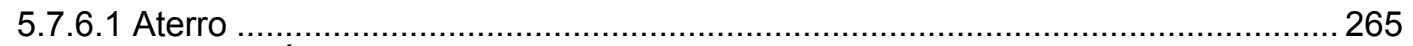

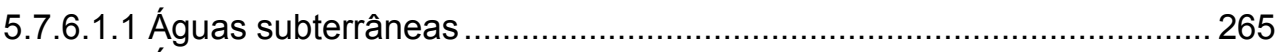

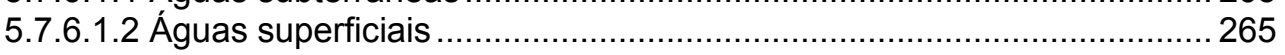

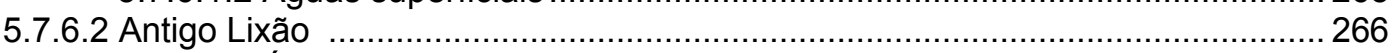

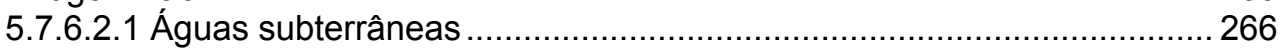

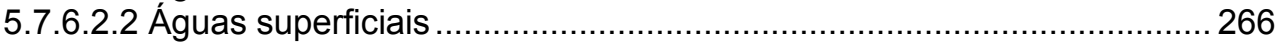

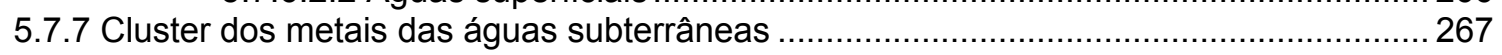

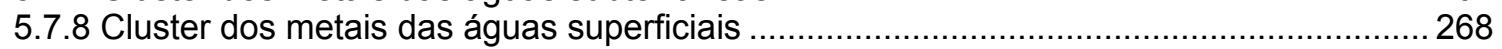




\section{PROPOSTAS DE GESTÃO INTEGRADA DE RESÍDUOS SÓLIDOS URBANOS}

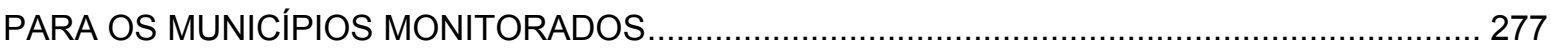

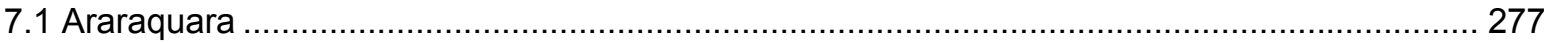

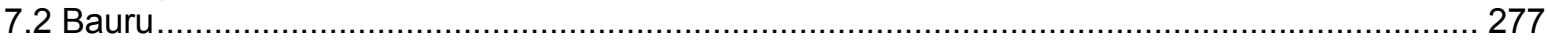

7.3 Brotas

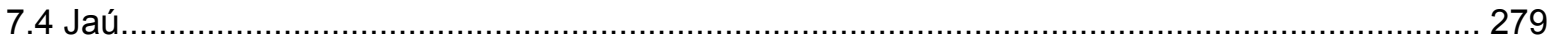

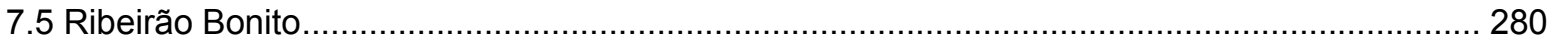

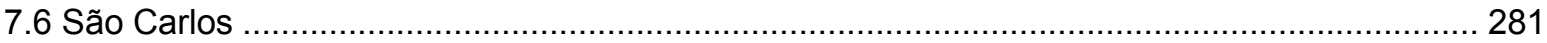

8 DIRETRIZES PARA IMPLANTAÇÃO DE UM PLANO DE GESTÃO INTEGRADA DE

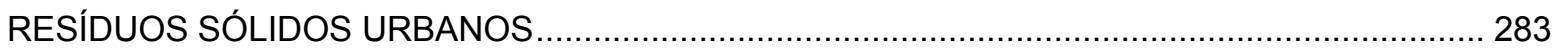

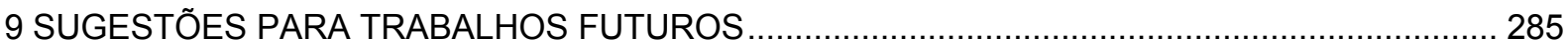

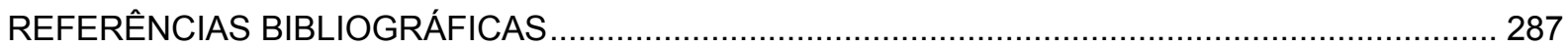

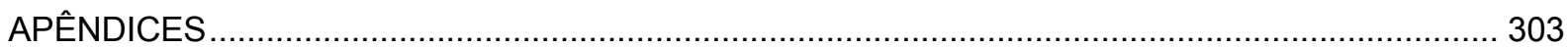

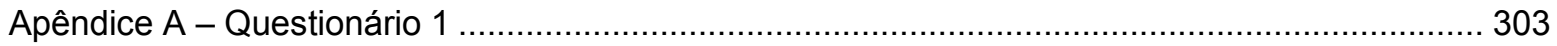

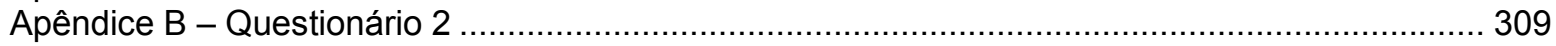

Apêndice C - Resíduos sólidos nos municípios da Bacia Tietê-Jacaré (UGRHI-13) ................... 311

Apêndice D - Resultados dos ensaios físico-químicos e microbiológicos com amostras

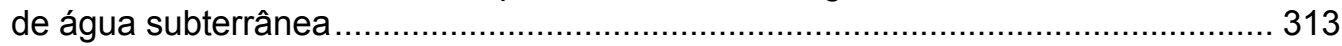

D.1 Aterro de Araraquara .................................................................... 313

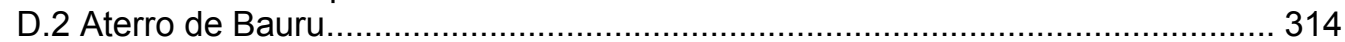

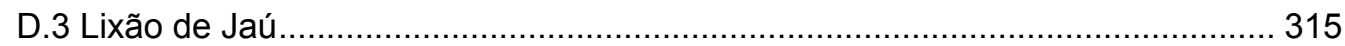

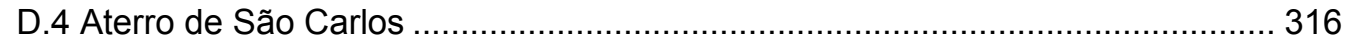

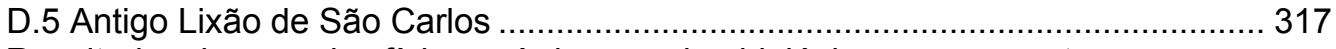

Apêndice $E$ - Resultados dos ensaios físico-químicos e microbiológicos com amostras

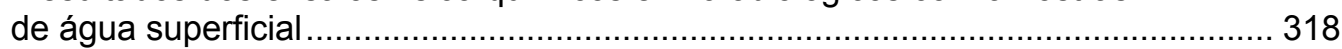

E.1 Córrego do Pinheirinho, Araraquara .................................................. 318

E.2 Córrego da Gabiroba, Bauru........................................................... 319

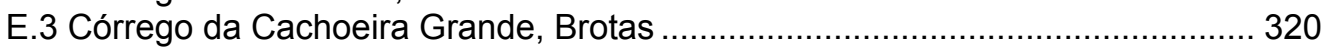

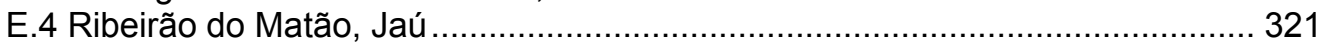

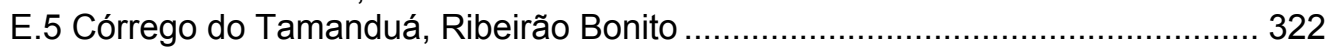

E.6 Córrego do Galdino, São Carlos ...................................................... 323

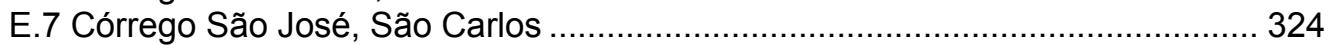

Apêndice F - Resultados dos ensaios ecotoxicológicos ................................................. 325

Apêndice G - Resultados dos ensaios de extração e quantificação de substâncias

orgânicas com amostras de água superficial ............................................... 327

G.1 Córrego do Pinheirinho, Araraquara...................................................... 327

G.2 Córrego da Gabiroba, Bauru ............................................................. 328

G.3 Córrego da Cachoeira Grande, Brotas.................................................. 329

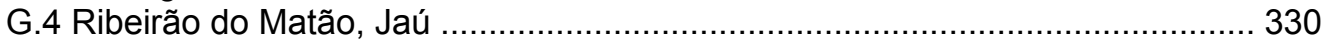

G.5 Córrego do Tamanduá, Ribeirão Bonito................................................ 331

G.6 Córrego do Galdino, São Carlos ....................................................... 332

G.7 Córrego São José, São Carlos ............................................................ 333

Apêndice H1 - Quantidade de amostras de água subterrânea fora dos limites recomendados pela Portaria $518 / 2004$ (\%) .................................................. 334

Apêndice $\mathrm{H} 2$ - Quantidade de amostras de água superficial fora dos limites recomendados pela CONAMA 357/2005 e pelo Decreto 8468/1976 (\%). 
xxiv

ANEXOS

Anexo 1 - Relatório de sondagem no aterro de Brotas.....

Anexo 2 - Relatório de sondagem e construção de poços no lixão de Jaú

Anexo 3 - Relatório de sondagem no aterro de Ribeirão Bonito 


\section{INTRODUÇÃO}

Grande quantidade de resíduos sólidos é produzida diariamente. A necessidade de solucionar os problemas gerados pelo gerenciamento inadequado destes resíduos faz com que a gestão dos mesmos se torne uma questão complexa, uma vez que inúmeros são os fatores envolvidos e suas relações, além do risco do comprometimento da saúde pública e do ambiente.

As questões sanitárias e ambientais são intrínsecas ao tema. Além das decisões políticas, elaboração de legislações e estratégias, aspectos técnicos e econômicos relacionados à gestão dos resíduos sólidos, existem aspectos operacionais relacionados ao gerenciamento dos mesmos como geração, armazenamento, coleta, transbordo, transporte, tratamento e disposição final que devem ser analisados, bem como aspectos sociais envolvidos. Essas questões são peculiares de cada localidade, se distinguem conforme a densidade populacional, cultura, administração política, situação econômica, características ambientais da região, entre outros fatores.

$\mathrm{Na}$ maioria dos municípios brasileiros, as administrações públicas visavam, exclusivamente, à coleta e à disposição final dos resíduos sólidos, visto que estes eram os itens cobrados pelos órgãos sanitários e ambientais. Uma vez definidos a forma de coleta e o local para o descarte dos mesmos, o problema da administração municipal estava aparentemente resolvido. Dessa forma, a receita municipal era destinada para contemplar estas etapas do gerenciamento.

Com isso, apenas uma pequena parte desses resíduos é devidamente tratada e disposta. Em grande parte dos municípios não há programas de coleta seletiva, tratamento de resíduos, locais apropriados para o descarte dos mesmos, entre outras deficiências.

Assim, subentende-se que o poder público demonstra pouca preocupação com a minimização da geração de resíduos e com a prevenção e o controle da poluição. Além disso, poucos municípios disponibilizam informações sobre os resíduos sólidos. A maioria deles não possui dados, as informações não são compartilhadas entre os órgãos de governo, nem tão pouco divulgadas à população.

No Brasil, existem normas e leis relacionadas aos resíduos sólidos que podem nortear os administradores públicos, carecendo de legislação específica em alguns setores, como no de eletroeletrônicos, por exemplo. A Política Nacional de Saneamento Básico, Lei № 11.445 , de 5 de janeiro de 2007, propõe uma visão integrada dos sistemas públicos de abastecimento de água e esgotamento sanitário, bem como o manejo das águas pluviais e resíduos sólidos. Porém, no que se refere aos resíduos sólidos, a lei apresenta de forma 
genérica as etapas do gerenciamento e algumas definições, não apresentando diretrizes específicas para os diferentes tipos de resíduos.

Há muito tempo algumas propostas nesta área tramitam no Congresso Nacional. Porém, a falta de uma Política Nacional de Resíduos Sólidos exige uma maior integração entre os governos nacional, estadual e municipal, bem como entre os diversos setores da sociedade em busca da prevenção e minimização dos impactos negativos. Recentemente está sendo discutido o Projeto de Lei (PL) 1991/2007 que visa instituir a Política Nacional de Resíduos Sólidos (PNRS).

No Estado de São Paulo, no âmbito da gestão, foi aprovada a Lei $n^{0} 12.300$, de 17 de março de 2006, que trata da Política Estadual de Resíduos Sólidos. Além disso, alguns municípios já possuem decretos que dispõem sobre o tratamento e a disposição final adequada dos diferentes tipos de resíduos sólidos. Quanto ao gerenciamento, nota-se que os aterros municipais estão melhorando gradativamente e unidades de tratamento estão sendo construídas, a fim de atenderem as exigências dos órgãos ambientais, especialmente da agência ambiental fiscalizadora do Estado, a Companhia de Tecnologia de Saneamento Ambiental (CETESB). Porém, em geral, as medidas ainda são emergenciais e corretivas.

Quando as áreas de disposição final de resíduos sólidos não são bem construídas e operadas, as substâncias presentes nesses resíduos podem migrar para o entorno e causar poluição e contaminação ambiental, o que pode afetar o ecossistema local (ar, água e solo), podendo comprometer a fauna, a flora, bem como a saúde da população.

Com base no exposto, as hipóteses deste trabalho foram: (1) não há gestão integrada dos resíduos sólidos nos municípios brasileiros e (2) a qualidade das águas no entorno de aterros e lixões está sendo alterada devido a possíveis vazamentos.

Nesse sentido, o enfoque do presente estudo foi analisar a situação dos resíduos sólidos em alguns municípios, bem como avaliar se a qualidade das águas superficiais e subterrâneas na área de influência dos seus respectivos aterros estava sendo alterada. Para o desenvolvimento da pesquisa, a $13^{a}$ Unidade de Gerenciamento de Recursos Hídricos (UGRHI-13) do Estado de São Paulo foi adotada como área de estudo. No total, sete áreas de disposição final de resíduos sólidos foram selecionadas: sete corpos d'água e 20 poços foram monitorados durante o período de um ano, entre 2004 e 2005.

O trabalho procurou retratar a realidade dos municípios de pequeno e médio porte do Estado de São Paulo no que se refere à gestão dos resíduos sólidos urbanos. 


\section{OBJETIVOS}

O objetivo geral desta pesquisa foi levantar e analisar as questões referentes à gestão dos resíduos sólidos urbanos (RSU) na Bacia Hidrográfica Tietê-Jacaré (BHTJ), pertencente à $13^{\mathrm{a}}$ Unidade de Gerenciamento dos Recursos Hídricos (UGRHI-13) do Estado de São Paulo, bem como verificar a influência dos mesmos na qualidade das águas superficiais e subterrâneas da região, por meio de coletas de água em 34 pontos, distribuídos na área de influência de sete aterros.

Objetivos específicos:

- reunir informações sobre a situação dos RSU na UGRHI-13;

- identificar as principais áreas de disposição final dos RSU na UGRHI-13;

- selecionar as áreas a serem monitoradas;

- realizar sondagem do solo e construir poços para o monitoramento das águas subterrâneas em área de influência dos aterros selecionados;

- analisar, por amostragem, a qualidade das águas superficiais e subterrâneas no entorno das áreas selecionadas, e comparar com os padrões recomendados pelas legislações vigentes;

- contribuir para o aprimoramento do Plano Diretor e da Lei Orgânica dos municípios pertencentes a Bacia Tietê-Jacaré;

- propor diretrizes para a elaboração de um programa de gestão integrada dos RSU na região. 


\section{REVISÃO BIBLIOGRÁFICA}

Este capítulo trata de conceitos e definições inerentes à gestão dos resíduos sólidos, bem como da sua relação com os recursos hídricos. São abordadas ainda questões relativas às áreas contaminadas, bacia hidrográfica e plano diretor.

\subsection{Gestão integrada de resíduos sólidos}

\subsubsection{Definições}

\subsubsection{Gestão integrada}

Gestão significa elaboração de estratégias, planejamento de ações; pressupõe visão holística, interação entre as partes, articulação entre os agentes, integrar e compartilhar informações. Por este motivo os termos "gestão integrada" e "gestão compartilhada" estão sendo muito empregados atualmente. Existe ainda o termo "gestão sustentada", que provém de "gestão sustentável", os quais enfatizam o planejamento a longo prazo.

De acordo com Souza (2000, p.27), o termo 'gestão' assume um significado amplo quando se refere à questão ambiental, pois envolve um grande número de variáveis que interagem simultaneamente.

Para Machado (2003), o conceito de gestão é usado no sentido global e diversificado, como gestão ambiental integrada, gestão dos recursos naturais, gestão do espaço, gestão integrada das águas, entre outros. Segundo o autor, a gestão integrada foi adotada por cientistas, administradores públicos, industriais, associações técnico-científicas e possui diferentes conotações e dimensões.

No contexto dos recursos hídricos, a integração se refere aos processos de transportes de massa de água; aos usos múltiplos dos cursos d'água, reservatórios artificiais ou naturais, lagos, lagoas ou aqüíferos; ao inter-relacionamento dos corpos hídricos com os outros elementos dos ecossistemas (solo, fauna e flora); à co-participação entre os gestores, usuários e população local no planejamento e na administração dos recursos hídricos e aos anseios da sociedade de desenvolvimento sócio-econômico com preservação ambiental, na perspectiva de um desenvolvimento sustentável (Machado, 2003).

No Brasil, muitas vezes, os termos gestão e gerenciamento são confundidos e usados como sinônimos. A literatura americana emprega para ambos a expressão management, sem distinção, pressupondo-se que seus significados estão englobados numa 
única palavra. No que se refere ao tema resíduos sólidos, são apresentadas algumas definições.

Conforme Projeto BRA/92/017 - Gestão e Tecnologias de Tratamento de Resíduos Sólidos (Leite, 1997), a gestão integrada de resíduos sólidos "compreende a articulação orgânica dos diferentes agentes públicos locais e regionais atuantes na região metropolitana, mediante planejamento integrado, coordenação, controle e fiscalização participativos, e execução descentralizada até garantir a racionalidade e a eficiência do setor".

Segundo Tchobanoglous (1993), gerenciamento de resíduos sólidos envolve a geração, armazenamento, coleta, transferência, transporte, tratamento e disposição final desses resíduos, bem como aspectos econômicos, de engenharia, de saúde pública, ambientais, entre outros fatores.

A Agência de Proteção Ambiental Americana, U.S. Environmental Protection Agency (USEPA, 2001), define gerenciamento integrado de resíduos sólidos como um processo por meio da combinação de quatro métodos: redução, reciclagem, combustão e disposição. Conforme a EPA, o gerenciamento integrado dos resíduos sólidos é composto de ações, etapas, métodos, processos e facilidades, como planejamento, financiamento, regulação, operação e gerenciamento. Incluí também a redução da geração desses resíduos, coleta, transferência, reciclagem dos materiais, compostagem, combustão (incineração ou geração de energia a partir da queima de resíduos) e disposição.

Com base em Leite (1997, p.89), gestão de resíduos sólidos trata-se de "um conjunto de referências político-estratégicas, institucionais, legais e financeiras capaz de orientar a organização do setor". Esta definição foi complementada por Lima (2003, p.35), que inseriu as variáveis operacional, social e ambiental.

Segundo a Lei $n^{\circ}$ 12.300/2006 que trata da Política Estadual de Resíduos Sólidos do Estado de São Paulo, gerenciamento de resíduos sólidos "é o estabelecimento de diretrizes e a implantação dos serviços de limpeza urbana, sobre os aspectos ambientais, econômicos, financeiros, administrativos, técnicos, sociais e legais, para todas as fases do manejo, de sua geração até a sua disposição final". Com base nesta mesma lei, gestão integrada de resíduos sólidos "é a maneira de conceber, implementar, administrar sistemas de Limpeza Urbana considerando uma ampla participação dos setores da sociedade com a perspectiva do desenvolvimento sustentável. A sustentabilidade do desenvolvimento é vista de forma abrangente, envolvendo as dimensões ambientais, sociais, culturais, econômicas, políticas e institucionais. Isso significa articular políticas e programas de vários setores da administração e vários níveis de governo, envolver o Legislativo e a comunidade locais, buscar garantir os recursos e continuidade das ações, identificar tecnologias e soluções adequadas à realidade local". 
Em suma, a gestão integrada de resíduos sólidos visa elaborar diretrizes para disciplinar as ações (gerenciamento), considerando os aspectos envolvidos (ambientais, culturais, econômicos, de saúde pública, políticos, sociais, técnicos, urbanísticos, entre outros), a fim de que as medidas adotadas sejam mais sustentáveis. Dessa forma, o gerenciamento faz parte da gestão e pode ser entendido como as etapas a serem executadas.

\subsubsection{Resíduos sólidos}

Quando a vida útil de um material é excedida, o produto se torna um resíduo (Nazaroff e Alvarez Cohen, 2001, p.10). O termo técnico "resíduo sólido" é empregado como sinônimo de "lixo" (Mancini, 1999). Com base em Bidone e Povinelli (1999, p.5), os lixos ou resíduos sólidos apresentam grande diversidade, são gerados pelas mais variadas atividades humanas e ambientes urbanos, constituem uma massa de materiais reunidos, julgada sem utilidade e posta fora.

No Brasil, os resíduos sólidos seguem os critérios estabelecidos pela Associação Brasileira de Normas Técnicas (ABNT), a qual apresenta uma relação de normas. A NBR 10004 (ABNT, 2004a) define resíduos sólidos como

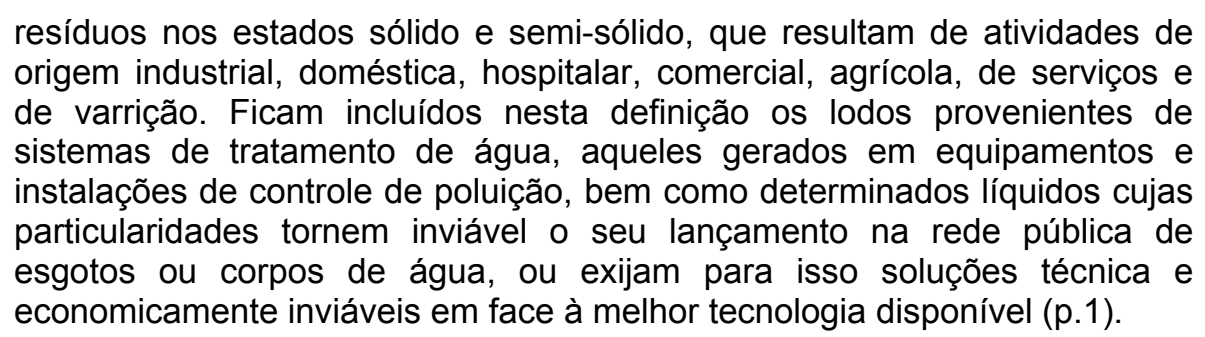

Por meio da NBR 10004 (ABNT, 2004a) os resíduos sólidos são classificados, conforme seu grau de periculosidade:

- Resíduos Classe I - Perigosos (os que apresentam pelo menos uma das seguintes características: podem ser tóxicos, corrosivos, inflamáveis, reativos ou patogênicos) e

- Resíduos Classe II - Não Perigosos:

- Resíduos Classe II A - Não Inertes (exemplo: resíduo sólido domiciliar) e

- Resíduos Classe II B - Inertes (exemplo: alguns resíduos da construção civil)

Os resíduos radioativos possuem legislação específica, não se enquadrando nessa classificação, pois o gerenciamento dos mesmos é de responsabilidade exclusiva da Comissão Nacional de Energia Nuclear (CNEN). 
Os resíduos sólidos podem ainda ser divididos de acordo com a fonte (Schalch, 1992, p.1-3, modificado):

- Resíduos Sólidos Urbanos (RSU): faz parte desta categoria o Resíduo Sólido Domiciliar (RSD), produzido nas residências; o comercial, proveniente de estabelecimentos como escritórios, lojas e hotéis; o institucional, gerado em unidades de ensino, repartições governamentais, etc; os de poda, capina, varrição e de serviços, gerados em locais públicos como feiras livres; ruas, praças, parques, praias, entre outros locais. Exemplo: restos de alimento, galhos, folhas, plástico, vidro, metal, papel, papelão, tecido, entre outros;

- $\quad$ Resíduos Sólidos Industriais (RSI): são resíduos gerados pelas diversas indústrias de processamento. Nesta categoria os resíduos devem ser estudados particularmente, de acordo com suas especificidades, para se obter uma solução técnica e economicamente adequada, já que pertencem a uma área complexa. Exemplo: metal pesado, amônia, ácidos, solventes, entre outros;

- Resíduos de Serviços de Saúde (RSS): são resíduos gerados pelos serviços prestadores de assistência médica, sanitária, podendo ser provenientes de farmácias, hospitais, unidades ambulatoriais de saúde, clínicas médicas e veterinárias, consultórios médicos e odontológicos, laboratórios de análises clínicas e patologias, instituições de ensino e pesquisa médica, bancos de sangue, entre outros locais. Exemplo: material cirúrgico (agulhas, seringas, bisturis, tesouras, luvas, algodão, etc), órgãos, membros, fraldas, medicamentos, entre outros;

- Resíduos Agrícolas: são resíduos gerados pelas atividades agropecuárias. Exemplo: fibras vegetais, cascas, folhas, sementes, embalagens de agrotóxicos, entre outros. $O$ Projeto de Lei da Política Nacional de Resíduos Sólidos (PL 1991/2007, Artigo 12, inciso I), denomina estes resíduos como "resíduos sólidos rurais";

- Resíduos Radioativos: são resíduos provenientes do aproveitamento de combustíveis nucleares, utilizados em hospitais, clínicas, instituições de ensino e pesquisa, entre outros locais. Exemplo: césio, urânio, radônio, estrôncio, entre outros.

Os Resíduos Sólidos Urbanos (RSU), tratados por este estudo, são definidos pela NBR 8419 (ABNT, 1992) como os "resíduos gerados num aglomerado urbano, excetuados os resíduos industriais perigosos, hospitalares sépticos e de aeroportos e portos". 
De acordo com a Resolução CONAMA 308/2002, que trata do Licenciamento ambiental de sistemas de disposição final de RSU gerados em municípios de pequeno porte, RSU são "os provenientes de residências ou qualquer outra atividade que gere resíduos com características domiciliares, bem como os resíduos de limpeza pública urbana". Com base no Artigo 2, ficam excluídos os resíduos perigosos desta definição.

O Artigo $6^{\circ}$ da Lei $n^{\circ} 1.445 / 2007$, que trata da Política Nacional de Saneamento Básico, propõe que "o lixo originário de atividades comerciais, industriais e de serviços cuja responsabilidade pelo manejo não seja atribuída ao gerador pode, por decisão do poder público, ser considerado resíduo sólido urbano".

O Artigo 12, inciso I do Projeto de Lei da Política Nacional de Resíduos Sólidos, PL 1991/2007, define resíduos sólidos urbanos como os "resíduos gerados por residências, domicílios, estabelecimentos comerciais, prestadores de serviços e oriundos dos serviços públicos de limpeza urbana e manejo de resíduos sólidos, que por sua natureza ou composição tenham as mesmas características dos gerados nos domicílios".

Entre os resíduos sólidos, destacam-se outros três grandes grupos:

- $\quad$ Resíduos da Construção Civil (RCC): gerados por obras, reformas e demolições. Exemplo: concreto, madeira, borracha, metal, plástico, cerâmica, tijolo, telha, vidro, gesso, areia, cal, amianto, pedra, resina, cola, entre outros. Estes resíduos possuem legislações aprovadas recentemente: A Resolução n ${ }^{\circ} 307$ do Conselho Nacional de Meio Ambiente (CONAMA) de 2002 trata da gestão e classificação dos resíduos da construção civil e a Resolução CONAMA n ${ }^{\circ} 348$ de 2004 inclui o amianto dentro da categoria de materiais perigosos. As normas da ABNT, NBR 15112, 15113, 15114, 15115 e 15116, aprovadas em 2004, tratam de projeto de áreas de transbordo e triagem, aterros, reciclagem e agregados reciclados. Estes resíduos são chamados por alguns pesquisadores de "Resíduos de Construção e Demolição (RCD)";

- Resíduo Domiciliar Perigoso (RDP): gerado nas residências, estabelecimentos comerciais e industriais. Exemplo: pilhas; baterias; lâmpadas; cosméticos; medicamentos; tintas; solventes; óleo; produtos de limpeza; venenos para roedores, insetos e plantas; entre outros. Estes resíduos são chamados por alguns pesquisadores de "resíduos especiais" e podem incluir bicicletas, pneus, eletroeletrônicos, entre outros. O PL 1991/2007 (Artigo 12, inciso I), os denomina como resíduos sólidos especiais ou diferenciados e os define como 
aqueles que por seu volume, grau de periculosidade, de degradabilidade ou outras especificidades, requeiram procedimentos especiais ou diferenciados para o manejo e a disposição final dos rejeitos, considerando os impactos negativos e os riscos à saúde e ao meio ambiente (p.5).

A Resolução CONAMA n 257/1999 estabelece que pilhas e baterias que contenham em suas composições chumbo, cádmio, mercúrio e seus compostos, tenham os procedimentos de reutilização, reciclagem, tratamento ou disposição final ambientalmente adequados. Ressalta-se que as baterias de máquinas digitais, por exemplo, contêm níquel e muitas vezes são dispostas junto aos RSD. As pilhas alcalinas, por sua vez, não apresentam mercúrio e cádmio em sua fórmula, assim podem ser descartadas em aterro sanitário, conforme a legislação;

Resíduos Eletroeletrônicos (REE): gerados por residências, estabelecimentos comerciais, instituições de ensino e pesquisa, entre outros locais. Exemplo: computador; impressora; aparelhos de som, fax, vídeo, rádio, telefone; CD-ROM; DVD, disquete; entre outros. Este resíduo ainda não possui legislação brasileira específica. Com base no PL 1991/2007 (Artigo 12, inciso I), estes resíduos podem ser classificados como "resíduos sólidos especiais" ou "diferenciados". De acordo com Ferraz e Basso (2003), estes resíduos podem conter plástico, metal, vidro e elementos químicos. O descarte desse material pode gerar subprodutos ambientalmente tóxicos. Estes aparelhos apresentam falhas nos seus componentes em pouco tempo, uma vez que possuem vida útil média de dois anos, programada pelo fabricante. Esse fenômeno é chamado de sucateamento tecnológico.

\subsubsection{Cenário dos resíduos sólidos no Brasil}

No Brasil, as informações sobre a geração de resíduos sólidos diferem conforme a fonte. Com base na Pesquisa Nacional de Saneamento Básico realizada pelo IBGE (2000), no Brasil são coletadas cerca de 228.413 toneladas de resíduos por dia.

O Ministério das Cidades publicou em 2004 um documento denominado "Diagnóstico do Manejo de Resíduos Sólidos no Brasil", Sistema Nacional de Informações sobre Saneamento (SNIS, 2003), que abrangeu 108 municípios. Não foram divulgados dados em termos de Brasil, mas sim as quantidades geradas por cada município consultado, as quais variam conforme o número de habitantes.

A Associação Brasileira de Empresas de Limpeza Pública e Resíduos Especiais (ABRELPE) realizou uma pesquisa em âmbito nacional, por meio de envio de questionários a 469 prefeituras. Os resultados foram divulgados num relatório denominado "Panorama dos 
Resíduos Sólidos no Brasil" (ABRELPE, 2005). Neste relatório a ABRELPE obteve que são geradas cerca de 113.774 toneladas por dia de RSU no Brasil, inferior ao valor divulgado pelo IBGE, porém ressalta que o universo consultado pelo IBGE foi maior. A ABRELPE destaca uma receita anual de $\mathrm{R} \$ 5$ bilhões referentes ao setor de resíduos sólidos urbanos no Brasil.

A Pesquisa Nacional por Amostra de Domicílios - PNAD 2005 (IBGE, 2006) publicou a forma de destino do lixo em relação ao número de domicílios particulares e ao número de moradores, conforme Quadro 1. Do total de moradores, 152.013 .993 correspondem à área urbana e 31.592.479 à área rural. Foram pesquisados 851 municípios das diferentes Unidades da Federação e regiões metropolitanas.

Quadro 1 - Destino do lixo no Brasil

\begin{tabular}{|c|c|c|}
\hline $\begin{array}{c}\text { Domicílios particulares } \\
\text { permanentes }\end{array}$ & Destino do lixo & $\begin{array}{c}\text { Moradores em domicílios } \\
\text { particulares permanentes }\end{array}$ \\
\hline 41.787 .758 & Coletado diretamente $^{*}$ & 141.032 .343 \\
3.711 .195 & Coletado indiretamente $^{* *}$ & 12.996 .350 \\
7.553 .668 & Outro $^{* * *}$ & 29.577 .879 \\
& & 183.606 .472 \\
\hline Total 53.052 .621 & & \\
& &
\end{tabular}

* quando o lixo fosse coletado diretamente por serviço ou empresa de limpeza, pública ou privada, que atendia ao logradouro em que se situava o domicílio;

** quando o lixo fosse depositado em caçamba, tanque ou depósito de serviço ou empresa de limpeza, pública ou privada, que posteriormente o recolhia;

*** queimado ou enterrado na propriedade, jogado em terreno baldio, logradouro, rio, lago ou mar, ou tivesse outro destino que não se enquadrasse nos anteriormente descritos.

Fonte: PNAD 2005 (IBGE, 2006)

No Estado de São Paulo, que possui mais de 40 milhões de habitantes distribuídos em 645 municípios, são geradas cerca de 28.397 toneladas por dia de RSD, segundo o Inventário Estadual de Resíduos Sólidos Domiciliares de 2006 (CETESB, 2007a, p.67). Estima-se que no município de São Paulo (o mais populoso do país) são geradas cerca de 15 mil toneladas por dia de lixo, segundo Fioratti (2007).

No Brasil, cerca de $50 \%$ dos RSU é composto por matéria orgânica (Bidone e Povinelli, 1999, p.10). Estudos sobre a caracterização dos RSU realizados no município de São Carlos (SP), por exemplo, mostram que entre 56 e 58\% destes resíduos corresponde à matéria orgânica (Gomes, 1989; Frésca, 2006).

A categoria "matéria orgânica" compreende os resíduos facilmente degradáveis; papéis, papelão e embalagens longa vida podem ser considerados resíduos moderadamente degradáveis; vidro, plásticos e metais são considerados materiais dificilmente degradáveis por levarem mais tempo para se decompor. 
O tempo de decomposição depende do tipo de material, umidade e clima (Lopes e Krüger, 1997, p.156-157). Segundo os autores, o papel pode levar mais de três meses para se decompor e os jornais podem permanecer intactos por décadas; a madeira pode levar cerca de seis meses para iniciar sua decomposição; o cigarro pode demorar de um a dois anos para se decompor, dependendo do local onde foi descartado; o chiclete cerca de cinco anos; os metais se desintegram em cerca de dez anos; os plásticos levam mais de cem anos e o vidro cerca de quatro mil anos. As estimativas apresentadas podem variar conforme o autor.

Vale ressaltar que a fração de matéria orgânica pode variar com o tempo, de acordo com os hábitos e situação econômica da população. Conforme caracterização dos RSU realizada no município de São Paulo entre 1927 e 1995, a fração de matéria orgânica variou entre 95,9 e 67,9\%, respectivamente (Bidone e Povinelli, 1999, p.14).

A quantidade de RSD gerada pode ser estimada em função do número de habitantes, conforme Tabela 1. Deve-se considerar que a produção de resíduos pode ser superior, principalmente nos grandes centros urbanos, devido ao consumo mais elevado, especialmente de embalagens.

Tabela 1 - Índices de produção per capita de RSD em função da população urbana

\begin{tabular}{c|c}
\hline População (hab) & Produção (kg/hab.dia) \\
\hline até 100.000 & 0,4 \\
de 100.001 a 200.000 & 0,5 \\
de 200.001 a 500.000 & 0,6 \\
maior que 500.000 & 0,7 \\
\hline
\end{tabular}

Fonte: CETESB (2007a)

$\mathrm{Na}$ maioria dos municípios brasileiros os resíduos sólidos são dispostos inadequadamente e não recebem tratamento, de acordo com Tabela 2. O Estado de São Paulo apresenta uma situação vantajosa, comparado aos demais Estados do país, com base em IBGE (2000). 
Tabela 2 - Disposição final e tratamento de resíduos sólidos nos distritos brasileiros e no Estado de São Paulo

\begin{tabular}{l|r|r}
\hline \multicolumn{1}{c|}{ Tipos de disposição e tratamento } & Brasil & Estado de São Paulo \\
\hline Lixão & 5.993 & 228 \\
Vazadouro em áreas alagadas & 63 & 12 \\
Aterro controlado & 1.868 & 334 \\
Aterro sanitário & 1.452 & 459 \\
Aterro de resíduos especiais & 810 & 283 \\
Usina de compostagem & 260 & 38 \\
Usina de reciclagem & 596 & 96 \\
Incineração & 325 & 144 \\
\hline Distritos & 8.381 & 941 \\
\hline
\end{tabular}

Fonte: IBGE (2000, Tabela 109)

Os dados apresentados na Tabela 2 foram baseados nos distritos que possuem limpeza urbana e coleta de lixo. Provavelmente estes dados estão sendo atualizados, porém são os números oficiais do Brasil.

O lixão é considerado uma forma inadequada de disposição final de resíduos sólidos, devido ao descontrole no recebimento dos diversos tipos de resíduos, podendo receber inclusive resíduos de serviços de saúde e industriais (Otero D’Almeida e Vilhena, 2000).

Os aterros controlados normalmente são aceitos pelas agências ambientais brasileiras, geralmente são antigos lixões onde os resíduos são apenas cobertos com terra. Vale destacar que a NBR 8849 (ABNT, 1985a) trata de projetos de aterros controlados.

Esses métodos não evitam a migração de lixiviado para o entorno, uma vez que não possuem medidas para minimização do impacto ambiental negativo. Nestes locais não há impermeabilização de base e taludes, drenos ou tratamento de gases e lixiviado, drenagem de águas pluviais, entre outras medidas.

O termo lixiviado é empregado pela comunidade científica como sinônimo de percolado ou chorume.

Conforme a NBR 8419 (ABNT, 1992, p.2), o chorume é um "líquido produzido pela decomposição de substâncias contidas nos resíduos sólidos, que tem como cacarcterísticas a cor escura, o mau cheiro e a elevada DBO (Demanda Bioquímica de Oxigênio)".

O percolado é formado quando as águas de chuva que caem sobre os aterros ou lixões infiltram pelo solo e através dos resíduos sólidos, carreando o chorume e a matéria orgânica (Schalch, 1984, p.33). Geralmente os líquidos percolados seguem um caminho preferencial pelo subsolo, no sentido descendente, por força da gravidade, mas nem sempre atinjem a água subterrânea. Segundo Schalch (1992, p.51), "esses líquidos ocupam, juntamente com os gases, os interstícios existentes na fase sólida". A NBR 8419 (ABNT, 1992, p.1) define percolado como o "líquido que passou através de um meio poroso". 
O lixiviado é formado pela mistura do chorume às águas de chuva (Bidone e Povinelli, 1999, p.17), superficiais ou subterrâneas. Esta mistura pode ocorrer de diversas formas: após a precipitação quando o chorume formado na superfície dos aterros ou lixões por capilaridade (movimento ascendente provocado pelo balanço hídrico ou pela compactação dos resíduos sólidos), se mistura às águas pluviais; após o escoamento de chorume pela superfície dos aterros ou lixões para os cursos d'água; após a percolação do chorume nos aterros ou lixões, atingindo as águas subterrâneas; entre outras. Segundo a NBR 8419 (ABNT, 1992, p.1), lixiviação é o "deslocamento ou arraste, por meio líquido, de certas substâncias contidas nos resíduos sólidos urbanos".

Poucos municípios brasileiros possuem aterro sanitário, que visa atender a alguns cuidados especiais e técnicas específicas como a seleção da área mais adequada dentro do território municipal, o preparo do local até o início de sua operação e monitoramento, tratamento dos efluentes líquidos e gasosos gerados pelos resíduos, compactação da massa de resíduos por um trator e recobrimento diário com terra (Lima, 2003).

No Brasil, os projetos para implantação de aterros sanitários devem seguir as normas da Associação Brasileira de Normas Técnicas, NBR 8419 (ABNT, 1992) e NBR 13896 (ABNT, 1997a). Existem normas que estabelecem restrições para a disposição dos resíduos sólidos em aterros, conforme a periculosidade do resíduo, a fim de prolongar a vida útil da área, bem como proteger a saúde humana e o ambiente.

Os locais para a destinação final de resíduos sólidos no país, em sua grande maioria, estão localizados nas periferias dos municípios, em áreas inadequadas, ausentes de estudo ambiental prévio. Segundo Nascimento (2001), a locação de áreas para disposição final dos resíduos sólidos é uma das etapas mais complexas do gerenciamento desses resíduos.

A seleção de áreas para implantação de aterros sanitários é a primeira etapa do projeto e envolve: distância dos pontos geradores de resíduos; condições de acesso; caracterização hidrogeológica; distância de rodovias e aeroportos; compatibilidade da vizinhança; profundidade do aqüífero freático; declividade do terreno; vida útil do aterro; previsão de usos futuros; entre outros. Algumas condições devem ser contempladas, como distância mínima de 500 metros de núcleos populacionais; distância mínima de 200 metros de cursos d'água mais próximos; baixo coeficiente de permeabilidade do subsolo, entre outros fatores. Ressalta-se a importância da adequação desses critérios às características ambientais do local que geralmente são distintas de lugar para lugar (ABNT, 1997a, p.3; Schalch et al., 2000, p.92; Gomes et al., 2003, p.145).

As questões levantadas devem ser consideradas, pois grandes quantidades de RSU são geradas diariamente e todo município, mesmo que tenha coleta seletiva e reciclagem, necessita de um local para disposição dos seus resíduos "últimos" que não comprometa a saúde pública e o ambiente. Isso significa que todo município necessita de um aterro 
sanitário para dispor os resíduos sólidos que não podem ser reaproveitados ou reciclados, como, por exemplo, fraldas, papel higiênico, absorventes, entre outros.

\subsubsection{Resíduos sólidos no contexto internacional}

A composição e a geração de RSU pode variar, conforme a localidade, devido à situação econômica, hábitos e cultura da população. No Japão, por exemplo, apenas $20 \%$ dos RSU é composto por matéria orgânica (Bidone e Povinelli, 1999, p.10).

Durante a Série "Desafio do Lixo" apresentada pelo jornalista Washington Novaes na TV Cultura em 2001, Nova lorque (que possuía cerca de oito milhões de habitantes) foi considerada a capital do lixo, produzindo (na época) cerca de 12 mil toneladas por dia de lixo, o que representa uma média de 2 a $3 \mathrm{~kg}$ de lixo/pessoa.dia. Segundo o documentário, em Copenhague (Dinamarca), que possuía cerca de um milhão e 500 mil habitantes, eram geradas cerca de 2 milhões e 800 mil toneladas de lixo por ano.

Segundo o governo europeu, atualmente nos Estados Membros da União Européia são gerados cerca de dois milhões de toneladas de resíduos sólidos, incluindo resíduos especialmente perigosos (Europa, 2007). A Figura 1 mostra a geração per capita por ano de vários países europeus.

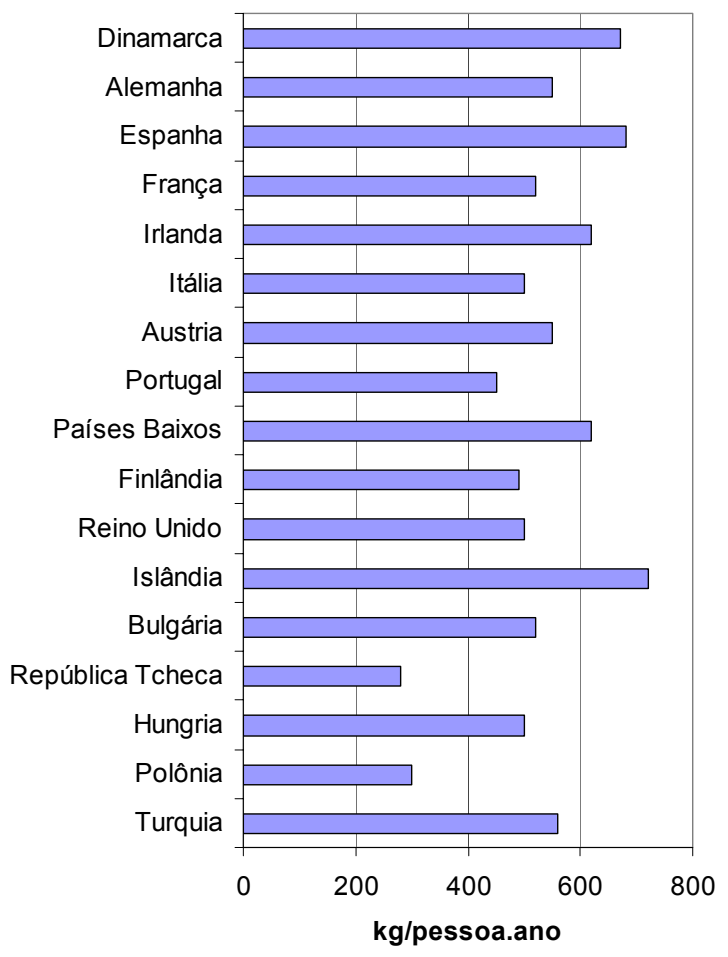

Figura 1 - Resíduos sólidos urbanos gerados em países europeus Fonte: European Commission (2003) 
A forma de disposição final e de tratamento também varia, conforme o local. A Figura 2 mostra a forma de gerenciamento dos RSU adotados nos países europeus. Os valores foram calculados proporcionalmente. Por exemplo, nos Estados Unidos cerca de $57 \%$ dos RSU são destinados a aterros, $28 \%$ é reciclado, recuperado ou compostado e $15 \%$ é incinerado, enquanto que no Japão $77,4 \%$ é incinerado, 5,8\% é encaminhado para aterros e $16,7 \%$ é reciclado (Williams, 2005, p.89).

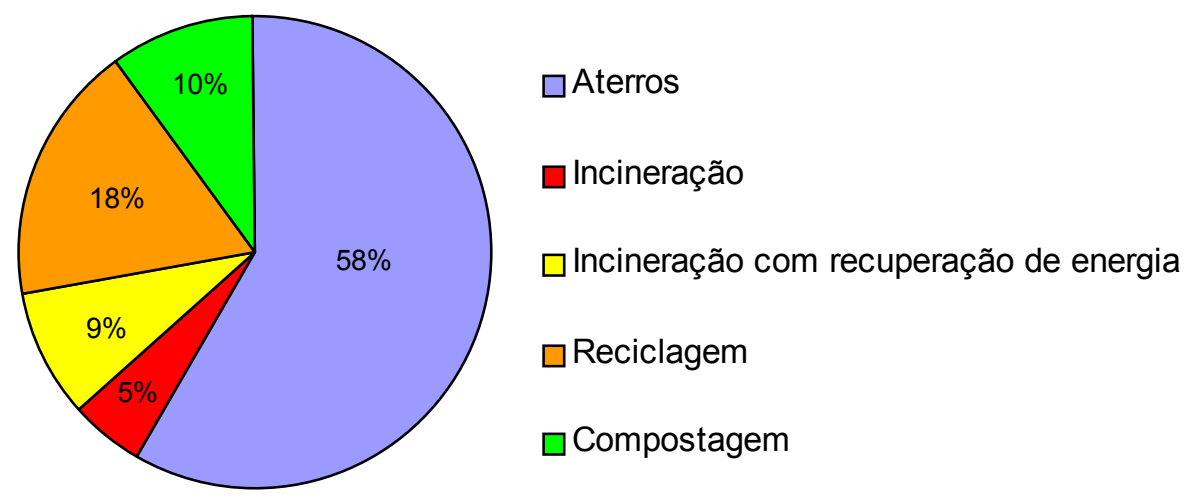

Figura 2 - Gerenciamento dos RSU em países europeus Fonte: Williams (2005, p.89), adaptado

Em muitos países os resíduos sólidos são exportados devido à falta de áreas disponíveis para o seu aterramento. No Canadá, por exemplo, toneladas de resíduos são enviadas para os aterros de Michigan, que juntos têm capacidade para receber resíduos por mais 18 anos. Em 2006 foram exportadas 5,7 milhões de toneladas, sendo que 818.500 toneladas foram enviadas por Toronto. Em 2007, 69,2\% dos resíduos dispostos nestes aterros foram gerados em Michigan, 19,5\% no Canadá e 11,2\% em outros Estados (Waste Age, 2007).

Há previsões de que no futuro haverá um boom de resíduos eletro-eletrônicos (REE). Neste caso, a articulação entre indústria, vendedores, governo e consumidores é fundamental na busca de soluções para minimizar os impactos negativos relacionados a estes resíduos.

Segundo O'Connell (2007), o crescimento dos REE é quase três vezes mais rápido que a geração de RSU. Nos Estados Unidos mais de 100 milhões de computadores, monitores e televisores tornam-se obsoletos a cada ano. Há estimativas de que cerca de 150 milhões de telefones celulares serão descartados no ano de 2007. Conforme a EPA, 2,6 milhões de toneladas de eletro-eletrônicos foram geradas e apenas 330.000 toneladas foram recicladas. O reúso e a reciclagem são considerados métodos preferenciais para o gerenciamento dos REE, que contêm substâncias tóxicas como chumbo, mercúrio, arsênico, 
cadmio e cromo hexavalente. A reciclagem pode reduzir os riscos ambientais, os gastos de energia, incentivar a economia local, gerar empregos, transferir tecnologia para o desenvolvimento mundial e evitar que estes materiais sejam dispostos em aterros. Para isso, toda a sociedade deverá se mobilizar. Assim, taxas de crédito e incentivos fiscais deverão ser criados para incentivar consumidores, produtores e recicladores. Alguns estados como California, Maine, Maryland e Washington já possuem legislações e programas que tratam da reciclagem dos REE, bem como da proibição do seu descarte em aterros e incineradores. Atualmente cerca de $80 \%$ dos REE coletados nos Estados Unidos para reciclagem são enviados para países em desenvolvimento, principalmente da Ásia, onde estes produtos são desmontados ou reusados. Porém, já se discute a necessidade de um programa nacional de reciclagem de eletro-eletrônicos nos Estados Unidos.

\subsection{Planejamento integrado de resíduos sólidos}

Devido à geração diária de resíduos sólidos e ao aumento da quantidade dos mesmos, em função do crescimento e hábitos da população, as administrações públicas municipais não devem adiar a tomada de decisões relacionadas ao equacionamento dos problemas gerados por esses resíduos.

A gestão integrada dos resíduos sólidos deve ser planejada desde a origem até a disposição final. Antes de serem dispostos, esses resíduos devem passar por processos de reutilização, reciclagem ou outro tipo de tratamento, sempre que possível.

Uma das estratégias para o gerenciamento integrado dos resíduos sólidos urbanos é a implantação de programas de coleta seletiva nas cidades, a fim de reduzir a quantidade de resíduos encaminhada aos aterros. Para que esses programas obtenham resultados positivos, a colaboração da comunidade é fundamental.

A coleta seletiva é uma estratégia para desviar os resíduos sólidos domiciliares das áreas de disposição final para centrais de tratamento de resíduos (triagem e compostagem), por meio da separação dos materiais. O inciso IV, Artigo 8 ${ }^{\circ}$, do PL 1991/2007 da PNRS emprega o termo coleta diferenciada como o

serviço que compreende a coleta seletiva, entendida como a coleta dos resíduos orgânicos e inorgânicos, e a coleta multi-seletiva, compreendida como a coleta efetuada por diferentes tipologias de resíduos sólidos, normalmente aplicada nos casos em que os resultados de programas de coleta seletiva implementados tenham sido satisfatórios.

Cerca de 25 a $40 \%$ dos resíduos sólidos urbanos são recicláveis, dessa forma a coleta seletiva pode contribuir para a conservação dos recursos naturais e para 0 
prolongamento da vida útil dos aterros sanitários (Neder, 1998). Porém, apenas uma pequena parcela dos RSU é reciclada no Brasil, enquanto que, em outros países estes resíduos são convertidos em energia e os índices de reciclagem são mais elevados.

Segundo Müller-Plantenberg e Ab'Saber (1994), em vários países os resíduos sólidos se tornaram uma questão de emergência por falta de áreas disponíveis para disposição final.

Em função dessa escassez de áreas, geralmente, o tratamento de resíduos mais adotado nos países desenvolvidos é a incineração, porém essa tecnologia pode causar a poluição do ar com a emissão de dioxinas, furanos e outras substâncias que devem ser controladas (Castro, 2001).

As autoridades públicas apresentam certa resistência para aprovação, construção e implantação de empreendimentos e equipamentos relacionados aos resíduos sólidos (aterros sanitários; centrais de triagem, reciclagem e compostagem; tratamento de resíduos de serviços de saúde, entre outros), devido aos custos e questões políticas.

Todas as instalações relacionadas aos resíduos sólidos devem passar por projetos de análise dos prováveis impactos ambientais. Esses empreendimentos não podem ser planejados isoladamente, o contexto regional e as características ambientais do entorno devem ser considerados. O Plano Diretor é um instrumento importante do planejamento municipal e pode auxiliar na escolha de áreas para a disposição final dos resíduos sólidos.

Os estudos de impacto ambiental têm a função de auxiliar a tomada de decisão das autoridades públicas e contribuir para minimização dos conflitos sociais.

Geralmente, os resíduos sólidos não são prioridade dos planos de governo e essa postura dos administradores públicos se reflete no cenário brasileiro. Os lixões predominam como forma de disposição final na maioria dos municípios brasileiros, porém, conforme IBGE (2000), cerca de 99,4\% dos municípios brasileiros possuem coleta de lixo.

O esgotamento da vida útil dos aterros é considerado um dos maiores problemas do gerenciamento de resíduos sólidos devido à grande quantidade de lixo descartada diariamente (São Paulo, 1998). A produção média diária de lixo por habitante é estimada em 600 gramas e nas cidades maiores, cerca de $1 \mathrm{~kg}$ (Eigenheer, 1999). Vale destacar que as localidades consideradas "desenvolvidas" são regiões populosas, industrializadas; com receita, infra-estrutura e nível sócio-econômico-cultural-intelectual mais elevado; entre outras qualidades, porém geram mais resíduos por habitante.

Assim, depreende-se que o esgotamento da vida útil dos aterros, a ampliação emergencial dos aterros, a falta de áreas disponíveis e adequadas para a disposição final dos resíduos sólidos, a exportação de resíduos para aterros de outros municípios, entre outras questões, são resultado da falta de planejamento da administração pública, visto que o crescimento dos municípios deve ser levado em consideração. 
Para que esses problemas sejam evitados, é necessário definir novas áreas para a construção de aterros sanitários, o que pode ser previsto na elaboração do Plano Diretor Municipal. Deve-se salientar que os aterros sanitários são projetados para armazenar resíduos durante um tempo determinado, considerando que a NBR 13896 (ABNT, 1997a, p.3) recomenda a construção de aterros com vida útil mínima de 10 anos.

Segundo Müller-Plantenberg e Ab'Saber (1994), a diminuição da quantidade de resíduos sólidos encaminhada para os aterros sanitários pode ser alcançada a longo prazo, a partir de um conjunto de medidas integradas, como redução da geração de resíduos e tratamento dos mesmos.

Uma das maneiras mais eficientes para redução dessa quantidade é evitar o consumo exagerado. Minimizar a geração de lixo e renunciar a produtos que não possam ser reutilizados ou reciclados são tarefas difíceis de serem adotadas pela população atualmente.

A presença de catadores nas áreas de disposição final de resíduos sólidos no Brasil é outra questão social relacionada à problemática dos resíduos sólidos (São Paulo, 1998). Diversos propagadores de moléstias podem estar presentes nesses locais, como ratos (causadores da peste bubônica e leptospirose), moscas (transmissoras de febres, cólera, tuberculose, lepra, varíola, hepatite, amebíase e teníase), mosquitos (transmissores de viroses, dengue, febre amarela e malária), baratas (possíveis veiculadoras do vírus da poliomielite), aves e urubus (transmissores de toxoplasmose), entre outros (Bidone e Povinelli, 1999).

Assim, os catadores podem contrair doenças devido ao contato direto com os diferentes tipos de resíduos descartados.

Segundo Rogers e Tibben-Lembke (1998), na metade dos anos 50 foi reconhecida a necessidade de analisar a qualidade da água subterrânea em aterros. Alguns estudos sobre aterros sanitários e efeitos na qualidade da água continuaram sendo desenvolvidos, bem como estudos sobre os lixiviados.

Segundo Christensen (1992), a contaminação das águas subterrâneas pelos lixiviados é uma das questões ambientais mais importantes relacionadas à disposição de resíduos sólidos. A diluição do lixiviado reduz a concentração de poluentes, porém grandes volumes de água subterrânea estão sendo poluídos. A diluição é considerada uma atenuação positiva apenas quando pequenas quantidades de lixiviado são liberadas.

A composição química do lixiviado varia conforme a composição dos resíduos sólidos; a localização e gerenciamento do aterro; o tempo de disposição dos resíduos, entre outros fatores (Andreotolla e Cannas, 1992). Segundo os autores, em lixiviados de aterros mais antigos, há uma atenuação na concentração de poluentes. 
Os lixiviados podem conter quantidades significativas de poluentes, como metais pesados, que podem permanecer no meio por muitos anos (Belevi e Baccini, 1992).

Em virtude desses fatores, o tratamento adequado desses líquidos e dos gases é essencial para o bom funcionamento dos aterros sanitários, bem como para prevenir impactos ambientais negativos. A aplicação dessas medidas pode minimizar as transferências de poluentes de um meio para outro.

Mesmo quando o tratamento dos resíduos sólidos é viável economicamente, como a compostagem, reciclagem ou incineração, vale ressaltar que o aterro sanitário não é dispensado, pois estes sistemas podem gerar resíduos que não são aproveitáveis. Além disso, no caso da ocorrência de problemas que paralisem essas instalações, os municípios devem estar prevenidos (Leite, 1991).

O método do aterro sanitário apresenta algumas vantagens: evita a disposição de qualquer tipo de resíduo; recupera áreas topograficamente inutilizadas; controla a proliferação de vetores; possibilita o uso de equipamentos e máquinas de serviços de terraplanagem; possibilita a disposição de lodos provenientes de estações de tratamento de esgoto; evita altos investimentos para sua construção, comparados aos necessários para implantação das usinas de compostagem ou instalações de incineração, entre outros fatores (Schalch et al., 2000).

Porém, esse método também pode apresentar algumas desvantagens, como: necessidade de grandes áreas distantes da área urbana, o que acarreta despesas com transporte; desvalorização imobiliária do terreno; vulnerabilidade às chuvas; produção de chorume; possibilidade de poluição do aqüífero freático quando o aterro é mal planejado ou operado inadequadamente; necessidade de um longo período de tempo para estabilização do solo do aterro; produção de ruídos e poeira durante a execução e operação do aterro (Schalch et al., 2000).

De acordo com Lima (2003), ressalta-se a importância do cuidado com a drenagem dos gases gerados nos aterros, como $\mathrm{CH}_{4}$ (metano), $\mathrm{CO}_{2}$ (dióxido de carbono) e outros, já que o metano é inflamável e pode explodir espontaneamente.

Em alguns países, como nos Estados Unidos, as restrições para dispor resíduos em aterros têm aumentado, a fim de prolongar a vida útil da área, bem como proteger a saúde humana e o ambiente (Rogers e Tibben-Lembke, 1998).

Existem normas que estabelecem restrições para a disposição de resíduos sólidos em aterros, conforme as características de cada resíduo. No Brasil, a NBR 13896 (ABNT, 1997, p.8) determina que aterros não devem receber resíduos inflamáveis, reativos ou que contenham líquidos livres. A NBR 10157 (ABNT, 1987b, p.16) permite o recebimento de resíduos inflamáveis ou reativos após tratamento prévio (neutralização, diluição, absorção, etc) se a mistura resultante não apresentar características de reatividade ou inflamabilidade. 
Além disso, esta norma não permite a disposição de resíduos com menos de $15 \%$ de sólidos totais (em massa) por não suportarem cobertura. Na União Européia, a Directiva 2003/33/CE, de 19/12/2002, estabelece os critérios e processos de admissão de resíduos em aterros.

Alguns dos problemas relacionados aos aterros sanitários são a falta de áreas adequadas para a implantação; o esgotamento da vida útil dos aterros em operação, em função da escassez de espaço, devido ao aumento da produção de resíduos sólidos e o aumento das exigências ambientais para a construção de novos aterros.

A escolha do local para implantação dos aterros de resíduos sólidos é de suma importância, bem como a análise do tipo de solo. Assim, é recomendado evitar terrenos com alta permeabilidade, como é o caso de solos arenosos, a fim de evitar a contaminação do aqüífero freático. Os terrenos rochosos também devem ser evitados para se evitar custos elevados com escavação.

O tempo de duração de um aterro sanitário é estimado em projeto, conforme sua capacidade de confinamento e o volume de resíduos para ele encaminhado. A NBR 13896 (ABNT, 1997a, p.3) recomenda a construção de aterros com vida útil mínima de 10 anos.

Quando mal projetados ou mal operados esses aterros podem prejudicar a qualidade ambiental da região. Dessa forma, um projeto criterioso deve ser elaborado para a implantação de um aterro sanitário, com base em estudos da área, a fim de evitar ou minimizar o comprometimento dos recursos hídricos. Todo projeto de aterro de resíduos deve ser submetido à aprovação do Órgão de Controle Ambiental (OCA), segundo NBR 13896 (ABNT, 1997a).

A Resolução CONAMA $n^{\circ}$ 1, de 23 de janeiro de 1986, estabelece que os projetos de aterros sanitários devem conter o Estudo de Impacto Ambiental (EIA), bem como o Relatório de Impacto ambiental (RIMA).

A Resolução CONAMA n ${ }^{\circ}$ 237, de 19 de dezembro de 1997, estabelece os critérios e fixa as competências para o licenciamento ambiental. Dessa forma, os órgãos integrantes do Sistema Nacional do Meio Ambiente (SISNAMA), o qual foi instituído pela Lei Federal $\mathrm{n}^{\circ}$ 6.938, de 31 de agosto de 1981, têm autoridade para definir procedimentos simplificados para o licenciamento de atividades e empreendimentos de pequeno potencial de impacto ambiental.

No Estado de São Paulo, os procedimentos para o licenciamento ambiental são estabelecidos pela Resolução $n^{\circ} 54$, de 30 de novembro de 2004, da Secretaria de Estado do Meio Ambiente (SMA), a qual substitui a antiga Resolução SMA 42/1994. Esta Resolução instituiu dois instrumentos preliminares ao EIA-RIMA, O Relatório Ambiental Preliminar (RAP) e o Termo de Referência (TR). O RAP pode ser aceito como dispensa do EIA-RIMA por ser um documento mais simplificado, portanto, mais rápido de ser aprovado. Ele deve 
apresentar o conteúdo mínimo a ser contemplado. Conforme o tamanho do empreendimento, da área de inserção e da capacidade suporte do meio, os dados apresentados deverão ser aprofundados e complementados, segundo SMA (1995).

O licenciamento ambiental é viabilizado por meio de três etapas: Licença Prévia (LP), Licença de Instalação (LI) e Licença de Operação (LO).

Com base na Resolução SMA 54/2004, bem como na Deliberação $n^{\circ}$ 33, de 17 de novembro de 2004, do Conselho Estadual do Meio Ambiente (CONSEMA), o licenciamento ambiental no Estado de São Paulo fica a cargo do Departamento de Avaliação de Impacto Ambiental (DAIA), da Coordenadoria de Licenciamento Ambiental e de Proteção dos Recursos Naturais (CPRN) da SMA.

O DAIA poderá exigir a elaboração do RAP, caso a atividade ou empreendimento sejam considerados "potencialmente" causadores de degradação ambiental, o que pode resultar em audiências públicas. A exigência do EIA-RIMA se dará, caso a atividade ou empreendimento sejam considerados "efetivamente" causadores de significativa degradação ambiental.

Para a elaboração do projeto para implantação de aterro de resíduos sólidos são necessários os seguintes estudos: caracterização e classificação dos resíduos e caracterização (geográfica, topográfica, hidrogeológica e climatológica) do local destinado à implantação do aterro. É recomendável ainda a adoção de múltiplas barreiras para evitar a liberação de poluentes ao ambiente. Essas barreiras podem ser associadas desde a escolha da área, como hidrogeologia favorável, isolamento em relação a aqüíferos aproveitáveis, colocação de camadas impermeabilizantes e sistemas de coleta e tratamento de líquidos percolados (Schalch et al., 2000).

Não é seguro afirmar que os aterros de resíduos sólidos aprovados pelos órgãos ambientais brasileiros recebam apenas os resíduos permitidos pelas normas da ABNT ou tenham sido construídos adequadamente, de maneira que os rios e aqüíferos não estejam sendo comprometidos.

Um dos aspectos para que os efluentes dos aterros não alterem a qualidade das águas superficiais no seu entorno é respeitar a classificação dos corpos d'água estabelecida pela legislação. Assim, o projeto para a construção desses aterros deve considerar os critérios estabelecidos pela Resolução CONAMA 20, de 18 de junho de 1986, atual Resolução CONAMA 357/2005. No Estado de São Paulo, o Decreto 8.468, de 08 de setembro de 1976, e o Decreto 10.755, de 22 de novembro de 1977, devem ser consultados.

Para evitar a poluição e contaminação das águas subterrâneas, o projeto de aterros de resíduos sólidos deve obedecer às normas da ABNT, bem como os padrões de potabilidade estabelecidos pela Portaria $N^{\circ} 518$, de 25 de março de 2004, do Ministério da Saúde (BRASIL, 2004). Nesse sentido, vale ressaltar a relação entre resíduos sólidos e recursos hídricos, a fim de que a qualidade da água que serve à população seja garantida. 
Os índices pluviométricos podem contribuir para a diluição de alguns elementos na água, dependendo da concentração da substância e do volume d'água. Contudo, essa não é a medida correta e sim o tratamento dos efluentes.

É difícil ter um controle sobre a percolação dos líquidos gerados no aterro, nesse sentido o monitoramento das águas pode ser fundamental, pois a análise da água pode revelar poluição e contaminação.

Conforme Sanchez (2001), a poluição das águas subterrâneas é um dos danos mais graves associados à desativação de empreendimentos, que deve prever a recuperação das áreas degradadas com o objetivo de minimizar o passivo ambiental gerado durante a construção e operação das áreas de disposição de resíduos sólidos.

Segundo o autor, passivo ambiental é "o acúmulo de danos ambientais que devem ser reparados a fim de que seja mantida a qualidade ambiental de um determinado local".

Os aterros de resíduos sólidos possuem vida útil estimada, conforme projeto, assim os planos de encerramento desses empreendimentos fazem parte do planejamento ambiental da atividade, complementam a avaliação de impacto e o sistema de gestão ambiental (Sanchez, 2001).

A falta de planejamento acarreta a escassez de espaço nos aterros sanitários e, geralmente, a vida útil dos aterros existentes é prolongada, em relação ao previsto. Esse fator pode desencadear alguns problemas ambientais, econômicos, políticos e operacionais, entre eles: (1) aumento da altura do aterro, o que pode provocar deslizamentos e erosões devido à maior declividade e, conseqüentemente, maior velocidade das águas de chuva; (2) aumento da geração dos lixiviados e dos gases devido à maior compressão na parte inferior da massa de resíduos, portanto, maior risco de explosão; (3) maiores investimentos e ampliações na infra-estrutura do aterro, bem como (4) desapropriação de terrenos vizinhos para aumento da área, entre outros.

Outra problemática relacionada aos resíduos sólidos é a disposição inadequada nas margens de rios, áreas localizadas nas periferias das cidades ou em terrenos baldios.

Dentro do gerenciamento de resíduos sólidos, outras questões podem ser destacadas, além da dificuldade para se encontrar uma nova área para disposição dos resíduos: os trâmites burocráticos envolvidos na aprovação do projeto de aterro; as taxas cobradas dos municípios desprovidos de aterros adequados para disposição de seus resíduos em áreas autorizadas pelos órgãos ambientais; a importância da implantação de programas de coleta seletiva, que visam à separação prévia dos resíduos sólidos na fonte geradora, com o propósito de minimizar a quantidade de resíduos encaminhados para os aterros e, conseqüentemente, a produção de chorume.

Dessa forma, os aterros de resíduos sólidos devem ser considerados locais de possível contaminação. 


\subsection{Impactos ambientais relacionados aos resíduos sólidos}

Os resíduos sólidos podem poluir e contaminar o ar, o solo e as águas, pois podem conter matéria orgânica, materiais perigosos, como matéria Termotolerante humana, lodos provenientes dos sistemas de tratamento de esgotos e os lodos industriais, entre outros (Bidone e Povinelli, 1999, p.5-6).

A poluição foi definida no Art $3^{\circ}$, inciso III da Lei 6938, de 31 de agosto de 1981, que trata da Política Nacional do Meio Ambiente (PNMA) como a degradação da qualidade ambiental resultante de atividades que direta ou indiretamente:

a) prejudiquem a saúde, a segurança e o bem-estar da população;

b) criem condições adversas às atividades sociais e econômicas;

c) afetem desfavoravelmente a biota;

d) afetem as condições estéticas ou sanitárias do meio ambiente;

e) lancem matérias ou energia em desacordo com os padrões ambientais estabelecidos.

A contaminação é a "introdução no meio ambiente de organismos patogênicos, substâncias tóxicas ou outros elementos, em concentrações que possam afetar a saúde humana. É um caso particular de poluição" (CETESB, 2001a: seção 200, p.2).

O metano liberado durante a decomposição da matéria orgânica pode ser tóxico e explosivo, dependendo da quantidade. Assim, recomenda-se que os gases gerados nos aterros sejam aproveitados como fonte de energia ou sejam queimados em equipamentos adequados, minimizando a poluição atmosférica.

Segundo a Fundação Christiano Ottoni de Belo Horizonte, a produção de metano em aterros em todo o mundo representa de 5 a $15 \%$ do metano total lançado na atmosfera. Além disso, o metano é de 20 a 25 vezes mais efetivo que o $\mathrm{CO}_{2}$ na absorção da energia infravermelha, contribuindo significativamente para o aumento do efeito estufa (Catapreta et al, 2006).

Durante a digestão da matéria orgânica nos aterros também é formado o chorume, que contêm elevada carga orgânica, microrganismos, metais, entre outros compostos. Quando este líquido é misturado às águas de chuva dá origem ao lixiviado que pode percolar pelo solo, alterando a qualidade das águas subterrâneas (Figura 3). O aqüífero freático abastece córregos e rios, assim os aterros podem oferecer risco ao ambiente e à população, principalmente às propriedades vizinhas, visto que estas podem utilizar águas de córregos e minas para abastecimento, irrigação e dessedentação de animais. 


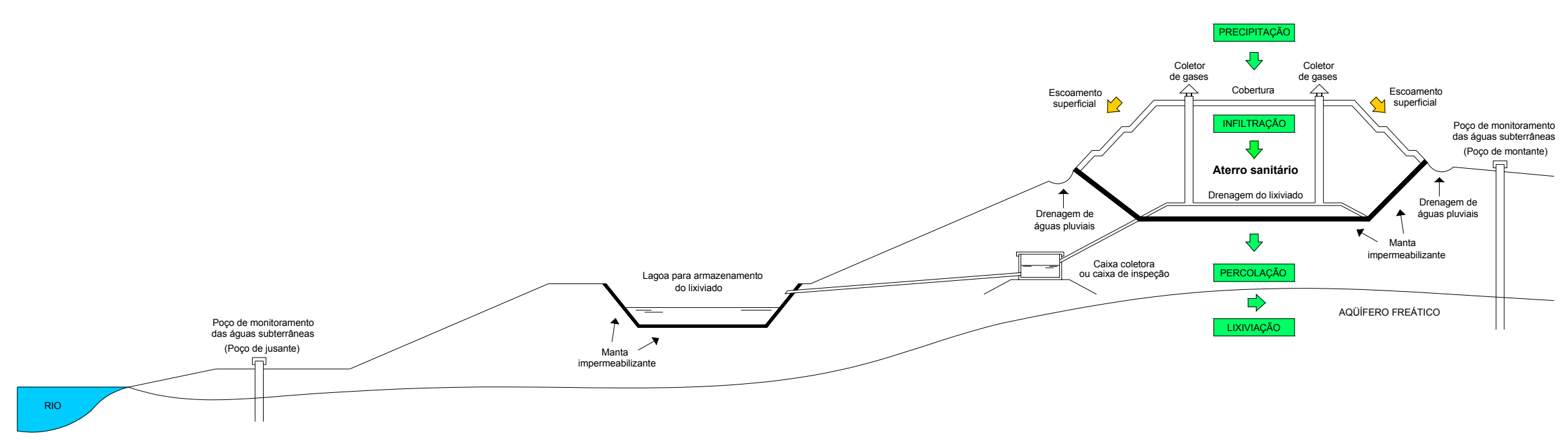

Figura 3 - Corte esquemático do aterro sanitário 
Os índices pluviométricos podem contribuir para a diluição de alguns elementos na água, dependendo da concentração da substância e do volume d'água. A diluição do lixiviado reduz a concentração de poluentes, por isso é considerada uma atenuação positiva, porém apenas quando pequenas quantidades de lixiviado são liberadas (Christensen, 1992).

Contudo, quanto maior a infiltração de água no aterro, maior a quantidade de lixiviado para ser tratado. O tratamento dos efluentes de aterro sanitário é raro nos municípios brasileiros devido aos custos. Geralmente o lixiviado é recirculado e encaminhado para Estações de Tratamento de Esgoto sanitário (ETEs). De acordo com alguns pesquisadores a recirculação acelera o processo de degradação dos resíduos, a fim de que o aterro se estabilize em 30 e 50 anos. Segundo Schalch (1984, p.88-89), a recirculação provocou aumento nas concentrações dos parâmetros, reativando a decomposição anaeróbia.

A contaminação do solo no entorno dos aterros também deve ser evitada, pois pode comprometer o desenvolvimento da flora, conseqüentemente podendo afetar a fauna.

Por isso, a percolação do lixiviado em aterros e lixões não deve ocorrer. Nesse sentido, a seleção de áreas adequadas para a disposição final de resíduos sólidos merece destaque na gestão dos resíduos sólidos, pois visa à minimização dos impactos negativos. Entre algumas recomendações, os aterros devem ser construídos em solos pouco permeáveis, não alagáveis, distante da área urbana, a fim de evitar usos conflitantes como presença de urubus em áreas aeroportuárias, reclamações de proprietários vizinhos quanto ao cheiro, trânsito de veículos, atração de vetores, entre outros.

Aterros bem projetados e construídos devem possuir medidas para o controle e prevenção da poluição como base impermeabilizante, coletores de gases, drenagem de água de chuva, coleta do lixiviado, entre outras. Geralmente, este líquido é armazenado em lagoas no próprio aterro e posteriormente encaminhado para uma Estação de Tratamento de Esgotos (ETE).

Vale ressaltar que a instalação de empreendimentos relacionados aos resíduos sólidos também pode causar desvalorização imobiliária.

Além disso, resíduos sólidos descartados em via pública ou rodovias, acumulados em terrenos baldios ou edifícios abandonados podem ser espalhados pelo vento, entupir bocas de lobo, causar depreciação estética e atrair vetores transmissores de doenças.

A matéria orgânica é a causadora de poluição das águas. Os principais componentes orgânicos são os compostos de proteína, carboidratos, óleos, além de uréia, surfactantes, fenóis, agrotóxicos, entre outros. A matéria orgânica apresenta-se na forma de sólidos em suspensão e sólidos dissolvidos (Von Sperling, 2005, p.40). Pode ser de origem natural (vegetal e animal) ou produzida por microrganismos, bem como pode ser originada por 
efluentes domésticos e industriais. É responsável pelo consumo do oxigênio dissolvido na água pelos microrganismos decompositores.

Segundo CETESB (1977) citado por Gonçalves (1986, p.94), o lixo contém 1\% em peso de nitrogênio e a poluição causada pelo mesmo tem sua importância.

Os resíduos sólidos urbanos podem conter uma população de microrganismos, quando dispostos junto com excrementos e carcaças de animais e resíduos de serviços de saúde (RSS), podem atuar como veículo de microrganismos patogênicos e apresentar risco à saúde pública (Andreottola e Cannas, 1992, p.80). De acordo com Bidone e Povinelli (1999, p.79), a legislação não evita as opiniões contraditórias sobre os riscos relacionados aos RSS. Para alguns especialistas estes resíduos não oferecem risco à saúde pública e para outros, são altamente perigosos e necessitam de gereciamento adequado. Porém, com base na NBR 10004 (ABNT, 2004), os RSS podem ser enquadrados na categoria Resíduos Classe I - Perigosos, por apresentarem patogenicidade.

Alguns pesquisadores defendem a codisposição dos lodos provenientes do tratamento de esgoto junto aos resíduos sólidos urbanos. Segundo Bidone e Povinelli (1999, p.6), a existência de organismos saprófitos (que se alimentam de animais e vegetais em decomposição) na massa de resíduos praticamente elimina a possibilidade de organismos patogênicos (de animais de sangue quente) no lixo. A estabilização da fração orgânica, a elevação de temperatura pelos processos aeróbios, bem como as variações de $\mathrm{pH}$ que ocorrem durante os processos anaeróbios contribuem para atenuação e diminuição dos riscos de enfermidade por origem fecal, ainda que proveniente de algum organismo humano doente. Com base nos autores, "fica improvável a ocorrência de problemas de saúde publica".

Em função dos seus possíveis constituintes, os resíduos sólidos podem alterar a qualidade ambiental. No Brasil, geralmente, as áreas de disposição final não são escolhidas conforme critérios estabelecidos pelas leis ambientais, que recomendam estudos para a previsão de impactos negativos. Na ausência de medidas para controle e prevenção da poluição, os líquidos gerados nessas áreas podem atingir as águas.

Segundo Bidone e Povinelli (1999, p.49), a DBO dos líquidos gerados em aterros sanitários pode variar de 30 a 150 vezes a do esgoto sanitário, ou seja, entre $6.000 \mathrm{mg} / \mathrm{L}$ a $45.000 \mathrm{mg} / \mathrm{L}$, aproximadamente. Conforme estudo realizado por Schalch (1984, p.73), o chorume decomposto durante sete meses apresentou redução de Nitrogênio Total, Fósforo, DBO, DQO e matéria orgânica e conseqüente aumento de pH. Porém, os valores médios de DBO e DQO foram $7.700 \mathrm{mg} / \mathrm{L}$ e $15.500 \mathrm{mg} / \mathrm{L}$, respectivamente.

Os efluentes de aterros sanitários também possuem elevadas concentrações de Nitrogênio Amoniacal (Bidone e Povinelli, 1999, p.5; Buss et al, 2004), cujo composto é solúvel em água e pode ser tóxico à vida aquática, dependendo da concentração. Por isso, 
estes líquidos devem ser tratados para redução da carga orgânica e amônia para posterior lançamento em corpos d'água ou no solo. Segundo Von Sperling (2005, p.97), elevadas concentrações de Nitrogênio Amoniacal indicam contaminação recente, enquanto elevados valores de nitratos indicam contaminação remota.

De acordo com a agência ambiental inglesa (Environment Agency, 1996), o nitrogênio inorgânico na forma de amônia e do íon amônio é reconhecido como um dos contaminantes mais comuns da água subterrânea, provenientes das atividades de disposição final de resíduos sólidos, uso de fertilizantes e solo contaminado.

Normalmente o Nitrogênio Amoniacal está presente em lixiviado de aterros em elevadas concentrações, comparadas aos padrões exigidos para água potável ou qualidade ambiental. O impacto do íon amônio com o corpo d'água superficial e os efeitos da liberação da água subterrânea poluída para as águas superficiais são fatores importantes que precisam ser analisados como parte do processo de caracterização da bacia hidrográfica (Buss et al, 2004).

$\mathrm{Na}$ água superficial a amônia pode causar a mortalidade de peixes mesmo em baixas concentrações (Environment Agency, 1996 citado por Buss et al, 2004).

A maioria dos agentes químicos orgânicos e inorgânicos, considerados mundialmente como prioritários para efeito de controle, é persistente e acumulativa no meio aquático, que pode estar sujeito aos efeitos dessas substâncias por períodos de tempo prolongado (Zagatto e Bertoletti, 2006). Substâncias que interferem em longo prazo sobre a biota podem ser provenientes das atividades agrícolas devido à aplicação crescente de fertilizantes e agrotóxicos que podem atingir os corpos d'água subterrâneos ou superficiais por vários processos como a lixiviação, o fluxo preferencial através do solo, a erosão, os ventos e também podem se volatilizar e ser depositadas por meio de trocas gasosas, na forma de precipitação seca ou úmida (Allan, 2002).

A contaminação de um manancial de superfície geralmente é visível e de fácil identificação, devido à mudança na cor da água, presença de espuma, odor e morte de organismos aquáticos. A contaminação de aquíferos não é visível e pode transformar-se em um problema crônico, pois só é identificada quando causa efeitos na saúde pública (Rebouças, 1992).

Assim, minimizar a infiltração de águas no aterro sanitário e a percolação pelo solo é essencial para evitar que as substâncias presentes nos resíduos atinjam o aqüífero freático. 


\subsection{Monitoramento de aterros sanitários}

Alguns estudos sobre monitoramento de aterros indicam falhas na construção e operação dos empreendimentos relacionados aos resíduos sólidos.

Segundo pesquisa realizada por Hassuda (1997, p.137), o lixão de Alvarenga, localizado na Região Metropolitana de São Paulo, foi o responsável pelo aparecimento de doenças dermatológicas e de veiculação hídrica na população residente no local e no entorno devido à contaminação da água subterrânea.

Um estudo realizado por Heitzmann Junior (1999, p.56-57) em três áreas de disposição final de resíduos sólidos (aterros de Paulínia e Piracicaba e lixão de Itatiba) concluiu que o grau de contaminação foi relativamente baixo, apesar dos valores elevados de condutividade elétrica e $\mathrm{pH}$ ácido das águas subterrâneas do lixão. Os valores médios obtidos estão apresentados na Tabela 3. Segundo o autor, a situação dos aterros era superior (mais adequada) comparada à do lixão, porém os aterros não apresentavam situação considerada satisfatóriamente adequada. Vale ressaltar que o solo dos aterros apresentou maior teor de argila, portanto menor quantidade de substâncias dissolvidas na água, comprovado pelos menores valores de condutividade elétrica. Esse fenômeno pode ser explicado pela adsorção dos compostos presentes no lixiviado na argila.

Tabela 3 - Valores médios nas águas subterrâneas de três locais de disposição final

\begin{tabular}{|c|c|c|}
\hline $\begin{array}{l}\text { Áreas de disposição final } \\
\text { de resíduos sólidos }\end{array}$ & $\mathbf{p H}$ & $\begin{array}{c}\text { Condutividade elétrica } \\
(\mu \mathrm{S} / \mathrm{cm})\end{array}$ \\
\hline $\begin{array}{c}\text { Lixão de Itatiba } \\
\text { Aterro de Piracicaba } \\
\text { Aterro de Paulínia }\end{array}$ & $\begin{array}{l}5,4 \\
7,0 \\
8,3\end{array}$ & $\begin{array}{l}4.060 \\
3.060 \\
2.180\end{array}$ \\
\hline
\end{tabular}

Outro estudo realizado por Nascimento (2001) constatou poluição do solo, bem como das águas superficiais e subterrâneas provocada pelo chorume no aterro sanitário São João, localizado no município de São Paulo (SP), o qual opera desde 1992. O aterro passou por um processo de seleção de áreas, porém sua operação não foi tão eficaz, de acordo com os resultados do monitoramento das águas.

Calvo et al (2005) concluíram que o compartimento mais afetado por três aterros analisados na região de Granada (Espanha) foi a água subterrânea, seguida do solo, saúde humana, atmosfera e água superficial. Assim, tornam-se prioritárias as atenções com a qualidade das águas subterrâneas, em especial com a sua potabilidade.

A qualidade da água subterrânea na área de influência dos aterros sanitários deve atender aos padrões de potabilidade estabelecidos pela legislação vigente. Quando estes 
padrões forem excedidos, o proprietário da instalação é obrigado a recuperar a qualidade do aqüífero contaminado, conforme recomendações da NBR 13896 (ABNT, 1997a). Este procedimento é recomendado pelas agências ambientais nacionais e internacionais. No Estado de São Paulo, os Valores Orientadores para Solo e Água Subterrânea (CETESB, 2005b) devem ser respeitados, especialmente quando algum parâmetro não for contemplado pela Portaria 518/2004.

Além disso, o monitoramento das águas subterrâneas deve ser realizado durante a vida útil do aterro, ou seja, enquanto estiver em operação, até 20 anos após o encerramento de suas atividades. As amostras devem ser retiradas do aqüífero mais alto e o sistema de monitorameto deve ser constituído de, no mínimo, quatro poços (um a montante e três a jusante), instalados no sentido do fluxo de escoamento preferencial do aqüífero freático, de acordo com a NBR 13896 (ABNT, 1997a).

Um dos principais parâmetros a ser avaliado no monitoramento de aterros é o nitrogênio amoniacal, um dos compostos presentes no lixiviado, encontrado em altas concentrações durante um longo período de tempo. Em amostras de lixiviado de aterros da Alemanha os valores de nitrogênio amoniacal variam com a idade do empreendimento, conforme Tabela 4.

Tabela 4 - Valores de nitrogênio amoniacal em lixiviado de aterros da Alemanha

\begin{tabular}{c|c}
\hline Idade do aterro (anos) & Valores médios de nitrogênio amoniacal (mg/L) \\
\hline 1 a 5 & 405 \\
6 a 10 & 600 \\
11 a 20 & 555 \\
21 a 30 & 445 \\
\hline
\end{tabular}

Fonte: Pivato e Raga (2006)

O nitrogênio amoniacal não é degradado em condições anaeróbias e sua toxicidade é comprovada, assim é indicador de contaminação da água subterrânea, causada pela difusão dos contaminantes presentes no lixiviado (Pivato e Raga, 2006). Vale ressaltar que os valores de nitrogênio amoniacal encontrados na água natural são bem inferiores aos encontrados no lixiviado, porém quando as concentrações desse composto na água se elevam significa que houve vazamento proveniente do aterro.

Com base em Tandel (1998), o íon amônio se oxida rapidamente em amônia, portanto altos teores de nitrogênio amoniacal indicam o estágio inicial do ciclo do nitrogênio, ou seja, contaminação recente.

A amônia pode ser tóxica aos organismos aquáticos, dependendo de sua concentração. Concentrações a partir de $0,25 \mathrm{mg} / \mathrm{L}$ afetam o crescimento de peixes, 
enquanto que concentrações superiores a $0,5 \mathrm{mg} / \mathrm{L}$ são letais, matando $50 \%$ dos indivíduos expostos (Esteves, 1988). Em condições naturais, raramente a amônia atinge valores letais, para isso devem ocorrer simultaneamente elevados valores de $\mathrm{pH}(>9,0)$, elevada temperatura $\left(>26^{\circ} \mathrm{C}\right)$ e baixos valores de potencial redox (Trussel, 1972 apud Esteves, 1988).

Além da amônia, outros contaminantes presentes nos resíduos sólidos podem causar efeitos tóxicos aos organismos aquáticos, como matéria orgânica, sais e metais. Os metais podem afetar o comportamento biológico, comprometendo a reprodução e/ou a sobrevivência dos organismos (Povinelli, 1987).

A matéria orgânica pode ser mensurada por meio de análises de Carbono Orgânico Total (COT), Demanda Bioquímica de Oxigênio (DBO) e Demanda Química de Oxigênio (DQO), já o teor de sais por meio de análise da condutividade elétrica, salinidade, cloretos, entre outros.

Segundo estudo realizado no antigo lixão de São Carlos por Gadotti (1997, p.138139), os elementos mais indicativos de alterações na qualidade da água foram cloretos e condutividade elétrica, por isso devem ter prioridade no monitoramento. Porém, o autor conclui que a formação geológica demonstrou alta capacidade de atenuação da poluição diante dos valores esperados.

Conforme Santos Filho (2001, p.67-81), os principais indicadores do impacto nas águas subterrâneas são condutividade elétrica, cloreto e sódio, os quais apresentam relação evidente, pois os íons cloreto e sódio são comuns em chorume gerado por lixões. Além disso, o cloreto e o sódio apresentam alta solubilidade (CETESB, 2001b, p.76). No seu estudo realizado no lixão de Tatuí, Santos Filho (2001) concluiu que a concentração dos constituintes analisados aumentou no período de chuvas e que houve alteração na qualidade das águas subterrâneas. Entre os valores encontrados, as amostras a jusante do lixão apresentaram condutividade elétrica entre 11,8 e $1.929 \mu \mathrm{S} / \mathrm{cm}$, já as amostras a montante apresentaram valores até $80 \mu \mathrm{S} / \mathrm{cm}$.

Compostos orgânicos e inorgânicos podem estar presentes em efluentes e corpos hídricos, devido a sua complexidade e variabilidade, por isso recomenda-se a caracterização biológica destas águas para complementação das informações não reveladas pelas análises físico-químicas. Atualmente, a realização dos testes de toxicidade é considerada indispensável para se obter um controle mais abrangente das fontes de poluição das águas.

A toxicidade pode ser avaliada por meio do efeito que a dose ou concentração de uma certa substância causará a determinado organismo num determinado intervalo de tempo. Esses efeitos podem ser classificados em agudos e crônicos. 
A Resolução CONAMA 357/2005 recomenda a realização de testes de toxicidade em amostras de água, porém poucos trabalhos foram encontrados na literatura abordando o impacto dos aterros na vida aquática, por meio de ensaios ecotoxicológicos. Alguns trabalhos relatam sobre a toxicidade do chorume e seu possível impacto no corpo receptor.

Sisinno (2002) realizou testes de toxicidade com peixes da espécie Danio rerio (vulgarmente conhecido como paulistinha) em cursos d' água superficiais próximos a aterros controlados de resíduos sólidos urbanos e industriais no Estado do Rio de Janeiro. Foi comprovada a alta toxicidade do chorume, evidenciando o impacto no ambiente aquático provocado pelo lançamento deste efluente. Amostras de resíduos industriais não-inertes apresentaram elevadas concentrações de alumínio, ferro, manganês e fenol, cerca de 300 vezes o limite estabelecido pela legislação, comprovando suas características tóxicas.

De acordo com Silva (2002), "a concentração de componentes inorgânicos do chorume é muito alta, sendo talvez a principal responsável pela toxicidade". A autora realizou testes de toxicidade aguda com Artemia salina (microcrustáceo de água salgada), Daphnia similis (microcrustáceo de água doce), Danio rerio (peixe de água doce) e a bactéria luminescente Vibrio fisheri (bactéria de origem marinha) em amostras de chorume bruto do Aterro Metropolitano de Gramacho (RJ) e constatou efeito tóxico do efluente para todos os organismos testados, apesar dos organismos de água doce terem sido os mais afetados. Daphnia similis se mostrou muito sensível aos efluentes testados, mesmo com a correção de salinidade.

Tandel (1998) constatou toxicidade aguda em poços de monitoramento no aterro controlado de Rio Claro (SP) devido à presença significativa de amônia, proveniente do

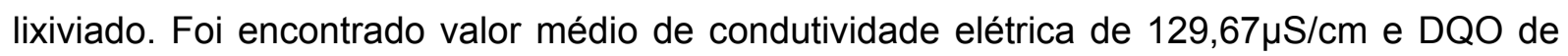
$13,68 \mathrm{mg} / \mathrm{L}$. O autor concluiu que não ocorreu contaminação do aqüífero por metais, devido à capacidade filtrante do solo.

Assim, o solo dos aterros e lixões também deve ser analisado com o objetivo de se verificar se suas características naturais estão sendo alteradas, principalmente quando os contaminantes atingem a água subterrânea. Segundo Alvarez (2004, p.98), "aqüíferos contaminados por lixiviado (chorume) de aterros sanitários municipais podem conter elevadas concentrações de ácidos orgânicos e pH's de até 3,0. Nestes casos, o pH pode representar um problema ambiental significativo para bactérias naturais do solo".

Diante dessas constatações, ressalta-se a importância do monitoramento das águas na área de influência de lixões e aterros de resíduos sólidos (sanitários, industriais ou de inertes), a fim de avaliar se está ocorrendo migração de lixiviado. 


\section{5 Áreas contaminadas}

Práticas empregadas nos anos 70 são inaceitáveis atualmente, como a disposição de materiais perigosos em aterros municipais; a descarga de resíduos líquidos perigosos em drenos de esgoto e de águas pluviais; o armazenamento de resíduos perigosos em tambores metálicos sem proteção, sujeitos à corrosão; a descarga de resíduos solventes ou resíduo de óleo de motor no solo ou poços secos. Estas práticas causaram a contaminação de um grande número de locais com materiais perigosos e estas impurezas ameaçam a água e o ar (Nazaroff e Alvarez Cohen, 2001, p.10-11).

No Estado de São Paulo foi elaborado o "Manual de Gerenciamento de Áreas Contaminadas" pela Companhia de Tecnologia de Saneamento Ambiental (CETESB, 2001a) em parceria com o governo alemão. Este documento está sendo atualizado anualmente. A CETESB passou então a cadastrar as áreas contaminadas do Estado por meio da seguinte classificação:

- área potencialmente contaminada (AP);

- área suspeita de contaminação (AS);

- área contaminada (AC).

Quando num local foi ou ainda é desenvolvida alguma atividade potencialmente contaminadora como, por exemplo, a disposição de resíduos em aterro sanitário, essa área pode ser considerada AP.

Áreas onde são realizadas atividades potencialmente contaminadoras podem ser consideradas AS, que são locais onde, "após a realização de uma avaliação preliminar, foram observadas indicações que induzem a suspeitar da presença de contaminação" (CETESB, 2001a: seção 200, p.1).

Uma atividade potencialmente contaminadora "é aquela em que ocorre o manejo de substâncias cujas características físico-químicas, biológicas e toxicológicas podem acarretar danos aos bens a proteger, caso entrem em contato com os mesmos" (CETESB, 2001a: seção 200, p.1).

Os bens que, segundo a Lei 6938, de 31 de agosto de 1981, que trata da Política Nacional do Meio Ambiente (PNMA) e legislações decorrentes, devem ser protegidos são: 
- saúde e bem-estar da população;

- fauna e flora;

- qualidade do solo, das águas e do ar;

- interesses de proteção da natureza/paisagem;

- ordenação territorial e planejamento regional e urbano;

- segurança e ordem pública.

Uma área só pode ser considerada AC quando houver "poluição ou contaminação causada pela introdução de quaisquer substâncias ou resíduos que tenham sido depositados, acumulados, armazenados, enterrados ou infiltrados de forma proposital, acidental ou até mesmo natural. Os poluentes ou contaminantes podem concentrar-se no solo, rochas e águas subterrâneas, podendo propagar-se através desses meios ou também pelo ar" (CETESB, 2007b, grifo nosso).

Os pontos dentro de uma AC onde são detectadas as maiores concentrações do(s) contaminante(s) são considerados focos de contaminação (Hot Spot).

Para se confirmar ou não a suspeita de contaminação são necessários levantamentos da área por meio de técnicas rápidas e de baixo custo, conhecidos como métodos de screening, ou seja, instrumentos para investigação confirmatória do local. Dessa forma, é importante prever quais contaminantes podem ser encontrados no local de acordo com a atividade estabelecida. Assim, faz-se necessário relacionar produtos e compostos inerentes à atividade desenvolvida na área investigada (CETESB, 2001a: seção 6100).

$\mathrm{Na}$ etapa de avaliação confirmatória são realizados métodos de campo para:

- confirmar a existência de contaminantes qualitativamente (orgânicos e inorgânicos);

- delimitar, se possível, a extensão da contaminação e

- estabelecer a faixa de concentração (magnitude) em que essa contaminação se encontra (quantitativamente ou semiquantitativamente).

Além disso, para a caracterização da área faz-se necessário:

- mapeamento dos pontos de maiores concentrações (hot spots);

- definição da localização de futuras sondagens e poços de monitoramento;

- conhecimento de questões relativas à segurança e higiene ocupacional dos trabalhadores que executam os levantamentos de campo, principalmente quando da existência de emanação de gases e vapores. 
Uma das metas do screening é a obtenção de dados analíticos para a caracterização detalhada do local afetado e também orientar futuros planos de monitoramento e recuperação.

O monitoramento é a "medição contínua ou periódica da qualidade ou características de um meio" (CETESB, 2001a: seção 200, p.4). Portanto, o monitoramento fornece resultados sobre a qualidade ou características do solo, da água e/ou do ar.

As ações de recuperação da área só serão iniciadas caso a concentração dos contaminantes ultrapassem os valores estabelecidos pela legislação ou os valores-limite estabelecidos pela CETESB. Na ausência destes, os valores obtidos devem ser comparados aos valores naturais de referência do local (background).

Conforme CETESB (2001a: seção 8000), quando a contaminação é confirmada, medidas devem ser adotadas conforme recomendações do órgão ambiental com o objetivo de proteger os possíveis receptores de risco no entorno da área. As medidas podem ser definidas com base na extensão da contaminação, natureza dos contaminantes, possíveis efeitos ao homem e ao ambiente. As possíveis medidas a serem adotadas podem ser:

- isolamento da área;

- restrição de uso do solo;

- restrição de consumo de águas superficiais ou subterrâneas;

- remoção imediata de resíduos, solos contaminados ou gases do subsolo;

- monitoramento ambiental;

- monitoramento de explosividade.

O "risco é a probabilidade de ocorrência de um efeito adverso aos bens a proteger em decorrência da sua exposição aos contaminantes presentes em uma AC" (CETESB, 2001a: seção 200, p.6).

Estrategicamente, medidas imediatas ou emergenciais devem ser adotadas sempre que a área oferecer risco iminente à população, com o objetivo de tornar o local seguro até que a remediação seja iniciada.

Assim, na etapa de avaliação confirmatória é detectada a presença de contaminantes numa área suspeita. Para a recuperação da área faz-se necessária a realização de uma investigação detalhada para quantificar os contaminantes (tipos, concentrações, extensão e volume). Esta etapa fornecerá subsídios para a avaliação de risco e definição do(s) método(s) de remediação a ser empregado. Estes métodos são definidos com base na natureza dos contaminantes, que é variada, e grau de investimento. 
De acordo com o cadastro de áreas contaminadas elaborado pela CETESB (2007b), constatou-se aumento no número de casos já confirmados no Estado de São Paulo, conforme Tabela 5.

Tabela 5 - Número de áreas contaminadas no Estado de São Paulo

\begin{tabular}{l|c|c}
\hline \multicolumn{1}{c|}{ Ano } & $\begin{array}{c}\text { Número de áreas } \\
\text { contaminadas }\end{array}$ & $\begin{array}{c}\text { Novos casos em } \\
\text { relação ao ano anterior }\end{array}$ \\
\hline Maio 2002 & 255 & - \\
Outubro 2003 & 727 & 470 \\
Novembro 2004 & 1.336 & 611 \\
Novembro 2005 & 1.596 & 260 \\
Novembro 2006 & 1.822 & 226 \\
\hline
\end{tabular}

Fonte: CETESB (2007b)

As causas da contaminação podem ser de origem diversa. O número de áreas contaminadas conforme a atividade é apresentado na Figura 4.

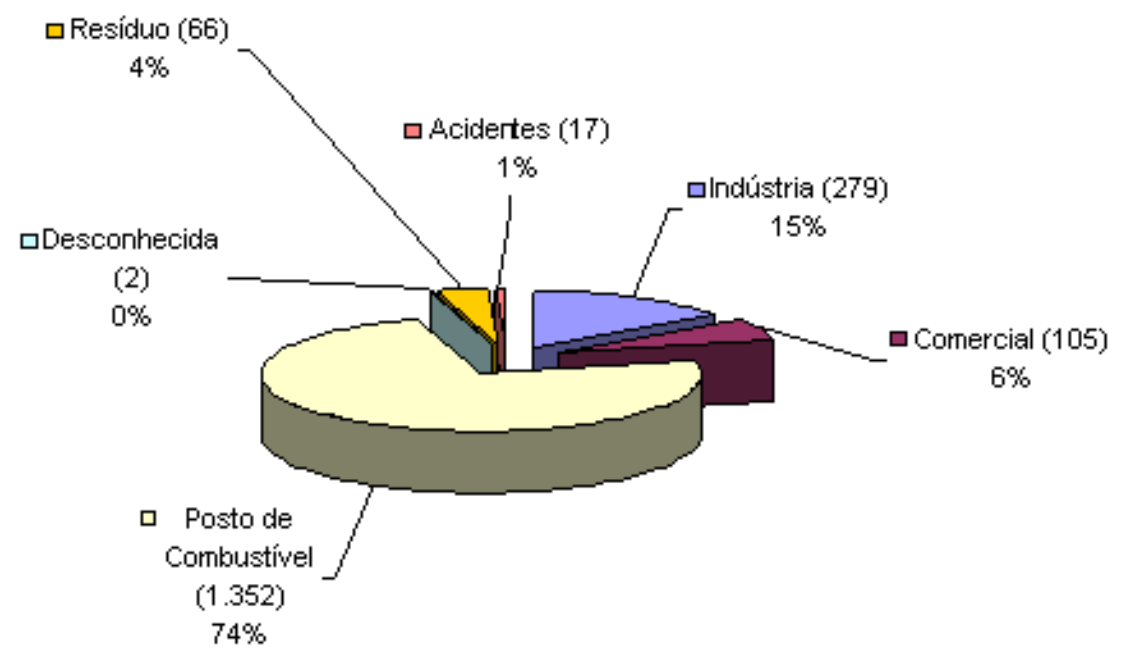

Figura 4 - Número de áreas contaminadas no Estado de São Paulo conforme a atividade Fonte: CETESB (2007b)

Com base na Figura 4, constata-se que o maior número de áreas contaminadas é proveniente dos postos de combustível, devido principalmente à fiscalização freqüente e licenciamento ambiental da atividade, de acordo com a Resolução CONAMA $n^{\circ} 273$, de 29 de novembro 2000. O maior número de áreas contaminadas confirmadas ocorreu no interior do Estado, conforme Tabela 6. 
Tabela 6 - Número de áreas contaminadas confirmadas no Estado de São Paulo

\begin{tabular}{l|c|c|c|c|c|c}
\hline \multicolumn{7}{c}{ Áreas Contaminadas no Estado de São Paulo } \\
\hline Região/Atividade & Comercial & Industrial & Resíduos & $\begin{array}{c}\text { Postos de } \\
\text { combustível }\end{array}$ & $\begin{array}{c}\text { Acidentes } \\
\text { desconhecidos }\end{array}$ & Total \\
\hline São Paulo & 28 & 56 & 22 & 486 & 2 & 594 \\
RMSP* outros & 14 & 76 & 11 & 273 & 4 & 378 \\
Interior & 49 & 93 & 22 & 432 & 72 & 608 \\
Litoral & 13 & 31 & 11 & 78 & 2 & 135 \\
Vale do Paraíba & 1 & 23 & 0 & 83 & 0 & 107 \\
\hline Total & $\mathbf{1 0 5}$ & $\mathbf{2 7 9}$ & $\mathbf{6 6}$ & $\mathbf{1 . 3 5 2}$ & $\mathbf{2 0}$ & $\mathbf{1 . 8 2 2}$ \\
\hline
\end{tabular}

*RMSP: Região Metropolitana de São Paulo (38 municípios, exceto a capital)

Fonte: CETESB (2007b)

Nesse sentido, estão sendo realizadas pesquisas na EESC/USP, uma de Doutorado, desenvolvida por Anne Alessandra Cardoso, intitulada "Estudo sobre resíduos sólidos em micro e pequenas empresas do município de São Carlos para composição dos indicadores de desenvolvimento sustentável, com aplicabilidade em políticas públicas", e uma iniciação científica, desenvolvida por Luciana Souza Marrara, intitulada "Estratégias para a gestão e o gerenciamento de resíduos sólidos de postos de combustíveis", com o objetivo de monitorar alguns postos de combustíveis e indústrias de galvanoplastia e funilarias de São Carlos.

Foi constatado aumento de 226 novos casos na última atualização realizada pela CETESB em 2006. Houve aumento em todas as regiões em relação à atualização de novembro de 2005, com destaque para o município de São Paulo que registrou aumento de 100 novas áreas, seguido do interior com aumento de 68 novas áreas e RMSP com 41 . 0 litoral e Vale do Paraíba registraram aumento de 13 e 4 novas áreas respectivamente. Quase todos os itens apresentaram aumento, com exceção do item resíduos que registrou aumento de apenas dois casos em São Paulo.

Os principais grupos de contaminantes encontrados nas áreas contaminadas foram: solventes aromáticos, combustíveis líquidos, Hidrocarbonetos Policíclicos Aromáticos (PAHs), metais e solventes halogenados, provenientes dos postos de combustível. Porém, a fiscalização de aterros sanitários e industriais é limitada e deve ser intensificada, a fim de verificar se os mesmos estão alterando a qualidade ambiental.

Os contaminantes podem ser contidos ou removidos, por métodos de remediação. A remediação de áreas contaminadas é a "aplicação de técnica ou conjunto de técnicas em uma área contaminada, visando à remoção ou contenção dos contaminantes presentes, de modo a assegurar uma utilização para a área, com limites aceitáveis de riscos aos bens a proteger" (CETESB, 2001a, seção 200, p.5). Esquemas das técnicas de contenção e remoção de contaminantes podem ser visualizados por meio da Figura 5 e Figura 6. 


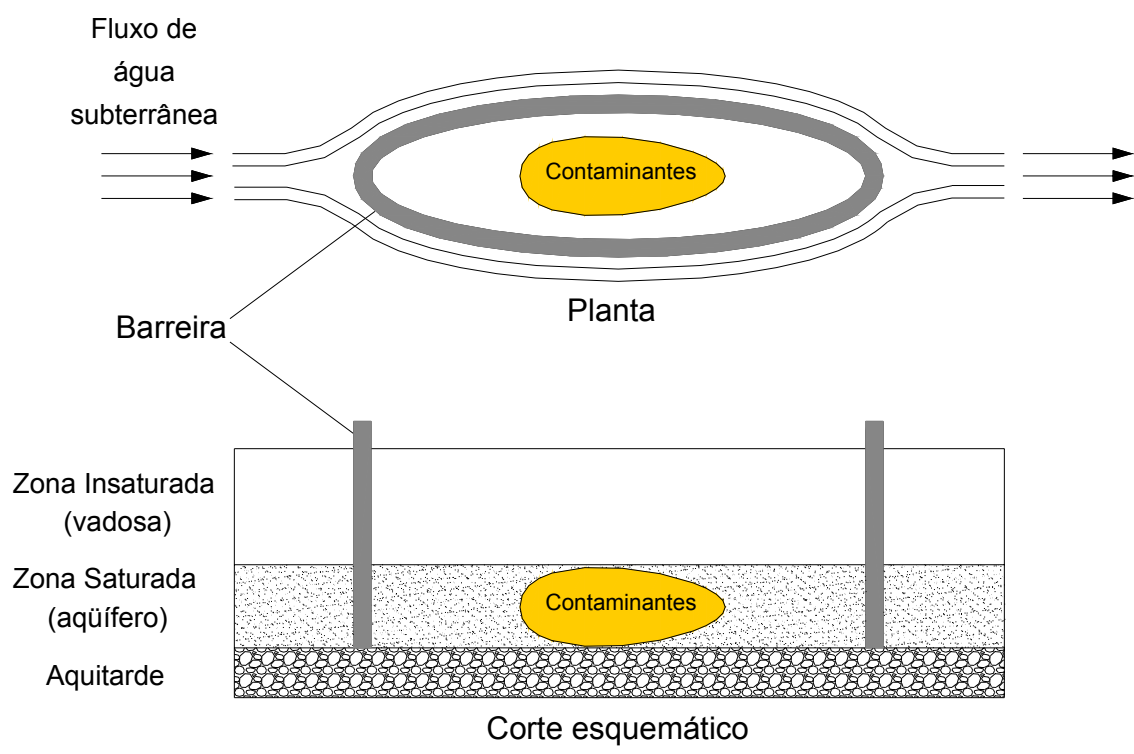

Figura 5 - Esquema da técnica para contenção de contaminantes Fonte: baseado em Nazaroff e Alvarez-Cohen (2001)

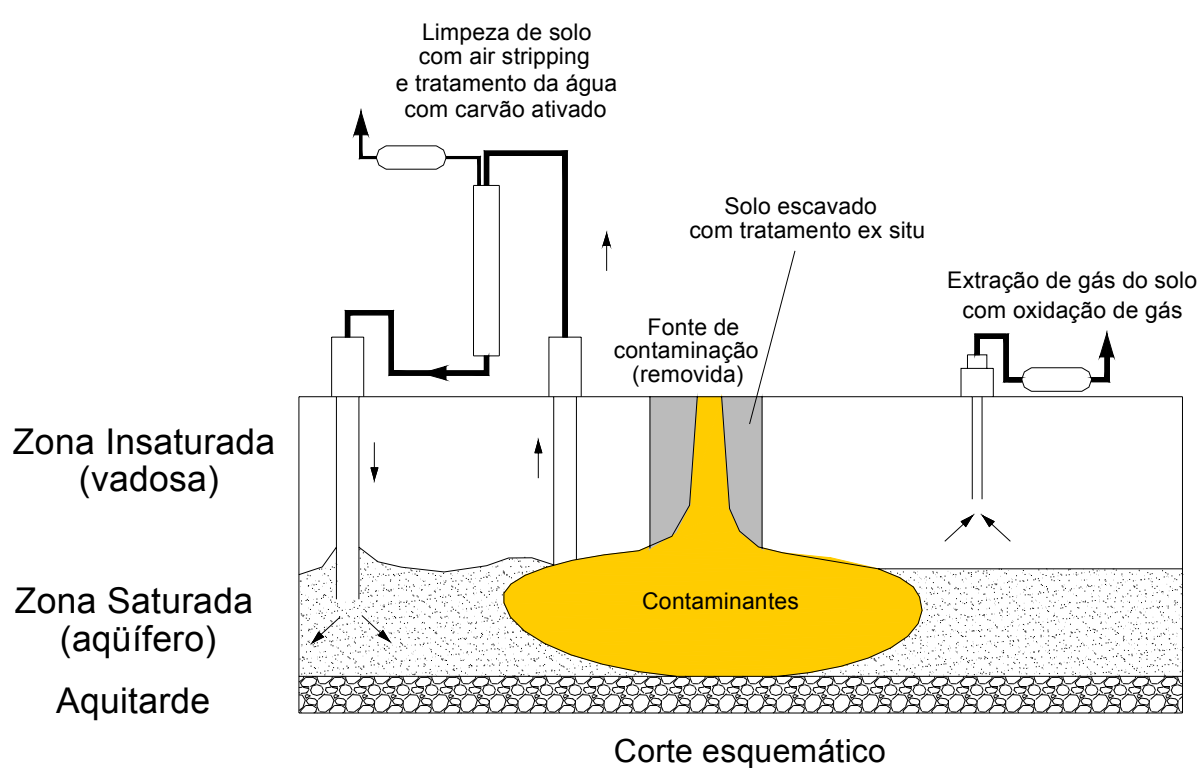

Figura 6 - Esquema de técnicas para remoção de contaminantes Fonte: baseado em Nazaroff e Alvarez-Cohen (2001)

No esquema apresentado na Figura 5 os contaminantes são apenas contidos, não há tratamento do solo ou da água enquanto que o esquema apresentado na Figura 6 sugere a reposição da água e do solo tratados.

Para a realização de um projeto de remediação, faz-se necessário o cumprimento das legislações nacional, estadual e municipal, além das diretrizes e recomendações vigentes. A transferência de contaminantes de um meio físico para outro, bem como sua 
disposição devem ser executadas adequadamente, com aprovação do órgão ambiental. Poços de monitoramento devem ser construídos para avaliar a eficácia da remediação. Além disso, dados de condutividade, $\mathrm{pH}$, temperatura e turbidez da água subterrânea devem ser obtidos para sua caracterização (CETESB, 2001a: seção 11000).

De acordo com Alves e Araújo (2006), no Brasil em 2003 foram investidos 151 milhões de Reais com remediação de áreas contaminadas, 209 milhões em 2004 e 256 milhões em 2005. Além disso, o número de pessoas empregadas para trabalhar no setor também está aumentando. Em 2003 eram 1.240 pessoas envolvidas em projetos de remediação, 1.481 pessoas em 2004 e 1.743 em 2005, conforme dados da Associação Brasileira das Empresas de Diagnóstico e Remediação de Solo e Águas Subterrâneas (AESAS). Segundo a AESAS, existem várias empresas capacitadas no país para fazer a remediação de solos e águas. Porém, o setor precisa avançar, por exemplo com a criação de selos de qualidade e normas ABNT para nortear os envolvidos e garantir a qualidade dos serviços.

Em 2005 foi criada uma Comissão de Estudo Especial Temporária de Avaliação da Qualidade do Solo e da Água para Levantamento de Passivo Ambiental e Análise de Risco à Saúde Humana, denominada Comissão ABNT/CEET 00:001.68, com 4 grupos de trabalho:

- $\quad$ Amostragem de água e revisão da norma de construção de poços de monitoramento;

- Sondagens e amostragem de solo para fim ambiental;

- Levantamento de passivo ambiental;

- Avaliação de risco ambiental.

O passivo ambiental pode ser entendido como "deposições antigas e sítios contaminados que produzem riscos para o bem-estar da coletividade, segundo a avaliação tecnicamente respeitada das autoridades competentes" (Schianetz, 1999).

O monitoramento ou a avaliação de um projeto de remediação devem ser realizados durante o período mínimo de um ano, caso não exista outra especificação. Vale ressaltar que são necessários oito conjunto de dados de água subterrânea para demonstrar que os valores estabelecidos em lei não estão sendo ultrapassados. Além disso, faz-se necessário validação estatística adequada dos dados (CETESB, 2001a: seção 12000).

Para que um projeto de remediação seja interrompido é necessário que os níveis de contaminantes do solo estejam próximos ou abaixo dos níveis de proteção da água subterrânea, os limites recomendados pela legislação para proteção da água subterrânea não devem ser ultrapassados no(s) limite(s) da área de interesse e a concentração dos 
contaminantes fora do(s) limite(s) da área de interesse não deve ser suficiente para impactar a saúde pública e o ambiente.

A recuperação de uma área poderá ser concluída quando o monitoramento indicar que a remediação atingiu os objetivos exigidos pelo órgão ambiental. A remediação poderá ser encerrada antes que os mesmos sejam contemplados, caso seja demonstrado que não é tecnicamente possível e/ou viável economicamente. Nestas condições outras medidas devem ser adotadas para que os resultados sejam alcançados.

Além disso, o responsável pela remediação poderá solicitar a interrupção do sistema de tratamento junto ao órgão ambiental quando:

- Os valores para remediação do solo forem atingidos;

- A água subterrânea contaminada puder ser descartada sem tratamento e/ou

- Não houver impacto significativo a jusante e o tratamento da água subterrânea não for necessário.

Monitoramentos futuros serão dispensados quando os níveis de contaminação do poço mais a jusante da pluma (poço sentinela ou de segurança) não ultrapassarem os valores de referência de qualidade estabelecidos pelo órgão ambiental em nenhum momento do programa de monitoramento (CETESB, 2001a: seção 12000, p.5, grifo nosso). Essa pode ser considerada uma medida preventiva, uma vez que quando este poço é atingido significa que os contaminantes transportados pela água subterrânea tiveram tempo suficiente para alcançá-lo, porém como a concentração dos contaminantes está dentro dos limites permitidos pela legislação, conclui-se que houve retardamento por sorção e/ou outros processos hidrogeológicos/hidrogeoquímicos que tornaram mais lenta a migração dos contaminantes.

A pluma de contaminação (Figura 7) pode ser entendida como a "delimitação da extensão da contaminação de um meio (água, ar e solo)" (CETESB, 2001a: seção 200, p.4). 


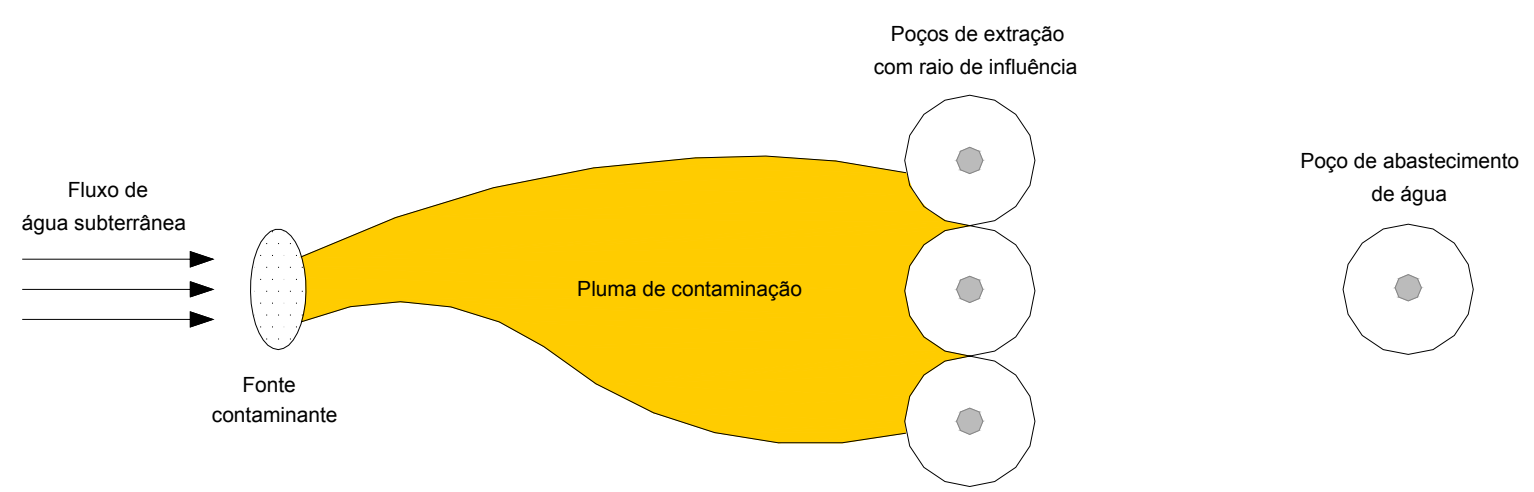

Figura 7 - Ilustração de uma pluma de contaminação

Fonte: Nazaroff e Alvarez-Cohen (2001)

A Figura 7 ilustra a localização de poços de extração de contaminantes construídos entre a fonte de contaminação e o poço de abastecimento de água como medida de proteção da qualidade da água. Subentende-se que a água removida deverá ser tratada e devolvida ao aqüífero para que não falte água à população. Dependendo do contaminante e de sua concentração o poço de abastecimento de água deverá ser fechado até a remoção do mesmo.

Nos Estados Unidos, dentre o conjunto de regulamentos que implementam a Comprehensive Environmental Response, Compensation and Liability Act (CERCLA) de 1980, conhecida como Superfund, lei que trata de locais contaminados, um deles é o fechamento do local e o monitoramento a longo prazo. Após encerradas a limpeza e a remediação, o local é fechado e monitorado. O monitoramento da água subterrânea é exigido por 30 anos, no mínimo, se as substâncias perigosas permanecerem no local. Estima-se que existam mais de 200.000 áreas contaminadas no país (USEPA ${ }^{1}, 1997$ citado por Nazaroff e Alvarez-Cohen, 2001, p.12).

Segundo Tardent (2005), um aterro de resíduos perigosos de Koelliken na Suíça foi fechado em 1985 por determinação da Câmara de Vereadores mesmo antes de atingir sua capacidade plena. O aterro não possuía nenhum sistema de contenção de gases, incomodando a população circunvizinha em função dos odores desagradáveis e poeira. No local já havia sido depositado cerca de $250.000 \mathrm{~m}^{3}$ de resíduos perigosos, que provocaram a mortandade de peixes a jusante devido ao descarte de materiais, como sais facilmente solúveis. Atualmente ainda é possível detectar poluentes orgânicos a uma distância de 80 metros da área. Cerca de $40.000 \mathrm{~m}^{3}$ de água contaminada são tratados por ano, mais de $80 \%$ do carbono orgânico é decomposto por processos biológicos e carvão ativado e mais de $96 \%$ da amônia é decomposta em nitrato ou $\mathrm{N}_{2}$. Durante o período de 2005 a 2012, o aterro será totalmente removido e o material tratado em estações externas.

\footnotetext{
${ }^{1}$ USEPA. Cleaning up the nation's waste sites: Markets and technology trends. Report 542-96-005A. U.S. Environmental Protection Agency. apr. 1997.
} 


\subsection{Substâncias perigosas}

Substâncias perigosas também são encontradas nos resíduos sólidos urbanos e podem ser originadas de forma natural ou manufaturada.

Em 1976 foi aprovada a Resource Conservation and Recovery Act (RCRA) nos Estados Unidos para tratar do manejo, tratamento e disposição final dos resíduos perigosos. A RCRA considera resíduos tóxicos e/ou perigosos se causarem ou contribuirem significativamente para o aumento da mortalidade, irreversibilidade, incapacidade, enfermidade; ou apresentar substância potencialmente perigosa à saúde humana ou ao ambiente quando indevidamente tratada, armazenada, transportada, disposta ou gerenciada.

No Brasil essas substâncias estão enquadradas na NBR 10004 (ABNT, 2004a, p.2-3) como Resíduos Classe I - Perigosos. A periculosidade de um resíduo é caracterizada em função de suas propriedades físicas, químicas ou infecto-contagiosas, podendo apresentar:

a) risco à saúde pública, provocando mortalidade, incidência de doenças ou acentuando seus índices;

b) riscos ao ambiente, qunado o resíduo for gerenciado de forma inadequada.

De acordo com essa norma, para uma substância ser considerada perigosa ela deve possuir uma das seguintes características: inflamabilidade, corrosividade, reatividade, toxicidade ou patogenicidade. Nos anexos A e B da NBR 10004 são apresentados os resíduos perigosos com suas respectivas fontes geradoras, constituintes e características.

As maiores fontes de resíduos perigosos são industrial, pesquisa médica (universidades, laboratórios e hospitais) e residencial. Entre as principais indústrias geradoras de resíduos perigosos estão as de produtos químicos, metálicos, componentes eletro-eletrônicos, equipamentos de transporte, papel, derivados de petróleo, borracha, móveis e alimentos (Nazaroff e Alvarez Cohen, 2001, p.498-499). A fabricação de produtos como plásticos, automóveis, remédios, têxteis, artefatos de couro, tintas, agrotóxicos, entre outros, também podem gerar resíduos perigosos (Enger e Smith, 2004, p.439).

Cerca de $75 \%$ dos resíduos perigosos são provenientes de três tipos de processo industrial: manufatura química, de metal e refino de petróleo (Marsh e Grossa Junior, 1996).

Até os anos 70, grande quantidade de químicos foram produzidos e usados com pouca ou nenhuma atenção para o manejo adequado dos resíduos (Nazaroff e Alvarez Cohen, 2001, p.10). De acordo com Marsh e Grossa Junior (1996), muitos produtos químicos são usados diariamente pelo homem, responsável pela produção, consumo e descarte. Estima-se que existam cerca de 63.000 diferentes químicos de uso geral e que 
aproximadamente 220 milhões de toneladas são usadas por ano nos Estados Unidos (Englande, $1994^{2}$ citado por Nazaroff e Alvarez Cohen, 2001, p.498).

Com o avanço da indústria química durante o século $X X$ surgiu a necessidade do gerenciamento dos resíduos perigosos (Nazaroff e Alvarez Cohen, 2001, p.10). Conforme Marsh e Grossa Junior (1996), existem seis classes de resíduos perigosos, de acordo com sua composição:

- metais pesados (chumbo, zinco, arsênio, outros);

- compostos orgânicos sintéticos (Bifenilas Policloradas-PCB, DDT, dioxina, outros);

- produtos do petróleo (graxa, óleo e gasolina);

- ácidos (ácido clorídrico, sulfúrico, entre outros);

- substâncias biológicas (bactérias e toxinas vegetais);

- materiais radioativos (armas nucleares, materiais hospitalares, outros).

Esses resíduos são distribuídos no ambiente, conforme o uso do solo. Há dois tipos de uso do solo responsáveis pela difusão da maioria dos resíduos perigosos no ambiente: industrial e agrícola. Estes setores são os maiores geradores de compostos orgânicos, metais pesados e ácidos, além de disseminadores para solo, ar e água.

Os meios de transporte também são importantes agentes de transferência de resíduos perigosos, especialmente de produtos do petróleo, devido a vazamentos e má vedação de tanques de armazenagem. Grande parte dos materiais perigosos é transportada por caminhões, assim, as rodovias podem formar redes de contaminação.

O uso residencial também contribui significativamente com o uso de vários produtos químicos dentro e no entorno das casas (solventes, gasolina, óleos, produtos de limpeza, tintas, agrotóxicos, etc) que entram em contato com o ambiente, por meio de aplicações em jardins, vazamentos ou descarte pelo lixo.

Alguns produtos químicos potencialmente perigosos são usados em residências como polidor de móveis; desinfetantes; anti-bactericidas; colas; cosméticos; baterias eletrônicas e automotivas; eletroeletrônicos; óleo de cozinha, de freio, de motor; álcool; medicamentos; cera para piso e automotiva, removedores de tinta e ferrugem; verniz para madeira; fertilizantes; fungicidas; inseticidas; exterminador de erva daninha; venenos para roedores, formigas e baratas; entre outros.

\footnotetext{
2 ENGLANDE, A. J. Status adn direction of waste minimization in the chemical and petrochemical industries. Water Science and Technology, 29, p.25-36. 1994.
} 
Por isso, aterros ativos e inativos podem conter quantidades significativas de resíduo perigoso, já que estes podem estar presentes no resíduo sólido urbano. Dessa forma, para detectar a presença deste compostos, faz-se necessário o monitoramento do solo e águas.

No âmbito federal, a Resolução CONAMA 257/1999 dispõe sobre pilhas e baterias, recomendando tratamento e disposição final ambientalmente adequados.

No Estado de São Paulo, a Lei $n^{\circ} 10.888$, de 20 de setembro de 2001, dispõe sobre o descarte final de produtos potencialmente perigosos do resíduo urbano que contenham metais pesados e dá outras providências. Esta lei considera como produtos potencialmente perigosos pilhas, baterias, lâmpadas fluorescentes e frascos de aerosóis, e recomenda que estes sejam separados e acondicionados em recipientes adequados para destinação específica. A lei estabelece ainda que os fabricantes, distribuidores, importadores, comerciantes ou revendedores são os responsáveis pela coleta, descontaminação e destinação final adequada destes resíduos. Porém, na prática isso não ocorre devido à falta de conscientização do usuário, bem como do fornecedor.

O uso de agrotóxicos em área urbana também ocorre, porém em menor quantidade. O emprego destes produtos na área rural preocupa, devido à escala (são aplicados em áreas extensas), bem como devido ao uso indiscriminado, não respeitando o intervalo de tempo entre uma aplicação e outra.

A aplicação de agrotóxicos em terras agrícolas é considerada um dos principais meios de distribuição de resíduo perigoso no solo. Além disso, alguns resíduos de agrotóxicos são dispersos para atmosfera. A aplicação do produto é distribuída em grandes áreas e, muitas vezes, aplicado repetidamente. Com o passar do tempo eles podem ser detectados no solo, água e alimentos. Assim, o intervalo de tempo entre as aplicações é fundamental para evitar riscos à saúde pública e manter o equilíbrio ambiental.

\subsubsection{Agrotóxicos}

Os agrotóxicos são considerados substâncias perigosas e podem ser chamados de agroquímicos, defensivos agrícolas, produtos fitossanitários, pesticidas, entre outros. Porém, o termo agrotóxico foi adotado neste trabalho, seguindo a nomenclatura empregada pela legislação brasileira. As embalagens de agrotóxicos são parte do problema do gerenciamento dos resíduos sólidos municipais e os compostos empregados na composição destes produtos foram detectados nas amostras de água coletadas, assim foi realizada revisão bibliográfica sobre o assunto.

No que se refere à legislação, a Lei $n^{0} 7.802$, de 11/07/1989 (Art.6 ${ }^{\circ}$, atualizado pela Lei $n^{\circ} 9.974$, de 06/06/2000), regulamentada pelo Decreto $n^{\circ} 4.074$, de 04/01/2002, trata da 
devolução das embalagens vazias de agrotóxicos aos estabelecimentos comerciais em que foram adquiridas. O Decreto $\mathrm{n}^{\circ} 5.981$, de 06/12/2006, complementa o anterior. Estas legislações determinam o prazo para a devolução da embalagem de até um ano da data da compra do produto, podendo ser intermediada por postos ou centros de recolhimento, desde que autorizados e fiscalizados pelo órgão competente. Além disso, estão previstos o projeto e fabricação de embalagens para facilitar a lavagem, reutilização e reciclagem; a tríplice lavagem; a responsabilidade pelo destino final das embalagens vazias dos produtos às empresas produtoras e comercializadoras de agrotóxicos, entre outros. A Resolução CONAMA $n^{\circ} 334$, de 03/04/2003, trata do licenciamento ambiental dos estabelecimentos destinados ao recebimento de embalagens vazias de agrotóxicos.

Os agrotóxicos são compostos sintetizados com a função de garantir o controle de pragas, doenças e plantas daninhas, evitando comprometer organismos não-alvo (Silva e Fay, 2004). Porém, compostos persistentes ou recalcitrantes podem provocar impactos negativos, como afetar a saúde humana e animal, a qualidade do solo e da água, entre outros. Por isso, os agrotóxicos podem ser considerados venenos, devido sua natureza, propósito e quantidade.

Atualmente o mercado dispõe de muitos produtos, porém novas moléculas são necessárias devido à resistência de espécies que se multiplicam rapidamente.

Os agrotóxicos podem ser classificados em inseticidas, fungicidas, herbicidas, nematicidas e moluscicidas, bem como divididos em não-sistêmicos e sistêmicos. Os nãosistêmicos ou de contato não penetram no tecido vegetal, portanto não são transportados dentro do sistema vascular das plantas; são suscetíveis ao clima e não protegem a planta contra o ataque de pragas. Os sistêmicos, introduzidos após 1940, penetram na cutícula das plantas e movimentam-se pelo sistema vascular.

\section{Inseticidas}

Os inseticidas têm a função de combater o ataque de insetos nas plantas, entre eles: arsenito de cobre impuro adaptado para combater o Colorado potato beetle, arsenito de chumbo (aerossol) usado em pomares, arsenato de cálcio (pó) usado em culturas, cianeto de hidrogênio adaptado para uso agrícola e um inseticida sintético introduzido em 1929, o éter ditiocianodietílico (aerossol) usado para combater moscas. O piretróide e a nicotina são exemplos de inseticidas orgânicos neurotóxicos.

Os inseticidas orgânicos, dentre eles os de origem vegetal, são menos tóxicos aos mamíferos e apresentam baixa persistência no ambiente, porém são muito tóxicos aos insetos, podendo ser usados em baixa dosagem. São formulados em aerossóis caseiros ou concentrados e em pó para uso em vegetais, frutíferas, arbustos e flores. 
O primeiro inseticida orgânico sintético foi o dicloro-difenil-tricloroetano (DDT). Os inseticidas organoclorados como DDT, benzeno, hexaclorobenzeno, clordano, heptacloro, toxafeno, metoxicloro, aldrim, dieldrim, endrim e endossulfam, contêm moléculas de carbono, cloro e hidrogênio, são persistentes em solo, tóxicos para artrópodes, relativamente não-solúveis, possuem baixa volatilidade e são lipofílicos. Não são muito tóxicos para mamíferos, porém são persistentes e tendem a bioconcentrar-se em tecidos vivos, além de apresentarem mobilidade na cadeia alimentar, por isso foram banidos ou restringidos. Os mais persistentes desse grupo são o DDT, endrim e dieldrim, por isso muitos rios e solos podem estar contaminados por estes compostos. As restrições legais quanto ao uso de organoclorados foram criadas devido à necessidade de substitutos.

Os organofosforados, derivados do ácido fosfórico, como parationa, diazinom, triclorfom, forato, carbofenotiona, dissulfotom, dimetoato, fentiona, tionazina, menazom, dinofenato e clorfenvinfós, surgiram em 1945 para substituir os organoclorados. São menos persistentes que os organoclorados, porém apresentam alta toxicidade para mamíferos (insuficiência respiratória), são potencialmente tóxicos para pássaros e outros animais, podem contaminar água e alimento humano.

Os inseticidas carbamatos incluem também acaricidas, fungicidas e nematicidas. São mais persistentes que os organofosforados no solo e tóxicos aos mamíferos. Segundo Câmara Neto e Augusto (2000), em locais onde as condições sanitárias são precárias, foram usados raticidas de uso proibido e inseticidas de classe toxicológica II (altamente tóxico), a base de carbamatos e organofosforados, os quais provocaram alergia, bronquite, asma, cefaléia e fadiga crônica na população.

\section{Fungicidas}

As doenças provocadas por fungos são as mais difíceis de serem tratadas. Compostos de enxofre e cobre eram usados para proteger as plantas, antes de fungicidas orgânicos sintéticos serem desenvolvidos. Os fungicidas com enxofre orgânico (captam, tiram, manebe e zinebe) ainda são usados como protetores, porém sua persistência é limitada nas folhagens ou no ambiente. O óxido cúprico e o oxicloreto de cobre são muito usados como protetores.

Os compostos mercuriais orgânicos foram introduzidos em 1915. Atualmente são pouco empregados devido à toxicidade de seus componentes e ao acúmulo no ambiente, porém foram muito utilizados para o tratamento de sementes de cereais.

Produtos com baixa toxicidade para mamíferos e eficiência no controle de doenças, como benomil, etirimol e tiofanato metílico, foram desenvolvidos posteriormente e possuem atividade sistêmica. A maioria dos fungicidas recentes possui baixa toxicidade aos 
mamíferos, exceto os carbamatos, e estreito espectro de toxicidade para organismos do solo e aquáticos, apresentando sério impacto ambiental em microrganismos do solo.

\section{Herbicidas}

Herbicidas são substâncias químicas que selecionam populações de plantas e são classificados em: seletivos (utilizados para matar ervas daninhas sem prejudicar o cultivo) e não seletivos (aplicados em folhagens ou no solo, dependendo do seu modo de ação). Existem também herbicidas "de contato", como dinitrofenóis, cianofenóis, pentaclorofenol e paraquatee, são mais efetivos contra ervas daninhas anuais e não são persistentes. As triazinas possuem baixa toxicidade aos mamíferos, mas podem persistir no solo por muitos anos, são ligeiramente tóxicas aos organismos do solo e moderadamente tóxicas aos organismos aquáticos, além de poderem causar outros danos ambientais diretos ou indiretos devido ao efeito residual.

Os herbicidas sistêmicos como triclorofenoxiacético (2,4,5-T, agente laranja); diclorofenol (2,4-D); ácido ariloxialcanóico (MCPA) e CMPP (Ácido 2-metil-4clorofenossipropanóico), herbicida fosforado, não são persistentes no solo e são seletivos em relação às espécies de plantas. A maioria desses compostos é solúvel, atinge facilmente as águas subterrâneas e não são muito tóxicos aos peixes.

Um dos primeiros herbicidas introduzidos como esterilizador de solo em 1900 foi o arsenato de sódio. Posteriormente surgiram o clorato de sódio, o óleo diesel e o solvente de Stoddard, considerado altamente fitotóxico. A seguir surgiram o monosódio metanoarsenato (MSMA), o dissódio metanoarsenato (DSMA) e o ácido cacodílico, usado para o controle de gramíneas indesejáveis.

No Brasil as culturas de soja, cana-de-açúcar, milho e arroz concentram mais de $80 \%$ dos negócios com herbicidas, atingindo cerca de U\$ 1,37 bilhão em 1998, devido ao aumento da produtividade e por exercerem influência na estabilização do preço da produção agrícola. Por isso o uso desses compostos está em expansão.

As vantagens do emprego desses compostos são pequeno acúmulo de resíduos quando aplicados antes da colheita e não apresentam toxicidade aguda para mamíferos. Porém podem causar intoxicação, relacionada ao manejo inadequado na preparação da calda ou na aplicação, bem como fitotoxicidade em áreas adjacentes, como é o caso da aplicação de 2,4-D no Paraná (Oliveira Junior, 2001 citado por Silva e Fay, 2004). A persistência pode causar limitação no desenvolvimento de espécies rotativas, bem como rejeição ao consumo devido à presença de resíduos em partes da planta. 


\section{Nematicidas}

Os nematicidas, empregados para o controle de nematóides, são altamente tóxicos aos mamíferos e apresentam amplo espectro, ou seja, podem matar ampla faixa de organismos tanto animal quanto vegetal. Não são persistentes no solo, porém pode causar danos localizados que podem permanecer por muito tempo. Entre os fumigantes do solo encontram-se o diclopropene, metil isocianato, cloropicrim e brometo de metila. Outros como aldicarbe, dazomete e sódio metam são eficazes através do contato.

A fumigação do solo com brometo de metila, usado desde 1940, é considerada uma técnica de desinfestação, ou seja, como tratamento de grande número de patógenos do solo antes do plantio. Porém o produto apresenta desvantagens, como alta toxicidade e volatilidade, oferecendo risco ao aplicador; a volatilidade polui o ar de áreas vizinhas; reduz a biodiversidade do solo; forma resíduos no solo; contamina a água em áreas com aqüífero freático alto; há o problema com o destino das embalagens e reduz a camada de ozônio. $\mathrm{O}$ produto deverá ser eliminado até 2010, segundo o Protocolo de Montreal, realizado em Viena em dezembro de 1995, do qual o Brasil é signatário. Assim, o país deve incentivar a pesquisa e a adoção de alternativas ao produto, bem como restringir o consumo.

\section{Moluscicidas}

Os moluscicidas, metaldeído e metiocarbe, são usados para o combate aos moluscos terrestres podendo matar vertebrados e insetos, outros são usados para o controle de cobras aquáticas, como o $\mathrm{N}$-tritil morfolina, sulfato de cobre, niclosamina e pentaclorofenato de sódio, tóxicos aos peixes. Há relatos da morte de mamíferos selvagens, de insetos que se alimentam de moluscos em decomposição, bem como de aves que se alimentam desses insetos e dos moluscos.

\section{Características gerais dos agrotóxicos}

É importante destacar que a maioria dos compostos orgânicos apresenta densidades menores que a água, como os hidrocarbonetos alifáticos, já os compostos orgânicos halogenados apresentam densidades maiores. A densidade do composto determina seu potencial de lixiviação e os efeitos da densidade e da miscibilidade determinam seu destino.

A bioacumulação de um agrotóxico aumenta com o declínio da solubilidade. A solubilidade do agrotóxico depende da quantidade do composto, bem como da temperatura e $\mathrm{pH}$ da água e indica a tendência do composto ser carreado no solo para as águas superficiais. Porém, para estimar a percolação do agrotóxico no solo, a solubilidade deve ser analisada em conjunto com a partição solo/água, a fim de prever uma possível 
contaminação da água subterrânea. Moléculas altamente solúveis tendem a ser mais rapidamente biodegradáveis no solo e na água. A solubilidade do composto também depende das características do solvente.

A degradabilidade dos agrotóxicos é expressa pela meia-vida, a qual é muito variável e influenciada pelas condições ambientais. A meia-vida de uma molécula orgânica é "o tempo requerido para que metade da concentração do agrotóxico desapareça, independentemente da sua concentração inicial no solo" (Silva e Fay, 2004). Os organofosforados têm longevidade de dias, os herbicidas (triazinas) de meses e compostos como o DDT e dieldrim têm longevidade de anos.

Com base na Agência Nacional de Vigilância Sanitária (ANVISA, 2005), o Brasil é o segundo maior consumidor mundial de agrotóxicos. Segundo a agência, o DDT e muitos organoclorados foram banidos do país devido aos efeitos nocivos. Nove culturas estão sendo monitoradas há quatro anos, a partir da criação do Programa de Análise de Resíduos de Agrotóxicos em Alimentos (PARA). Entre 2001 e 2004, quatro mil amostras de alimentos foram analisadas e $28 \%$ apresentaram problemas devido ao uso de agrotóxico não autorizado para determinada cultura e uso do produto sem orientação técnica, registrando valores estavam acima do permitido pela legislação. A ANVISA destaca que atualmente as culturas são rastreáveis, pois os supermercados são obrigados a identificar o produtor, caso contrário pagarão multa de $\mathrm{R} \$ 3$ mil.

Os danos causados pelo consumo de produtos com agrotóxico podem ser cumulativos e desconhecidos, assim o risco para o consumidor é a longo prazo. Porém, para o trabalhador rural o risco é imediato, principalmente devido à falta de equipamentos de proteção individual. Dessa forma, estudos sobre os riscos que esses produtos podem causar à saúde humana devem ser incentivados.

\subsection{Recursos Hídricos}

O modelo de gestão das águas adotado pelo Brasil se baseou na experiência francesa, tomando a bacia hidrográfica como unidade territorial para o planejamento, com base no Artigo $1^{\circ}$, inciso V, da Lei 9.433/1997 que institui a Política Nacional de Recursos Hídricos.

"A expressão bacia hidrográfica significa território, área e não água. Trata-se da área de drenagem de um curso de água ou lago e não destes. São áreas geográficas dotadas de determinada inclinação, em virtude da qual todas as águas se dirigem, direta ou indiretamente, a um corpo de água central. A bacia hidrográfica pode ser marítima, fluvial ou lacustre, segundo a classificação do corpo de água para o qual convirjam as águas." "As 
bacias hidrográficas são separadas entre si por montanhas ou colinas, cuja linha mais alta é denominada divisor de águas e a mais baixa talvegue" (Pompeu, 2003).

De acordo com Marcondes (1999), os recursos hídricos devem ser geridos com base em suas bacias hidrográficas e não baseados apenas nos limites administrativos dos municípios. Para um planejamento ambiental efetivo nas bacias, a formação de consórcios intermunicipais é uma proposta viável para reunir os interesses comuns dos municípios, com vistas à formulação de políticas públicas que atendam às necessidades regionais.

Dessa forma, foi criado o Conselho de Recursos Hídricos para garantir a participação paritária de membros da sociedade civil, representantes do Estado e dos municípios. O modelo é composto por Unidades de Gerenciamento de Recursos Hídricos (UGRHIs), Comitês de Bacias e outras instâncias com a função de oferecer suporte técnico às decisões. Para viabilizar as propostas foi criado o Fundo Estadual de Recursos Hídricos (FEHIDRO) para financiar a execução das ações. Às Agências de Bacias foi dado autonomia administrativa para gerir os recursos financeiros de cada bacia.

O Estado de São Paulo, por exemplo, foi dividido em 22 UGRHIs (Quadro 2), criadas pela Lei Estadual nº 9.034, de 27/12/1994.

Quadro 2 - UGRHIs do Estado de São Paulo

\begin{tabular}{|cl|cl|}
\hline UGRHI & Bacia Hidrográfica & UGRHI & Bacia Hidrográfica \\
\hline 1 & Mantiqueira & 12 & Baixo Pardo/Grande \\
2 & Paraíba do Sul & 13 & Tietê/Jacaré \\
3 & Litoral Norte & 14 & Alto Paranapanema \\
4 & Pardo & 15 & Turvo/Grande \\
5 & Piracicaba/Capivari/Jundiaí & 16 & Tietê/Batalha \\
6 & Alto Tietê & 17 & Médio Paranapanema \\
7 & Baixada Santista & 18 & São José dos Dourados \\
8 & Sapucaí/Grande & 19 & Baixo Tietê \\
9 & Mogi-Guaçu & 20 & Aguapeí \\
10 & Tietê-Sorocaba & 21 & Peixe \\
11 & Ribeira de lguape/Litoral Sul & 22 & Pontal do Paranapanema \\
\hline
\end{tabular}

A Lei Estadual 9.866/1997 estabelece diretrizes e normas para a proteção das bacias hidrográficas dos mananciais de interesse regional no Estado de São Paulo. As medidas de controle do território devem abordar as relações entre o espaço urbano e o ambiente, principalmente às margens dos mananciais. Essa lei é conhecida como Lei das Águas, a qual determina que a 
gestão deve contemplar seu uso múltiplo, não favorecendo determinada atividade ou determinado grupo social, devendo por isso ser integrada, descentralizada e contar com ampla participação social, de forma a incorporar representantes do poder público, dos usuários (aqueles que fazem uso econômico da água) e das diversas comunidades, através de um ente colegiado, o Comitê de Bacia Hidrográfica, cujo objetivo seria garantir a pluralidade de interesses na definição final do destino a ser dado aos recursos hídricos no âmbito de cada bacia hidrográfica, possibilitar a mais ampla fiscalização das ações desde sua definição, a elaboração de projetos e o controle da eficácia e da destinação dos recursos, assim como a universalização das informações existentes e produzidas sobre recursos hídricos.

A referida lei apresenta dispositivos para disciplinar o uso do solo nas bacias, ou seja, o controle espacial. Esses dispositivos provêm da legislação urbana e servem para indicar uma ocupação desejável na bacia, a qual é formada por um conjunto de municípios interligados por corpos d'água.

A intensa urbanização gera um volume grande de carga poluidora nos corpos d'água e pode comprometer a capacidade de assimilação dos recursos hídricos e provocar perda de água potável. Cada reservatório possui suas características, capacidade de diluição e autodepuração próprias, assim a ocupação do solo deve respeitar a qualidade de água que se pretende manter.

A instalação de equipamentos urbanos deve se dar em áreas ambientais menos frágeis, principalmente quando estes podem oferecer risco de poluição e contaminação aos recursos naturais. Conforme a finalidade da obra, as restrições ambientais são maiores, um exemplo é o distanciamento dos recursos hídricos.

Esta pesquisa adotou a bacia hidrográfica Tietê-Jacaré (UGRHI-13) como unidade de planejamento para o estudo dos resíduos sólidos urbanos, destacando sua relação com os recursos hídricos.

\subsubsection{Bacia Tietê - Jacaré}

A Bacia Hidrográfica Tietê - Jacaré (BHTJ) está localizada no centro do Estado de São Paulo, Brasil, e pertence a $13^{a}$ Unidade de Gerenciamento dos Recursos Hídricos (UGRHI - 13), conforme Figura 8.

A BHTJ drena área de $11.779 \mathrm{~km}^{2}$ e possui cerca de 1.423 .618 habitantes, o que corresponde a mais de $3 \%$ da população do Estado. O grau de urbanização da UGRHI-13 é de $96 \%$. A BHTJ é composta por culturas da laranja, cana-de-açúcar, reflorestamento e pastagem. Dentre as principais atividades industriais destacam-se a sucroalcooleira, mineração, fundição, refino de óleos vegetais e calçados (CETESB, 2007c, p.198). 

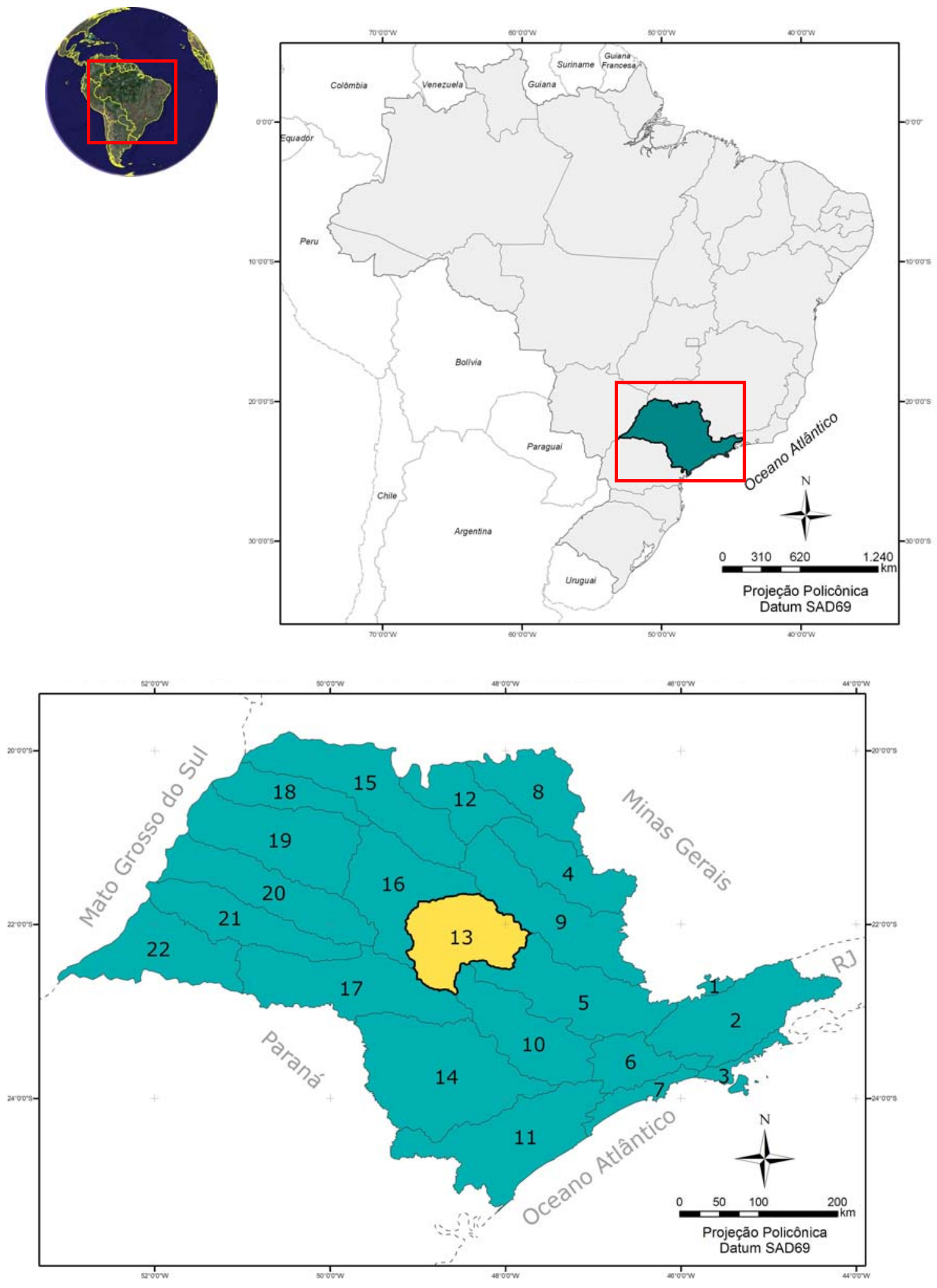

Figura 8 - Localização da UGRHI - 13 no Estado de São Paulo 
De acordo com a caracterização das Unidades de Gerenciamento de Recursos Hídricos do Estado de São Paulo (SÃO PAULO, 2001), a Bacia Tietê-Jacaré está localizada na Depressão Periférica e pertence aos Sistemas Aqüíferos Bauru, Guarani e Serra Geral. Segundo IPT (1981), as Formações Marília, Santo Anastácio, Adamantina e Caiuá pertencem ao Grupo Bauru e as Formações Botucatu, Pirambóia e Serra Geral pertencem ao Grupo São Bento e fazem parte da Bacia do Paraná.

Conforme CETESB (2007e, p.1), o Aqüífero Bauru ocupa 42\% da área do Estado de São Paulo; o Aqüífero Guarani apresenta extensa área de afloramento e excelente potencial de abastecimento tanto em quantidade como em qualidade e o Aqüífero Serra Geral apresenta viabilidade econômica de abastecimento.

As águas do Aqüífero Bauru são pouco salinas, com $\mathrm{pH}$ tendendo à neutralidade. $\mathrm{O}$ aqüífero é poroso, praticamente de ocorrência livre em toda a sua extensão, havendo localmente regimes de semi-confinamento ou confinamento, o que o torna a principal fonte de explotação de água subterrânea da região, com a mesma importância no Estado que o Aqüífero Guarani, além disso é vulnerável à influência de cargas poluidoras de fontes difusas de origem antrópica. A qualidade das águas do Aqüífero Guarani, em geral, é ótima, apresenta baixa salinidade e $\mathrm{pH}$ tendendo à neutralidade. Em poços profundos foram obtidos valores mais elevados de temperatura, condutividade elétrica, sódio e fluoreto. Foram detectadas concentrações elevadas de bário e nitrato na UGRHI 13. As águas do Aqüífero Serra Geral apresentam boa qualidade, são predominantemente alcalinas e têm baixa salinidade. Na UGRHI 13 as águas deste aqüífero requerem atenção quanto ao nitrato (CETESB, 2007e, p.136).

A BHTJ é composta pelos rios Tietê, Jacaré - Guaçu, Jacaré - Pepira, Lençóis, Bauru e Jaú (Figura 9), bem como pelos reservatórios de Bariri, Ibitinga, Lobo e Barra Bonita. 


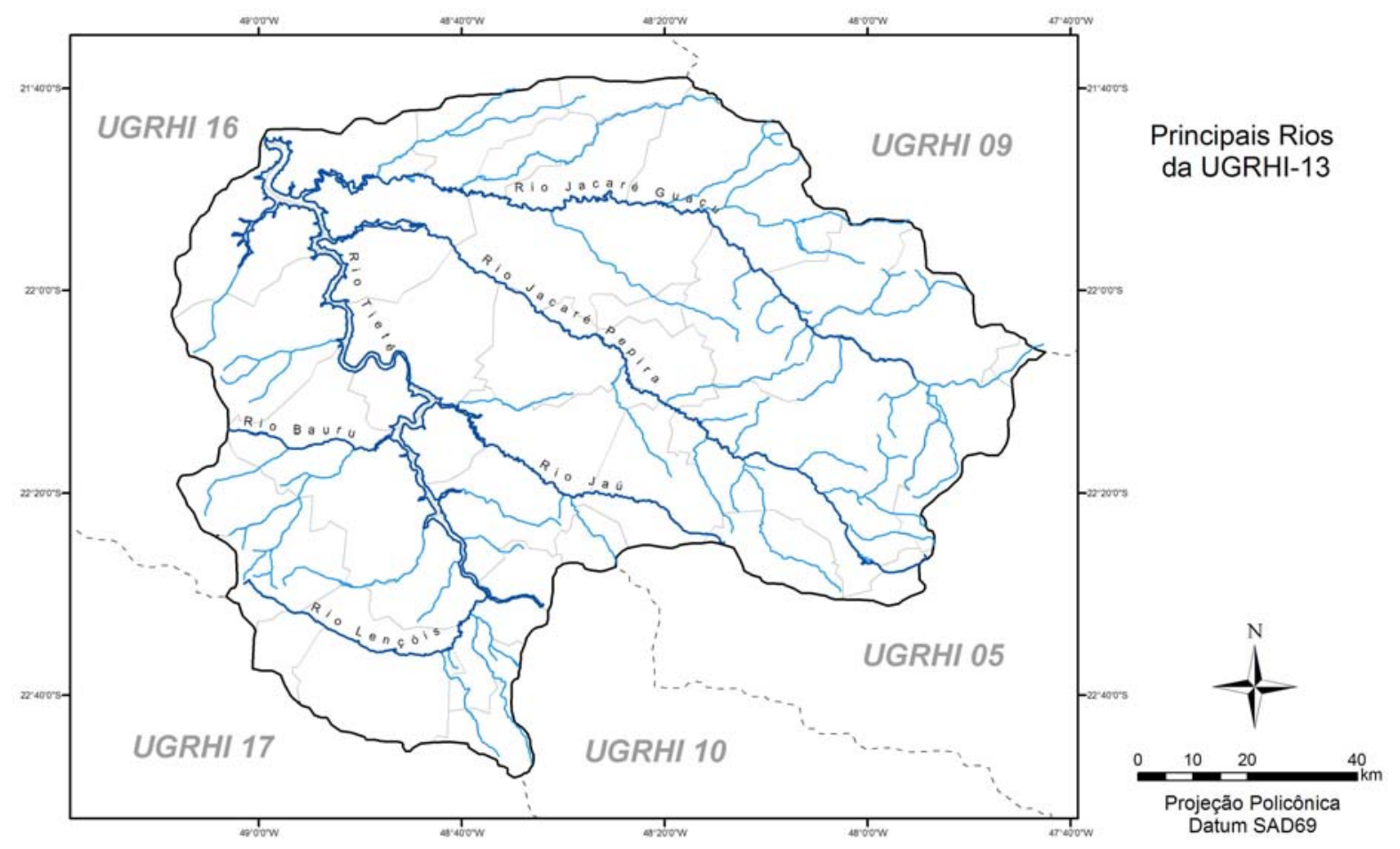

Figura 9 - Principais rios da UGRHI - 13

De acordo com CETESB (2001b), a água subterrânea é a principal fonte de abastecimento público de 13 UGRHIs do Estado, inclusive da UGRHI-13, portanto deve ser priorizada dentro da gestão dos recursos hídricos desta região com políticas para controlar e prevenir a poluição, com o objetivo de proteger sua qualidade para o consumo.

Seus recursos hídricos servem para o abastecimento público e industrial, geração de energia elétrica, recepção de efluentes domésticos e industriais, bem como para a irrigação.

De acordo com o Índice de Qualidade das Águas para fins de Abastecimento Público (IAP), $80 \%$ das águas superficiais da bacia apresentam qualidade boa e $20 \%$ qualidade regular. Com base no Índice de Qualidade das Águas para Proteção da Vida Aquática (IVA), $20 \%$ das águas superficiais apresentam qualidade boa, $60 \%$ qualidade regular e $20 \%$ qualidade ruim (CETESB, 2007c, p.310).

Conforme CETESB (2007c, p.310), apenas 33\% do esgoto gerado na bacia é tratado. Com base nesse dado, a CETESB em seu Relatório de Qualidade das Águas Interiores no Estado de São Paulo de 2006 recomenda investimentos no tratamento de esgoto sanitário nos municípios de Bauru, São Carlos e Lençóis Paulista. Vale ressaltar que em São Carlos a Estação de Tratamento de Esgoto (ETE) está sendo construída.

Os municípios que compõe a BHTJ são de pequeno e médio porte (Apêndice $C$ ), dos quais 33 municípios são de pequeno porte e apenas quatro são de porte médio, com base na classificação adotada pelo IBGE (2004), apresentada na Tabela 7. 
Tabela 7 - Classificação dos municípios por número de habitantes

\begin{tabular}{c|c}
\hline Classificação dos municípios & População \\
\hline Grande porte & acima de 500 mil habitantes \\
Médio porte & entre 100 e 500 mil habitantes \\
Pequeno porte & até 100 mil habitantes \\
\hline
\end{tabular}

Fonte: IBGE (2004)

De acordo com o Relatório Zero elaborado pelo Instituto de Pesquisas Tecnológicas (IPT, 2000), 34 municípios possuem sede administrativa na UGRHI - 13: 1-Agudos, 2Araraquara, 3-Arealva, 4-Areiópolis, 5-Bariri, 6-Barra Bonita, 7-Bauru, 8-Boa Esperança do Sul, 9-Bocaina, 10-Boracéia, 11-Borebi, 12-Brotas, 13-Dois Córregos, 14-Dourado, 15Gavião Peixoto, 16-lacanga, 17-Ibaté, 18-Ibitinga, 19-Igaraçu do Tietê, 20-Itaju, 21-Itapuí, 22-Itirapina, 23-Jaú, 24-Lençóis Paulista, 25-Macatuba, 26-Mineiros do Tietê, 27-Nova Europa, 28-Pederneiras, 29-Ribeirão Bonito, 30-São Carlos, 31-São Manuel, 32-Tabatinga, 33-Torrinha e 34-Trabiju.

Outros três municípios possuem parte de seus territórios na UGRHI-13, porém sede administrativa em outras UGRHIs: Analândia (UGRHI-5), Matão (UGRHI-16) e São Pedro (UGRHI-5).

De acordo com o Artigo 70, parágrafo 20, da Lei Estadual n 9.034, de 27/12/1994, que criou a divisão do Estado de São Paulo em UGRHIs, "os Municípios cujo território compreende mais de uma bacia hidrográfica poderão participar dos comitês dessas diferentes bacias".

Assim, este estudo procurou conseguir informações sobre os resíduos sólidos gerados nos 37 municípios com território na UGRHI-13, conforme Apêndice C. Os espaços territoriais dos municípios devem estar incluídos no planejamento ambiental das bacias hidrográficas, uma vez que entende-se por território a base física que compreende os espaços terrestre, aquático e aéreo, onde há interação entre os seres bióticos e abióticos dentro deste limite geográfico.

O Comitê de Bacia Hidrográfica do Tietê-Jacaré (CBH-TJ) é constituído por municípios contidos e parcialmente contidos na bacia, desde que requeiram, conforme Artigo 50 de seu estatuto (CBH-TJ, 1999).

O CBH-TJ foi criado em 10/11/1995 (IPT, 2000), de acordo com o disposto no Art.70, inciso II, da Lei Estadual n. ${ }^{\circ}$ 9.034/1994, que trata do Plano Estadual de Recursos Hídricos (PERH). O Comitê é um órgão colegiado, de caráter consultivo e deliberativo do Sistema Integrado de Gerenciamento de Recursos Hídricos (SIGRH), com atuação na BHTJ, definida 
pelo PERH. Seus objetivos, competências, sede, composição, reuniões, procedimentos e disposições transitórias foram estabelecidos em estatuto, conforme CBH-TJ (1999).

Segundo informações de Braz Aureliano Biagioni Passalacqua, secretário executivo do CBH-TJ, até maio de 2007 nenhum Consórcio Intermunicipal havia sido constituído na bacia, conforme recomenda o Art.70, inciso V, da Lei Estadual n. ${ }^{\circ}$ 9.034/1994: "o incentivo a formação de consórcios intermunicipais nas bacias ou regiões hidrográficas, em conformidade com o artigo 31 , da Lei $n^{\circ} 7.663$, de 30 de dezembro de 1991", que dispõe sobre a Política Estadual de Recursos Hídricos.

\subsubsection{Resíduos sólidos domiciliares na UGRHI-13}

Com base no Inventário Estadual de Resíduos Sólidos Domiciliares (CETESB, 2007a), em 2006 foram geradas cerca de 748,5t/d de RSD na Bacia Tietê-Jacaré, considerando-se a produção dos 37 municípios com território na UGRHI-13 (Apêndice C).

Em 2000 a BHTJ gerava cerca de 610t/d de RSD e possuía uma população de 1.254.100 habitantes (CETESB, 2001c, p.65). Comparativamente, depreende-se que em seis anos houve um aumento de 169.518 habitantes e de 138,5t/dia de RSD. Esses resultados indicam que a região necessita de maiores investimentos em infra-estrutura e nos serviços de saneamento.

Ao longo dos dez anos de publicação do Inventário Estadual de Resíduos Sólidos Domiciliares, foram constatadas alterações no IQR dos municípios da UGRHI-13, o que reflete as mudanças que ocorrem nas áreas de disposição final de resíduos sólidos, conforme (CETESB, 2007a, p.14-17; 26).

As Agências Ambientais da CETESB de Araraquara e Bauru são as responsáveis pelo controle e fiscalização dos aterros e lixões da UGRHI - 13.

Com base em CETESB (2007a), 16,21\% dos municípios da BHTJ dispõe inadequadamente seus RSD, 40,54\% dispõe em condições controladas e 43,24\% dispõe adequadamente, como mostra a Tabela 8.

Tabela 8 - Condições das áreas de disposição final de resíduos sólidos na UGRHI-13 em 2006

\begin{tabular}{|c|c|c|}
\hline $\begin{array}{c}\text { Número de municípios com território na } \\
\text { UGRHI-13 }\end{array}$ & IQR & Enquadramento \\
\hline 06 & $0,0-6,0$ & Inadequadas (I) \\
\hline 15 & $6,1-8,0$ & Controladas (C) \\
\hline 16 & $8,1-10,0$ & Adequadas $(\mathrm{A})$ \\
\hline Total & & \\
\hline
\end{tabular}

IQR: Índice de Qualidade de Aterro de Resíduos

Fonte: CETESB (2007a) 
Vale ressaltar que os dados da Tabela 9 não significam que a BHTJ possui 16 aterros sanitários, 15 aterros controlados e seis lixões. Dentro das áreas consideradas adequadas podem estar incluídos aterros sanitários e controlados.

Os itens considerados pela CETESB para o enquadramento em relação ao IQR são: profundidade do aqüífero freático, proximidade de corpos d’água, proximidade de núcleos habitacionais, permeabilidade do solo, disponibilidade de material para recobrimento e qualidade do mesmo, isolamento visual da vizinhança, legalidade de localização, cercamento da área, portaria, impermeabilização da base do aterro, drenagem de chorume, gases e águas pluviais, trator de esteiras, vigilantes, acesso à frente de trabalho, monitoramento de águas subterrâneas, presença de catadores, urubus, garças, moscas, criação de animais, resíduo descoberto, descarga de resíduos de serviços de saúde ou industriais, entre outros.

Em 2000 apenas $34,3 \%$ dos municípios da BHTJ depositavam seus RSD adequadamente (CETESB, 2001c, p.65). Dessa forma, conclui-se que a situação de disposição final destes resíduos na UGRHI-13 melhorou, com base no levantamento realizado pela CETESB entre 1997 e 2007.

Com relação os recursos aplicados na área de resíduos sólidos na BHTJ, todas as solicitações foram canceladas em 2006 e não houve solicitação em 2007, segundo Braz Aureliano Biagioni Passalacqua, secretário executivo do Comitê da bacia.

\subsubsection{Problemática}

A água é um bem essencial, pois é fonte de vida para os seres vivos. É um recurso precioso que deve ser conservado e protegido, visto que é bastante explorado pelo homem devido à sua grande utilidade. Ela pode servir para abastecimento doméstico e industrial, geração de energia elétrica, irrigação, recreação, pesca, navegação, entre outras finalidades. Além de ser elemento necessário para várias atividades humanas, faz parte do meio ambiente, por isso não pode ser comprometido.

Com o passar do tempo, a urbanização tende a aumentar e, conseqüentemente, o consumo de água. Devido ao crescimento populacional, ao assoreamento dos mananciais, à poluição provocada por diversas fontes, entre outros fatores, provavelmente a quantidade de água disponível por habitante será reduzida nos próximos anos.

Aproximadamente 1,1 bilhão de pessoas não têm acesso ao fornecimento de água potável e saneamento adequado, segundo o Programa Mundial da Preservação Hídrica da UNESCO (Mendes, 2003). Dos 1.385 milhões de $\mathrm{Km}^{3}$ de água existente no planeta, apenas 
$3 \%$ é de água doce. Cerca de $11,6 \%$ da água doce do mundo se encontra no Brasil (UNESCO, 2004).

As principais fontes de abastecimento de água doce são os rios, lagos e represas. Deste total, a maior parte é difícil de ser aproveitada por concentrar-se em calotas polares e à grandes profundidades. Cerca de $30 \%$ da água doce do mundo está armazenada como água subterrânea. Apesar dessas águas serem mais protegidas da poluição, quando comprometidas, sua recuperação é mais lenta quando comparada às águas superficiais.

O adensamento populacional desordenado somado à instalação progressiva das diversas atividades antrópicas provocam impactos negativos sobre 0 ambiente, principalmente, sobre os recursos hídricos, refletindo na qualidade e quantidade das águas que servem à população.

A água pode definir o desenvolvimento de uma região, porém é um recurso finito, por isso ressalta-se a importância do uso adequado e controlado. A escassez de água é um problema enfrentado por vários países devido, principalmente, à poluição (UNESCO, 2004).

O Brasil se caracteriza pela distribuição diferenciada da água pelas diversas regiões do país. Algumas dessas regiões são mais populosas, o que exige uma demanda maior do recurso, assim o bom gerenciamento dos recursos hídricos é fundamental. 0 comprometimento da qualidade das águas ocorre, principalmente, em áreas urbanizadas, industrializadas, bem como em áreas agrícolas e de pastagem (Daniel, 2001). Efluentes domésticos e industriais são lançados in natura nos corpos d'água, sem tratamento prévio, bem como resíduos sólidos são depositados nas margens de cursos d'água, provocando assoreamento.

As emissões de substâncias como metais pesados, por exemplo, estão associados aos problemas ambientais causados nos recursos hídricos subterrâneos, enquanto que o lançamento das cargas orgânicas degradáveis polui os recursos hídricos superficiais (São Paulo, 1997).

As águas superficiais e subterrâneas são consideradas o mesmo recurso, porém fluem por meios físicos distintos (CETESB, 2001b). Ambas são bens dos Estados, segundo o Artigo 26, Capítulo III, da Constituição Federal.

Alguns fatores contribuem para o agravamento do uso das águas superficiais no Brasil, entre eles: a quantidade de água disponível não é mais suficiente para suprir a demanda atual, a deficiência dos sistemas de saneamento básico e a dificuldade em tornar a água potável devido aos custos elevados para o tratamento (CETESB, 2001b).

A maioria dos municípios brasileiros é abastecida por águas superficiais e subterrâneas não tratadas, assim ao consumir essas águas a população pode adquirir doenças de veiculação hídrica, como febres, desinterias, giardíase, hepatites, entre outras. 
A gestão das águas subterrâneas envolve algumas questões como: atividades antrópicas, transporte de contaminantes, atenuação das cargas poluidoras, construção dos poços tubulares e extração do recurso hídrico.

Em virtude dos problemas apontados em relação às águas superficiais, a exploração dos recursos hídricos subterrâneos como fonte de abastecimento público, uso industrial, agricultura, mineração e geração de energia é crescente e se tornou viável no Brasil devido à maior disponibilidade, eficácia e custos reduzidos (CETESB, 2001b).

A exploração das águas subterrâneas intensificou-se no país a partir da década de 70 . Atualmente cerca de 200.000 poços de águas subterrâneas estão ativos no Brasil e servem para abastecimento urbano (São Paulo, 1997). Segundo o Departamento de Águas e Energia Elétrica, atualmente existe cerca de 18.000 poços cadastrados no Estado Estado de São Paulo.

Conforme CETESB (2001b), cerca de 71\% dos municípios do Estado de São Paulo é abastecido total ou parcialmente por águas subterrâneas. A água subterrânea é encontrada nos espaços vazios do solo preenchidos por água, ou seja, nas zonas saturadas. A migração de poluentes pelo solo pode alterar a qualidade das águas tanto superficiais quanto subterrâneas. Dessa forma pode ocorrer o comprometimento do abastecimento público, industrial, agrícola, comercial, lazer e serviços.

Porém, a maioria dos poços não é perfurada adequadamente, tão pouco, autorizada.

Dos 184 poços monitorados no Estado de São Paulo, alguns apresentaram alteração de qualidade, principalmente por nitrato, cromo e fluoreto (CETESB, 2007e, p.135). No período entre 2004 e 2006, 29 pontos apresentaram indícios de alteração antrópica, com concentração de Nitrogênio Nitrato superir a 5,0mg/L (CETESB, 2007e, p.126). Com relação ao cromo, 47 análises, o equivalente a $4 \%$ das amostras, apresentaram valores acima de 0,05mg/L (CETESB, 2007e, p.129). Foram obtidos valores elevados de fluoreto em três pontos localizados em Amparo, São Paulo e Cesário Lange (CETESB, 2007e, p.130).

Devido à expansão demográfica e econômica, estima-se que o uso dos recursos hídricos subterrâneos aumente nos próximos anos para atender as necessidades da população.

Em virtude disso, os aqüíferos estão vulneráveis aos impactos da extração descontrolada. Dessa forma, a qualidade das águas subterrâneas pode estar sendo prejudicada devido à má ocupação e uso inadequado do solo. Assim, a CETESB (2007e, p.135) recomenda "o monitoramento e a vigilância da qualidade das águas subterrâneas quanto a substâncias orgânicas voláteis e metais, principalmente em poços localizados em centros intensamente urbanizados e industrializados". Além disso, com o objetivo de ampliar o conhecimento sobre a qualidade das águas subterrâneas no Estado e subsidiar ações de prevenção e controle da poluição, a CETESB (2007e, p.136) aponta a necessidade de integração das informações obtidas nos monitoramentos executados por outras instituições, em um sistema de informações georeferenciado. 
Além do problema relacionado à intensa extração das águas subterrâneas, os locais de disposição final de resíduos sólidos podem comprometê-las, principalmente na ausência de sistemas para evitar a poluição e contaminação ambiental.

Segundo o mapeamento realizado no Estado de São Paulo em 1997, cerca de 10 desses empreendimentos estavam localizados em áreas de alta vulnerabilidade e 23 em áreas de vulnerabilidade média, como mostra o Quadro 3 (São Paulo, 1997).

Quadro 3 - Índice de vulnerabilidade do empreendimento no Estado de São Paulo

\begin{tabular}{|c|cccc|}
\hline Carga & \multicolumn{4}{|c|}{ Índice de vulnerabilidade } \\
\cline { 2 - 5 } Poluidora & Baixo & Médio & Alto & Não definido \\
\hline Lixão & 25 & 20 & 4 & 12 \\
Aterro Sanitário & - & 3 & 6 & 4 \\
\hline
\end{tabular}

Fonte: São Paulo (1997)

O tipo de disposição final dos resíduos sólidos domiciliares nas bacias hidrográficas do Estado de São Paulo está apresentado no Quadro 4.

Quadro 4 - Destino dos RSD e tipos de disposição nas bacias hidrográficas paulistas

\begin{tabular}{|c|c|c|c|c|c|}
\hline \multirow{2}{*}{ Bacia Hidrográfica } & \multirow{2}{*}{ UGRHI* } & \multicolumn{3}{|c|}{ Disposição final } & \multirow{2}{*}{ Tota } \\
\hline & & Adequada & Controlada & Inadequada & \\
\hline Mantiqueira & $\overline{1}$ & 2 & 1 & $\overline{0}$ & $\overline{3}$ \\
\hline Paraíba do Sul & 2 & 24 & 6 & 4 & 34 \\
\hline Litoral Norte & 3 & 2 & 0 & 2 & 4 \\
\hline Pardo & 4 & 8 & 6 & 9 & 23 \\
\hline Piracicaba/Capivari/Jundiaí & 5 & 35 & 12 & 10 & 57 \\
\hline Alto Tietê & 6 & 21 & 13 & 2 & 36 \\
\hline Baixada Santista & 7 & 6 & 1 & 2 & 9 \\
\hline Sapucaí/Grande & 8 & 14 & 5 & 3 & 22 \\
\hline Mogi-Guaçu & 9 & 14 & 8 & 16 & 38 \\
\hline Tietê-Sorocaba & 10 & 18 & 8 & 7 & 33 \\
\hline Ribeira de Iguape/Litoral Sul & 11 & 4 & 3 & 16 & 23 \\
\hline Baixo Pardo/Grande & 12 & 7 & 2 & 3 & 12 \\
\hline Tietê/Jacaré & $13^{* *}$ & 17 & 13 & 5 & 35 \\
\hline Alto Paranapanema & 14 & 9 & 12 & 13 & 34 \\
\hline Turvo/Grande & 15 & 25 & 23 & 16 & 64 \\
\hline Tietê/Batalha & 16 & 23 & 7 & 3 & 33 \\
\hline Médio Paranapanema & 17 & 26 & 12 & 3 & 41 \\
\hline São José dos Dourados & 18 & 5 & 18 & 2 & 25 \\
\hline Baixo Tietê & 19 & 16 & 9 & 17 & 42 \\
\hline Aguapeí & 20 & 18 & 8 & 6 & 32 \\
\hline Peixe & 21 & 9 & 12 & 2 & 23 \\
\hline Pontal do Paranapanema & 22 & 7 & 15 & 2 & 24 \\
\hline Total & & 310 & 194 & 143 & 647 \\
\hline
\end{tabular}

* Unidade de Gerenciamento de Recursos Hídricos

** o município de Pratânia foi considerado pela CETESB

Fonte: CETESB (2007a) 
Vale destacar que os dados do Quadro 3 podem ser atualizados pelos órgãos responsáveis com base nas informações divulgadas por CETESB (2007a). Segundo São Paulo (1997), os lixões pesquisados causam algum tipo de poluição nas águas subterrâneas. Dessa forma, a falta de planejamento com relação à disposição de resíduos sólidos acaba gerando gastos para as prefeituras, além de problemas ambientais futuros. Com isso, as políticas públicas devem estar pautadas em projetos de monitoramento regular dos recursos naturais.

Antes mesmo de alguma medida ser adotada, principalmente na área ambiental, é necessário que se tenha conhecimento da legislação já existente. Por exemplo, o Artigo $5^{\circ}$ da Resolução $n^{\circ}$ 12, de 19 de julho de 2000, do Conselho Nacional de Recursos Hídricos, estabelece que no diagnóstico do uso e ocupação do solo e dos recursos hídricos alguns itens devem ser abordados, entre eles: os aspectos sócio-econômicos; uso e ocupação atual do solo; usos, disponibilidade e demanda atual de águas superficiais e subterrâneas; identificação das fontes pontuais e difusas de poluição, além do estudo atual dos corpos hídricos, incluindo a condição de qualidade por trecho, baseado em estudos de autodepuração.

De acordo com CETESB (2001b), são necessárias informações sobre atividades clandestinas que possam representar riscos ambientais, visto que já se tem conhecimento sobre as áreas vulneráveis à poluição e à exploração intensa dos poços de água subterrânea.

O Estado de São Paulo é considerado uma região privilegiada por ser área de ocorrência de 10 sistemas aqüíferos, entre eles o Aqüífero Guarani, considerado um dos maiores sistemas aqüíferos do mundo, bem como a maior reserva estratégica de água doce da América Latina (CETESB, 2001b).

Um aqüífero funciona como um sistema básico de água, um reservatório que aumenta ou diminui com mudanças no balanço entre infiltração e escoamento de água. A infiltração originária da percolação de água superficial através do solo é denominada recarga. O escoamento, representado pelo transporte de água para corpos d'água, a evaporação, o bombeamento de poços e perdas para outros aqüíferos são denominados descarga.

Existem dois sistemas aqüíferos, o simples e o complexo. O primeiro possui apenas o aqüífero freático, que pode ter ou não área exposta na superfície, conhecida como área de afloramento. Vale ressaltar que o aqüífero freático é que abastece os corpos d'água. $O$ segundo possui o aqüífero freático (parte superior) e o aqüífero confinado (parte inferior), alimentado pelo primeiro e protegido por uma camada de solo ou rocha. 
O Sistema Aqüífero Guarani possui uma superfície de cerca de $1.194 \mathrm{~km}^{2}$ e 50 mil $\mathrm{km}^{3}$ de água doce armazenada. Cerca de 1/3 do seu manancial ocorre em partes da Argentina, Paraguai e Uruguai e cerca de 2/3 de sua área está situada na porção brasileira, que corresponde aos Estados de Goiás, Mato Grosso, Mato Grosso do Sul, Minas Gerais, Paraná, Rio Grande do Sul, Santa Catarina e São Paulo, conforme Figura 10.

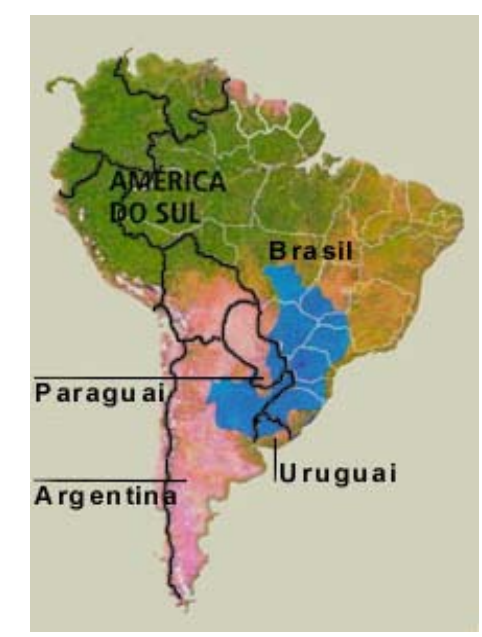

Figura 10 - Área de ocorrência do Aquífero Guarani Fonte: DAEE (2003)

No Estado de São Paulo a área do Aquífero Guarani é estimada em cerca de $115.800 \mathrm{~km}^{2}$, sendo o responsável pelo abastecimento parcial dos municípios de Araraquara, Ribeirão Preto, São Carlos e São José do Rio Preto (DAAE, 2003). O Aqüífero Botucatu se destaca como um dos seus mananciais mais importantes devido à sua área de ocorrência $\left(180.000 \mathrm{~km}^{2}\right)$, a qualidade de suas águas e por possuir cerca de $90 \%$ de sua área confinada em derrames basálticos da formação Serra Geral (Freitas, 1996).

Assim, para que a poluição e contaminação das águas subterrâneas por aterros e lixões sejam evitadas, a instalação destes empreendimentos em áreas de recarga não deve ocorrer. Nesse sentido, as áreas onde existem aterros e lixões, ativos ou desativados, devem ser monitoradas, a fim de verificar se a qualidade da água subterrânea está sendo alterada devido à migração de lixiviado.

Outros países já demonstram preocupação com a proteção do recurso subterrâneo devido à sua importância. Segundo Marsh e Grossa Junior (1996), nos Estados Unidos cerca de $50 \%$ da população usa água subterrânea como fonte de abastecimento. Como o recurso é protegido pelo solo e por rochas, apresenta poucos problemas ambientais. Porém, desde há algumas décadas, os suprimentos subterrâneos começaram a se extinguir em algumas regiões devido ao bombeamento excessivo. 
A Comunidade Comum Européia criou algumas leis para impedir descargas de substâncias tóxicas, persistentes e bioacumuláveis nas águas subterrâneas, a Directiva 90/656/CEE do Conselho, de 4 de dezembro de 1990, e a Directiva 91/692/CEE do Conselho, de 23 de dezembro de 1991 (Comissão Européia, 2004).

No Estado de São Paulo, Brasil, o Decreto $n^{\circ}$ 32.955, de 7 de fevereiro de 1991, regulamenta a Lei $n^{\circ} 6.134$, de 2 de junho de 1988, que dispõe sobre a preservação dos depósitos naturais de águas subterrâneas do Estado de São Paulo e dá outras providências. Além desse documento, a Portaria DAEE 717, de 12 de dezembro de 1996, do Departamento de Águas e Energia Elétrica disciplina o uso dos recursos hídricos superficiais e subterrâneos do Estado de São Paulo.

Segundo CETESB (2007e, p.136), para "melhorar o conhecimento sobre a condição de qualidade das águas subterrâneas no Estado e subsidiar as ações de prevenção e controle da poluição, faz-se necessária a integração das informações obtidas nos diferentes monitoramentos existentes, e executados por outras instituições, em um sistema de informações georeferenciado".

\subsubsection{Qualidade da Água}

A água deve possuir determinadas características para ser classificada como "água de boa qualidade", considerando as características naturais da região onde se encontra e seu uso. Porém, algumas dessas características podem ser alteradas devido às ações antrópicas.

A capacidade do recurso hídrico de diluir, assimilar e autodepurar a poluição é limitada devido à quantidade e à qualidade da água existente, as quais estão estreitamente relacionadas. Alguns desequilíbrios ecológicos têm ocorrido em locais onde a capacidade de assimilação natural é excedida (Tchobanoglous, 1993). Com o crescimento das cidades, ocorre o crescimento da demanda pela água e surgem conflitos entre usos e usuários. Com isso, o recurso torna-se escasso.

A qualidade da água pode ser alterada mesmo em condições naturais, em função das inter-relações dos componentes ambientais. O uso intenso demandado pelas áreas urbanas, agrícolas e industriais também influenciam a qualidade do recurso hídrico. Assim, os efluentes lançados em córregos e rios devem ser previamente tratados, pois algumas substâncias podem se acumular na água e causar riscos à saúde pública, fauna e flora.

Nesse sentido, no Brasil as águas potáveis devem seguir o padrão de qualidade recomendado pela Portaria $\mathrm{n}^{\circ}$ 518, de 25 de março de 2004, do Ministério da Saúde, antiga Portaria 1469/2000. As águas superficiais, por sua vez, devem seguir os padrões de 
qualidade de água estabelecidos pela Resolução $n^{\circ} 357$ do Conselho Nacional do Meio Ambiente (CONAMA), de 17 de março de 2005, antiga Resolução CONAMA 20/1986.

Alguns parâmetros para o monitoramento da água são adotados no Brasil, a fim de caracterizar a qualidade e a contaminação dos corpos d'água.

No Estado de São Paulo, a Companhia de Tecnologia de Saneamento Ambiental (CETESB, 2005a) analisa nove parâmetros para obtenção do Índice de Qualidade das Águas (IQA) superficiais: Temperatura, potencial Hidrogeniônico $(\mathrm{pH})$, Oxigênio Dissolvido, Demanda Bioquímica de Oxigênio, Coliforme Fecal (Termotolerante), Fósforo Total, Nitrogênio Total, Resíduo Total (Sólidos Totais) e Turbidez. Além desses, outros parâmetros podem ser recomendados, como Demanda Química de Oxigênio, Condutividade Elétrica, Metais, etc. Com base nos relatórios mais recentes elaborados pela CETESB, 43 parâmetros foram analisados para a avaliação das águas subterrâneas (CETESB, 2007e, p.157) e 29 parâmetros para a avaliação das águas superficiais (CETESB, 2007c, Anexo I).

A água potável deve estar sempre disponível à população, porém existem muitas doenças vinculadas aos recursos hídricos. Programas de educação sanitária podem ser eficazes na redução de doenças associadas à água, porém os custos e benefícios devem ser estudados (Setti et al., 2001).

A água pode ser veículo para a transmissão de doenças, constituindo sério risco à saúde pública. A incidência de doenças depende do clima, geografia, cultura, hábitos sanitários, da quantidade e qualidade da água utilizada no abastecimento local, além dos métodos de tratamento e lançamento de seus efluentes (Daniel, 2001).

Conforme o autor, as doenças dependem ainda das alterações na qualidade da água, da disponibilidade de água e dos efeitos indiretos provocados pela água parada. $\mathrm{A}$ implantação de um sistema de abastecimento de água potável em determinada comunidade pode evitar que a população adquira algumas doenças, como cólera; esquistossomose; doenças de pele e diarréias (causadas pela falta de higiene pessoal) e febres (transmitidas por mosquitos que vivem em águas paradas). As águas naturais contêm microorganismos inofensivos à saúde humana e a isenção de patógenos é imprescindível para o consumo. A Tabela 9 apresenta algumas doenças que podem ser transmitidas pela água. 
Tabela 9 - Principais doenças de veiculação hídrica

\begin{tabular}{l|l|l|l}
\hline \multicolumn{1}{c|}{ Doença } & \multicolumn{1}{c|}{ Agente etiológico } & \multicolumn{1}{c|}{ Sintomas } & \multicolumn{1}{c}{$\begin{array}{c}\text { Fontes de } \\
\text { contaminação }\end{array}$} \\
\hline $\begin{array}{l}\text { Febre tifóide e } \\
\text { paratifóide }\end{array}$ & $\begin{array}{l}\text { Salmonella typhi } \\
\text { Salmonella paratyphi A e B }\end{array}$ & $\begin{array}{l}\text { Febre elevada, } \\
\text { diarréia }\end{array}$ & Fezes humanas \\
\hline Disenteria bacilar & Shigella dysenteriae & Diarréia & Fezes humanas \\
\hline $\begin{array}{l}\text { Disenteria } \\
\text { amebiana }\end{array}$ & Entamoeba histolytica & $\begin{array}{l}\text { Diarréia, abscessos } \\
\text { no fígado e intestino } \\
\text { delgado }\end{array}$ & Fezes humanas \\
\hline Cólera & Vibrio cholerae & $\begin{array}{l}\text { Diarréia e } \\
\text { desidratação }\end{array}$ & $\begin{array}{l}\text { Fezes humanas e } \\
\text { águas costeiras }\end{array}$ \\
\hline Giardíase & Giardia lamblia & $\begin{array}{l}\text { Diarréia, náusea, } \\
\text { indigestão, } \\
\text { flatulência }\end{array}$ & $\begin{array}{l}\text { Fezes humanas e } \\
\text { de animais }\end{array}$ \\
\hline Hepatite A e B & Vírus da hepatite A e B & Febre, icterícia & Fezes humanas \\
\hline Poliomielite* & Vírus da poliomielite & Paralisia & Fezes humanas \\
\hline Criptosporidiose & $\begin{array}{l}\text { Cryptosporidium parvum } \\
\text { Cryptosporidium muris } \\
\text { dor intestinal, } \\
\text { náusea, indigestão, } \\
\text { flatulência }\end{array}$ & $\begin{array}{l}\text { Fezes humanas e } \\
\text { de animais }\end{array}$ \\
\hline Gastroenterite & $\begin{array}{l}\text { Escherichia coli, } \\
\text { Campylobacter jejuni, } \\
\text { Yersinia enterocolitica, } \\
\text { Aeromonas hydrophila, } \\
\text { Rotavírus e outros entéricos }\end{array}$ & Diarréia & Fezes humanas \\
\hline
\end{tabular}

* Enfermidade erradicada no Brasil

Fonte: Daniel (2001)

Segundo Ganzeli (1995), algumas medidas corretivas podem auxiliar na recuperação da qualidade das águas, como a melhoria dos serviços de limpeza pública, a proibição da disposição aleatória de lixo doméstico, entre outras medidas.

O despejo de resíduos sólidos e detritos é fonte de poluição e contaminação, além de poder assorear cursos d'água. A poluição das águas pode ser minimizada com medidas preventivas como, por exemplo, o incentivo ao tratamento de efluentes e um plano de gerenciamento integrado dos resíduos sólidos.

\subsection{Princípio poluidor-pagador}

Os serviços de limpeza pública têm custo e para ampliação ou implantação de melhorias são necessários investimentos. Segundo os administradores públicos, as prefeituras estão "quebradas" e não há verba para a área dos resíduos sólidos. Por isso, a "taxa do lixo" está sendo implantada em alguns municípios.

Com base no princípio do "poluidor-pagador", quem polui ou pode poluir o ambiente deve pagar por isso. Porém, há críticas com relação a esta denominação. Há quem defenda 
o uso da expressão "usuário-pagador", pois a primeira pode ser interpretada como "poluo porque posso pagar" e a segunda "uso, por isso pago". Segundo Braga et al (2005, p.231), o princípio do "beneficiário-pagador" complementa o do usuário-pagador, pois quem se beneficia com o uso de um serviço ou empreendimento deve pagar pelos danos ambientais causados por sua construção e operação.

Além disso, as discussões tratam da atribuição de valor monetário ao uso dos recursos naturais, uma vez que o seu pagamento nunca será proporcional ao benefício e à qualidade oferecidos pelo meio ambiente. Entretanto, não se pode aceitar que o dano ambiental não seja reparado, por isso surgiu a necessidade de mensurar os impactos ambientais.

Essa necessidade surgiu em função da exploração irracional e desordenada dos recursos naturais e por não haver preocupação com a "fonte" ou responsabilidade pósconsumo, por exemplo: a extração de água de boa qualidade dos mananciais para a geração de produtos e posterior lançamento de efluentes poluidores em corpos d'água, comprometendo sua qualidade; o consumo de produtos e seu lançamento em local inadequado; entre outros.

Vale ressaltar que a recuperação da qualidade ambiental nunca se igualará à prevenção do dano. Conforme o Artigo 225 da Constituição Federal de 1988, $\S 1^{\circ}$, inciso V, incumbe ao poder público "controlar a produção, a comercialização e o emprego de técnicas, métodos e substâncias que comportem risco para a vida, a qualidade de vida e o ambiente". O $\S 3^{\circ}$ dispõe que "as condutas e atividades consideradas lesivas ao meio ambiente sujeitarão os infratores, pessoas físicas ou jurídicas, a sanções penais e administrativas, independentemente da obrigação de reparar os danos causados".

Nesse sentido, quanto à prevenção do dano causado à água, que é um bem essencial à vida, o Artigo 21, inciso XIX, da Constituição Federal já estabelecia a necessidade de instituir um sistema nacional de gerenciamento de recursos hídricos e definir critérios de outorga de direitos de seu uso.

Assim, a Lei 9.433, de 08 de janeiro de 1997, que trata da Política Nacional de Recursos Hídricos, cria o Sistema Nacional de Gerenciamento de Recursos Hídricos e dispõe no seu Artigo $5^{\circ}$, inciso IV, sobre a cobrança pelo uso de recursos hídricos. O Artigo 22 dispõe que os valores arrecadados com a cobrança deverão ser aplicados prioritariamente na bacia hidrográfica em que foram gerados e dispõe como os recursos deverão ser utilizados.

Vale destacar que a cobrança pode ser entendida como "preço público" pelo uso do bem natural. Para disciplinar a cobrança foi necessária a criação de lei específica, visto que o grau de poluição varia conforme a atividade. 
No caso dos recursos hídricos do Estado de São Paulo, foi aprovado o Decreto 50.667 , de 30 de março de 2006, que regulamenta a Lei 12.183, de 29 de dezembro de 2005, que trata da cobrança pelo uso da água no Estado. Os objetivos da cobrança pelo uso da água estão definidos no Artigo $4^{\circ}$ dessa lei:

I - reconhecer a água como um bem público de valor econômico e dar ao usuário uma indicação de seu real valor;

II - incentivar o uso racional e sustentável da água;

III - obter recursos financeiros para o financiamento dos programas e intervenções contemplados nos planos de recursos hídricos e saneamento, vedada sua transferência para custeio de quaisquer serviços de infra-estrutura;

IV - distribuir o custo sócio-ambiental pelo uso degradador e indiscriminado da água;

$\mathrm{V}$ - utilizar a cobrança da água como instrumento de planejamento, gestão integrada e descentralizada do uso da água e seus conflitos.

Os serviços de infra-estrutura mencionados no inciso III são aqueles relativos ao sistema de abastecimento de água; coleta, afastamento e tratamento de esgotos; coleta e tratamento de lixo; e drenagem urbana. O custeio destes serviços compreende o pagamento de despesas com pessoal, serviços de reposição e manutenção em equipamentos e instalações.

Com base no Artigo $5^{\circ}$ dessa mesma lei, todos os usuários que utilizam os recursos hídricos superficiais e subterrâneos estão sujeitos à cobrança, exceto propriedades ou pequenos núcleos populacionais distribuídos no meio rural que utilizam a água para fins domésticos, usuários com extração de água subterrânea em vazão inferior a $5 \mathrm{~m}^{3} /$ dia, usuários de baixa renda, entre outras especificidades. O valor total da cobrança deverá ser definido pelo respectivo Comitê de Bacia Hidrográfica, conforme Artigo $9^{\circ}$.

Dessa forma, as atividades poluentes poderão ser tributadas, a fim de minimizar os danos ambientais, por meio do pagamento das conseqüências que determinada atividade pode causar.

Portanto, qualquer atividade potencialmente poluidora, urbana, rural ou industrial, deve monitorar a água superficial e subterrânea em sua área de influência, a fim de verificar se a qualidade do recurso hídrico está sendo alterada. Caso isso ocorra, o empreendimento poderá ser multado.

Dentro desse contexto, há uma interface com a área dos resíduos sólidos, um dos principais poluidores dos recursos hídricos (Mota, 2006, p.157).

No caso dos RSU, a prefeitura coloca a disposição dos munícipes os serviços relacionados ao gerenciamento destes resíduos, pois ela é a responsável pelos mesmos. 
Conforme o Artigo 23 da Constituição Federal, é de competência da União, Estados e municípios: inciso $\mathrm{VI}$ - proteger o meio ambiente e combater a poluição em qualquer de suas formas e inciso IX - promover melhoria das condições de saneamento básico.

Dessa forma, os munícipes se beneficiam com os serviços prestados pela administração pública por meio do pagamento de impostos, o que os tornam contribuintes.

A principal arrecadação municipal utilizada para o pagamento de serviços públicos, incluindo o gerenciamento dos RSU, é o Imposto sobre Propriedade Predial e Territorial Urbana (IPTU). O IPTU é cobrado anualmente e tem como base de cálculo o valor do imóvel localizado na zona urbana.

A cobrança de tributos (impostos, taxas e contribuições de melhoria) está prevista no Artigo 30, inciso III, da Constituição Federal: compete aos municípios "instituir e arrecadar tributos de sua competência, bem como aplicar suas rendas, sem prejuízo da obrigatoriedade de prestar contas e publicar balancetes nos prazos fixados em lei”. O Artigo 156, dispõe que compete aos municípios instituir imposto sobre: inciso I - propriedade predial e territorial urbana e inciso III - serviços de qualquer natureza, definidos em lei complementar.

A aprovação de novos impostos é um processo demorado e pode interferir no Código Tributário Nacional (CTN), Lei $n^{\circ} 5.172$, de 25 de outubro de 1966. Além disso, os impostos não estão vinculados a nenhum serviço específico (Artigo 16 do CTN: "imposto é o tributo cuja obrigação tem por fato gerador uma situação independente de qualquer atividade estatal específica, relativa ao contribuinte"), diferente das taxas que são mais fáceis de serem aprovadas e têm caráter específico (Artigo 77 do CTN: "as taxas cobradas pela União, pelos Estados, pelo Distrito Federal ou pelos Municípios, no âmbito de suas respectivas atribuições, têm como fato gerador o exercício regular do poder de polícia, ou a utilização, efetiva ou potencial, de serviço público específico e divisível, prestado ao contribuinte ou posto à sua disposição").

Dessa maneira, apesar da existência de vários impostos que deveriam atender todas as necessidades dos moradores do município, as prefeituras podem criar taxas para ampliar ou melhorar a prestação de serviços públicos, o que geralmente ocorre por falta de receita.

Porém, conforme Artigo 145, inciso III, $\S 2^{\circ}$ da Constituição Federal, "as taxas não poderão ter base de cálculo própria de impostos".

Atualmente em alguns municípios está sendo criada uma taxa para o gerenciamento dos resíduos sólidos, conhecida como "taxa do lixo", a qual está gerando polêmica entre os diversos setores da sociedade, pois trata-se de uma discussão que envolve várias áreas: Administração Pública, Ambiental, Direito, Economia, entre outras.

A implantação dessa taxa no município de São Paulo e Rio de Janeiro, por exemplo, foi muito criticada por ter sido calculada com base no valor do imóvel, conforme o IPTU. 
Vale destacar que existem formas diversificadas de cobrança, como a que ocorre na Dinamarca, baseada na medida frontal do lote. Porém, a forma de cobrança deve ser condizente com a realidade de cada região.

A taxa do lixo não deveria ser criada para custear a coleta regular dos RSD e a limpeza pública, que são de direito da coletividade e já são pagas com parte da arrecadação do IPTU. Por isso, conforme Pinheiro Pedro (2003), a criação dessa taxa é uma medida inconstitucional e trata-se do fenômeno da bi-tributação.

Segundo alguns administradores públicos, o IPTU é um "cabide de taxas", é o "caixa comum" da prefeitura, usado para o pagamento de diversos serviços: iluminação, feira-livre, poda e capina, entre outros. Dessa forma, não há receita suficiente para ampliações ou inovações. Como o lixo não é prioridade do governo, a criação de uma nova taxa só teria como justificativa plausível custear novas implementações na área dos resíduos sólidos, como ampliação e melhorias da coleta seletiva e tratamento desses resíduos.

Nesse sentido, uma estratégia para a administração pública ter mais autonomia e implantar novos serviços na área dos resíduos sólidos, seria o cálculo da nova taxa com base no volume de resíduos gerado por cada estabelecimento, assim "quem gera menos paga menos, quem gera mais paga mais", o que poderia incentivar a redução de resíduos, que é o $1^{\circ}$ e mais importante dos $3 R$ s (reduzir, reutilizar e reciclar). A forma de medir este volume pode se dar por meio de pesagem em balança ou número de recipientes com volumes diferenciados e previamente estabelecidos.

Os estabelecimentos que participam de programas ambientais poderiam receber algum benefício da prefeitura como, por exemplo, desconto no valor da taxa como forma de estímulo a práticas mais sustentáveis.

Com base nas dificuldades encontradas pelas prefeituras, novas taxas tendem a ser criadas para atender novas demandas e necessidades que surgem com o crescimento da população e, conseqüentemente, da cidade. No caso dos resíduos sólidos, o poder público raramente investe em medidas preventivas.

A questão tributária é apenas um dos tópicos relacionados aos resíduos sólidos. A discussão é atual e não foi esgotada ou equacionada, porém a "tributação do lixo" é uma tendência, trata-se de um desafio a ser enfrentado pelos municípios.

O princípio da cobrança de taxas pelos serviços públicos é o de que "quem usa deve pagar". Dessa forma, "como se paga pela água e pelo esgoto, se pagará pelo lixo". Porém, uma vez que taxas relacionadas às "inovações" na área dos resíduos sólidos serão cobradas de todos os munícipes, os "novos" serviços deverão ser oferecidos a todos.

Um fator positivo de toda essa discussão é que, recentemente, o saneamento está em pauta. Especificamente os resíduos sólidos, que geralmente não são prioridade dos 
planos de governo, estão sendo discutidos pela sociedade que deve cobrar pelo seu gerenciamento adequado.

\subsection{Plano diretor municipal}

O plano diretor foi difundido no país a partir de 1940 e durante as décadas de 60 e 70 foi denominado "planejamento local integrado". "O plano diretor não é uma peça puramente científica e técnica, mas uma peça política", e é evidente que as propostas urbanísticas apresentam implicações econômicas e financeiras. O plano diretor destaca os aspectos que são da competência municipal, porém não se pode compreender a cidade desvinculada de sua região. Dessa forma, as ações governamentais sobre determinada cidade devem ser coordenadas entre os diferentes níveis de governo e o plano diretor deve apresentar propostas de desenvolvimento regional (Villaça, 1999).

No Brasil não existe a cultura do planejamento a longo prazo. Segundo Villaça (1999), o planejamento urbano no país é uma atividade desvinculada de políticas públicas, diferente dos planos dos Estados Unidos e Europa, e não tem sido uma atividade orientadora. O planejamento urbano é um processo contínuo, uma atividade multidisciplinar para resolver os problemas urbanos e seus desdobramentos futuros. Suas soluções devem integrar os aspectos econômicos, físicos, sociais e políticos das cidades. "O planejamento é um conjunto de diretrizes e ações" e os problemas urbanos derivam da falta de planejamento das cidades.

Segundo Mota (1999), plano diretor é o instrumento básico de orientação do desenvolvimento e expansão urbana. Para auxiliar as práticas de conservação ambiental, o plano diretor deve contemplar os aspectos naturais, sociais, econômicos e culturais da cidade.

A articulação entre cidade e ambiente foi estabelecida pelo Relatório Brudtland em 1987 e a temática ambiental passou a ser tratada no campo do planejamento urbano com a Agenda 21, aprovada pela Conferência das Nações Unidas para o Meio Ambiente e Desenvolvimento (Rio 92). O planejamento das cidades deixa de abordar apenas aspectos sociais e de desenvolvimento e passa a incorporar a questão ambiental (Ribeiro e Cardoso, 1996).

A Lei $n^{\circ} 10.257 / 2001$, de 10 de julho de 2001, originária do Projeto de Lei $n^{\circ} 5.788$ de 1990 (conhecido como "Estatuto da Cidade"), foi aprovada pelo Congresso Nacional e estabelece diretrizes gerais da política urbana do Brasil.

Esse Estatuto define princípios, objetivos, diretrizes de ação e instrumentos de gestão urbana, os quais deverão ser empregados pelo Poder Público Municipal, 
regulamentando o artigo 182 da Constituição da República Federativa Brasileira (CF) de 1988, que obriga as cidades com mais de 20.000 habitantes a elaborarem seus planos diretores.

Conforme o Estatuto da Cidade, o período de duração do plano diretor é de 10 anos e deve ser revisto após esse prazo. O Estatuto também estabelece a participação da comunidade e de representantes da sociedade civil durante o processo de elaboração e implementação do Plano, bem como a divulgação e o acesso às informações coletadas.

Segundo Mukai (2001), a Lei $n^{0}$ 10.257/2001 complementa a Lei de Responsabilidade Fiscal (LRF), Lei Complementar $n^{\circ}$ 101/2000, para a efetivação do planejamento governamental. $\mathrm{O}$ artigo 16 da LRF torna obrigatório o planejamento dos gastos públicos, ou seja, os municípios não devem gastar mais do que arrecadam.

Nesse sentido, o Capítulo III da Lei $\mathrm{n}^{\circ}$ 10.257/2001 trata do plano diretor e estabelece que as partes integrantes do planejamento municipal (plano plurianual, diretrizes orçamentárias e orçamento anual) contemplem as diretrizes e prioridades do referido plano. O artigo 40 estabelece que o plano diretor deve abranger todo o território municipal e não apenas a zona urbana.

O plano diretor pode auxiliar na determinação de áreas adequadas dentro do município para o tratamento e a disposição final de resíduos sólidos. A proximidade dessas instalações pode causar incômodos à população, devido a odores, ruídos, fumaça, poeira, trânsito de caminhões, presença de catadores, entre outros. O encerramento das atividades deve ser planejado, de maneira a evitar prejuízos à qualidade de vida da comunidade. Vale ressaltar que os aterros e as centrais de tratamento de resíduos sólidos podem atender diversos municípios, dessa forma a gestão destes resíduos torna-se uma questão regional.

Além disso, o plano diretor pode fornecer diretrizes para a revitalização das áreas degradadas e contaminadas dentro do território municipal. A ocupação de vazios urbanos é um dos objetivos das administrações municipais, pois são locais com infra-estrutura já instalada. Um exemplo é a descontaminação de locais onde antigas indústrias operavam. Estas áreas abandonadas pela desativação de atividades industriais, conhecidas como brownfields, geralmente estão instaladas no tecido urbano. Estes locais se tornaram um problema para o poder público, pois além de serem considerados de risco devido ao passivo ambiental, causam incômodo à vizinhança, desvalorização imobiliária, afastam investidores, entre outros problemas. Com base em Grimski (2004), a reintegração das áreas degradadas à vida urbana é um dos desafios enfrentados pela Alemanha, onde estima-se que extensas áreas verdes serão destruídas pelo setor da construção civil.

Uma das estratégias para se obter cidades sustentáveis é a previsão dos possíveis problemas causados pelos resíduos sólidos, relacionados ao planejamento urbano e ambiental. Nesse sentido, o inciso VI, Art $2^{\circ}$ da Lei 10.257/2001, trata da ordenação e 
controle do uso do solo, de forma a evitar a proximidade de usos incompatíveis e inconvenientes, bem como a poluição e a degradação ambiental, entre outras. O inciso VIII recomenda a "adoção de padrões de produção e consumo de bens e serviços e de expansão urbana compatíveis com os limites da sustentabilidade ambiental, social e econômica do Município e do território sob sua área de influência". O inciso XIII indica a "audiência do Poder Público municipal e da população interessada nos processos de implantação de empreendimentos ou atividades com efeitos potencialmente negativos sobre o meio ambiente natural ou construído, o conforto ou a segurança da população".

Vale descatar que, além do Plano Diretor, outros instrumentos são necessários para uma boa gestão municipal, como Zoneamento Ambiental, Lei de Parcelamento do Solo Urbano (Lei $n^{0}$ 6.766/1979, atualizada pela Lei 9.785, de 29/01/1999), Lei de Uso e Ocupação do Solo, Código de Obras, Código de Posturas e a Lei Orgânica Municipal. 


\section{MATERIAL E MÉTODOS}

Para a realização deste estudo, foram monitoradas sete áreas de disposição final de resíduos sólidos, localizadas na Bacia Tietê - Jacaré: (1) Aterro de Araraquara, (2) Aterro de Bauru, (3) Aterro de Brotas, (4) Lixão de Jaú, (5) Aterro de Ribeirão Bonito, (6) Aterro de São Carlos e (7) Antigo Lixão de São Carlos.

\section{1 Áreas monitoradas}

Seis municípios da UGRHI - 13 foram monitorados, devido ao acesso facilitado às áreas de disposição final de resíduos sólidos: (1) Araraquara, (2) Bauru, (3) Brotas, (4) Jaú, (5) Ribeirão Bonito e (6) São Carlos, conforme Figura 11. Estes municípios merecem destaque na bacia Tietê-Jacaré, seja pela densidade populacional, potencial turístico ou desenvolvimento econômico e tecnológico.

Com base no Apêndice $\mathrm{C}$, os municípios da BHTJ com maior densidade demográfica são: Araraquara, Bauru, Jaú e São Carlos. Assim, depreende-se que estes geram maior quantidade de resíduos sólidos e, conseqüentemente, suas áreas de disposição final são maiores, podendo causar impactos negativos mais graves em relação aos demais municípios. Ressalta-se que nenhum município da Bacia possui aterro industrial.

Apesar do aterro de Bauru estar localizado na UGRHI-16, os geradores dos resíduos aterrados no local residem na UGRHI-13. Vale destacar que o município de Bauru possui um número de habitantes superior aos demais municípios da BHTJ (Apêndice $\mathrm{C}$ ). $\mathrm{O}$ monitoramento das águas no entorno do aterro se justifica, pois as águas superficiais e subterrâneas são consideradas o mesmo recurso, apenas fluem por meios físicos distintos (CETESB, 2001b). Além disso, as inter-relações territoriais e ambientais devem ser consideradas. 


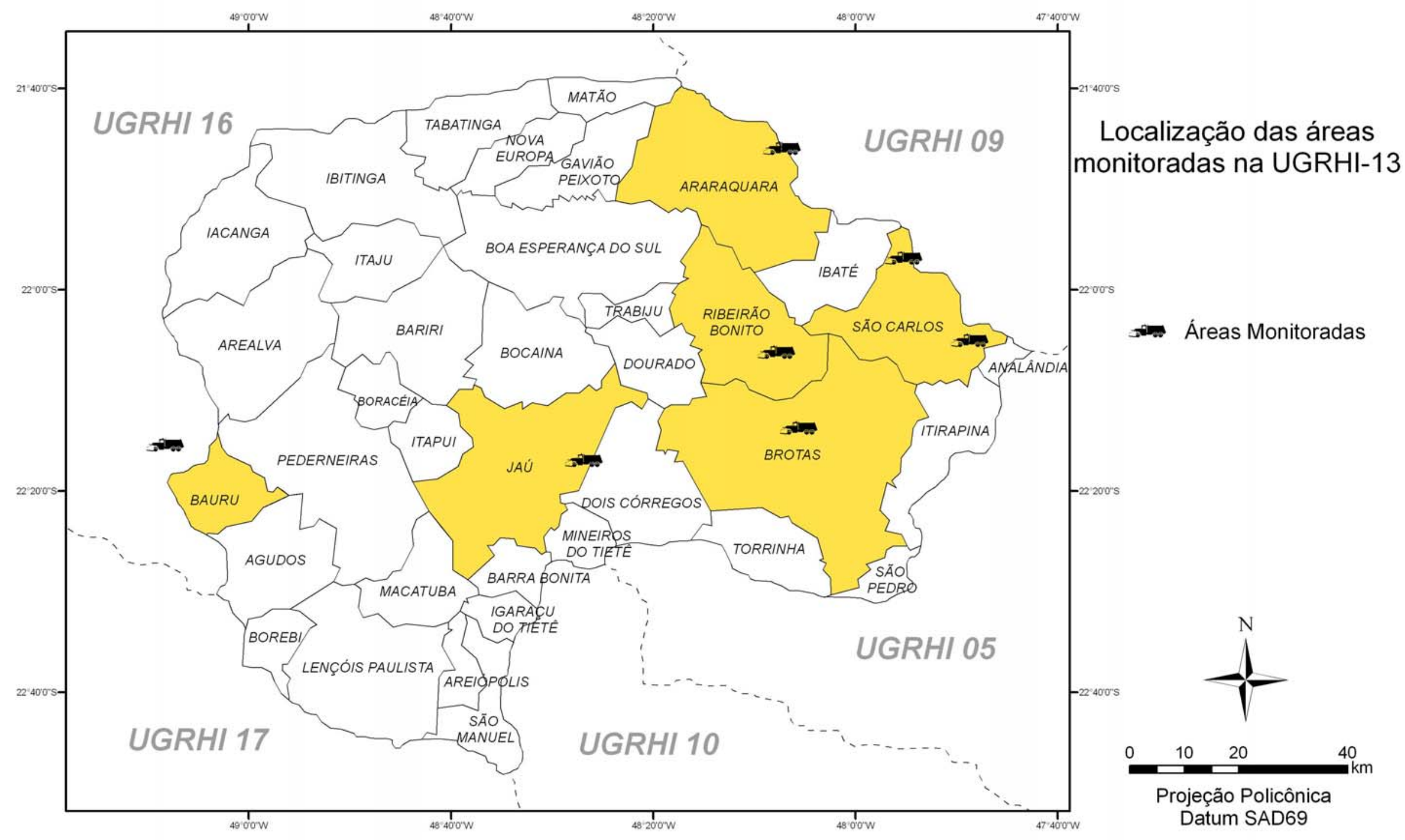

Figura 11 - Localização das áreas monitoradas na UGRHI-13 
As áreas de disposição final monitoradas foram denominadas com base no Índice de Qualidade de Aterro de Resíduos (IQR) adotado pela CETESB (2007a). A avaliação das áreas monitoradas referente ao ano de 2006 está apresentada no Quadro 5

Quadro 5 - Avaliação das áreas de disposição final monitoradas

\begin{tabular}{|l|l|c|c|}
\hline \multicolumn{2}{|c|}{ Município } & Avaliação em 2006 & Enquadramento \\
\hline 1 & Araraquara & 8,5 & Condições Adequadas (A) \\
\hline 2 & Bauru & 8,7 & Condições Adequadas (A) \\
\hline 3 & Brotas & 7,5 & Condições Controladas (C) \\
\hline 4 & Jaú & 5,5 & Condições Inadequadas (I) \\
\hline 5 & Ribeirão Bonito & 7,6 & Condições Controladas (C) \\
\hline 6 & São Carlos & 9,0 & Condições Adequadas (A) \\
\hline 7 & São Carlos (Antigo Lixão) $^{*}$ & - & - \\
\hline
\end{tabular}

Fonte: CETESB (2007a)

O Antigo Lixão de São Carlos não foi avaliado, pois a área não recebe resíduos sólidos desde 1996, ano em que o aterro sanitário do município passou a operar. Os resíduos foram cobertos com terra e argila, segundo a prefeitura e, atualmente, a área serve como pasto para animais.

Quanto à pedologia, o tipo de solo sobre o qual cada área monitorada está situada pode ser visualizado por meio da Figura 12. O mapa pedológico foi baseado na classificação adotada por IPT (2000). 


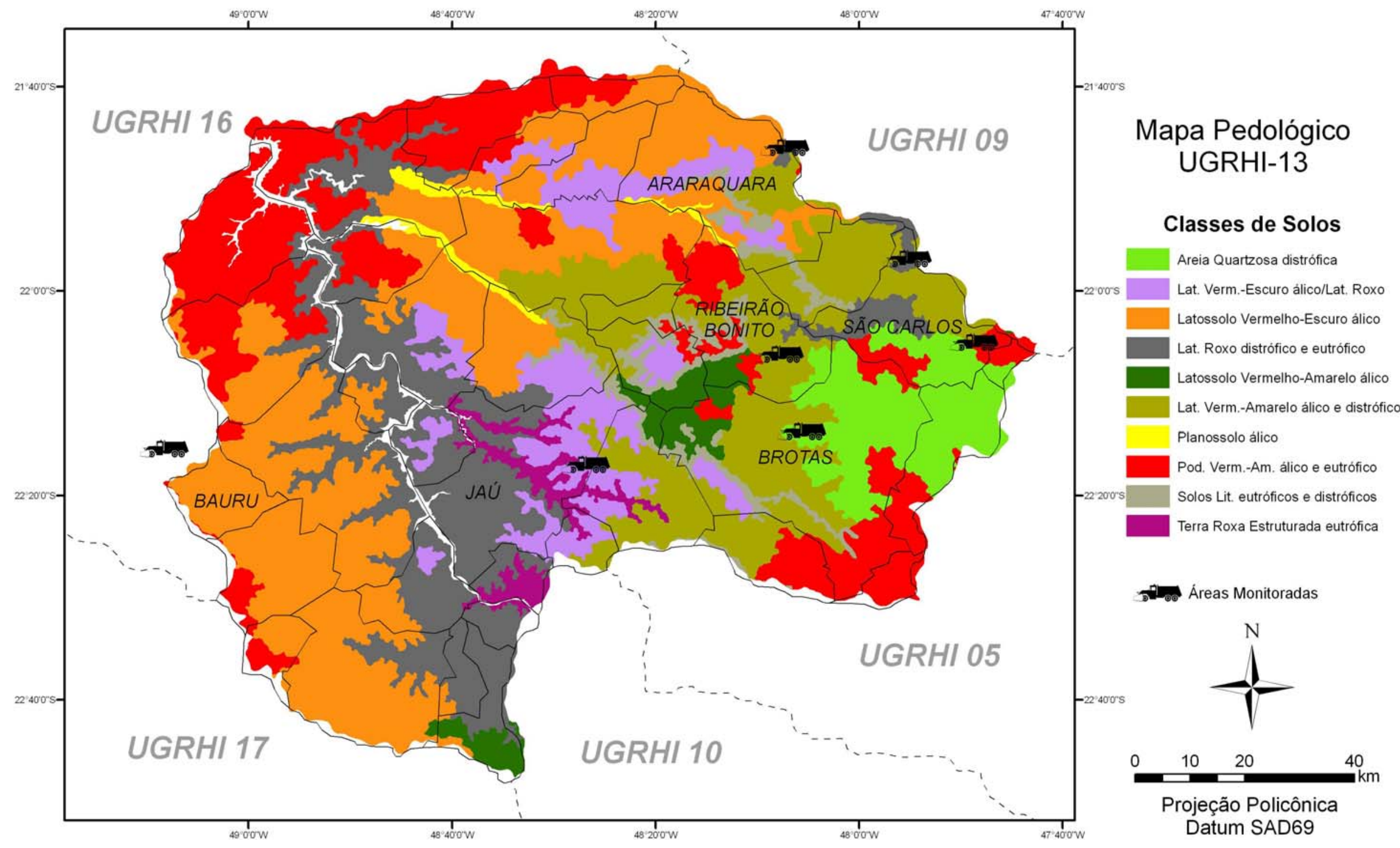

Figura 12 - Mapa pedológico da UGRHI-13 com a localização das áreas monitoradas 


\subsubsection{Localização dos pontos de amostragem}

As coordenadas dos pontos de coleta foram georreferenciados com o uso do Sistema de Posicionamento Global (GPS), receptor ETREX Vista Garmin, e estão apresentadas nas Tabela 10. As distâncias entre os pontos monitorados são aproximadas devido à imprecisão do GPS. O equipamento utilizado apresentou precisão em torno de 15 metros.

As coordenadas foram padronizadas no sistema de projeção Universal Transverso de Mercator (UTM). O Datum (nível de referência) adotado foi o South American Datum 1969 (SAD-69), conforme sistema de referência adotado oficialmente no Brasil para elaboração de bases cartográficas, com base no Decreto 89.317, de 20 de junho de 1984 (ROCHA, 2003, p.61). 
Tabela 10 - Coordenadas e distâncias aproximadas entre os pontos monitorados

\begin{tabular}{|c|c|c|c|c|c|c|c|}
\hline Municípios & \multicolumn{2}{|r|}{ Pontos } & \multicolumn{2}{|c|}{$\begin{array}{l}\text { Coordenadas UTM } \\
\text { (Datum SAD-69) }\end{array}$} & \multicolumn{2}{|c|}{$\begin{array}{c}\text { Distâncias } \\
\text { aproximadas (m) }\end{array}$} & \multirow{2}{*}{$\begin{array}{c}\begin{array}{c}\text { Altitude } \\
\text { (m) }\end{array} \\
754\end{array}$} \\
\hline \multirow{6}{*}{ São Carlos } & 1 & PM RIO SC & $1: 23 \mathrm{~K}$ & $\begin{array}{l}0197881 \mathrm{E} \\
7569643 \mathrm{~N} \\
\end{array}$ & $1-2$ & 803,88 & \\
\hline & 2 & PJ RIO SC & $2: 23 \mathrm{~K}$ & $\begin{array}{l}0198128 \mathrm{E} \\
7570408 \mathrm{~N}\end{array}$ & $3-4$ & 513,63 & 746 \\
\hline & 3 & PM SC & $3: 23 \mathrm{~K}$ & $\begin{array}{l}0198430 \mathrm{E} \\
7569655 \mathrm{~N}\end{array}$ & $4-5$ & 55,65 & 783 \\
\hline & 4 & PJ1 SC & $4: 23 \mathrm{~K}$ & $\begin{array}{l}0198326 \mathrm{E} \\
7570158 \mathrm{~N}\end{array}$ & $5-6$ & 39,81 & 750 \\
\hline & 5 & PJ2 SC & $5: 23 \mathrm{~K}$ & $\begin{array}{l}0198379 \mathrm{E} \\
7570175 \mathrm{~N}\end{array}$ & $1-3$ & 549,13 & 750 \\
\hline & 6 & PJ3 SC & $6: 23 \mathrm{~K}$ & $\begin{array}{l}0198415 \mathrm{E} \\
7570158 \mathrm{~N}\end{array}$ & $2-4$ & 318,91 & 753 \\
\hline \multirow{6}{*}{$\begin{array}{l}\text { São Carlos } \\
\text { Antigo Lixão }\end{array}$} & 7 & PML RIO SC & $13: 23 \mathrm{~K}$ & $\begin{array}{l}0210132 \mathrm{E} \\
7555694 \mathrm{~N}\end{array}$ & $7-8$ & 893,99 & 778 \\
\hline & 8 & PJL RIO SC & $14: 23 \mathrm{~K}$ & $\begin{array}{l}0209320 \mathrm{E} \\
7555320 \mathrm{~N}\end{array}$ & $9-10$ & 706,62 & 764 \\
\hline & 9 & PML SC & $15: 23 \mathrm{~K}$ & $\begin{array}{l}0210309 \mathrm{E} \\
7554690 \mathrm{~N}\end{array}$ & $10-11$ & 60,30 & 798 \\
\hline & 10 & PJL1 SC & $16: 23 \mathrm{~K}$ & $\begin{array}{l}0209822 \mathrm{E} \\
7555202 \mathrm{~N}\end{array}$ & $11-12$ & 64,19 & 779 \\
\hline & 11 & PJL2 SC & $17: 23 \mathrm{~K}$ & $\begin{array}{l}0209861 \mathrm{E} \\
7555248 \mathrm{~N}\end{array}$ & $7-9$ & $1.019,48$ & 775 \\
\hline & 12 & PJL3 SC & $18: 23 \mathrm{~K}$ & $\begin{array}{l}0209797 \mathrm{E} \\
7555243 \mathrm{~N}\end{array}$ & 8-12 & 483,17 & 776 \\
\hline \multirow{6}{*}{ Araraquara } & 13 & PM RIO AR & $7: 22 \mathrm{~K}$ & $\begin{array}{l}0797456 \mathrm{E} \\
7591230 \mathrm{~N}\end{array}$ & $13-14$ & 292,79 & 719 \\
\hline & 14 & PJ RIO AR & $8: 22 \mathrm{~K}$ & $\begin{array}{l}0797409 \mathrm{E} \\
7590941 \mathrm{~N}\end{array}$ & $15-16$ & 276,84 & 710 \\
\hline & 15 & PM AR & $9: 22 \mathrm{~K}$ & $\begin{array}{l}0797991 \mathrm{E} \\
7590820 \mathrm{~N} \\
\end{array}$ & $16-17$ & 774,21 & 745 \\
\hline & 16 & PJ1 AR & $10: 22 \mathrm{~K}$ & $\begin{array}{l}0797870 \mathrm{E} \\
7591069 \mathrm{~N}\end{array}$ & $17-18$ & 338,66 & 742 \\
\hline & 17 & PJ2 AR & $11: 22 \mathrm{~K}$ & $\begin{array}{l}0797690 \mathrm{E} \\
7590316 \mathrm{~N}\end{array}$ & $13-15$ & 674,03 & 739 \\
\hline & 18 & PJ3 AR & $12: 22 \mathrm{~K}$ & $\begin{array}{l}0797634 \mathrm{E} \\
7589982 \mathrm{~N} \\
\end{array}$ & $13-16$ & 444,20 & 732 \\
\hline \multirow{6}{*}{ Bauru } & 19 & PM RIO BA & $19: 22 \mathrm{~K}$ & $\begin{array}{l}0691657 \mathrm{E} \\
7537447 \mathrm{~N}\end{array}$ & $19-20$ & 200,44 & 537 \\
\hline & 20 & PJ RIO BA & $20: 22 \mathrm{~K}$ & $\begin{array}{l}0691633 \mathrm{E} \\
7537646 \mathrm{~N} \\
\end{array}$ & $21-22$ & 490,16 & 521 \\
\hline & 21 & PM BA & $21: 22 \mathrm{~K}$ & $\begin{array}{l}0692284 \mathrm{E} \\
7537473 \mathrm{~N}\end{array}$ & $22-23$ & 60,92 & 548 \\
\hline & 22 & PJ1 BA & $22: 22 \mathrm{~K}$ & $\begin{array}{l}0691818 \mathrm{E} \\
7537625 \mathrm{~N}\end{array}$ & $23-24$ & 192,40 & 537 \\
\hline & 23 & PJ2 BA & $23: 22 \mathrm{~K}$ & $\begin{array}{l}0691842 \mathrm{E} \\
7537569 \mathrm{~N} \\
\end{array}$ & $21-24$ & 559,12 & 541 \\
\hline & 24 & PJ3 BA & $24: 22 \mathrm{~K}$ & $\begin{array}{l}0691728 \mathrm{E} \\
7537414 \mathrm{~N}\end{array}$ & $19-24$ & 78,29 & 541 \\
\hline
\end{tabular}


Tabela 10 - Coordenadas e distâncias aproximadas entre os pontos monitorados (continuação)

\begin{tabular}{|c|c|c|c|c|c|c|c|}
\hline Municípios & \multicolumn{2}{|r|}{ Pontos } & \multicolumn{2}{|c|}{$\begin{array}{c}\text { Coordenadas UTM } \\
\text { (Datum SAD-69) }\end{array}$} & \multicolumn{2}{|c|}{$\begin{array}{c}\text { Distâncias } \\
\text { aproximadas (m) }\end{array}$} & \multirow{2}{*}{$\begin{array}{c}\begin{array}{c}\text { Altitude } \\
\text { (m) }\end{array} \\
616\end{array}$} \\
\hline \multirow{6}{*}{ Jaú } & 25 & PM RIO JA & $25: 22 \mathrm{~K}$ & $\begin{array}{l}0762840 \mathrm{E} \\
7533289 \mathrm{~N}\end{array}$ & $25-26$ & 18,02 & \\
\hline & 26 & PJ RIO JA & $26: 22 \mathrm{~K}$ & $\begin{array}{l}0762846 \mathrm{E} \\
7533306 \mathrm{~N}\end{array}$ & $27-28$ & 159,53 & 613 \\
\hline & 27 & PM JA & $27: 22 \mathrm{~K}$ & $\begin{array}{l}0763168 \mathrm{E} \\
7534093 \mathrm{~N}\end{array}$ & $28-29$ & 68,59 & 704 \\
\hline & 28 & PJ1 JA & $28: 22 \mathrm{~K}$ & $\begin{array}{l}0763083 \mathrm{E} \\
7533958 \mathrm{~N}\end{array}$ & $29-30$ & 267,57 & 685 \\
\hline & 29 & PJ2 JA & $29: 22 \mathrm{~K}$ & $\begin{array}{l}0763015 \mathrm{E} \\
7533949 \mathrm{~N}\end{array}$ & $25-30$ & 420,18 & 680 \\
\hline & 30 & PJ3 JA & $30: 22 \mathrm{~K}$ & $\begin{array}{l}0762986 \mathrm{E} \\
7533683 \mathrm{~N} \\
\end{array}$ & $27-30$ & 448,57 & 661 \\
\hline \multirow{4}{*}{ Brotas } & 31 & PM RIO BR & $31: 22 \mathrm{~K}$ & $\begin{array}{l}0799596 \mathrm{E} \\
7538969 \mathrm{~N}\end{array}$ & \multirow{2}{*}{$31-32$} & \multirow{2}{*}{242,53} & 679 \\
\hline & 32 & PJ RIO BR & $32: 22 \mathrm{~K}$ & $\begin{array}{l}0799425 \mathrm{E} \\
7539141 \mathrm{~N}\end{array}$ & & & 667 \\
\hline & & PM BR* & $22 \mathrm{~K}$ & $\begin{array}{l}0798444 \mathrm{E} \\
7538378 \mathrm{~N} \\
\end{array}$ & PM-PJ & 182,14 & 722 \\
\hline & & $\mathrm{PJ} \mathrm{BR}^{*}$ & $22 \mathrm{~K}$ & $\begin{array}{l}0798761 \mathrm{E} \\
7538330 \mathrm{~N} \\
\end{array}$ & PJ-31 & $1.051,44$ & 710 \\
\hline \multirow{4}{*}{$\begin{array}{l}\text { Ribeirão } \\
\text { Bonito }\end{array}$} & 33 & PM RIO RB & $33: 22 \mathrm{~K}$ & $\begin{array}{l}0796093 \mathrm{E} \\
7552974 \mathrm{~N} \\
\end{array}$ & \multirow{2}{*}{$33-34$} & \multirow{2}{*}{$2.735,73$} & 662 \\
\hline & 34 & PJ RIO RB & $34: 22 \mathrm{~K}$ & $\begin{array}{l}0796900 \mathrm{E} \\
7555588 \mathrm{~N}\end{array}$ & & & 627 \\
\hline & & $\mathrm{PM} \mathrm{RB}^{* *}$ & $22 \mathrm{~K}$ & $\begin{array}{l}0795480 \mathrm{E} \\
7554841 \mathrm{~N} \\
\end{array}$ & PM-PJ & 156,26 & 688 \\
\hline & & PJ RB ${ }^{\star *}$ & $22 \mathrm{~K}$ & $\begin{array}{l}0795337 \mathrm{E} \\
7554778 \mathrm{~N}\end{array}$ & PJ-33 & $1.956,00$ & 687 \\
\hline
\end{tabular}

${ }^{*}$ Pontos perfurados no aterro de Brotas

** Pontos perfurados no aterro de Ribeirão Bonito

Com a obtenção das coordenadas geográficas foi possível verificar sobre qual estrutura geológica os aterros estão inseridos (Figura 13). A relação das unidades litoestratigráficas dos aterros monitorados está apresentada no Quadro 6, com base em IPT (1981).

Quadro 6 - Unidades litoestratigráficas das áreas de disposição final monitoradas

\begin{tabular}{|l|l|l|l|l|}
\hline \multicolumn{2}{|c|}{ Número do Aterro } & \multicolumn{1}{c|}{ Município } & \multicolumn{2}{c|}{ Unidades Litoestratigráficas } \\
\hline 1 & Aterro & Araraquara & Ka & Formação Adamantina \\
\hline 2 & Aterro & Bauru & Km & Formação Marília \\
\hline 3 & Aterro & Brotas & TRJp & Formação Pirambóia \\
\hline 4 & Lixão & Jaú & KTi & Formação Itaqueri \\
\hline 5 & Aterro & Ribeirão Bonito & $\mathrm{JKb}$ & Formação Botucatu \\
\hline 6 & Aterro & São Carlos & $\mathrm{JKb}$ & Formação Botucatu \\
\hline 7 & Antigo Lixão & São Carlos & $\mathrm{JKb}$ & Formação Botucatu \\
\hline
\end{tabular}




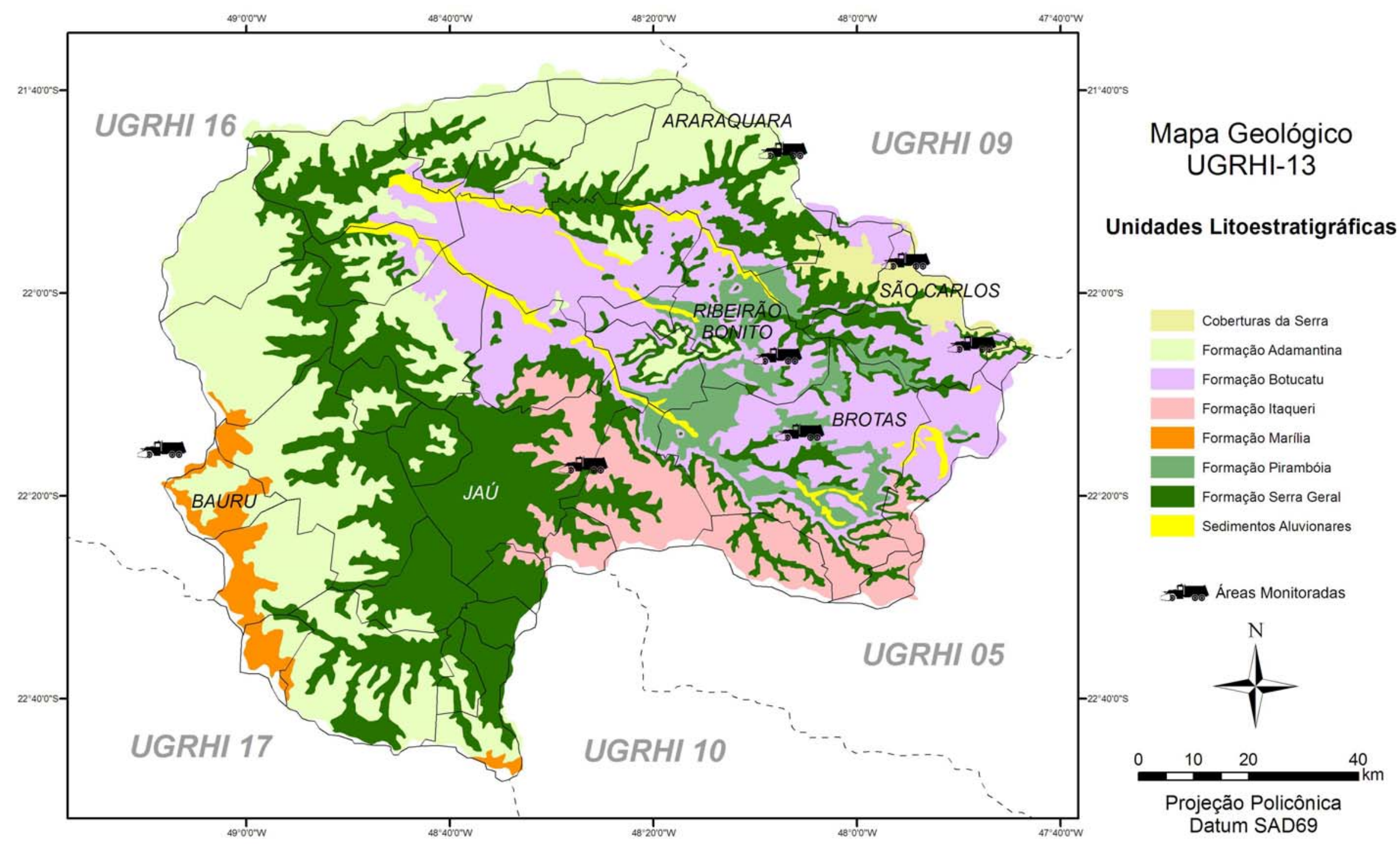

Figura 13 - Mapa geológico da UGRHI-13 com a localização das áreas monitoradas 


\subsection{Elaboração de mapas}

As bases cartográficas da UGRHI -13 com a localização das áreas monitoradas (Figuras 10 a 13), bem como da sua localização no Estado de São Paulo (Figura 8) foram geradas utilizando-se mapas oficiais do Instituto Geográfico e Cartográfico (IGC, 1996) do Estado de São Paulo, em formato analógico e digitalizadas. O software utilizado foi o SPRING 4.2, desenvolvido pelo Instituto Nacional de Pesquisa Espacial (INPE), disponibilizado gratuitamente no site http://www.dpi.inpe.br. As bases estavam em formato de imagem e foram digitalizadas (vetorizadas). A Projeção utilizada foi a Policônica e o Datum foi o SAD 69, oficial no Brasil.

A classificação adotada no mapa pedológico (Figura 12) foi baseada em IPT (2000). O mapa geológico (Figura 13) foi elaborado com base em Fernandes (2004) e IPT (1981, 1993a e 1993b).

\subsection{Levantamento de dados}

Para a realização deste estudo foram consultadas teses, dissertações, jornais, livros, legislações, revistas, Internet, bem como órgãos públicos, privados e ambientais (Secretarias Municipais, CETESB, Comitê da Bacia Hidrográfica Tietê-Jacaré, IBGE, Ministério do Meio Ambiente, empresas coletoras de lixo, entre outros) para aquisição de dados sobre a UGRHI-13 e sobre a situação dos resíduos sólidos urbanos nos municípios da BHTJ.

Foram levantados os seguintes dados os municípios da BHTJ: população; quantidade, tratamento e disposição final de resíduos sólidos; mapas (geologia; hidrologia; pedologia); clima; Plano Diretor; Lei Orgânica Municipal; uso e ocupação do solo; legislações ambientais; entre outros. Foram analisados os programas e estudos existentes relacionados aos resíduos sólidos implantados nos municípios monitorados.

Algumas informações foram obtidas por meio de questionários elaborados (Apêndices A e B) e enviados às 37 prefeituras dos municípios com território na UGRHI - 13, especialmente aos agentes envolvidos com a limpeza pública.

Foram enviadas solicitações às Prefeituras de Brotas, Jaú e Ribeirão Bonito para a realização de sondagens no solo, a fim de verificar a existência de aqüífero freático na área dos seus aterros, os quais não possuíam poços de monitoramento no início do estudo.

Também foram realizadas visitas às prefeituras dos municípios da BHTJ, órgãos responsáveis pelos resíduos sólidos e às instalações relacionadas aos mesmos. As visitas foram realizadas para para obtenção de imagens, informações, acompanhamento da 
construção dos poços para o monitoramento de água subterrânea e coleta das amostras de água.

Para o enriquecimento dos dados obtidos foram adquiridas fotos aéreas dos aterros monitorados, o que permitiu o registro do entorno.

\subsection{Coleta das amostras de água}

As amostras de água superficial e subterrânea foram coletadas a montante e jusante da área de influência dos aterros.

As amostras de água subterrânea foram coletadas em quatro poços de monitoramento localizados nos aterros (um a montante e três a jusante), denominados PM, PJ1, PJ2 e PJ3, respectivamente, de acordo com procedimentos recomendados pela NBR 13895 (ABNT, 1997b) e Norma 6410 (CETESB, 1988), atualizada em novembro de 1999.

Para coleta das amostras de água nos poços de 4 polegadas foi usado um coletor confeccionado com tubo de PVC (Cloreto de Polivinila) de 1,70 metros de comprimento, diâmetro de 3 polegadas e capacidade para 5 litros (Figura 14). A sucção da água foi realizada por uma válvula de retenção encaixada em uma das extremidades do coletor, conforme (Figura 15). O tubo foi perfurado na outra extremidade para passagem de uma corda, que permitiu alcançar o nível da água subterrânea nos poços de monitoramento.

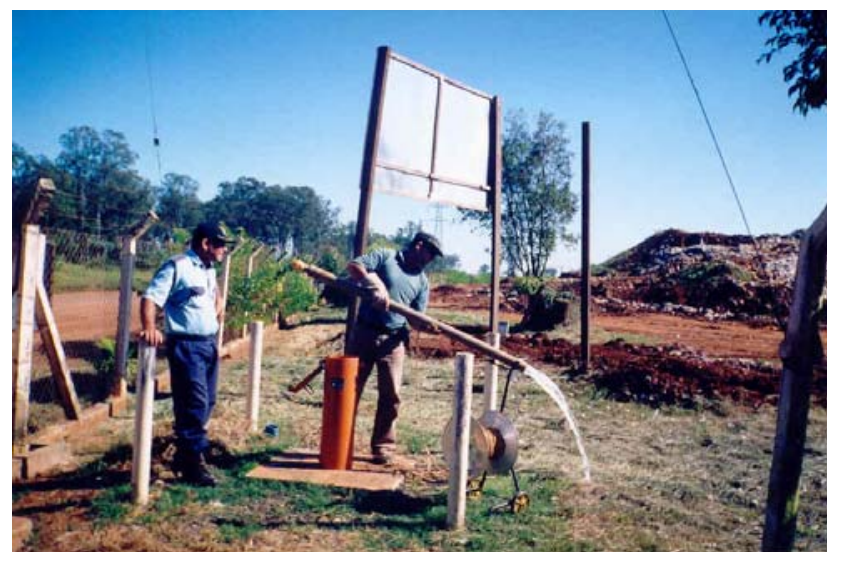

Figura 14 - Esvaziamento de poço no aterro de Araraquara

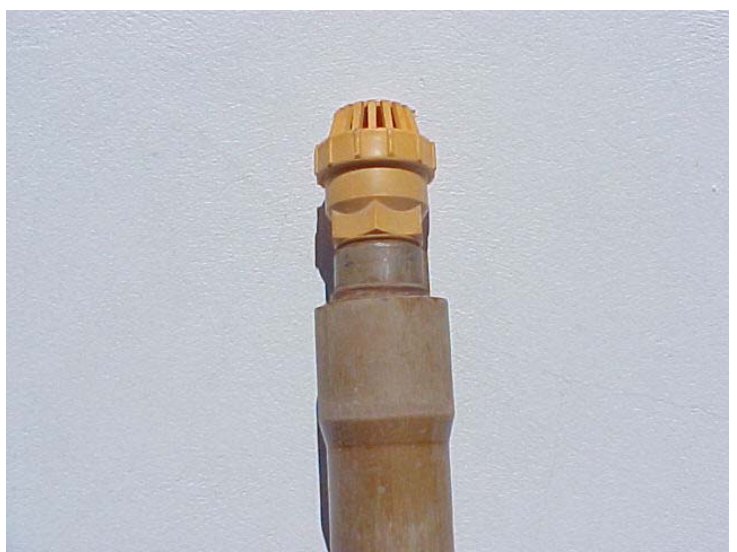

Figura 15 - Detalhe do coletor de água subterrânea utilizado nos poços de 4"

Conforme CETESB (1987), quando as amostras de água não forem coletadas com o auxílio de bombas, a amostragem deverá ser realizada diretamente no poço. Porém, não é recomendado analisar a camada superficial da água, a fim de evitar a contaminação com a espuma ou com o material da parede do poço. Assim, após a medida do nível d'água foram retirados 15 litros de água de cada poço antes da coleta da amostra final. 
De acordo com CETESB (2007d): Procedimento para Amostragem de Água Subterrânea, deve-se "purgar 3 volumes da água existente no interior do poço, com a finalidade de assegurar que toda a água que por ventura esteja estagnada no poço seja removida, possibilitando a coleta de uma amostra representativa de água".

Nos poços de 2 polegadas, construídos em Jaú, foi usado coletor de água descartável (bailer) de PVC da marca Hidrosuprimentos, de 1 metro de comprimento, capacidade para 1 litro, conforme Figura 16 e Figura 17.

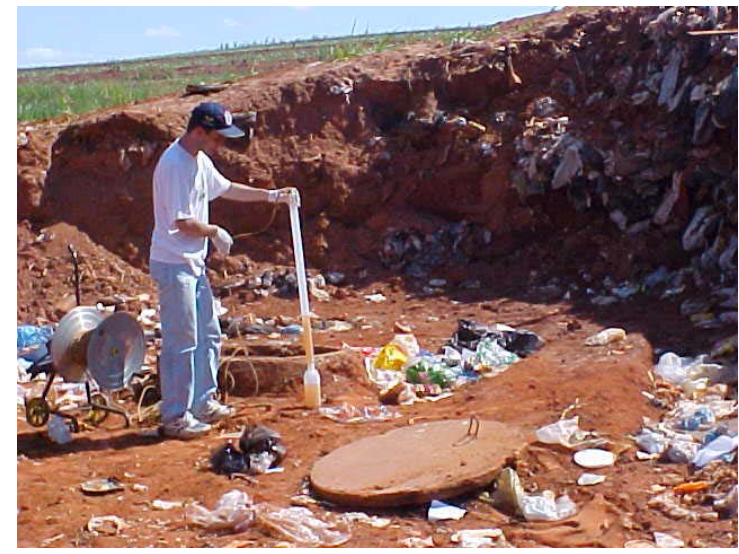

Figura 16 - Coleta da amostra de água subterrânea em Jaú

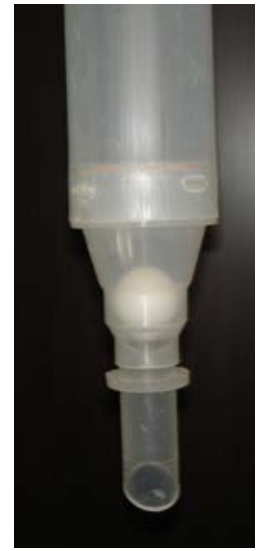

Figura 17 - Detalhe do coletor de água subterrânea utilizado nos poços de 2"

Nos aterros que não possuíam poços de monitoramento (Brotas, Jaú e Ribeirão Bonito) foi realizada sondagem no solo, a montante e a jusante da área de influência dos aterros, para verificação do aqüífero subterrâneo. Porém, nos aterros de Brotas e Ribeirão Bonito não foi encontrado aqüífero freático. Assim, foram perfurados quatro poços de monitoramento, um a montante e três a jusante, no aterro de Jaú, conforme NBR 13895 (ABNT, 1997b) e Norma 6410 (CETESB, 1988), atualizada em novembro de 1999. Após a conclusão do presente estudo, a NBR 13895 (ABNT, 1997b) foi substituída pela NBR 15495-1 (ABNT, 2007a) e foi criada a NBR 15492 (ABNT, 2007b), que trata da sondagem de reconhecimento para fins de qualidade ambiental.

Foram coletadas amostras de água nos córregos mais próximos dos aterros em dois pontos, um a montante e outro a jusante, denominados PMRIO e PJRIO, respectivamente, conforme Tabela 11. 
Tabela 11 - Locais de coleta das amostras de água superficial

\begin{tabular}{l|l}
\hline \multicolumn{1}{c|}{ Municípios } & \multicolumn{1}{c}{ Local } \\
\hline Araraquara & 1. córrego do Pinheirinho \\
\hline Bauru & 2. córrego da Gabiroba \\
\hline Brotas & 3. córrego da Cachoeira Grande \\
\hline Jaú & 4. ribeirão do Matão \\
\hline Ribeirão Bonito & 5. córrego do Tamanduá \\
\hline São Carlos & $\begin{array}{l}\text { 6. córrego do Galdino } \\
\text { 7. córrego São José }\end{array}$ \\
\hline
\end{tabular}

Dos seis municípios monitorados, apenas o município de Araraquara está incluído na atual rede de monitoramento da CETESB. Dos 14 pontos de água superficial monitorados por este estudo, nenhum pertence à rede da CETESB (2007c, p.200).

Durante a coleta, as amostras de água foram armazenadas em galões plásticos de cinco litros, um litro e frascos plásticos de 300 mililitros para fixar o sulfeto com um mililitro de acetato de zinco 2N, conforme CETESB (1987). Posteriormente, no Laboratório de Ecotoxicologia e Ecofisiologia de Organismos Aquáticos (CRHEA/EESC/USP), dois litros de cada amostra foram transferidos dos galões para frascos de um litro, a fim de serem transportados para o Laboratório de Saneamento. Os três litros restantes foram submetidos aos ensaios ecotoxicológicos.

Durante duas coletas, amostras de água superficial de cada ponto foram reservadas em frascos de um litro para análise de substâncias orgânicas no Laboratório de Química Ambiental (IQ/EESC/USP).

No período de 08/03/2004 a 18/08/2005 foram realizadas quatro coletas de amostras de água superficial na área de influência dos aterros de Araraquara, Bauru, Brotas, Jaú, Ribeirão Bonito e São Carlos, bem como quatro coletas de água subterrânea nos poços de monitoramento, localizados nos aterros de Araraquara, Bauru, Jaú e São Carlos, conforme Tabela 12 e Tabela 13.

No total, 34 pontos de amostragem foram avaliados dentro da BHTJ: 14 pontos de água superficial e 20 pontos de água subterrânea.

Durante as coletas, o nível d'água dos poços de monitoramento foi obtido com uso do Medidor Elétrico de Nível d’água, modelo HSNA - 100 da marca Hidrosuprimentos. 
Tabela 12 - Pontos de amostragem e número de coletas

\begin{tabular}{|c|c|c|c|c|c|c|c|c|}
\hline \multicolumn{2}{|r|}{ Municípios } & \multirow{2}{*}{\begin{tabular}{|l} 
Áreas \\
Aterro
\end{tabular}} & \multirow{2}{*}{$\begin{array}{c}\mathrm{N}^{\circ} \text { de } \\
\text { áreas }\end{array}$} & \multicolumn{2}{|c|}{ Pontos } & \multirow{2}{*}{$\begin{array}{c}\begin{array}{c}\text { Total de } \\
\text { pontos }\end{array} \\
6\end{array}$} & \multirow{2}{*}{$\begin{array}{c}\begin{array}{c}\mathbf{N}^{\circ} \mathrm{de} \\
\text { coletas/área }\end{array} \\
4\end{array}$} & \multirow{2}{*}{$\begin{array}{c}\begin{array}{c}\text { Total de } \\
\text { coletas }\end{array} \\
24\end{array}$} \\
\hline 1 & Araraquara & & & $\begin{array}{l}\text { rio } \\
\text { poços }\end{array}$ & $\begin{array}{l}2 \\
4\end{array}$ & & & \\
\hline 2 & Bauru & Aterro & 1 & $\begin{array}{l}\text { rio } \\
\text { pocos }\end{array}$ & $\begin{array}{l}2 \\
4\end{array}$ & 6 & 4 & 24 \\
\hline 3 & Brotas & Aterro & 1 & rio & 2 & 2 & 4 & 8 \\
\hline 4 & Jaú & Lixão & 1 & \begin{tabular}{|l|} 
rio \\
poços
\end{tabular} & $\begin{array}{l}2 \\
4\end{array}$ & 6 & 4 & 24 \\
\hline 5 & $\begin{array}{l}\text { Ribeirão } \\
\text { Bonito }\end{array}$ & Aterro & 1 & rio & 2 & 2 & 4 & 8 \\
\hline 6 & São Carlos & $\begin{array}{l}\text { Aterro e } \\
\text { Antigo Lixão }\end{array}$ & 2 & \begin{tabular}{|l|} 
rio \\
poços
\end{tabular} & $\begin{array}{l}2 \\
4\end{array}$ & 12 & 4 & 48 \\
\hline \multicolumn{2}{|c|}{ Total } & & $\overline{7}$ & \multicolumn{3}{|c|}{34} & 28 visitas & 136 \\
\hline
\end{tabular}

Tabela 13 - Coletas de amostras de água superficial e subterrânea

\begin{tabular}{|c|c|c|c|c|c|c|}
\hline \multirow{2}{*}{ Município } & \multirow{2}{*}{ Local } & \multirow{2}{*}{$\begin{array}{c}\text { Tipo de } \\
\text { amostra de } \\
\text { água }\end{array}$} & \multirow{2}{*}{\multicolumn{2}{|c|}{ Data das coletas }} & \multicolumn{2}{|c|}{ Horário das coletas } \\
\hline & & & & & Poço & Rio \\
\hline Araraquara & $\begin{array}{c}\text { Aterro } \\
\text { Controlado }\end{array}$ & $\begin{array}{c}\text { subterrânea e } \\
\text { superficial }\end{array}$ & $\begin{array}{l}1^{\mathrm{a}} \\
2^{\mathrm{a}} \\
3^{\mathrm{a}} \\
4^{\mathrm{a}}\end{array}$ & $\begin{array}{l}08 / 03 / 2004 \\
02 / 07 / 2004 \\
09 / 11 / 2004 \\
11 / 02 / 2005\end{array}$ & $\begin{array}{c}13: 00-14: 45 \\
9: 40-11: 05 \\
11: 55-13: 00 \\
9: 32-10: 10\end{array}$ & $\begin{array}{l}15: 00-16: 00 \\
11: 20-11: 45 \\
13: 13-13: 30 \\
10: 29-10: 45\end{array}$ \\
\hline Bauru & $\begin{array}{c}\text { Aterro } \\
\text { Sanitário }\end{array}$ & $\begin{array}{c}\text { subterrânea e } \\
\text { superficial }\end{array}$ & $\begin{array}{l}1^{a} \\
2^{a} \\
3^{a} \\
4^{a}\end{array}$ & $\begin{array}{l}13 / 04 / 2004 \\
02 / 09 / 2004 \\
23 / 11 / 2004 \\
21 / 03 / 2005\end{array}$ & $\begin{array}{l}11: 00-13: 00 \\
11: 00-12: 10 \\
10: 55-11: 50 \\
11: 39-12: 30\end{array}$ & $\begin{array}{l}13: 15-14: 00 \\
10: 15-10: 30 \\
12: 05-12: 20 \\
12: 40-12: 47\end{array}$ \\
\hline Brotas & $\begin{array}{l}\text { Aterro } \\
\text { Sanitário } \\
\text { (valas) }\end{array}$ & superficial & $\begin{array}{l}1^{a} \\
2^{a} \\
3^{a} \\
4^{a}\end{array}$ & $\begin{array}{l}08 / 09 / 2004 \\
23 / 11 / 2004 \\
22 / 03 / 2005 \\
17 / 06 / 2005\end{array}$ & - & $\begin{array}{c}14: 00-14: 40 \\
14: 00-14: 30 \\
9: 40-9: 55 \\
12: 00-13: 00\end{array}$ \\
\hline \multirow{4}{*}{ Jaú } & \multirow{4}{*}{ Lixão } & $\begin{array}{c}\text { subterrânea e } \\
\text { superficial }\end{array}$ & $\begin{array}{l}1^{a} \\
2^{a}\end{array}$ & $\begin{array}{l}08 / 09 / 2004 \\
24 / 11 / 2004\end{array}$ & $\begin{array}{l}10: 20-11: 30 \\
10: 36-11: 45\end{array}$ & $\begin{array}{l}11: 45-12: 10 \\
12: 00-12: 35\end{array}$ \\
\hline & & subterrânea & \multirow{2}{*}{$3^{a}$} & 04/05/2005 & 12:00-14:05 & - \\
\hline & & superficial & & $22 / 03 / 2005^{*}$ & - & $12: 00-12: 35$ \\
\hline & & $\begin{array}{c}\text { subterrânea e } \\
\text { superficial }\end{array}$ & $4^{a}$ & $18 / 08 / 2005$ & $10: 25-12: 50$ & $13: 00-14: 20$ \\
\hline $\begin{array}{l}\text { Ribeirão } \\
\text { Bonito }\end{array}$ & $\begin{array}{l}\text { Aterro } \\
\text { Sanitário } \\
\text { (valas) }\end{array}$ & superficial & $\begin{array}{l}1^{a} \\
2^{a} \\
3^{a} \\
4^{a}\end{array}$ & $\begin{array}{l}09 / 09 / 2004 \\
24 / 11 / 2004 \\
21 / 03 / 2005 \\
17 / 06 / 2005\end{array}$ & - & $\begin{array}{c}14: 00-15: 00 \\
8: 20-8: 44 \\
9: 05-9: 24 \\
8: 30-9: 15\end{array}$ \\
\hline \multirow{2}{*}{ São Carlos } & $\begin{array}{l}\text { Antigo } \\
\text { Lixão }\end{array}$ & $\begin{array}{c}\text { subterrânea e } \\
\text { superficial }\end{array}$ & $\begin{array}{l}1^{a} \\
2^{a} \\
3^{a} \\
4^{a}\end{array}$ & $\begin{array}{l}09 / 03 / 2004 \\
01 / 07 / 2004 \\
08 / 11 / 2004 \\
10 / 02 / 2005\end{array}$ & $\begin{array}{c}9: 30-11: 20 \\
11: 30-13: 45 \\
10: 00-11: 45 \\
13: 54-15: 00\end{array}$ & $\begin{array}{l}11: 30-12: 15 \\
14: 00-14: 23 \\
12: 00-12: 20 \\
15: 14-15: 25\end{array}$ \\
\hline & $\begin{array}{c}\text { Aterro } \\
\text { Sanitário }\end{array}$ & $\begin{array}{c}\text { subterrânea e } \\
\text { superficial }\end{array}$ & $\begin{array}{l}1^{a} \\
2^{a} \\
3^{a} \\
4^{a}\end{array}$ & $\begin{array}{l}08 / 03 / 2004 \\
01 / 07 / 2004 \\
09 / 11 / 2004 \\
10 / 02 / 2005\end{array}$ & $\begin{array}{c}9: 00-11: 20 \\
9: 00-10: 20 \\
8: 33-9: 30 \\
10: 23-11: 20\end{array}$ & $\begin{array}{c}11: 30-12: 00 \\
10: 30-10: 50 \\
9: 45-10: 09 \\
11: 38-12: 05\end{array}$ \\
\hline
\end{tabular}

* Nesta data não foi possível realizar coleta de água nos poços de Jaú devido às fortes chuvas, o que impossibilitou o acesso aos mesmos, bem como devido ao aterramento de um dos poços. Observação: Nos aterros de Brotas e Ribeirão Bonito não há poços de monitoramento 
Todas as amostras foram coletadas, preservadas e armazenadas em frascos adequados e analisadas dentro do prazo, de acordo com APHA et al (1998). As amostras foram coletadas a cada três meses (sempre que possível) durante um ano (2004 e 2005), aproximadamente, englobando os diferentes períodos climáticos.

\subsection{Análise das amostras de água}

\subsubsection{Ensaios físico-químicos e microbiológicos}

Os parâmetros físico-químicos e microbiológicos foram analisados no Laboratório de Saneamento do Departamento de Hidráulica e Saneamento da EESC/USP, com base em APHA et al (1998). As amostras foram analisadas em duplicatas. A Metodologia analítica dos parâmetros analisados está apresentada no Quadro 7. Os parâmetros $\mathrm{pH}$, Temperatura, Condutividade Elétrica, Oxigênio Dissolvido e Salinidade foram obtidos in situ com o auxílio do multisensor Horiba U-10. Os resultados estão apresentados nos Apêndices D e E.

A qualidade das amostras de água superficial também foi avaliada, conforme o Índice de Qualidade das Águas (IQA) recomendado pela CETESB. Os parâmetros analisados para o cálculo do IQA foram: Temperatura da amostra, pH, OD, $\mathrm{DBO}_{5,20}$, Coliformes Termotolerantes, Fósforo Total, Nitrogênio Total, Sólidos Totais e Turbidez.

Vale destacar que a análise de Nitrogênio Total foi iniciada em agosto de 2004, quando as coletas já haviam iniciado, devido a falhas no equipamento. 
Quadro 7 - Metodologia analítica dos parâmetros analisados

\begin{tabular}{|c|c|c|c|c|}
\hline & Parâmetros & unidade & \multicolumn{2}{|l|}{ Método* } \\
\hline 1 & Temperatura (TEMP) & ${ }^{\circ} \mathrm{C}$ & \multirow{5}{*}{\multicolumn{2}{|c|}{$\begin{array}{l}\text { Horiba U-10 } \\
\quad \text { (in situ) }\end{array}$}} \\
\hline 2 & $\mathrm{pH}$ & - & & \\
\hline 3 & Oxigênio Dissolvido (OD) & $\mathrm{mg} / \mathrm{L}$ & & \\
\hline 4 & Condutividade Elétrica (CE) & $\mu \mathrm{S} / \mathrm{cm}$ & & \\
\hline 5 & Salinidade (SAL) & $\%$ & & \\
\hline 6 & Turbidez (TURB) & $\mathrm{UT}^{3}$ & Nefelométrico & $2130 \mathrm{~B}$ \\
\hline 7 & Cor Aparente (COR) & $U C^{4}$ & Espectrofotometria & $2120 \mathrm{C}$ \\
\hline 8 & Fósforo Total (P) & $\mathrm{mg} \mathrm{P} / \mathrm{L}$ & Ácido Ascórbico, Espectrofotometria & $4500 \mathrm{PE}$ \\
\hline 9 & Carbono Orgânico Total (COT) & $\mathrm{mg} \mathrm{C/L}$ & Combustão a alta temperatura & $5310 \mathrm{~B}$ \\
\hline 10 & Nitrogênio Amoniacal (NNH3) & $\mathrm{mg} \mathrm{N} / \mathrm{L}$ & Titulometria & $4500 \mathrm{NH}_{3} \mathrm{C}$ \\
\hline 11 & Nitrogênio Nitrato (NNO3) & $\mathrm{mg} \mathrm{N} / \mathrm{L}$ & Espectrofotometria de ultravioleta & $4500 \mathrm{NO}_{3}^{-} \mathrm{B}$ \\
\hline 12 & Nitrogênio Nitrito (NNO2) & $\mathrm{mg} \mathrm{N} / \mathrm{L}$ & Colorimétrico & $4500 \mathrm{NO}_{2}^{-} \mathrm{B}$ \\
\hline 13 & Nitrogênio Total (NT) & $\mathrm{mg} \mathrm{N} / \mathrm{L}$ & Kjeldahl & $4500 \mathrm{NB}$ \\
\hline 14 & Cloretos $(\mathrm{CL})$ & $\mathrm{mg} \mathrm{Cl}^{-} / \mathrm{L}$ & Nitrato Mercurico & $4500 \mathrm{Cl}^{-} \mathrm{C}$ \\
\hline 15 & Sulfatos (SO4) & $\mathrm{mg} \mathrm{SO}_{4}^{2-} / \mathrm{L}$ & Turbidímetro & $4500 \mathrm{SO}_{4}{ }^{2-} \mathrm{E}$ \\
\hline 16 & Sulfetos & $\mathrm{mg} \mathrm{S}^{2-} / \mathrm{L}$ & Azul de Metileno & $4500 S^{2-} D$ \\
\hline 17 & Fluoretos (F) & $\mathrm{mg} \mathrm{F}^{-} / \mathrm{L}$ & SPADNS & $4500 \mathrm{~F}^{-} \mathrm{D}$ \\
\hline 18 & Sólidos Totais (ST) & \multirow{4}{*}{$\mathrm{mg} / \mathrm{L}$} & \multirow{3}{*}{ Gravimetria } & $2540 \mathrm{~B}$ \\
\hline 19 & Sólidos Totais Fixos (STF) & & & $2540 \mathrm{E}$ \\
\hline 20 & Sólidos Totais Voláteis (STV) & & & $2540 \mathrm{G}$ \\
\hline 21 & Sólidos Totais Dissolvidos (STD) & & Gravimetria & \\
\hline 22 & DemandaBioquímica de Oxiqênio(DBO) & \multirow{2}{*}{$\mathrm{mg} \mathrm{O}_{2} / \mathrm{L}$} & Incubação $\left(20^{\circ} \mathrm{C}, 5\right.$ dias $)$ & $5210 \mathrm{~B}$ \\
\hline 23 & Demanda Química de Oxigênio (DQO) & & Colorimetria, refluxo fechado & $5220 \mathrm{D}$ \\
\hline 24 & Coliformes Termotolerantes & \multirow{2}{*}{ UFC $/ 100 \mathrm{~mL}$} & \multirow{2}{*}{ Membrana filtrante } & $9222 \mathrm{D}$ \\
\hline 25 & Coliformes Totais & & & $9222 \mathrm{~B}$ \\
\hline 26 & Zinco $(\mathrm{ZN})$ & $\mathrm{mg} \mathrm{Zn/L}$ & \multirow{8}{*}{$\begin{array}{l}\text { Espectrofotometria de } \\
\text { absorção atômica }\end{array}$} & \multirow{8}{*}{$\begin{array}{l}3111 \mathrm{~B} \\
\text { (chama ar } \\
\text { acetileno) }\end{array}$} \\
\hline 27 & Chumbo (PB) & $\mathrm{mg} \mathrm{Pb/L}$ & & \\
\hline 28 & Cádmio & $\mathrm{mg} \mathrm{Cd} / \mathrm{L}$ & & \\
\hline 29 & Níquel & $\mathrm{mg} \mathrm{Ni} / \mathrm{L}$ & & \\
\hline 30 & Ferro Solúvel (FE) & $\mathrm{mg} \mathrm{Fe} / \mathrm{L}$ & & \\
\hline 31 & Manganês Solúvel (MN) & $\mathrm{mg} \mathrm{Mn} / \mathrm{L}$ & & \\
\hline 32 & Cobre (CU) & $\mathrm{mg} \mathrm{Cu} / \mathrm{L}$ & & \\
\hline 33 & Cromo Total (CR) & $\mathrm{mg} \mathrm{Cr} / \mathrm{L}$ & & \\
\hline 34 & Cromo Hexavalente & $\mathrm{mg} \mathrm{Cr} / \mathrm{L}$ & Método 95 & \multirow[t]{2}{*}{$(\mathrm{HACH}, 1992)$} \\
\hline 35 & Alumínio (AL) & $\mathrm{mg} \mathrm{Al} / \mathrm{L}$ & Método 8012 & \\
\hline
\end{tabular}

* Parâmetros de 6 a 33 seguem as recomendações de APHA et al (1998)

${ }^{3}$ UT: Unidade de Turbidez

${ }^{4}$ UC: Unidade de Cor

${ }^{5}$ UFC: Unidade Formadora de Colônia 
Os metais foram analisados por espectrofotometria de absorção atômica por chama, utilizando-se espectrofotômetro da marca VARIAN, modelo AA-1275. Antes de iniciar a digestão, as amostras foram filtradas a vácuo para análise de ferro e manganês solúveis. Para análise dos outros metais foram digeridas amostras brutas. Na primeira fase de digestão foram adicionados $6 \mathrm{~mL}$ de ácido nítrico a $25 \mathrm{~mL}$ de amostra. Na segunda fase foram adicionados $10 \mathrm{~mL}$ de ácido nítrico à amostra restante. Na terceira fase foram adicionados $10 \mathrm{~mL}$ de ácido clorídrico à amostra restante e $15 \mathrm{~mL}$ de água destilada. As amostras foram digeridas a quente e sofreram evaporação. Em seguida, após o esfriamento do frasco, o volume foi completado com água destilada até completar $25 \mathrm{~mL}$. Também foi realizada digestão com água destilada no lugar da amostra, a qual correspondeu ao branco. Os metais alumínio e o cromo hexavalente foram analisados por metodologias diferentes.

O cromo hexavalente foi analisado pelo Método $95(\mathrm{HACH}, 1992)$. Em 40mL de amostra bruta foram quebradas ampolas a vácuo de Chromover $3(\mathrm{HACH})$. Após 5 minutos foi realizada leitura no espectrofotômetro da marca HACH, modelo DR 2500.

O alumínio foi analisado pelo Método $8012(\mathrm{HACH}, 1992)$. Em $50 \mathrm{~mL}$ de amostra foi adicionado o $1^{\circ}$ reagente, ácido ascórbico (em pó, saché da $\mathrm{HACH}$ ), e a amostra foi agitada até dissolver. Em seguida adicionou-se o $2^{\circ}$ reagente, Aluver 3 para alumínio em saché $(\mathrm{HACH})$, e a amostra foi agitada por 1 minuto. Foram separados $25 \mathrm{~mL}$ num frasco a parte. Nos $25 \mathrm{~mL}$ de amostra restante foi adicionado o $3^{\circ}$ reagente, branqueante, e a amostra foi agitada por 30 segundos. Após 15 minutos foi realizada a leitura no espectrofotômetro da marca HACH, modelo DR 2500. Quanto mais avermelhada a amostra, maior é a concentração de alumínio.

\subsubsection{Ensaios ecotoxicológicos}

Os ensaios ecotoxicológicos foram realizados com duas amostras de água de cada ponto monitorado, a fim de verificar se haveria influência das mesmas na mobilidade, sobrevivência ou na reprodução de organismos aquáticos durante períodos climáticos distintos.

As amostras de água foram submetidas aos testes de toxicidade aguda e crônica no Laboratório de Ecotoxicologia e Ecofisiologia de Organismos Aquáticos do Centro de Recursos Hídricos e Ecologia Aplicada da Escola de Engenharia de São Carlos, Universidade de São Paulo, de acordo com ABNT (2004b) e (ABNT, 2005). Os resultados estão apresentados no Apêndice F. 
A toxicidade pode ser entendida como a "propriedade potencial que o agente tóxico possui de provocar, em maior ou menor grau, um efeito adverso em conseqüência de sua interação com o organismo" (ABNT, 2004a, p.2).

Para a realização dos ensaios, a Ceriodaphnia silvestrii foi usada como organismoteste, especialmente por ser um microcrustáceo nativo, o que evita o uso de organismos exóticos. As características físico-químicas da água de diluição e manutenção do organismo-teste são apresentadas na Tabela 14, com base na NBR 12713 (ABNT, 2004b) e NBR 13373 (ABNT, 2005).

Tabela 14 - Dados físico-químicos da água de cultivo de Ceriodaphnia silvestrii

\begin{tabular}{lc}
\hline \multicolumn{1}{c}{ Parâmetros } & Valores \\
\hline $\mathrm{pH}$ & $7,2-7,6$ \\
\hline Condutividade & $180 \mu \mathrm{S} / \mathrm{cm}$ \\
\hline Dureza Total & $40-48 \mathrm{mg} \mathrm{CaCO} / \mathrm{L}$ \\
\hline Oxigênio Dissolvido & $7,4-8,2 \mathrm{mg} / \mathrm{L}$ \\
\hline Temperatura (controlada) & $23 \pm 1^{\circ} \mathrm{C}$ \\
\hline
\end{tabular}

Os microcrustáceos foram alimentados com solução algal de Selenastrum capricornutum na concentração de $10^{5}$ células/litro/dia e alimento composto preparado com fermento biológico e adição de ração para peixes na concentração de $1 \mathrm{~mL} /$ Litro.dia. $A$ idade das fêmeas adultas para obtenção de neonatos variou entre 7 e 15 dias.

\section{Teste de sensibilidade}

As culturas de Ceriodaphnia silvestrii testadas quanto aos valores de $\mathrm{CE}(\mathrm{I}) 50 ; 48 \mathrm{~h}$ (concentração efetiva do agente tóxico que causa efeito adverso a $50 \%$ dos organismosteste) para o Cloreto de Sódio, têm-se mantido adequadas para serem utilizadas nos testes de toxicidade (ABNT, 2004b). O valor de $\mathrm{CE}(\mathrm{I}) 50 ; 48 \mathrm{~h}$ de $1,48 \mathrm{~g} \mathrm{~L}^{-1}$ com intervalo de confiança (95\%) de 1,54-1,73, está dentro do intervalo de $\pm 2 \delta$ ( $\delta=$ desvio padrão) em relação ao valor médio obtido no laboratório de $1,43 \mathrm{~g} \mathrm{~L}^{-1}$ e desvio padrão de 0,23 (Tabela 15). A CE(I)50;48h é calculada através do método estatístico Trimmed Spearman-Karber (Hamilton et al., 1978). 
Tabela 15 - Sensibilidade (CE(I)50;48h) de Ceriodaphnia silvestrii ao $\mathrm{NaCl}$

\begin{tabular}{|c|c|c|c|c|c|}
\hline \multicolumn{6}{|c|}{ Cloreto de sódio $\left(\mathrm{g} \mathrm{L}^{-1}\right)$ - Ceriodaphnia silvestrii } \\
\hline Mês/Ano & CE50(48h) & IC (95\%) & Mês/Ano & CE50(48h) & IC (95\%) \\
\hline 21.05 .02 & 1,89 & $1,75-2,04$ & 18.01 .03 & 1,32 & $1,10-1,58$ \\
\hline 04.06 .02 & 1,48 & $1,37-1,59$ & 24.07 .03 & 1,63 & $1,52-1,74$ \\
\hline 12.07 .02 & 1,63 & $1,34-1,98$ & 02.09 .03 & 1,46 & $1,30-1,63$ \\
\hline 06.08 .02 & 1,61 & $1,48-1,75$ & 09.10 .03 & 1,30 & $1,19-1,43$ \\
\hline 31.08 .02 & 1,24 & $1,13-1,36$ & 24.02 .04 & 1,20 & $1,12-1,29$ \\
\hline 17.09 .02 & 1,28 & $1,11-1,49$ & 02.03 .04 & 1,03 & $0,86-1,22$ \\
\hline 06.11 .02 & 1,41 & $1,29-1,54$ & 20.07.04 & 1,79 & $1,69-1,91$ \\
\hline 19.11 .02 & 1,23 & $1,08-1,40$ & 25.10 .04 & 1,48 & $1,54-1,73$ \\
\hline \multicolumn{3}{|c|}{ CE50,48h média $=1,43$} & \multicolumn{3}{|c|}{ Coeficiente de Variação $=16,78 \%$} \\
\hline \multicolumn{3}{|c|}{ Desvio Padrão $=0,23$} & \multicolumn{3}{|c|}{ Faixa aceitável $=0,95-1,91$} \\
\hline
\end{tabular}

\subsubsection{Toxicidade aguda}

A toxicidade aguda é o "efeito deletério causado pela amostra na mobilidade dos organismos-teste, em um período de 48 h de exposição", segundo a NBR 12713 (ABNT, 2004b).

O princípio do teste de toxicidade aguda consiste em avaliar a porcentagem de imobilidade dos organismos-teste após 48 horas de exposição à amostra. Neonatos com idade de seis a vinte e quatro horas foram expostos às amostras de água $(100 \%$ de concentração de amostras de água de rio e poço) e a um controle (água de cultivo). Foram testadas quatro réplicas, com cinco organismos cada.

Durante o período de teste, os organismos foram mantidos no escuro e sem alimento em sala com temperatura de $23^{\circ} \mathrm{C}( \pm 2)$. Após o período de exposição procedeu-se à contagem dos organismos imóveis, sendo considerados imóveis aqueles que não conseguiram nadar dentro de um intervalo de quinze segundos após leve agitação da amostra (ABNT, 2004b).

No início e no final do teste foram feitas medidas das variáveis, $\mathrm{pH}$, condutividade elétrica e concentração de oxigênio dissolvido, nas amostras e no controle. Para que o resultado de um bioensaio de toxicidade aguda seja válido, é aceito um máximo de $10 \%$ de imobilidade dos organismos-teste na amostra controle. Amostras com valores de OD inferiores a 3,6 $\mathrm{mg} \mathrm{L}^{-1}$ foram aeradas antes do início dos testes de toxicidade.

Para o cálculo dos resultados dos testes de toxicidade aguda foi adotada a seguinte metodologia:

1) Não Tóxica (NT), quando causar até $10 \%$ de imobilidade aos organismos-teste;

2) Indício de Toxicidade Aguda, quando causar imobilidade acima de $10 \%$ e abaixo de $50 \%$;

3) Tóxica, quando causar imobilidade igual ou superior a $50 \%$. 
Todas as amostras que apresentaram imobilidade dos organismos em diferentes porcentagens são consideradas amostras que causam algum efeito agudo, sendo então submetidas a uma análise estatística que compara as porcentagens de imobilidade das amostras em relação ao controle. A partir dessa análise estatística é possível avaliar se as diferenças são ou não significativas. A análise estatística utilizou o Aplicativo Graph Pad InStat, versão 3.00 (Motulsky, 1995).

\subsubsection{Toxicidade crônica}

A toxicidade crônica é o "efeito deletério causado pela amostra, na sobrevivência e reprodução dos organismos-teste, em um período de exposição que pode abranger a totalidade de seu ciclo de vida ou parte dele", segundo a NBR 13373 (ABNT, 2005).

O princípio do teste de toxicidade crônica consiste em avaliar a sobrevivência e a fecundidade dos organismos-teste durante o período de exposição à amostra-teste (100\% de concentração de amostras de água de rio e poço) e um controle (água de cultivo). Neonatos de seis a vinte e quatro horas de vida foram mantidos, individualmente, em $15 \mathrm{~mL}$ de amostra, acrescida de alimento. Foram realizadas dez réplicas, mantidas sob iluminação e à temperatura de $23^{\circ} \mathrm{C}( \pm 2)$. A cada dois dias, e até atingir a terceira cria, foi feita a reposição total do volume da amostra e novamente alimentados os organismos-teste, anotando-se o número de organismos vivos e de neonatos nascidos.

Foram obtidas medidas das variáveis, $\mathrm{pH}$, condutividade elétrica, dureza e concentração de oxigênio dissolvido, na amostra e no controle, conforme ABNT (2005). Para que o resultado de um ensaio ecotoxicológico crônico seja válido é necessário, no mínimo, $60 \%$ das fêmeas se reproduzindo na amostra controle e somando pelo menos 15 neonatos cada, e não superando oito dias de teste.

O resultado expresso em presença/ausência de toxicidade crônica foi calculado estatisticamente através do Aplicativo Graph Pad InStat, versão 3.00 (Motulsky, 1995). O número de neonatos produzidos por cada fêmea foi submetido a uma análise de normalidade e, em seguida, ao teste de Tukey (teste paramétrico). A ausência de distribuição normal exige que os dados sejam submetidos à estatística Kruskal-Wallis (Dunn's Multiple Comparisions Test), teste não paramétrico, a fim de verificar diferenças significativas ou não, para cada amostra em relação ao controle. 


\subsubsection{Ensaios de extração e quantificação de substâncias orgânicas}

Os ensaios de extração e quantificação de substâncias orgânicas foram realizados no Laboratório de Química Ambiental do Instituto de Química de São Carlos, EESC/USP, conforme procedimentos recomendados pela Environmental Protection Agency (EPA). Os resultados estão apresentados no Apêndice G.

\section{Orgânicos}

Os ensaios realizados para as substâncias orgânicas, Benzeno-Tolueno-EtilbenzenoXileno (BTEX) foram baseados nos Métodos 3810 (EPA, 1986a) e 8020A (EPA, 1999). A identificação dos compostos orgânicos estudados foi feita por cromatógrafo gasoso da marca SHIMADZU com detector FID, modelo 17 A. Para a extração dos BTEX nas amostras foi utilizada a técnica Headspace no modo estático. A coluna utilizada para a separação dos analitos foi a HP1 (30m x 0,25mm). O Nitrogênio foi usado como gás de arraste com uma razão de fluxo de $1,0 \mathrm{~mL} / \mathrm{min}$. A rampa de aquecimento utilizada foi $40^{\circ} \mathrm{C}$ por 1 minuto, $5^{\circ} \mathrm{C}$ por minuto até $60^{\circ} \mathrm{C}$, e $10^{\circ} \mathrm{C}$ por minuto até $120^{\circ} \mathrm{C}$, totalizando um tempo de análise de 11 minutos. A temperatura utilizada para o injetor foi $220^{\circ} \mathrm{C}$ e para o detector $280^{\circ} \mathrm{C}$. O modo de injeção utilizado foi split 1:10. A temperatura utilizada para a encubação do frasco foi de $80^{\circ} \mathrm{C}$, com um tempo de 10 minutos, e a temperatura da seringa foi de $80^{\circ} \mathrm{C}$. O volume injetado de amostra foi de $800 \mu \mathrm{L}$.

O Benzo-a-pireno foi analisado com base nos Métodos 610 (EPA, 1984a) e 8310 (EPA, 1986b). A determinação foi feita por cromatógrafo líquido da marca SHIMADZU com detector UV-Vis e fluorescência, modelo SD -10A.

A coluna utilizada para a separação do Benzo-a-pireno foi a Wakosil II 5C18-AR (dimensão: $250 \mathrm{~mm} \times$ x 4,6mm) com uma coluna de guarda conectada. Acetonitrila e água deionizada foram usadas como solventes de eluição com razão de fluxo de $1,8 \mathrm{~mL} / \mathrm{min}$.

\section{Organoclorados}

A extração dos organoclorados em água foi baseada na extração em fase sólida, utilizando cartuchos de $\mathrm{C}_{18}$, obtidos comercialmente, por ser um método que utiliza pouco solvente e é relativamente mais rápido que a extração líquido-líquido. As análises foram realizadas com base no Método 608 (EPA, 1984b), utilizando-se cromatógrafo gasoso com detector de captura de elétrons GC-ECD, injetor split, HP 5890, Série II. A coluna utilizada foi SPB5 (5\% difenil/95\% dimetilsiloxano; 30m $\times 0,25 \mathrm{~mm} \times 0,25 \mu \mathrm{m})$. A rampa de aquecimento utilizada foi $170^{\circ} \mathrm{C}$ por $1 \mathrm{~min}, 5^{\circ} \mathrm{C}$ por min até $300^{\circ} \mathrm{C}$. A temperatura do injetor foi $280^{\circ} \mathrm{C}$ e para o detector $300^{\circ} \mathrm{C}$, utilizando como gás de arraste $\mathrm{H}_{2}$, a uma razão de fluxo 
de $1 \mathrm{~mL} / \mathrm{min}$. O modo de injeção utilizado foi split 1:12. O volume injetado de amostra foi de

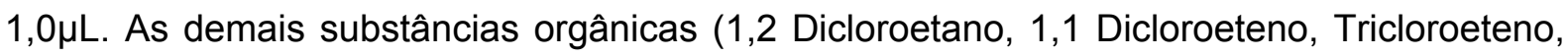
Tetracloreto de Carbono e Tetracloroeteno) foram analisadas com base no mesmo método utilizado para os organoclorados.

\section{Organofosforados}

A extração dos organofosforados em água foi baseada na extração em fase sólida, utilizando cartuchos de $\mathrm{C}_{18}$. As determinações foram realizadas com base no Método $8141 \mathrm{~A}$ (EPA, 1994), utilizando-se cromatógrafo líquido da marca SHIMADZU com detector UV-Vis e fluorescência, modelo SD-10A, em comprimentos de onda de $254 \mathrm{~nm}$ e $365 \mathrm{~nm}$. Foi utilizada coluna Shim-pack $\mathrm{C}_{18}$ fase reversa. Como fase móvel, utilizou-se metanol/água 70:30 (v/v), com fluxo de $1 \mathrm{~mL} / \mathrm{min}$ e um volume de injeção de $20 \mu \mathrm{L}$ de cada amostra.

\subsection{Análise das amostras de solo}

Foram coletadas amostras de solo no lixão de Jaú durante sondagem realizada em agosto de 2004 para construção de poços de monitoramento do aqüífero freático. As análises de metais foram realizadas no Laboratório de Química Analítica do Instituto de Química da UNESP, Câmpus Araraquara. Os metais analisados foram: Zinco, Chumbo, Cádmio, Níquel, Ferro, Manganês, Cobre, Cromo Total e Alumínio.

As amostras analisadas foram: (1) do poço a montante (PM), aos 15 metros de profundidade e (2) do poço a jusante (PJ3), aos 8 metros de profundidade (Figura 18). Essas amostras foram escolhidas com o objetivo de comparar os valores e avaliar se está ocorrendo contaminação do solo por percolação do lixiviado no lixão de Jaú, desprovido de medidas de controle e prevenção da poluição.

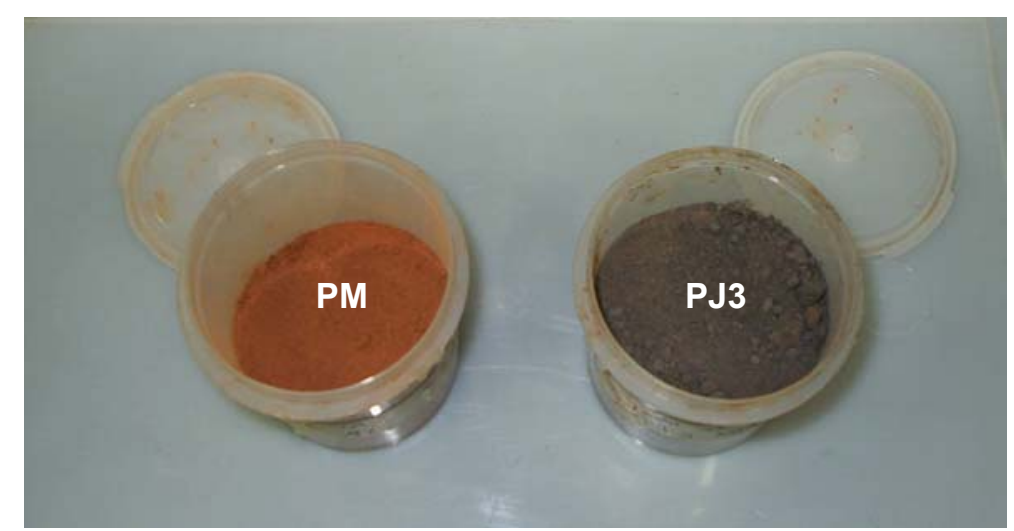

Figura 18 - Amostras de solo do PM e do PJ3 do lixão de Jaú 
Era pressuposto que as amostras do PM apresentariam concentrações de metais presentes naturalmente no solo da área e, portanto, não estariam contaminadas. Ao contrário, era previsto que as amostras do PJ3, localizado próximo aos resíduos na cota mais baixa do terreno, apresentariam concentrações de metais mais elevadas devido à percolação do chorume. De acordo com Anexo 2 e informações do geólogo responsável pela sondagem e construção dos poços, as amostras do PM foram classificadas como solo residual de arenito na profundidade entre os 11,47 e 29,00m, com coloração vermelha clara. As amostras do PJ3 foram classificadas como solo aluvionar na profundidade entre os 5,20 e 9,50m, que naturalmente apresentam cor cinza devido à presença de matéria orgânica.

As amostras foram maceradas e pesadas. Foi separado 1 grama de solo em balança analítica da marca Mettler Toledo, modelo AG 245. As amostras foram analisadas em duplicata. O peso das amostras está apresentado no Quadro 8.

Quadro 8 - Peso das amostras de solo para análise de metais

\begin{tabular}{|c|c|c|c|}
\hline Amostras & Peso $(\mathbf{g})$ & \multirow{2}{*}{ Poços } & Profundidade (m) \\
\hline 1 & 1,0090 & \multirow{2}{*}{ PM } & 15 \\
\hline 2 & 1,0021 & & \multirow{2}{*}{ PJ3 } \\
\hline 3 & 1,0081 & \multirow{2}{*}{ PJ3 } & 8 \\
\hline
\end{tabular}

Foi realizado digestão das amostras na chapa elétrica em capela com adição de água oxigenada $\left(\mathrm{H}_{2} \mathrm{O}_{2}\right) 30$ volumes, marca Merck e ácido nítrico $\left(\mathrm{HNO}_{3}\right)$, Synth, 64-66\%. $\mathrm{O}$ branco foi preparado com mistura de $\mathrm{HNO}_{3}$ e $\mathrm{H}_{2} \mathrm{O}_{2}$, sem amostra de solo.

Foi adicionado $20 \mathrm{~mL}$ de $\mathrm{HNO}_{3}$ a 1 grama de amostra de solo, aquecida até ebulição. Em seguida foi adicionado $10 \mathrm{~mL}$ de $\mathrm{H}_{2} \mathrm{O}_{2}$ e aquecida até ebulição. Esse processo foi repetido três vezes até a água ficar límpida, ou seja, até a abertura das amostras. Caso contrário, os metais ficam complexados na matéria orgânica. Antes da terceira adição de $\mathrm{H}_{2} \mathrm{O}_{2}$ foi adicionado $10 \mathrm{~mL}$ de $\mathrm{HNO}_{3}$. Dessa forma, os metais ficam na forma de íons nitrato: nitrato de cádmio, nitrato de chumbo, etc. Esse procedimento facilita a leitura dos metais, pois todos os nitratos são solúveis. Quando o líquido evapora, os metais atomizam e ficam na forma elementar.

Após digeridas, as amostras foram colocadas em balão volumétrico de $100 \mathrm{~mL}$, com ajuda de um funil. O volume do balão foi completado com água destilada. As amostras ficaram reservadas na bancada do laboratório até leitura no espectrofotômetro de absorção atômica, realizada no dia 04/05/2005.

Os metais foram determinados pelo Espectrofotômetro de Absorção Atômica com chama da Perkin-Elmer, modelo Aanalyst 300, de acordo com as recomendações do 
fabricante. Como fontes foram usadas lâmpadas individuais para cada metal. Apenas o alumínio foi obtido por meio do Espectrômetro de Emissão Atômica com Plasma de Argônio Induzido (ICP-OES).

\subsection{Análise estatística}

Foi realizada Análise Multivariada (MANOVA) dos dados, ou seja, as variáveis foram analisadas estatisticamente em conjunto com o objetivo de verificar se havia diferença significativa entre os poços. A probabilidade adotada foi $p<0,05$, porcentagem de acerto equivalente a $95 \%$.

Utilizou-se a Análise de Componentes Principais (PCA), método de ordenação descrito por Karl Pearson em 1901. A PCA consiste em uma auto-análise de uma matriz de correlação ou variância/covariância calculada a partir dos dados originais. A PCA gera vários resultados, denominados autovalores, que significam quanto cada eixo da PCA explica a variação dos dados. O auto valor do primeiro eixo é maior que do segundo eixo e assim por diante. Espera-se que os dois ou três primeiros eixos expliquem $60 \%$ ou mais da variação. Assim, foram utilizados os três primeiros eixos de referência e nota de corte 0,7. Quando a mesma não foi alcançada, os parâmetros foram descartados.

As variáveis bacteriológicas (Coliformes Totais e Termotolerantes) não fizeram parte da análise, pois a PCA é indicada apenas para variáveis abióticas. Além disso, os parâmetros que não apresentaram variação significativa ou que se mantiveram constantes foram descartados. Portanto, os Sulfetos não fizeram parte da análise.

A PCA foi realizada com o objetivo de hierarquizar os parâmetros por ordem de importância e, assim, verificar qual deles apresentou maior variação, podendo ter influenciado mais significativamente a qualidade da água.

Partindo das PCAs, procurou-se descobrir padrões de similaridade entre os aterros e córregos estudados, por meio da análise de agrupamento sobre a matriz dos escores da PCA de cada aterro e de cada córrego. Para isso foi realizada Análise de Cluster das médias das variáveis selecionadas na PCA de cada aterro e de cada córrego, agrupando-os por similaridade. O método adotado foi a Análise de Agrupamento de Média Não Ponderada (UPGMA). Foram selecionadas as variáveis comuns entre os aterros e córregos. A similaridade entre eles foi identificada pela menor distância euclidiana média (eixo $\mathrm{x}$ do gráfico). Na Análise de Cluster foi calculado o coeficiente de correlação cofenética, que segundo Legendre (1983) devem ser aceitos valores superiores a 0,8. 


\subsection{Análise dos resultados}

Os resultados das análises realizadas foram comparados aos limites estabelecidos pelas legislações vigentes (Quadro 9).

Os resultados obtidos nas amostras de água subterrânea foram comparados aos limites estabelecidos pela Portaria 518/2004 do Ministério da Saúde que estabelece Padrões de Potabilidade, visto que a NBR 13896 da Associação Brasileira de Normas Técnicas (ABNT, 1997a, p.4) recomenda que a qualidade da água subterrânea na área de influência dos aterros sanitários atenda aos padrões de potabilidade estabelecidos pela legislação vigente. Além disso, "a utilização dos padrões de potabilidade para comparação é efetuada em atendimento à Lei Federal n 9433 de 08/01/1997, que estabelece que a qualidade das águas deve atender aos múltiplos usos, sendo, no caso das águas subterrâneas, o consumo humano, o uso mais restritivo para a maioria dos parâmetros analisados" (CETESB, 2007e, p.2).

Os parâmetros não contemplados pela Portaria 518/2004 foram comparados aos limites estabelecidos pela CONAMA 357/2005 para águas superficiais Classe 2, destinadas ao abastecimento público após tratamento convencional, à pesca, irrigação e recreação. Esta medida foi adotada para se ter um parâmetro de comparação, já que os córregos mais próximos às áreas monitoradas pertencem à Classe 2. Segundo CETESB (2002, p.165), a maioria dos corpos d'água superficiais do Estado de São Paulo estão enquadrados nesta classe, que é adequada para usos nobres dos recursos hídricos. Os resultados das amostras de água subterrânea também foram comparados aos valores encontrados por CETESB (2007e) no mesmo Sistema Aqüífero das áreas monitoradas, pois "as concentrações naturais das substâncias na água subterrânea variam de aqüífero para aqüífero" CETESB (2004, p.72). Além disso, foi realizada comparação com valores encontrados na literatura.

Os resultados obtidos nas amostras de água superficial foram comparados aos limites estabelecidos pela Resolução CONAMA 357/2005, que estabelece padrões de qualidade para água doce (Classe 2), uma vez que os córregos monitorados foram enquadrados nesta classificação, com base no Decreto 10.755, de 22 de novembro de 1977, do Estado de São Paulo, que dispõe sobre o enquadramento dos corpos de água receptores na classificação prevista do Decreto 8.468, de 8 de setembro de 1976. Vale ressaltar que "o fato de um trecho de rio estar enquadrado em determinada classe não significa que, necessariamente, esse seja o nível de qualidade que apresenta, mas sim aquela que se busca alcançar ou manter ao longo do tempo" (IPT, 2000).

Para o cálculo das médias, os valores abaixo do limite de detecção do aparelho foram considerados nulos. Os resultados obtidos em laboratório, bem como pela análise 
estatística, somados às informações obtidas por meio das visitas e dos questionários, subsidiaram as discussões e conclusões da tese.

Quadro 9 - Padrões de qualidade de água, segundo as legislações vigentes

\begin{tabular}{|c|c|c|c|c|c|}
\hline \multirow{2}{*}{\multicolumn{2}{|c|}{ Parâmetros }} & \multirow[b]{2}{*}{ unidade } & \multirow{2}{*}{$\begin{array}{c}\text { Água subterrânea } \\
\text { Portaria } \\
518 / 2004^{*}\end{array}$} & \multicolumn{2}{|c|}{ Água superficial Classe 2} \\
\hline & & & & $\begin{array}{l}\text { CONAMA } \\
357 / 2005^{* *}\end{array}$ & $\begin{array}{c}\text { Decreto } \\
8468 / 1976^{\star * \star}\end{array}$ \\
\hline 1 & Temperatura & ${ }^{\circ} \mathrm{C}$ & - & - & - \\
\hline 2 & $\mathrm{pH}$ & - & $6,0-9,5$ & $6,0-9,0$ & - \\
\hline 3 & Oxigênio Dissolvido & $\mathrm{mg} / \mathrm{L}$ & - & $\geq 5,0$ & $\geq 5,0$ \\
\hline 4 & Condutividade Elétrica & $\mu \mathrm{S} / \mathrm{cm}$ & - & - & - \\
\hline 5 & Salinidade & $\%$ & - & - & - \\
\hline 6 & Turbidez & UT & 5,0 & 100,0 & - \\
\hline 7 & Cor Aparente & UC & 15,0 & 75,0 & - \\
\hline 8 & Fósforo Total & $\mathrm{mg} \mathrm{P/L}$ & - & 0,05 & - \\
\hline 9 & Carbono Orgânico Total & $\mathrm{mg} \mathrm{C} / \mathrm{L}$ & - & - & - \\
\hline 10 & Nitrogênio Amoniacal & $\mathrm{mg} \mathrm{N} / \mathrm{L}$ & 1,5 & 3,7 & 0,5 \\
\hline 11 & Nitrogênio Nitrato & $\mathrm{mg} \mathrm{N} / \mathrm{L}$ & 10,0 & 10,0 & 10,0 \\
\hline 12 & Nitrogênio Nitrito & $\mathrm{mg} \mathrm{N} / \mathrm{L}$ & 1,0 & 1,0 & 1,0 \\
\hline 13 & Nitrogênio Total & $\mathrm{mg} \mathrm{N} / \mathrm{L}$ & - & 2,18 & - \\
\hline 14 & Cloretos & $\mathrm{mg} \mathrm{Cl} / \mathrm{L}$ & 250,0 & 250,0 & - \\
\hline 15 & Sulfatos & $\mathrm{mg} \mathrm{SO}_{4}{ }^{2-} / \mathrm{L}$ & 250,0 & 250,0 & - \\
\hline 16 & Sulfetos & $\mathrm{mg} \mathrm{S}^{2-} / \mathrm{L}$ & 0,05 & 0,002 & - \\
\hline 17 & Fluoretos & $\mathrm{mg} \mathrm{F}^{-} / \mathrm{L}$ & 1,5 & 1,4 & - \\
\hline 18 & Sólidos Totais & $\mathrm{mg} / \mathrm{L}$ & - & - & - \\
\hline 19 & Sólidos Totais Fixos & $\mathrm{mg} / \mathrm{L}$ & - & - & - \\
\hline 20 & Sólidos Totais Voláteis & $\mathrm{mg} / \mathrm{L}$ & - & - & - \\
\hline 21 & Sólidos Totais Dissolvidos & $\mathrm{mg} / \mathrm{L}$ & - & 500 & - \\
\hline 22 & Demanda Bioquímica de Oxigênio & $\mathrm{mg} \mathrm{O}_{2} / \mathrm{L}$ & - & $\leq 5,0$ & $\leq 5,0$ \\
\hline 23 & Demanda Química de Oxigênio & $\mathrm{mg} \mathrm{O}_{2} / \mathrm{L}$ & - & - & - \\
\hline 24 & Coliformes Termotolerantes & UFC/100mL & - & 1000 & 1000 \\
\hline 25 & Coliformes Totais & UFC/100mL & - & - & 5000 \\
\hline 26 & Zinco & $\mathrm{mg} \mathrm{Zn/L}$ & 5,0 & 0,18 & 5,0 \\
\hline 27 & Chumbo & $\mathrm{mg} \mathrm{Pb/L}$ & 0,01 & 0,01 & 0,1 \\
\hline 28 & Cádmio & $\mathrm{mg} \mathrm{Cd} / \mathrm{L}$ & 0,005 & 0,001 & 0,01 \\
\hline 29 & Níquel & $\mathrm{mg} \mathrm{Ni} / \mathrm{L}$ & - & 0,025 & - \\
\hline 30 & Ferro Solúvel & $\mathrm{mg} \mathrm{Fe} / \mathrm{L}$ & 0,3 & 0,3 & - \\
\hline 31 & Manganês Solúvel & $\mathrm{mg} \mathrm{Mn/L}$ & 0,1 & 0,1 & - \\
\hline 32 & Cobre & $\mathrm{mg} \mathrm{Cu} / \mathrm{L}$ & 2,0 & 0,009 & 1,0 \\
\hline 33 & Cromo Total & $\mathrm{mg} \mathrm{Cr} / \mathrm{L}$ & 0,05 & 0,05 & 0,05 \\
\hline 34 & Cromo Hexavalente & $\mathrm{mg} \mathrm{Cr} / \mathrm{L}$ & - & 0,05 & - \\
\hline 35 & Alumínio & $\mathrm{mg} \mathrm{Al} / \mathrm{L}$ & - & 0,1 & - \\
\hline
\end{tabular}

* Portaria ${ }^{0} 518$, de 25 de março de 2004, do Ministério da Saúde. Estabelece os Padrões de Potabilidade. Revoga a Portaria 1469, de 29 de dezembro de 2000.

** Resolução $n^{\circ} 357$, de 17 de março de 2005, do Conselho Nacional do Meio Ambiente (CONAMA). Dispõe sobre a classificação e diretrizes ambientais para o enquadramento dos corpos d'água superficiais, bem como estabelece as condições e padrões de lançamento de efluentes. Revoga a Resolução CONAMA 20/1986.

${ }^{* * *}$ Decreto ${ }^{\circ} 8468$, de 08 de setembro de 1976, do Governo do Estado de São Paulo. Regulamenta a Lei 997, 31 de maio de 1976. Dispõe sobre a Prevenção e o Controle da Poluição do Meio Ambiente. 


\section{RESULTADOS E DISCUSSÕES}

Neste capítulo foram apresentados e discutidos os dados referentes à gestão dos resíduos sólidos urbanos nos municípios monitorados, bem como os resultados dos ensaios físico-químico, microbiológico e toxicológico, realizados com amostras de água subterrânea, coletadas nas áreas de disposição final de Araraquara, Bauru, Jaú e São Carlos. Foram analisados os resultados obtidos com amostras de água superficial, coletadas nos córregos do Pinheirinho em Araraquara, da Gabiroba em Bauru, da Cachoeira Grande em Brotas, no Ribeirão do Matão em Jaú, nos córregos do Tamanduá em Ribeirão Bonito, do Galdino e São José em São Carlos, localizados na área de influência dos aterros e lixões. Ao final, foi realizada a comparação entre as áreas de disposição final e os córregos.

Vale destacar que dos 37 questionários enviados, apenas dez foram respondidos, o que correspondeu a $27 \%$. As prefeituras que responderam os questionários foram: (1) Araraquara, (2) Bariri, (3) Barra Bonita, (4) Bauru, (5) Brotas, (6) Dois Córregos, (7) Itirapina, (8) Jaú, (9) Ribeirão Bonito e (10) São Carlos. As prefeituras que forneceram autorização para visitas e obtenção de imagens foram: (1) Araraquara, (2) Bauru, (3) Brotas, (4) Dois Córregos, (5) Itirapina, (6) Jaú, (7) Ribeirão Bonito e (8) São Carlos. O município de Dois Córregos possui um aterro em valas, semelhante ao de Ribeirão Bonito, e Itirapina possui um aterro em trincheiras, impermeabilizadas com manta, semelhante ao de Brotas.

\subsection{Caracterização dos municípios monitorados quanto aos resíduos sólidos}

\subsubsection{Araraquara}

\subsubsection{Resíduos Sólidos Domiciliares (RSD)}

O município de Araraquara possui cerca de 195.815 habitantes (IBGE, 2007) e gera em torno de 165 toneladas por dia de RSD.

\section{Coleta regular}

Os RSD são coletados pela empresa Leão Ambiental e transportados ao aterro. Os RSD gerados na área rural também são coletados. A coleta regular atende $100 \%$ dos bairros de Araraquara. Para a coleta dos RSD, a cidade foi dividida em 19 setores, são 
utilizados seis caminhões compactadores no período diurno e seis no período noturno. No total, são 12 motoristas e 36 coletores.

\section{Coleta seletiva de materiais recicláveis}

A coleta seletiva foi implantada em novembro de 2005. Atendia $25 \%$ da população, contava com 14 pessoas da cooperativa Acácia e um caminhão compactador. O caminhão foi adquirido por meio de um convênio da prefeitura com o Fundo Estadual de Prevenção e Controle da Poluição (FECOP) e cedido ao DAAE (Departamento Autônomo de Água e Esgotos de Araraquara).

A coleta é realizada porta-porta, porém a população pode descartar os recicláveis nos PEVs (Pontos de Entrega Voluntária) implantados para receber os RCC. Segundo o DAAE, eram coletadas cerca de $22 \mathrm{t} /$ mês de recicláveis provenientes da coleta seletiva. Os dados referentes aos anos de 2005, 2006 e 2007 estão apresentados na Figura 19.

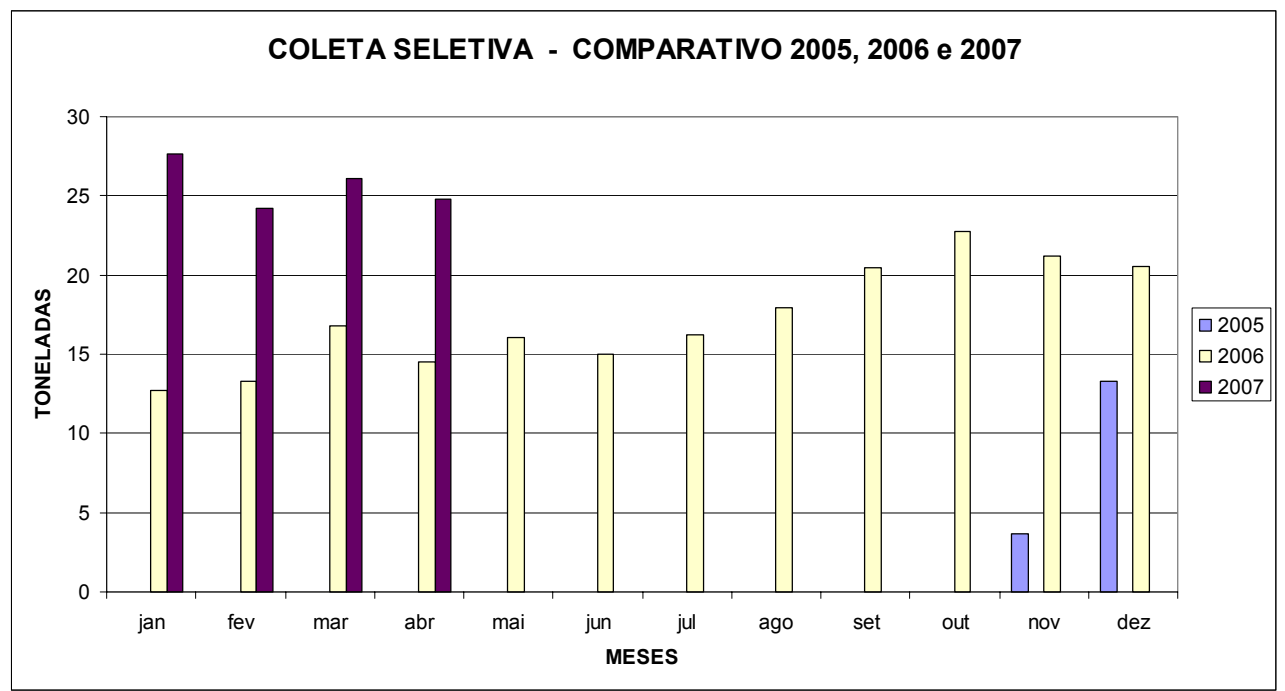

Figura 19 - Quantidade de recicláveis provenientes da coleta seletiva de Araraquara Fonte: DAAE de Araraquara, junho de 2007

Em 24 de setembro de 2007 a coleta foi ampliada para 100\% do município, que foi dividido em quatro setores (A, B, C e D). Para cada um destes setores foi alocado um caminhão tipo baú, com exceção do setor $A$, que era o existente, que continuou com o caminhão compactador.

A freqüência da coleta é semanal e sua distribuição é apresentada no Quadro 10. Vale destacar que o DAAE possui os dados da geração de recicláveis por bairro. 
Quadro 10 - Distribuição da coleta seletiva em Araraquara

\begin{tabular}{|l|l|}
\hline \multicolumn{1}{|c|}{ Dia da semana } & \multicolumn{1}{c|}{ Bairros } \\
\hline segunda-feira & São José \\
\hline terça-feira & Santana e São Geraldo \\
\hline quarta-feira & Centro, Carmo e Jardim Morumbi \\
\hline quinta-feira & Centro e Jardim Primavera \\
\hline sexta-feira & Quitandinha, Jardim Santa Lúcia e Jardim Tamoio \\
\hline
\end{tabular}

Fonte: Estação de Tratamento de Resíduos Sólidos de Araraquara, 2007

Segundo o DAAE, a despesa com a coleta seletiva era de $\mathrm{R} \$ 3.425,00 / \mathrm{mês}$, considerando gastos com o combustível e com o motorista do caminhão. Atualmente a despesa é de $\mathrm{R} \$ 38.375,62 / \mathrm{mês}$, devido à locação de três caminhões baú.

Para a ampliação do serviço foi necessário o aumento do número de participantes da cooperativa de catadores, distribuição de panfletos, avisos na televisão e internet com orientações para a população sobre o funcionamento da coleta seletiva. Em 2006 foi realizado estudo com vistas à inclusão dos catadores autônomos no programa de coleta seletiva. É proposta do DAAE a implantação de um Disque Coleta ou Coleta Agendada, voltada a estabelecimentos que armazenem um determinado volume de materiais recicláveis como escolas, postos de gasolina, entre outros.

\section{Tratamento}

Triagem dos materiais recicláveis

Na Estação de Tratamento de Resíduos Sólidos (ETRS) funciona uma Central de Triagem desde 1988 (Figura 20 e Figura 21), onde os materiais recicláveis são separados.

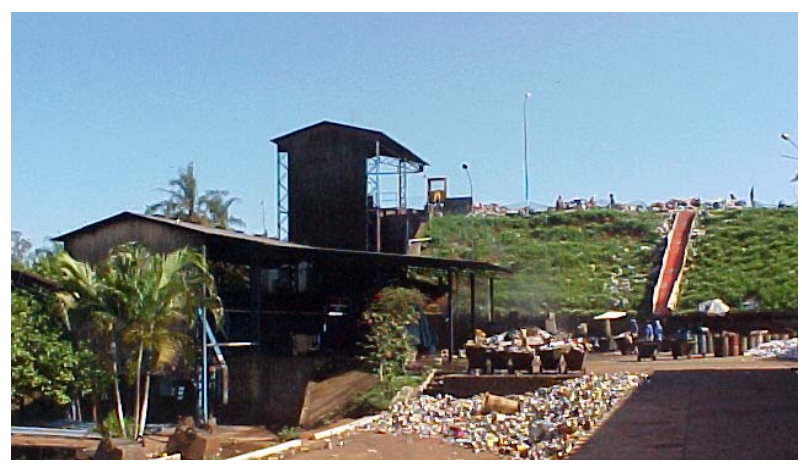

Figura 20 - Central de Triagem de recicláveis no aterro de Araraquara, 04/11/2003

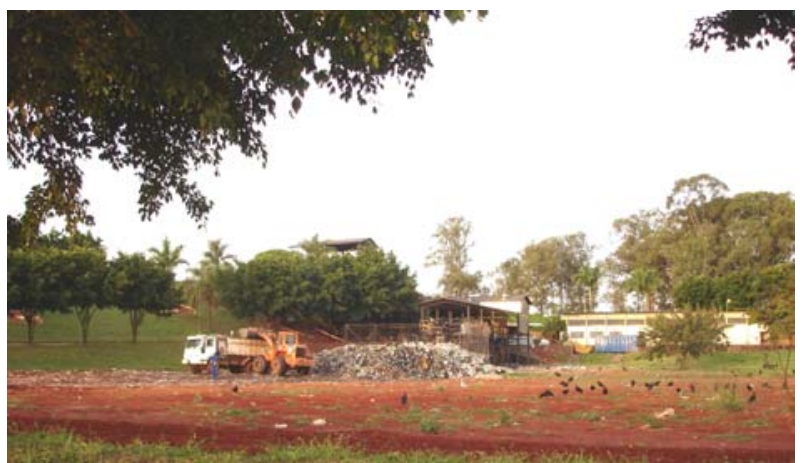

Figura 21 - Central de Triagem de recicláveis no aterro de Araraquara, 10/05/2007

Até 2003 uma parte dos recicláveis era separada no pátio ao lado da Central de Triagem, porém atualmente os recicláveis são separados dentro desta Central, equipada 
com duas esteiras e quatro prensas. Eram encaminhadas para venda cerca de $87 \mathrm{t} / \mathrm{mês}$ de recicláveis, 22t/mês procediam da coleta seletiva e $65 \mathrm{t} / \mathrm{mês}$ da coleta regular.

Atualmente a usina recebe apenas o material procedente da coleta seletiva, os resíduos da coleta regular são encaminhados para o aterro.

Segundo o DAAE, a despesa com a usina de triagem é de $\mathrm{R} \$ 34.660,00 / \mathrm{mês}$. Vale ressaltar que este valor não é dedutível dos ganhos da cooperativa de catadores, pois sozinha a mesma não se mantém.

Atualmente a cooperativa Acácia possui 116 catadores, 60 trabalham na central e 56 na coleta seletiva porta a porta. Segundo dados do DAAE, o valor médio obtido com a venda de recicláveis foi de $\mathrm{R} \$ 28.591,16$ entre os meses de janeiro a abril de 2007 . Neste mesmo período cada catador lucrou em média $\mathrm{R} \$ 375,17 /$ mês, deduzindo-se as despesas. Conforme o DAAE, com o aumento do número de catadores na cooperativa, a renda média individual aumentou para cerca de $\mathrm{R} \$ 500,00 /$ mês.

\section{Compostagem}

Até 2002, parte dos RSD era encaminhada para compostagem num pátio ao lado da central de triagem, atualmente desativado. Posteriormente, o pátio foi coberto com terra e transformado num mini campo de futebol (Figura 24, item 4). O lixiviado gerado pelo composto é drenado para a ETE do município.

Atualmente cerca de 9,0t/d de resíduos de poda e capina são dispostas no aterro. Apesar da prefeitura possuir um picador de galhos, a compostagem não é mais realizada em função das dificuldades na operação e venda do composto. Conforme o DAAE, este é um dos maiores problemas da ETRS.

\section{Disposição Final}

O terreno onde está localizado o aterro de Araraquara pertence à prefeitura que deu concessão de uso ao Departamento Autônomo de Água e Esgotos (DAAE) em 2003, responsável por sua operação.

De acordo com o DAAE, os RSD gerados por Araraquara são dispostos num antigo lixão, transformado em aterro controlado que opera desde 1975 (Figura 22 e Figura 23). 

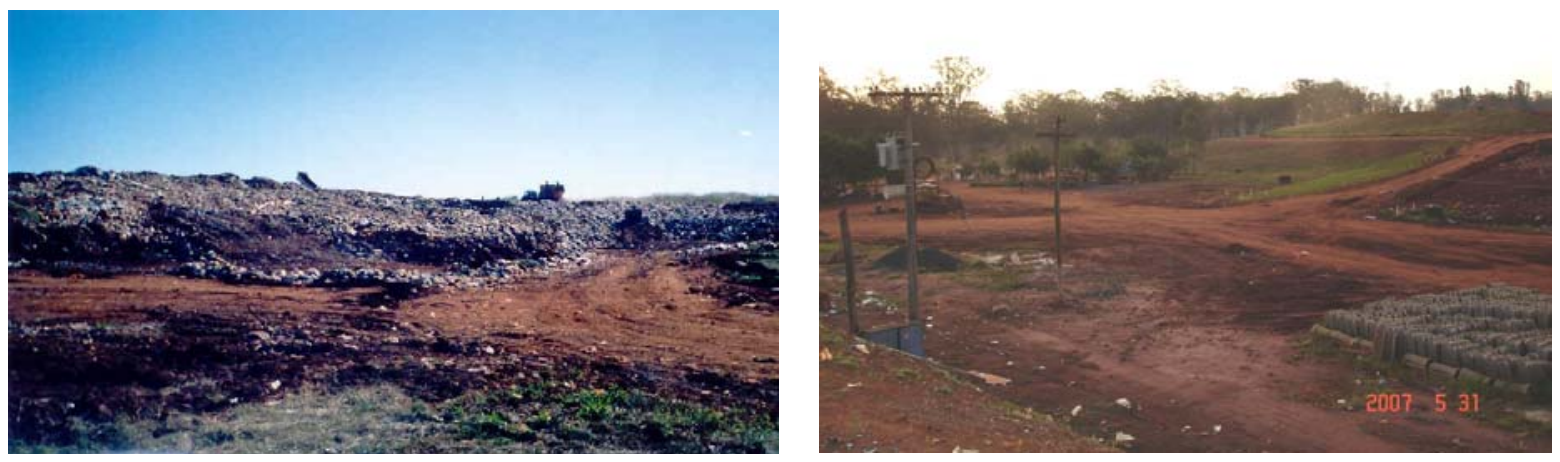

Figura 22 - Aterro de Araraquara, 11/02/2005 Figura 23 - Aterro de Araraquara, 31/05/2007

O aterro está localizado na Av. Gervásio Brito Teixeira, 750, Jardim Pinheiros, a nordeste do centro urbano, nas coordenadas $21^{\circ} 45^{\prime} \mathrm{S}$ e $48^{\circ} 07^{\prime} \mathrm{W}$, próximo ao $\mathrm{km} 74 \mathrm{da}$ Rodovia Antonio Machado Sant'ana SP 255 e ao Parque Ecológico do Pinheirinho. A área onde funciona o aterro (Figura 24) é chamada de Estação de Tratamento de Resíduos Sólidos (ETRS) de Araraquara. Nela são realizadas as seguintes operações:

- 1 - Disposição final dos resíduos sólidos domiciliares (Aterro Controlado);

- 2 - Triagem dos materiais recicláveis (Central de Triagem);

- 3 - Tratamento dos resíduos de serviços de saúde (Incinerador). 


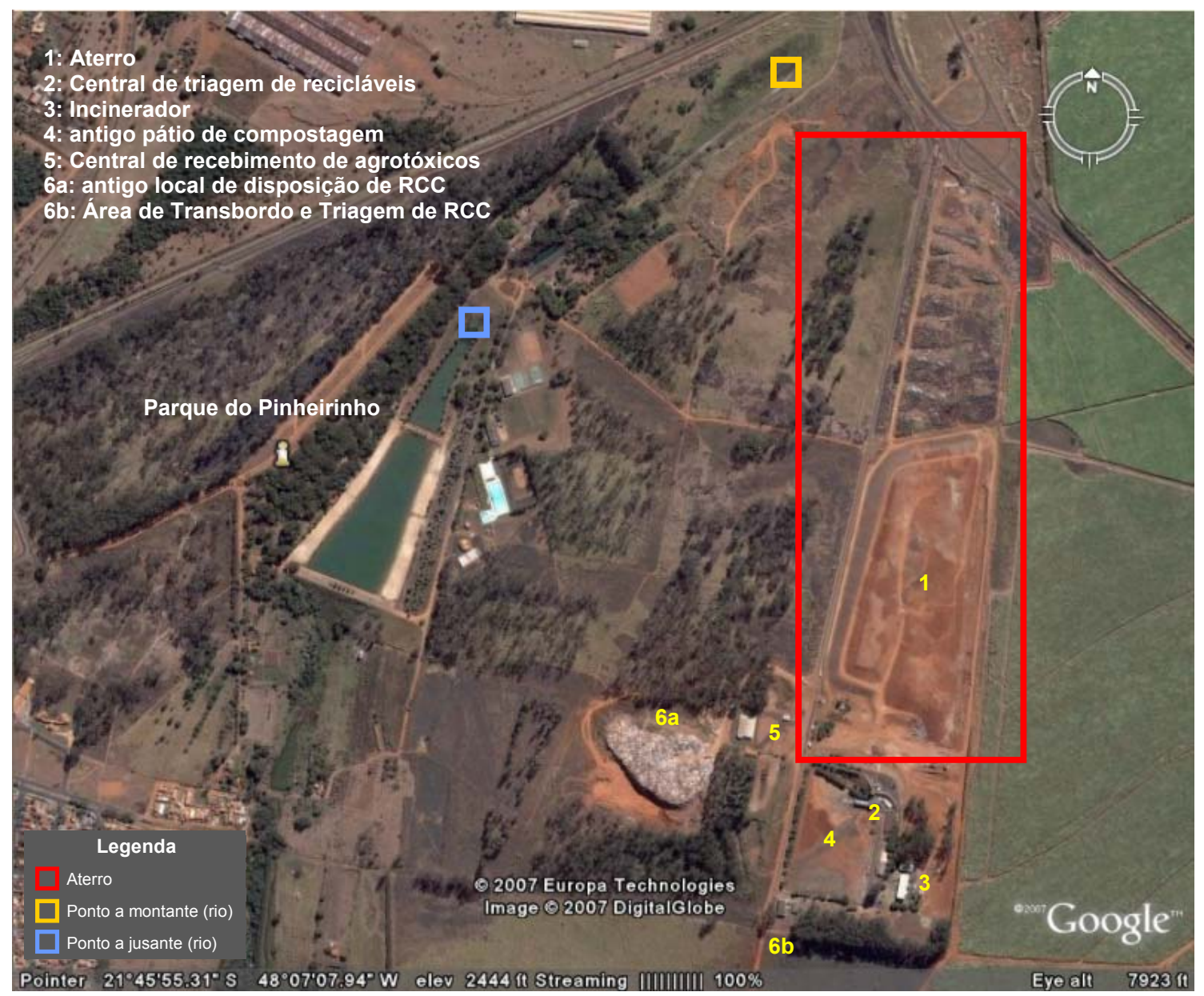

Figura 24 - Estação de Tratamento de Resíduos Sólidos de Araraquara

Fonte: Google Earth (2007)

Os pontos de coleta das águas superficiais estão identificados na Figura 24.

A área da ETRS de Araraquara é de $80.000 \mathrm{~m}^{2}$ e está localizada sobre a Formação Adamantina do Grupo Bauru, com base em IPT (1981). De acordo com relatório da empresa responsável pela sondagem do terreno, o solo recebeu duas classificações: coluvionar (com areias finas siltosas e argilosas, marrom avermelhadas, gradando a vermelhas com a profundidade) e residual de arenito/siltito (com argila e silte de coloração variegada, amarela). O aqüífero freático foi classificado como semi-confinado.

Segundo dados do DAAE, a permeabilidade do solo natural é de $10^{-5} \mathrm{~cm} / \mathrm{s}$ até a profundidade média de 10 metros e de $10^{-6} \mathrm{~cm} / \mathrm{s}$ até os 16 metros, ou seja, solo pouco permeável.

O local recebe os RSD gerados por Araraquara e por dois municípios vizinhos (Américo Brasiliense e Santa Lúcia). O primeiro gera em torno de 13,9t/d de RSD e o segundo cerca de 3,3t/d (CETESB, 2007a, p.40 e 58). 
Além dos RSD, animais mortos, resíduos não perigosos gerados pelas indústrias (Classe II), resíduos de poda e capina, bem como resíduos de varrição também são dispostos no aterro.

Segundo o DAAE, o lodo da ETE de Araraquara ainda não foi encaminhado para o aterro, desde o início da operação da estação. A lagoa de sedimentação está com um metro de lodo, sendo que possui uma profundidade total de cerca de quatro metros. Portanto, ainda não há previsão de quando o lodo será retirado. Porém, o aterro recebe os resíduos do desarenador da ETE, que constitui a penúltima fase dos processos mecânicos do tratamento de esgotos, antes da última peneira.

A vida útil do aterro já está quase esgotada. Segundo o DAAE, a previsão era que o aterro funcionasse até 2006. Está previsto ampliação do aterro em área contígua. $A$ intenção do DAAE é construir um aterro sanitário com projeto que considere vida útil de 40 anos para a futura área.

Na última avaliação da CETESB (2007a, p.14), o Índice de Qualidade de Aterro de Resíduos (IQR) foi 8,5. Segundo a CETESB, IQR entre 0 e 6 é considerado aterro em condições inadequadas; entre 6 e 8 condições controladas e entre 8 e 10 condições adequadas. Portanto, atualmente, o aterro de Araraquara foi classificado como adequado.

$O$ aterro possui guarita e balança na entrada para o controle da entrada de pessoas e caminhões, bem como da quantidade e tipo de resíduo encaminhado ao aterro.

Apesar do cercamento da área e da presença de vigilância, foi constatado presença de catadores no aterro, principalmente próximo ao local de disposição dos resíduos de poda e capina, conforme Figura 25 e Figura 26.
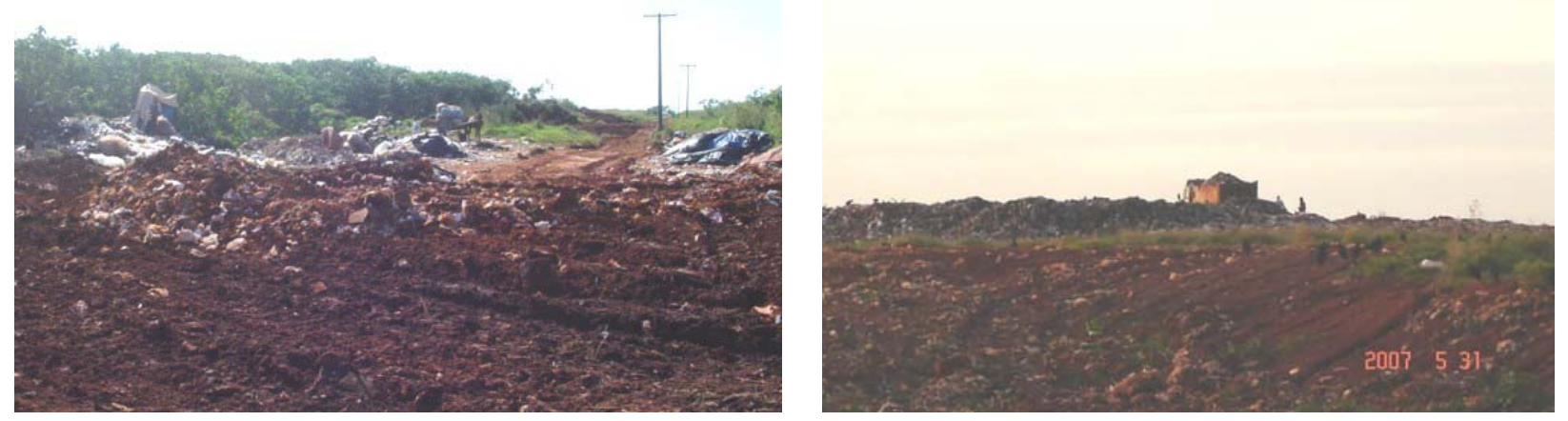

Figura 25 - Catadores no aterro de Araraquara Figura 26 - Presença de catadores no aterro de 02/07/2004 Araraquara, 31/05/2007 
Cobertura e compactação dos resíduos

Os resíduos são compactados e cobertos com terra regularmente (Figura 27 e Figura 28), porém em períodos chuvosos a operação do aterro é prejudicada devido à dificuldade de acesso dos caminhões. O solo usado para cobertura é retirado de área contígua ao aterro (Figura 24, item 6a).

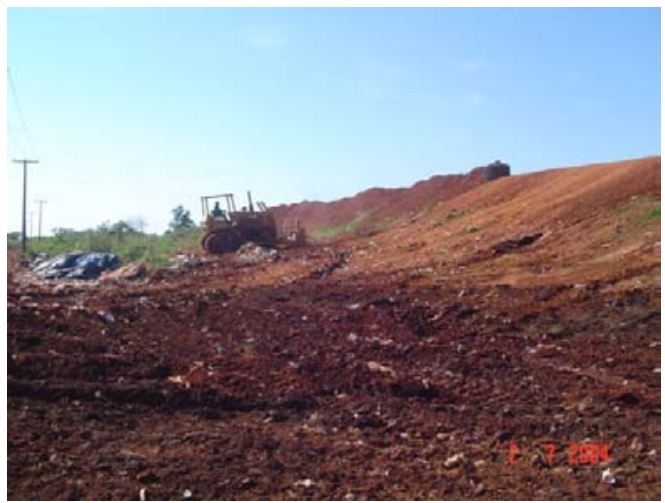

Figura 27 - Compactação de terra no aterro de Araraquara em 02/07/2004

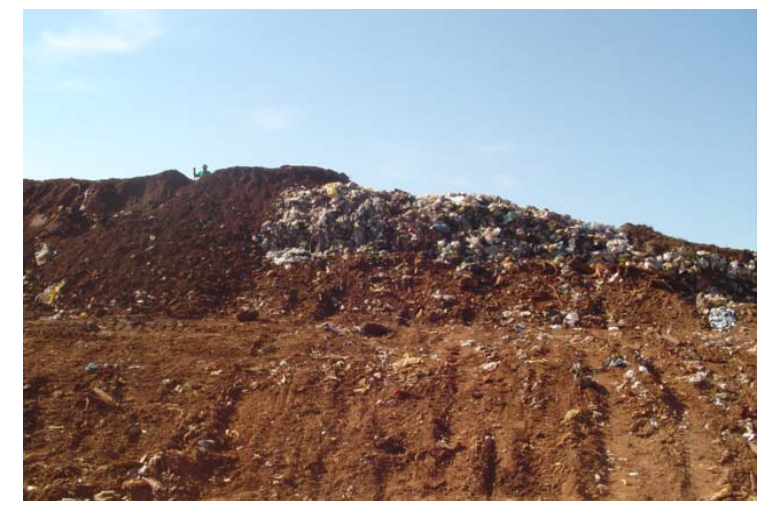

Figura 28 - Cobertura de resíduos no aterro de Araraquara em 09/11/2004

Coleta de gás e drenagem do lixiviado

O aterro possui coletores de gases e drenagem do lixiviado, porém o terreno não é impermeabilizado. O lixiviado coletado era aspergido no aterro para recirculação, porém atualmente é encaminhado para uma lagoa impermeabilizada (Figura 29) e desta é canalizado até a ETE do município. Estima-se uma geração média de $18 \mathrm{~m}^{3} /$ dia de lixiviado.

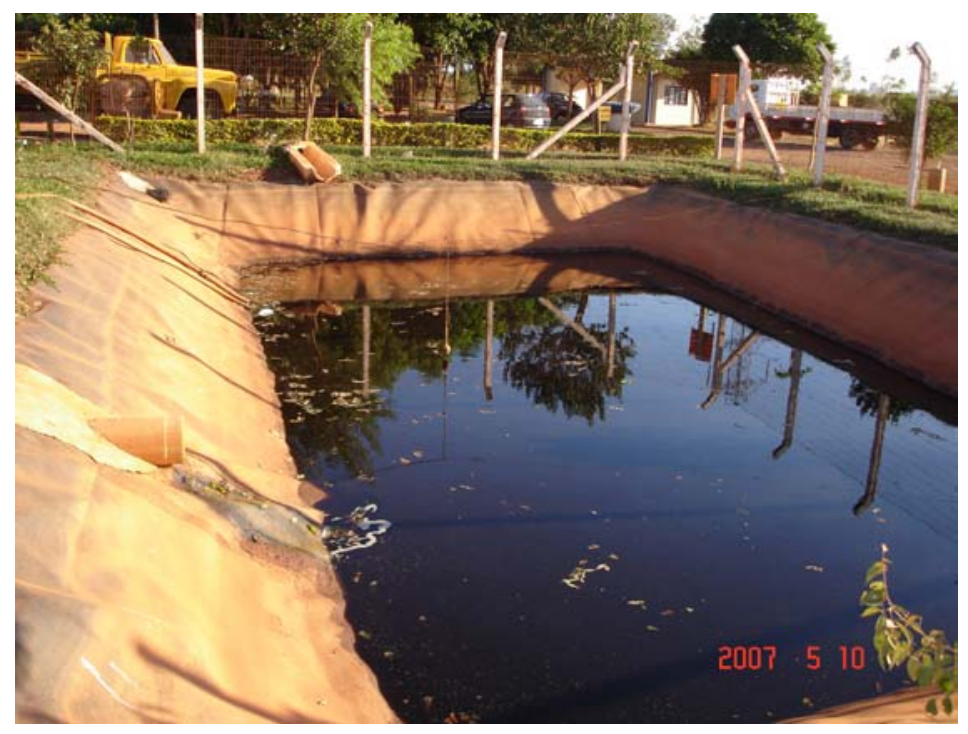

Figura 29 - Lagoa de lixiviado do aterro de Araraquara, 10/05/2007 
Monitoramento das águas subterrâneas

Em janeiro de 2004 foram construídos quatro poços para o monitoramento das águas subterrâneas (um a montante e três a jusante do aterro) com tubo de quatro polegadas no entorno do aterro, os quais foram protegidos, identificados e cercados. O posicionamento dos poços em relação ao aterro está apresentado na Figura 30.

A profundidade e o nível d'água nos poços de monitoramento, medido após a construção, estão apresentados na Tabela 16.

Tabela 16 - Profundidade e nível d'água dos poços do aterro de Araraquara

\begin{tabular}{c|c|c|c}
\hline \multicolumn{2}{c|}{ Poço } & Profundidade $(\mathbf{m})$ & Nível d'água $(\mathbf{m})$ \\
\hline Poço a Montante & PM1 & 17,00 & 11,39 \\
\hline \multirow{2}{*}{ Poços a Jusante } & PJ1 & 17,70 & 10,18 \\
& PJ2 & 16,60 & 13,41 \\
& PJ3 & 17,00 & 13,44 \\
\hline
\end{tabular}

Fonte: Estação de Tratamento de Resíduos Sólidos de Araraquara

O aspecto do aterro se modifica com o passar do tempo, à medida que vai expandindo e conforme a necessidade de melhorias. Em visita realizada em 11/02/2005, os resíduos estavam descobertos próximo ao poço PJ2 (Figura 22). Em 10/05/2007 constatouse que esta parte do aterro foi finalizada, inclusive com plantação de gramínea e construção de drenos para águas pluviais. Constatou-se também que os poços de monitoramento foram protegidos por uma parede de blocos de concreto, a fim de evitar vandalismo ou acidentes devido ao trânsito de caminhões. 


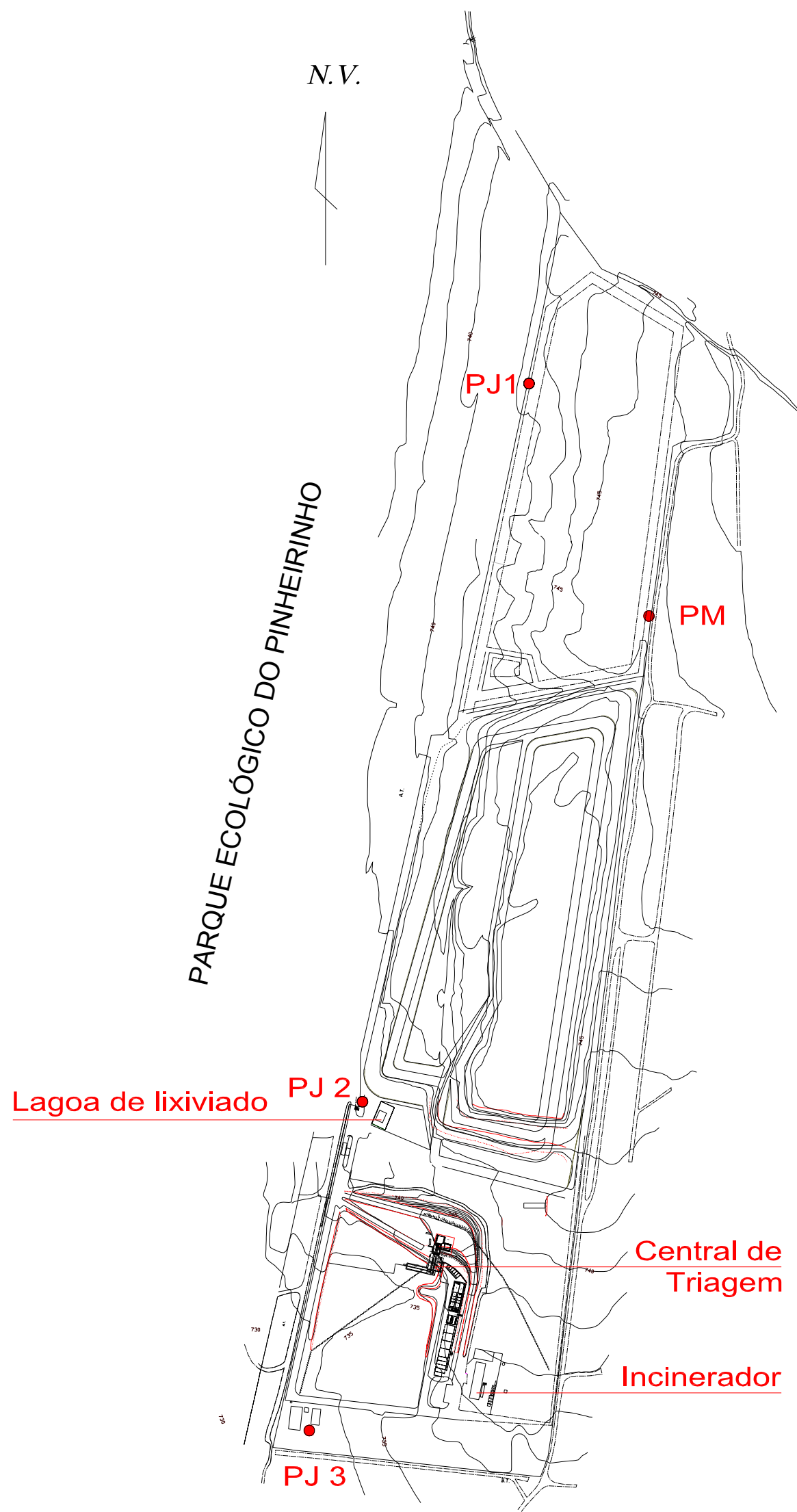

Figura 30 - Mapa do aterro de Araraquara, adaptado

Fonte: DAAE de Araraquara, 15/06/2007 


\subsubsection{Resíduo Domiciliar Perigoso (RDP)}

As pilhas e baterias são descartadas junto com os RSD, porém deveriam ser recebidas pelos distribuidores, revendedores e fabricantes destes produtos, conforme determinação da Lei Municipal $n^{\circ}$ 5.728, de 03/12/2001. Porém, segundo o DAAE, apenas um estabelecimento da cidade encaminha estes resíduos para tratamento em Campinas.

As lâmpadas fluorescentes passarão a ser recebidas e tratadas na ETRS. O DAAE já adquiriu um equipamento para descaracterização e descontaminação do material. O custo do equipamento foi de $R \$ 27.000,00$. A aquisição do equipamento foi necessária em função do alto custo para o tratamento destas lâmpadas, cerca de $\mathrm{R} \$ 0,70 /$ âmpada, além do transporte até o local de tratamento adequado.

\subsubsection{Resíduos de Serviços de Saúde (RSS)}

\section{Coleta}

Os RSS gerados na área urbana de Araraquara, Américo Brasiliense, Santa Lúcia, Rincão, Gavião Peixoto e Motuca são coletados pela prefeitura de Araraquara e encaminhados ao incinerador. A coleta é realizada por duas pessoas, um motorista e um ajudante, com uso de um furgão. A freqüência é diária em hospitais e alternada nos demais geradores.

\section{Tratamento}

No aterro de Araraquara havia um antigo incinerador (Figura 16, item 3), que funcionou entre 1990 e 2003. Assim, emergencialmente, a CETESB autorizou a disposição dos RSS em valas sépticas construídas no próprio aterro, no período de 2003 a 2005.

As valas possuíam as seguintes dimensões: 5 metros de largura, 12 metros de comprimento e 4 metros de profundidade. Posteriormente passaram a ser construídas com 34 metros de comprimento. As valas eram impermeabilizadas com asfalto e cal, quando preenchidas recebiam cobertura de terra. Antes de serem seladas, as valas eram cobertas com lona plástica para evitar infiltração de água de chuva e acesso de vetores.

A partir de maio de 2005 , os RSS passaram a ser tratados em um novo incinerador (Figura 31 e Figura 32), construído pelo DAAE e equipado com lavador de gases ácidos gerados durante a combustão. O equipamento tem capacidade para processar $100 \mathrm{~kg} / \mathrm{hora}$ de RSS. A obra custou cerca de $\mathrm{R} \$ 400.000,00$ e o custo da operação do equipamento é de $\mathrm{R} \$ 64.000,00 / \mathrm{mês}$. 


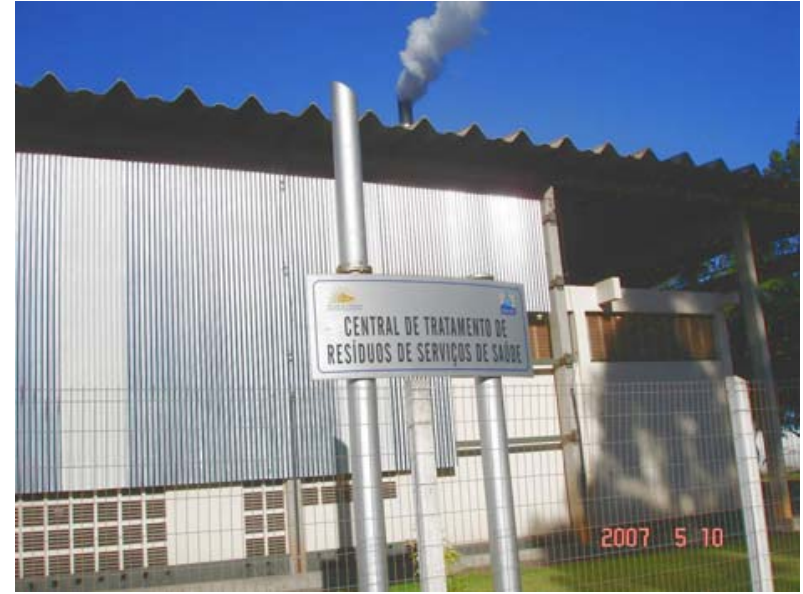

Figura 31 - Incinerador do aterro de Araraquara, 10/05/2007

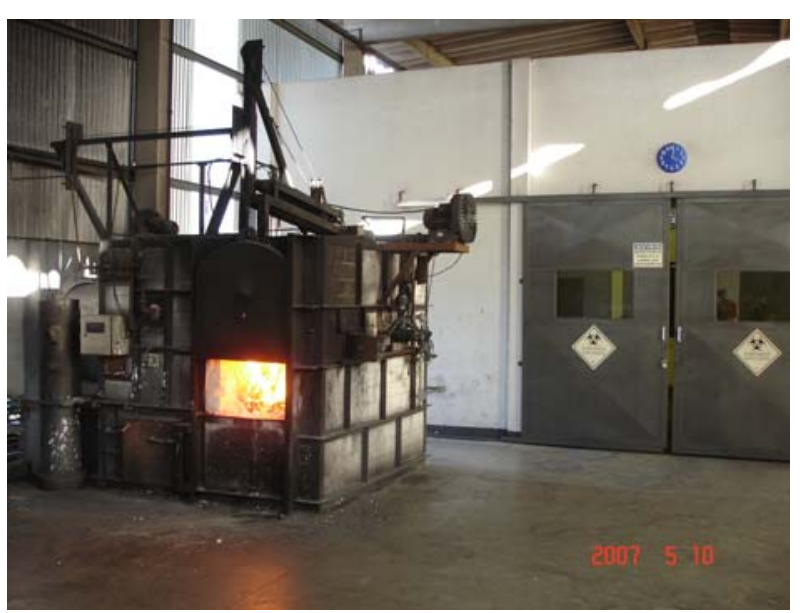

Figura 32 - Vista interna do incinerador do aterro de Araraquara, 10/05/2007

A Figura 32 mostra o símbolo de "substância infectante" nas portas do abrigo para armazenamento temporário dos RSS, conforme NBR 7500 (ABNT, 1987a), onde aqueles classificados como infectantes (composto por fetos, membros, órgãos e tecidos humanos) são acondicionados em saco plástico branco leitoso, conforme NBR 9190 (ABNT, 1985b).

Segundo o DAAE, o incinerador recebe cerca de 1,24t/d de RSS, provenientes de cerca de 420 geradores. Cada gerador paga $\mathrm{R} \$ 2,22 / \mathrm{kg}$ ao $\mathrm{DAAE}$ pelo tratamento.

\section{Disposição final}

As cinzas geradas durante a incineração dos RSS, cerca de $100 \mathrm{~kg} / \mathrm{d}$, são dispostas no aterro, bem como 5,57t/mês de animais mortos, uma vez que o incinerador não é adequado para recebê-los, devido ao porte e quantidade.

\subsubsection{Resíduos da Construção Civil (RCC)}

Segundo informações do DAAE, estima-se que sejam geradas cerca de $388 \mathrm{t} / \mathrm{d}$ de RCC em Araraquara. Estes resíduos eram dispostos em área anexa ao aterro (Figura 24, item 6a), porém atualmente estão sendo dispostos em uma Área de Transbordo e Triagem (ATT), licenciada, localizada próxima ao aterro (Figura 24, item 6b). Os RCC são depositados temporariamente em bolsões espalhados pela cidade e encaminhados a ATT.

Em junho de 2005 foi lançado um Plano de Gestão de Resíduos da Construção e Volumosos, com base na Lei Municipal $n^{\circ} 6.352$ de 09/12/2005, regulamentada pelo Decreto $n^{\circ} 8.431$ de 30/06/2006 em cumprimento a Resolução CONAMA 307/2002. Este plano foi elaborado em conjunto pela prefeitura, DAAE e por uma empresa de São Paulo, contratada pelo DAAE por $\mathrm{R} \$ 60.000,00$ para realizar estudos para a gestão dos RCC. 
Por meio da Portaria 17.349 de $01 / 08 / 2006$ foi formado um núcleo permanente de gestão dos RCC do qual várias secretarias da prefeitura fazem parte.

A triagem dos RCC teve início em 27/11/2006. Uma empresa de caçamba montou uma Central de Processamento de Resíduos da Construção Civil (Figura 33 e Figura 34), onde funciona a ATT. A sua localização segue as recomendações do Plano Diretor, que previu duas áreas para esta finalidade, uma próxima à vicinal Nelson Barbieri e outra nas proximidades do aterro.

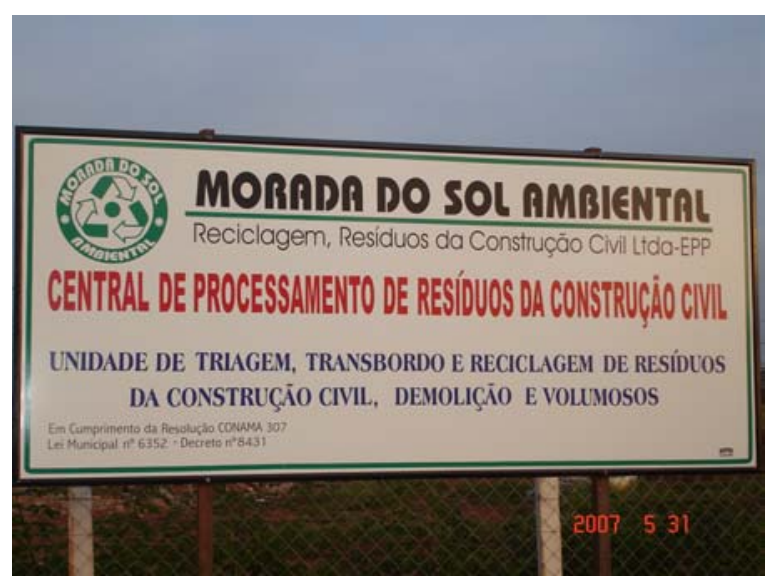

Figura 33 - Identificação da ATT de RCC de Araraquara, 31/05/2007

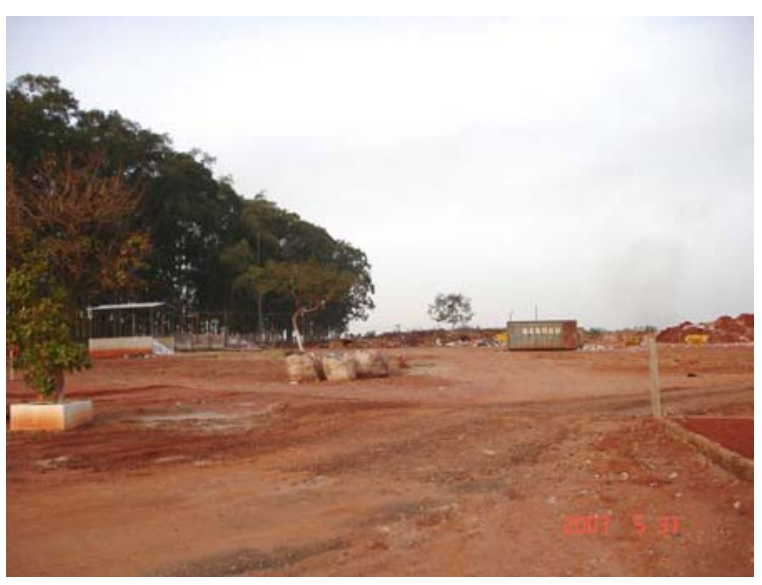

Figura 34 - ATT de RCC de Araraquara, $31 / 05 / 2007$

Está prevista a implantação de uma usina de reciclagem de material inerte na ATT, localizada próxima ao aterro. Os agregados reciclados serão aplicados em serviços de manutenção na cidade.

Atualmente Araraquara possui quatro Pontos de Entrega Voluntária (PEVs) ou bolsões de RCC, licenciados em novembro de 2006, cercados e identificados. Os PEVs são voltados aos pequenos geradores e gerenciados pelo DAAE. Um deles possui guarita com vigia para intimidar queimadas, que ocorrem freqüentemente. Os PEVs foram distribuídos em diversos bairros da cidade, estrategicamente localizados nos locais onde eram dispostos os RCC inadequadamente. Os pontos podem receber até $1 \mathrm{~m}^{3}$ de RCC ou de material reciclável por produtor, além de resíduos volumosos. O investimento previsto para implantação de cada PEV é de $\mathrm{R} \$ 60.000,00$. Está prevista a implantação de treze PEVs.

\subsubsection{Pneus}

Em cumprimento a Resolução CONAMA 258/1999, que considera os pneumáticos inservíveis abandonados ou dispostos inadequadamente um passivo ambiental, cerca de $21 \mathrm{t} /$ mês de pneus são coletados e armazenados temporariamente em área coberta (Figura 
35), anexa ao aterro, e encaminhados à reciclagem ou à disposição final pela Associação Nacional da Indústria de Pneumáticos (ANIP), por meio de um convênio firmado em 2003.

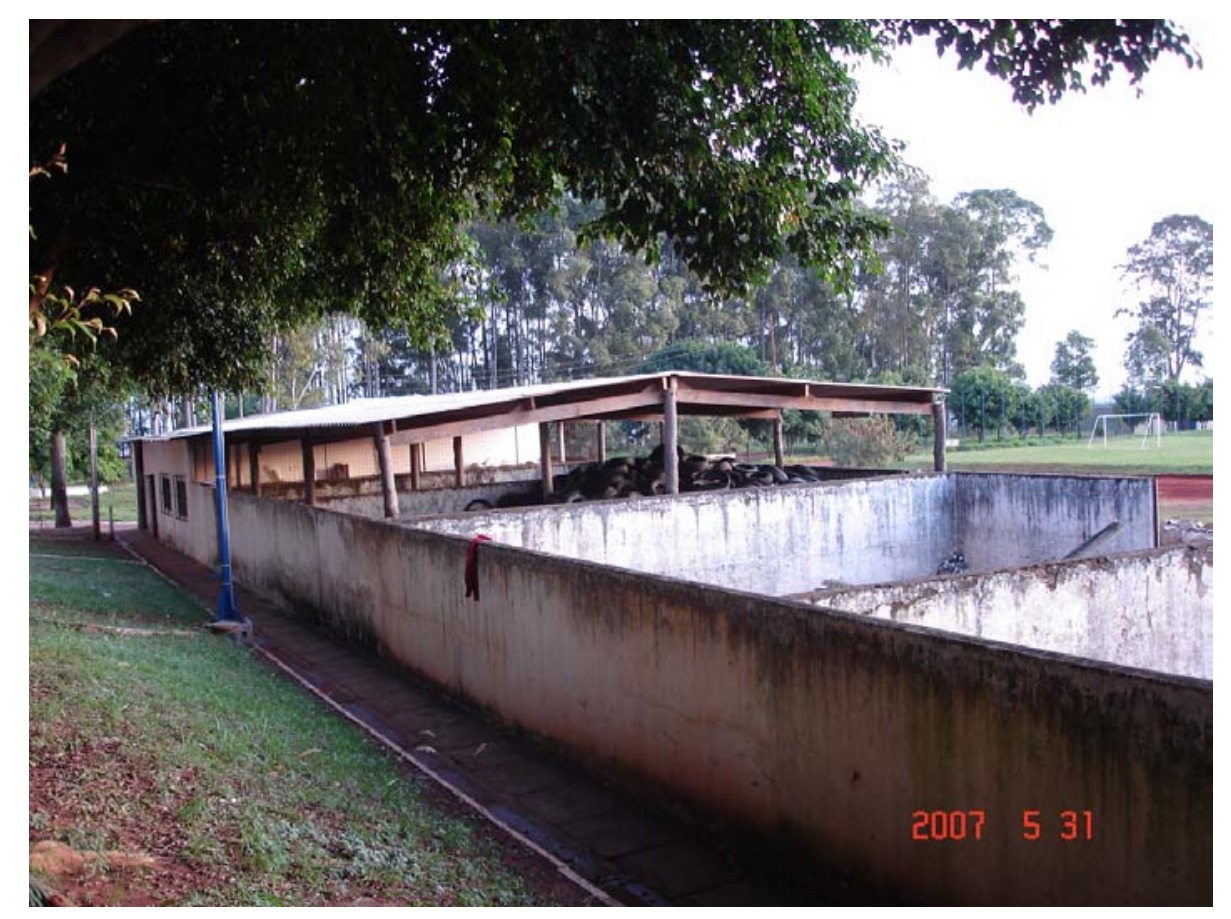

Figura 35 - Pneus armazenados na ETRS de Araraquara, 31/05/2007

Foi implantado um ponto de recepção de pneus na cidade. Uma das recicladoras para onde os pneus usados são encaminhados está localizada em Jundiaí. Os pneus podem ser aplicados em asfalto, em sola de sapato, em alto forno de cimenteiras, entre outras aplicações.

\subsubsection{Embalagens de Agrotóxicos}

Desde 2002 já era realizado o armazenamento de embalagens vazias de agrotóxicos em galpão construído (Figura 36) em área anexa ao aterro (Figura 24, item 5), onde hoje funciona a Central de Recebimento de Embalagens de Agrotóxicos (Figura 37), inaugurada em junho de 2005. 


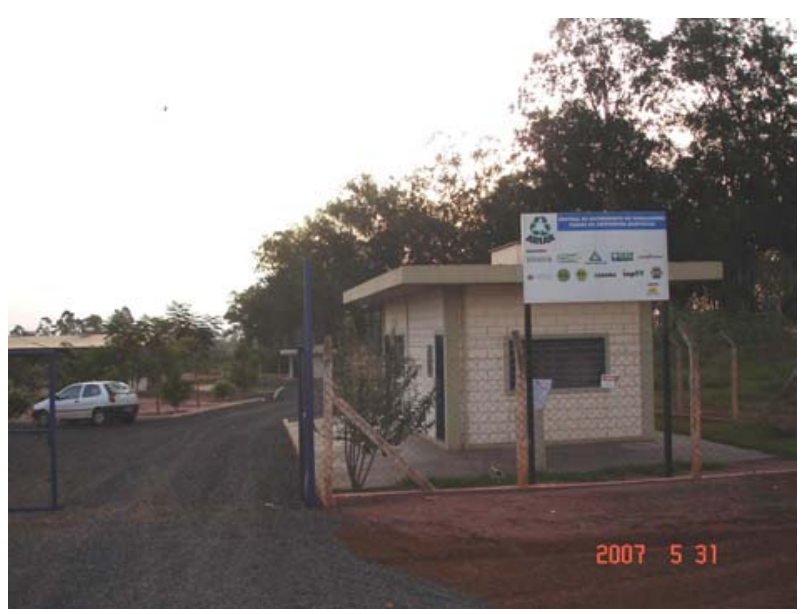

Figura 36 - Central de Recebimento de Embalagens Agrotóxicos, 31/05/2007

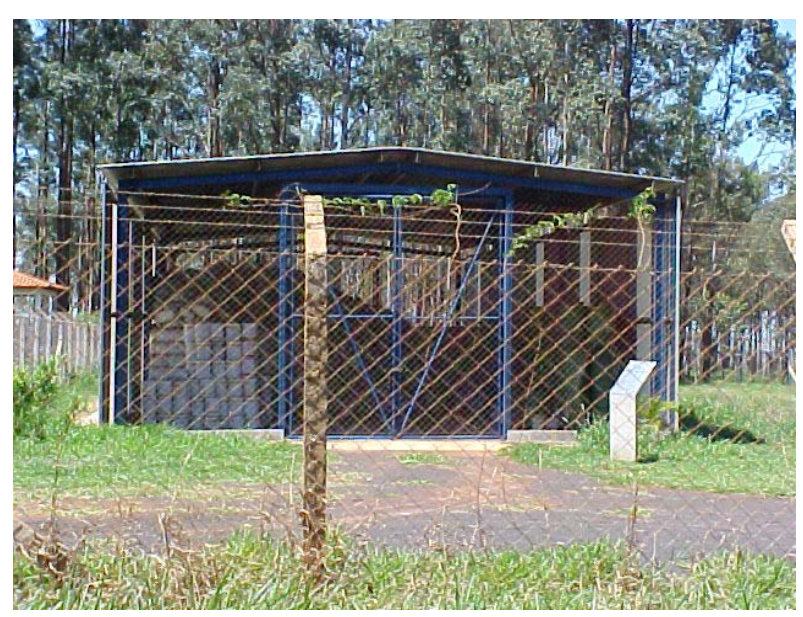

Figura 37 - Armazenamento de embalagens de agrotóxicos, 04/11/2003

A Central de Recebimento de Embalagens de Agrotóxicos foi construída por meio de parceria entre prefeitura e Associação de Revendas e Insumos Agrícolas de Araraquara e região. Possui capacidade para receber entre 10 e 12t/mês de embalagens, as quais são comercializadas a $\mathrm{R} \$ 2,00 /$ t. As embalagens não reaproveitadas são encaminhadas para um incinerador de resíduos químicos. As embalagens potencialmente recicláveis são encaminhadas para recicladoras de diversos municípios, conforme Tabela 17.

Tabela 17 - Quantidade e destino das embalagens de agrotóxicos recebidas em Araraquara

\begin{tabular}{l|r}
\hline \multicolumn{1}{c|}{ Municípios } & \multicolumn{1}{c}{ Quantidade (kg) } \\
\hline Barra do Piraí (RJ) & 19.030 \\
Bragança Paulista (SP) & 11.970 \\
Louveira (SP) & 82.380 \\
Suzano (SP) & 38.480 \\
Xerém (RJ) & 4.230 \\
\hline Total & 156.090 \\
\hline
\end{tabular}

Fonte: Estação de Tratamento de Resíduos Sólidos de Araraquara

\subsubsection{Orçamento}

Os custos dos serviços relacionados com os resíduos sólidos em Araraquara estão apresentados na Tabela 18. 
Tabela 18 - Custos dos serviços com os resíduos sólidos em Araraquara

\begin{tabular}{l|r}
\hline \multicolumn{1}{c|}{ Tipo de Serviço } & \multicolumn{1}{c}{ Custo (R\$/t) } \\
\hline Coleta regular dos RSU & 53,02 \\
Coleta de RSS & 390,70 \\
Triagem de materiais & 279,28 \\
Operação do aterro & 66,00 \\
\hline
\end{tabular}

Fonte: Estação de Tratamento de Resíduos Sólidos de Araraquara

Está prevista a implantação da "Taxa de Preservação e Controle do Meio Ambiente" (TPCMA) que passará a ser cobrada a partir de novembro de 2007, de acordo com o volume de lixo gerado. A cobrança da taxa será em conta individualizada ou junto com a conta de água em campo específico, a escolha do contribuinte

A taxa mínima será de $R \$ 3,10 /$ mês dos domicílios que gerarem até dez litros de lixo por dia. Os valores serão mais elevados, a partir desta quantidade. Haverá descontos para os geradores que declararem que participam da coleta seletiva, incluindo escolas, entidades, portadores de necessidades especiais, aposentados e pensionistas com renda igual ou inferior a três salários mínimos, entre outros que poderão ser contemplados com o fator redutor. O volume gerado será declarado pelo próprio morador. Porém, está prevista uma amostragem por bairro com efeito de fiscalização, a ser realizada posteriormente.

\subsubsection{Bauru}

O município de Bauru possui cerca de 347.601 habitantes (IBGE, 2007) e gera em torno de 200 toneladas por dia de RSD.

\subsubsection{Resíduos Sólidos Domiciliares (RSD)}

\section{Coleta regular}

A coleta dos RSD é realizada na área urbana do município, em $100 \%$ dos bairros, pela Empresa Municipal de Desenvolvimento Urbano e Rural de Bauru (EMDURB) e transportados ao aterro. Não há coleta na área rural.

A cidade foi dividida em 22 setores, 16 diurnos e seis noturnos. São utilizados 20 caminhões, porém alguns estão em manutenção. $O$ critério adotado foi a facilidade de trânsito quanto ao horário, os caminhões basculantes são utilizados em ruas de terra e os compactadores em ruas pavimentadas. No total, são 25 motoristas e 90 coletores. 


\section{Coleta seletiva de materiais recicláveis}

A coleta seletiva foi implantada em 05/06/1992. Atualmente atende $40 \%$ da população (cerca de 60 bairros), conta com cerca de 20 pessoas (quatro motoristas e 16 coletores) da Cooperativa dos Trabalhadores de Materiais Recicláveis de Bauru (COOTRAMAT) e quatro caminhões pertencentes à prefeitura.

A coleta é realizada porta-porta, porém a população também pode descartar os recicláveis em seis Pontos de Entrega Voluntária (PEVs) implantados na cidade. São coletadas cerca de $80 t /$ mês de recicláveis. A freqüência da coleta é semanal e a cidade foi dividida em 15 setores.

Segundo a Secretaria Municipal de Meio Ambiente de Bauru (SEMMA), a coleta seletiva representa um custo de $\mathrm{R} \$ 400.000,00 /$ ano. A prefeitura pretende ampliar o serviço e para isso será necessário aumentar o número de participantes da cooperativa, porém os catadores autônomos resistem em aderir ao programa.

\section{Tratamento}

Triagem dos materiais recicláveis

No bairro Jardim Redentor funciona uma Central de Triagem (Figura 38 e Figura 39) desde 05/06/1992, onde os materiais recicláveis são separados por catadores da cooperativa COOTRAMAT. A central é equipada com apenas uma prensa.

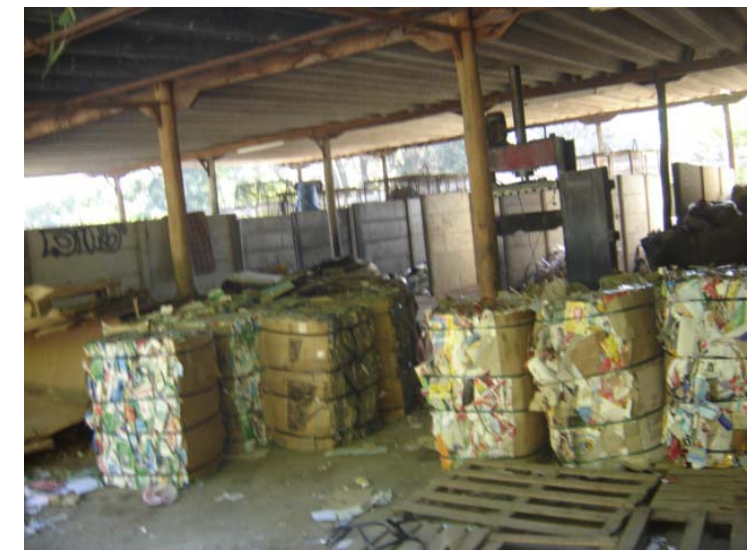

Figura 38 - Central de Triagem de Bauru, junho de 2007

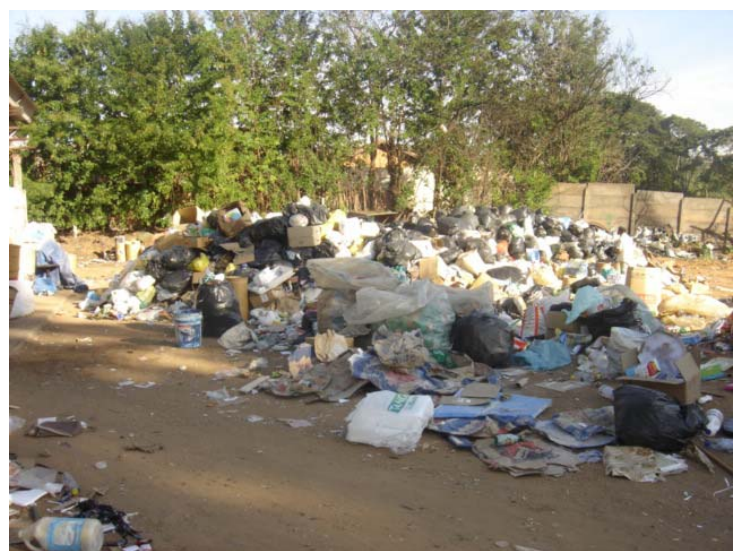

Figura 39 - Área externa da Central de Triagem de Bauru

De acordo com a SEMMA, é feito o agendamento para coleta de grandes quantidades de recicláveis em estabelecimentos específicos, os quais são encaminhados para a central. Recentemente a central foi alvo de incêndio. 


\section{Compostagem}

Não há compostagem dos RSD em Bauru, porém os resíduos de poda e capina são encaminhados para o viveiro municipal. Alguns galhos são dispostos no aterro devido a eventuais falhas no picador de galhos.

\section{Disposição Final}

Os RSD gerados por Bauru são dispostos num aterro sanitário localizado na zona rural, a noroeste do centro urbano, nas coordenadas $22^{\circ} 15^{\prime} \mathrm{S}$ e $49^{\circ} 08^{\prime} \mathrm{W}$, próximo ao km 353 da Rodovia Marechal Rondon SP 300 e ao córrego da Gabiroba (afluente do rio Batalha). A Figura 40 apresenta os pontos de monitoramento das águas superficiais.

$\mathrm{Na}$ área onde funciona o aterro (Figura 40) são realizadas as seguintes operações:

- 1 - Disposição final dos resíduos sólidos domiciliares (Aterro Sanitário) e

- 2 - Disposição final dos resíduos de serviços de saúde (valas sépticas).

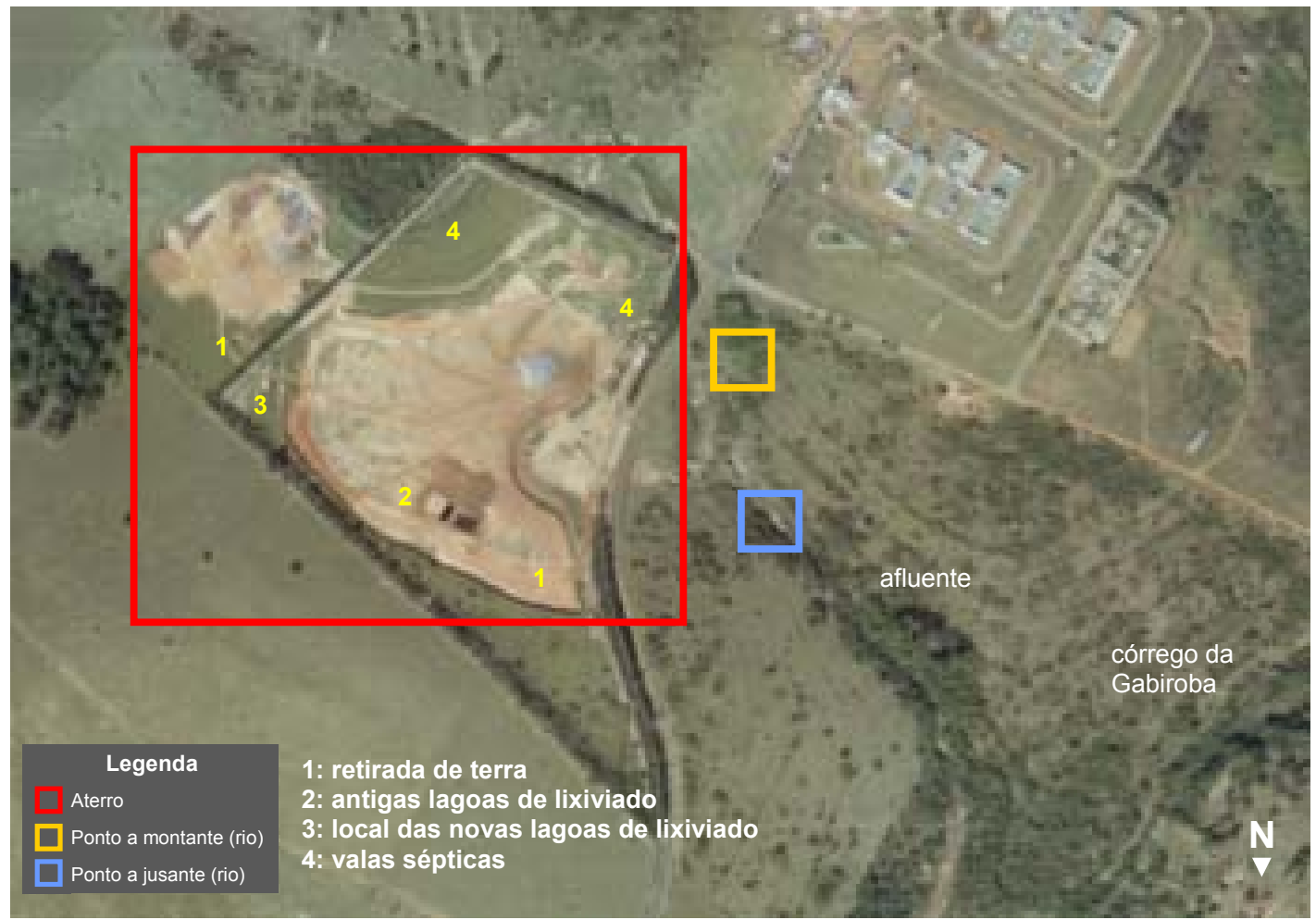

Figura 40 - Localização do aterro de Bauru

Fonte: Base Aerofotogrametria e Projetos S.A. São Paulo, 18/07/2000 Escala 1:30.000 
O aterro está localizado sobre a Formação Marília do Grupo Bauru, com base em IPT (1981). De acordo com Lago (2004), o aterro está posicionado sobre área de afloramento de arenitos do Grupo Bauru.

O solo do aterro foi classificado como residual do Grupo Bauru, sobreposto por camadas de aluvião e colúvio, de areia argilosa vermelha laterítica, com textura de areia fina a média argilosa (Mondelli et al, 2006). O coeficiente de permeabilidade do solo natural do aterro é de $10^{-3} \mathrm{~cm} / \mathrm{s}$ (Mondelli, 2007). Dessa forma, conclui-se que o solo do aterro tem permeabilidade alta. De acordo com FIPAI (1992), o solo foi classificado como Latossolo Vermelho-Escuro com textura média arenosa e Podzólico Vermelho-Amarelo abrupto de textura arenosa.

Conforme o EIA-RIMA do aterro de Bauru (FIPAI 1992), a base do aterro está cerca de cinco metros acima do topo da zona saturada.

Com base no Projeto de Lei № 75, de 16 de setembro de 2006, que institui o Plano Diretor Participativo do Município de Bauru (2006), o aterro está localizado na Área de Proteção Ambiental (APA) da Água Parada.

Conforme CETESB (2007a, p.16), a área obteve o Índice de Qualidade de Aterro de Resíduos (IQR) em 2006 de 8,7. Portanto, o aterro está operando em condições adequadas (Figura 41 e Figura 42).

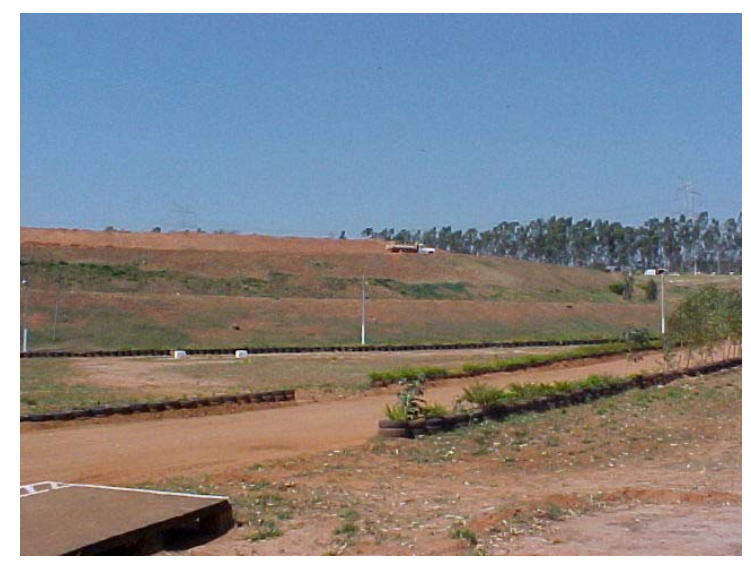

Figura 41 - Aterro de Bauru, 02/09/2004

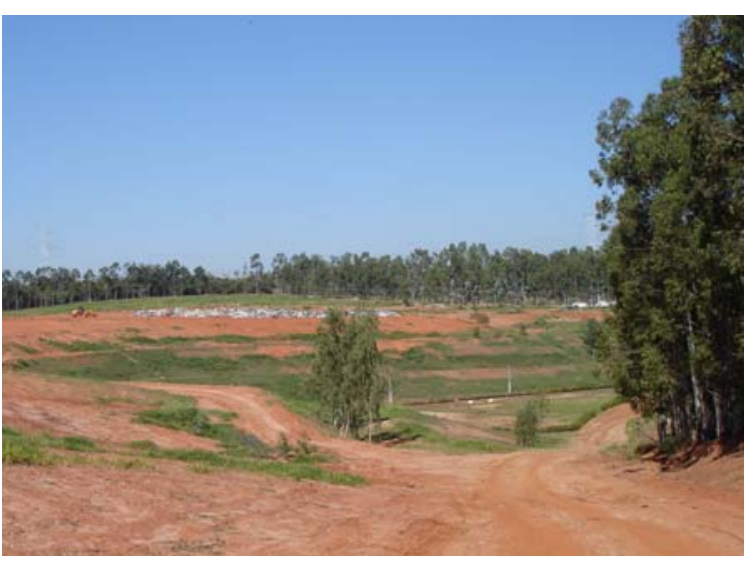

Figura 42 - Aterro de Bauru, 08/06/2007

Segundo informações da Empresa Municipal de Desenvolvimento Urbano e Rural de Bauru (EMDURB), responsável pela operação do aterro, a área possui $300.000 \mathrm{~m}^{2}$, opera desde 1993 e recebe atualmente cerca de 200t/d de RSD. Conforme a EMDURB, o aterro é considerado sanitário.

Além dos RSD, o aterro recebe resíduos de poda e capina, RSS, pneus, bem como resíduos Classe II provenientes das indústrias, ou seja, os não perigosos. 
Segundo a EMDURB os maiores problemas relacionados ao gerenciamento dos resíduos sólidos são os gastos com manutenção de equipamentos antigos e a falta de espaço físico no aterro. Porém ainda nenhum Relatório Ambiental Preliminar (RAP), para ampliação do atual aterro, ou EIA-RIMA, para construção de um novo empreendimento, está sendo elaborado.

A vida útil do aterro já está quase esgotada, a previsão era que o aterro funcionasse até 2006. Em vista disso, foi protocolado junto à CETESB um pedido de licença para alteamento do aterro ( $4^{\mathrm{a}}$ camada). A nova camada tem vida útil prevista para quatro anos.

Durante as visitas realizadas não foi constatado presença de catadores no aterro. A área é cercada, identificada e possui uma guarita com balança na entrada para o controle da entrada de pessoas e caminhões, bem como da quantidade e tipo de resíduo.

\section{Cobertura e compactação dos resíduos}

Os RSD são descarregados pelos caminhões, compactados e cobertos com terra. $\mathrm{O}$ material de cobertura é retirado de áreas contíguas ao aterro (Figura 40, item 1).

Coleta de gás e drenagem do lixiviado

O aterro possui impermeabilização de base realizada com camadas de solo compactada e asfalto diluído CM 30 (Figura 43), coletores de gás (Figura 44) e uma lagoa para infiltração do lixiviado, situada no topo do aterro.

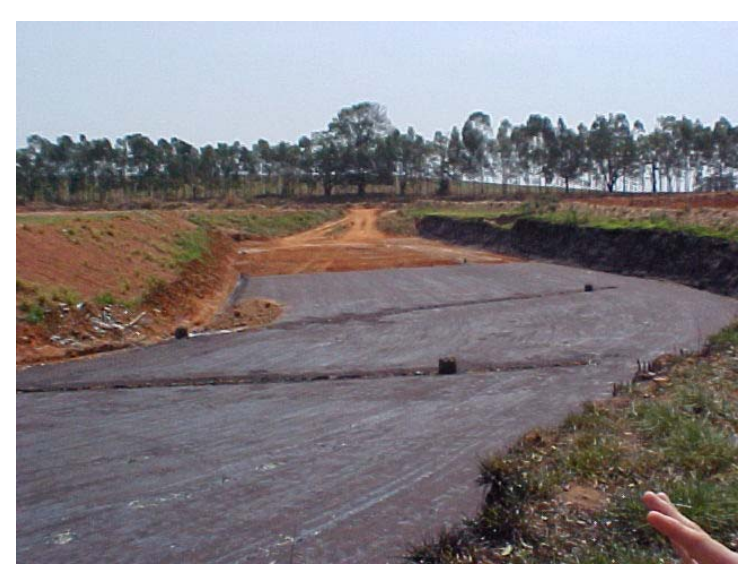

Figura 43 - Impermeabilização de base no aterro de Bauru, 25/09/2003

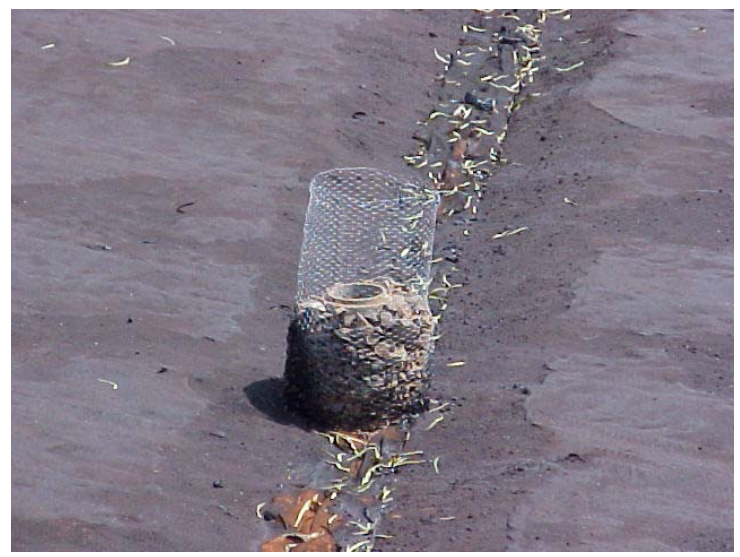

Figura 44 - Coletor de gás no aterro de Bauru, 25/09/2003

Segundo a EMDURB, a quantidade e posição das lagoas para o armazenamento de lixiviado varia com o tempo, como pode ser observado pela Figura 40 (item 2), Figura 45 e Figura 46. 


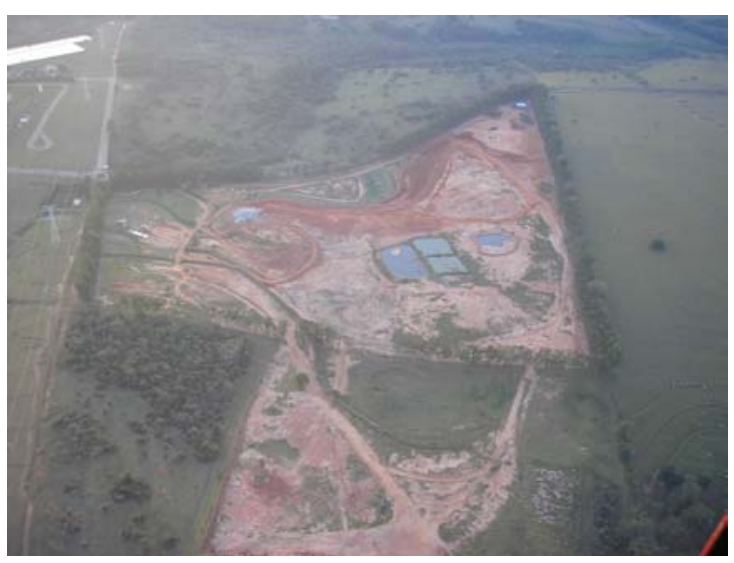

Figura 45 - Vista aérea do aterro de Bauru

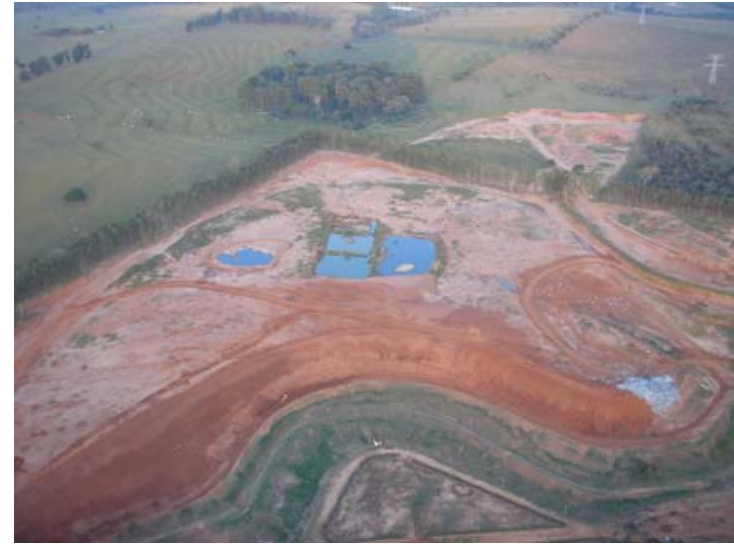

Figura 46 - Lagoas de lixiviado no aterro de Bauru

Fonte: EMDURB, 2006

Atualmente existe apenas uma lagoa para o armazenamento de lixiviado no aterro de Bauru (Figura 47 e Figura 48) no mesmo local das lagoas apresentadas na Figura 45 e Figura 46.

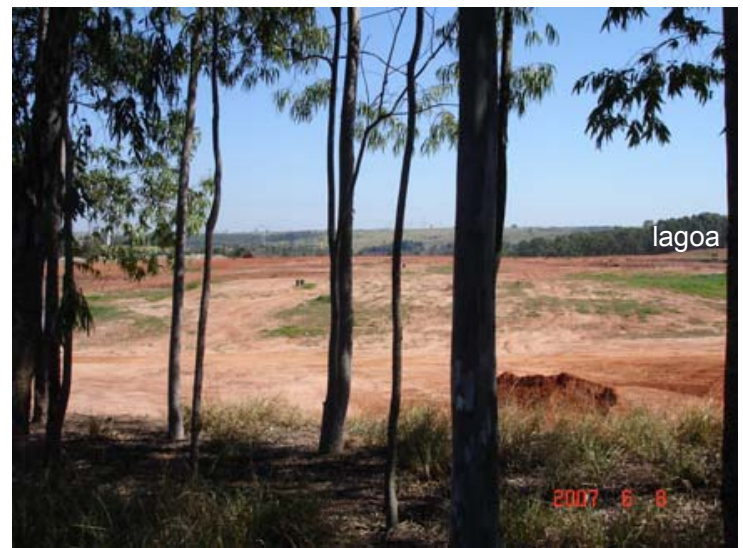

Figura 47 - Vista da parte superior do aterro de Bauru, 08/06/2007

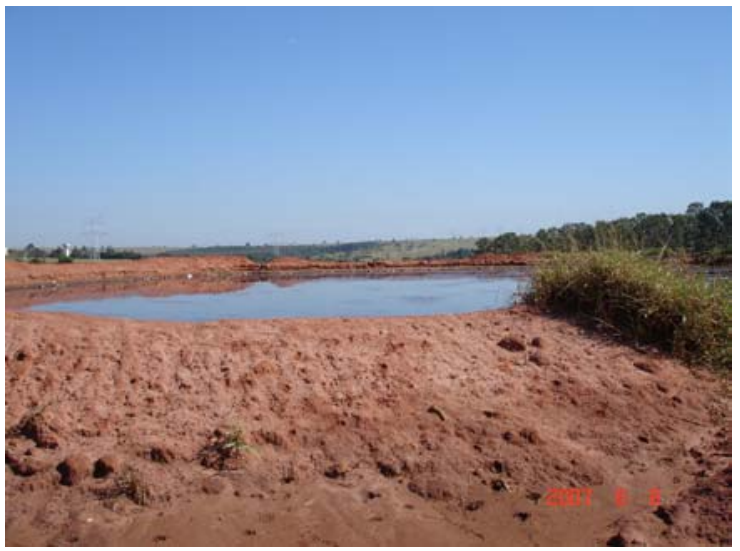

Figura 48 - Lagoa de lixiviado no aterro de Bauru, 08/06/2007

O lixiviado da lagoa infiltra pelos resíduos, é drenado para um reservatório construído na base do aterro, onde foram instaladas uma caixa coletora e uma bomba que faz a recirculação. $O$ aterro também possui drenos para o escoamento da água de chuva.

Segundo informações da EMDURB, em dias chuvosos são gerados cerca de 12 a $13 \mathrm{~m}^{3} /$ dia de lixiviado e em dias de seca cerca de 3 a $5 \mathrm{~m}^{3} /$ dia. Por exigência da CETESB, lagoas para o armazenamento de lixiviado estão sendo construídas (Figura 49 e Figura 50) na parte leste do aterro (Figura 40, item 3 ) e serão cercadas. 


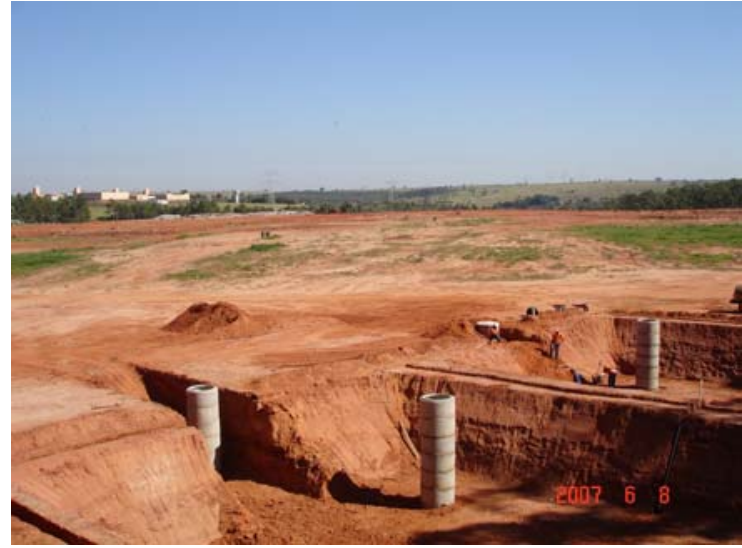

Figura 49 - Construção de lagoas para o armazenamento de lixiviado no aterro de Bauru

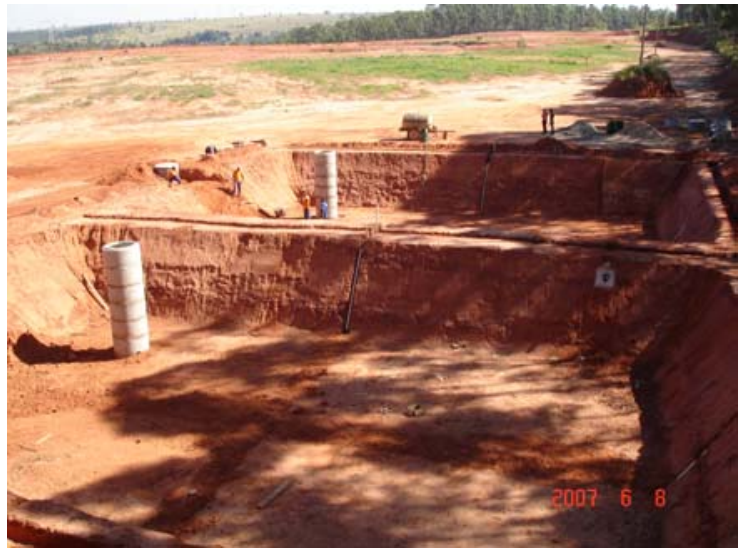

Figura 50 - Lagoas para o armazenamento de lixiviado no aterro de Bauru, 08/06/2007

Monitoramento das águas subterrâneas

O aterro possui 16 poços de monitoramento (Figura 51 e Figura 52) de 4 polegadas, sendo que 9 deles foram construídos em 2002 e o restante foi construído em 2006.
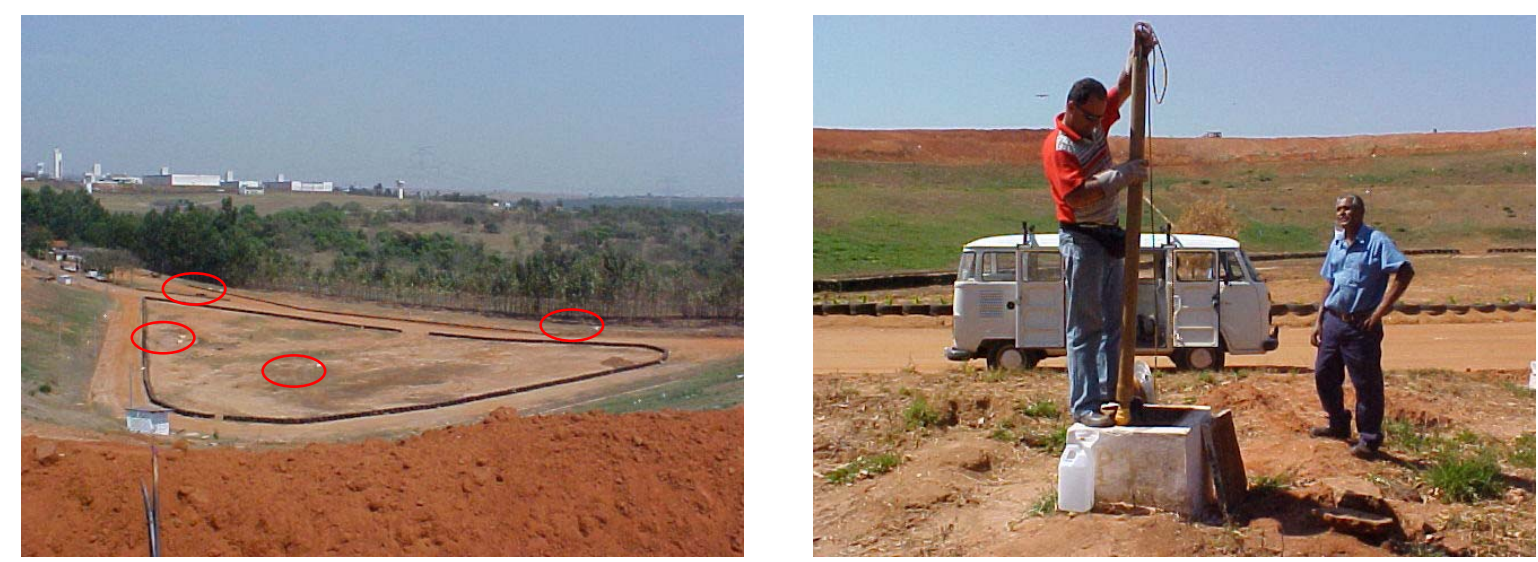

Figura 51 - Poços de monitoramento a jusante Figura 52 - Poço de monitoramento (PJ1) no no aterro de Bauru, 25/09/2003 aterro de Bauru, 02/09/2004

Os poços foram denominados da seguinte forma: PP1, PP2, PP3, PP3A, PP4, PP5, PP5A, PP5B, PP6, PP7, PP8, PP9, PP10, PP11, PP12 e PP13 (Figura 53). Alguns destes poços foram construídos e vêm sendo monitorados por pesquisadores da UNESP (Bauru) e USP (São Carlos). A EMDURB permite o desenvolvimento de alguns estudos com finalidade didática desde que os dados sejam compartilhados.

O presente estudo monitorou quatro poços (Figura 53). A profundidade dos poços monitorados e o nível d'água medidos após a construção dos mesmos estão apresentados na Tabela 19. 
Tabela 19 - Profundidade e nível d'água dos poços monitorados no aterro de Bauru

\begin{tabular}{c|c|c}
\hline Poços & Profundidade $(\mathrm{m})$ & Nível d'água $(\mathrm{m})$ \\
\hline PM (PP4) & 37,4 & 32,0 \\
PJ1 (PP1) & 12,0 & 8,5 \\
PJ2 (PP8) & 23,0 & 7,2 \\
PJ3 (PP3) & 14,0 & 10,75 \\
\hline
\end{tabular}

Fonte: EMDURB

Vale destacar que o poço PP3 não apresentou mais volume d'água suficiente para coleta de amostras, por esse motivo em 2006 foi construído outro poço de monitoramento ao seu lado, denominado PP3A. Assim, o PP3 deixou de ser monitorado. 


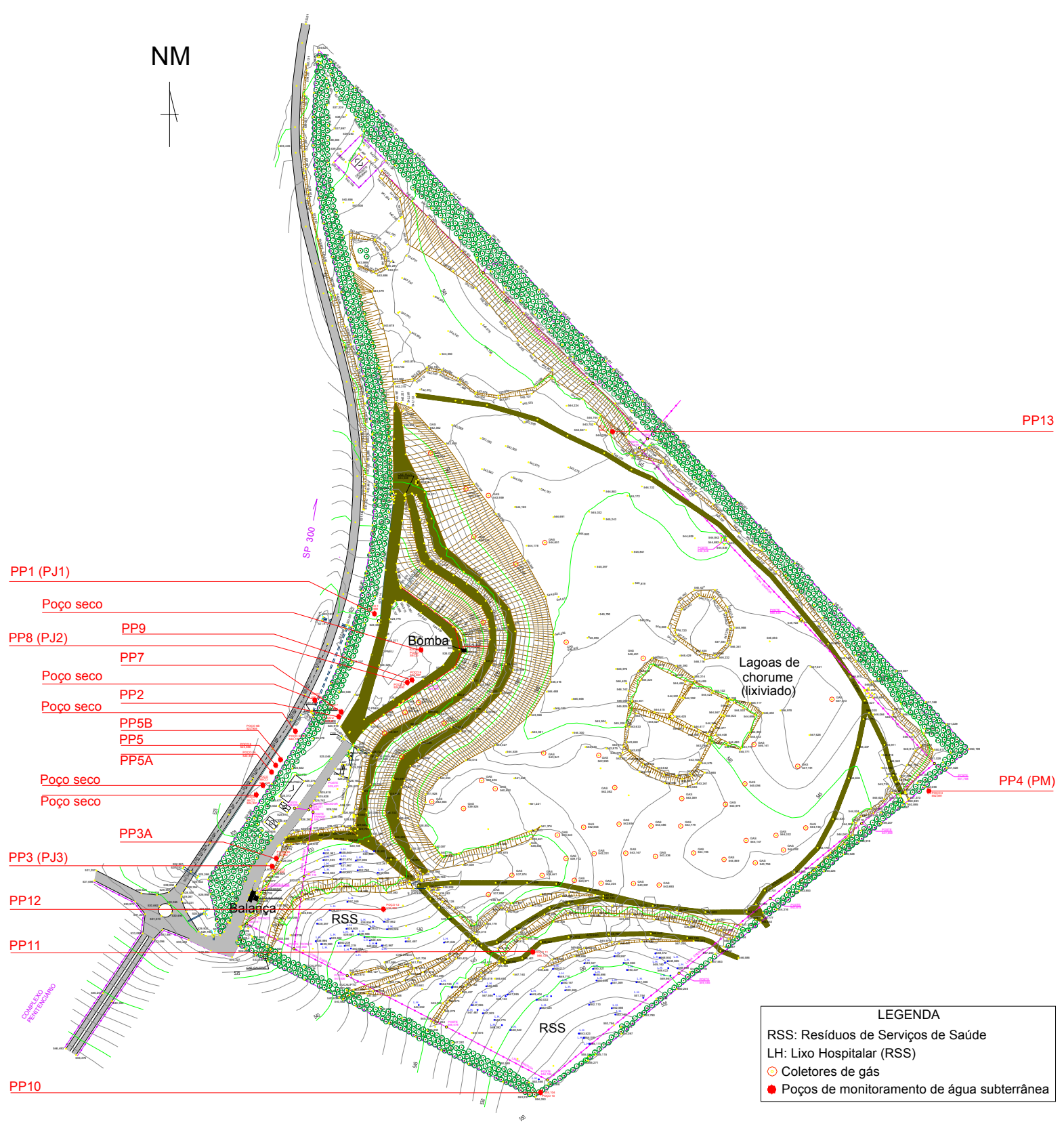

PP6

Figura 53 - Localização dos poços de monitoramento no aterro de Bauru

Fonte: Departamento de Água e Esgoto de Bauru, Divisão de Planejamento, agosto de 2006, adaptado 


\subsubsection{Resíduo Domiciliar Perigoso (RDP)}

As pilhas são descartadas no aterro sanitário, porém existem pontos de coleta nos Supermercados Confiança e na rádio FM 94 de Bauru, que também recebe baterias de celulares.

As lâmpadas fluorescentes são armazenadas em pé em tambores de $200 \mathrm{~L}$ e descontaminadas nas instalações da própria EMDURB por uma empresa especializada a um custo de $\mathrm{R} \$ 0,60 /$ unidade. O mesmo valor é cobrado pela EMDURB para o recebimento destes resíduos. A descontaminação é feita por um equipamento importado que separa os componentes da lâmpada, assim o vidro e o alumínio são armazenados em compartimentos diferentes. O gás mercúrio, por sucção, é conduzido para um filtro de carvão ativado. $O$ vidro e o alumínio são encaminhados para reciclagem e o restante para o aterro industrial de Paulínia (Classe I). São descontaminadas cerca de 3.000 unidades duas vezes ao ano.

\subsubsection{Resíduos de Serviços de Saúde (RSS)}

\section{Coleta}

Cerca de 1,8t/d de RSS são coletados pela prefeitura em veículo especial e transportados até o aterro. A coleta de RSS é realizada por três motoristas e três coletores. São utilizados um caminhão para coleta dos grandes geradores (hospitais e clínicas veterinárias) e uma fiorino para pequenos geradores (consultórios e clínicas médicas).

Os sacos plásticos brancos leitosos usados para o acondicionamento dos RSS, as caixas usadas para o acondicionamento de materiais perfurocortantes e o caminhão de coleta possuem o símbolo de "substância infectante", conforme recomendam a NBR 9190 (ABNT, 1985) e NBR 7500 (ABNT, 1987a), respectivamente (Figura 54 e Figura 55).

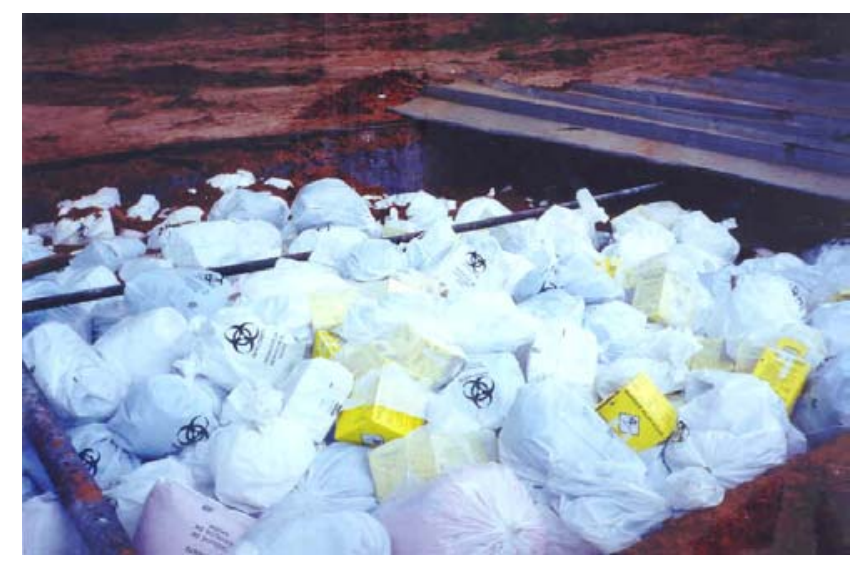

Figura 54 - Identificação de "substância infectante" nos sacos e caixas com RSS em Bauru, 21/03/2005

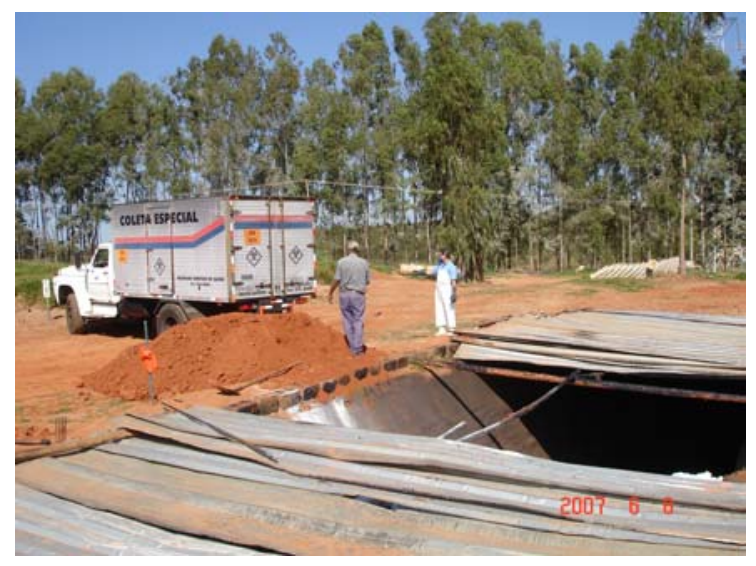

Figura 55 - Veículo de coleta dos RSS em Bauru, 08/06/2007 
O funcionário responsável pelo manejo dos RSS deve utilizar Equipamentos de Proteção Individual (EPIs), conforme Figura 56 e Figura 57.

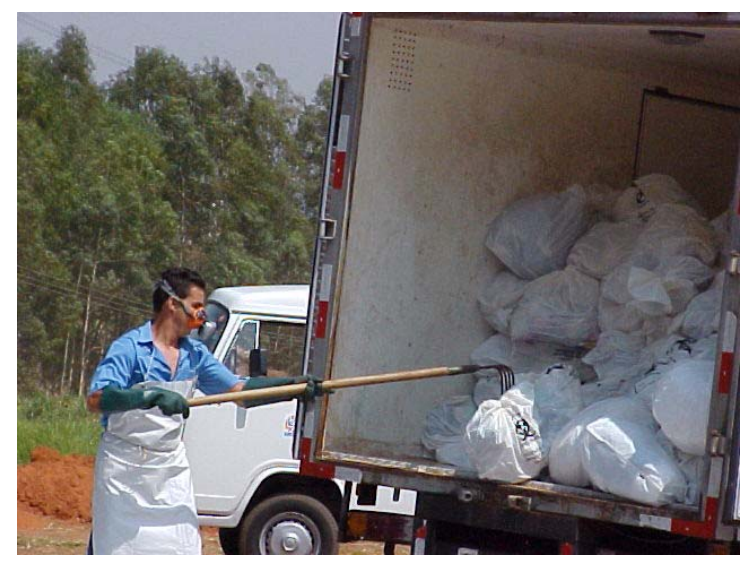

Figura 56 - Manejo dos RSS no aterro de Bauru, 08/06/2007

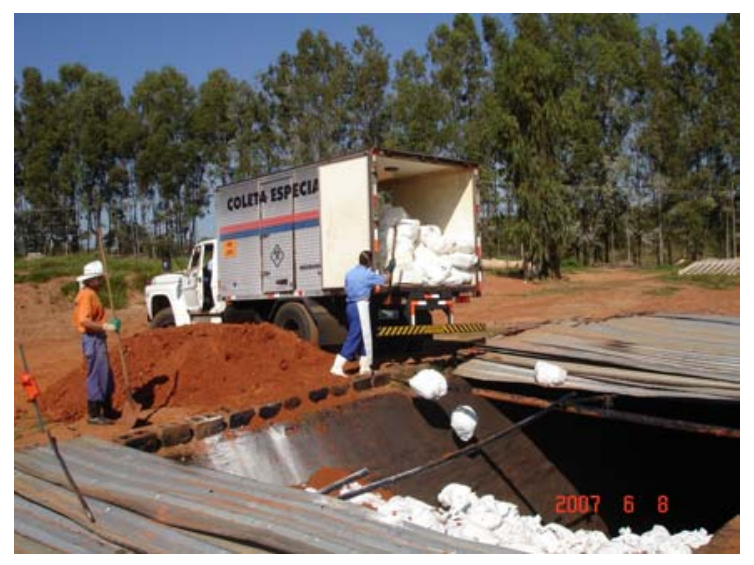

Figura 57 - Manejo dos RSS no aterro de Bauru, 25/09/2003

\section{Tratamento}

Bauru não possui equipamento especifico para o tratamento dos RSS, assim estes resíduos são dispostos em valas sépticas, com autorização da CETESB. Segundo a EMDURB, está em estudo a viabilidade da aquisição de um equipamento para o tratamento dos RSS, o qual deverá ser instalado no próprio aterro, ou a contratação de uma empresa para prestar o serviço.

\section{Disposição Final}

Os RSS são dispostos em valas sépticas (Figura 40, item 4), tratadas com material asfáltico e cal. As dimensões das valas são $15 \times 4 \times 5 \mathrm{~m}^{3}$. As valas são identificadas e numeradas em placas com o símbolo de material infectante. Segundo a EMDURB um dos problemas relacionados aos RSS é a falta de área para construção de novas valas.

\subsubsection{Resíduos da Construção Civil (RCC)}

Segundo informações da Secretaria Municipal de Meio Ambiente de Bauru (SEMMA), estima-se que sejam geradas cerca de 600t/d de RCC em Bauru, dispostas em erosões.

De acordo com pesquisa realizada por Freitas (2007), em Bauru foram identificados 20 pontos de descarte de RCC. 
A partir de fevereiro de 2007 foi licenciado um bolsão de RCC (Figura 58 e Figura 59), localizado na chácara conhecida como Granja Adachi, onde havia uma antiga erosão, às margens da Rodovia Marechal Rondon, próximo ao Núcleo Habitacional Gasparini. O proprietário cedeu a área em troca de regularizar o perfil do terreno e recuperar a erosão.

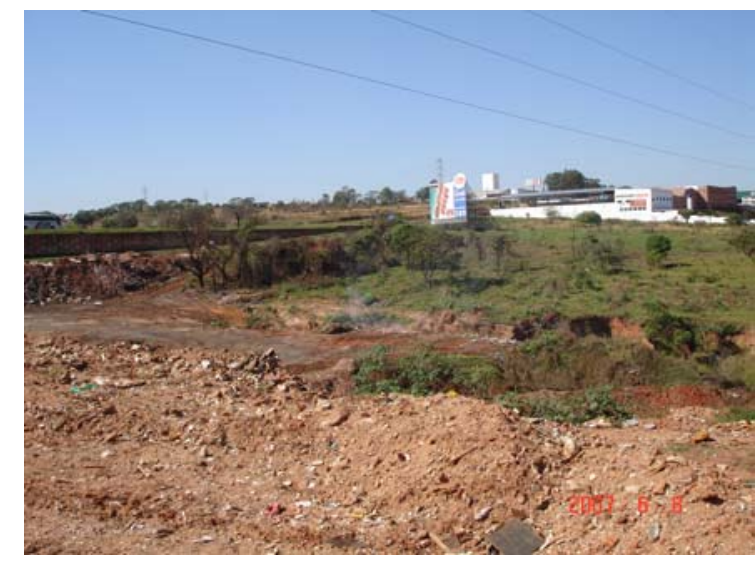

Figura 58 - Disposição de RCC em Bauru, 08/06/2007

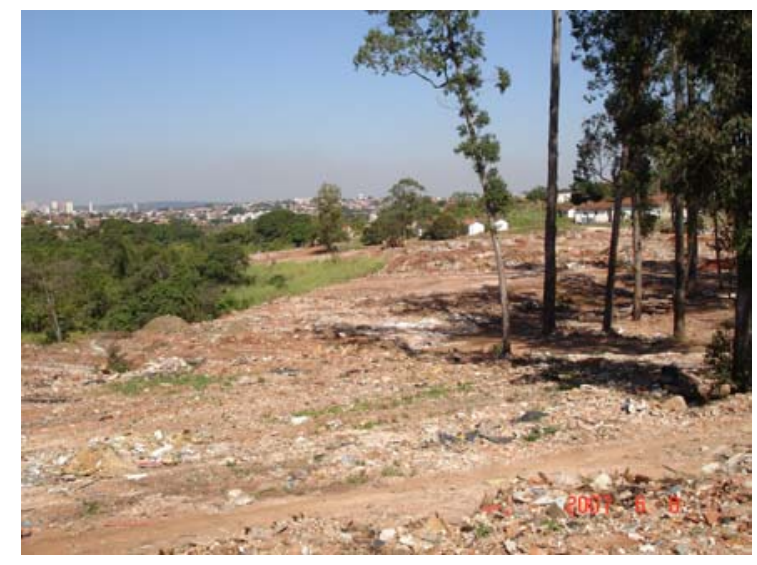

Figura 59 - Bolsão de RCC em Bauru, 08/06/2007

Os RCC são transportadas ao bolsão por caçambas. O bolsão não é cercado e não há controle da quantidade e tipo de material depositado no local. Além dos RCC, o bolsão também recebe galhos.

$\mathrm{Na}$ cidade existem 13 empresas de caçambas cadastradas junto a SEMMA. Foi fundada a Associação dos Transportadores de Entulhos e Agregados de Bauru (ASTEN), que reúne os transportadores de resíduos da construção civil, os quais se comprometem a transportar os resíduos até o Bolsão Adachi. A máquina utilizada para empurrar os resíduos é mantida pela própria Associação.

Não há quantidade de RCC limite imposta por produtor ou caçamba para o descarte no bolsão e custo para sua implantação não foi estimado.

Ainda não há reciclagem de RCC em Bauru. Apesar disso, os resíduos não são encaminhados para tratamento em outro município. Segundo a SEMMA, está sendo estudada a possibilidade de implantação de uma usina de reciclagem de RCC em Bauru em conjunto com a iniciativa privada.

\subsubsection{Pneus}

Cerca de 3.000 a 4.000 pneus/mês são armazenados temporariamente no aterro, em local coberto ao lado do almoxarifado (Figura 60 e Figura 61), e posteriormente são 
encaminhados para reciclagem pela Associação Nacional da Indústria de Pneumáticos (ANIP) desde 2003.

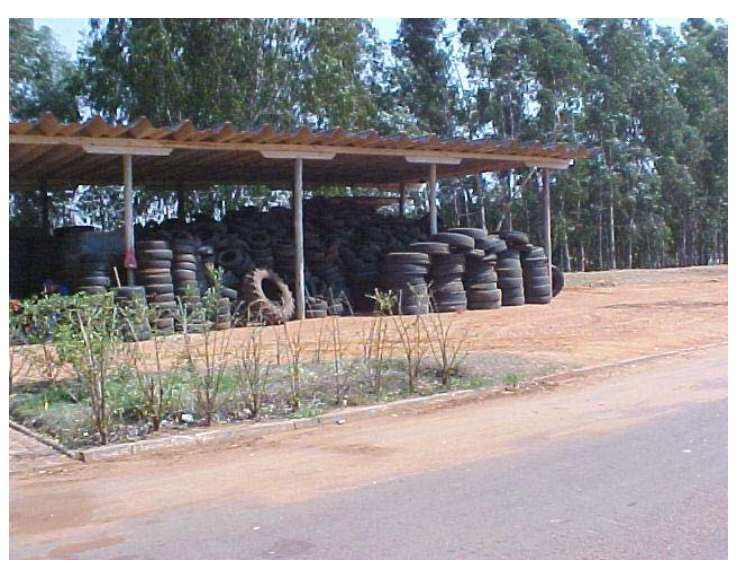

Figura 60 - Armazenamento de pneus no aterro de Bauru, 25/09/2003

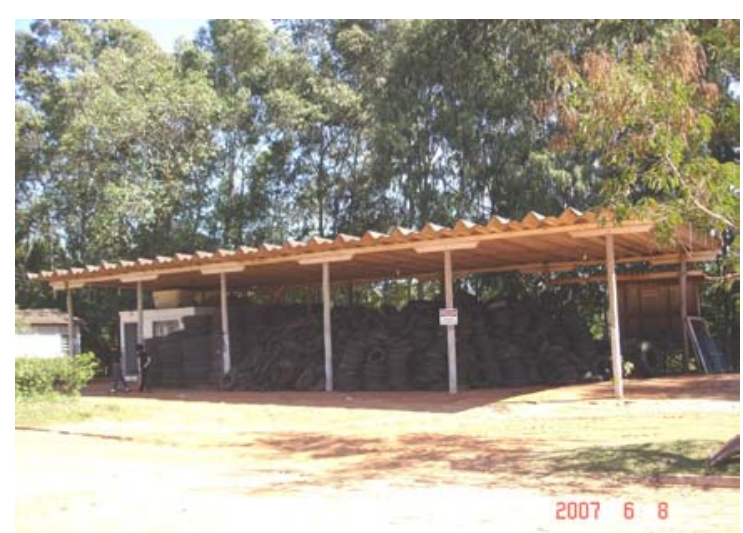

Figura 61 - Pneus armazenados no aterro de Bauru, 08/06/2007

\subsubsection{Orçamento}

Com base no Decreto 10463, de 13/06/2007, e na Resolução EMDURB 07/07, os valores dos serviços de limpeza pública do município estão apresentados na Tabela 20.

Tabela 20 - Custos dos serviços com os resíduos sólidos em Bauru

\begin{tabular}{l|r}
\hline \multicolumn{1}{c|}{ Tipo de Serviço } & \multicolumn{1}{c}{ Custo (R\$/t) } \\
\hline Coleta regular dos RSU & 63,51 \\
Operação do aterro & 24,68 \\
Coleta e disposição de RSS & 782,51 \\
\hline
\end{tabular}

Fonte: EMDURB, 25/07/2007

\subsubsection{Brotas}

O município de Brotas possui cerca de 20.996 habitantes (IBGE, 2007) e gera em torno de 9,44 toneladas por dia de RSD. Está localizado sobre a Formação Pirambóia (que faz parte do Sistema Aqüífero Guarani), segundo IPT (1981). Cerca de 85\% do seu território está localizado em área de afloramento do Sistema Aqüífero Guarani (uma das maiores reservas de água doce do mundo), conforme a Companhia de Tecnologia de Saneamento Ambiental (CETESB, 2004, p.37-38). Por isso, as atividades antrópicas desenvolvidas nessa região podem afetar diretamente a qualidade da água subterrânea. 


\subsubsection{Resíduos Sólidos Domiciliares (RSD)}

\section{Coleta regular}

Os RSD são coletados, transportados e dispostos no aterro pela prefeitura, conforme Lei Municipal $n^{\circ} 1.574$ de 15 de outubro de 1998. A coleta atende $100 \%$ do município. Os RSD gerados na área rural são coletados, destacando os Sítios Turísticos e grandes propriedades, bem como os bairros do Patrimônio (353 casas) e do Broa (362 casas), distantes cerca de 25 a $30 \mathrm{~km}$ do centro.

A coleta na cidade é realizada das 07:00 às 19:00h por três motoristas e seis coletores. São utilizados um caminhão caçamba e duas prensas. No bairro do Patrimônio a coleta é realizada por um motorista e dois coletores e é utilizado um caminhão caçamba. No bairro do Broa a coleta é realizada por um motorista e um coletor e é utilizado um caminhão caçamba.

É utilizado o critério do melhor trajeto em função do horário de coleta. A cidade foi dividida em dois setores: parte antiga (Av. Lorival Jaubert da Silva Braga até o Bairro Bela Vista) e parte nova (da Av. Marginal até o Bairro Taquaral). Às segundas, quartas e sextasfeiras a coleta é realizada em toda a cidade e nos bairros do Patrimônio e do Broa. Aos sábados e domingos a coleta também é realizada na área central e nos atrativos turísticos.

\section{Coleta seletiva de materiais recicláveis}

A coleta seletiva ainda não foi implantada no município, apenas a Associação de Pais e Amigos dos Excepcionais de Brotas (APAE) realiza a separação dos resíduos com o uso de um caminhão, um motorista e dois coletores (Figura 62). 


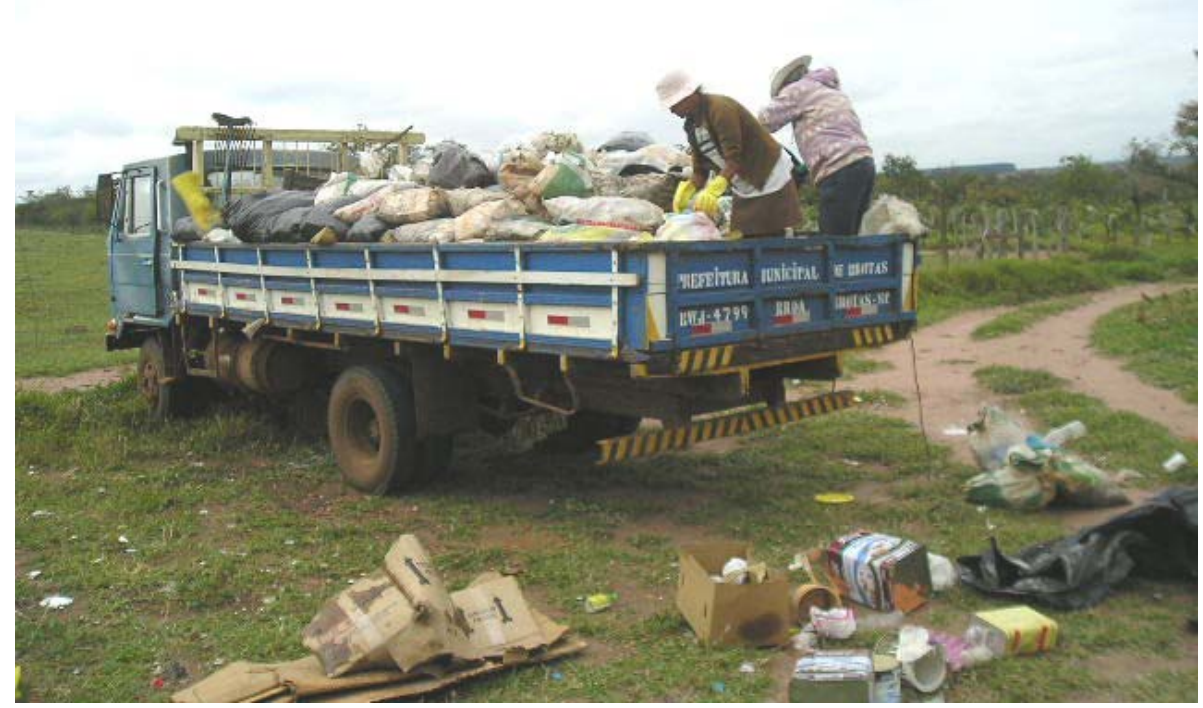

Figura 62 - Coleta seletiva realizada pela APAE de Brotas

Fonte: Prefeitura Municipal de Brotas, junho de 2007

A separação dos recicláveis é realizada em um barracão alugado pela APAE, ao lado da própria associação (Figura 63 e Figura 64). No barracão há uma prensa doada pela prefeitura, adquirida pela Secretaria de Ação Social, dentro do Projeto Brotas Recicla, elaborado junto com a Diretoria de Meio Ambiente da Prefeitura no ano de 2003.

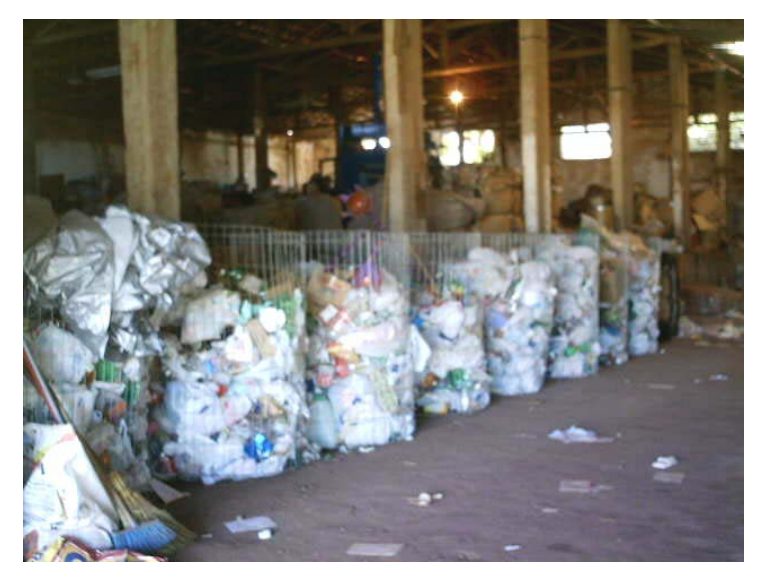

Figura 63 - Barracão onde é realizada a triagem de materiais em Brotas

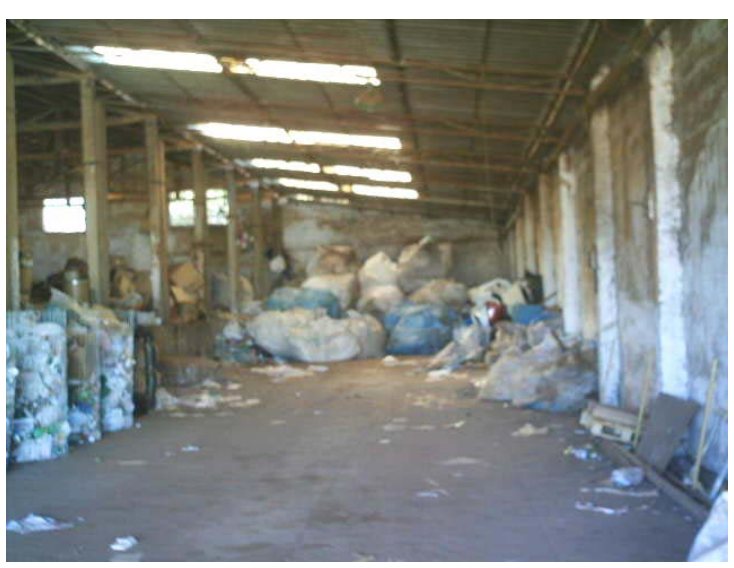

Figura 64 - Separação dos recicláveis no barracão da APAE de Brotas

Fonte: Prefeitura Municipal de Brotas, junho de 2007

A coleta seletiva atende uma pequena parcela da população (entre 10 e 20\%). A solicitação da coleta dos recicláveis é feita pela comunidade por telefone. Segundo a 
prefeitura, até junho de 2007 ainda não havia sido implantada uma logística para atender os bairros e ainda não havia dados quantitativos.

Vale destacar que a prefeitura está em fase de licitação pública para terceirizar os Serviços de Coleta de Resíduos Sólidos Domiciliares e Comerciais, bem como a Coleta Seletiva, com início previsto para Agosto de 2007.

\section{Tratamento}

Triagem dos materiais recicláveis

A triagem dos materiais recicláveis de parte do município é realizada desde $2003 \mathrm{em}$ um barracão ao lado da APAE.

\section{Compostagem}

A compostagem ainda não foi implantada no município de Brotas. A prefeitura pretende iniciar um projeto piloto em um bairro da cidade com base na metodologia empregada no "Projeto ABC da Compostagem", desenvolvido pela USP.

\section{Disposição Final}

O aterro de Brotas está localizado na porção norte do município, em área rural, na estrada BRO 105, nas coordenadas $22^{\circ} 13^{\prime} \mathrm{S}$ e $48^{\circ} 05^{\prime} \mathrm{W}$, próximo à área de eucalipto da International Paper. Os RSD gerados pelo município são dispostos num aterro sanitário em valas (Figura 65), cujo terreno pertence à prefeitura, responsável por sua operação. $O$ aterro possui cerca de $54.000 \mathrm{~m}^{2}$, está rodeado por pasto, plantação de laranja e eucalipto 


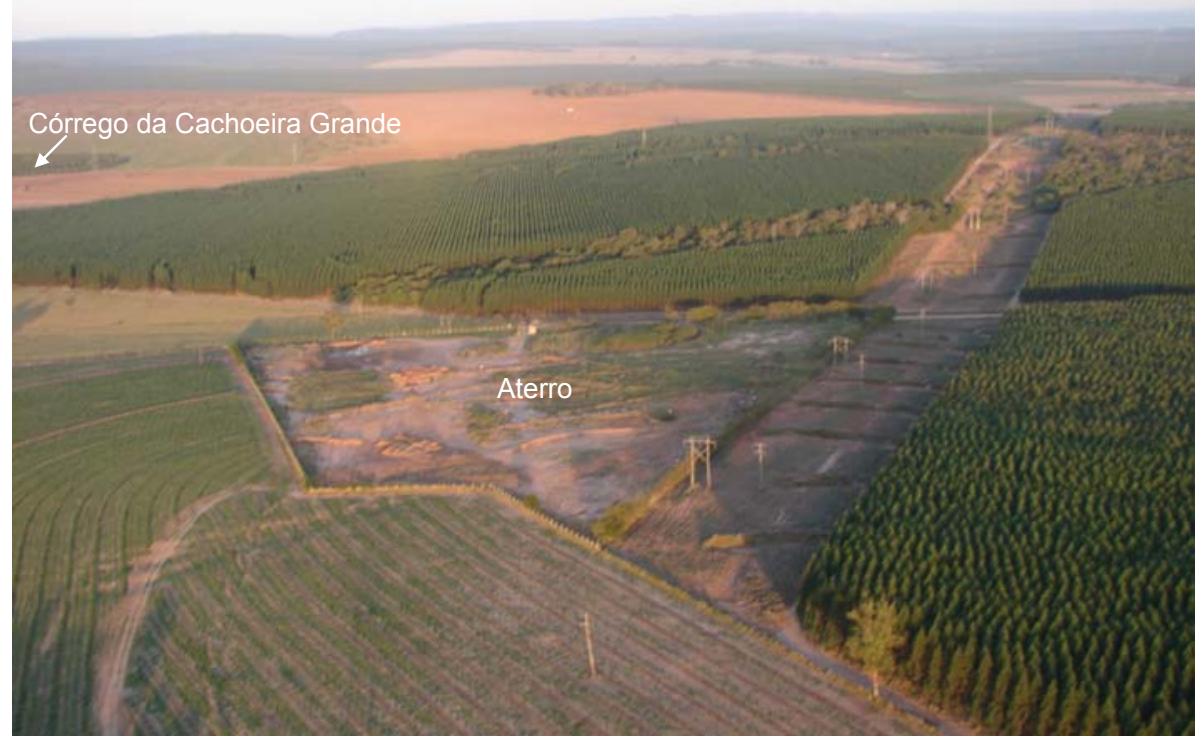

Figura 65 - Aterro de Brotas

Fonte: Prefeitura Municipal de Brotas, agosto de 2006

$\mathrm{Na}$ cota mais baixa do aterro encontra-se o córrego da Cachoeira Grande (Figura 66), afluente do ribeirão da Rasteira, previsto como futuro ponto de captação de água para abastecimento da população, conforme Plano Diretor de Brotas, Lei Complementar Municipal n 12/2006 (Capítulo II, Seção I, Art. 6º), aprovado em 22 de novembro de 2006.

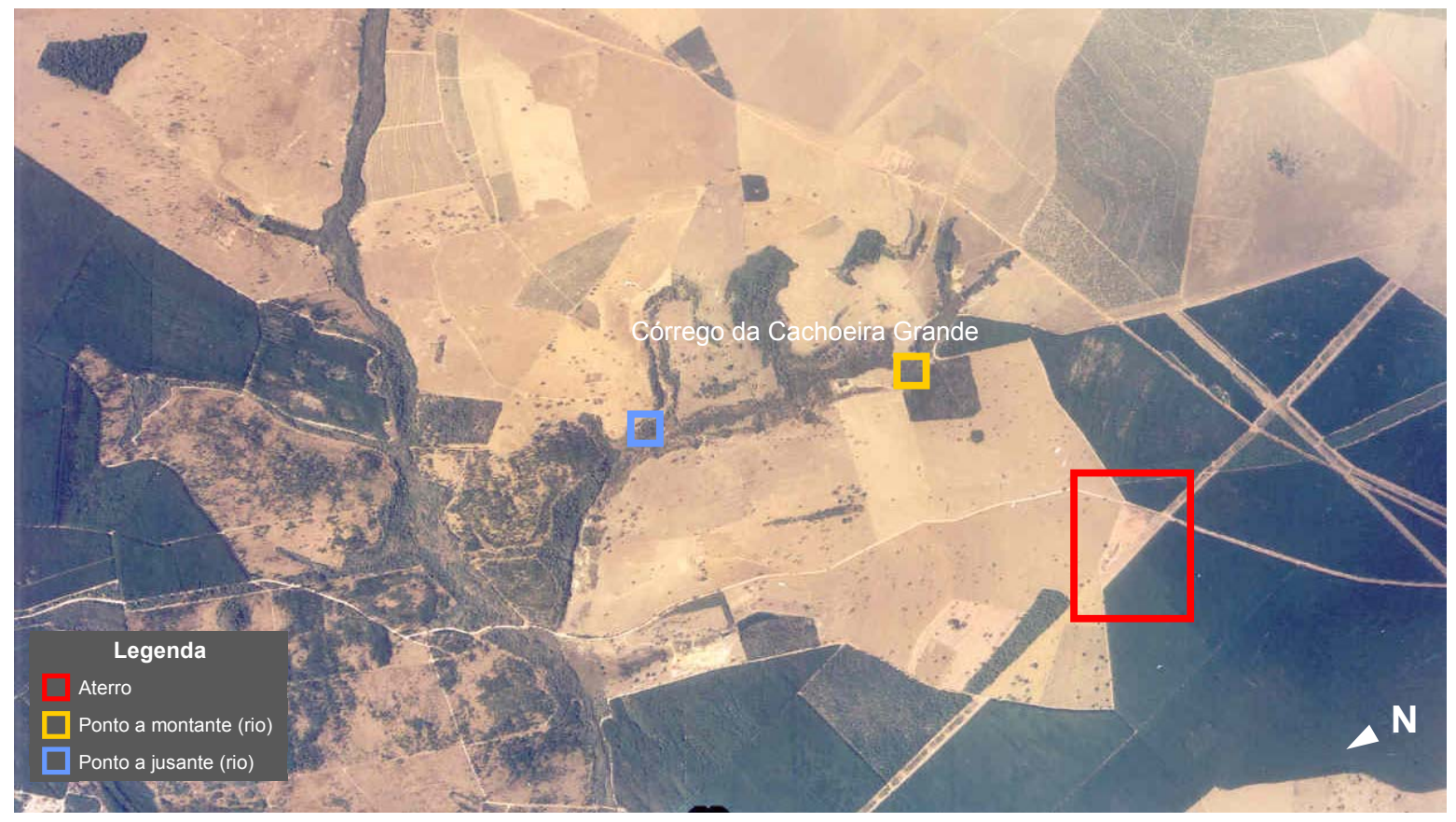

Figura 66 - Localização do aterro de Brotas

Fonte: Base Aerofotogrametria e Projetos S.A. São Paulo, 18/07/2000 Escala 1:30.000 
A Figura 66 apresenta os pontos de monitoramento das águas superficiais. De acordo com a prefeitura, o aterro (Figura 67 e Figura 68) opera desde 2004. O local recebe cerca de $9,44 \mathrm{t} / \mathrm{d}$ de RSD gerados pelo próprio município.

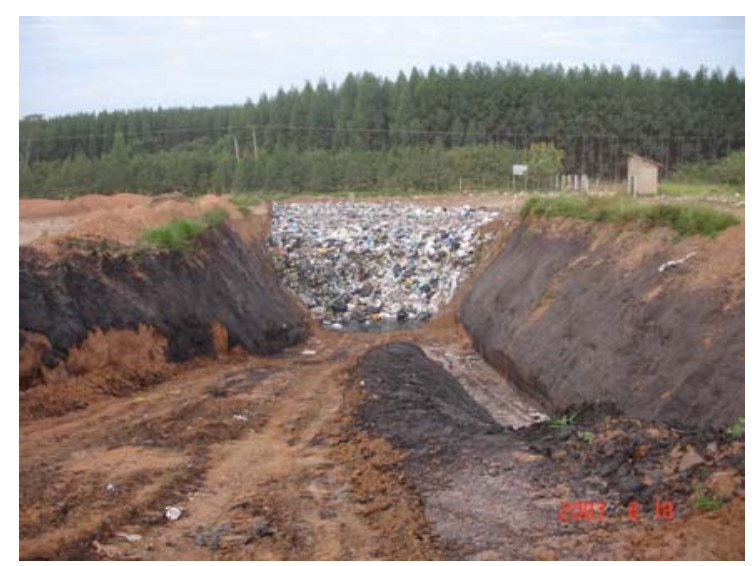

Figura 67 - Aterro em trincheiras de Brotas

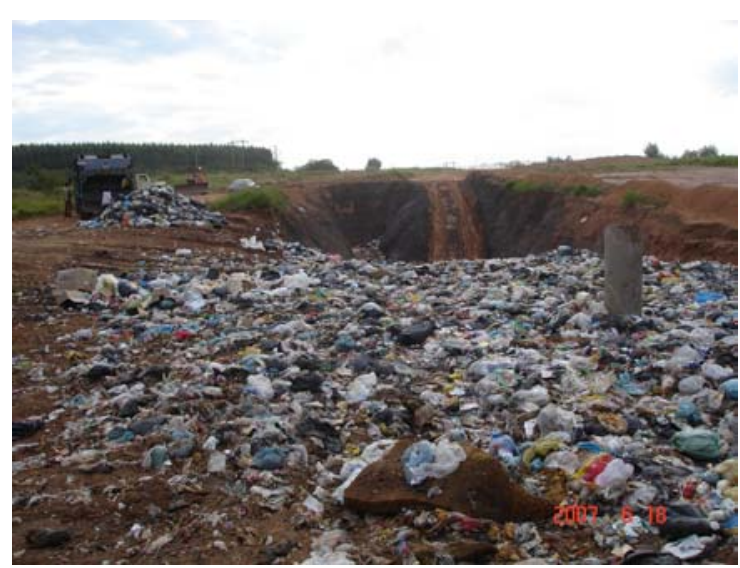

Figura 68 - Disposição de resíduos em Brotas

Além dos RSD, resíduos não perigosos gerados pelas indústrias (Classe II), resíduos de poda e capina volumosos, pneus bem como resíduos de varrição também são dispostos no aterro.

A vida útil do aterro já está quase esgotada, a previsão é que o aterro funcione até 2008. Já está prevista a ampliação do aterro em área contígua. A intenção da prefeitura é construir um aterro sanitário com projeto que considere vida útil de 10 a 15 anos. Na última avaliação da CETESB (2007a, p.14), o Índice de Qualidade de Aterro de Resíduos (IQR) foi 7,5 , indicando que o local opera em condições controladas.

$O$ aterro possui guarita para o controle da entrada de pessoas e caminhões, bem como do tipo de resíduo recebido. Foi plantado cerca viva no entorno do aterro para dificultar a invasão e visualização por catadores. Apesar do cercamento da área, foi constatado presença de catadores no aterro. Porém, segundo a prefeitura, este problema foi solucionado com apoio da polícia.

\section{Cobertura dos resíduos}

Os resíduos são cobertos com terra, porém em períodos chuvosos a operação do aterro é prejudicada devido à dificuldade de acesso dos caminhões. 


\section{Drenagem do lixiviado}

De acordo com a prefeitura, a CETESB passou a exigir impermeabilização das valas (trincheiras) e coleta do lixiviado. Em visita realizada em 17/06/2005 uma vala estava sendo preparada, conforme Figura 69 e Figura 70.

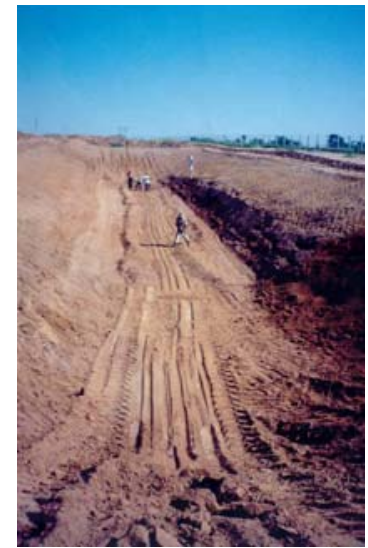

Figura 69 - Preparação de trincheira no aterro de Brotas

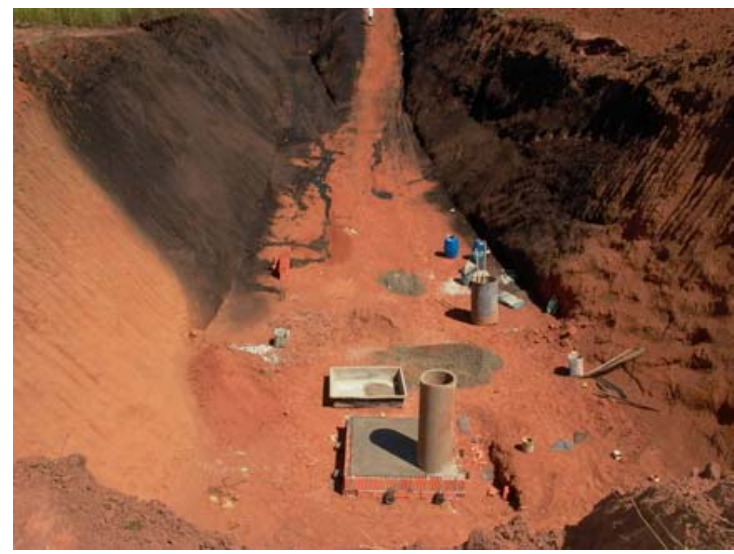

Figura 70 - Impermeabilização de vala no aterro de Brotas

Fonte: Prefeitura Municipal de Brotas

As valas possuem as seguintes dimensões: $6 \times 50 \times 3 \mathrm{~m}^{3}$. Na base da vala foi colocada uma camada de argila e aplicado uma camada de material asfáltico, CM 30 (Figura 67). O lixiviado é drenado para uma caixa coletora a jusante do aterro e encaminhado para a Estação de Tratamento de Esgoto (ETE) do município. Estima-se uma geração média de até $3 \mathrm{~m}^{3} /$ mês de lixiviado.

\section{Sondagem no terreno do aterro}

No período de 04/08/2004 a 06/08/2004 foi realizada sondagem no aterro de Brotas para verificação do aqüífero freático (Anexo 1). O terreno foi perfurado em dois locais, a montante (ST-02), Figura 71, e a jusante do aterro (ST-01), Figura 72. 


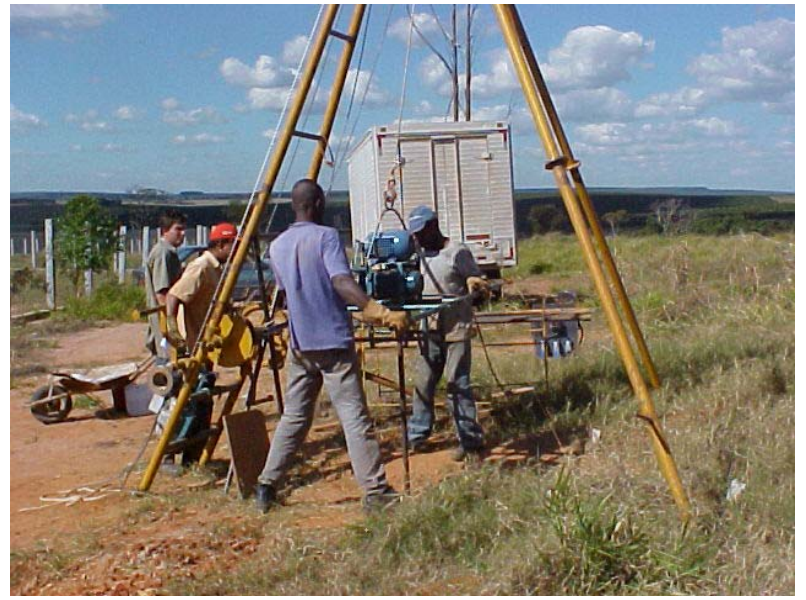

Figura 71 - Sondagem realizada no ponto a montante do aterro de Brotas

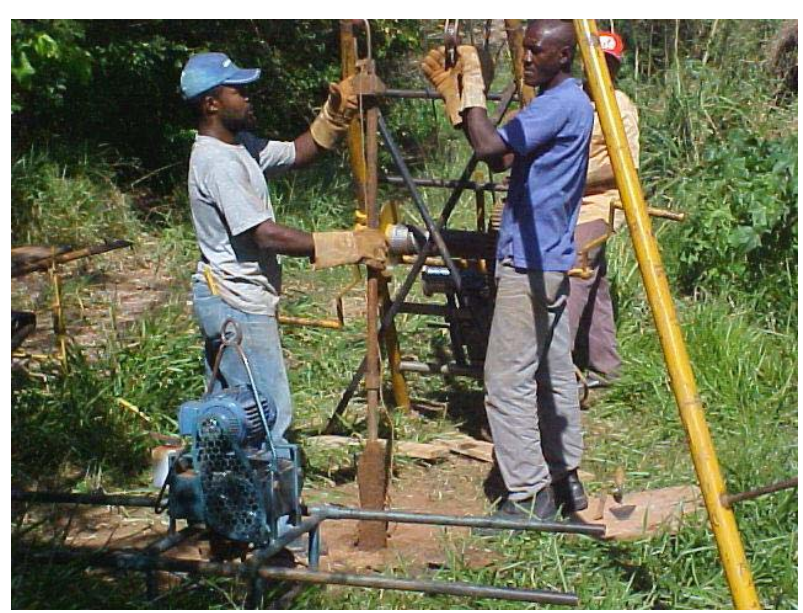

Figura 72 - Sondagem realizada no ponto a jusante do aterro de Brotas

Foram coletadas amostras de solo do aterro a cada metro (Figura 73 e Figura 74), o qual foi caracterizado como arenito da Formação Pirambóia.

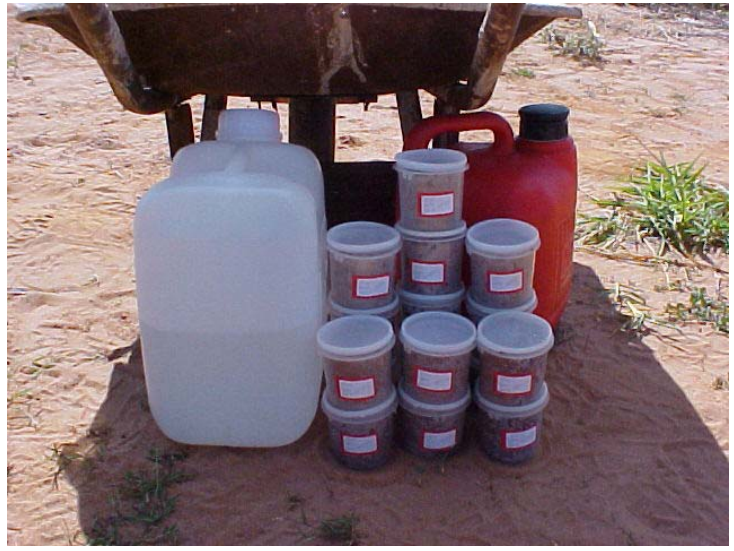

Figura 73 - Amostras de solo do aterro de Brotas armazenadas, 06/08/2004

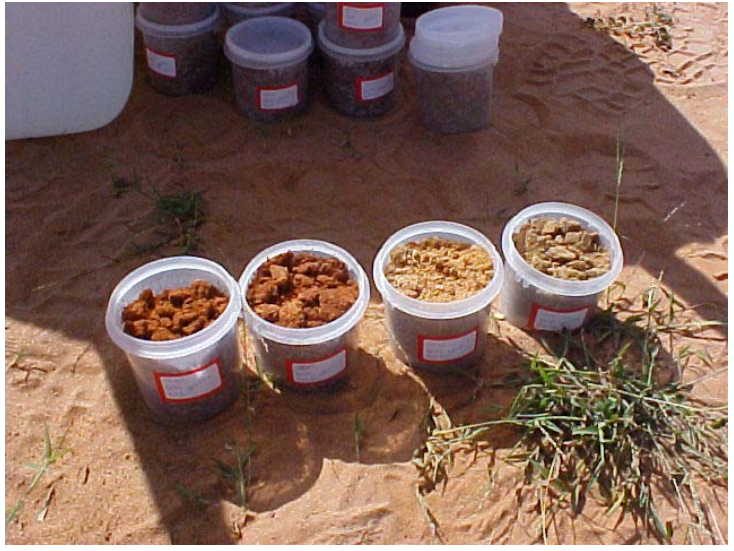

Figura 74 - Amostras de solo do aterro de Brotas, 06/08/2004

De acordo com o relatório da empresa responsável pela sondagem do terreno (Anexo 1), o solo recebeu as seguintes classificações: coluvionar (com areia fina a média siltosa de coloração variegada) e residual de arenito (com areia fina siltosa de coloração variegada). Segundo a empresa, a permeabilidade estimada do solo natural do aterro é da ordem de $10^{-3} \mathrm{~cm} / \mathrm{s}$, ou seja, solo muito permeável.

Durante a sondagem não foi encontrado aqüífero freático no aterro, o trado mecanizado atingiu substrato impenetrável aos $18,18 \mathrm{~m}$ no ponto a montante (ST-02) do aterro e aos 19,32m no ponto a jusante (ST-01). Dessa forma não foi possível monitorar as águas subterrâneas. A proposta era construir poços de monitoramento a montante e jusante dos resíduos aterrados. 


\subsubsection{Resíduos de Serviços de Saúde (RSS)}

De acordo com informações da prefeitura, o município gera cerca de $60 \mathrm{~kg} / \mathrm{dia}$ de RSS. No período de 1996 a 2004 estes resíduos eram dispostos em valas sépticas em área reservada e cercada no aterro, conforme Figura 75 e Figura 76. As valas eram impermeabilizadas com asfalto e cal, quando preenchidas recebiam cobertura de terra.

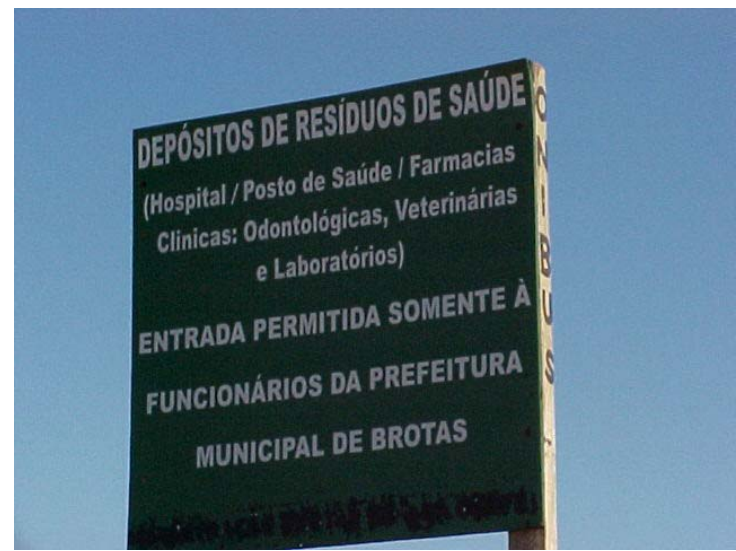

Figura 75 - Disposição de RSS no aterro de Brotas, 14/07/2004

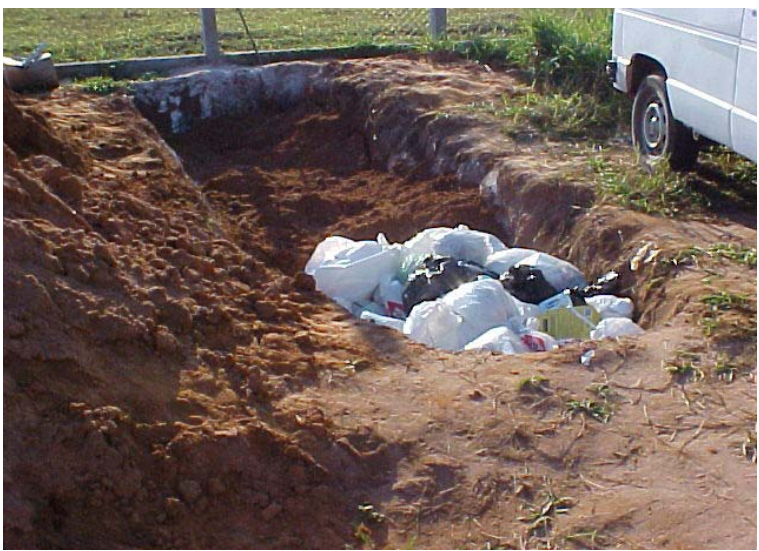

Figura 76 - Disposição de RSS no aterro de Brotas, 14/07/2004

Atualmente os RSS gerados na área urbana de Brotas são coletados por uma empresa de Botucatu no hospital municipal e encaminhados para tratamento por microondas em Paulínia. A coleta dos RSS é realizada três vezes por semana por uma pessoa, com uso de um furgão. Os custos com transporte e tratamento dos RSS são de $\mathrm{R} \$ 900,00 /$ mês.

\subsubsection{Resíduos da Construção Civil (RCC)}

Ainda não há registro sobre a quantidade de RCC e resíduos sólidos industriais gerados pelo município. Materiais como tijolos, pedras, telhas, entre outros, são utilizados na conservação de estradas. A Prefeitura coleta cerca de 36t/mês entre resíduos de poda, capina e entulho de residências que geram até $1 \mathrm{~m}^{3}$ destes resíduos.

\subsubsection{Embalagens de Agrotóxicos}

Foi constatado descarte de embalagens de agrotóxicos (Figura 77) nas margens do córrego da Cachoeira Grande. Esse fato demonstra a falta de consciência ambiental da comunidade, principalmente no que se refere à qualidade da água. 


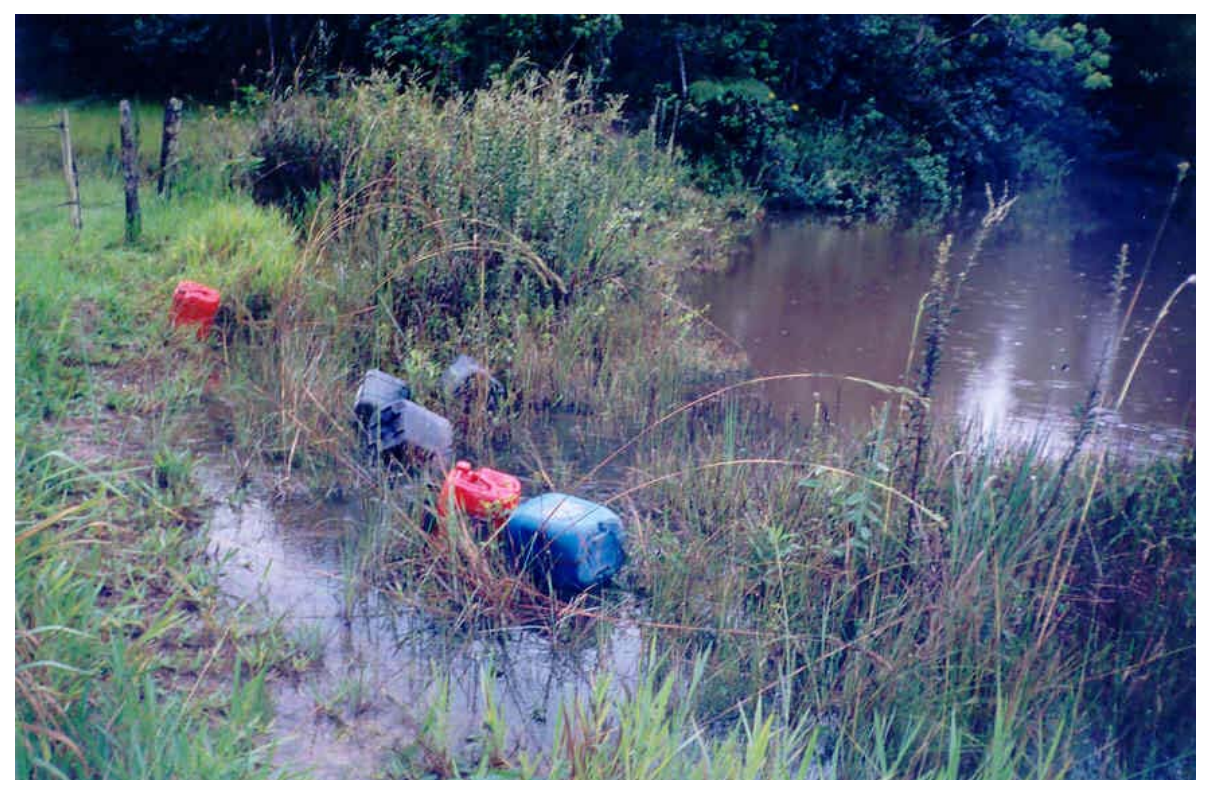

Figura 77 - Embalagens de agrotóxicos nas margens do córrego da Cachoeira Grande em Brotas, 22/03/2005

Nesse sentido, a prefeitura está promovendo eventos para conscientizar a população.

\subsubsection{Orçamento}

As despesas relacionadas aos resíduos sólidos em Brotas estão apresentados na Tabela 21.

Tabela 21 - Custos dos serviços com os resíduos sólidos em Brotas

\begin{tabular}{l|r|r}
\hline \multicolumn{1}{c|}{ Despesas } & Custo (R\$/mês) & \multicolumn{1}{c}{ Custo (R\$/t) } \\
\hline Coleta regular & $35.000,00$ & 97,22 \\
Funcionários & $24.204,00$ & - \\
Materiais, óleo diesel e serviços & $11.200,00$ & - \\
\hline
\end{tabular}

Fonte: Prefeitura Municipal de Brotas, junho 2007 


\subsubsection{Jaú}

O município de Jaú possui cerca de 125.469 habitantes (IBGE, 2007) e, segundo a prefeitura, gera em torno de 115 toneladas por dia de RSD.

\subsubsection{Resíduos Sólidos Domiciliares (RSD)}

\section{Coleta regular}

Os RSD gerados na área urbana e em parte da área rural do município são coletados pela prefeitura e transportados ao aterro. A coleta regular atende $100 \%$ dos bairros da cidade, incluindo estabelecimentos comerciais e industriais.

Para a coleta dos RSD, a cidade foi setorizada da seguinte forma: nos bairros a coleta é diurna e no centro é noturna. Conforme dados de $05 / 12 / 2005$, no centro foram coletadas cerca de 5,5t de RSD. Os setores de coleta são apresentados no Quadro 11.

Quadro 11 - Setores de coleta de RSD do município de Jaú

\begin{tabular}{|lc|}
\hline Dias da semana & Setor \\
\hline $2^{\mathrm{a}}, 4^{\mathrm{a}}$ e $6^{\mathrm{a}}$ feiras & Margem direita do rio Jaú \\
$3^{\mathrm{a}}, 5^{\mathrm{a}}$ e sábados & Margem esquerda do rio Jaú \\
\hline
\end{tabular}

Segundo a prefeitura, em dezembro e janeiro a coleta é realizada diariamente. Para a realização da coleta são utilizados nove caminhões, sendo três compactadores.

No total, a prefeitura conta com 58 funcionários na seção de coleta de lixo: 03 chefes, 40 coletores, 10 motoristas, 01 operador de pá mecânica, 01 operador de máquina de esteira, 02 agentes de serviços gerais para manutenção da estrada e do lixão e 01 agente de serviços gerais de plantão na porteira de estrada de acesso ao lixão. Segundo informações da prefeitura, dois vigilantes foram contratados para fazerem a segurança do lixão.

\section{Coleta seletiva de materiais recicláveis}

Não há coleta seletiva na cidade e ainda não há previsão de implantação. Existe um estudo da Secretaria do Meio Ambiente de Jaú sobre a viabilidade de implantação do programa. Atualmente apenas catadores informais e a Associação dos Catadores de Papel (ACAP) recolhem os materiais recicláveis, os quais são vendidos posteriormente. 
Segundo informações da prefeitura, ainda não existem Pontos de Entrega Voluntária (PEVs) implantados na cidade para o descarte dos recicláveis. Porém, está prevista a instalação destes pontos inicialmente em escolas junto a um trabalho de conscientização da comunidade, incluindo empresas, estabelecimentos comerciais e instituições.

\section{Tratamento}

Triagem dos materiais recicláveis

O município não possui Central de Triagem para separação dos materiais recicláveis, porém possui um galpão, pertencente a uma igreja, onde funciona a ACAP, que possui 25 cooperados. Estima-se que em média sejam coletadas cerca de 40t/mês de materiais recicláveis. Não há previsão da quantidade de recicláveis coletada pela coleta informal.

\section{Compostagem}

Até início de 2007 a prefeitura coletava os resíduos de poda e capina e encaminhava para o Centro de Produção Municipal de Jaú (CEPROM), onde eram compostados. Porém, devido a falhas no triturador, a compostagem destes resíduos foi interrompida. O composto era encaminhado para hortas da cidade.

Cerca de 12t/d entre resíduos de poda e capina, volumosos e resíduos de varrição são dispostas em uma vala, localizada nas proximidades da Rodovia Jaú - Brotas, junto aos RCC.

Até o momento não há previsão para implantação da compostagem dos RSD no município, bem como estudos previstos ou instituições que a praticam. Segundo a prefeitura, apenas a Escola Agrícola Urias Ferreira do Amaral realiza a compostagem dos seus resíduos.

\section{Disposição Final}

Os RSD gerados por Jaú são dispostos num lixão localizado a $12,5 \mathrm{~km}$ do centro urbano, nas coordenadas $22^{\circ} 16^{\prime} \mathrm{S}$ e $48^{\circ} 26^{\prime} \mathrm{W}$, próximo ao km 165 da Rodovia Engenheiro Paulo Nilo Romano SP 225 e ao ribeirão do Matão (a sudoeste do aterro).

O aterro possui $48.400 \mathrm{~m}^{2}$ e está localizado sobre a Formação Itaqueri do Grupo Bauru, com base em IPT (1981). De acordo com sondagem do terreno realizada em agosto de 2004, o solo do aterro recebeu três classificações: coluvionar (com areia fina siltoargilosa, vermelha clara); residual de arenito/Formação Itaqueri (com areia fina a média silto-argilosa, de coloração variegada) e paleoaluvião (com areia fina siltosa de coloração 
variegada), conforme Anexo 2. Estima-se que a permeabilidade do solo natural do aterro esteja entre $10^{-4}$ e $10^{-5} \mathrm{~cm} / \mathrm{s}$, conforme informações da empresa responsável pela sondagem do terreno.

O lixão (Figura 78 e Figura 79) opera desde 1992. A prefeitura é a responsável pela operação da área e a previsão é de que os resíduos continuem a ser encaminhados para o local até que o projeto do aterro sanitário seja aprovado.

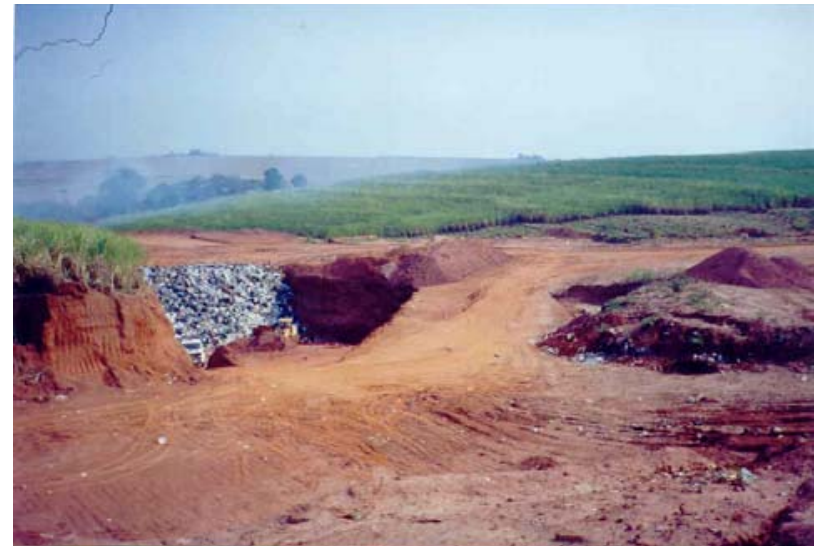

Figura 78 - Lixão de Jaú, 18/08/2005

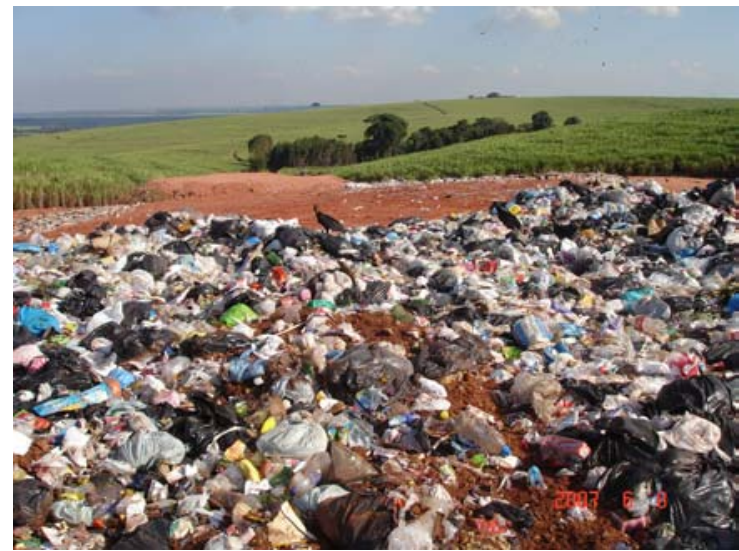

Figura 79 - Lixão de Jaú, 08/06/2007

Segundo informações do Secretário de Planejamento e Obras, no dia 02/07/07 foi dado entrada na CETESB do documento de licença de instalação e funcionamento do aterro sanitário. O aterro será implantado na Fazenda São Francisco de Paula, localizada na Rodovia Jaú - Brotas, que deverá ser desapropriada. Ainda não há previsão para início das obras.

O lixão recebe cerca de $115 \mathrm{t} / \mathrm{d}$ de RSD gerados pelo próprio município, conforme informações da prefeitura. Além dos RSD, resíduos não perigosos gerados pelas indústrias (Classe II) também são dispostos no local. Porém, segundo a prefeitura, muitos destes resíduos são vendidos para ferro velho ou desviados pela coleta informal.

Em visita realizada no dia 18/08/2005 foi constatado presença de catadores no local, bem como disposição de resíduo volumoso (sofá) e animais de grande porte (gado), conforme Figura 80. 


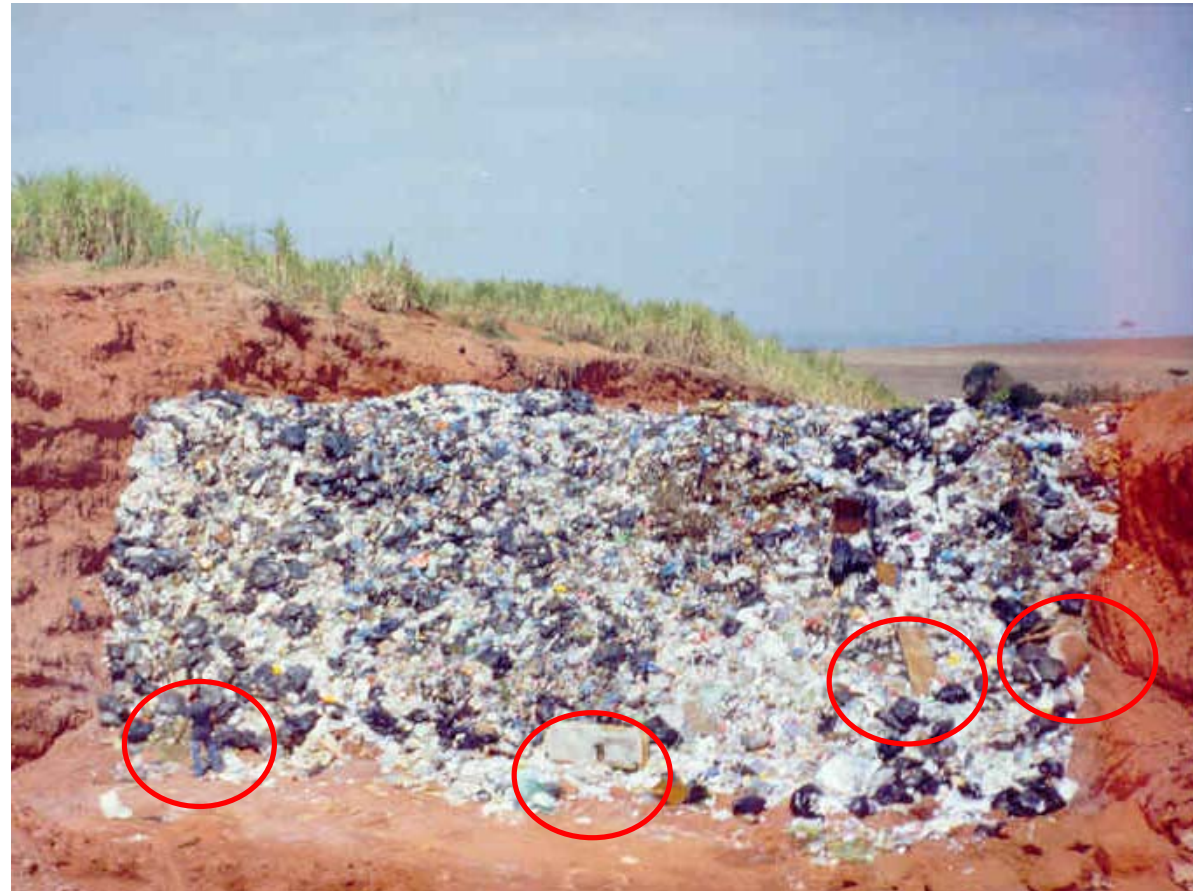

Figura 80 - Presença de catador, disposição de resíduo volumoso e animais de grande porte no lixão de Jaú, 18/08/2005

Durante algumas visitas realizadas no lixão de Jaú, constatou-se ateamento de fogo nos resíduos, conforme Figura 81.

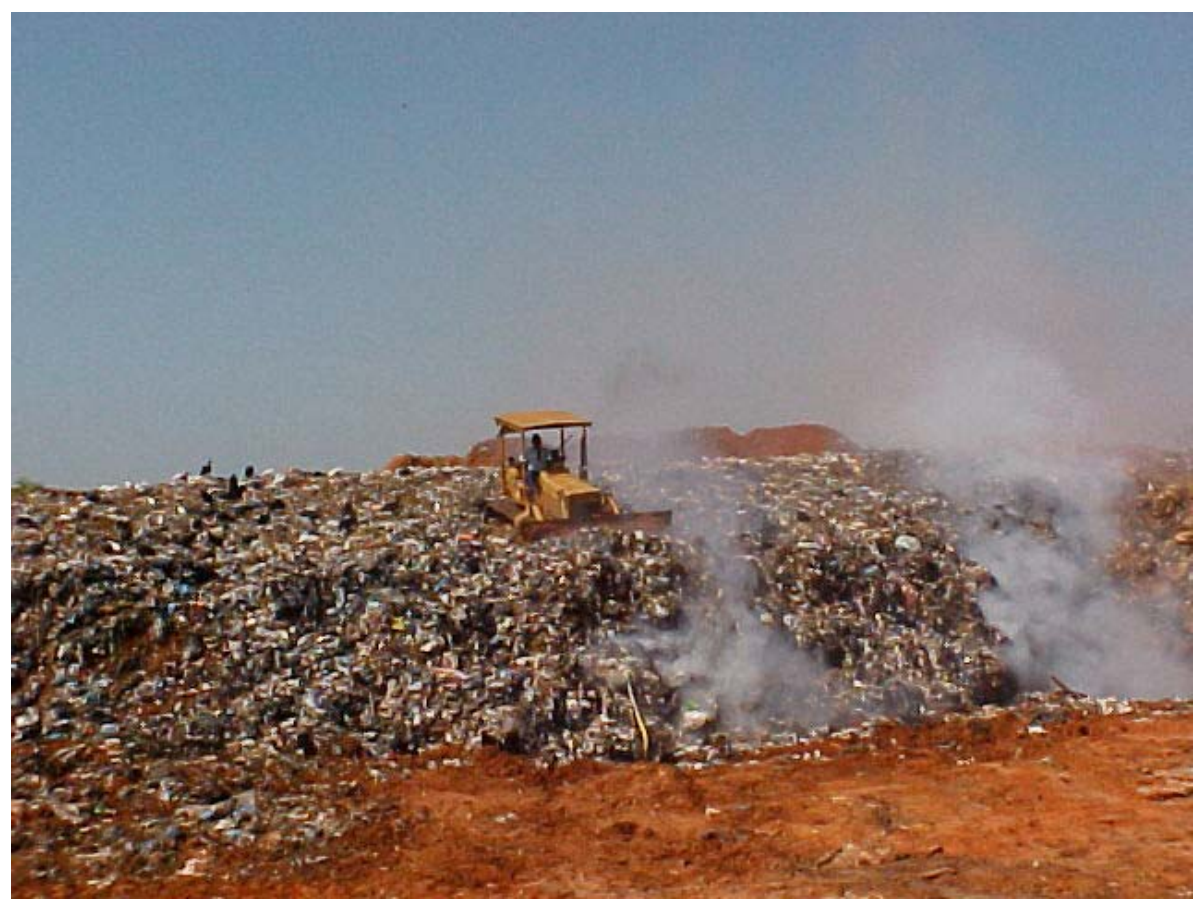

Figura 81 - Fogo no lixão de Jaú, 24/11/2004 
Na última avaliação da CETESB (2007a, p.17), o Índice de Qualidade de Aterro de Resíduos (IQR) foi 5,5. Portanto, atualmente o lixão opera em condições inadequadas. Segundo a prefeitura, o local é fiscalizado pela CETESB cerca de uma vez por mês.

O lixão foi implantado em área de cana-de-açúcar. O terreno pertence a dois proprietários rurais e, segundo a prefeitura, não há risco de desapropriação.

Há uma cabine instalada na entrada do lixão de Jaú onde um funcionário da prefeitura controla a entrada de pessoas e veículos. Apesar da presença de funcionários da prefeitura na entrada do local e trabalhando nas máquinas, os catadores invadem a área (Figura 82 e Figura 83).

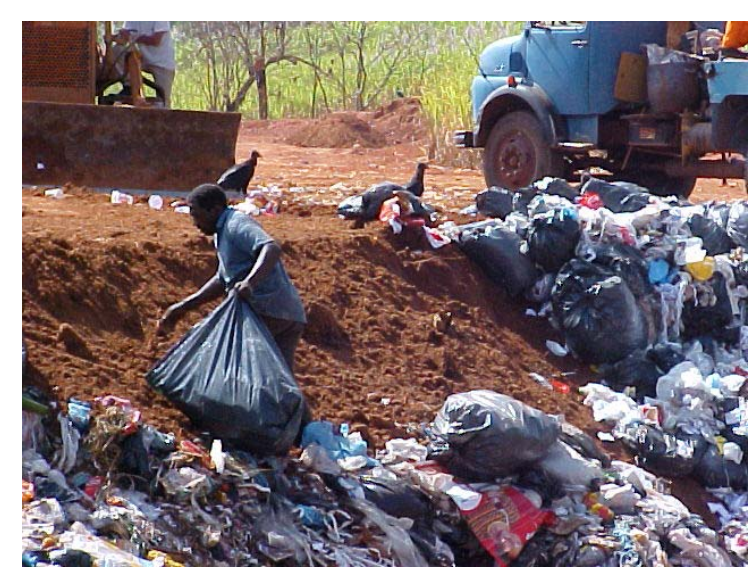

Figura 82 - Lixão de Jaú, 23/08/2004

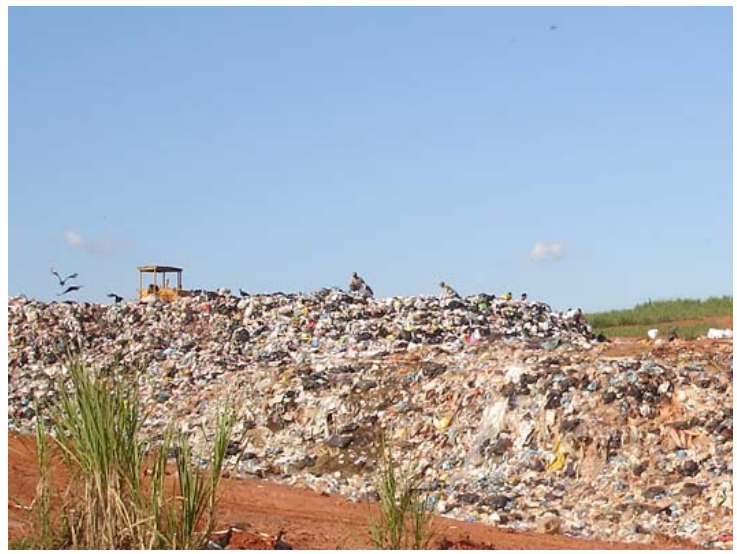

Figura 83 - Lixão de Jaú, 08/06/2007

Durante os últimos anos o lixão se expandiu em direção a uma das nascentes do ribeirão do Matão (Figura 84 e Figura 85) e parte do canavial foi ocupada. Os pontos de coleta de água superficial estão apresentados na Figura 84 Atualmente, a massa de resíduos cresce em altura (Figura 86 ). 


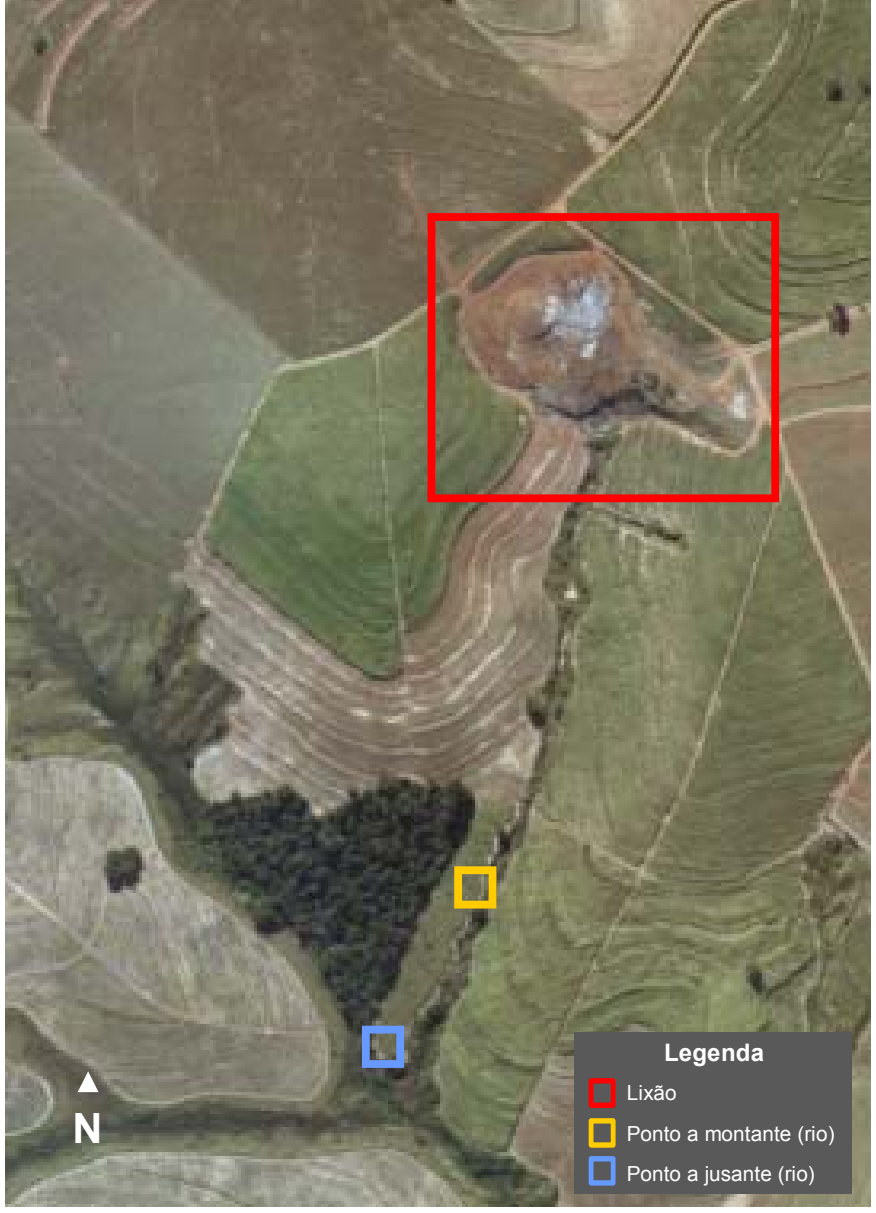

Figura 84 - Localização do lixão de Jaú

Fonte: Base Aerofotogrametria e Projetos S.A. São Paulo, 18/07/2000, Escala 1:30.000

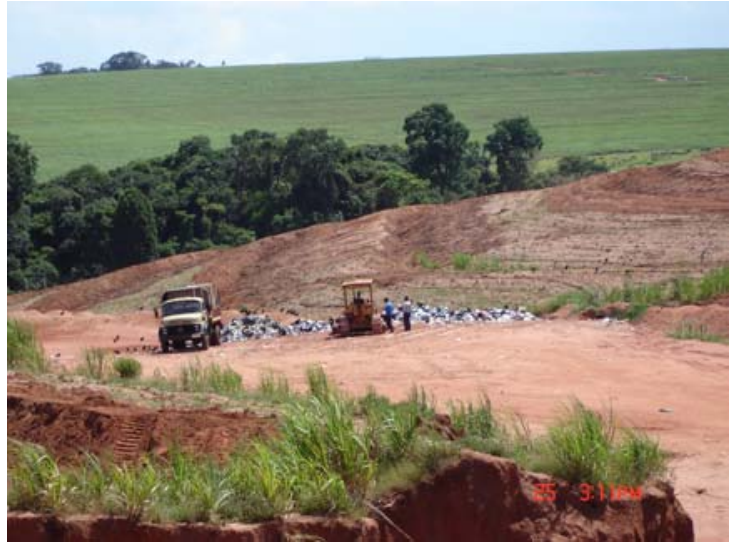

Figura 85 - Disposição de resíduos no lixão de Jaú, 25/01/2007

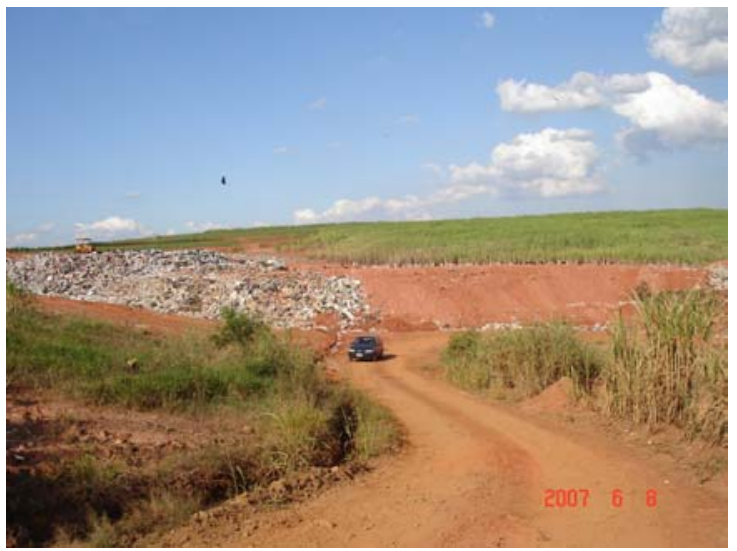

Figura 86 - Disposição de resíduos no lixão de Jaú, 08/06/2007

Cobertura e compactação dos resíduos

Os resíduos são descarregados, compactados e cobertos com terra.

Coleta de gás, drenagem da água de chuva e do lixiviado

O terreno não é impermeabilizado e a área não possui coletores de gases e drenagem do lixiviado (Figura 87, Figura 88 e Figura 89). Como os líquidos gerados não são canalizados e armazenados em um único local, formam-se várias poças ao longo da área e pode ocorrer infiltração pelo solo. Assim, não há estimativas da geração média destes líquidos. 


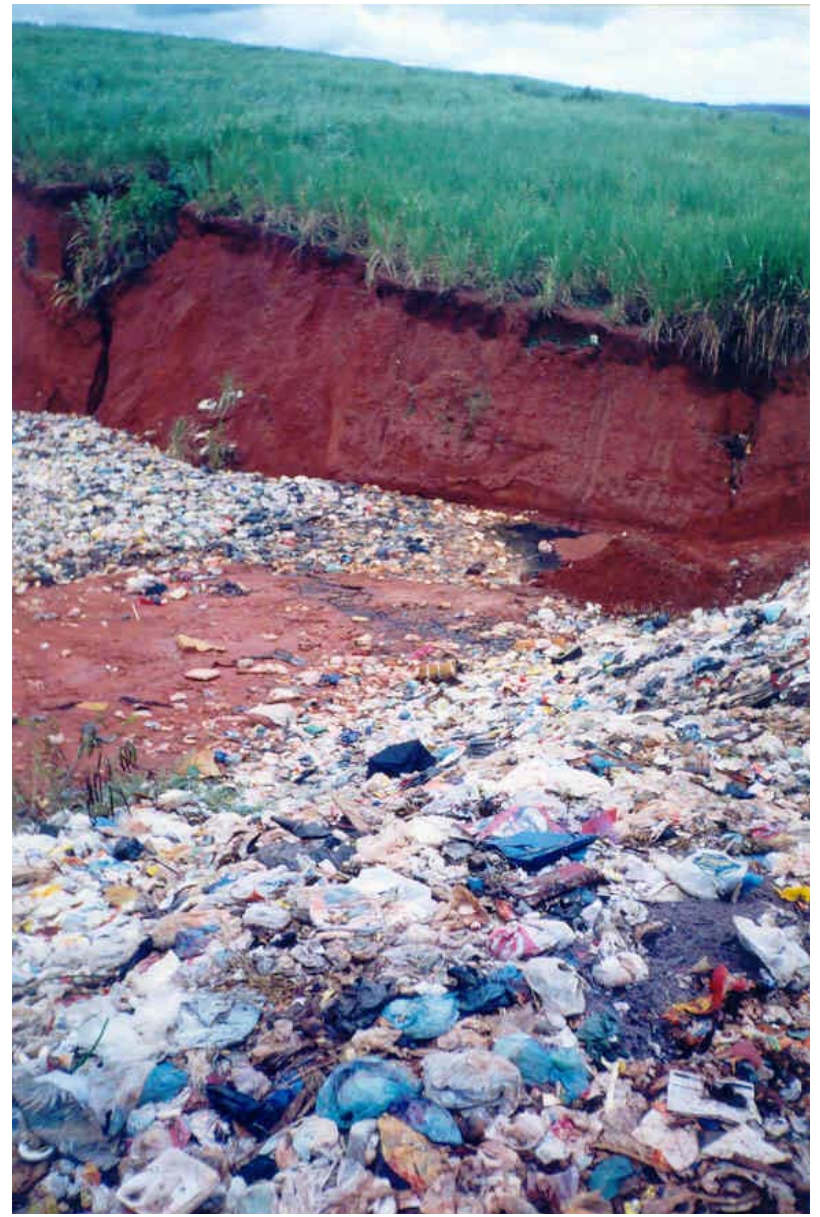

Figura 88 - Formação de lixiviado no lixão de Jaú, 22/03/2005

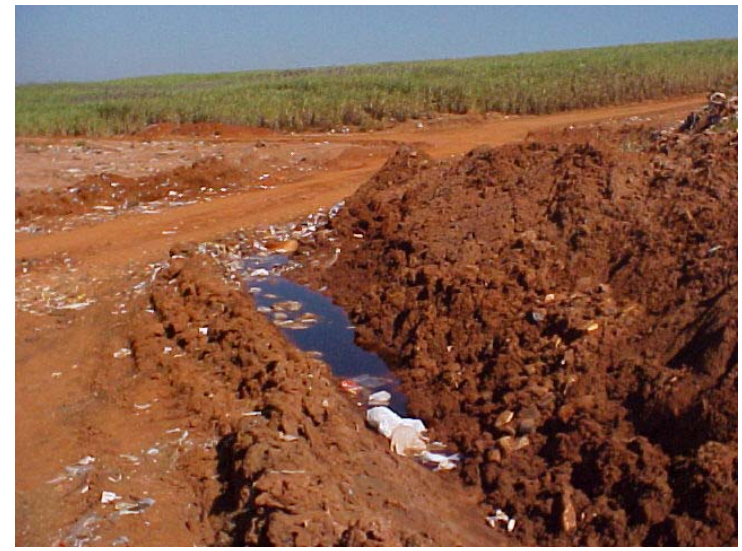

Figura 87 - Acúmulo de lixiviado no lixão de Jaú, 10/08/2004

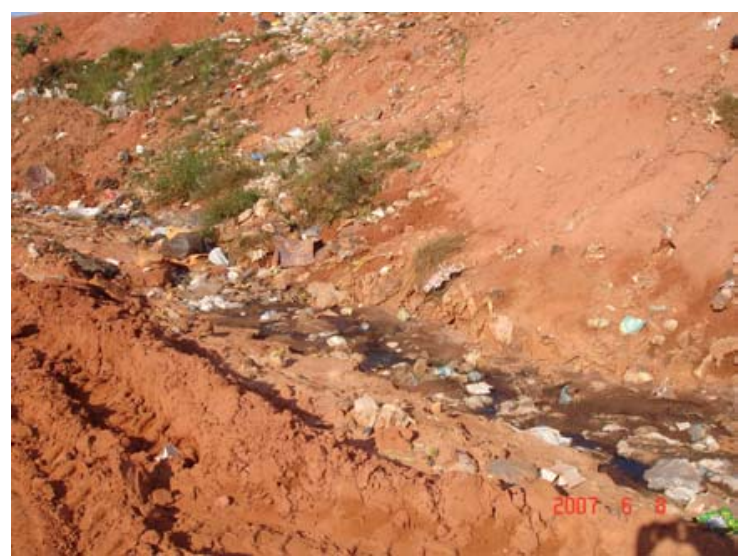

Figura 89 - Lixiviado no lixão de Jaú, 08/06/2007

A área não possui drenagem para água de chuva, assim parte dos resíduos fica acumulada nas curvas de nível ou é carreada para o ribeirão do Matão (Figura 90, Figura 91 e Figura 92). 


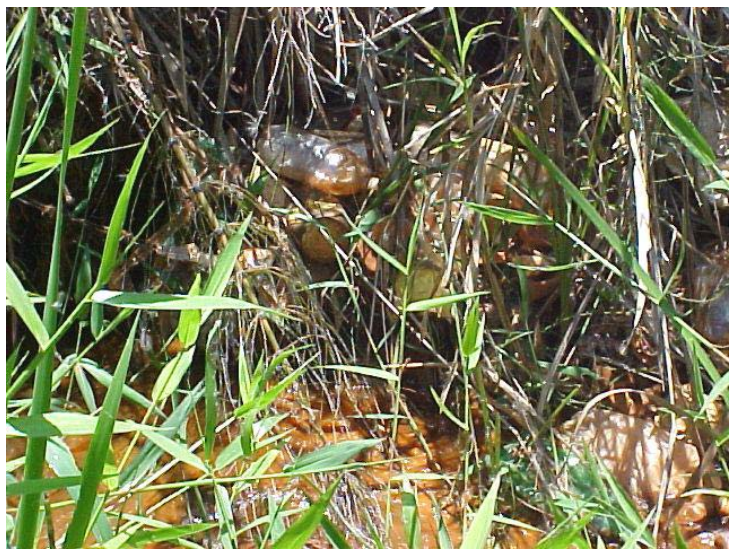

Figura 90 - Resíduos carreados para o ribeirão do Matão em Jaú, 24/11/2004

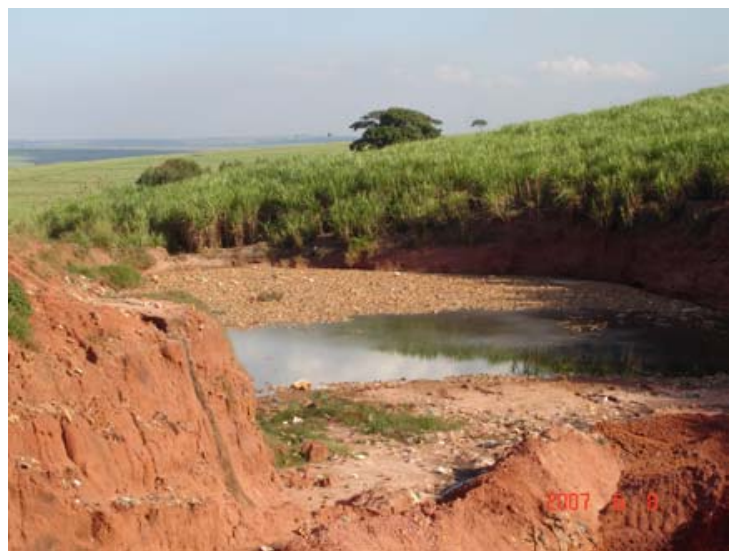

Figura 91 - Resíduos acumulados no lixão de Jaú devido às chuvas, 08/06/2007

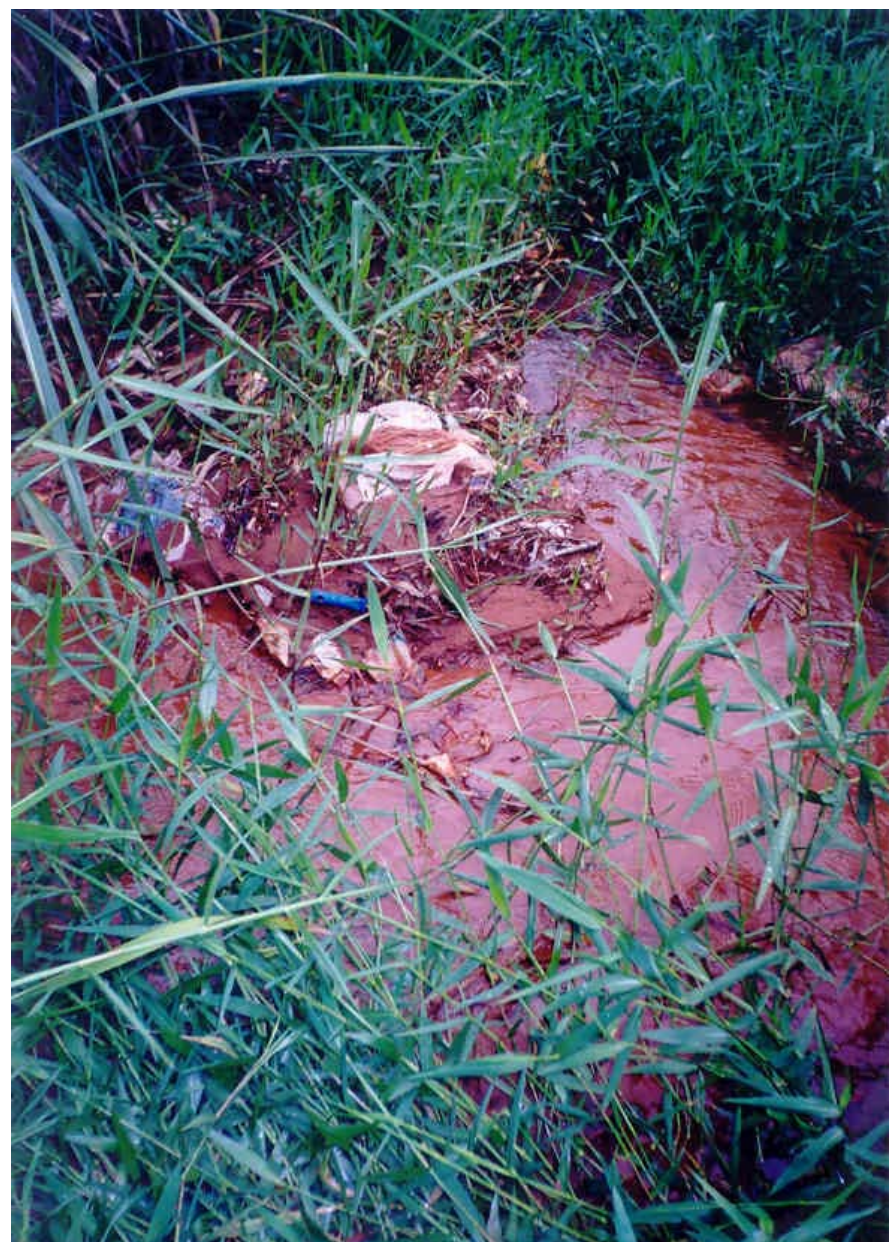

Figura 92 - Resíduos carreados para o ribeirão do Matão em Jaú, 22/03/2005

A falta de drenagem de água de chuva favorece a formação de processo erosivo que avança no entorno do lixão até o ribeirão do Matão, conforme constatado durante as visitas realizadas (Figura 93, Figura 94 e Figura 95). 


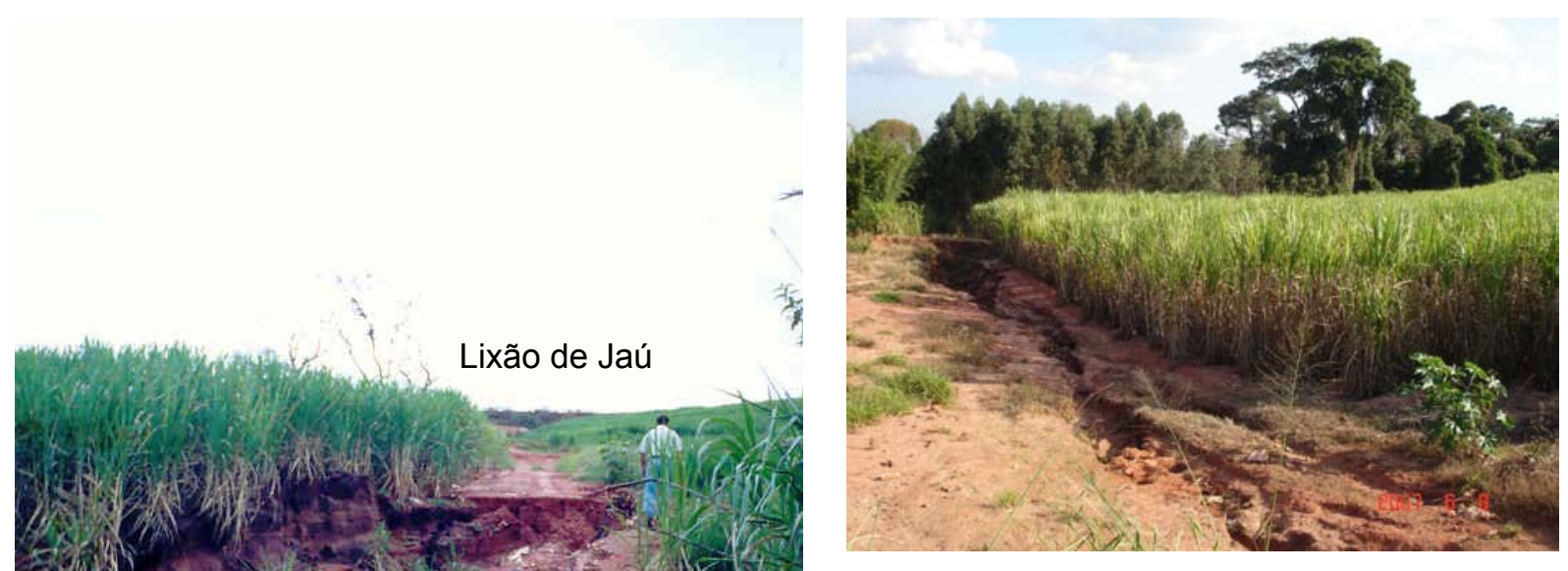

Figura 93 - Erosão próxima ao ribeirão do Matão em Jaú, 08/06/2007

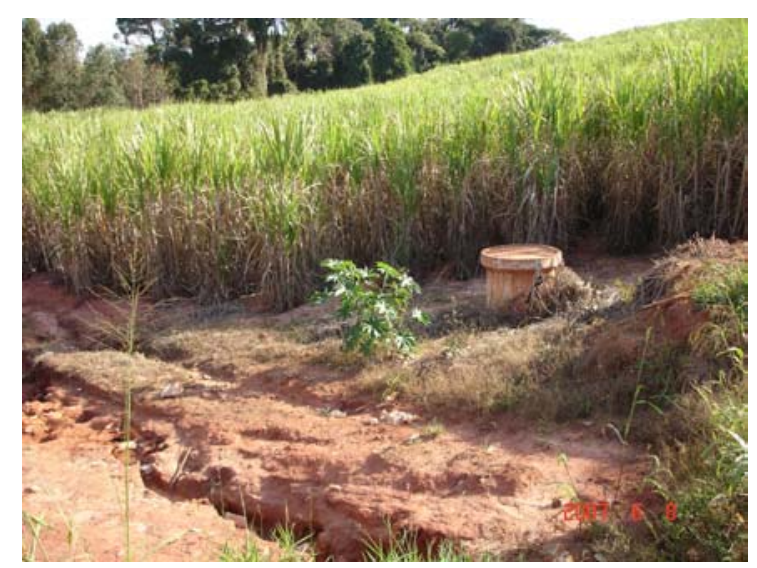

Figura 95 - Erosão próxima ao poço de monitoramento no lixão de Jaú, 08/06/2007
Figura 94 - Formação de erosão no entorno do lixão de Jaú, 22/03/2005

Com base na situação atual do lixão de Jaú, Bernardi Filho (2005) propõe que sejam realizadas novas pesquisas no local para busca de melhorias ambientais e sociais.

Monitoramento das águas subterrâneas

O aterro possui quatro poços para o monitoramento das águas subterrâneas, construídos em agosto de 2004 para realização desta pesquisa, conforme Figura 96. A localização dos poços está apresentada no Anexo 2. 


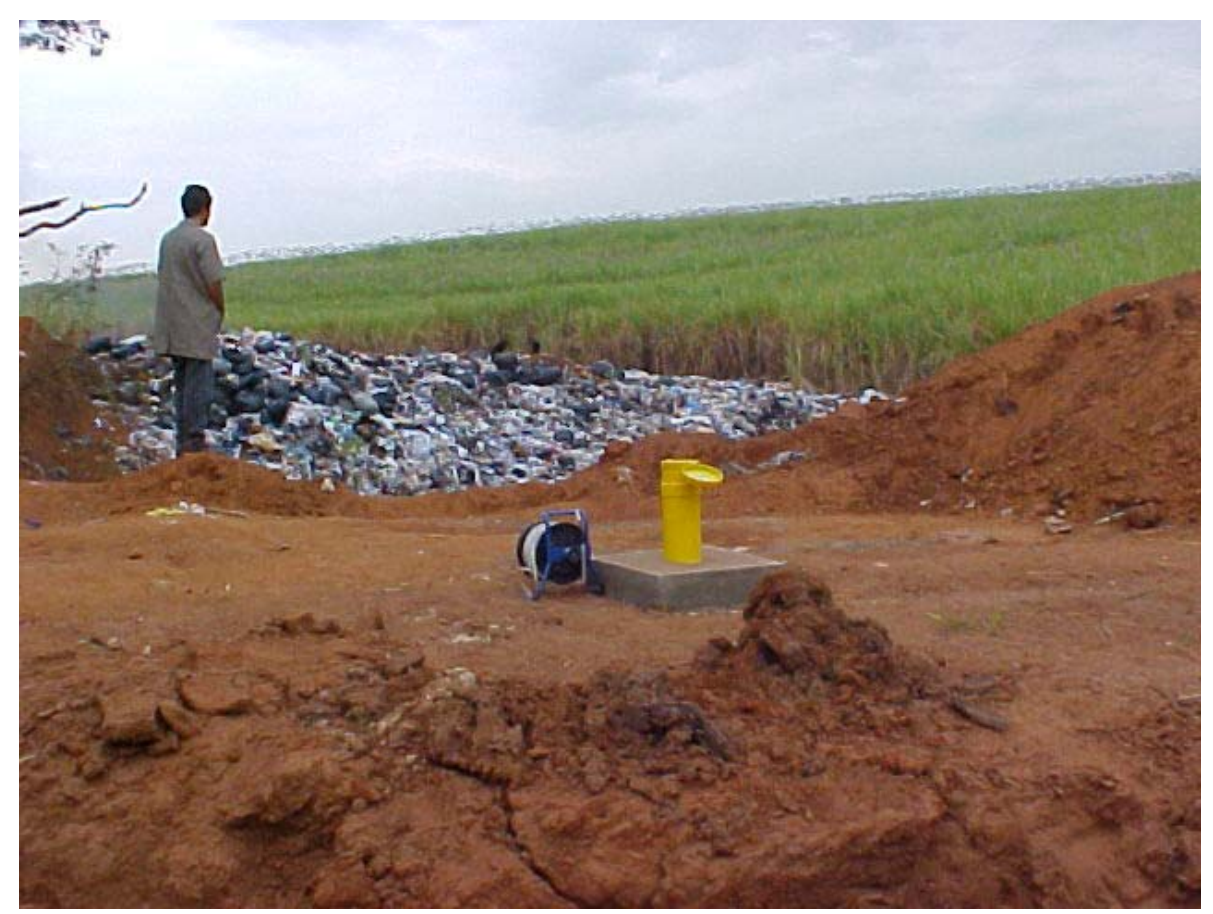

Figura 96 - Poço a jusante do lixão de Jaú (PJ3), 27/08/2004

Após a construção dos poços no lixão de Jaú, foi medido o nível da água subterrânea. Os níveis obtidos estão apresentados na Tabela 22.

Tabela 22 - Nível d’água inicial dos poços do aterro de Jaú

\begin{tabular}{ccc}
\hline Poços & $\begin{array}{c}\text { Nível d'água }(\mathbf{m}) \\
\mathbf{2 7 / 0 8 / 2 0 0 4}\end{array}$ & Horário (h) \\
\hline PM & 25,12 & $08: 45$ \\
PJ1 & 13,48 & $09: 04$ \\
PJ2 & 16,07 & $09: 19$ \\
PJ3 & 5,99 & $09: 27$ \\
\hline
\end{tabular}

A pedido do fiscal da CETESB, a prefeitura colocou manilhas de concreto com tampa ao redor dos poços para proteção contra possíveis roubos e arrombamentos. Os resíduos avançaram em direção ao poço PJ1, que acabou sendo enterrado, o que dificultou as coletas de água subterrânea por um período.

Vale ressaltar que a construção dos poços de monitoramento foi autorizada pela prefeitura e sua localização foi acompanhada por funcionário responsável pela operação da área. Em agosto de 2004, quando os poços foram construídos, não estava previsto o avanço do lixão na direção dos mesmos.

Atualmente, os poços continuam protegidos. A disposição dos resíduos estava sendo desviada dos poços. Porém, com o aumento da altura do lixão, a prefeitura elevou o tubo do PJ1 (Figura 97). 


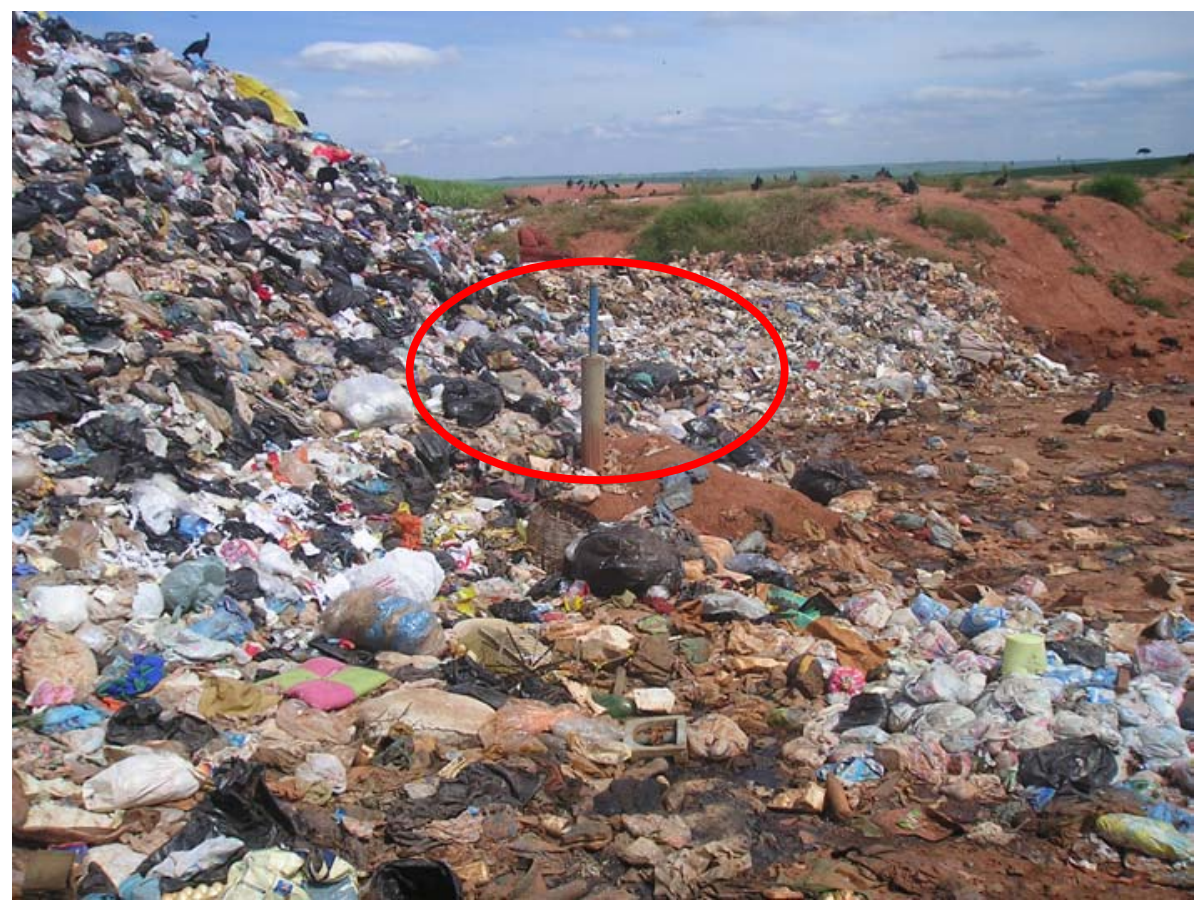

Figura 97 - Poço PJ1 no lixão de Jaú

Fonte: Prefeitura Municipal de Jaú, 21/03/2007

\subsubsection{Resíduo Domiciliar Perigoso (RDP)}

Segundo a prefeitura, as pilhas são descartadas no lixão e as baterias de celular são coletadas por pontos de venda e assistência da cidade. No dia 26/06/2007 foi realizada a primeira reunião entre prefeitura e revendedores de lâmpadas fluorescentes para discutir sobre sua destinação correta.

\subsubsection{Resíduos de Serviços de Saúde (RSS)}

\section{Coleta}

Os RSS gerados na área urbana de Jaú são coletados por duas empresas, a Empresa Cheiro Verde contratada pela prefeitura e outra contratada pelo Hospital Amaral Carvalho. Provavelmente, a atuação de duas empresas no município de deve à cobrança de valores diferentes.

A coleta realizada pela primeira empresa ocorre duas vezes por semana e é realizada por duas pessoas, um motorista e um ajudante, com uso de um caminhão baú. Esta coleta atende 25 pontos entre escolas com tratamento dentário, serviço de autopsia da polícia, Posto de Atendimento Sanitário (PAS), Pronto Socorro Municipal, Santa Casa e demais geradores. Os RSS gerados em Jaú são transportados para Bauru, onde são armazenados temporariamente até serem encaminhados para tratamento. 
Os RSS coletados pela segunda empresa são encaminhados para tratamento num incinerador, localizado em área rural de Jaú. A coleta é realizada com uso de um caminhão baú. Esta coleta atende ao Hospital Amaral Carvalho e a outros geradores.

\section{Tratamento}

Os RSS coletados pela Cheiro Verde são encaminhados para tratamento em Paulínia em autoclave ou incinerador, conforme a classificação do resíduo. Cerca de $300 \mathrm{~kg} / \mathrm{dia}$ de RSS são geradas pelos estabelecimentos atendidos por esta empresa.

Os RSS coletados pela segunda empresa são encaminhados para o incinerador do município. Vale ressaltar que o equipamento recebe entre 15 a 18t/mês de RSS gerados por Jaú e outros 10 municípios da região.

\section{Disposição final}

Os RSS coletados pela empresa Cheiro Verde, após tratados são dispostos no Aterro Industrial Mauá em São Paulo. Os RSS coletados pela segunda empresa, após tratados são dispostos na propriedade onde está instalado o incinerador de Jaú.

Vale destacar que Jaú possui um Decreto Municipal $n^{\circ} 4.889$, de 24 de julho de 2002, que dispõe sobre a exigência de prestação comprobatória de inutilização adequada dos resíduos de serviço de saúde.

\subsubsection{Resíduos da Construção Civil (RCC)}

Segundo informações da prefeitura, estima-se que sejam geradas cerca de $40 \mathrm{t} / \mathrm{d}$ de RCC em Jaú. Estes resíduos são coletados por cinco empresas de caçambas e dispostos na periferia da cidade, próximo a Rodovia Jaú - Brotas.

Ainda não existe nenhuma área licenciada para armazenamento temporário ou disposição final dos RCC, porém está previsto desapropriação de uma área para esta finalidade.

Segundo informações da prefeitura, ainda não há previsão de nenhum projeto para reciclagem dos RCC no município, bem como não está previsto encaminhá-los para reciclagem em outra cidade. Porém, a implantação de uma usina de reciclagem de RCC já foi discutida pela prefeitura. 


\subsubsection{Pneus}

Cerca de 2.000 unidades são armazenadas no CEPROM (único Ecoponto de Jaú) e coletadas a cada dois ou três meses pela ANIP. Os pneus são encaminhados para trituração e emprego em asfalto ou para o auto-forno em Jundiaí. O Ecoponto pode ser entendido como um PEV, Ponto de Entrega Voluntária.

\subsubsection{Resíduos Sólidos Industriais (RSI)}

Várias fábricas de bolsas e calçados foram instaladas no município de Jaú, por isso até 2004 os resíduos gerados na fabricação destes produtos eram encaminhados para o lixão (Figura 98 e Figura 99).

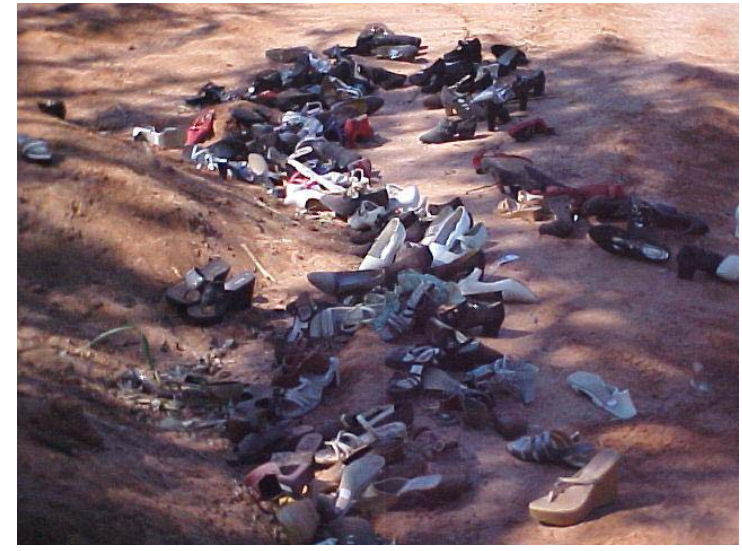

Figura 98 - Resíduos da indústria calçadista no lixão de Jaú, 10/08/2004

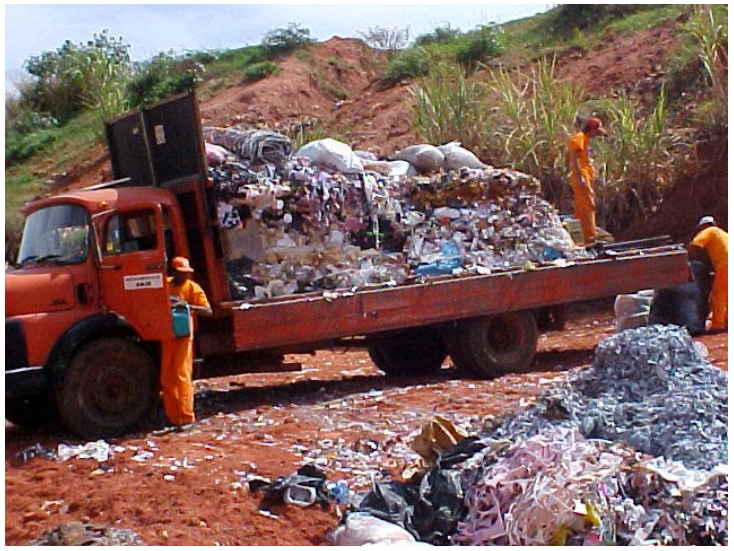

Figura 99 - Disposição de resíduos de artefatos de couro no lixão de Jaú

Segundo a prefeitura, a partir de 2005 os resíduos das indústrias filiadas ao Sindicato Patronal de Jaú passaram a ser coletados por uma empresa e encaminhados para o aterro da Estre em Paulínia. Uma parte destes resíduos, que pode ser reciclada, é encaminhada para Bocaina, um município vizinho.

Em Jaú são geradas cerca de 18t/d de RSI Classe I e o custo da coleta e disposição final é de $\mathrm{R} \$ 231,00 / t$, segundo o Sindicato. Até junho de 2007 não havia previsão para instalação de um aterro industrial na cidade ou na região.

\subsubsection{Orçamento}

Segundo a prefeitura, os custos com os serviços de limpeza pública do município estão apresentados na Tabela 23. 
Tabela 23 - Custos dos serviços com os resíduos sólidos em Jaú

\begin{tabular}{l|r}
\hline \multicolumn{1}{c|}{ Tipo de Serviço } & \multicolumn{1}{c}{ Custo (R\$/mês) } \\
\hline Aluguel do terreno do lixão & $1.800,00$ \\
Coleta regular dos RSU & $125.000,00$ \\
Operação do lixão & $41.666,00$ \\
Limpeza de parques e jardins & $83.330,00$ \\
Pintura de faixas, guias, outros & 833,00 \\
\hline
\end{tabular}

Fonte: Prefeitura Municipal de Jaú, junho de 2007

Segundo a prefeitura, até junho de 2007 não estava prevista a implantação de nenhuma taxa específica para os serviços relacionados aos resíduos sólidos como implantação de coleta seletiva, construção de uma central de triagem de recicláveis, entre outros

\subsubsection{Ribeirão Bonito}

O município de Ribeirão Bonito possui cerca de 11.383 habitantes (IBGE, 2007) e gera em torno de 10,0 toneladas por dia de RSD.

\subsubsection{Resíduos Sólidos Domiciliares (RSD)}

\section{Coleta regular}

Os RSD gerados na área rural e urbana do município são coletados pela prefeitura e transportados ao aterro. A coleta regular atende $100 \%$ dos bairros da cidade, cerca de 288 estabelecimentos comerciais e industriais são atendidos. Para a coleta destes resíduos é utilizado o critério do melhor trajeto, a cidade não é setorizada. Para a realização da coleta são utilizados dois caminhões e seis funcionários: dois motoristas e quatro coletores.

\section{Coleta seletiva de materiais recicláveis}

Não há coleta seletiva na cidade e ainda não há previsão de implantação. Apenas catadores informais recolhem os materiais recicláveis, os quais são vendidos posteriormente.

Segundo informações da prefeitura, nenhuma instituição realiza este serviço e não existem Pontos de Entrega Voluntária (PEVs) implantados na cidade para descarte dos recicláveis. 


\section{Tratamento}

Triagem dos materiais recicláveis

O município não possui Central de Triagem para separação dos materiais recicláveis, nem cooperativa de catadores. Não há previsão da quantidade de recicláveis coletada pela coleta informal.

\section{Compostagem}

Não há compostagem dos RSD em Ribeirão Bonito, porém vale ressaltar que os resíduos de poda e capina não são dispostos no aterro. Não há instituições no município que praticam a compostagem.

\section{Disposição Final}

Os RSD gerados por Ribeirão Bonito são dispostos num aterro sanitário em valas (Figura 100 e Figura 101), que opera desde 2004. Segundo informações da prefeitura, a previsão é de que o aterro opere até 2008.

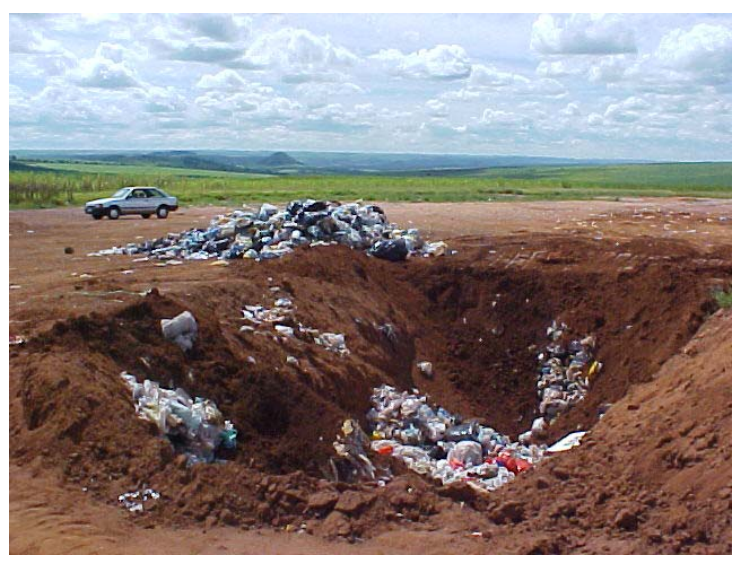

Figura 100 - Aterro em valas de Ribeirão Bonito, 12/04/2004

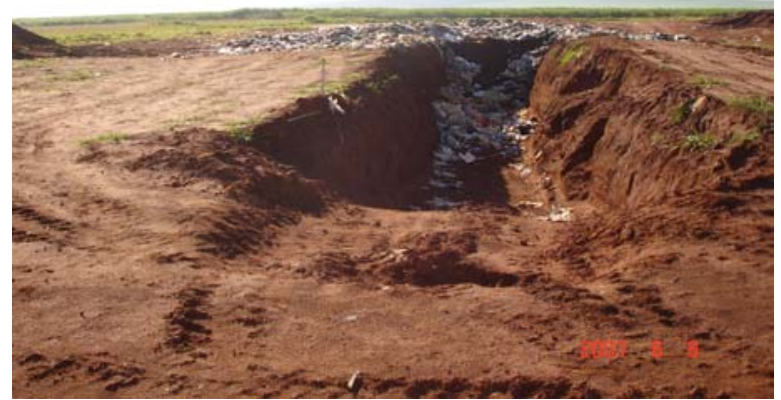

Figura 101 - Aterro de Ribeirão Bonito, 08/06/2007

O aterro de Ribeirão Bonito está localizado, a sudeste do centro urbano, nas coordenadas $22^{\circ} 04^{\prime} \mathrm{S}$ e $48^{\circ} 07^{\prime} \mathrm{W}$, a aproximadamente $400 \mathrm{~m}$ da Rodovia Estadual SP 215 , na Rodovia Municipal RBB135.

O aterro possui $40.000 \mathrm{~m}^{2}$ e está localizado sobre a Formação Botucatu do Grupo São Bento, com base em IPT (1981). De acordo com sondagem no terreno realizada em julho de 2004, o solo do aterro recebeu três classificações: coluvionar (com areia fina siltoargilosa, de coloração predominante vermelha clara amarronzada); residual de arenito/Formação 
Botucatu (com areia fina siltosa de coloração variegada) e residual de basalto/Formação Serra Geral (com silte argiloso de coloração variegada), conforme Anexo 3.

Segundo a empresa contratada pela prefeitura, a permeabilidade do solo natural do aterro é de $10^{-2} \mathrm{~cm} / \mathrm{s}$, conforme ensaio de infiltração realizado em 18/09/2001. Porém, este valor pode não ser muito confiável ou representativo. Por comparação com o solo do aterro de São Carlos, que apresentou permeabilidade entre $10^{-3}$ e $10^{-4} \mathrm{~cm} / \mathrm{s}$ e é mais arenoso que o solo do aterro de Ribeirão Bonito, a permeabilidade deste último deveria ser menor.

O aterro de Ribeirão Bonito é distante do núcleo urbano, rodeado por plantação de cana e por glebas com árvores (Figura 102). Os pontos de coleta das águas superficiais estão identificados nesta figura.

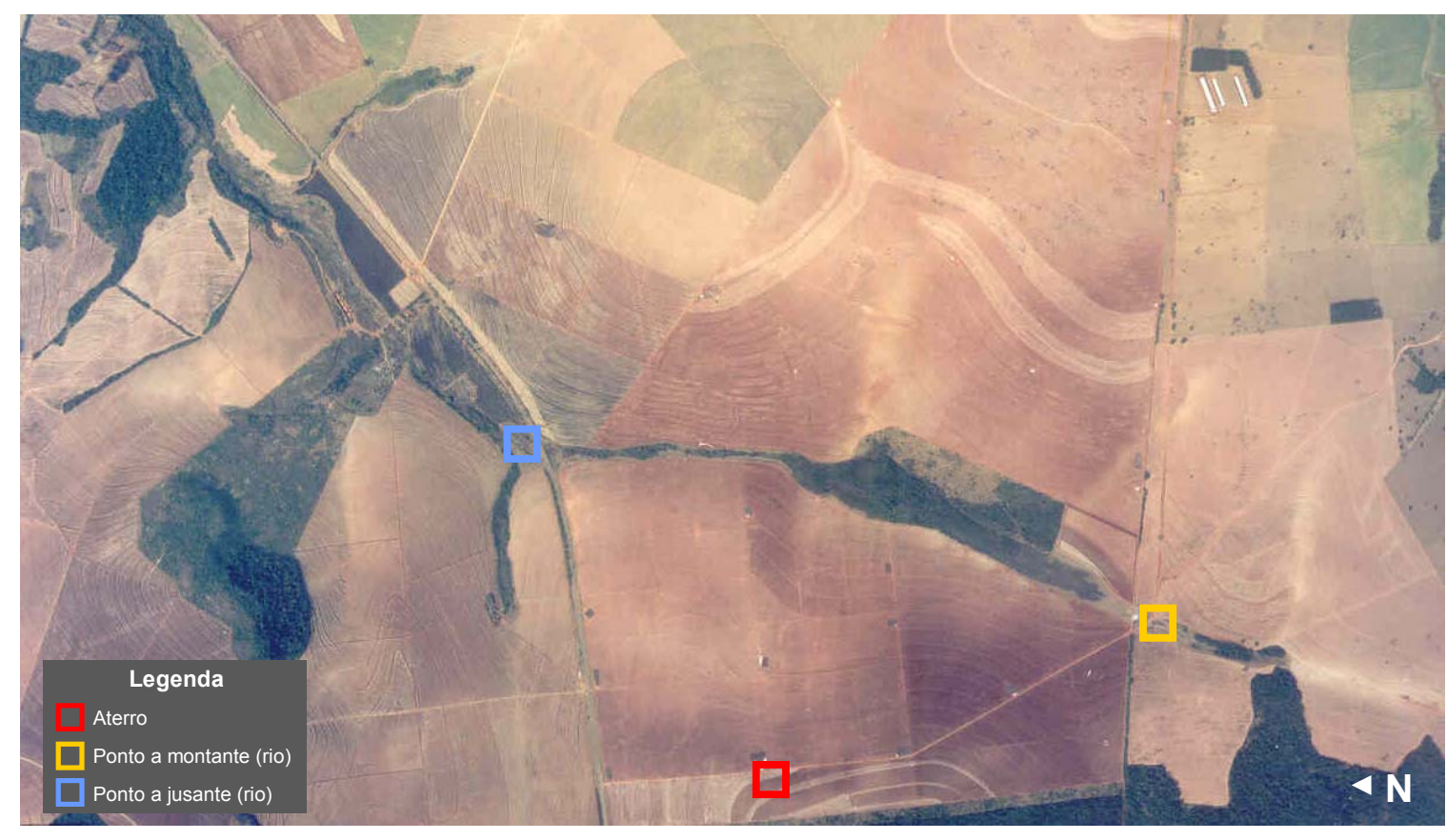

Figura 102 - Aterro de Ribeirão Bonito

Fonte: Base Aerofotogrametria e Projetos S.A. São Paulo, 18/07/2000 Escala 1:30.000

O terreno pertence à prefeitura, responsável por sua operação. O local recebe cerca de 10t/d de RSD gerados pelo próprio município. Além dos RSD, resíduos não perigosos gerados pelas indústrias (Classe II) também são dispostos no aterro. Porém, segundo a prefeitura, muitos destes resíduos são vendidos para ferro velho ou desviados pela coleta informal.

De acordo com projeto do aterro, foi prevista a abertura de 230 valas na área, com vida útil prevista para 20 anos. Estava previsto que cada vala armazenasse cerca de $243 \mathrm{~m}^{3}$ de resíduos e fosse preenchida em um mês. Conforme projeto inicial, as valas deveriam apresentar as seguintes dimensões: $27,00 \times 3,00 \times 3,00 \mathrm{~m}$. Porém, devido a problemas 
operacionais, atualmente as dimensões das valas foram alteradas, a fim de aumentar sua capacidade.

Na última avaliação da CETESB (2007a, p.15), o Índice de Qualidade de Aterro de Resíduos (IQR) foi 7,6. Portanto, atualmente o aterro opera em condições controladas.

A área é cercada, porém não há funcionários da prefeitura trabalhando no local. Dessa forma, a área está vulnerável a invasões. Contudo, em nenhuma das visitas realizadas foi constatado presença de catadores.

O projeto do aterro em valas foi aprovado pela CETESB e pelo Departamento Estadual de Proteção dos Recursos Naturais (DEPRN). Até junho de 2007 não havia previsão para ampliação do aterro.

Em visita ao aterro de Ribeirão Bonito no dia 17/06/2005, o local foi encontrado fechado com resíduos descobertos, o que atraiu alguns urubus. Segundo informações da prefeitura, o lixo é acumulado por uma semana no aterro para posterior recobrimento, já que o município gera pouca quantidade. Além disso, o engenheiro responsável pelo aterro informou que a máquina que cobre os resíduos com terra é usada pela prefeitura para realização de outros serviços, pois é a única. Porém, apesar da pouca quantidade de resíduos gerada diariamente, os resíduos deveriam ser cobertos com terra ao final do dia, a fim de evitar impactos ambientais negativos, já que se trata de um "aterro sanitário em valas".

Cobertura e compactação dos resíduos

Os resíduos são descarregados dentro da vala, cobertos com terra e não são compactados.

Coleta de gás e drenagem do lixiviado

O aterro não possui coletores de gases e drenagem do lixiviado, além disso o terreno não é impermeabilizado. Segundo a prefeitura, a CETESB não fez nenhuma exigência quanto à impermeabilização das valas e construção de drenos para coleta do lixiviado. Assim, não há estimativas da geração média deste líquido.

Monitoramento das águas subterrâneas

O aterro não possui poços para o monitoramento das águas subterrâneas, pois não foi encontrado aqüífero freático no local, conforme Anexo 3. 


\subsubsection{Resíduo Domiciliar Perigoso (RDP)}

Segundo a prefeitura, nenhum estabelecimento recebe lâmpadas fluorescentes, pilhas e baterias para encaminhá-las para tratamento. Estes materiais são descartados no aterro ou desviados pela coleta informal.

\subsubsection{Resíduos de Serviços de Saúde (RSS)}

\section{Coleta}

Os RSS gerados na área urbana de Ribeirão Bonito eram coletados e dispostos no aterro pela prefeitura até maio de 2007. A partir de junho do mesmo ano os RSS passaram a ser coletados por uma empresa especializada que efetua a coleta semanalmente. A coleta é realizada por duas pessoas, um motorista e um ajudante, com uso de um caminhão. Os RSS gerados pelos pequenos estabelecimentos de saúde são encaminhados ao hospital da cidade, onde são armazenados até o dia da coleta.

\section{Tratamento}

Cerca de 200kg/semana de RSS, gerados por Ribeirão Bonito, são encaminhados para tratamento por microondas em Campinas.

\section{Disposição final}

Os RSS, após tratados em Campinas, são dispostos no aterro da Estre em Paulínia.

\subsubsection{Resíduos da Construção Civil (RCC)}

Segundo informações da prefeitura, estima-se que sejam geradas cerca de 1,43t/d de RCC em Ribeirão Bonito. Estes resíduos são coletados e dispostos pela prefeitura em uma grande erosão localizada na periferia da cidade.

Ainda não existe nenhuma área licenciada para armazenamento temporário ou disposição final dos RCC. Segundo informações da prefeitura, ainda não há previsão de nenhum projeto para reciclagem dos RCC no município, bem como não está previsto encaminhá-los para reciclagem em outra cidade. 


\subsubsection{Pneus}

Os pneus são coletados e dispostos pela prefeitura em uma erosão da cidade junto aos resíduos de poda e capina, os RCC, os volumosos (móveis) e os resíduos de varrição.

\subsubsection{Orçamento}

Segundo a prefeitura, os custos com os serviços de limpeza pública do município estão apresentados na Tabela 24.

Tabela 24 - Custos dos serviços com os resíduos sólidos em Ribeirão Bonito

\begin{tabular}{l|r|r}
\hline \multicolumn{1}{c|}{ Tipo de Serviço } & \multicolumn{1}{c|}{ Custo (R\$/t) } & \multicolumn{1}{c}{ Custo (R\$/mês) } \\
\hline $\begin{array}{l}\text { Coleta regular dos RSU e } \\
\text { Operação do aterro }\end{array}$ & 92,17 & $27.653,71$ \\
\hline Coleta de RSS & - & $2.650,00$ \\
\hline
\end{tabular}

Fonte: Prefeitura Municipal de Ribeirão Bonito, junho de 2007

Segundo a prefeitura, até junho de 2007 não estava prevista a implantação de nenhuma taxa específica para os serviços relacionados aos resíduos sólidos como implantação de coleta seletiva, construção de uma central de triagem de recicláveis, tratamento de RSS, entre outros.

\subsubsection{São Carlos}

O município de São Carlos possui cerca de 212.956 habitantes (IBGE, 2007) e gera em torno de 150 toneladas por dia de RSD.

\subsubsection{Resíduos Sólidos Domiciliares (RSD)}

\section{Coleta regular}

Os RSD são coletados pela empresa Vega Engenharia Ambiental S/A desde 1980 e transportados ao aterro. Do total de 150t/d de RSD, cerca de 20t/d são referentes aos resíduos sólidos gerados na área rural, os quais também são coletados.

A coleta regular atende $100 \%$ dos bairros do município. A cidade foi dividida em sete setores e são utilizados oito caminhões compactadores. 


\section{Coleta seletiva de materiais recicláveis}

A coleta seletiva foi implantada em junho de 2002 e atendia 12 bairros inicialmente. Atualmente atende 61 bairros, correspondendo a $70 \%$ do município, o que equivale a 40 mil pontos de coleta.

Participam do programa 50 trabalhadores das cooperativas ECOATIVA, COOPERVIDA e COOLETIVA. Cada uma possui um caminhão e uma Central de Triagem com balança, prensa, entre outros equipamentos. Dois veículos foram doados à Prefeitura Municipal de São Carlos (PMSC), um pela Associação de Proteção Ambiental de São Carlos (APASC) que o recebeu da Fundação Banco do Brasil, e outro pela empresa São Carlos S/A Indústria de Papel e Embalagens. O terceiro caminhão é alugado por $\mathrm{R} \$ 3.600,00 /$ mês.

A coleta seletiva é realizada porta-porta, uma vez por semana, e sua distribuição está apresentada no Quadro 12.

Quadro 12 - Distribuição da coleta seletiva em São Carlos

\begin{tabular}{|c|c|c|}
\hline Dia da semana & Cooperativa & Bairros \\
\hline segunda-feira & \multirow{4}{*}{ ECOATIVA } & $\begin{array}{l}\text { Centro, Jardim Brasil, Jardim Cardinali, Vila } \\
\text { Rancho Velho. }\end{array}$ \\
\hline terça-feira & & $\begin{array}{l}\text { Vila Santo Antônio, Vila Faria, Vila Max, Vila } \\
\text { Nery; Chácara do Parque, Rua Américo Alves } \\
\text { Margarido. }\end{array}$ \\
\hline quarta-feira & & $\begin{array}{l}\text { Vila Deriggi, Vila Arnaldo, Vila Albertini, Chácara } \\
\text { Parolo. }\end{array}$ \\
\hline quinta-feira & & $\begin{array}{l}\text { Vila Laura, Chácara Bataglia, Chácara Paraíso, } \\
\text { Jardim Macarengo, Vila Costa do Sol, Tijuco } \\
\text { Preto, Parque Sabará. }\end{array}$ \\
\hline segunda-feira & \multirow{4}{*}{ COOPERVIDA } & $\begin{array}{l}\text { Centro, Jardim São Carlos, Jardim Bethânia, } \\
\text { Parque Santa Mônica, Jardim Paraíso. }\end{array}$ \\
\hline terça-feira & & $\begin{array}{l}\text { Jardim Lutfalla, Solar dos Engenheiros, Parque } \\
\text { Arnold Schimdt, Chácara Casalle, Cidade } \\
\text { Jardim. }\end{array}$ \\
\hline quarta-feira & & $\begin{array}{l}\text { Jardim Paulistano, Parque Delta, Vila P. } \\
\text { Industrial, Jardim Hikare, Jardim Nova Santa } \\
\text { Paula, Jardim Santa Paula, Jardim Centenário, } \\
\text { Jardim Bandeirantes. }\end{array}$ \\
\hline quinta-feira & & $\begin{array}{l}\text { Parque Santa Marta, Jardim Acapulco, Planalto } \\
\text { Paraíso, Jardim Alvorada. }\end{array}$ \\
\hline segunda-feira & \multirow{5}{*}{ COOLETIVA } & Jardim Cruzeiro do Sul, Jardim Pacaembu. \\
\hline terça-feira & & Vila Prado, Bela Vista. \\
\hline quarta-feira & & $\begin{array}{l}\text { Boa Vista, Jardim Beatriz, Jardim Medeiros, Boa } \\
\text { Vista II. }\end{array}$ \\
\hline quinta-feira & & $\begin{array}{l}\text { Vila Monteiro, Centreville, Jardim Ricetti, Vila } \\
\text { Marcelino, Vila Lutfalla, Lagoa Serena, Parque } \\
\text { Faber. }\end{array}$ \\
\hline sexta-feira & & $\begin{array}{l}\text { Jardim Botafogo, Jardim das Torres, Vila } \\
\text { Carmem. }\end{array}$ \\
\hline
\end{tabular}

Fonte: Secretaria Municipal de Desenvolvimento Sustentável, Ciência e Tecnologia de São Carlos (SMDSCT) 
São coletadas cerca de 100t/mês de recicláveis e 80t/mês são comercializadas. Segundo informações da Secretaria Municipal de Desenvolvimento Sustentável, Ciência e Tecnologia de São Carlos (SMDSCT) em 30/06/2005, estima-se que cerca de 300t/mês de recicláveis sejam coletados pelos catadores informais e cerca de $1.000 \mathrm{t} / \mathrm{mês}$ sejam coletados de estabelecimentos comerciais e industriais pelos sucateiros.

Segundo a SMDSCT, para a ampliação do serviço faz-se necessário implantar ecopontos ou PEVs, o que já está em processo, expandir porta-a-porta e melhorar as rotas para a coleta seletiva (parte logística). Há um projeto em andamento voltado para os catadores autônomos, que visa reuní-los num barracão e talvez formar uma associação. Vale ressaltar que muitos catadores informais optaram por não aderir ao programa implantado pela prefeitura por não aceitarem dividir os lucros entre os cooperados e preferirem trabalhar como autônomos, livres de regulamentos que estabelecem horários, formas de trabalho e setores de coleta, entre outras questões.

$\mathrm{Na}$ prática os coletores informais se antecipam e passam nos bairros onde será realizada a coleta seletiva para coletar os recicláveis deixados pelos moradores nas lixeiras ou nas calçadas das residências. Os informais são beneficiados naqueles bairros que não são atendidos pelo programa da prefeitura.

De acordo com a SMDSCT, entre algumas das dificuldades do programa de coleta seletiva estão (1) a falta de motivação dos catadores, os quais encaram a triagem dos resíduos como um trabalho temporário, mesmo alguns que já estão nesta atividade há anos, e (2) a falta de manutenção dos caminhões.

\section{Tratamento}

Triagem dos materiais recicláveis

São Carlos possui três Centrais de Triagem (Tabela 25), implantadas entre 2002 e 2003, onde os materiais recicláveis são separados.

Tabela 25 - Centrais de Triagem de recicláveis de São Carlos

\begin{tabular}{l|l}
\hline \multicolumn{1}{c|}{ Cooperativa } & \multicolumn{1}{c}{ Localização } \\
\hline ECOATIVA & R. Peru, 375, Vila São José \\
\hline COOPERVIDA & R. El Salvador, 65, Nova Estância \\
\hline COOLETIVA & R. Juscelino Kubitscheck, s/n, Chácara das Flores \\
\hline
\end{tabular}

Os materiais vendidos pelas cooperativas entre janeiro e julho de 2007 estão apresentados na Figura 103. Ressalta-se que a grande parcela do alumínio é desviada pela coleta informal. 


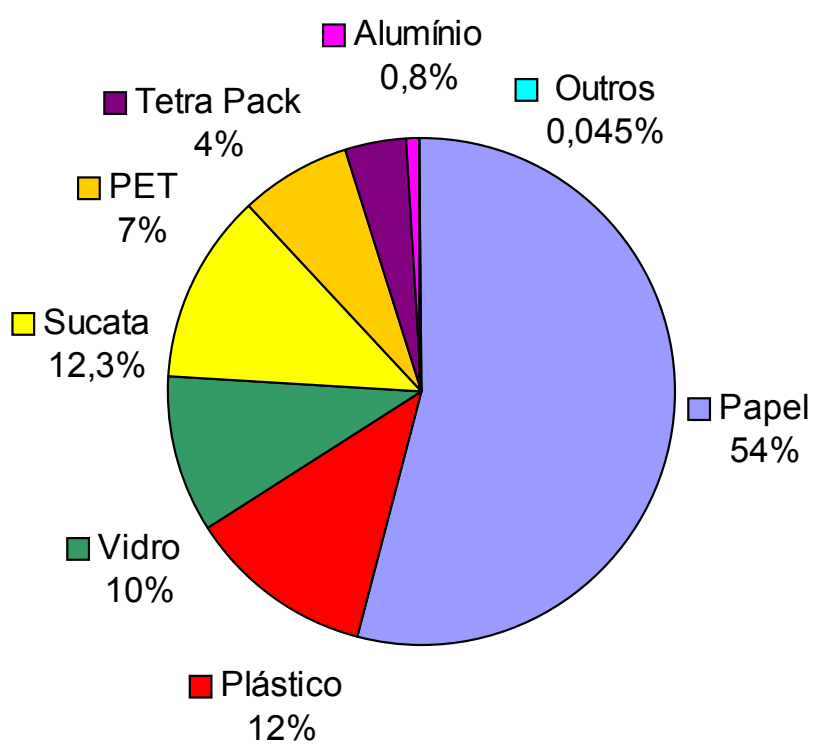

Figura 103 - Materiais vendidos pelas cooperativas de São Carlos em 2007 Fonte: SMDSCT, 2007

Segundo Matos (2006), 10,47\% em massa dos RSD que chegam ao aterro sanitário são poliméricos, bem como $20,60 \%$ dos resíduos encaminhados à coleta seletiva, com destaque para o Politereftalato de Etila (PET). Em termos percentuais volumétricos, 27,20\% destes resíduos são provenientes da coleta regular e 56,56\% da coleta seletiva. Atualmente o pesquisador desenvolve a pesquisa de Doutorado intitulada "Avaliação da viabilidade de aplicação de resíduos poliméricos pós-consumo, tipo PET, na construção civil”.

Comparando-se os dados obtidos por Matos (2006) com os dados obtidos por Gomes (1989) e Frésca (2006), constata-se que em São Carlos o consumo de materiais poliméricos aumentou, conforme Tabela 26.

Tabela 26 - Composição gravimétrica dos RSU destinados às áreas de disposição final de São Carlos

\begin{tabular}{l|c|c}
\hline \multirow{2}{*}{ Tipos de resíduos } & \multicolumn{2}{|c}{ Média Final (\%) } \\
\cline { 2 - 3 } & Gomes (1989) & Frésca (2006) \\
\hline Matéria Orgânica & 56,7 & 58,78 \\
\hline Papel e Papelão & 21,3 & 6,44 \\
\hline Embalagem Longa Vida & - & 0,94 \\
\hline Vidro & 1,4 & 1,61 \\
\hline Plástico Mole & 8,5 & 6,17 \\
\hline Plástico Duro & 5,4 & 2,84 \\
\hline Alumínio e Metal & 7,0 & 1,57 \\
\hline Outros & & 21,64 \\
\hline
\end{tabular}


A Tabela 26 retrata a composição média dos resíduos sólidos urbanos destinados às áreas de disposição final de São Carlos, de acordo com estudos desenvolvidos pela Escola de Engenharia de São Carlos (USP) em 1989 e 2005. A primeira caracterização foi realizada com base nos resíduos destinados ao antigo lixão do município e a segunda caracterização com base nos resíduos destinados ao aterro atual. A categoria "outros" pode incluir trapos, couro, borracha, madeira, cigarro, isopor, entre outros materiais.

Ressalta-se que em São Carlos a Coleta Seletiva foi implantada em 2002, por isso a redução da quantidade de papel e papelão destinada ao aterro em 2005. Também foi constatada redução de alumínio e componentes metálicos, devido principalmente à coleta informal. Por meio da Tabela 26 nota-se que materiais potencialmente recicláveis ainda são encaminhados ao aterro, mesmo após a implantação do programa de coleta seletiva no município, o que pode refletir a falta de conscientização da população quanto à importância da separação.

\section{Compostagem}

Segundo Frésca (2006), 58,78\% dos RSD que chegam ao aterro são compostos por matéria orgânica. Porém, em São Carlos ainda não há um programa de coleta de resíduos orgânicos voltado para todo o município.

Em julho de 2006 a PMSC iniciou um projeto piloto de coleta de resíduos orgânicos provenientes de restaurantes e lanchonetes de médio e grande porte, os quais são encaminhados para o processo de compostagem na Horta Municipal, próxima ao Horto Florestal Municipal Navarro de Andrade. Vale destacar que a Horta Municipal já há algum tempo recebia resíduos de poda e capina limpos para fabricação de composto.

O programa chamado "Gerenciamento de Resíduos Compostáveis" conta com a adesão de aproximadamente 50 estabelecimentos, dentre restaurantes, lanchonetes, supermercados, universidades, escolas estaduais e hospitais, os quais somados geram cerca de 800 a $900 \mathrm{~kg} / \mathrm{d}$ de resíduos orgânicos.

Os resíduos são coletados diariamente (exceto aos domingos), encaminhados para a Horta Municipal e depositados em leiras a céu aberto, as quais são cobertas por palha. $O$ composto é utilizado na própria Horta Municipal, reduzindo os custos com adubos e suplementos.

Segundo a PMSC, em sete meses de operação (de julho de 2006 a fevereiro de 2007), o programa desviou do aterro sanitário cerca de 127 toneladas de resíduos orgânicos, o que representou $0,4 \%$ do total gerado no município para o mesmo período. $O$ caminhão usado na coleta dos resíduos é terceirizado e o custo total do serviço é de $\mathrm{R} \$ 84,00 / t$, inferior ao da coleta regular e disposição final no aterro que é de $\mathrm{R} \$ 104,33 / \mathrm{t}$. 
Além do programa da prefeitura, está sendo desenvolvido desde 2004 pela USP, uma parceria entre o Centro de Divulgação Científica e Cultural (CDCC) e o Departamento de Hidráulica e Saneamento (SHS/EESC/USP) com apoio da prefeitura, o "Projeto ABC da Compostagem". Trata-se de um projeto piloto de coleta seletiva de materiais compostáveis em um bairro do município. Faz parte do projeto a pesquisa de Doutorado desenvolvida desde 2006 por Luciana Miyoko Massukado, que tem como título "Estratégias de gestão e gerenciamento integrado de resíduos sólidos domiciliares: desenvolvimento de software e unidades descentralizadas de compostagem".

Segundo Massukado (2007), os resíduos são coletados em dias coincidentes aos da coleta regular e encaminhados para um Pátio de Compostagem construído na Escola Estadual Prof. Bento da Silva César, localizada no bairro Jardim São Carlos V. O Pátio passou a funcionar em maio de 2005 e já desviou do aterro cerca de 20 toneladas de material compostável e produziu cinco toneladas de composto. O composto não é vendido, parte é doada à comunidade do bairro, especialmente aos participantes do projeto, e parte é empregada como adubo na escola (na horta e em árvores).

Segundo a SMDSCT, a creche da Igreja Santa Izabel, localizada na Vila Izabel, recebia doações de restaurantes, supermercados e lanchonetes de produtos com prazo de validade a vencer. Alguns estabelecimentos doam para criadores de animais.

\section{Disposição final}

\subsubsection{Antigo lixão}

Segundo informações da SMDSCT, entre os anos de 1976 e 1996 os resíduos sólidos gerados em São Carlos eram dispostos em um antigo lixão. Até 1980, a coleta, o transporte e a disposição final destes resíduos eram realizados pela prefeitura. A partir de 1980 até os dias atuais, o gerenciamento dos RSD de São Carlos passou para ser realizado pela empresa Vega Sopave (atualmente Vega Engenharia Ambiental).

Com base em Gonçalves (1986, p.94), o local passou a ser coberto com terra a partir de 1980 . A coleta era realizada em $100 \%$ da área urbana e a quantidade média de lixo coletada era de cerca de 2.000t/mês. Porém, conforme Contin Neto et al (1995, p.153), a cobertura dos resíduos deve ter sido adotada devido às exigências legais. A partir de então, o antigo lixão passou a ser considerado pela administração pública como um aterro controlado.

A área recebeu resíduos de diversas origens (domiciliar, industrial e de serviços de saúde). Atualmente não é avaliada pela CETESB, pois não recebe resíduos sólidos há dez anos aproximadamente. 
O antigo lixão de São Carlos está localizado a sudeste da área urbana, no Sítio Santa Madalena, nas coordenadas $2^{\circ} 05^{\prime} \mathrm{S}$ e $47^{\circ} 48^{\prime} \mathrm{W}$, próximo ao km 221 da Rodovia Washington Luis SP 310. A área está localizada sobre a Formação Botucatu do Grupo São Bento, com base em IPT (1981) e Aguiar (1989, Anexo V).

Segundo Gonçalves (1986, p.123) e com base no mapeamento geotécnico realizado por Aguiar (1989) citado no Plano Diretor de São Carlos (2004, p.5), o antigo lixão de São Carlos está localizado em área de recarga do Aqüífero Guarani.

Os resíduos foram dispostos numa grande erosão. Durante visitas realizadas no local, foram constatados indícios do antigo lixão, conforme Figura 104.

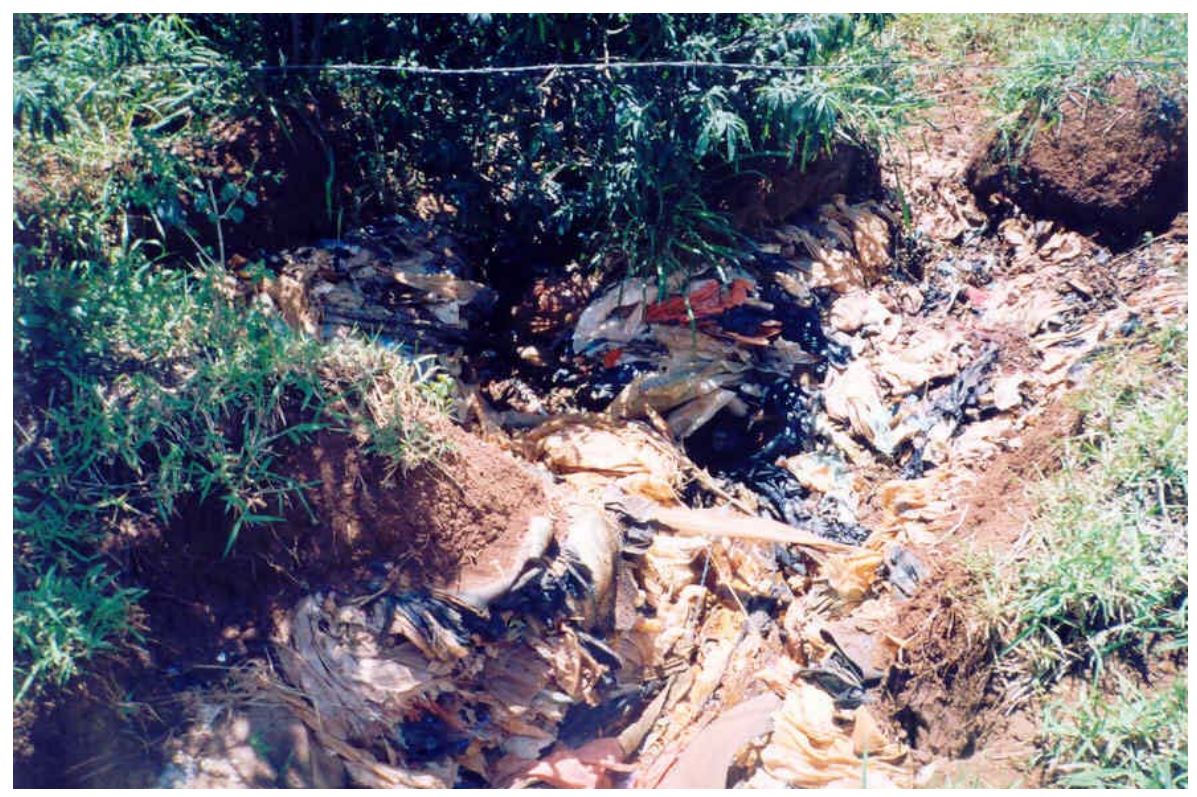

Figura 104 - Resíduos dispostos no antigo lixão de São Carlos, 10/02/2005

Segundo Menezes (1995, p.65), o coeficiente de permeabilidade do solo do local situa-se entre $10^{-4}$ e $10^{-6} \mathrm{~cm} / \mathrm{s}$, indicando permeabilidade moderada a alta, o que corresponde a atributo intermediário a desfavorável. Conforme a autora, a área é constituída de arenitos permeáveis e materiais predominantemente arenosos.

Atualmente a área serve de pasto para animais (Figura 105 e Figura 106). Segundo a SMDSCT, já foram realizados diversos serviços e obras para recuperação e conservação física da área, a fim de conter a erosão. Várias pesquisas foram desenvolvidas no local: Gonçalves (1986), Ellert et al (1990), Schalch (1992), Bossolan (1993), Rios (1993), Teixeira (1993), Menezes (1995), Contin Neto et al (1995), Freitas (1996), Gadotti (1997), Polaz (2004), entre outras. 


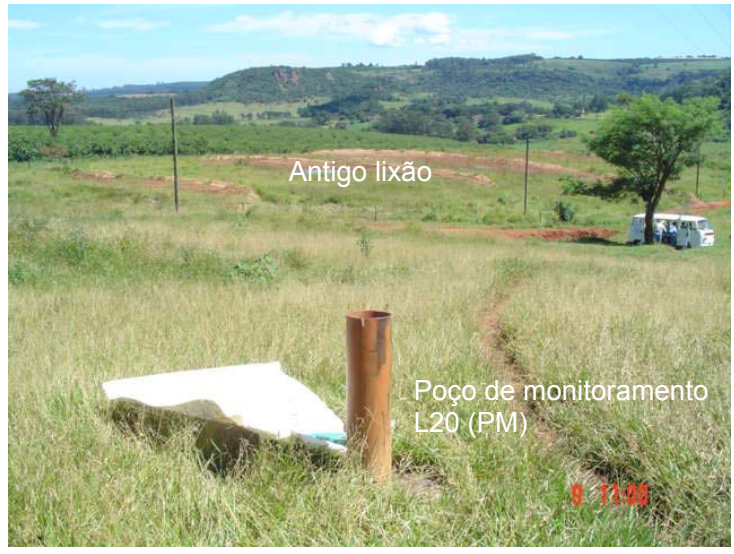

Figura 105 - Vista da área onde o antigo lixão de São Carlos era operado, 09/03/2004

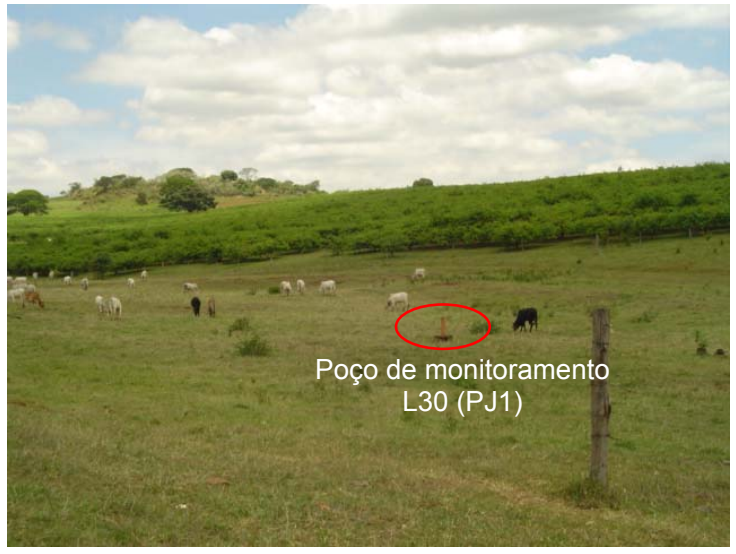

Figura 106 - Pastagem de animais na área do antigo lixão de São Carlos, 01/07/2004

A área possui cerca de $48.400 \mathrm{~m}^{2}$ e no local foram construídos cerca de 33 poços para o monitoramento das águas subterrâneas. Porém, com base em Gadotti (1997, p.50), vários poços foram encobertos pelos resíduos. Conforme Polaz (2004, p.54), as amostras do poço L5 apresentaram alterações na população de bactérias e valores de $\mathrm{pH}$, por isso não deve ser adotado como controle. Assim, a presente pesquisa adotou o poço L20 como referência. A Figura 107 mostra a localização dos poços monitorados.

Segundo Gonçalves (1986, p.90), o lixiviado gerado no antigo lixão caía em um afluente do córrego São José (situado ao norte do aterro, Figura 108 e Figura 109), que deságua no córrego São João que, por sua vez, é afluente do ribeirão da Laranja Azeda. Este último é um dos afluentes do ribeirão do Feijão, que abastece o município. Conforme o autor (p.94), o antigo lixão dista cerca de $15 \mathrm{~km}$ do ribeirão do Feijão, classificado como Classe 2 (Decreto Estadual 10.755/1977), e localizado na Área de Proteção Ambiental (APA Corumbataí-Botucatu-Tejupá), conforme Decreto Estadual $n^{\circ} 20.960$, de 08 de junho de 1983. 


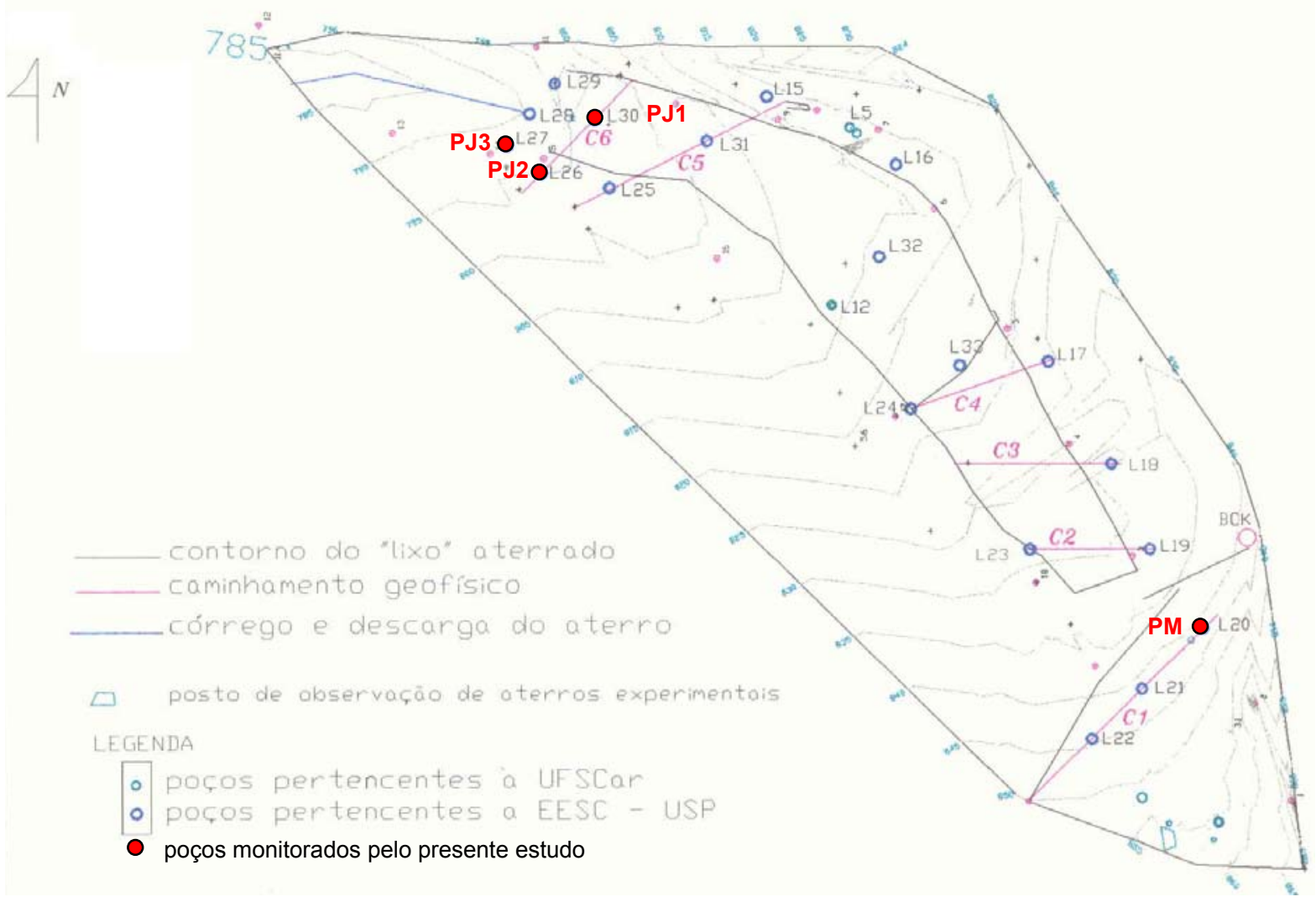

Figura 107 - Levantamento planialtimétrico da região do lixão de São Carlos - SP

Fonte: Gadotti (1997), adaptado

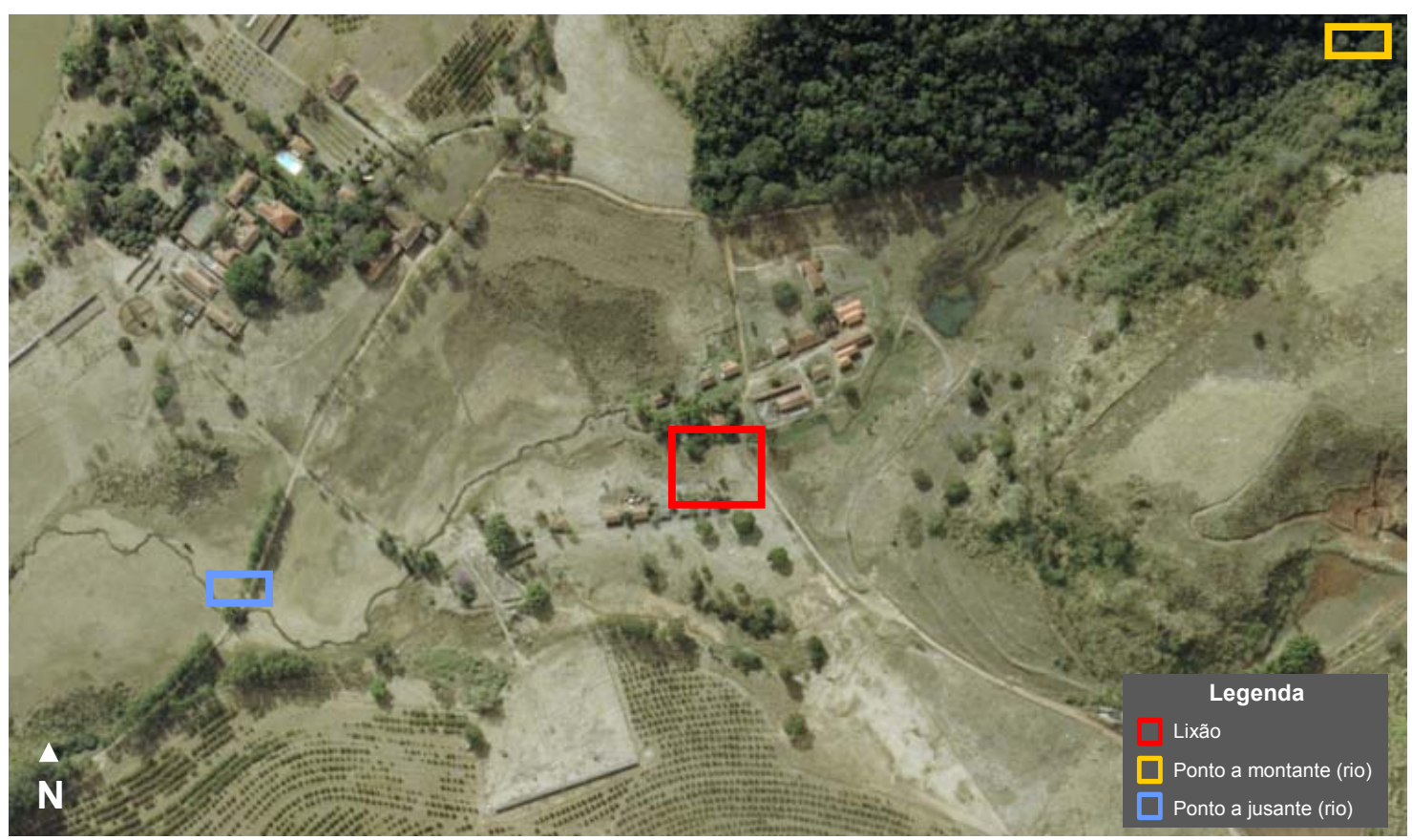

Figura 108 - Localização do antigo lixão de São Carlos

Fonte: Base Aerofotogrametria e Projetos S.A. São Paulo, 18/07/2000

Escala 1:30.000 


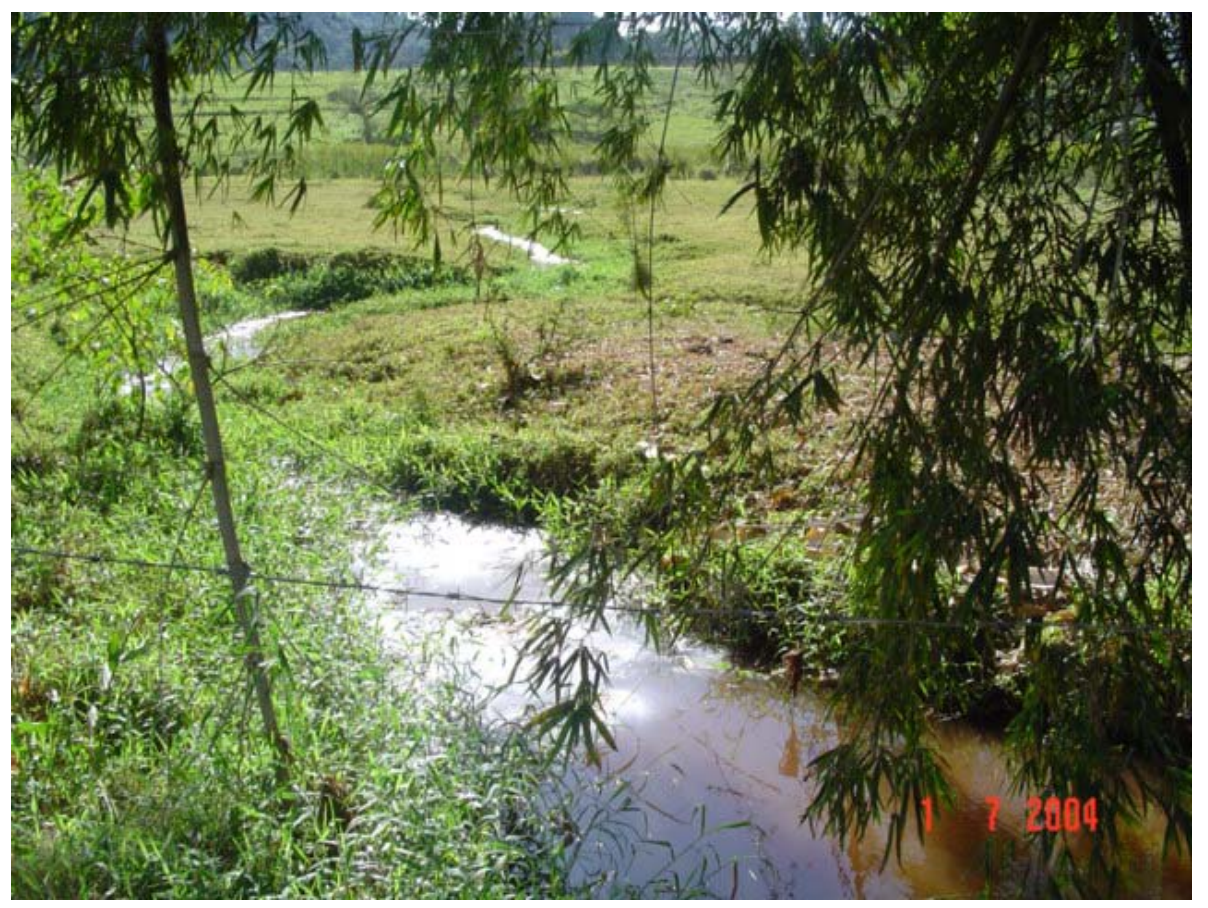

Figura 109 - Córrego São José em São Carlos

Os pontos de coleta das águas superficiais estão identificados na Figura 108. Vale destacar que no entorno do córrego São José há pastagem de animais e ocupação por chácaras.

A bacia do ribeirão do Feijão está localizada sobre solos da Formação Botucatu, assim o córrego São José e o antigo lixão estão localizados sobre os mesmos, os quais aparecem como leito destes riachos por 9Km aproximadamente.

Com base em Gonçalves (1986, p.124-125), o antigo lixão não oferece risco de contaminação aos poços construídos ou aos futuros poços da área urbana de São Carlos, uma vez que o fluxo predominante do aqüífero freático livre é de leste para oeste e as camadas da bacia mergulham para oeste. Porém, com relação às águas superficiais, o local pode ser considerado como fonte de carga poluente.

Segundo a SMDSCT, está sendo desenvolvida uma investigação detalhada pela Fundação de Apoio à Física e à Química da EESC/USP (FAFQ), a fim de confirmar ou não o cadastramento do antigo lixão como área contaminada. Porém, com base no último cadastro de áreas contaminadas divulgado pela CETESB (2007b), referente ao ano de 2006, o local não foi incluído.

\subsubsection{Aterro sanitário}

A partir de 1996, os RSU gerados em São Carlos passaram a ser encaminhados para o aterro sanitário localizado a noroeste do centro urbano na Fazenda Guaporé, nas 
coordenadas $21^{\circ} 57^{\prime} \mathrm{S}$ e $47^{\circ} 55^{\prime} \mathrm{W}$, próximo ao km 230 da rodovia Washington Luis SP 310 e a um dos afluentes do córrego do Galdino (situado a oeste do aterro), conforme Figura 110. Os pontos de coleta das águas superficiais também estão identificados nesta figura.

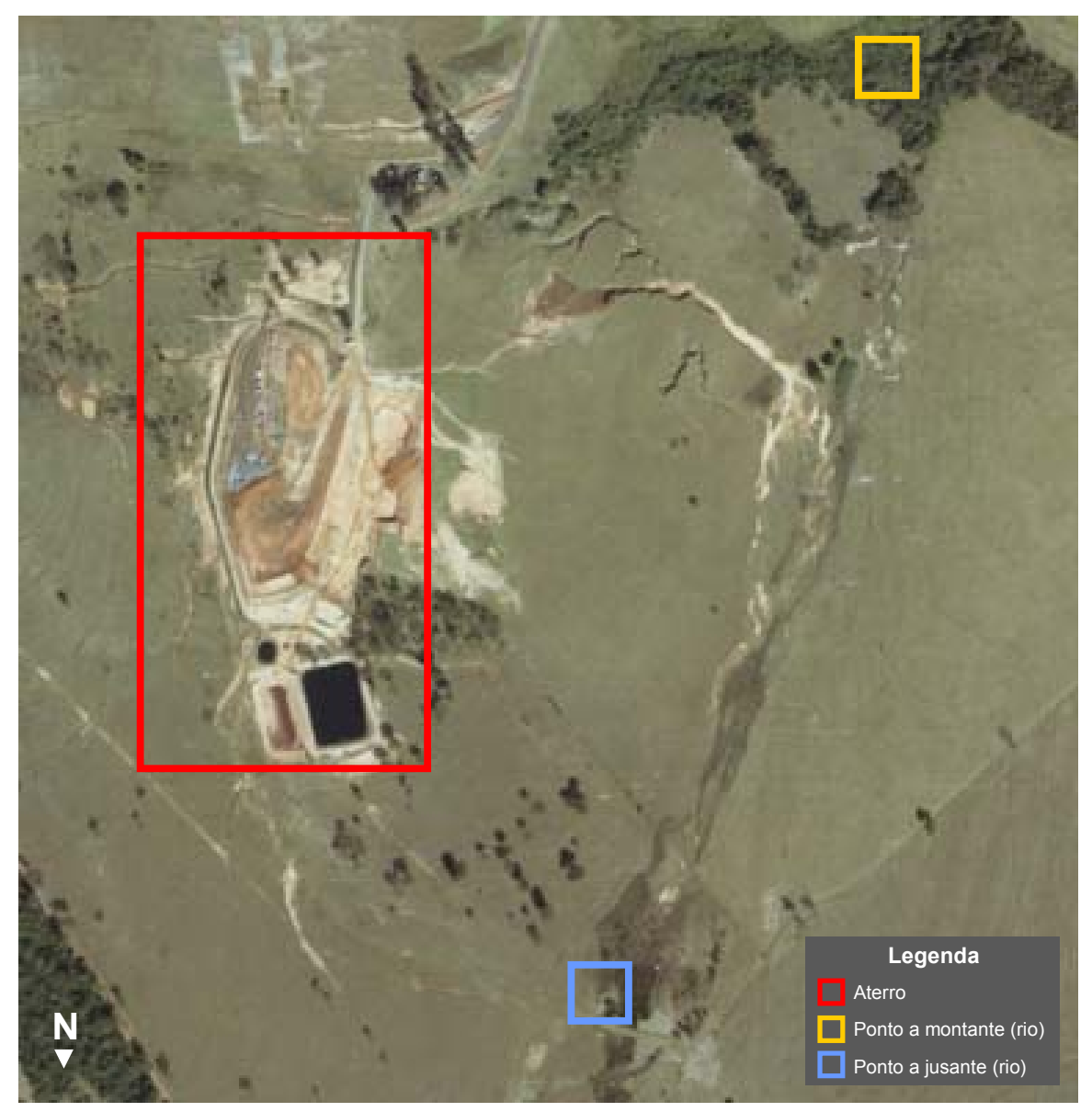

Figura 110 - Aterro de São Carlos

Fonte: Base Aerofotogrametria e Projetos S.A. São Paulo, 18/07/2000 Escala 1:30.000

A área está localizada sobre a Formação Botucatu do Grupo São Bento, com base em IPT (1981) e Aguiar (1989, Anexo V). Segundo informações da SMDSCT, há fortes indícios de que o aterro de São Carlos esteja localizado em área de afloramento do Sistema Aqüífero Guarani.

O coeficiente de permeabilidade do solo natural na área do aterro sanitário de São Carlos situa-se entre $10^{-3}$ e $10^{-5} \mathrm{~cm} / \mathrm{s}$, predominantemente arenoso, e foi classificado como Latossolo Vermelho-Amarelo álico (Prefeitura Municipal de São Carlos, 1989).

A prefeitura locava a área por cerca de $\mathrm{R} \$ 5.000,00 /$ mês, a qual pertencia a proprietários rurais. Atualmente pertence à prefeitura, que adquiriu a área por $\mathrm{R} \$ 200.000,00$.

O aterro sanitário de São Carlos é operado pela empresa Vega Engenharia Ambiental desde 1996 e possui cerca de $100.000 \mathrm{~m}^{2}$ de área, aproximadamente. Recebe 
cerca de 150t/d de RSD, dentre os quais cerca de 20t/d são provenientes de estabelecimentos comerciais e $5 \mathrm{t} / \mathrm{d}$ de serviços de varrição.

Entre 2001 e 2007 o aterro cresceu verticalmente (Figura 111) e lateralmente, devido às ampliações. Portanto, o local de disposição dos resíduos se alternou entre o topo e a lateral oeste do aterro. Nota-se que, com a plantação de gramíneas, o aterro está se integrando à paisagem, conforme Figura 112.

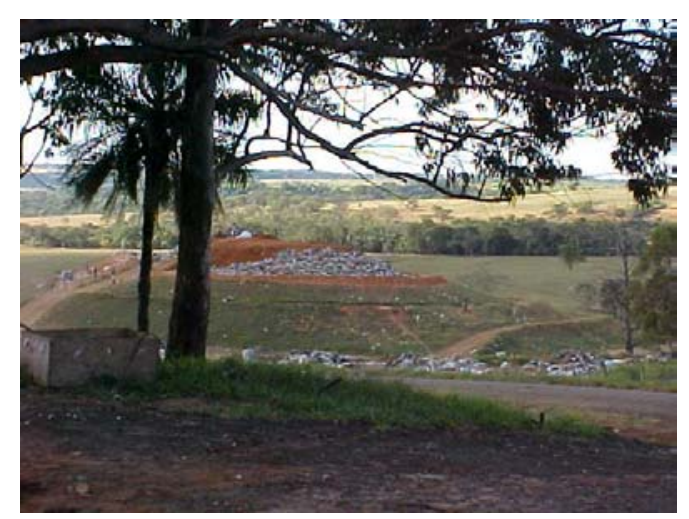

Figura 111 - Aterro de São Carlos (face sul), Figura 112 - Aterro de São Carlos (face sul), julho de 2002

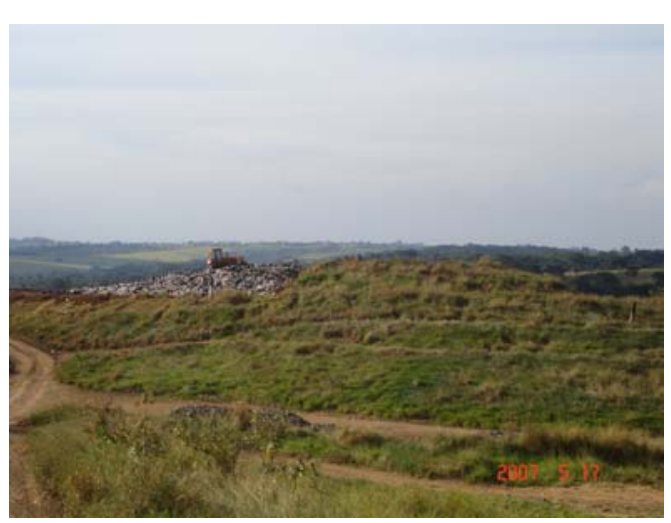

maio de 2007

Durante visitas realizadas no aterro constatou-se que os rejeitos do aterro ou da usina de RCC estão sendo encaminhados ao aterro sanitário, por estarem misturados a outros resíduos, geralmente a RSD.

Conforme CETESB (2007a, p.15), o Índice de Qualidade de Aterro de Resíduos (IQR) foi 9,0 em 2006, considerado em condições adequadas. O aterro é identificado na entrada e possui guarita e balança para controle de pessoas, bem como da quantidade e tipo de resíduos encaminhados ao local.

Vale destacar que até 2002 havia catadores no local. Porém, com a implantação da coleta seletiva no município, alguns aderiram ao programa e passaram a trabalhar nas Centrais de Triagem em condições mais salubres.

Cobertura e compactação dos resíduos

Os resíduos são dispostos, compactados e cobertos com terra. A cobertura ocorre regularmente a cada três dias.

Impermeabilização de base e taludes

Até 2005 o aterro de São Carlos havia recebido apenas uma camada de argila em sua base e taludes. Porém, em 2005 iniciou-se a ampliação do aterro mediante assinatura 
de um Termo de Ajustamento de Conduta (TAC) junto a CETESB e ao Ministério Público. Em abril uma nova célula passou a ser preparada e foi impermeabilizada com manta de Polietileno de Alta Densidade (PEAD) de 2,0mm de espessura para recebimento dos resíduos, conforme Figura 113 e Figura 114. O custo da construção desta nova célula foi de cerca de $\mathrm{R} \$ 500.000,00$.

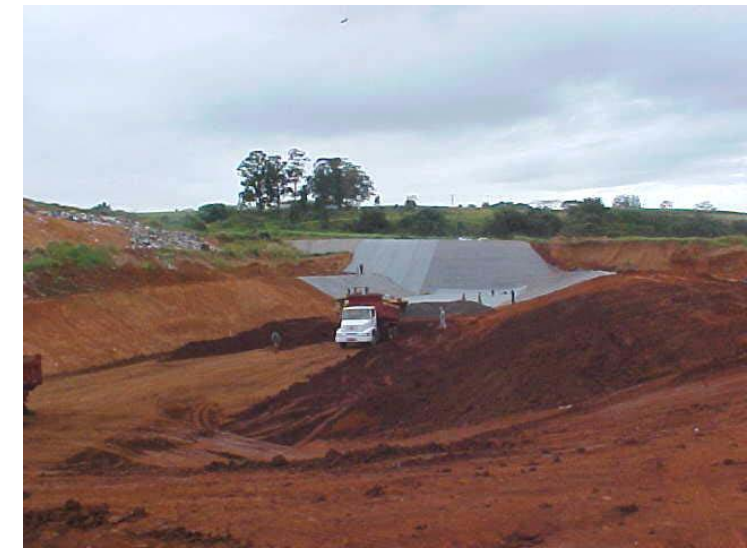

Figura 113 - Construção de nova célula no aterro de São Carlos, 28/04/2005

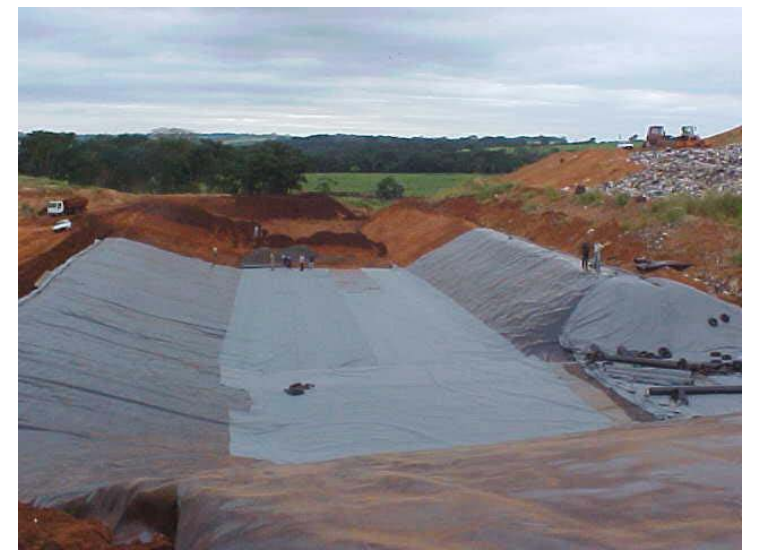

Figura 114 - Impermeabilização de nova célula no aterro São Carlos, 28/04/2005

Em agosto de 2005 os resíduos já estavam sendo dispostos na nova célula.

Coleta de gases

O aterro possui coletores de gás com queimador na extremidade (Figura 115 e Figura 116), o que evita a liberação do gás metano para a atmosfera.

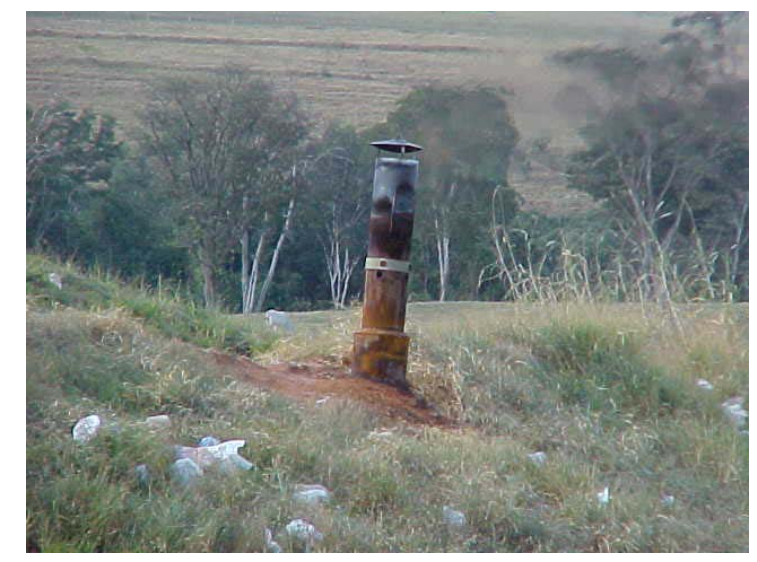

Figura 115 - Coletor de gás no aterro de São Carlos, julho de 2002

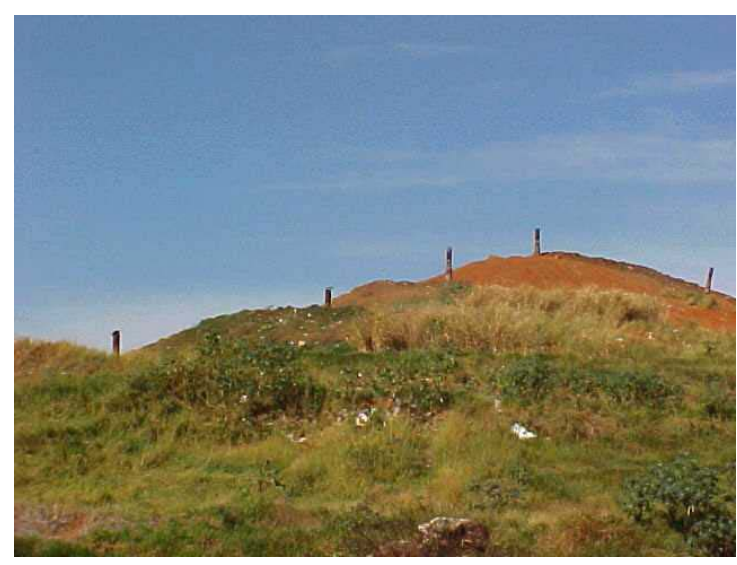

Figura 116 - Coletores de gás no aterro de São Carlos, junho de 2003

Desde 2006, na EESC/USP, está sendo desenvolvida por José Berto Neto uma pesquisa de Doutorado intitulada "Estudo preliminar para medição estimativa das emissões 
de gases de aterros sanitários extra-sistema de coleta vertical", na qual os gases gerados pelos aterros dos municípios de Araraquara, Brotas, Campinas, Jaú, Ribeirão Bonito, Ribeirão Preto, São Carlos e São Paulo estão sendo monitorados. O objetivo do estudo é estimar a emissão de gases estufa, $\mathrm{CO}_{2}$ e $\mathrm{CH}_{4}$, de aterros sanitários.

Drenagem das águas pluviais e do lixiviado

No aterro de São Carlos não foram construídas calhas para drenar a água de chuva, o sistema foi adaptado com lona plástica, brita e pneus nas laterais e no topo do aterro, a fim de facilitar o trânsito dos caminhões em épocas chuvosas. Essa calha com brita também ajuda na drenagem do lixiviado formado.

Até 2006 o aterro de São Carlos possuía três lagoas para armazenamento do lixiviado. Eventualmente estes líquidos são aspergidos no aterro, promovendo a recirculação. Em épocas de chuva o lixiviado foi encaminhado para a ETE de Araraquara para evitar transbordamento das lagoas.

Atualmente existem quatro lagoas de lixiviado, conforme Figura 117. 


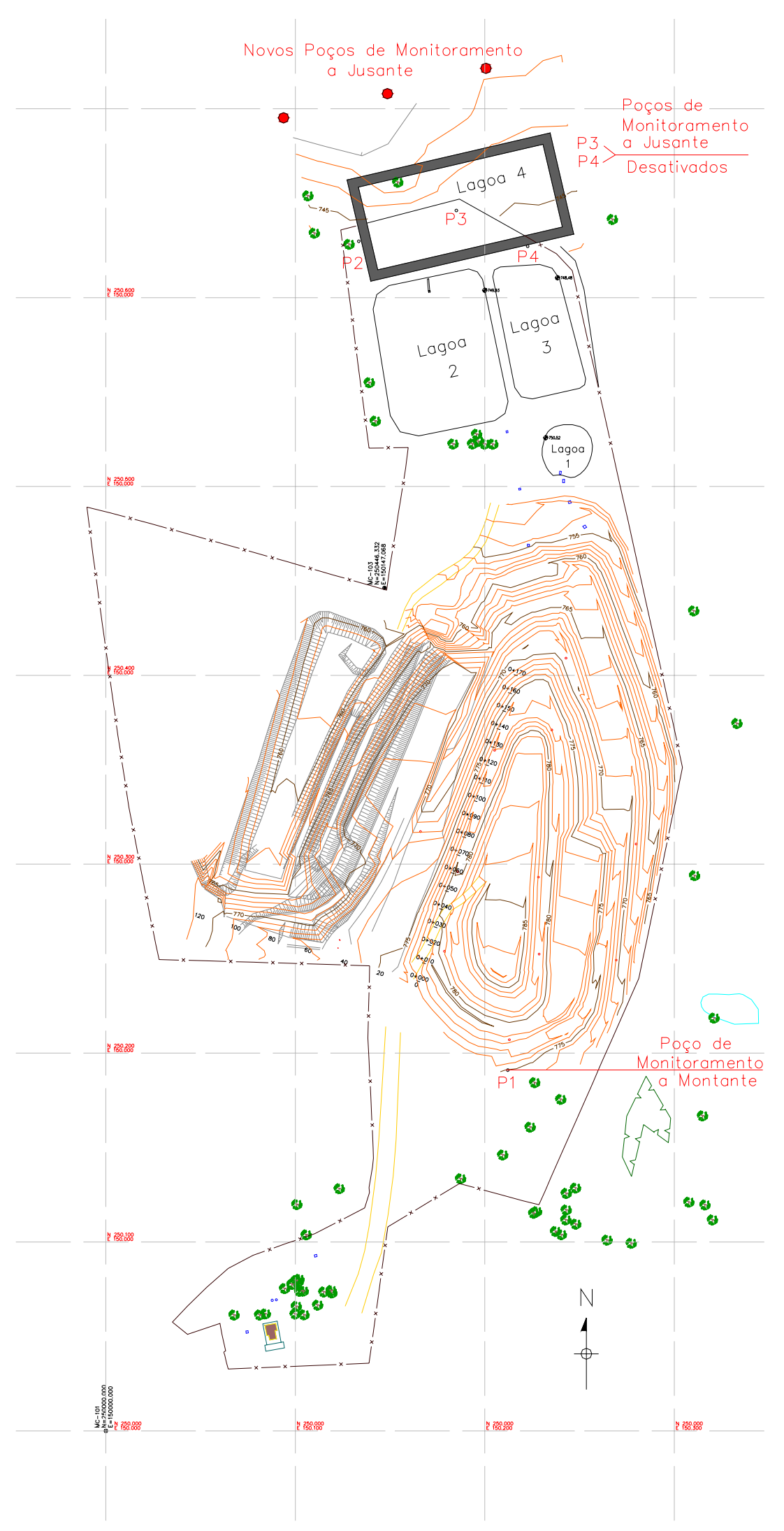

Figura 117 - Localização das lagoas e poços de monitoramento no aterro de São Carlos Fonte: Secretaria Municipal de Desenvolvimento Sustentável Ciência e Tecnologia (2005), adaptado 
Entre os meses de abril e maio de 2006 foi construída a quarta lagoa para armazenamento de lixiviado, por $\mathrm{R} \$ 200.000,00$, com as dimensões $100 \times 45 \mathrm{~m}$, profundidade de 4,5m e membrana de Polietileno de Alta Densidade (PEAD) de 1,0mm de espessura (Figura 118).

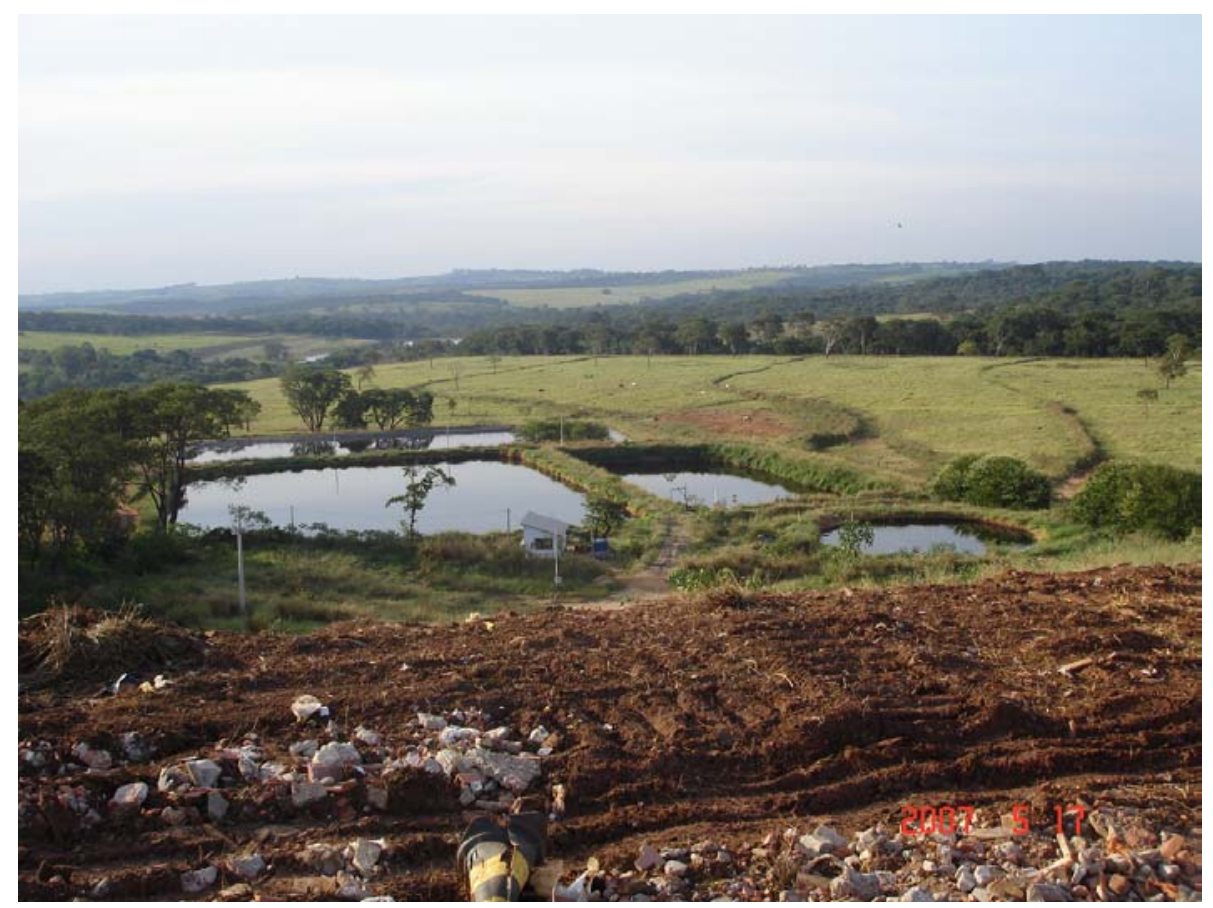

Figura 118 - Lagoas de lixiviado no aterro de São Carlos, 17/05/2007

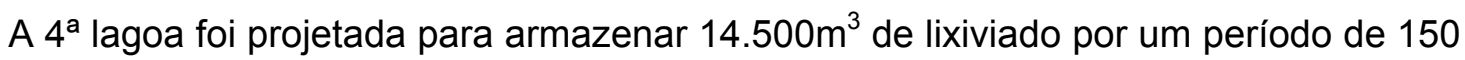
dias, aproximadamente, considerando que o volume teórico total produzido de lixiviado seja de $95 \mathrm{~m}^{3} / \mathrm{d}$. O volume de armazenamento das outras lagoas não foi considerado (Prefeitura Municipal de São Carlos, 2005). Porém, devido às fortes chuvas no início de 2007, a $4^{\text {a }}$ lagoa foi esvaziada e o lixiviado enviado a ETE de Santa Eudóxia.

Considerando a geração de lixiviado um dos maiores problemas dos aterros sanitários, Contrera (2003) concluiu que o tratamento deste líquido pode ser viável, pois conseguiu remoção de DQO da ordem de $80 \%$. Assim, o pesquisador deu continuidade ao estudo em seu Doutorado intitulado "Tratamento de lixiviados de aterros sanitários em sistema de reatores anaeróbio e aeróbio operados em batelada seqüencial”, desenvolvido na EESC/USP e financiado pela FAPESP, durante o qual estão sendo operados dois reatores no aterro de São Carlos com a finalidade de tratar o lixiviado. 
Monitoramento das águas subterrâneas

O aterro possuía quatro poços de monitoramento de quatro polegadas (Figura $117 \mathrm{e}$ Figura 119), construídos pela Higesa Poços Artesianos em janeiro de 1995. Os poços a jusante do aterro estavam localizados na face norte. A profundidade dos poços e nível d'água medidos após a construção estão apresentados na Tabela 27.

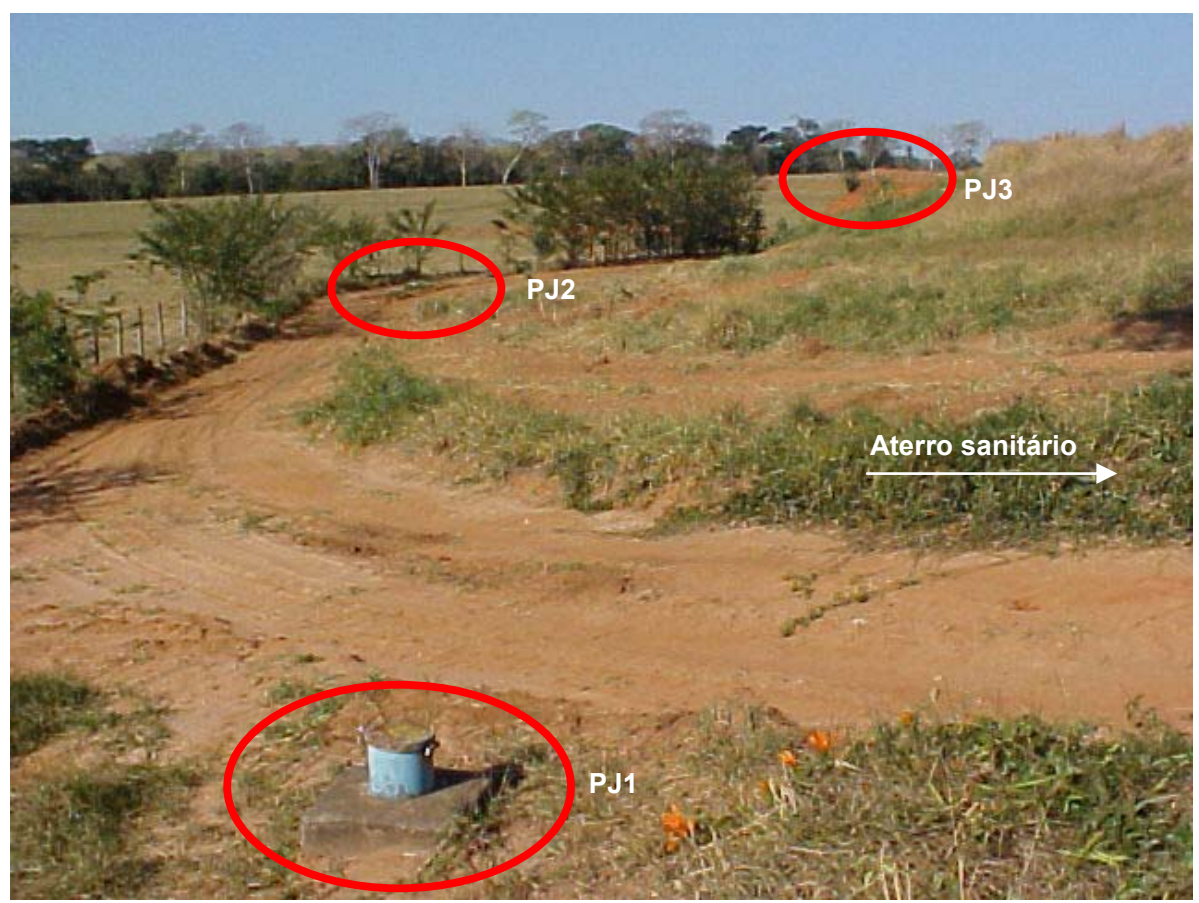

Figura 119 - Poços de monitoramento a jusante do aterro de São Carlos, 08/03/2004

Tabela 27 - Profundidade e nível d'água dos poços do aterro de São Carlos

\begin{tabular}{c|c|c}
\hline Poços & Profundidade $(\mathbf{m})$ & Nível estático $(\mathbf{m})$ \\
\hline PM (P1) & 61,00 & 34,00 \\
PJ1 (P2) & 20,00 & 17,85 \\
PJ2 (P3) & 22,50 & 17,00 \\
PJ3 (P4) & 22,50 & 17,60 \\
\hline
\end{tabular}

Fonte: Prefeitura Municipal de São Carlos (2001)

Com a construção da $4^{\text {a }}$ lagoa de lixiviado, os poços PM (P1) e PJ1 (P2) permaneceram, porém os poços PJ2 (P3) e PJ3 (P4) foram desativados. Atualmente o aterro possui cinco poços de monitoramento das águas subterrâneas. Os novos poços foram construídos em 2006 pela mesma empresa e locados a jusante da $4^{\text {a }}$ lagoa de chorume.

O monitoramento das águas subterrâneas na área de influência do aterro sanitário é realizado com a finalidade de verificar se o lixiviado está atingindo o aqüífero freático. Diante 
desta problemática, Almeida (2005) em seu mestrado concluiu que o solo do aterro de São Carlos apresentou bom potencial para retenção dos contaminantes presentes no lixiviado. Como trata-se de um solo arenoso, a pesquisa continua sendo realizada na EESC/USP pela autora em seu Doutorado com o título "Implicações ambientais dos processos de atenuação de chorume em locais de disposição de resíduos sólidos".

Segundo a SMDSCT, o maior problema do aterro atual é que foi projetado para receber até 90.000 toneladas de RSU, porém, com o crescimento populacional, está sendo adaptado freqüentemente para comportar cerca de 500.000 toneladas.

Outro problema do aterro é a geração de lixiviado. As lagoas têm uma capacidade limitada de armazenamento e, com o passar do tempo, o volume deste líquido aumenta. Dessa forma, o poder público necessita adotar medidas para evitar o impacto ambiental negativo, transportando os efluentes do aterro para uma ETE ou construindo novas lagoas, o que reflete um acúmulo de problemas. Segundo a SMDSCT, em 2007 o custo do transporte e do tratamento do lixiviado foi de $\mathrm{R} \$ 16,50 / \mathrm{m}^{3}$.

A vida útil do aterro atual já está praticamente esgotada e uma outra área já está sendo analisada para construção do novo aterro sanitário. Dessa forma, até a escolha da área e início das obras, o aterro atual provavelmente será ampliado e uma nova célula será construída. Em julho de 2007 foi protocolado no DAIA um relatório da prefeitura solicitando ampliação do aterro. Recentemente estão sendo realizadas reuniões entre representantes dos municípios de Araraquara, Ibaté e São Carlos para a construção de um aterro regional.

\subsubsection{Resíduo Domiciliar Perigoso (RDP)}

O município possuía um programa de coleta de resíduos perigosos entre 2002 e 2004, que tinha como pontos de entrega a Federação das Indústrias do Estado de São Paulo (FIESP), Empresa Brasileira de Pesquisa Agropecuária (EMBRAPA), Universidade de São Paulo (USP), Universidade Federal de São Carlos (UFSCar) e o Serviço Social da Indústria (SESI).

Segundo a SMDSCT, foram recolhidas cerca de 10 toneladas entre pilhas, baterias e lâmpadas, as quais eram armazenadas na Progresso Habitação de São Carlos (PROHAB) e enviadas para Paulínia. O programa foi extinto devido ao custo elevado do transporte, tratamento e disposição final dos materiais. O custo para a disposição final é de cerca de $\mathrm{R} \$ 1.000,00 /$ tonelada, além do transporte e do Certificado de Autorização e Destinação de Resíduos Industriais (CADRI). Está prevista a implantação de pontos de coleta no município, com vistas a apoiar um projeto do Banco Real, implantado em nível nacional. Segundo a prefeitura, acredita-se que os pontos de coleta existentes atualmente na cidade não 
destinam adequadamente estes resíduos. Há previsão de compra de um equipamento para descontaminação de lâmpadas pela PROHAB.

Com base em Fernandez (2006), cerca de 10,25kg/semana destes resíduos são encaminhados para a Central de Triagem da Ecoativa. Deste total, 50,05\% são pilhas, $9,33 \%$ são lâmpadas fluorescentes e 1,96\% são baterias. Desde 2004 a autora avalia também a quantidade destes produtos encaminhada às outras Centrais de Triagem e ao aterro em seu Doutorado intitulado "Gerenciamento de resíduos sólidos perigosos de origem domiciliar: proposta de prevenção à poluição para o município de São Carlos/SP".

Vale ressaltar que ainda não há previsão para implantação de programa voltado para os eletroeletrônicos.

\subsubsection{Resíduos de Serviços de Saúde (RSS)}

\section{Coleta}

Os RSS gerados no município são coletados pela Vega Engenharia Ambiental e encaminhados para tratamento em Campinas. São geradas cerca de 20 toneladas por mês de RSS. A coleta é realizada por duas pessoas, um motorista e um ajudante, com uso de um furgão. A coleta é realizada entre três e quatro vezes por semana. A estimativa da geração de RSS em São Carlos está apresentada na Tabela 28.

Tabela 28 - Estimativa da geração de RSS em São Carlos

\begin{tabular}{l|r}
\hline \multicolumn{1}{c|}{ Unidade de Saúde } & Geração de RSS (t/mês) \\
\hline Santa Casa & 12 \\
Casa de Saúde & 0,5 \\
Pronto Socorro & 0,5 \\
UNIMED & 0,3 \\
Pequenos geradores & 7 \\
\hline Total & $\mathbf{2 0 , 3}$ \\
\hline
\end{tabular}

Fonte: SMDSCT, agosto de 2007

\section{Tratamento}

São Carlos possuía um antigo incinerador instalado no bairro São Carlos $V$, que funcionou até 2002. A partir de então os RSS passaram a ser tratados por microondas em Campinas. O equipamento pertence a MB Engenharia e Meio Ambiente. Os RSS gerados por São Carlos não são encaminhados para o incinerador de Araraquara, pois o equipamento ainda não tem capacidade para recebê-los. 


\section{Disposição final}

Os RSS gerados na área urbana do município são encaminhados ao aterro sanitário onde são armazenados temporariamente em contêineres brancos fechados em um local protegido com tela, a fim de evitar a atração de vetores e animais, conforme Figura 120.

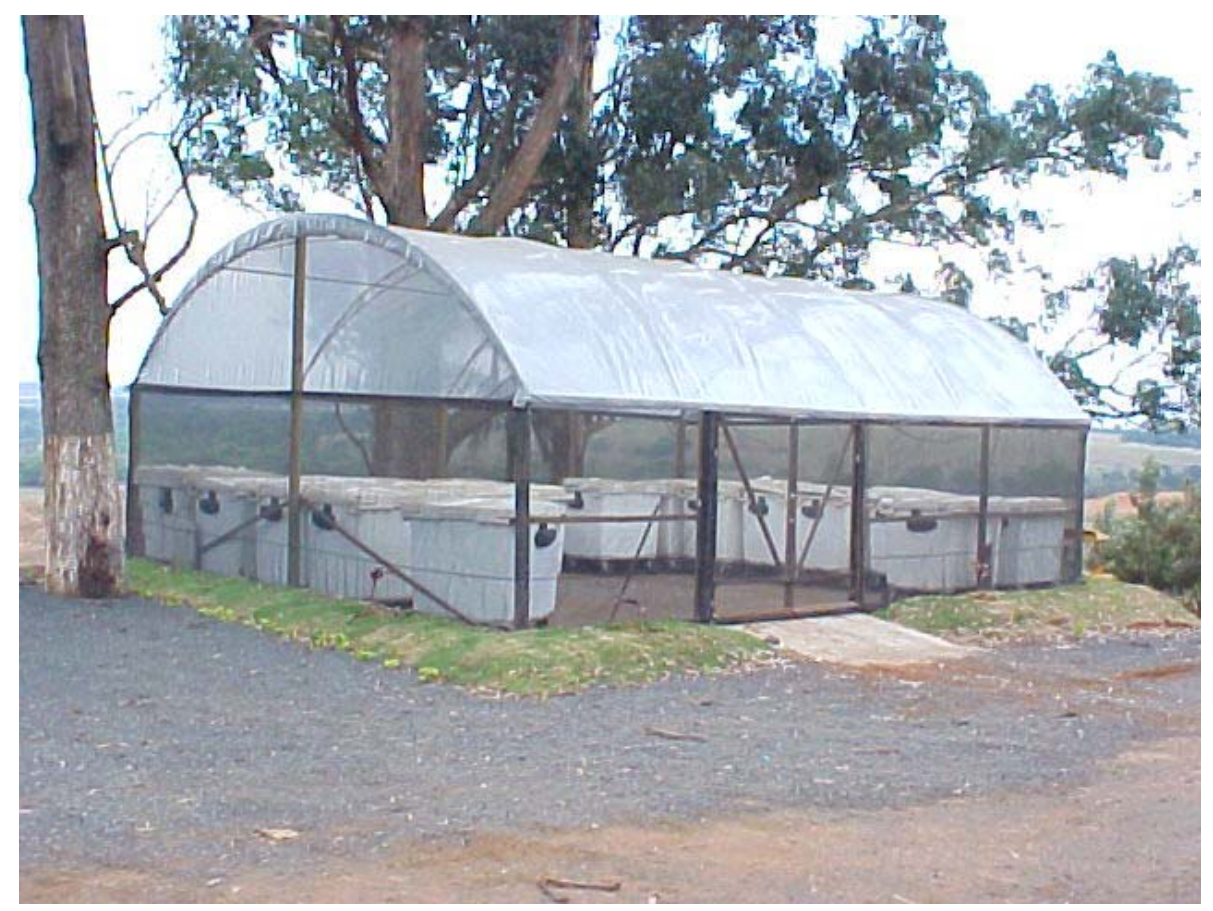

Figura 120 - Armazenamento de RSS no aterro de São Carlos

Os RSS gerados na Irmandade da Santa Casa de Misericórdia de São Carlos, maior gerador do município, são armazenados temporariamente num abrigo, localizado em área externa do próprio hospital, e posteriormente encaminhados ao aterro sanitário. Os resíduos contaminados são separados dos resíduos comuns. Os primeiros são acondicionados em sacos brancos leitosos, encaminhados para tratamento em Campinas e retornam a São Carlos para serem dispostos no aterro sanitário do município. Os segundos são acondicionados em sacos pretos e dispostos no aterro sanitário.

Estão sendo realizadas duas pesquisas da EESC/USP na Santa Casa de São Carlos, um Doutorado intitulado "Gestão e gerenciamento de resíduos de serviços de saúde: proposta de modelo para as unidades da Irmandade Santa Casa de Misericórdia de São Carlos, SP”, desenvolvido por Érica Pugliesi desde 2005, e uma iniciação científica intitulada "Caracterização qualitativa e quantitativa dos resíduos de serviços de saúde gerados na Irmandade Santa Casa de Misericórdia de São Carlos, SP", desenvolvida por Tatiana Novis Lopes Gil, desde 2006. O objetivo das pesquisas é analisar o manejo dos RSS na Santa Casa de São Carlos. 


\subsubsection{Resíduos da Construção Civil (RCC)}

\section{Coleta}

O município de São Carlos gera em média cerca de 500t/d de RCC. Estes resíduos são coletados por cerca de 15 empresas de caçambas, parte dos resíduos é encaminhada para a Usina de Reciclagem de Entulho e parte para o aterro de RCC.

\section{Tratamento}

Em 2004 foi inaugurada a Fábrica de Artefatos de Cimento e em 2006 a Usina de Reciclagem de Entulho na Chácara das Flores (Figura 121 e Figura 122), próximo ao Serviço Social da Indústria (SESI).

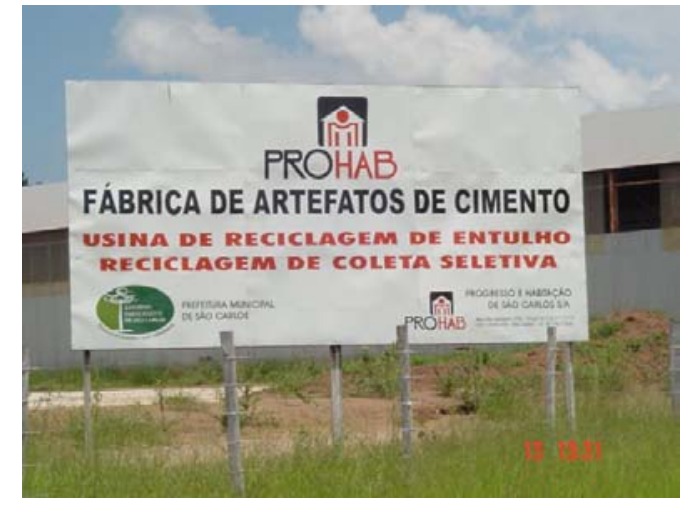

Figura 121 - Entrada da Fábrica de Artefatos de Cimento de São Carlos, 13/01/2004

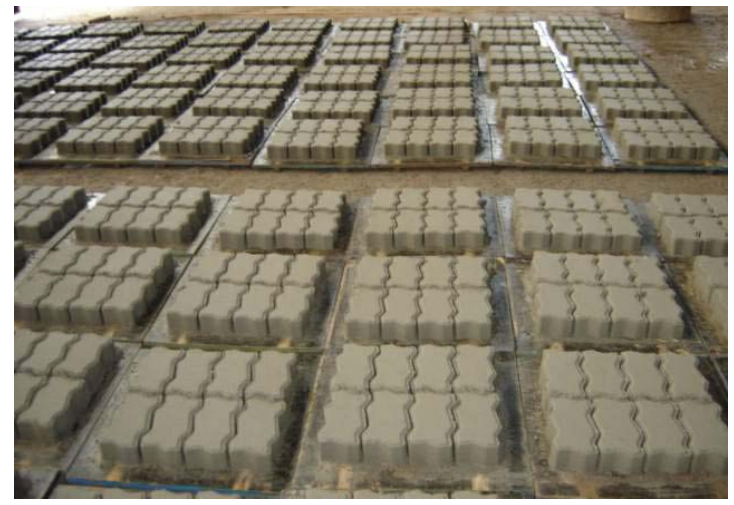

Figura 122 - Cura de blocos na Fábrica de Artefatos de Cimento de São Carlos

O terreno pertence à prefeitura. O projeto da usina e da fábrica foi desenvolvido pela PROHAB.

O processo de licenciamento levou cerca de doze meses. A licença prévia foi concedida pela CETESB em 06 de setembro de 2005, a licença de instalação em 28 de outubro de 2005 e a licença de operação em 2006.

A usina recebe cerca de 20 caçambas por dia e tem capacidade para reciclar cerca de $160 \mathrm{t} / \mathrm{d}$ de $\mathrm{RCC}$, porém atualmente recicla apenas $80 \mathrm{t} / \mathrm{d}$. O resíduo reciclado é usado para fabricação de artefatos de cimento (blocos, canaletas, pisos de concreto e sub-base), de acordo com Resíduos Classe A da Resolução CONAMA 307/2002, que podem ser empregados na pavimentação de calçadas e como material de vedação na construção de condomínios populares. Vale ressaltar que as peças não possuem função estrutural.

A usina e a fábrica são operadas por doze detentos da Penitenciária de Itirapina que cumprem pena em regime semi-aberto, dois funcionários da prefeitura e um engenheiro da PROHAB de São Carlos. 
Para a construção da usina foram investidos cerca de $\mathrm{R} \$ 60.000,00$ em obras e $\mathrm{R} \$ 240.000,00$ em equipamentos instalados (trituradores, britador e pá carregadeira). Alguns equipamentos já pertenciam a PROHAB como compressor, máquina de solda e máquina de fazer blocos (vibro-prensa hidráulica).

\section{Disposição final}

Até 2004 os RCC eram coletados por caçambas e dispostos numa antiga erosão localizada entre os bairros Cidade Aracy II e Antenor Garcia. O local era autorizado pela prefeitura para o descarte destes resíduos, porém está localizado na APA Corumbataí, às margens do Córrego Água Quente, o qual corria risco de assoreamento nesta região, conforme Figura 123.

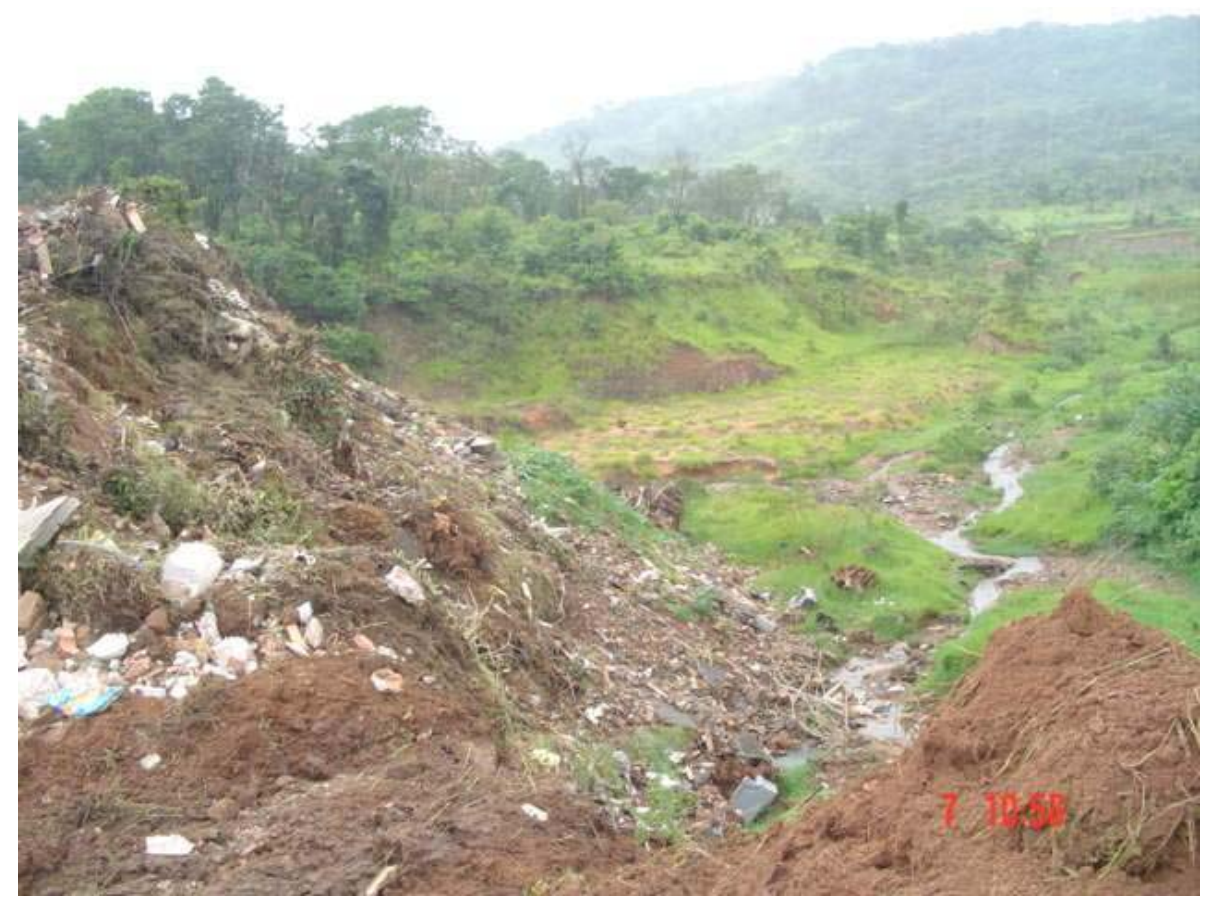

Figura 123 - Córrego Água Quente em São Carlos, 07/01/2004

Havia também alguns bolsões de entulho, autorizados pela prefeitura, espalhados pela cidade. Os RCC depositados ali eram coletados pelos caçambeiros e encaminhados para o "antigo local de disposição final de RCC". Neste local também eram descartados pneus e resíduos volumosos. Os resíduos reaproveitáveis descartados nas caçambas eram separados por catadores que freqüentavam o local.

A partir de 29/10/2006 a prefeitura proibiu a disposição de RCC no local, onde nenhum Projeto de Recuperação de Área Degradada foi realizado até o momento. A área 
está localizada em solos frágeis, suscetíveis à erosão, no entanto constata-se pastagem de gado e ocupação residencial no entorno.

Os administradores públicos devem estar atentos à ocupação irregular sobre os RCC aterrados, devido a possíveis recalques e deslizamentos. Vale destacar que o Plano Diretor do Município de São Carlos, Lei n 13.691 de 25/11/2005, aponta parte desta região como inadequada para assentamento urbano.

Devido ao descarte irregular dos RCC, Marques Neto (2003) ressaltou a importância do licenciamento ambiental das áreas de disposição final de RCC e a conscientização dos agentes envolvidos no setor da construção civil sobre a necessidade da redução do volume de resíduos gerado nos canteiros de obra.

Como a Usina de Reciclagem de Entulho ainda não tem capacidade para receber todo RCC gerado pelo município, parte destes resíduos é encaminhada para o aterro de RCC, implantado numa erosão no bairro Cidade Aracy I (Figura 124), localizado próximo à escola Caíque.

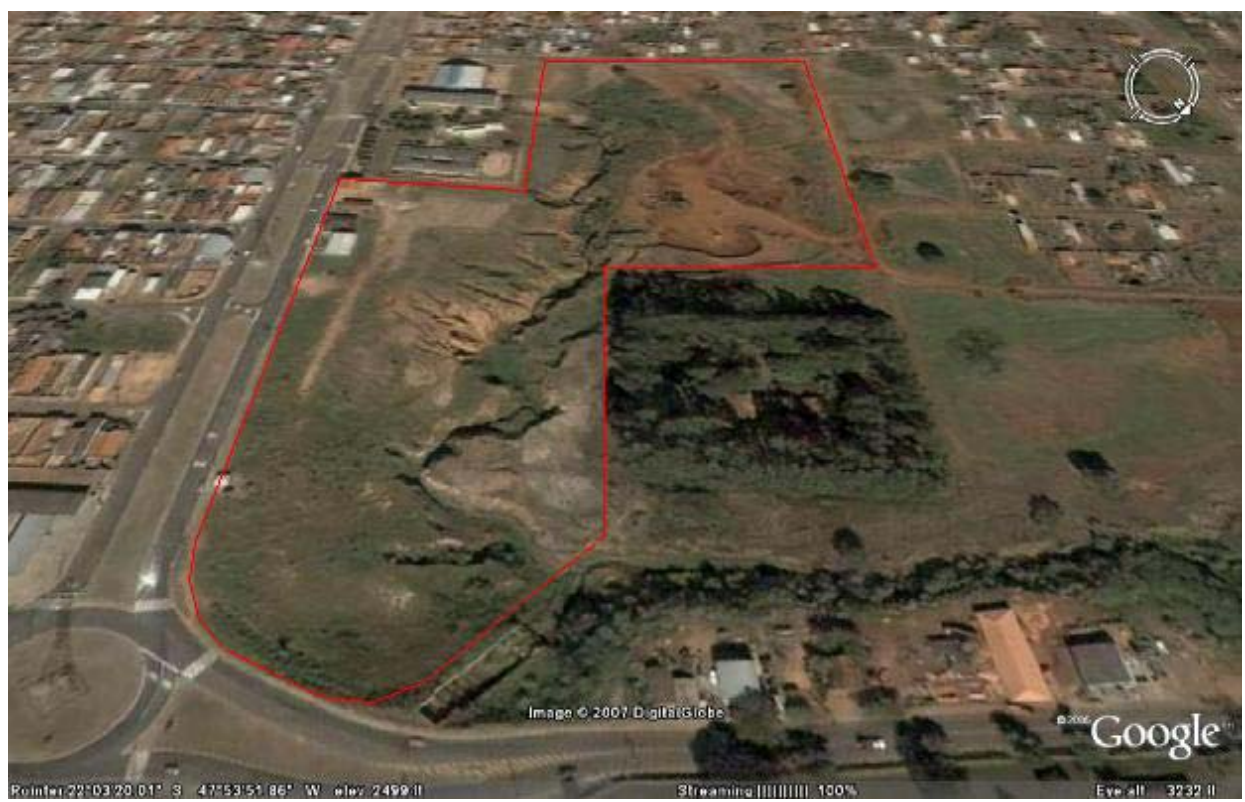

Figura 124 - Local de implantação do aterro de RCC de São Carlos Fonte: Google Earth, 2007, adaptado

O aterro de RCC foi inaugurado em 16/09/2006 e está previsto para operar durante três anos. O projeto demorou um ano e meio para ser concluído e a área está operando com uma Licença de Instalação provisória. A Licença de Operação será obtida quando forem atendidas todas as exigências da CETESB, como obras para drenagem da água de um afloramento na erosão onde os resíduos deverão ser dispostos, as quais deverão iniciar após aprovação de verba. 
Já está previsto licenciamento de uma futura área, próxima ao local, para disposição final dos RCC, que deverá ter vida útil superior à atual devido ao tamanho da erosão.

O aterro de RCC possui quatro poços para o monitoramento da água subterrânea. Ao lado do aterro foi construído pela prefeitura um galpão para separação dos recicláveis descartados nas caçambas. Para sua construção foram investidos cerca de $R \$ 150.000,00$. O galpão possui refeitório, sanitários e um pátio que atende 21 cooperados. Essas pessoas trabalhavam junto com outras 40 na antiga área onde os RCC eram dispostos, próxima ao local. Os critérios para escolha dos cooperados foram: idade superior a 18 anos, ser carente (renda inferior a um salário mínimo) e tempo de permanência no antigo depósito de RCC.

Os Equipamentos de Proteção Individual (EPIs) são cedidos pela prefeitura como colete, crachá, luva, sapatão, visor, além de calculadora. A alimentação e os cuidados com a saúde são de responsabilidade dos próprios cooperados. A isenção da prefeitura está prevista em contrato e no estatuto, assim como as normas para permanência dos mesmos, bem como para o ingresso de novos trabalhadores, os quais são escolhidos por três representantes da cooperativa e por três representantes da prefeitura.

Os cooperados são assistidos pelo Departamento de Economia Solidária, que os orienta sobre a geração de emprego e renda; pelo Departamento de Política Ambiental, que os orienta sobre a separação e disposição adequada dos recicláveis; pela Secretaria da Cidadania, que os orienta sobre a importância da educação dos filhos e todas às quintasfeiras pela Secretaria de Saúde que realiza vacinação e os orienta sobre os exames médicos necessários e saúde dentária. Os cooperados participam de cursos para qualificação profissional e sobre segurança do trabalho.

O conceito de "coletivo" está sendo trabalhado gradualmente, a fim de evitar imposição ou intromissão de pessoas externas. Assim, no momento, os cooperados recebem pagamento individual pelo que cada um separou. Atualmente estão conseguindo obter renda próxima a um salário mínimo, segundo uma das cooperadas.

Ao lado do galpão há uma horta orgânica onde estão sendo plantadas verduras e ervas medicinais para prevenção de doenças, sob a orientação de profissionais da Horta Municipal. Há também uma área destinada à compostagem dos resíduos de poda e capina. A grama descartada nas caçambas é recuperada e reutilizada nos taludes do aterro.

O local não está preparado para receber materiais volumosos. Os que são descartados nas caçambas são reaproveitados pelos cooperados ou são moídos, triturados e encaminhados para o aterro sanitário.

O local recebe papel, papelão, plásticos (PET, PVC, plástico mole, embalagens de lixo, garrafas de água, etc), materiais ferrosos (ferro, lata, latinha de alumínio, arame, portas, portão, material inoxidado, cobre, etc), vidro e madeira. 
O vidro não é de interesse do cooperado devido ao baixo preço, por isso é separado num canto do pátio. Como exemplo, atualmente o ferro está sendo vendido entre $R \$ 0,25$ a $\mathrm{R} \$ 0,27 / \mathrm{kg}$, dependendo da peça. As telhas, tijolos e madeira também são separados para venda. Os tijolos são vendidos a $\mathrm{R} \$ 80,00$ o milheiro. A lenha bruta é vendida para padarias, carvoarias e olarias; as tábuas, vigas, caibros, sarrafos e ripas para pizzarias.

Cerca de 600t/mês de RCC são encaminhadas ao aterro, em média cerca de 130 caminhões de $5 \mathrm{~m}^{3} /$ dia. Os RCC ainda não são encaminhados para a Usina de Reciclagem de Entulho, pois a mesma não tem capacidade para reciclar esta quantidade.

Está prevista a instalação de cerca de 14 ecopontos (locais para armazenamento temporário de RCC) no município. Por enquanto existem quatro bolsões de RCC que deverão ser preparados, porém ainda faltam as caçambas para o descarte dos materiais separadamente. Os bolsões existentes estão localizados nos bairros São Carlos VIII, Santa Felícia, Jardim Botafogo e Vila Marina.

\subsubsection{Pneus}

No município ainda não há um local apropriado para armazenamento temporário de pneus usados. Os pneus são coletados aos sábados pela prefeitura em pontos geradores de até 30 pneus/mês. Os pneus são aproveitados no próprio aterro para proteger a manta impermeabilizante e na drenagem das águas de chuva, dos gases e do lixiviado.

Segundo a SMDSCT, está previsto firmar convênio com a Associação Nacional da Indústria de Pneumáticos (ANIP) para dar tratamento e destino final adequado a estes resíduos.

\subsubsection{Embalagens de Agrotóxicos}

Não existe no município um local licenciado para o recebimento e armazenamento temporário de embalagens vazias de agrotóxicos. Estas embalagens são enviadas para a Central de Recebimento de Embalagens de Agrotóxicos, instalada em Araraquara, a qual envia um caminhão itinerante a São Carlos duas vezes por ano.

Segundo informações dessa Central, o veículo fica estacionado no pátio da Macrosema (uma das lojas de produtos agrícolas de São Carlos). O serviço é voltado ao pequeno e médio produtor rural, que deve entregar a embalagem tríplice lavada, mediante apresentação de nota fiscal do produto. Este serviço não tem custo para o produtor, que é avisado e orientado por meio de panfletos e pelas lojas de produtos agrícolas sobre o 
procedimento a ser adotado e sobre o dia e horário que o caminhão estará recolhendo as embalagens.

Conforme informações da Casa da Agricultura de São Carlos, cerca de 50 propriedades do município fazem a tríplice lavagem e devolvem as embalagens vazias. Alguns produtores levam pessoalmente as embalagens para Araraquara.

\subsubsection{Resíduos Sólidos Industriais (RSI)}

Em São Carlos são geradas cerca de 500t/d de RSI, segundo a SMDSCT. Cerca de 1.000t/mês de RSI Classe II são dispostos no aterro sanitário. O custo deste serviço é de $\mathrm{R} \$ 33,00 /$ t. Para isso, é exigido das industrias o Certificado de Autorização e Destinação de Resíduos Industriais (CADRI).

Cerca de 2.338t/mês de RSI são geradas por 27 indústrias do município, com destaque para a Volkswagen do Brasil Ltda, Tecumseh do Brasil Ltda e A. W. Faber-Castell S.A., segundo levantamento realizado por Campos (2000, p.37). Segundo o autor, sete empresas são geradoras de resíduo Classe I e 14 geradoras de resíduo Classe II.

Conforme Campos (2000), a Volkswagen é a responsável por $85,8 \%$ dos resíduos Classe I, a Tecumseh por $64,1 \%$ dos resíduos Classe II e a Faber-Castell por $75 \%$ dos resíduos Classe III, atualmente classificados como Classe II B, conforme ABNT (2004).

Porém, estes dados precisam ser atualizados. Segundo o Centro de Processamento de Dados da prefeitura, em 2002 haviam 656 indústrias cadastradas em operação (Lopes, 2003, p.119), atualmente existem cerca de 800 indústrias cadastradas.

\subsubsection{Orçamento}

Segundo a SMDSCT, são gastos cerca de $\mathrm{R} \$ 641.670,00 /$ mês com os serviços relacionados com os resíduos sólidos em São Carlos. Os custos destes serviços estão apresentados na Tabela 29.

Tabela 29 - Custos dos serviços com os resíduos sólidos em São Carlos

\begin{tabular}{l|r}
\hline \multicolumn{1}{c|}{ Tipo de Serviço } & \multicolumn{1}{c}{ Custo (R\$/t) } \\
\hline Coleta regular dos RSU & 77,84 \\
Operação do aterro sanitário & 32,50 \\
Coleta seletiva & 140,00 \\
Coleta de RSS & 870,70 \\
Tratamento e disposição final de RSS & $2.082,92$ \\
\hline
\end{tabular}


Já foi proposta da SMDSCT a implantação da "Taxa do Lixo", porém não foi aprovada. Também foi tentado parceria com o Serviço Autônomo de Água e Esgoto (SAAE), mas também não houve apoio.

Com base nos dados coletados e nas visitas realizadas, constatou-se que desde 1980 o município de São Carlos enfrentou diversas dificuldades na área de resíduos sólidos, como a construção de um aterro sanitário, a fim de paralisar as atividades no antigo lixão; posteriormente a presença de catadores no aterro sanitário; a desativação do incinerador de RSS; a falta do gerenciamento adequado para os resíduos de construção civil, entre outras.

A partir de 2002 o município tem apresentado avanços nessa área como a implantação do programa de coleta seletiva; a implantação de Centrais de Triagem, a construção da usina de reciclagem de entulho, da fábrica de artefatos de cimento e do aterro de RCC, conforme diretrizes estabelecidas pela Resolução CONAMA 307/2002; a impermeabilização da nova lagoa de chorume no aterro sanitário; a implantação do projeto piloto de compostagem dos resíduos orgânicos; entre outras melhorias. Porém, atualmente enfrenta a escassez da vida útil do aterro sanitário. Os resíduos sólidos estão sendo exportados para o aterro de Guatapará, a $86 \mathrm{~km}$ de São Carlos aproximadamente, por $\mathrm{R} \$ 250.000,00 /$ mês, até a liberação da licença ambiental para conclusão das obras da quarta célula do aterro sanitário.

Vale ressaltar que São Carlos pode avançar mais na área e se tornar referência para outros municípios, contudo o gerenciamento dos resíduos sólidos de um município tem um custo e para que as melhorias sejam implementadas são necessários investimentos e parcerias. Uma estratégia seria passar a responsabilidade para o SAAE ou firmar parceria com o mesmo para o poder público ter mais autonomia. Porém, para que isso seja possível são necessárias algumas medidas como estrutura, contrapartida, entre outras, para que a autarquia possa fazer a cobrança. 


\subsection{Análise das amostras de água}

\subsubsection{Araraquara}

\subsubsection{1 Água subterrânea}

De acordo com Apêndice D1, foram realizadas coletas de amostras de água subterrânea nos poços de monitoramento do aterro de Araraquara nos dias 08/03/2004, 02/07/2004, 09/11/2004 e 11/02/2005.

As amostras de água subterrânea do aterro de Araraquara apresentaram valores de pH entre 3,57 e 5,17, abaixo do recomendado pela Portaria 518/2004, indicando pH ácido. Os valores também foram inferiores ao intervalo de 5,4 a 8,6, obtido por CETESB (2004, p.54) durante o monitoramento das águas subterrâneas do Aqüífero Adamantina do Sistema Aqüífero Bauru. Segundo CETESB (2007e, p.12), dos 65 poços do Sistema Aqüífero Bauru analisados entre 2004 e 2006, o pH variou entre 5,4 e 9,9.

A Temperatura das amostras variou entre 23,4 e $25,6^{\circ} \mathrm{C}$. A variação foi de $2,2^{\circ} \mathrm{C}$. Os valores estão dentro do intervalo de 15 e $29^{\circ} \mathrm{C}$, apresentado pelas águas subterrâneas do Aqüífero Adamantina, conforme CETESB (2004, p.54). Com base em CETESB (2007e, p.12), a temperatura das águas subterrâneas do Sistema Aqüífero Bauru variou entre 20 e $29^{\circ} \mathrm{C}$.

As quatro amostras dos poços PJ1, PJ2 e PJ3 e três amostras do PM apresentaram Cor Aparente acima de 15UC, valor máximo recomendado pela Portaria 518/2004. Os valores variaram de 3 a 3970UC. A segunda amostra do PJ2 e a segunda amostra do PJ3 apresentaram os maiores valores, 3970 e $715 \mathrm{UC}$ respectivamente.

As quatro amostras do poço PJ2 e três amostras dos outros poços apresentaram valores de Turbidez acima de $5 \mathrm{UT}$, limite máximo recomendado pela legislação. Foram obtidos valores entre 0,71 e 1040UT. A segunda amostra do PJ2 e a terceira amostra do PJ3 apresentaram os maiores valores, 1040 e 181UT respectivamente.

As amostras não atingiram o limite máximo de $1.000 \mathrm{mg} / \mathrm{L}$ estabelecido pela legislação para os Sólidos Totais Dissolvidos. Os valores variaram entre 6 e 485mg/L. Porém, uma amostra do PJ1 e duas amostras do PJ2 apresentaram concentrações acima de $305 \mathrm{mg} / \mathrm{L}$, valor máximo obtido por CETESB (2004, p.54) em águas subterrâneas do Aqüífero Adamantina. Conforme CETESB (2007e, p.12), a concentração de STD das águas subterrâneas do Sistema Aqüífero Bauru variou entre 36 e 706mg/L e de Sólidos Totais 
entre 40 e $776 \mathrm{mg} / \mathrm{L}$. Nenhuma amostra ultrapassou o valor de STD e apenas a segunda amostra do PJ2 ultrapassou o valor de ST.

As amostras apresentaram teores de Oxigênio Dissolvido entre 0,27 e 4,55mg/L. Segundo a Fundação Norte Rio-Grandense de Pesquisa e Cultura (FUNPEC, 2004, p.76), as águas subterrâneas não contaminadas apresentam concentrações típicas de oxigênio dissolvido inferiores a $5,0 \mathrm{mg} / \mathrm{L}$. Porém, as legislações vigentes recomendam valores superiores a 5,0mg/L para as águas superficiais Classe 2, conforme Quadro 9.

As concentrações de Fluoreto nas amostras variaram entre 0,001 e 0,18mg/L. Portanto, nenhuma amostra ultrapassou o limite máximo de $1,5 \mathrm{mg} / \mathrm{L}$ estabelecido pela Portaria 518/2004, bem como não superou o teor máximo de 0,88mg/L, obtido por CETESB (2007e, p.12) em amostras de água subterrânea do Aqüífero Bauru.

As amostras dos poços PJ1 e PJ2 apresentaram concentrações de Cloreto mais elevadas que as demais. Os valores das amostras variaram entre 0 e $102 \mathrm{mg} / \mathrm{L}$, não atingindo o limite máximo permitido pela Portaria 518/2004 de 250mg/L. Vale destacar que as quatro amostras do PJ1 e três amostras do PJ2 superaram o teor máximo de $14 \mathrm{mg} / \mathrm{L}$ encontrado por CETESB (2004, p.54) em águas subterrâneas do Aqüífero Adamantina. Segundo CETESB (2007e, p.12), o cloreto das águas subterrâneas do Sistema Aqüífero Bauru apresentou teor máximo de $38 \mathrm{mg} / \mathrm{L}$. Todas as amostras do PJ1 e duas do PJ2 ultrapassaram este valor.

A Portaria 518/2004 não estabelece limite para Condutividade Elétrica. Os valores das amostras variaram de 8 a $611 \mu \mathrm{S} / \mathrm{cm}$. Duas amostras do PJ2 superaram o valor máximo de $408 \mu \mathrm{S} / \mathrm{cm}$ encontrado por CETESB (2004, p.54) em águas subterrâneas do Aqüífero Aqüífero Adamantina. As amostras do PJ2 variaram entre 216 e $611 \mu \mathrm{S} / \mathrm{cm}$. Com base em CETESB (2007e, p.12), a CE das águas subterrâneas do Sistema Aqüífero Bauru variou entre 26 e $647 \mu \mathrm{S} / \mathrm{cm}$.

As amostras do poço PJ2 apresentaram Salinidade entre 1 e $2 \%$ em duas coletas, as demais amostras não apresentaram salinidade. A Portaria 518/2004 não estabelece limite para este parâmetro. Porém, com base na Resolução CONAMA 357/2005, águas doces apresentam salinidade igual ou inferior a $0,5 \%$; águas salobras apresentam salinidade superior a $0,5 \%$ e inferior a $30 \%$ e águas salinas apresentam salinidade igual ou superior a $30 \%$. Portanto, as amostras do PJ2 podem ser classificadas como águas salobras.

Nas amostras do PJ2 em que foram obtidos os maiores valores de Condutividade Elétrica também foram constatadas os maiores valores de Salinidade.

A Portaria 518/2004 recomenda a ausência de coliformes em águas potáveis. A Resolução CONAMA 357/2005 não apresenta padrão para Coliformes Totais, porém a Resolução CONAMA 20/1986 que a precedeu recomendava o limite de 5000UFC/100mL para águas superficiais Classe 2, conforme o Decreto 8468/1976 do Estado de São Paulo. 
Para os Coliformes Termotolerantes, a Resolução CONAMA 357/2005 e o Decreto $8468 / 1976$ recomendam o limite de 1000 UFC/100mL para águas superficiais Classe 2. Três amostras do PJ2 apresentaram Coliformes Totais acima de 5.000 UFC/100mL. Uma amostra deste poço atingiu o limite de 1.000 UFC/100mL de Coliformes Termotolerantes. Duas amostras do PM, uma amostra do PJ1, todas as amostras do PJ2 e três amostras do PJ3 superaram o valor máximo de $296 \mathrm{NCMF}^{6} / 100 \mathrm{mg} / \mathrm{L}$ de Coliformes Totais obtido por CETESB (2004, p.55) em amostras de água subterrânea do Aqüífero Adamantina, nas quais não foram detectados Coliformes Termotolerantes. Os valores obtidos no PJ2 variaram entre $2,5 \times 10^{3}$ e $16 \times 10^{3}$ UFC $/ 100 \mathrm{~mL}$. Segundo CETESB (2007, p.12), foram identificados Coliformes Totais em 12 das 363 amostras de água subterrânea do Sistema Aqüífero Bauru e não foram detectados Coliformes Termotolerantes.

As amostras dos poços de jusante (PJ1, PJ2 e PJ3) apresentaram DBO acima de $10 \mathrm{mg} / \mathrm{L}$ na segunda coleta (02/07/2004), indicando descarga efluente, segundo EMBRAPA (2004, p.27). A Portaria 518/2004 não estabelece limite para esta variável. Porém, a Resolução CONAMA 357/2005 recomenda o limite máximo de 5mg/L para águas superficiais Classe 2. A DQO da segunda amostra do poço PJ3 atingiu 102mg/L, superando $5 \mathrm{mg} / \mathrm{L}$ encontrado por Valente et al (1997) e 10mg/L indicado por Von Sperling (2006) como o teor máximo de DQO para a água natural não poluída. Magalhães (2006, p.76) também encontrou concentrações de DQO inferiores a $10 \mathrm{mg} / \mathrm{L}$ em amostras de água subterrânea.

As amostras dos poços PM e PJ2 e três amostras dos poços PJ1 e PJ3 apresentaram relação DQO/DBO maior que 4, indicando fração inerte elevada. Apenas uma amostra do PJ1 e uma amostra do PJ3 apresentaram relação DQO/DBO menor que 2,5, indicando fração biodegradável elevada (Von Sperling, 2005, p.94).

A Portaria 518/2004 não estabelece limite para Carbono Orgânico Total, que mede os constituintes orgânicos presentes na amostra. As amostras apresentaram concentrações entre 0,718 e 6,962mg/L. Segundo Libânio (2005, p.35), as águas subterrâneas podem apresentar concentração de COT entre 0,1 e 2,0mg/L. As amostras dos poços PJ1 e PJ2 apresentaram concentrações mais elevadas, comparadas às amostras dos outros poços. As concentrações do PJ1 variaram entre 1,670 e 4,102mg/L e as do PJ2 variaram entre 2,252 e $6,962 \mathrm{mg} / \mathrm{L}$.

As amostras apresentaram concentrações entre 0 e $7,95 \mathrm{mg} / \mathrm{L}$ de Nitrogênio Amoniacal. As amostras do poço PJ1 apresentaram concentrações entre 5,20 e 7,95mg/L durante as quatro coletas, superando o limite máximo de $1,5 \mathrm{mg} / \mathrm{L}$ recomendado pela legislação. A maior concentração encontrada equivale a cerca de cinco vezes o limite da legislação, indicando contaminação recente, conforme Von Sperling (2005, p.97). Segundo

\footnotetext{
${ }^{6}$ NCMF: Número de Colônias na Membrana Filtrante, equivale a UFC
} 
CETESB (2007e, p.12), a concentração máxima encontrada nas águas subterrâneas do Sistema Aqüífero Bauru foi 1,0mg/L.

A Portaria 518/2004 não estabelece limite para Nitrogênio Total, porém a concentração máxima encontrada por CETESB (2004, p.55) em águas subterrâneas do Aqüífero Adamantina foi $0,54 \mathrm{mg} / \mathrm{L}$. As amostras do aterro apresentaram concentrações entre 0,12 e 37,17 . As amostras dos poços de jusante ultrapassaram a concentração máxima encontrada por CETESB (2004). Segundo CETESB (2007e, p.12), a concentração máxima encontrada nas águas subterrâneas do Sistema Aqüífero Bauru foi 1,0mg/L. Por comparação, o esgoto sanitário não tratado pode apresentar concentrações entre 20 e 70mg/L (Metcalf e Eddy, 2003, p.186).

A Portaria 518/2004 não estabelece limite para Fósforo Total. Segundo EMBRAPA (2004, p.29), as águas subterrâneas apresentam teores médios de 0,02mg/L. As amostras apresentaram concentrações entre 0,001 e 0,061 mg/L. Uma amostra do PM e duas amostras dos poços PJ1, PJ2 e PJ3 apresentaram concentrações acima de 0,02mg/L.

De acordo com a análise de metais, foram obtidas concentrações entre 0,09 e 4,87mg/L de Ferro. Duas amostras do PM e do PJ3, quatro do PJ1, três do PJ2 superaram o limite máximo de $0,3 \mathrm{mg} / \mathrm{L}$ recomendado pela Portaria 518/2004. O Manganês variou entre $<0,003$ e 3,79mg/L. Três amostras do PJ1 e do PJ2 superaram o limite máximo de $0,1 \mathrm{mg} / \mathrm{L}$ recomendado pela legislação. O poço PJ2 apresentou uma amostra com 0,14mg/L de Cromo Total, cerca de quase três vezes o limite máximo da legislação, que é de 0,05mg/L.

Vale destacar que durante o monitoramento realizado por CETESB (2004, p.55) foram obtidas concentrações máximas de 0,58mg/L de Ferro, 0,05mg/L de Manganês e $0,17 \mathrm{mg} / \mathrm{L}$ de Cromo Total no Aqüífero Adamantina. Com base nestes valores, uma amostra do PM, duas do PJ1, três do PJ2 e duas do PJ3 superaram a concentração máxima de Ferro e todas as amostras do PJ1 e do PJ2 superaram a concentração máxima de Manganês. Segundo CETESB (2007e, p.12), a concentração máxima encontrada nas águas subterrâneas do Sistema Aqüífero Bauru foi $0,26 \mathrm{mg} / \mathrm{L}$ de Ferro, $0,11 \mathrm{mg} / \mathrm{L}$ de Manganês e $0,1 \mathrm{mg} / \mathrm{L}$ de Cromo Total. Os demais parâmetros não atingiram valores preocupantes.

Com base nos ensaios ecotoxicológicos (Apêndice $F$ ), todas as amostras apresentaram efeito tóxico. Dentre as amostras coletadas em 08/03/2004, as amostras do PJ1 e do PJ3 apresentaram toxicidade aguda, causando imobilidade de 100 e $90 \%$ dos organismos respectivamente. As amostras do PM e do PJ2 apresentaram indício de toxicidade aguda e toxicidade crônica, o primeiro com efeito na reprodução e o segundo com efeito na sobrevivência. Dentre as amostras coletadas em 09/11/2004, as amostras dos poços de jusante apresentaram toxicidade aguda, causando imobilidade de $100 \%$ no PJ1 e PJ2 e de $90 \%$ no PJ3. A amostra do PM apresentou toxicidade crônica com efeito na 
sobrevivência. As amostras do PM podem ter sido influenciadas por produtos agrícolas aplicados no canavial no entorno do aterro.

Com base nos resultados, deve estar ocorrendo vazamento de lixiviado no aterro devido aos valores elevados de Cor, Turbidez, Nitrogênio Amoniacal, Nitrogênio Total, DBO, DQO e Fósforo nas amostras dos poços a jusante do aterro. A baixa concentração de alguns parâmetros no PJ3 pode ter ocorrido, provavelmente, devido à distância do PM e do aterro.

Os resultados indicam que os contaminantes se movem, principalmente, em direção ao PJ1 e PJ2, devido às concentrações mais elevadas de STD, Cloreto, CE, Salinidade, Coliformes, COT, Nitrogênio Amoniacal nestes poços. O monitoramento indicou que houve contaminação do PJ1 por Nitrogênio Amoniacal. Assim, conclui-se que o sentido preferencial do fluxo subterrâneo no aterro de Araraquara é para noroeste, ou seja, na direção do córrego do Pinheirinho.

\subsubsection{2 Água superficial}

De acordo com Apêndice E1, foram coletadas amostras de água no córrego do Pinheirinho em Araraquara nos dias 08/03/2004, 02/07/2004, 09/11/2004 e 11/02/2005.

Com base nas análises realizadas, foram obtidos valores de pH entre 4,57 e 5,98, abaixo do intervalo recomendado pela Resolução CONAMA 357/2005, indicando que durante as coletas as amostras apresentaram pH ácido. A Temperatura das amostras variou entre 21,2 e $25,6^{\circ} \mathrm{C}$. A variação foi de $4,4^{\circ} \mathrm{C}$.

As amostras apresentaram valores de Cor Aparente entre 6 e 35UC, portanto nenhuma amostra ultrapassou o valor máximo recomendado pela Resolução CONAMA 357/2005. A Turbidez das amostras variou entre 1,19 e 262UT. O maior valor foi obtido pela primeira amostra do ponto PM, a qual ultrapassou o limite máximo de 100UT, recomendado pela Resolução CONAMA 357/2005. Este resultado pode ter ocorrido devido às chuvas no período. A média obtida por CETESB (2007c, p.203) no rio Jacaré Guaçu (Classe 3) em Araraquara, na UGRHI-13, entre 1996 e 2005 foi 39UT.

As amostras não atingiram o limite máximo de $500 \mathrm{mg} / \mathrm{L}$ de Sólidos Totais Dissolvidos, estabelecido pela Resolução CONAMA 357/2005. As concentrações variaram entre 9 e $88 \mathrm{mg} / \mathrm{L}$.

As amostras apresentaram teores de Oxigênio Dissolvido entre 5,70 e 6,88mg/L, conforme recomendado pela Resolução CONAMA 357/2005 e pelo Decreto 8468/1976 do Estado de São Paulo. CETESB (2007c, p.203) obteve média de 5,0mg/L no rio Jacaré Guaçu em Araraquara entre 1996 e 2005. 
As concentrações de Fluoreto nas amostras variaram entre <0,01 e 0,36mg/L. Portanto, nenhuma amostra ultrapassou o limite máximo de 1,4mg/L estabelecido pela Resolução CONAMA 357/2005.

As amostras apresentaram concentrações de Cloreto entre 0,3 e 0,6mg/L, não atingindo o limite máximo de 250mg/L, recomendado pela Resolução CONAMA 357/2005.

A Resolução CONAMA 357/2005 e o Decreto 8468/1976 do Estado de São Paulo não estabelecem limite para Condutividade Elétrica. Os valores das amostras variaram de 12 a $20 \mu \mathrm{S} / \mathrm{cm}$. Porém, conforme CETESB (2005a, p.16), valores acima de $100 \mu \mathrm{S} / \mathrm{cm}$ representam ambientes impactados. Portanto, nenhuma amostra superou este valor. A média obtida por CETESB (2007c, p.203) no rio Jacaré Guaçu em Araraquara entre 1996 e 2005 foi $60 \mu \mathrm{S} / \mathrm{cm}$.

As amostras apresentaram valores entre 150 e 883 UFC/100mL de Coliformes Totais, não atingindo 5000UFC/100mL, recomendado pelo Decreto 8468/1976 do Estado de São Paulo. Para os Coliformes Termotolerantes, a Resolução CONAMA 357/2005 e o Decreto 8468/1976 recomendam o limite de 1000UFC/100mL para águas superficiais Classe 2. As amostras apresentaram valores entre 2 e $42 \mathrm{UFC} / 100 \mathrm{~mL}$, não atingindo o limite das legislações. CETESB (2007c, p.203) obteve média de $9,3 \times 10^{3}$ no rio Jacaré Guaçu em Araraquara entre 1996 e 2005.

A Resolução CONAMA 357/2005 e o Decreto 8468/1976 do Estado de São Paulo recomendam concentrações inferiores a $5 \mathrm{mg} / \mathrm{L}$ para a DBO das águas superficiais Classe 2 . Nenhuma amostra atingiu esta concentração. CETESB (2007c, p.203) obteve média de $4,9 \mathrm{mg} / \mathrm{L}$ no rio Jacaré Guaçu em Araraquara entre 1996 e 2005. As legislações não estabelecem limite para a DQO, porém segundo Von Sperling (2006), a água natural não poluída não deve superar $10 \mathrm{mg} / \mathrm{L}$. Com base nesta informação, apenas uma amostra do PJ não superou esta concentração. As amostras apresentaram concentrações entre 6 e 33mg/L. Conforme Valente et al (1997), em trechos de água limpa a DQO não ultrapassa $5 \mathrm{mg} / \mathrm{L}$.

A relação $\mathrm{DQO} / \mathrm{DBO}$ foi maior que $4 \mathrm{em}$ todas as amostras, indicando fração inerte elevada (Von Sperling, 2005, p.94).

As legislações não estabelecem limite para Carbono Orgânico Total. As amostras apresentaram concentrações entre 0,775 e 3,819mg/L. Segundo Libânio (2005, p.35), as águas superficiais podem apresentar concentração de COT entre 1 e $20 \mathrm{mg} / \mathrm{L}$. Dessa forma, nenhuma amostra superou $20 \mathrm{mg} / \mathrm{L}$.

As amostras apresentaram concentrações entre 0,02 e 0,07mg/L de Nitrogênio Amoniacal. Portanto, nenhuma amostra ultrapassou o limite máximo de $3,7 \mathrm{mg} / \mathrm{L}$, estabelecido pela Resolução CONAMA 357/2005, e de 0,5mg/L, estabelecido pelo Decreto 8468/1976. A Resolução CONAMA 357/2005 estabelece o limite máximo de 2,18mg/L de 
Nitrogênio Total. As amostras apresentaram concentrações entre 0,20 e 0,57. Assim, nenhuma amostra ultrapassou o limite estabelecido pela legislação. Segundo CETESB (2007c, p.203), a média obtida no rio Jacaré Guaçu em Araraquara entre 1996 e 2005 foi $0,19 \mathrm{mg} / \mathrm{L}$.

Uma amostra do PM e uma do PJ apresentaram concentrações de Fósforo Total acima do limite máximo de 0,05mg/L, recomendado pela CONAMA 357/2005 para ambientes lóticos de águas Classe 2 , durante a segunda coleta. As amostras apresentaram concentrações entre $<0,001$ e 0,20mg/L. A média obtida por CETESB (2007c, p.203) no rio Jacaré Guaçu em Araraquara entre 1996 e 2005 foi 0,144mg/L.

A partir das análises de metais, foram obtidas concentrações entre <0,002 e 2,13mg/L de Zinco. A primeira e a terceira amostra do PM e do PJ superaram o limite máximo de 0,18mg/L da CONAMA 357/2005. A maior concentração foi obtida no PM, 11 vezes o limite da legislação. Conforme CETESB (2005a), as concentrações variam em torno de $<0,001$ a 0,10 mg/L nas águas superficiais. Dessa forma, quatro amostras ultrapassaram este valor. Porém, nenhuma amostra superou 5,0mg/L, limite máximo estabelecido pelo Decreto 8468/1976. Acima deste valor, o metal confere sabor à água (CETESB, 2005a).

Foram obtidas concentrações entre $<0,005$ e $0,80 \mathrm{mg} / \mathrm{L}$ de Ferro. Uma amostra do PM e três do PJ superaram o limite máximo de $0,3 \mathrm{mg} / \mathrm{L}$ recomendado pela CONAMA $357 / 2005$. O Manganês variou entre $<0,003$ e 0,02 mg/L. Nenhuma amostra superou o limite máximo de 0,1 mg/L recomendado pela legislação. O Cobre variou entre $<0,005$ e 0,88mg/L, 97 vezes o limite. A primeira e a terceira amostra do PM e do PJ superaram o limite máximo de $0,009 \mathrm{mg} / \mathrm{L}$ da CONAMA 357/2005, que é mais restritiva que o Decreto Estadual, que estabelece o limite máximo de 1,0mg/L. Nenhuma amostra superou este valor. Segundo CETESB (2005a), o cobre está presente naturalmente nas águas em concentrações inferiores a $20 \mu \mathrm{g} / \mathrm{L}$. Em concentrações elevadas, pode prejudicar a saúde e conferir sabor às águas. Quatro amostras ultrapassaram este valor. Apenas uma amostra do PM superou o limite de Cromo Total estabelecido pelas legislações. A terceira amostra do PM apresentou $0,30 \mathrm{mg} / \mathrm{L}$, seis vezes o limite das legislações. Os outros parâmetros não atingiram valores preocupantes.

Conforme os ensaios ecotoxicológicos (Apêndice $F$ ), as amostras coletadas em 08/03/2004 não apresentaram efeito tóxico. As amostras coletadas em 09/11/2004 apresentaram toxicidade crônica, sendo que a de montante causou efeito na reprodução dos organismos e a de jusante causou efeito na sobrevivência.

Os resultados das análises de Substâncias Orgânicas demonstraram presença de organoclorados no PM e no PJ e de organofosforado no PM, acima dos limites máximos recomendados pela CONAMA 357/2005 (Apêndice G1). Estes resultados podem ter 
ocorrido devido à plantação de cana ao redor do aterro. Vale destacar que no entorno do trecho monitorado há plantação de eucalipto.

CETESB (2007c, p.203) obteve resultados de não conformidade com a CONAMA 357/2005 no rio Jacaré Guaçu em Araraquara entre 1996 e 2005 para Nitrogênio Amoniacal, Fósforo Total, Manganês, Níquel, Zinco e Toxicidade.

Com base no IQA calculado para o período (Apêndice E1), as amostras do PM apresentaram qualidade Boa e as do PJ qualidade Ótima. Vale destacar que, durante o monitoramento, as margens do córrego do Pinheirinho, próximas à nascente, não estavam protegidas por vegetação e o ponto de jusante apresentava bom volume de água. Com base nos resultados, pode-se inferir que não houve contaminação das águas no período de 2004 a 2005. Não se pode afirmar que houve influência do aterro na qualidade das águas do córrego e não houve diferença significativa entre as amostras de montante e jusante.

\subsubsection{Bauru}

\subsubsection{1 Água subterrânea}

De acordo com Apêndice D2, foram realizadas coletas de amostras de água subterrânea nos poços de monitoramento do aterro de Bauru nos dias 13/04/2004, 02/09/2004, 23/11/2004 e 21/03/2005.

As amostras de água subterrânea do aterro de Bauru apresentaram valores de $\mathbf{p H}$ entre 4,81 a 6,57. As amostras dos poços PJ1 e PJ2 e duas amostras do poço PJ3 apresentaram valores abaixo do recomendado pela Portaria 518/2004, indicando pH ácido. Segundo CETESB (2007e, p.90), dos quatro poços do Sistema Aqüífero Bauru analisados entre 2004 e 2006 na UGRHI-16, da qual o aterro de Bauru faz parte, o pH variou entre 5,4 e 7,0. Dessa forma, todas as amostras do PJ1 e uma do PJ2 apresentaram pH inferior ao valor mínimo encontrado por CETESB (2007e).

A Temperatura das amostras variou entre 23,4 e $25,6^{\circ} \mathrm{C}$. A variação foi de $2,2^{\circ} \mathrm{C}$. Os valores estão dentro do intervalo de 22 e $29^{\circ} \mathrm{C}$, apresentado pelas águas subterrâneas do Sistema Aqüífero Bauru na UGRHI-16, conforme CETESB (2007e, p.90).

As quatro amostras dos poços PM, PJ1 e PJ3 e três amostras do PJ2 apresentaram valores de Cor Aparente acima de 15UC, limite máximo recomendado pela Portaria $518 / 2004$. Os valores variaram entre 8 e 2.120UC. As duas primeiras amostras do PJ1 apresentaram os maiores valores, 2120 e 1563UC respectivamente. As quatro amostras do PJ1 e três amostras dos poços PM, PJ2 e PJ3 apresentaram valores de Turbidez acima de 5UT, limite máximo recomendado pela legislação. Foram obtidos valores entre 1,44 e 
613UT. Semelhante a Cor, as duas primeiras amostras do PJ1 apresentaram os maiores valores, 613 e 480UT respectivamente.

As amostras não atingiram o limite máximo de $1.000 \mathrm{mg} / \mathrm{L}$ estabelecido pela legislação para os Sólidos Totais Dissolvidos. As concentrações variaram entre 121 e 788mg/L. Porém, todas as amostras do PM, PJ2 e PJ3 e três do PJ1, apresentaram concentração acima de 158mg/L, valor máximo obtido por CETESB (2007e, p.90) em águas subterrâneas do Sistema Aqüífero Bauru na UGRHI-16. Apenas a primeira amostra do PJ1 ultrapassou a concentração máxima de $776 \mathrm{mg} / \mathrm{L}$ de Sólidos Totais obtida por CETESB (2007e).

Todas as amostras de poços apresentaram teores de Oxigênio Dissolvido abaixo de $5 \mathrm{mg} / \mathrm{L}$, concentração típica de águas subterrâneas não contaminadas (FUNPEC, 2004, p.76). Os teores variaram entre 0,49 e $3,32 \mathrm{mg} / \mathrm{L}$.

Foram obtidas concentrações de Sulfato entre $<1$ e $11 \mathrm{mg} / \mathrm{L}$, de forma que nenhuma amostra ultrapassou o limite máximo de 250mg/L estabelecido pela Portaria 518/2004. As maiores concentrações obtidas foram no PJ2, entre 7 e 11mg/L. Segundo CETESB (2007e, p.90), em águas subterrâneas do Sistema Aqüífero Bauru na UGRHI-16 o Sulfato atingiu o valor máximo $<10 \mathrm{mg} / \mathrm{L}$.

As concentrações de Fluoreto nas amostras variaram entre <0,01 e 0,15mg/L. Portanto, nenhuma amostra ultrapassou o limite máximo de 1,5mg/L estabelecido pela Portaria 518/2004, bem como não superou o teor máximo de 0,62mg/L, obtido por CETESB (2007e, p.90) em amostras de água subterrânea do Aqüífero Bauru na UGRHI-16.

As maiores concentrações de Cloreto foram detectadas nas amostras dos poços PJ1 e PJ2, porém não atingiram o limite máximo de 250mg/L estabelecido pela legislação. Os valores das amostras variaram entre 1,5 e 77,5mg/L. Todas as amostras do PJ1 e PJ2 superaram a concentração máxima de $4,7 \mathrm{mg} / \mathrm{L}$, encontrada por CETESB (2007e, p.90) em águas subterrâneas do Sistema Aqüífero Bauru.

A Portaria 518/2004 não estabelece limite para Condutividade Elétrica. Os valores das amostras variaram entre 96 e $404 \mu \mathrm{S} / \mathrm{cm}$. Todas as amostras do PM, uma do PJ1 e do PJ3 superaram o valor máximo de $218 \mu S / c m$, obtido por CETESB (2007e, p.90) em águas subterrâneas do Sistema Aqüífero Bauru. Os maiores valores foram apresentados pelas amostras do PM, as quais variaram entre 317 e $404 \mu \mathrm{S} / \mathrm{cm}$. A profundidade do PM pode ter influenciado os resultados. Segundo estudo realizado por Mondelli (2004, p.216-217) no aterro de Bauru, foram coletadas duas amostras de água em 2003 e o poço PM apresentou Condutividade Elétrica média de $271 \mu \mathrm{S} / \mathrm{cm}$, o poço PJ1 (P1) $558 \mu \mathrm{S} / \mathrm{cm}$, o poço PJ2 (P8) $268 \mu \mathrm{S} / \mathrm{cm}$ e o poço PJ3 (P3) $195 \mu \mathrm{S} / \mathrm{cm}$.

As quatro amostras do poço PM, uma amostra do PJ1 e do PJ3 apresentaram Salinidade de 1\%. Seguindo a classificação da Resolução CONAMA 357/2005, estas 
amostras podem ser consideradas águas salobras, as quais apresentam salinidade superior a $0,5 \%$ e inferior a $30 \%$.

Os maiores valores de Condutividade Elétrica foram constatados no PM, bem como os maiores valores de Salinidade.

A Portaria 518/2004 recomenda a ausência de coliformes em águas potáveis, porém três amostras dos poços PM e PJ1 e uma amostra do PJ2 apresentaram Coliformes Totais acima de 5.000UFC/100mL, limite máximo recomendado pelo Decreto 8468/1976 do Estado de São Paulo. Nenhuma amostra atingiu o limite máximo de $1.000 U F C / 100 \mathrm{~mL}$ de Coliformes Termotolerantes, recomendado pela Resolução CONAMA 357/2005 para águas superficiais Classe 2. Os maiores valores de Coliformes Termotolerantes foram obtidos nas três primeiras amostras do poço PJ1, atingindo o valor de $250 \mathrm{UFC} / 100 \mathrm{~mL}$ na segunda coleta. Em amostras de água subterrânea do Sistema Aqüifero Bauru na UGRHI16 não foram detectados Coliformes Totais e Termotolerantes, segundo CETESB (2007e, p.90).

A terceira amostra do poço PM apresentou DBO acima de $10 \mathrm{mg} / \mathrm{L}$, indicando descarga efluente, segundo EMBRAPA (2004, p.27). A Portaria 518/2004 não estabelece limite para esta variável. Porém, a Resolução CONAMA 357/2005 recomenda o limite máximo de $5 \mathrm{mg} / \mathrm{L}$ para águas superficiais Classe 2. Valores acima de $5 \mathrm{mg} / \mathrm{L}$ foram constatados na segunda e terceira coletas do PM e na primeira coleta do PJ2. Segundo Mondelli (2004), o PM apresentou DBO média de 1,75mg/L.

Todas as amostras superaram 5mg/L de DQO encontrado por Valente et al (1997) em águas subterrâneas. Quatro amostras do PM e do PJ3 e três amostras do PJ1 e do PJ2 superaram 10mg/L, indicado por Von Sperling (2006) como a concentração máxima de DQO para a água natural não poluída. Magalhães (2006, p.76) também encontrou valores de DQO inferiores a $10 \mathrm{mg} / \mathrm{L}$ em amostras de água subterrânea. A maior concentração obtida foi 88mg/L na primeira amostra do PJ2. Segundo Mondelli (2004), o PJ2 apresentou DQO média de 10mg/L.

A relação DQO/DBO foi elevada (maior que 4) nas amostras dos poços PM e PJ1 durante três coletas e nas amostras dos poços PJ2 e PJ3 durante as quatro coletas. Com base em Von Sperling (2005, p.94), a terceira amostra do PM apresentou relação DQO/DBO igual a 2,1, indicando fração biodegradável elevada e a terceira amostra do PJ1 apresentou relação $\mathrm{DQO} / \mathrm{DBO}$ intermediária (entre 2,5 e 3,5), igual a 2,6, indicando que a fração biodegradável não é elevada.

A Portaria 518/2004 não estabelece limite para Carbono Orgânico Total, que mede os constituintes orgânicos presentes na amostra. As amostras apresentaram concentrações entre 1,016 e 16,99mg/L. Segundo Libânio (2005, p.35), as águas subterrâneas podem apresentar concentração de COT entre 0,1 e 2,0mg/L. Duas amostras do PM e uma amostra 
do PJ1 e do PJ2 apresentaram concentrações acima de 2,0mg/L. A primeira amostra do poço PM apresentou a concentração mais elevada. Os valores do PM variam entre 1,251 e $16,99 \mathrm{mg} / \mathrm{L}$.

As amostras apresentaram concentrações entre 0 e 1,68mg/L de Nitrogênio Amoniacal. A segunda amostra do poço PM apresentou a concentração mais elevada, superando o limite máximo de $1,5 \mathrm{mg} / \mathrm{L}$ recomendado pela legislação, o que pode indicar que pode ter ocorrido contaminação neste poço. Em amostras de água subterrânea do Sistema Aqüífero Bauru na UGRHI-16 foi obtida a concentração máxima de 0,8mg/L (CETESB, 2007e, p.90). Segundo Mondelli (2004), o PM apresentou concentração média de Nitrogênio Amoniacal de 0,25mg/L. A Portaria 518/2004 não estabelece limite para Nitrogênio Total, porém a concentração máxima encontrada por CETESB (2007e, p.90) em águas subterrâneas do Aqüífero Bauru na UGRHI-16 foi $0,8 \mathrm{mg} / \mathrm{L}$. As amostras do aterro apresentaram concentrações entre 0,22 e 0,91. As amostras do PM e uma amostra do PJ3 ultrapassaram este valor.

A Portaria 518/2004 não estabelece limite para Fósforo Total. As amostras apresentaram teores entre 0,0166 e 0,2666mg/L. Segundo EMBRAPA (2004, p.29), as águas subterrâneas apresentam teores médios de 0,02mg/L. As amostras do PM, PJ1 e PJ3, bem como três amostras do PJ2 apresentaram concentrações acima de 0,02mg/L.

De acordo com a análise de metais, foram obtidas concentrações entre <0,005 e 7,37mg/L de Ferro. Uma amostra do PM, PJ1 e do PJ3 superaram o limite máximo de $0,3 \mathrm{mg} / \mathrm{L}$ recomendado pela Portaria 518/2004. O Manganês variou entre $<0,003$ e 0,75mg/L. Duas amostras do PM, quatro do PJ1, três do PJ2 e uma do PJ3 superaram o limite máximo de $0,1 \mathrm{mg} / \mathrm{L}$ recomendado pela legislação.

Vale destacar que durante o monitoramento realizado por CETESB (2007e, p.90) em águas subterrâneas do Sistema Aqüífero Bauru na UGRHI-16, foram obtidas concentrações máximas de $0,18 \mathrm{mg} / \mathrm{L}$ de Ferro e 0,02mg/L de Manganês. Três amostras do PM, duas do PJ1, PJ2 e PJ3 superaram a concentração máxima de Ferro. Duas amostras do PM, todas as amostras do PJ1 e P2 e uma do PJ3 ultrapassaram a concentração máxima de Manganês. Apesar das concentrações de Zinco não superarem o limite máximo da Portaria 518/2004, todas as amostras do PM, PJ1, PJ2 e três do PJ3 apresentaram concentrações acima de $0,17 \mathrm{mg} / \mathrm{L}$, valor máximo obtido por CETESB (2007e, p.90). As concentrações de Cobre também não atingiram o limite máximo da legislação, porém as segundas e terceiras amostras dos poços superaram o valor máximo de 0,09mg/L obtido por CETESB (2007e, p.90). A segunda amostra do PJ1 e do PJ3 ultrapassou a concentração máxima de 0,09mg/L de Cromo Total obtida por CETESB (2007e, p.90). Os demais parâmetros não atingiram valores preocupantes. 
A comparação entre os valores obtidos no lixiviado e na água subterrânea do aterro de Bauru está apresentada na Tabela 30. Por meio da Tabela 30 constata-se que o lixiviado "fresco" de Bauru apresentou elevadas concentrações de metais, principalmente Ferro, e pH alcalino. Algumas amostras de água apresentaram concentrações de Zinco, Cobre, Cromo Total e Coliformes Totais mais elevadas que o lixiviado analisado por Contrera (2003), caracterizado como "diluído" devido às chuvas anteriores à coleta, "velho" (não fresco) e "misturado", uma vez que os lixiviados do aterro são direcionados para a mesma caixa coletora e, posteriormente, recirculados. 
Tabela 30 - Valores obtidos na água subterrânea e no lixiviado do aterro de Bauru

\begin{tabular}{|c|c|c|c|c|c|c|c|c|c|}
\hline \multirow{3}{*}{ PARÂMETROS } & \multicolumn{9}{|c|}{ Aterro de Bauru } \\
\hline & \multicolumn{5}{|c|}{ Médias da Água Subterrânea } & \multirow{3}{*}{$\begin{array}{c}\text { Portaria } 518 / 2004^{*} \\
\text { VMP }\end{array}$} & \multirow{3}{*}{\begin{tabular}{|l|} 
Limite de \\
Deteç̧ão
\end{tabular}} & \multicolumn{2}{|c|}{ Lixiviado } \\
\hline & Lopes $2007^{1}$ & Mondelli $2006^{2}$ & Cintra $2004^{3}$ & FIPAI $2001^{5}$ & EMDURB $2004^{6}$ & & & & \\
\hline Nivel Estático dos Poços (metro) & 15,02 & 10,70 & - & - & - & & & Contrera $2003^{4}$ & FIPAI $2001^{5}$ \\
\hline $\mathrm{pH}$ & 5,70 & 6,06 & 5,56 & - & 5,91 & $6,0-9,5$ & 0,00 & 8,10 & - \\
\hline Cor Aparente (uC) & 396 & - & - & - & - & 15 & 1 & - & - \\
\hline Turbidez (UT) & 110,72 & - & - & - & - & 5 & 0,01 & - & - \\
\hline Condutividade Elétrica $(\mu \mathrm{S} / \mathrm{cm})$ & 238 & 309 & 238 & - & 284 & - & 0 & - & - \\
\hline Temperatura $\left({ }^{\circ} \mathrm{C}\right)$ & 24,6 & - & - & - & 25,1 & - & 0,0 & - & - \\
\hline Salinidade (\%) & 0 & - & - & - & - & - & 0 & - & - \\
\hline Oxigênio Dissolvido (mg/L) & 1,88 & - & - & - & - & - & 0,00 & - & - \\
\hline Cloreto (mg Cl/L) & 17,4 & 13,0 & 26,2 & - & 32,0 & 250 & 0,1 & - & - \\
\hline Fósforo Total (mg P/L) & 0,0796 & - & - & - & - & - & 0,0001 & - & - \\
\hline Fluoreto (mg F/L) & 0,05 & - & - & - & - & 1,5 & 0,01 & - & - \\
\hline Coliformes Totais (UFC/100mL) & $3,97 \mathrm{E}+07$ & $6,96 \mathrm{E}+04$ & - & - & - & ausência & 1 & $4,10 E+03$ & - \\
\hline Coliformes Fecais (UFC/100mL) & 47 & 583 & - & - & - & ausência & 1 & $1,00 \mathrm{E}+03$ & - \\
\hline Demanda Quimica de Oxigênio $\left(\mathrm{mg} \mathrm{O}_{2} / \mathrm{L}\right)$ & 26 & 33 & 28 & - & 25 & - & 1 & 5340 & - \\
\hline Demanda Bioquimica de Oxigênio $\left(\mathrm{mg} \mathrm{O}_{2} / \mathrm{L}\right)$ & 4 & 6 & 21 & - & 6 & - & 1 & 2500 & - \\
\hline Nitrogênio Amoniacal (mg N/L) & 0,20 & 0,24 & 0,39 & - & 0,21 & 1,5 & 0,01 & 1630 & - \\
\hline Nitrogênio Nitrato (mg N/L) & 0,2722 & 0,5500 & 1,6200 & - & 8,2466 & 10 & 0,0001 & - & - \\
\hline Nitrogênio Nitrito (mg N/L) & 0,0062 & 0,0061 & 0,0100 & - & 0,0492 & 1 & 0,0001 & - & - \\
\hline Nitrogênio Total (mg N/L) & 0,63 & - & - & - & 1,07 & - & 0,01 & 1722,00 & - \\
\hline Carbono Orgânico Total (mg C/L) & 2,592 & - & - & - & - & - & 0,001 & - & - \\
\hline Sulfato ( $\left.\mathrm{mg} \mathrm{SO}_{4}{ }^{2} / \mathrm{L}\right)$ & 3 & 7 & - & - & - & 250 & 1 & - & - \\
\hline Sulfeto (mg S S/L) & $<0,001$ & $<0,001$ & - & - & - & 0,05 & 0,001 & - & - \\
\hline Sólidos Totais (mg/L) & 450,56 & - & - & - & - & - & 0,0001 & 9067,00 & - \\
\hline Sólidos Totais Fixos (mg/L) & 436,25 & - & - & - & - & - & 0,0001 & 7133,00 & - \\
\hline Sólidos Totais Voláteis (mg/L) & 190,63 & - & - & - & - & - & 0,0001 & 1933,00 & - \\
\hline Sólidos Totais Dissolvidos (mg/L) & 294,88 & - & - & - & - & 1000 & 0,0001 & 8949,00 & - \\
\hline Zinco (mg/L) & 0,678 & 0,018 & - & 0,170 & 0,051 & 5 & 0,002 & 0,18 & 40,00 \\
\hline Chumbo (mg/L) & $<0,02$ & - & 0,204 & $<0,02$ & 0,033 & 0,01 & 0,02 & 0,18 & 1,92 \\
\hline Cádmio (mg/L) & $<0,0006$ & - & - & 0,009 & 0,004 & 0,005 & 0,0006 & 0,02 & 0,35 \\
\hline Niquel $(\mathrm{mg} / \mathrm{L})$ & $<0,008$ & - & - & - & 0,021 & - & 0,008 & 0,42 & - \\
\hline Ferro Solúvel (mg/L) & 1,05 & 3,956 & 15,600 & 9,623 & 13,461 & 0,3 & 0,005 & 18,00 & 720,00 \\
\hline Manganês Solúvel (mg/L) & 0,17 & - & - & - & - & 0,1 & 0,003 & 1,37 & - \\
\hline Cobre $(\mathrm{mg} / \mathrm{L})$ & 0,521 & - & - & - & - & 2 & 0,005 & 0,06 & - \\
\hline Cromo Total $(\mathrm{mg} / \mathrm{L})$ & 0,019 & 0,026 & - & 0,051 & 0,071 & 0,05 & 0,005 & $<0,01$ & 2,50 \\
\hline Cromo Hexavalente (mg/L) & $<0,001$ & - & - & - & - & - & 0,001 & - & - \\
\hline Alumínio (mg/L) & 0,01 & - & - & - & - & 0,2 & 0,01 & - & - \\
\hline
\end{tabular}

$\square$ Valores abaixo dos limites recomendados pela legislação vigente

$\square$ Valores acima dos limites recomendados pela legislação vigente

VMP: Valor Máximo Permitido

* Portaria n 518, 25 de março de 2004. Ministério da Saúde. Padrões de Potabilidade

1 Lopes, A. A. 2007. Estudo da gestão integrada dos residuos sólidos urbanos na Bacia Tietê-Jacaré (UGRHI-13). Tese (Doutorado).

São Carlos, Escola de Engenharia de São Carlos, Universidade de São Paulo. (4 poços)

${ }^{2}$ Mondelli, G., Zuquette, L. V., Giacheti, H. L., Hamada, J. e Elis, V. R. 2006. Considerações sobre a implantação de sistemas de monitoramento de águas subterrâneas em aterros de residuos sólidos urbanos: um estudo de caso. XIII Congresso Brasileiro de Mecânica dos Solos e Engenharia Geotécnica, Curitiba - PR, v.1, 6p. (9 poços)

${ }^{3}$ Cintra, F. H. 2004. Avaliação preliminar da qualidade das águas superficiais e sub-superficiais no entorno de um sistema de disposição final de residuos sólidos urbanos. Dissertação (Mestrado). Bauru, Faculdade de Engenharia, Universidade Estadual Paulista "Júlio de Mesquita Filho". 89p. (5 poços)

${ }^{4}$ Contrera, R. C. 2003. Tratamento biológico de líquidos percolados de aterros sanitários utilizando reator anaeróbio horizontal de leito fixo (RAHLF).

Dissertação (Mestrado). São Carlos, Escola de Engenharia de São Carlos, Universidade de São Paulo. p.43.

${ }^{5} \mathrm{FIPAl}$. 2001. Parecer técnico das análises de liquidos percolados gerados no aterro sanitário municipal de Bauru/SP. Ensaios com chorume fresco.

Fundação para o Incremento a Pesquisa e Aperfeiçoamento Industrial. São Carlos, Escola de Engenharia de São Carlos, Universidade de São Paulo. 7p. (3 poços)

${ }^{6}$ EMDURB. 2004. Resultado das campanhas de 23/01/2003, 11/08/2003 e 16/08/2004 de análise das águas dos 9 poços de monitoramento permanentes instalados

no aterro de residuos sólidos de Bauru. 
Com base nos ensaios ecotoxicológicos (Apêndice $F$ ), as amostras dos poços PM, PJ1 e PJ3 apresentaram efeito tóxico durante as coletas. Na coleta de 23/11/2004, todas as amostras apresentaram toxicidade crônica: o PM e o PJ3 causando efeito na sobrevivência e o PJ1 e o PJ2 causando efeito na reprodução. Na coleta de 13/04/2004, a amostra do PM apresentou toxicidade aguda, causando imobilidade em $50 \%$ dos organismos e as amostras do PJ1 e do PJ3 apresentaram toxicidade crônica, com efeito na sobrevivência e na reprodução respectivamente. Na coleta de 02/09/2004, a amostra do PM apresentou toxicidade crônica com efeito na reprodução e na sobrevivência e as amostras do PJ1 e do PJ3 apresentaram toxicidade aguda, causando imobilidade em $65 \%$ dos organismos.

As concentrações de Ferro e Manganês podem ter influenciado na cor e na turbidez da água. De acordo com a análise estatística, os metais Cobre, Zinco, Cromo, Ferro e Alumínio apresentaram maior variação, por ordem de importância, em relação aos outros metais analisados, apesar de não terem ultrapassado os limites recomendados pela Portaria $518 / 2004$. A presença destes metais na água, embora em baixas concentrações, e outros parâmetros físico-químicos podem ter contribuído para a toxicidade das amostras. Estes metais podem estar presentes naturalmente no solo ou podem ser provenientes do lixiviado.

O poço PM não corresponde ao branco de campo, ou seja, as águas do aqüífero freático que se movem na direção deste poço estão recebendo contaminantes. Elevada Condutividade Elétrica e Salinidade, elevadas concentrações de Fósforo, Coliformes Totais, DBO, DQO, COT, Nitrogênio Amoniacal e Nitrogênio Total no PM devem ter ocorrido devido à influência de fatores externos ao aterro, como a entrada de anuros e aracnídeos no poço, uso de produtos agrícolas no entorno do poço, entre outros. Esta constatação também havia sido obtida por Mondelli et al (2007). Segundo os autores, o poço PP-4 (PM) pode estar próximo a um caminho preferencial do fluxo subterrâneo, porém não pode ser considerado poço de referência. Nesse sentido, o poço PM merece atenção e recomenda-se que novos estudos sejam realizados no aterro e no seu entorno, a fim de se encontrar as causas da alteração da qualidade das águas subterrâneas.

Os resultados indicam que a pluma de contaminantes se move, principalmente, em direção ao PJ1, devido aos elevados valores de Cor, Turbidez, Coliformes Totais, DQO, COT, maior número de Coliformes Termotolerantes, maiores concentrações de STD e Cloreto neste poço. Na maioria das amostras, os parâmetros $\mathrm{pH}$, Cor, Turbidez, coliformes, Ferro e Manganês, ultrapassaram os limites recomendados pela Portaria 518/2004. Os valores de alguns parâmetros indicam que está ocorrendo vazamento, apesar de ter sido aplicado asfalto líquido para a impermeabilização do aterro.

Com base no monitoramento realizado pelo presente trabalho, conclui-se que o sentido preferencial do fluxo subterrâneo no aterro de Bauru é para noroeste, na direção do córrego da Gabiroba, concordante com dados obtidos por ensaios de caminhamento elétrico 
realizados por Lago (2004), que concluiu que o principal sentido do fluxo subterrâneo é para oeste-noroeste.

\subsubsection{2 Água superficial}

Conforme Apêndice E2, foram coletadas amostras de água em um dos afluentes do córrego da Gabiroba em Bauru nos dias 13/04/2004, 02/09/2004, 23/11/2004 e 21/03/2005.

De acordo com as análises realizadas o pH variou entre 6,26 e 7,97, conforme o intervalo recomendado pela Resolução CONAMA 357/2005. A Temperatura das amostras variou entre 23,6 e $29,7^{\circ} \mathrm{C}$. A variação foi de $6,1^{\circ} \mathrm{C}$.

Foram obtidos valores de Cor Aparente acima de 75UC em todas as amostras, limite máximo recomendado pela CONAMA 357/2005 para águas superficiais Classe 2. Os valores variaram entre 136 e $1.566 \mathrm{UC}$. O maior valor foi obtido na quarta coleta do ponto PJ.

Foram obtidos valores de Turbidez entre 15,9 e 186UT. A primeira amostra do ponto PM e a última amostra do ponto PJ apresentaram valores acima de 100UT, limite máximo recomendado pela legislação.

Duas amostras do PM e uma do PJ superaram $500 \mathrm{mg} / \mathrm{L}$, limite máximo estabelecido pela legislação para os Sólidos Totais Dissolvidos. As concentrações variaram entre 69 e $3327 \mathrm{mg} / \mathrm{L}$. O maior valor foi obtido no PM. Com base em Von Sperling (2005, p.112), o esgoto sanitário apresenta concentração típica de $700 \mathrm{mg} / \mathrm{L}$. As concentrações de sólidos obtidas na primeira coleta no ponto PM e na última coleta nos dois pontos (PM e PJ) foram superiores à distribuição de sólidos no esgoto bruto, o que pode indicar lançamento de esgoto sanitário in natura no córrego ou vazamento de lixiviado do aterro sanitário.

Foi constatado teor de Oxigênio Dissolvido abaixo de $5 \mathrm{mg} / \mathrm{L}$, limite mínimo recomendado pela Resolução CONAMA 357/2005 para águas Classe 2, em duas amostras do ponto PM e em três amostras do ponto PJ. O menor teor foi constatado na última coleta do PJ. As concentrações variaram entre 1,90 e 5,6.

Foram obtidas concentrações de Sulfato entre $<1$ e $75 \mathrm{mg} / \mathrm{L}$. Nenhuma amostra ultrapassou o limite máximo de 250mg/L estabelecido pela Resolução CONAMA 357/2005. Os maiores teores obtidos foram no PM.

Foram constatadas elevadas concentrações de Fluoreto em duas amostras do ponto $\mathrm{PM}$, com base no limite máximo de $1,4 \mathrm{mg} / \mathrm{L}$, recomendado pela Resolução CONAMA $357 / 2005$ para águas Classe 2 . As concentrações variaram entre $<0,01$ e $6,40 \mathrm{mg} / \mathrm{L}$. O maior valor foi obtido na primeira amostra do PM.

Uma amostra do ponto PM apresentou concentração de $335 \mathrm{mg} / \mathrm{L}$ de Cloreto na última coleta, superando o limite máximo de $250 \mathrm{mg} / \mathrm{L}$ estabelecido pela legislação. 
Constatou-se que as amostras deste ponto apresentaram concentrações superiores as do PJ, considerando o dia da coleta.

A Condutividade Elétrica das amostras variou entre 140 e $2700 \mu \mathrm{S} / \mathrm{cm}$. Portanto, todas as amostras superaram $100 \mu \mathrm{S} / \mathrm{cm}$, o que representa ambiente impactado, conforme CETESB (2005a, p.16).

As amostras apresentaram Salinidade entre 0 e $13 \%$. Os maiores valores foram obtidos em duas amostras dos pontos PM e PJ. Com base na Resolução CONAMA $357 / 2005$, estas amostras podem ser classificadas como águas salobras (salinidade superior a $0,5 \%$ e inferior a $30 \%$ ).

Os valores de Coliformes Totais foram elevados em todas as coletas, acima de $5000 U F C / 100 \mathrm{~mL}$, limite recomendado para águas superficiais Classe 2 pelo Decreto 8468/1976 do Estado de São Paulo. Os valores de Coliformes Termotolerantes foram superiores a 1000UFC/100L, limite recomendado pela CONAMA 357/2005 para águas Classe 2, na última coleta dos dois pontos.

A DBO das amostras variou entre $<1$ e $1498 \mathrm{mg} / \mathrm{L}$. Todas as amostras do PM e duas do PJ superaram 5mg/L, valor máximo recomendado pela Resolução CONAMA 357/2005 e pelo Decreto 8468/1976 para águas Classe 2. As amostras apresentaram DQO acima de $10 \mathrm{mg} / \mathrm{L}$, concentração máxima indicada por Von Sperling (2006) para as águas naturais não poluídas. Duas amostras do PM e uma do PJ apresentaram DQO superior à concentração típica de $600 \mathrm{mg} / \mathrm{L}$ do esgoto sanitário, segundo Von Sperling (2005, p.112). Isso demonstra que pode estar ocorrendo lançamento de esgoto in natura no córrego, proveniente da penitenciária, e escoamento de lixiviado do aterro. A DQO variou entre 23 e $2552 \mathrm{mg} / \mathrm{L}$. As maiores concentrações de DBO e DQO foram obtidas na última coleta.

A relação DQO/DBO foi elevada (maior que 4) em uma amostra do PM e em duas amostras do PJ, indicando fração inerte elevada Três amostras do PM e uma amostra do PJ apresentaram relação DQO/DBO menor que 2,5, indicando fração biodegradável elevada (Von Sperling, 2005, p.94).

A CONAMA 357/2005 não estabelece limite para Carbono Orgânico Total, que mede os constituintes orgânicos presentes na amostra. Os valores variaram entre 2,734 e $666,6 \mathrm{mg} / \mathrm{L}$. A última amostra do ponto PJ apresentou a concentração mais elevada. Três amostras do ponto PM também apresentaram concentrações elevadas (247,9 na primeira coleta, 52,25 na segunda e $337,1 \mathrm{mg} / \mathrm{L}$ na última coleta). Segundo Libânio (2005, p.35), as águas superficiais podem apresentar COT entre 1 a $20 \mathrm{mg} / \mathrm{L}$. Provavelmente, ocorreu lançamento de esgoto sanitário no córrego e escoamento de lixiviado do aterro.

Três amostras do PM e todas do PJ ultrapassaram 0,5mg/L, limite máximo estabelecido pelo Decreto 8468/1976 para o Nitrogênio Amoniacal. As amostras da última coleta nos pontos PM e PJ apresentaram concentrações de Nitrogênio Amoniacal acima de 
3,7mg/L, limite máximo recomendado pela Resolução CONAMA 357/2005. As concentrações variaram entre 0,2 e $90 \mathrm{mg} / \mathrm{L}$. No ponto $P M$ a concentração foi $66 \mathrm{mg} / \mathrm{L}$ (cerca de 17 vezes o limite) e no ponto PJ a concentração foi 90mg/L (cerca de 24 vezes o limite), indicando contaminação recente. Segundo Von Sperling (2005, p.112), o esgoto sanitário apresenta concentração típica de $25 \mathrm{mg} / \mathrm{L}$.

As amostras apresentaram concentrações de Nitrogênio Total elevadas, variando de 5,0 a $124 \mathrm{mg} / \mathrm{L}$. As maiores concentrações foram registradas na última coleta. A Resolução CONAMA 357/2005 recomenda o limite máximo de 2,18mg/L para ambientes lóticos de águas Classe 2. O esgoto sanitário não tratado pode apresentar valores entre 20 e 70mg/L (Metcalf e Eddy, 2003, p.186). Segundo Von Sperling (2005, p.112), o esgoto sanitário apresenta concentração típica de $45 \mathrm{mg} / \mathrm{L}$.

Duas amostras do ponto PM e uma do ponto PJ apresentaram concentrações de Fósforo Total acima do limite máximo de $0,05 \mathrm{mg} / \mathrm{L}$, recomendado pela Resolução CONAMA 357/2005 para ambientes lóticos de águas Classe 2. As concentrações variaram entre 0,03 e 1,9333mg/L. A maior concentração foi obtida na última coleta do ponto PJ, cerca de 38 vezes o limite da legislação.

De acordo com as análises de metais, foram obtidas concentrações de Zinco acima do limite máximo de 0,18mg/L, recomendado pela Resolução CONAMA 357/2005, em todas as coletas. As concentrações variaram entre 0,21 e 2,93mg/L. A maior concentração foi obtida na última coleta do ponto PM, 16 vezes o limite da CONAMA. Nas águas superficiais, as concentrações variam em torno de $<0,001$ a 0,10mg/L (CETESB, 2005a). Foi registrada concentração de Cromo Total de $0,17 \mathrm{mg} / \mathrm{L}$ na mesma amostra do $\mathrm{PM}, 3,4$ vezes o limite máximo de 0,05mg/L da CONAMA 357/2005. Segundo CETESB (2005a), as concentrações de cromo na água doce são inferiores a $1 \mu \mathrm{g} / \mathrm{L}$. Conforme AWWA (1990), o cromo ocorre na água potável, sendo a forma trivalente a mais comum, não é tóxica e pouco absorvida. Abaixo de $0,1 \mathrm{mg} / \mathrm{L}$ o cromo não causa efeito cancerígeno. Também foi registrada concentração de $0,11 \mathrm{mg} / \mathrm{L}$ de Alumínio na mesma amostra, superando o limite máximo da CONAMA.

Foram obtidas concentrações de Ferro acima do limite máximo de 0,3mg/L, recomendado pela Resolução CONAMA 357/2005, em três amostras do PM e em todas as amostras do PJ. As concentrações variaram entre 0,27 e $24,7 \mathrm{mg} / \mathrm{L}$. A maior concentração foi obtida na última amostra do PJ, 82,33 vezes o limite da CONAMA. Três amostras de cada ponto apresentaram concentrações de Manganês acima do limite máximo de $0,1 \mathrm{mg} / \mathrm{L}$, recomendado pela CONAMA 357/2005. As concentrações variaram entre 0,02 e 1,79mg/L. Conforme o Ferro, a maior concentração foi obtida na última amostra do PJ, 17,9 vezes o limite da CONAMA. O manganês pode provocar coloração negra à água acima de $0,05 \mathrm{mg} / \mathrm{L}$ (CETESB, 2005a). 
Foram obtidas concentrações de Cobre acima do limite máximo de 0,009mg/L da Resolução CONAMA 357/2005 em todas as amostras do ponto PM e em três do ponto PJ. As concentrações variaram entre $<0,005$ e de $1,93 \mathrm{mg} / \mathrm{L}$. A maior concentração foi obtida na segunda amostra do PM, 214,44 vezes o limite da CONAMA. Segundo CETESB (2005a), o Cobre está presente nas águas, naturalmente, em concentrações inferiores a $20 \mu \mathrm{g} / \mathrm{L}$.

Os outros parâmetros não apresentaram concentrações superiores aos limites das legislações.

Conforme os ensaios ecotoxicológicos (Apêndice F), em amostras coletadas em 13/04/2004, a amostra do ponto PM apresentou toxicidade aguda, causando imobilidade a $100 \%$ dos organismos. A amostra do ponto PJ não apresentou efeito tóxico. Em amostras coletadas em 02/09/2004, não foi constatado efeito tóxico. Em amostras coletadas em 23/11/2004, a amostra do PM apresentou toxicidade crônica, causando efeito na reprodução dos organismos, enquanto que a amostra do ponto PJ não apresentou efeito tóxico.

As análises de Substâncias Orgânicas constataram presença de organoclorados e organofosforados no PM e no PJ e de Tetracloreto de Carbono no PJ, acima dos limites máximos recomendados pela CONAMA 357/2005 (Apêndice G2). Vale destacar que no entorno do trecho monitorado há pastagem de gado, eucalipto e pouca vegetação às margens do córrego, além disso possui pouco volume d'água.

De acordo com o IQA calculado para o período de 2004 a 2005 (Apêndice E2), as amostras do PM apresentaram qualidade Ruim e as do PJ qualidade Regular.

Com base nesses resultados, pode-se inferir que ocorreu poluição e contaminação das águas do afluente do córrego da Gabiroba durante o período de monitoramento, principalmente próximo ao dia 21/03/2005, quando a maioria dos parâmetros apresentou concentrações superiores às estabelecidas pela CONAMA 357/2005. Além disso, segundo informações da CETESB, regional de Bauru, este córrego está enquadrado como Classe 2. Porém suas características físico-químicas não correspondem à classificação apresentada no Decreto 10.755, de 22 de novembro de 1977.

\subsubsection{Brotas}

\subsubsection{1 Água superficial}

Conforme Apêndice E3, foram coletadas amostras de água no córrego da Cachoeira Grande em Brotas nos dias 08/09/2004, 23/11/2004, 22/03/2005 e 17/06/2005.

De acordo com as análises realizadas, foram obtidos valores de pH fora do intervalo recomendado pela Resolução CONAMA 357/2005 para águas superficiais Classe 2. O 
ponto PM (P1) apresentou três amostras fora dos limites e o ponto PJ (P2) apresentou quatro amostras. Os valores oscilaram entre 5,39 e 6,14 no PM e 4,89 e 5,70 no PJ.

A Temperatura das amostras variou entre 22,3 e $26,5^{\circ} \mathrm{C}$, apresentando uma variação de $4,2^{\circ} \mathrm{C}$.

Duas amostras de cada ponto apresentaram valores de Cor Aparente acima do limite máximo de 75UC, recomendado pela CONAMA 357/2005, durante a segunda e terceira coleta. Os valores variaram entre 25 e 132UC. O maior valor obtido foi $121 \mathrm{UC}$ no PM e 132UC no ponto PJ.

A Turbidez das amostras variou entre 2 e 11,1UT. O maior valor foi obtido na segunda amostra do ponto PM. Nenhuma amostra ultrapassou o limite máximo de 100UT, recomendado pela Resolução CONAMA 357/2005 para águas Classe 2.

As amostras não atingiram o limite máximo de $500 \mathrm{mg} / \mathrm{L}$ para os Sólidos Totais Dissolvidos, estabelecido pela Resolução CONAMA 357/2005. As concentrações variaram entre 39 e $225 \mathrm{mg} / \mathrm{L}$. O maior valor foi obtido no PM.

As amostras apresentaram teores de Oxigênio Dissolvido entre 3,67 e 6,92mg/L. A primeira amostra do PM e do PJ apresentaram teores inferiores a $5 \mathrm{mg} / \mathrm{L}$, valor mínimo recomendado pela Resolução CONAMA 357/2005 e pelo Decreto 8468/1976 do Estado de São Paulo para águas Classe 2.

As concentrações de Fluoreto nas amostras variaram entre <0,01 e 0,07mg/L. Portanto, nenhuma amostra ultrapassou o limite máximo de $1,4 \mathrm{mg} / \mathrm{L}$ estabelecido pela Resolução CONAMA 357/2005.

As amostras apresentaram concentrações de Cloreto entre <0,1 e 0,9mg/L, não atingindo o limite máximo de 250mg/L, recomendado pela Resolução CONAMA 357/2005.

Os valores de Condutividade Elétrica das amostras variaram de 7 a $90 \mu \mathrm{S} / \mathrm{cm}$. Conforme CETESB (2005a, p.16), valores acima de $100 \mu \mathrm{S} / \mathrm{cm}$ representam ambientes impactados. Portanto, nenhuma amostra superou este valor.

As amostras apresentaram valores entre 650 e $5 \times 10^{10}$ UFC/100mL de Coliformes Totais. Três amostras do PM e duas do PJ superaram o limite máximo de $5000 \mathrm{UFC} / 100 \mathrm{~mL}$, recomendado pelo Decreto 8468/1976 do Estado de São Paulo. Para os Coliformes Termotolerantes, a Resolução CONAMA 357/2005 e o Decreto 8468/1976 recomendam o limite máximo de $1000 \mathrm{UFC} / 100 \mathrm{~mL}$ para águas superficiais Classe 2. As amostras apresentaram valores entre 2 e $6 \times 10^{3} \mathrm{UFC} / 100 \mathrm{~mL}$. Três amostras do PM superaram o limite das legislações.

A DBO das amostras foi inferior a $5 \mathrm{mg} / \mathrm{L}$, valor máximo recomendado pela Resolução CONAMA 357/2005 e pelo Decreto 8468/1976. As concentrações variaram entre $<1$ e 3mg/L. A maior concentração foi obtida na segunda amostra do PM. A DQO das amostras apresentou concentrações mais elevadas durante a segunda e terceira coleta, a 
maior concentração detectada foi $18 \mathrm{mg} / \mathrm{L}$ na segunda amostra do PM e $14 \mathrm{mg} / \mathrm{L}$ na terceira amostra do PJ. A CONAMA 357/2005 não estabelece limite para esta variável. Assim, quatro amostras superaram $10 \mathrm{mg} / \mathrm{L}$, concentração máxima recomendada por Von Sperling (2006) para a água natural, não poluída.

A relação DQO/DBO foi elevada (maior que 4) em três amostras do ponto $P M$ e em duas amostras do ponto PJ, indicando fração inerte elevada Uma amostra do PM e uma do PJ apresentaram relação DQO/DBO intermediária (entre 2,5 e 3,5), indicando fração biodegradável não elevada. Apenas uma amostra do PJ apresentou relação DQO/DBO menor que 2,5, indicando fração biodegradável elevada (Von Sperling, 2005, p.94).

O Carbono Orgânico Total das amostras variou entre 1,169 e 2,294mg/L. As concentrações mais elevadas foram constatadas nas amostras da terceira coleta. A CONAMA 357/2005 não estabelece limite para esta variável. Segundo Libânio (2005, p.35), as águas superficiais podem apresentar COT entre 1 e $20 \mathrm{mg} / \mathrm{L}$. Portanto, nenhuma amostra atingiu este valor.

As amostras apresentaram concentrações entre 0,06 e 0,22mg/L de Nitrogênio Amoniacal. Portanto, nenhuma amostra ultrapassou o limite máximo de $3,7 \mathrm{mg} / \mathrm{L}$, estabelecido pela Resolução CONAMA 357/2005, e de 0,5mg/L, estabelecido pelo Decreto 8468/1976. A Resolução CONAMA 357/2005 estabelece o limite máximo de 2,18mg/L de Nitrogênio Total. As amostras apresentaram concentrações entre 0,29 e 1,12. Assim, nenhuma amostra ultrapassou o limite estabelecido pela legislação.

As amostras apresentaram concentrações de Fósforo Total entre 0,0052 e $0,1333 \mathrm{mg} / \mathrm{L}$. A maior concentração foi obtida no PJ, 2,66 vezes o limite máximo de 0,05mg/L, recomendado pela CONAMA 357/2005 para ambientes lóticos (Água Classe 2).

De acordo com as análises de metais foram obtidas concentrações de Zinco acima do limite máximo de 0,18mg/L, recomendado pela Resolução CONAMA 357/2005, em duas amostras no ponto PM e em três amostras no ponto PJ. As concentrações variaram entre 0,05 e 4,27mg/L A maior concentração foi obtida na primeira coleta do ponto PJ, 23,72 vezes o limite da CONAMA, porém não ultrapassou o limite máximo de 5,0mg/L do Decreto 8468/1976. Vale destacar que, segundo CETESB (2005a), nas águas superficiais as concentrações variam em torno de $<0,001$ a $0,10 \mathrm{mg} / \mathrm{L}$.

Foram obtidas concentrações de Ferro acima do limite máximo de 0,3mg/L da CONAMA 357/2005 em três amostras do PM e do PJ. As concentrações variaram entre 0,10 e 1,46mg/L. O maior valor obtido foi na segunda coleta do PJ.

Foram obtidas concentrações de Cobre acima do limite máximo de 0,009mg/L da CONAMA 357/2005 em todas as amostras do PM e em três do PJ. As concentrações variaram entre $<0,005$ e $0,90 \mathrm{mg} / \mathrm{L}$. A maior concentração foi obtida na segunda coleta no ponto PM, 100 vezes o limite recomendado pela CONAMA. Segundo CETESB (2005a), o 
cobre está presente nas águas, naturalmente, em concentrações inferiores a $20 \mu \mathrm{g} / \mathrm{L}$. Os outros parâmetros não apresentaram concentrações preocupantes.

Conforme os ensaios ecotoxicológicos (Apêndice F), na coleta realizada em 08/09/2004, as amostras não apresentaram efeito tóxico. Na coleta realizada em 23/11/2004, as amostras apresentaram toxicidade crônica, causando efeito na reprodução dos organismos.

As análises de Substâncias Orgânicas demonstraram presença de organoclorados no PM e PJ acima dos limites máximos recomendados pela CONAMA 357/2005 (Apêndice G3).

O córrego da Cachoeira Grande atravessa propriedades agrícolas com cultura de laranja, plantação de eucalipto e pasto. Com base nos resultados, pode-se inferir que as alterações nas características naturais da água se devem, provavelmente, à pastagem de gado e à aplicação de produtos agrícolas no entorno do córrego durante o período de monitoramento, devido aos valores de Fósforo, Zinco, Ferro e Cobre na água. Substâncias como piritionato de zinco, fosfato férrico e arsenito de cobre, entre outros, são usados como inseticidas, herbicidas, fungicidas e fertilizantes.

Com base no IQA calculado para o período de 2004 a 2005 (Apêndice E3), as amostras do PM e do PJ apresentaram qualidade Boa. Os ensaios laboratoriais não apresentaram diferença significativa entre os pontos. Destaca-se que as margens do córrego no ponto de montante é rodeada por eucaliptos e no ponto de jusante por pasto.

O córrego da Cachoeira Grande é o corpo d'água mais próximo do aterro e está localizado a sua jusante. Porém, devido à distância de cerca de $1,0 \mathrm{~km}$ e do pequeno porte do aterro, este não deve influenciar a qualidade de suas águas. O córrego é afluente do ribeirão da Rasteira, previsto como futuro ponto de captação de água para abastecimento da população, conforme Plano Diretor de Brotas de 22 de novembro de 2007 (Lei Complementar Municipal $n^{\circ}$ 0012/2007, Capítulo II, Seção I, Art. $6^{\circ}$ ), por isso a importância do seu monitoramento.

\subsubsection{Jaú}

\subsubsection{1 Água subterrânea}

Conforme Apêndice D3, foram coletadas amostras de água nos poços de monitoramento do lixão de Jaú nos dias 08/09/2004, 24/11/2004, 04/05/2005 e 18/08/2005.

As amostras de água subterrânea do lixão de Jaú apresentaram pH entre 3,63 e 6,58. Foram obtidos valores de $\mathrm{pH}$ abaixo do valor mínimo recomendado pela Portaria 
518/2004 em todas as amostras do PM e PJ2, em três amostras do PJ1 e em uma amostra do PJ3, indicando $\mathrm{pH}$ ácido. Todas as amostras do PM, PJ1 e PJ2 apresentaram pH inferior ao valor mínimo de 5,4, encontrado por CETESB (2007e, p.12) em águas subterrâneas do Sistema Aqüífero Bauru.

A Temperatura das amostras variou entre 22,9 e $26,8^{\circ} \mathrm{C}$. A variação foi de $3,9^{\circ} \mathrm{C}$. Os valores estão dentro do intervalo de 20 e $29^{\circ} \mathrm{C}$, apresentado pelas águas subterrâneas do Sistema Aqüífero Bauru, conforme CETESB (2007e, p.12).

As amostras de todos os poços apresentaram valores de Cor Aparente acima de 15UC, valor máximo recomendado pela Portaria 518/2004, durante as quatro coletas. Os valores variaram entre 55 e $2.096 \mathrm{UC}$ no PM. Os maiores valores obtidos foram 2.096UC na primeira coleta no PM e 1125UC no PJ1.

Todas as amostras apresentaram valores de Turbidez acima de 5UT, limite máximo recomendado pela legislação, em todas as coletas. Foram obtidos valores entre 9,03 e 908UT. Os maiores valores obtidos foram 908UT na primeira coleta no PM e 230UT no PJ1 e PJ3.

A primeira amostra do $\mathrm{PM}$ e a terceira do PJ3 superaram o limite máximo de $1.000 \mathrm{mg} / \mathrm{L}$ estabelecido pela legislação para os Sólidos Totais Dissolvidos. As concentrações variaram entre 30 e 1605mg/L. A primeira amostra do PM, PJ1 e do PJ2 e a terceira amostra do PJ3 apresentaram concentração acima de 706mg/L, valor máximo obtido por CETESB (2007e, p.12) em águas subterrâneas do Sistema Aqüífero Bauru. A primeira amostra do PM, PJ1 e do PJ2 e duas amostras do PJ3 apresentaram concentração acima de 776mg/L, valor máximo obtido por CETESB (2007e, p.12) para os Sólidos Totais.

As primeiras amostras dos poços PM, PJ1 e PJ2 apresentaram concentrações de STD mais elevadas em relação às demais amostras dos seus respectivos poços. Apesar de terem sido esgotados antes do início da primeira coleta, o término da construção dos mesmos foi em agosto de 2004 e a primeira coleta foi em 08/09/2004. Este fato pode ter influenciado os valores iniciais. Porém, a concentração de $1035 \mathrm{mg} / \mathrm{L}$ apresentada pela terceira amostra do PJ3 pode ter ocorrido devido à proximidade do poço com os resíduos recentemente dispostos. Vale ressaltar que a concentração média de STD no esgoto sanitário é de 700mg/L (Von Sperling, 2005, p.112).

Todas as amostras apresentaram teores de Oxigênio Dissolvido abaixo de $5 \mathrm{mg} / \mathrm{L}$, variando entre 1,06 e 3,90mg/L. Porém, segundo FUNPEC (2004, p.76), valores inferiores a $5 \mathrm{mg} / \mathrm{L}$ são típicos de águas subterrâneas não contaminadas.

Foram obtidas concentrações de Sulfato entre $<1$ e $10 \mathrm{mg} / \mathrm{L}$, de forma que nenhuma amostra ultrapassou o limite máximo de $250 \mathrm{mg} / \mathrm{L}$ estabelecido pela Portaria 518/2004. A maior concentração foi obtida na quarta amostra do PM. Conforme CETESB (2007e, p.12), 
em águas subterrâneas do Sistema Aqüífero Bauru o Sulfato atingiu a concentração máxima de $<10 \mathrm{mg} / \mathrm{L}$.

As concentrações de Fluoreto nas amostras variaram entre $<0,01$ e $0,15 \mathrm{mg} / \mathrm{L}$. Portanto, nenhuma amostra ultrapassou o limite máximo de 1,5mg/L estabelecido pela Portaria 518/2004, bem como não superou a concentração máxima de $0,28 \mathrm{mg} / \mathrm{L}$, obtida por CETESB (2007e, p.12) em amostras de água subterrânea do Aqüífero Bauru.

As concentrações de Cloreto variaram entre 1,1 e 200mg/L. As mais elevadas foram detectadas nas amostras do PJ3, porém não atingiram o limite máximo de $250 \mathrm{mg} / \mathrm{L}$ estabelecido pela legislação. As concentrações no PJ3 variaram entre 58 e $200 \mathrm{mg} / \mathrm{L}$, superando a concentração máxima de 38mg/L, encontrada por CETESB (2007e, p.12) em águas subterrâneas do Aqüífero Bauru.

A Portaria 518/2004 não estabelece limite para Condutividade Elétrica. Os valores das amostras variaram entre 23 e $2.030 \mu \mathrm{S} / \mathrm{cm}$. Os maiores valores foram obtidos no PJ3, entre 950 e $2.030 \mu \mathrm{S} / \mathrm{cm}$, superando o valor máximo de $647 \mu \mathrm{S} / \mathrm{cm}$, obtido por CETESB (2007e, p.12) em águas subterrâneas do Sistema Aqüífero Bauru. A proximidade do PJ3 com o local de disposição dos resíduos durante as coletas de água pode ter influenciado os resultados.

As quatro amostras do PJ3 apresentaram Salinidade entre 4 e 9\%, as demais amostras não apresentaram salinidade. A Portaria 518/2004 não estabelece limite para este parâmetro, porém a Resolução CONAMA 357/2005 classifica como águas doces àquelas com salinidade igual ou inferior a $0,5 \%$; como águas salobras àquelas com salinidade superior a $0,5 \%$ e inferior a $30 \%$ e como águas salinas àquelas com salinidade igual ou superior a $30 \%$. Portanto, as amostras do PJ3 podem ser classificadas como águas salobras.

Os maiores valores de Condutividade Elétrica foram constatados no PJ3, onde foi detectada Salinidade.

A Portaria 518/2004 recomenda a ausência de coliformes em águas potáveis, porém três amostras do PM e PJ1, bem como uma amostra do PJ3 apresentaram valores de Coliformes Totais acima de 5.000 UFC $/ 100 \mathrm{~mL}$, enquanto que nenhuma amostra atingiu o limite de 1.000 UFC/100mL de Coliformes Termotolerantes. Estes são os limites máximos recomendados pela Resolução CONAMA 357/2005 para águas superficiais Classe 2. O valor máximo obtido de Coliformes Termotolerantes foi $190 \mathrm{UFC} / 100 \mathrm{~mL}$ na última amostra do PJ3. Segundo CETESB (2007e, p.12), foram identificados Coliformes Totais em 12 das 363 amostras de água subterrânea do Sistema Aqüífero Bauru e não foram detectados Coliformes Termotolerantes.

A Portaria 518/2004 não estabelece limite para a DBO, porém a Resolução CONAMA 357/2005 recomenda o limite máximo de $5 \mathrm{mg} / \mathrm{L}$ para águas superficiais Classe 2. 
As concentrações variaram entre 1 e 46 . Concentrações acima de $5 \mathrm{mg} / \mathrm{L}$ foram constatadas em duas amostras do PM, em uma amostra do PJ1 e em todas do PJ3. Concentrações acima de 10mg/L foram obtidas em uma amostra do PM e PJ1 e em três amostras do PJ3, indicando descarga efluente, conforme EMBRAPA (2004, p.27).

Todas as amostras, exceto uma do PJ1, superaram a concentração máxima de 10mg/L de DQO, indicada por Von Sperling (2006) para a água natural não poluída. As concentrações variaram entre 9 e 276. Assim como a DBO, a miaor concentração foi obtida na primeira amostra do PJ3.

A relação DQO/DBO foi elevada (maior que 4) em três amostras do poço $P M$, em duas amostras do poço PJ1 e em todas as amostras dos poços PJ2 e PJ3. A quarta amostra do PM apresentou relação DQO/DBO baixa (menor que 2,5), igual a 2,0, indicando fração biodegradável elevada e a primeira amostra do PJ1 apresentou relação DQO/DBO intermediária (entre 2,5 e 3,5), igual a 2,7, indicando que a fração biodegradável não é elevada, com base em Von Sperling (2005, p.94).

As amostras apresentaram concentrações de Carbono Orgânico Total entre 0,94 e $58,4 \mathrm{mg} / \mathrm{L}$. Segundo Libânio (2005, p.35), as águas subterrâneas podem apresentar concentrações de COT entre 0,1 e 2,0mg/L. As primeiras amostras do PM, PJ1 e PJ2 e todas as amostras do PJ3 apresentaram concentrações acima de 2,0mg/L. A terceira amostra do PJ3 apresentou a concentração mais elevada. As concentrações do PJ3 variam entre 10,33 e 58,4mg/L. A Portaria 518/2004 não estabelece limite para variável.

As amostras apresentaram concentrações entre 0,04 e 48,75mg/L de Nitrogênio Amoniacal. As amostras do PJ3 apresentaram concentrações acima de 1,5mg/L, limite máximo recomendado pela legislação, indicando contaminação recente. A maior concentração foi obtida na terceira coleta do PJ3, cerca de 32 vezes o limite da Portaria 518/2004. Segundo CETESB (2007e, p.12), a concentração máxima encontrada nas águas subterrâneas do Sistema Aqüífero Bauru foi 1,0mg/L.

As amostras do aterro apresentaram concentrações entre 0,22 e 58mg/L de Nitrogênio Total. A concentração máxima encontrada por CETESB (2007e, p.12) em águas subterrâneas do Aqüífero Bauru foi 1,0mg/L. Duas amostras do PM, uma do PJ1 e PJ2 e todas as amostras do PJ3 ultrapassaram este valor. As concentrações no PJ3 foram as mais elevadas, variaram entre 22,12 e 58. Vale lembrar que o esgoto sanitário não tratado pode apresentar concentrações entre 20 e 70mg/L, segundo Metcalf e Eddy (2003, p.186).

A Portaria 518/2004 não estabelece limite para Fósforo Total. As amostras apresentaram concentrações entre 0,0166 e 0,1966mg/L. Segundo EMBRAPA (2004, p.29), as águas subterrâneas apresentam concentrações médias de 0,02mg/L. As amostras do PM e PJ1, três amostras do PJ2 e PJ3 ultrapassaram este valor. A maior concentração foi 
obtida no PM, onde as concentrações variaram entre 0,0233 e 0,1966mg/L, 9,8 vezes o valor recomendado por EMBRAPA (2004).

De acordo com a análise de metais, foram obtidas concentrações entre <0,005 e 37mg/L de Ferro. Uma amostra do PM e PJ1, duas do PJ2 e todas do PJ3 superaram o limite máximo de 0,3mg/L recomendado pela Portaria 518/2004. O Manganês variou entre $<0,003$ e 19,6mg/L. Duas amostras do PM, três do PJ1, uma do PJ2 e todas do PJ3 superaram o limite máximo de $0,1 \mathrm{mg} / \mathrm{L}$ recomendado pela legislação. As primeiras amostras dos poços apresentaram concentrações de Zinco, Chumbo e Cromo Total superiores ao limite da legislação. A concentração de Cromo foi 12 vezes superior ao limite da Portaria 518/2004 no PJ3 e a de Chumbo 65 vezes no PM.

No monitoramento realizado por CETESB (2007e, p.12) em águas subterrâneas do Sistema Aqüífero Bauru, foram obtidas concentrações máximas de 0,26mg/L de Ferro, 0,11 mg/L de Manganês, 0,69mg/L de Zinco, 0,05 de Chumbo e 0,1 mg/L de Cromo Total. Com base nestes valores, uma amostra do PM, PJ1, duas do PJ2 e todas do PJ3 superaram a concentração máxima de Ferro; duas amostras do PM, três do PJ1, uma do PJ2 e todas do PJ3 superaram a concentração máxima de Manganês; três amostras do PM, duas do PJ1, uma do PJ2 e PJ3 superaram a concentração máxima de Zinco; uma amostra de cada poço superou a concentração máxima de Chumbo e Cromo Total. Apesar das concentrações de Cobre não atingirem o limite da legislação, duas amostras do PM, PJ2 e PJ3 e uma do PJ1 superaram a concentração máxima de 0,09mg/L obtida por CETESB (2007e, p.12). Os demais parâmetros não atingiram valores preocupantes.

Com base nos ensaios ecotoxicológicos (Apêndice F), o PJ3 apresentou toxicidade aguda, causando imobilidade em $100 \%$ dos organismos nas amostras de 08/09/2004 e 24/11/2004. Na coleta de 08/09/2004, as amostras do PM, PJ1 e PJ2 apresentaram indício de toxicidade aguda, causando imobilidade em $40 \%$ dos organismos no PM e $45 \%$ no PJ1 e PJ2.

As concentrações elevadas de Zinco, Chumbo e Cromo Total nas primeiras amostras dos poços podem ter ocorrido devido à disposição de resíduos de artefatos de couro no local, que foi interrompida em 2004, antes da segunda coleta. Estes metais associados ao Ferro e Manganês e a outros parâmetros físico-químicos podem ter contribuído para a toxicidade das amostras.

O PM pode ter sido influenciado pela plantação de cana no seu entorno e pela proximidade com uma parte dos resíduos depositados, devido aos elevados valores de Cor, Turbidez, Fósforo, Coliforme Totais, DBO, DQO, COT e sólidos na primeira amostra. Assim, o poço PM merece atenção e recomenda-se que novos estudos sejam realizados no local e no seu entorno, a fim de se encontrar as causas da alteração da qualidade das águas subterrâneas. 
Os resultados indicam que os contaminantes do lixão se movem, principalmente, em direção ao poço PJ3, devido aos elevados valores de Cor, Turbidez, Condutividade Elétrica, Salinidade, Coliformes Totais, DBO, DQO, Nitrogênio Amoniacal, Nitrogênio Total e sólidos. Durante o monitoramento, os resíduos estavam sendo depositados nas proximidades do PJ3. Foi constatado contaminação deste poço por Nitrogênio Amoniacal. Com base nos resultados obtidos pelo presente trabalho, conclui-se que o sentido preferencial do fluxo subterrâneo no lixão de Jaú é para sudoeste, ou seja, no sentido do ribeirão do Matão.

\subsubsection{2 Água superficial}

Conforme Apêndice E4, foram coletadas amostras de água no ribeirão do Matão em Jaú nos dias 09/09/2004, 24/11/2004, 22/03/2005 e 18/08/2005.

Com base nas análises realizadas, foram obtidos valores de pH entre 6,69 e 7,62, dentro do intervalo recomendado pela Resolução CONAMA 357/2005. A Temperatura das amostras variou entre 19,6 e $23,9^{\circ} \mathrm{C}$. A variação foi de $4,3^{\circ} \mathrm{C}$.

As amostras apresentaram valores de Cor Aparente entre 13 e 342UC. Duas amostras de cada ponto apresentaram valores superiores a $75 \mathrm{UC}$, limite máximo recomendado pela CONAMA 357/2005 para águas superficiais Classe 2. O maior valor foi obtido na terceira amostra do PM (P1). A Turbidez das amostras variou entre 1,32 e 44UT. O maior valor foi obtido pela terceira amostra do PM. Nenhuma amostra ultrapassou o limite máximo de 100UT, recomendado pela Resolução CONAMA 357/2005.

As amostras não atingiram o limite máximo de $500 \mathrm{mg} / \mathrm{L}$ para os Sólidos Totais Dissolvidos, estabelecido pela Resolução CONAMA 357/2005. As concentrações variaram entre 50 e $257 \mathrm{mg} / \mathrm{L}$. Como a Cor e Turbidez, a concentração máxima de STD foi obtida na terceira amostra do PM.

As amostras apresentaram teores de Oxigênio Dissolvido entre 3,58 e 6,16 $\mathrm{mg} / \mathrm{L}$. Uma amostra do PM e duas do PJ (P2) apresentaram teores inferiores a 5mg/L, valor mínimo recomendado pela Resolução CONAMA 357/2005 e pelo Decreto 8468/1976 do Estado de São Paulo para águas Classe 2.

As concentrações de Fluoreto nas amostras variaram entre 0,05 e 0,18mg/L. Nenhuma amostra ultrapassou o limite máximo de $1,4 \mathrm{mg} / \mathrm{L}$ estabelecido pela Resolução CONAMA 357/2005.

As amostras apresentaram concentrações de Cloreto entre 0,8 e 21,9 mg/L, não atingindo o limite máximo de 250mg/L, recomendado pela Resolução CONAMA 357/2005. 
Os valores de Condutividade Elétrica das amostras variaram de 42 a $185 \mu \mathrm{S} / \mathrm{cm}$. Conforme CETESB (2005a, p.16), valores acima de $100 \mu \mathrm{S} / \mathrm{cm}$ representam ambientes impactados. Portanto, uma amostra do PM e três do PJ superaram este valor.

As amostras apresentaram valores entre 2277 e $9 \times 10^{9} \mathrm{UFC} / 100 \mathrm{~mL}$ de Coliformes Totais. Duas amostras de cada ponto superaram $5000 \mathrm{UFC} / 100 \mathrm{~mL}$, limite máximo recomendado pelo Decreto 8468/1976 do Estado de São Paulo. Para os Coliformes Termotolerantes, a Resolução CONAMA 357/2005 e o Decreto 8468/1976 recomendam o limite máximo de $1000 \mathrm{UFC} / 100 \mathrm{~mL}$ para águas superficiais Classe 2. As amostras apresentaram valores entre 12 e 299UFC/100mL, não atingindo o limite das legislações.

A Resolução CONAMA 357/2005 e o Decreto 8468/1976 do Estado de São Paulo recomendam concentrações inferiores a $5 \mathrm{mg} / \mathrm{L}$ para a DBO das águas superficiais Classe 2. Nenhuma amostra superou este valor. As concentrações variaram entre $<1$ e $5 \mathrm{mg} / \mathrm{L}$. As legislações não estabelecem limite para a DQO. Porém, segundo Von Sperling (2006), a água natural não poluída não deve superar a concentração de $10 \mathrm{mg} / \mathrm{L}$. Uma amostra do PM e duas do PJ superaram este valor. As amostras apresentaram concentrações entre 2 e 32mg/L. Conforme Valente et al (1997), em trechos de água limpa a DQO não ultrapassa $5 \mathrm{mg} / \mathrm{L}$. Com base nesta informação, seis amostras superaram este valor.

A relação DQO/DBO foi maior que 4 em três amostras de cada ponto, indicando fração inerte elevada. Apenas uma amostra do PM apresentou relação DQO/DBO menor que 2,5, indicando fração biodegradável elevada (Von Sperling, 2005, p.94).

As concentrações de Carbono Orgânico Total variaram entre 1,046 e 1,708mg/L. A primeira amostra do PJ apresentou a concentração mais elevada. Segundo Libânio (2005, p.35), as águas superficiais podem apresentar COT entre 1 e $20 \mathrm{mg} / \mathrm{L}$. Portanto, nenhuma amostra superou este valor.

Uma amostra do PM ultrapassou a concentração máxima de 0,5mg/L estabelecida pelo Decreto 8468/1976 para Nitrogênio Amoniacal. Nenhuma amostra apresentou concentração acima de 3,7mg/L, limite máximo recomendado pela CONAMA 357/2005. As concentrações variaram entre 0,04 e $0,51 \mathrm{mg} / \mathrm{L}$. O maior valor foi obtido na terceira amostra do PM.

A Resolução CONAMA 357/2005 recomenda o limite máximo de 2,18mg/L de Nitrogênio Total para ambientes lóticos de águas Classe 2. Nenhuma amostra superou este valor. As concentrações variaram entre 0,25 e 1,31mg/L. A maior concentração foi registrada na última coleta do $\mathrm{PM}$.

Nenhuma amostra apresentou concentração de Fósforo Total acima do limite máximo de 0,05mg/L, recomendado pela CONAMA 357/2005 para ambientes lóticos de águas Classe 2. As concentrações variaram entre 0,0066 e 0,05mg/L. A maior concentração foi obtida na terceira coleta do PM. 
De acordo com as análises de metais, foram obtidas concentrações de Zinco acima do limite máximo de $0,18 \mathrm{mg} / \mathrm{L}$, recomendado pela Resolução CONAMA 357/2005, em uma coleta do PM e em três do PJ. As concentrações variaram entre 0,08 e 1,15mg/L. A maior concentração foi obtida na primeira amostra do PJ, seis vezes o limite da CONAMA. Segundo CETESB, 2005a, nas águas superficiais as concentrações variam em torno de $<0,001$ a $0,10 \mathrm{mg} / \mathrm{L}$.

Foram obtidas concentrações de Ferro acima do limite máximo de 0,3mg/L da CONAMA 357/2005 em três amostras de cada ponto. As concentrações variaram entre 0,01 e 2,46mg/L. A maior concentração foi obtida na segunda amostra do PJ, oito vezes o limite da CONAMA. Duas amostras de cada ponto apresentaram concentrações de Manganês acima do limite máximo de $0,1 \mathrm{mg} / \mathrm{L}$ da CONAMA 357/2005. As concentrações variaram entre $<0,003$ e $0,92 \mathrm{mg} / \mathrm{L}$. A maior concentração foi obtida no $\mathrm{PM}$, nove vezes o limite da CONAMA.

Foram obtidas concentrações de Cobre acima do limite de $0,009 \mathrm{mg} / \mathrm{L}$ da CONAMA 357/2005 em duas amostras do PM e em três do PJ. As concentrações variaram entre $<0,005$ e 0,49mg/L. A maior concentração foi obtida no PM, 54 vezes o limite da CONAMA. Segundo CETESB (2005a), o Cobre está presente nas águas, naturalmente, em concentrações inferiores a $20 \mu \mathrm{g} / \mathrm{L}$. Os outros parâmetros não superaram os limites das legislações.

Conforme os ensaios ecotoxicológicos (Apêndice F), em amostras coletadas em 08/09/2004, a amostra do ponto PM não apresentou efeito tóxico e a amostra do ponto PJ apresentou toxicidade aguda, causando imobilidade a $50 \%$ dos organismos. Em amostras coletadas em 24/11/2004, não foi constatado efeito tóxico na amostra do PM, enquanto que a amostra do ponto PJ apresentou toxicidade crônica, causando efeito tanto na reprodução quanto na sobrevivência dos organismos.

As análises de Substâncias Orgânicas constataram presença de organoclorados no PM e no PJ e de Benzo-a-pireno e Tetracloreto de Carbono no PM, acima dos limites máximos recomendados pela CONAMA 357/2005 (Apêndice G4). Ressalta-se que o ribeirão do Matão atravessa plantações de cana.

Com base no IQA calculado para o período de 2004 a 2005 (Apêndice E4), em média as amostras do PM e do PJ apresentaram qualidade Boa. Os ensaios laboratoriais não apresentaram diferença significativa entre os pontos. Vale destacar que, durante o monitoramento, as margens do ribeirão estavam protegidas por vegetação e o ponto de jusante apresentava bom volume de água. Durante as coletas foi constatado carreamento de resíduos sólidos para suas águas, o que pode ter contribuído para os valores elevados de DQO e Coliformes Totais de algumas amostras. Porém, se o lixão continuar operando, a qualidade da água pode ser alterada. 


\subsubsection{Ribeirão Bonito}

\subsubsection{1 Água superficial}

Conforme Apêndice E5, foram coletadas amostras de água no córrego do Tamanduá em Ribeirão Bonito nos dias 09/09/2004, 24/11/2004, 21/03/2005 e 17/06/2005.

Com base nas análises realizadas, foram obtidos valores de pH entre 5,45 e 6,91. Duas amostras de cada ponto apresentaram valores inferiores ao valor mínimo do intervalo recomendado pela Resolução CONAMA 357/2005 para águas superficiais Classe 2. A Temperatura das amostras variou entre 17,2 e $24,2^{\circ} \mathrm{C}$. A variação foi de $7^{\circ} \mathrm{C}$.

As amostras apresentaram valores de Cor Aparente entre 28 e 558UC. Duas amostras do PM e uma amostra do PJ apresentaram valores superiores a $75 \mathrm{UC}$, limite máximo recomendado pela CONAMA 357/2005 para águas superficiais Classe 2. O maior valor foi obtido na segunda amostra do PM, 7,44 vezes o limite da CONAMA. A Turbidez das amostras variou entre 2,57 e 61,9UT. Conforme a Cor, o maior valor foi obtido na segunda amostra do PM. Porém, nenhuma amostra ultrapassou o limite máximo de 100UT, recomendado pela Resolução CONAMA 357/2005.

As amostras não atingiram o limite máximo de $500 \mathrm{mg} / \mathrm{L}$ para os Sólidos Totais Dissolvidos, estabelecido pela Resolução CONAMA 357/2005. As concentrações variaram entre 10 e 75mg/L. A maior concentração foi obtida na última amostra do PM.

As amostras apresentaram teores de Oxigênio Dissolvido entre 1,09 e 6,75mg/L. Todas as amostras do ponto PM apresentaram teores inferiores a $5 \mathrm{mg} / \mathrm{L}$, contrário às recomendações da Resolução CONAMA 357/2005 e do Decreto 8468/1976 do Estado de São Paulo para águas superficiais Classe 2.

As concentrações de Fluoreto nas amostras variaram entre <0,01 e 0,10mg/L. Nenhuma amostra ultrapassou o limite máximo de 1,4mg/L, estabelecido pela Resolução CONAMA 357/2005.

As amostras apresentaram concentrações de Cloreto entre 0,1 e 1,6mg/L, não atingindo o limite máximo de 250mg/L, recomendado pela Resolução CONAMA 357/2005.

Os valores de Condutividade Elétrica das amostras variaram de 7 a $43 \mu \mathrm{S} / \mathrm{cm}$. Conforme CETESB (2005a, p.16), valores acima de $100 \mu \mathrm{S} / \mathrm{cm}$ representam ambientes impactados. Portanto, nenhuma amostra superou este valor.

As amostras apresentaram valores entre 168 e $6 \times 10^{4} \mathrm{UFC} / 100 \mathrm{~mL}$ de Coliformes Totais. A segunda amostra do ponto PM superou 5000 UFC $/ 100 \mathrm{~mL}$, limite máximo recomendado pelo Decreto 8468/1976 do Estado de São Paulo. Para os Coliformes Termotolerantes, a Resolução CONAMA 357/2005 e o Decreto 8468/1976 recomendam o 
limite máximo de $1000 \mathrm{UFC} / 100 \mathrm{~mL}$ para águas superficiais Classe 2. As amostras apresentaram valores entre 2 e 200 UFC/100mL, não atingindo o limite das legislações.

A Resolução CONAMA 357/2005 e o Decreto 8468/1976 do Estado de São Paulo recomendam concentrações inferiores a $5 \mathrm{mg} / \mathrm{L}$ para a DBO das águas superficiais Classe 2 . A segunda amostra do ponto PM superou este valor. As concentrações variaram entre $<1$ e $7 \mathrm{mg} / \mathrm{L}$. As legislações não estabelecem limite para a DQO. Porém, segundo Von Sperling (2006), a água natural não poluída não deve superar 10mg/L. Duas amostras de cada ponto superaram este valor. As amostras apresentaram concentrações entre 3 e $44 \mathrm{mg} / \mathrm{L}$. Como a DBO, a maior concentração foi obtida na segunda amostra do ponto PM. Conforme Valente et al (1997), em trechos de água limpa a DQO não ultrapassa 5mg/L. Com base nesta informação, três amostras do PM e duas do PJ superaram este valor.

A relação $\mathrm{DQO} / \mathrm{DBO}$ foi maior que 4 em duas amostras de cada ponto, indicando fração inerte elevada. Duas amostras do PJ apresentaram relação DQO/DBO intermediária (entre 2,5 e 3,5), indicando fração biodegradável não elevada. Apenas uma amostra do PM apresentou relação DQO/DBO menor que 2,5, indicando fração biodegradável elevada (Von Sperling, 2005, p.94).

As concentrações de Carbono Orgânico Total variaram entre 1,091 e 4,123mg/L. A segunda amostra do PM apresentou a concentração mais elevada. Segundo Libânio (2005, p.35), as águas superficiais podem apresentar COT entre 1 e $20 \mathrm{mg} / \mathrm{L}$. Portanto, nenhuma amostra superou este valor.

Nenhuma amostra ultrapassou $0,5 \mathrm{mg} / \mathrm{L}$, limite máximo estabelecido pelo Decreto 8468/1976 para Nitrogênio Amoniacal, e nenhuma amostra apresentou concentração acima de $3,7 \mathrm{mg} / \mathrm{L}$, limite máximo recomendado pela CONAMA 357/2005. As concentrações variaram entre 0,03 e $0,17 \mathrm{mg} / \mathrm{L}$. A maior concentração foi obtida na segunda amostra do PM.

A Resolução CONAMA 357/2005 recomenda o limite máximo de 2,18mg/L de Nitrogênio Total para ambientes lóticos de águas Classe 2. Nenhuma amostra superou este valor. As concentrações variaram entre 0,12 e $0,84 \mathrm{mg} / \mathrm{L}$. Conforme o Nitrogênio Amoniacal, a maior concentração foi registrada na segunda amostra do PM.

Uma amostra do ponto PM apresentou concentração de Fósforo Total acima do limite máximo de 0,05mg/L, recomendado pela CONAMA 357/2005 para ambientes lóticos de águas Classe 2. As concentrações variaram entre 0,01 e 0,0666mg/L. A maior concentração foi obtida na segunda amostra do PM.

De acordo com as análises de metais, foram obtidas concentrações de Zinco acima do limite máximo de 0,18mg/L, recomendado pela Resolução CONAMA 357/2005, em uma coleta do PM e em todas do PJ. As concentrações variaram entre 0,03 e 4,72mg/L. A maior concentração foi obtida na primeira amostra do PJ, 26,22 vezes o limite da CONAMA. 
Segundo CETESB (2005a), nas águas superficiais as concentrações de Zinco variam em torno de $<0,001$ a $0,10 \mathrm{mg} / \mathrm{L}$.

Foram obtidas concentrações de Ferro acima do limite máximo de 0,3mg/L da CONAMA 357/2005 em uma amostra de cada ponto. As concentrações variaram entre 0,05 e 5,93mg/L. A maior concentração foi obtida na segunda amostra do PM, 19,76 vezes o limite da CONAMA. Uma amostra do ponto PM apresentou concentração de Manganês acima do limite máximo de $0,1 \mathrm{mg} / \mathrm{L}$ da CONAMA 357/2005. As concentrações variaram entre $<0,003$ e 0,36mg/L. A maior concentração foi 3,6 vezes o limite da CONAMA.

Foram obtidas concentrações de Cobre acima do limite máximo de 0,009mg/L da CONAMA 357/2005 em três amostras de cada ponto. As concentrações variaram entre $<0,005$ e $0,55 \mathrm{mg} / \mathrm{L}$. A maior concentração foi obtida na segunda amostra do PM, cerca de 61 vezes o limite da CONAMA. Segundo CETESB (2005a), o Cobre está presente nas águas, naturalmente, em concentrações inferiores a $20 \mu \mathrm{g} / \mathrm{L}$. Os outros parâmetros não superaram os limites das legislações.

Conforme os ensaios ecotoxicológicos (Apêndice F), a amostra do ponto PJ coletada em 09/09/2004 não apresentou efeito tóxico. Na coleta realizada em 24/11/2004, a amostra do PM não apresentou efeito tóxico e a amostra do PJ apresentou toxicidade crônica, causando efeito na reprodução dos organismos.

Os resultados das análises de Substâncias Orgânicas demonstraram presença de organoclorados tanto no PM quanto no PJ, acima dos limites máximos recomendados pela CONAMA 357/2005 (Apêndice G5). Ressalta-se que o córrego do Tamanduá atravessa plantações de cana e está distante do aterro, que possui pequenas dimensões. Por isso, suas águas devem receber influência do canavial.

Com base no IQA calculado para o período de 2004 a 2005 (Apêndice E5), em média as amostras do PM apresentaram qualidade Regular e as amostras do PJ apresentaram qualidade Boa. O córrego apresenta pouco volume de água no ponto PM e grande volume de água no PJ. As margens do ponto PM apresentam vegetação rasteira e as margens do ponto PJ apresentam vegetação densa. Estas características podem ter contribuído para que a qualidade da água do PJ fosse superior a do PM. 


\subsubsection{São Carlos}

\subsubsection{Aterro}

\subsubsection{1 Água subterrânea}

De acordo com Apêndice D4, foram coletadas amostras de água nos poços de monitoramento do aterro de São Carlos nos dias 08/03/2004, 01/07/2004, 09/11/2004 e 10/02/2005.

As amostras de água subterrânea do aterro de São Carlos apresentaram valores de pH entre 3,46 e 5,90, indicando pH ácido. Estes valores estão abaixo do valor mínimo recomendado pela Portaria 518/2004 em todos os poços durante as quatro coletas. No entanto, esta é uma característica natural das águas subterrâneas da região.

Vale lembrar que o aterro de São Carlos está localizado em área de afloramento do Aqüífero Guarani. Assim, segundo CETESB (2004, p.98), o pH do Sistema Aqüífero Guarani é mais ácido na porção livre e mais alcalino na zona confinada, onde os valores de temperatura, salinidade e condutividade elétrica também são mais elevados. No monitoramento realizado por CETESB (2004, p.57), o pH da porção livre do Aqüífero Botucatu variou entre 4,6 e 7,8. Segundo CETESB (2007e, p.74), dos 11 pontos do Sistema Aqüífero Guarani na UGRHI-13 analisados entre 2004 e 2006, o pH variou entre 5 e 9,52.

A Temperatura das amostras variou entre 21,6 e $23,9^{\circ} \mathrm{C}$. A variação foi de $2,3^{\circ} \mathrm{C}$. Os valores estão dentro do intervalo de 22 e $25^{\circ} \mathrm{C}$, apresentado pelas águas de poços em afloramentos do Aqüífero Guarani, segundo Boscardin Borghetti et al (2004, p.154). Conforme CETESB (2004, p.57), as águas subterrâneas da porção livre do Aqüífero Botucatu apresentaram variação de temperatura entre 22 e $34,5^{\circ} \mathrm{C}$. No monitoramento realizado por CETESB (2007e, p.74) no Sistema Aqüífero Guarani na UGRHI-13, os valores variaram entre 16 e $28^{\circ} \mathrm{C}$.

Três amostras dos poços PM e PJ1, todas as amostras do poço PJ2 e duas do PJ3 apresentaram valores de Cor Aparente acima de 15UC, limite máximo recomendado pela Portaria 518/2004. Os valores variaram de 10 a 1425UC. Os maiores valores foram obtidos no PJ2, onde as concentrações variaram entre 201 e $1425 \mathrm{UC}$.

Assim como a Cor, três amostras do poço PM e PJ1, todas as amostras do PJ2 e duas do PJ3 apresentaram valores de Turbidez acima de 5UT, limite máximo recomendado pela legislação. Foram obtidos valores entre 1,28 e 216UT. Os maiores valores foram obtidos no PJ2, onde as concentrações variaram entre 39,7 e 216UT.

As amostras apresentaram concentrações de Sólidos Totais Dissolvidos entre 15 e 2344mg/L. Duas amostras do PJ2 superaram o limite máximo de $1.000 \mathrm{mg} / \mathrm{L}$, estabelecido pela Portaria 518/2004. As concentrações neste poço variaram entre 72 e $2344 \mathrm{mg} / \mathrm{L}$. Para 
fins de comparação, a concentração média de STD no esgoto sanitário é de $700 \mathrm{mg} / \mathrm{L}$ (Von Sperling, 2005, p.112). Concentrações acima de 96mg/L, valor máximo obtido por CETESB (2004, p.57) em águas subterrâneas da porção livre do Aqüífero Botucatu, foram obtidas por duas amostras do PM, três do PJ1 e PJ2 e uma do PJ3. Uma amostra do PJ1 e três do PJ2 apresentaram concentrações acima de 252mg/L, valor máximo obtido por CETESB (2007e, p.74) em águas subterrâneas do Aqüífero Guarani na UGRHI-13. As mesmas amostras apresentaram concentrações superiores a $260 \mathrm{mg} / \mathrm{L}$, valor máximo obtido por CETESB (2007e, p.74) para Sólidos Totais.

Todas as amostras dos poços apresentaram teores de Oxigênio Dissolvido abaixo de $5 \mathrm{mg} / \mathrm{L}$, concentração típica de águas subterrâneas não contaminadas (FUNPEC, 2004, p.76). A concentrações variaram entre 0,34 e $4,13 \mathrm{mg} / \mathrm{L}$.

Foram obtidas concentrações de Sulfato entre $<1$ e 3mg/L, assim nenhuma amostra ultrapassou o limite máximo de 250mg/L, estabelecido pela Portaria 518/2004. A maior concentração foi obtida na segunda amostra do PJ2. Conforme CETESB (2007e, p.74), a concentração máxima obtida foi $<10 \mathrm{mg} / \mathrm{L}$ em amostras de água subterrânea do Aqüífero Guarani na UGRHI-13.

As concentrações de Fluoreto nas amostras variaram entre 0,01 e 0,72mg/L. Portanto, nenhuma amostra ultrapassou o limite máximo de $1,5 \mathrm{mg} / \mathrm{L}$, estabelecido pela Portaria 518/2004. Porém, a segunda amostra do PJ3 superou a concentração máxima de 0,5mg/L, obtida por CETESB (2007e, p.74) em amostras de água subterrânea do Aqüífero Guarani na UGRHI-13.

As concentrações de Cloreto nas amostras variaram entre 0,4 e $680 \mathrm{mg} / \mathrm{L}$. Todas as amostras do poço PJ2 apresentaram concentrações superiores ao limite máximo de $250 \mathrm{mg} / \mathrm{L}$, recomendado pela Portaria 518/2004. As concentrações neste poço variaram entre 452,5 e 680mg/L. Segundo Baccini et al (1987) citado por Belevi e Baccini (1989, p.395), a concentração média de Cloreto em lixiviado de aterros de dez anos é de $1300 \mathrm{mg} / \mathrm{L}$, aproximadamente. Todas as amostras do PJ1 e PJ2 superaram a concentração máxima de 11,5mg/L, encontrada por CETESB (2004, p.57) em águas subterrâneas da porção livre do Aqüífero Botucatu. Com relação ao monitoramento realizado por CETESB (2007e, p.74) em amostras de água subterrânea do Aqüífero Guarani na UGRHI-13, todas as amostras do PJ1 e PJ2 e uma do PJ3 superaram a concentração máxima de 4,7mg/L.

A Portaria 518/2004 não estabelece limite para Condutividade Elétrica. Os valores das amostras variaram de 21 a $3280 \mu \mathrm{S} / \mathrm{cm}$. Uma amostra do PJ1 e PJ3 e todas as amostras do PJ2 superaram o valor máximo de $186 \mu \mathrm{S} / \mathrm{cm}$ encontrado por CETESB (2007e, p.74) em águas subterrâneas do Aqüífero Guarani na UGRHI-13. As amostras do PJ2 variaram entre 1970 e $3280 \mu \mathrm{S} / \mathrm{cm}$. Vale ressaltar que, apesar do poço PM ser mais profundo, apresentou CE entre 21 e $49 \mu \mathrm{S} / \mathrm{cm}$, inferior aos outros poços. Duas amostras do PJ1, todas as 
amostras do PJ2 e uma amostra do PJ3 superaram o valor máximo de $136 \mu \mathrm{S} / \mathrm{cm}$ encontrado por CETESB (2004, p.57) em águas subterrâneas da porção livre do Aqüífero Botucatu.

As amostras do PJ1 apresentaram Salinidade de 4 e 2\% na primeira e última coleta, respectivamente. O PJ2 apresentou Salinidade em todas as coletas, entre 9 e 16\%. Portanto, estas amostras podem ser classificadas como águas salobras (salinidade superior a $0,5 \%$ e inferior a 30\%), conforme Resolução CONAMA 357/2005. A Portaria 518/2004 não estabelece limite para este parâmetro. Porém, segundo CETESB (2004, p.37), os arenitos que formam o Aqüífero Guarani não são ricos em sais e minerais.

Os valores de Coliformes Totais foram elevados, acima do limite máximo de 5000UFC/100mL, recomendado pelo Decreto 8468/1976 do Estado de São Paulo, em duas amostras dos poços PM e PJ1 e em três amostras do poço PJ2. Os valores variaram entre $1,45 \times 10^{2}$ e $1,43 \times 10^{5} \mathrm{UFC} / 100 \mathrm{~mL}$. Apenas a quarta amostra do PJ2 superou o limite máximo de 1000 UFC $/ 100 \mathrm{~mL}$ de Coliformes Termotolerantes, recomendado pela CONAMA 357/2005. Os valores variaram entre 1 e 1480UFC/100mL. Segundo CETESB (2007e, p.74), em águas subterrâneas do Aqüífero Guarani na UGRHI-13 foi obtido $<1 \mathrm{P} / \mathrm{A}^{7} / 100 \mathrm{~mL}$ para Coliformes Totais e não foram detectados Coliformes Termotolerantes. Em águas subterrâneas da porção livre do Aqüífero Botucatu, o valor máximo encontrado foi 9NCMF/100mg/L de Coliformes Totais e não foram detectados Coliformes Termotolerantes (CETESB, 2004, p.58).

A Portaria 518/2004 não estabelece limite para a DBO. As concentrações variaram entre <1 e 76mg/L. Uma amostra do poço PM, três amostras do poço PJ1 e todas as amostras do poço PJ2 apresentaram DBO acima de $5 \mathrm{mg} / \mathrm{L}$, limite máximo recomendado pela Resolução CONAMA 357/2005 para águas superficiais Classe 2. Todas as amostras do PJ2 apresentaram DBO acima de 10mg/L, indicando descarga efluente, segundo EMBRAPA (2004, p.27).

As concentrações de DQO variaram entre 5 e 200mg/L. Três amostras do PM e todas as amostras dos outros poços superaram $5 \mathrm{mg} / \mathrm{L}$, concentração encontrada por Valente et al (1997) em águas limpas. Três amostras do PM e PJ1 e todas as amostras dos outros poços superaram 10mg/L, concentração máxima indicada por Von Sperling (2006) para a água natural não poluída.

A relação DQO/DBO foi elevada (maior que 4) em todas as amostras coletadas nos poços PM, PJ1 e PJ3 e em três amostras do poço PJ2, indicando fração inerte elevada. Apenas a quarta amostra do PJ2 apresentou relação DQO/DBO igual a 2,6, indicando fração biodegradável não elevada (Von Sperling, 2005, p.94).

\footnotetext{
${ }^{7}$ P/A/100mL: Presença ou Ausência de Escherichia coli em 100mL
} 
As amostras apresentaram concentrações de Carbono Orgânico Total entre 1,07 e 33,8mg/L. Segundo Libânio (2005, p.35), as águas subterrâneas podem apresentar concentração de COT entre 0,1 e 2,0mg/L. Duas amostras do PM e PJ1, todas as amostras do PJ2 e uma do PJ3 superaram 2,0mg/L. As maiores concentrações de COT foram obtidas nas amostras do PJ2, onde os valores variaram entre 13,61 e 33,80mg/L.

As amostras apresentaram concentrações entre 0,01 e $15 \mathrm{mg} / \mathrm{L}$ de Nitrogênio Amoniacal. Uma amostra do PM e duas amostras do PJ2 apresentaram concentrações de Nitrogênio Amoniacal acima de $1,5 \mathrm{mg} / \mathrm{L}$, limite máximo recomendado pela Portaria $518 / 2004$, indicando que pode estar ocorrendo contaminação nestes poços. A maior concentração obtida foi $15 \mathrm{mg} / \mathrm{L}$ na última coleta do poço $\mathrm{PJ} 2$, dez vezes o limite da legislação. Uma amostra do PM, duas do PJ1 e três do PJ2 apresentaram concentrações superiores a 0,5mg/L, limite máximo obtido por CETESB (2007e, p.74) em águas subterrâneas do Aqüífero Guarani na UGRHI-13.

A Portaria 518/2004 não estabelece limite para Nitrogênio Total, porém a concentração máxima encontrada por CETESB (2004, p.59) em águas subterrâneas do Aqüífero Guarani foi $1,01 \mathrm{mg} / \mathrm{L}$, bem como na porção livre do Aqüífero Botucatu. As amostras apresentaram concentrações entre 0 e $71 \mathrm{mg} / \mathrm{L}$. Uma amostra do PM e duas do PJ1 e PJ2 apresentaram concentrações acima de 1,01. A maior concentração foi obtida no PJ2, a qual atingiu a concentração do esgoto sanitário não tratado, entre 20 a $70 \mathrm{mg} / \mathrm{L}$, segundo Metcalf e Eddy (2003, p.186). Uma amostra do PM e duas do PJ1 e PJ2 apresentaram concentrações superiores a $0,6 \mathrm{mg} / \mathrm{L}$, concentração máxima obtida por CETESB (2007e, p.74) em águas subterrâneas do Aqüífero Guarani na UGRHI-13.

As amostras apresentaram concentrações de Fósforo Total entre 0,0066 e 5,70mg/L. A Portaria 518/2004 não estabelece limite para este parâmetro. Segundo EMBRAPA (2004, p.29), as águas subterrâneas apresentam concentrações médias de 0,02mg/L. Duas amostras do PM e PJ3 e três do PJ1 e PJ2 apresentaram concentrações acima de $0,02 \mathrm{mg} / \mathrm{L}$. A maior concentração foi obtida no poço PJ3.

De acordo com a análise de metais, foram obtidas concentrações entre <0,005 e 89mg/L de Ferro. Todas as amostras do PM, três do PJ1 e PJ2 e uma do PJ3 superaram o limite máximo de 0,3mg/L, recomendado pela Portaria 518/2004. O Manganês variou entre $<0,003$ e 2,72mg/L. Todas as amostras do PJ1 e três do PJ2 superaram o limite máximo de $0,1 \mathrm{mg} / \mathrm{L}$, recomendado pela legislação. As primeiras amostras dos poços PJ2 e PJ3 apresentaram concentrações de Cromo Total superiores ao limite máximo de 0,05mg/L, estabelecido pela Portaria 518/2004. Uma amostra do PJ1 apresentou concentração de Alumínio 18 vezes superior ao limite de $0,2 \mathrm{mg} / \mathrm{L}$, estabelecido pela legislação. Os demais parâmetros não atingiram valores preocupantes. 
Conforme CETESB (2007e, p.74), foram obtidos concentrações máximas de 0,18 de Ferro, 0,18 de Manganês, 0,01 de Cromo Total e 0,15 de Alumínio em águas subterrâneas do Aqüífero Guarani na UGRHI-13. Todas as amostras do PM, três do PJ1 e PJ2 e duas do PJ3 superaram a concentração do Ferro; três amostras do PJ1 e PJ2 superaram a concentração do Manganês; duas amostras do PJ2 e uma do PJ3 superaram a concentração do Cromo e uma amostra do PJ1 e do PJ2 superaram a concentração do Alumínio.

Com base nos ensaios ecotoxicológicos (Apêndice F), na coleta de 08/03/2004, todas as amostras apresentaram toxicidade aguda. As amostras do PM e PJ3 causaram imobilidade em $50 \%$ dos organismos e as amostras do PJ1 e PJ2 causaram imobilidade em $100 \%$ dos organismos, como em 09/11/2004. Nesta data, as amostras do PM apresentaram indício de toxicidade aguda, provocando imobilidade em $45 \%$ dos organismos, bem como apresentaram toxicidade crônica, com efeito na sobrevivência.

$\mathrm{O} \mathrm{pH}$ das amostras de água pode ter sido influenciado pelo $\mathrm{pH}$ do solo. Em análises realizadas com solo do próprio aterro foi obtido pH entre 5,6 e 5,7 (Prefeitura Municipal de São Carlos, 1989, p.27).

As elevadas concentrações de Ferro, Manganês, Alumínio e Cromo, provavelmente são provenientes do tipo de solo do local. As concentrações de Ferro foram mais elevadas em relação aos outros metais, o que pode ter contribuído para a coloração laranja da água. Conforme Braga et al (2005, p.136), Latossolos possuem elevados teores de óxidos de Ferro e Alumínio.

Com base na caracterização química realizada com amostras de solo do aterro, foram detectados traços de Alumínio (Prefeitura Municipal de São Carlos, 1989, p.27). Segundo Almeida (2005, p.65), foram obtidos teores mais elevados de Ferro, Cobre, Zinco e Manganês e as concentrações de Cromo foram baixas. De acordo com Silva e Cotta (2004), amostras de solo coletadas no município de São Carlos em diferentes profundidades apresentaram teores mais elevados de Alumínio, Ferro e Manganês, conforme Tabela 31. 
Tabela 31 - Determinação de metais em amostras de solo de São Carlos

\begin{tabular}{|c|c|c|c|c|c|c|c|}
\hline \multirow{2}{*}{$\begin{array}{l}\text { Metais } \\
(\mathrm{mg} / \mathrm{kg})\end{array}$} & \multicolumn{3}{|c|}{$\begin{array}{l}\text { Profundidade }(\mathbf{c m}) \\
\text { (Silva e Cotta, 2004) }\end{array}$} & \multirow{2}{*}{$\begin{array}{c}\text { Aterro } \\
\text { de São } \\
\text { Carlos } \\
\text { (Almeida, } \\
2005)\end{array}$} & \multicolumn{3}{|c|}{$\begin{array}{l}\text { Valores orientadores para solos e águas } \\
\text { subterrâneas no Estado de São Paulo* }\end{array}$} \\
\hline & 0 a 10 & 10 a 20 & 20 a 30 & & \begin{tabular}{|c|} 
Valores de \\
Referência de \\
Qualidade $^{* *}$
\end{tabular} & $\begin{array}{l}\text { Valores de } \\
\text { Prevenção** }\end{array}$ & $\begin{array}{l}\text { Valores de } \\
\text { Intervenção } \\
\text { (Agrícola)** }\end{array}$ \\
\hline Alumínio & 750,34 & 861,14 & 775,24 & - & - & - & - \\
\hline Ferro & 246,64 & 363,59 & 427,32 & 5500,0 & - & - & - \\
\hline Cobre & 9,49 & 10,54 & 10,28 & 50,0 & 35 & 60 & 200 \\
\hline Zinco & 8,97 & 7,50 & 7,04 & 32,0 & 60 & 300 & 450 \\
\hline Manganês & 154,41 & 88,59 & 68,11 & 29,0 & - & - & - \\
\hline Chumbo & 0,47 & 0,36 & - & $<0,1$ & 17 & 72 & 180 \\
\hline Níquel & - & - & - & $<0,4$ & 13 & 30 & 70 \\
\hline Cádmio & - & - & - & $<0,3$ & $<0,5$ & 1,3 & 3 \\
\hline Cromo Total & - & - & - & $<0,25$ & 40 & 75 & 150 \\
\hline
\end{tabular}

$\square$ Valor acima dos Valores de Referência de Qualidade (VRQ)

* CETESB. 2004. Relatório de Qualidade das Águas Subterrâneas no Estado de São Paulo 2001-2003

** CETESB. 2005b. Decisão da Diretoria n 195-2005-E, de 23 de novembro de 2005

Com base no monitoramento, está ocorrendo migração de contaminantes em direção ao PM, provavelmente, por influência de empreendimentos no entorno do aterro. Com isso, o poço PM merece atenção e recomenda-se que outros estudos continuem sendo realizados no aterro e no seu entorno, a fim de se encontrar as causas da alteração da qualidade das águas subterrâneas.

Os resultados indicam que há uma pluma de contaminantes se movendo principalmente em direção ao poço PJ1 e PJ2. Com base no monitoramento realizado, houve contaminação por cloreto nas amostras de água subterrânea do poço PJ2. As amostras deste poço apresentaram ainda elevados valores de Cor, Turbidez, DBO, DQO, Nitrogênio Amoniacal, COT, STD, Ferro e exalavam odor forte. Estes fatores, associados às elevadas concentrações de metais podem ter provocado o efeito tóxico nas amostras. Assim, os resultados indicam que o sentido preferencial do fluxo subterrâneo no aterro de São Carlos é para norte e noroeste, ou seja, na direção do córrego do Galdino.

\subsubsection{2 Água superficial}

Conforme Apêndice E6, foram coletadas amostras de água no córrego do Galdino em São Carlos nos dias 08/03/2004, 01/07/2004, 09/11/2004 e 10/02/2005.

Com base nas análises realizadas, foram obtidos valores de pH entre 5,08 e 6,54. A primeira amostra de cada ponto apresentou valores inferiores ao valor mínimo do intervalo recomendado pela Resolução CONAMA 357/2005 para águas superficiais Classe 2. A Temperatura das amostras variou entre 18 e $25,1^{\circ} \mathrm{C}$. A variação foi de $7,1^{\circ} \mathrm{C}$. 
As amostras apresentaram valores de Cor Aparente entre 66 e 596UC. Duas amostras do PM e em todas as amostras do PJ apresentaram valores superiores a 75UC, limite máximo recomendado pela CONAMA 357/2005 para águas superficiais Classe 2. O maior valor foi obtido na primeira amostra do PJ, 7,94 vezes o limite da CONAMA. A Turbidez das amostras variou entre 9,32 e 68,9UT. Conforme a Cor, o maior valor foi obtido na primeira amostra do PJ. Porém, nenhuma amostra ultrapassou o limite máximo de 100UT, recomendado pela Resolução CONAMA 357/2005.

As amostras não atingiram o limite máximo de $500 \mathrm{mg} / \mathrm{L}$ para os Sólidos Totais Dissolvidos, estabelecido pela Resolução CONAMA 357/2005. As concentrações variaram entre 15 e 123mg/L. A maior concentração foi obtida na terceira amostra do PJ.

As amostras apresentaram teores de Oxigênio Dissolvido entre 2,12 e 8,56mg/L. Todas as amostras do ponto $\mathrm{PJ}$ apresentaram teores inferiores a $5 \mathrm{mg} / \mathrm{L}$, contrário às recomendações da Resolução CONAMA 357/2005 e do Decreto 8468/1976 do Estado de São Paulo para águas Classe 2.

As concentrações de Fluoreto nas amostras variaram entre 0,03 e 0,11mg/L. Nenhuma amostra ultrapassou o limite máximo de 1,4mg/L, estabelecido pela Resolução CONAMA 357/2005.

As amostras apresentaram concentrações de Cloreto entre 0,4 e 11,3mg/L, não atingindo o limite máximo de 250mg/L, recomendado pela Resolução CONAMA 357/2005.

Os valores de Condutividade Elétrica das amostras variaram de 12 a $151 \mu \mathrm{S} / \mathrm{cm}$. Conforme CETESB (2005a, p.16), valores acima de $100 \mu \mathrm{S} / \mathrm{cm}$ representam ambientes impactados. Portanto, a terceira amostra do PJ superou este valor.

As amostras apresentaram valores entre $1,3 \times 10^{3}$ e $1,6 \times 10^{4} \mathrm{UFC} / 100 \mathrm{~mL}$ de Coliformes Totais. Duas amostras do PJ superaram 5000UFC/100mL, limite máximo recomendado pelo Decreto 8468/1976 do Estado de São Paulo. Para os Coliformes Termotolerantes, a Resolução CONAMA 357/2005 e o Decreto 8468/1976 recomendam o limite máximo de $1000 \mathrm{UFC} / 100 \mathrm{~mL}$ para águas superficiais Classe 2. As amostras apresentaram valores entre $7,0 \times 10^{1}$ e 3550 UFC/100mL. Apenas a segunda amostra do PJ superou o limite das legislações.

A Resolução CONAMA 357/2005 e o Decreto 8468/1976 do Estado de São Paulo recomendam concentrações inferiores a $5 \mathrm{mg} / \mathrm{L}$ para a DBO das águas superficiais Classe 2 . Nenhuma amostra superou este valor. As concentrações variaram entre $<1$ e $5 \mathrm{mg} / \mathrm{L}$. As legislações não estabelecem limite para a DQO. Porém, segundo Von Sperling (2006), a água natural não poluída não deve superar $10 \mathrm{mg} / \mathrm{L}$. Duas amostras do PM e todas do PJ superaram este valor. As amostras apresentaram concentrações entre 6 e 47mg/L. Conforme Valente et al (1997), em trechos de água limpa a DQO não ultrapassa 5mg/L. Com base nesta informação, todas as amostras superaram este valor. 
A relação DQO/DBO foi elevada (maior que 4) em todas as amostras coletadas, indicando fração inerte elevada (Von Sperling, 2005, p.94).

As concentrações de Carbono Orgânico Total variaram entre 3,555 e 10,82mg/L. A primeira amostra do PM apresentou a concentração mais elevada. Segundo Libânio (2005, p.35), as águas superficiais podem apresentar COT entre 1 e $20 \mathrm{mg} / \mathrm{L}$. Portanto, nenhuma amostra superou este valor.

Uma amostra ultrapassou o limite máximo de 3,7mg/L de Nitrogênio Amoniacal, estabelecido pela CONAMA 357/2005. As concentrações variaram entre 0,02 e 5,25mg/L. A maior concentração foi obtida na terceira amostra do PJ, indicando contaminação recente.

A Resolução CONAMA 357/2005 recomenda o limite máximo de 2,18mg/L de Nitrogênio Total para ambientes lóticos de águas Classe 2. As amostras analisadas (uma do PM e duas do PJ) superaram este valor. As concentrações variaram entre 2,75 e $27,20 \mathrm{mg} / \mathrm{L}$. Conforme o Nitrogênio Amoniacal, a maior concentração foi registrada na terceira amostra do PJ.

Duas amostras do PJ apresentaram concentração de Fósforo Total acima do limite máximo de 0,05mg/L, recomendado pela CONAMA 357/2005 para ambientes lóticos de águas Classe 2. As concentrações variaram entre 0,0076 e 0,14mg/L. A maior concentração foi obtida na segunda amostra do PJ, 2,8 vezes o limite.

De acordo com as análises de metais, foram obtidas concentrações de Zinco acima do limite máximo de $0,18 \mathrm{mg} / \mathrm{L}$, recomendado pela Resolução CONAMA 357/2005, em duas amostras do ponto PJ. As concentrações variaram entre <0,002 e 1,00mg/L. A maior concentração foi obtida na terceira amostra do PJ, 5,55 vezes o limite da CONAMA. Segundo CETESB (2005a), nas águas superficiais as concentrações variam em torno de $<0,001$ a $0,10 \mathrm{mg} / \mathrm{L}$.

Foram obtidas concentrações de Ferro acima do limite máximo de $0,3 \mathrm{mg} / \mathrm{L}$ da CONAMA 357/2005 em três amostras de cada ponto. As concentrações variaram entre $<0,005$ e 4,36mg/L. Conforme o Zinco, a maior concentração foi obtida na terceira amostra do PJ, 14,53 vezes o limite da CONAMA. A mesma amostra apresentou concentração de Manganês acima do limite máximo de $0,1 \mathrm{mg} / \mathrm{L}$ da CONAMA 357/2005. As concentrações variaram entre $<0,003$ e $0,39 \mathrm{mg} / \mathrm{L}$. A maior concentração obtida foi 3,9 vezes o limite da CONAMA.

Foram obtidas concentrações de Cobre acima do limite máximo de 0,009mg/L da CONAMA 357/2005 em uma amostra do PM e em duas amostras do PJ. As concentrações variaram entre $<0,005$ e $0,79 \mathrm{mg} / \mathrm{L}$. A maior concentração foi obtida na primeira amostra do PJ, cerca de 87,77 vezes o limite da CONAMA. Segundo CETESB (2005a), o Cobre está presente nas águas, naturalmente, em concentrações inferiores a $20 \mu \mathrm{g} / \mathrm{L}$. Os outros parâmetros não superaram os limites das legislações. 
Conforme os ensaios ecotoxicológicos (Apêndice F), as amostras coletadas em 08/03/2004 e 09/11/2004 não apresentaram efeito tóxico.

As análises de Substâncias Orgânicas constataram presença de organoclorados tanto no PM quanto no PJ, acima dos limites recomendados pela CONAMA 357/2005 (Apêndice G6). Ressalta-se que o córrego atravessa plantação de cana e pasto.

Com base no IQA calculado para o período de 2004 a 2005 (Apêndice E6), em média as amostras do PM apresentaram qualidade Boa e as amostras do PJ apresentaram qualidade Regular.

Com base nesses resultados pode-se inferir que ocorreu contaminação das águas desse córrego durante o período de monitoramento, pois a maioria dos parâmetros apresentou concentração superior às estabelecidas pela CONAMA 357/2005 no ponto PJ. Porém, não se pode afirmar que a alteração da qualidade das águas ocorreu devido à proximidade com o aterro, pois há pastagem de animais no entorno do córrego, o que pode ter contribuído para aumento da carga orgânica, coliformes e nutrientes na água. O PM pode ter sido influenciado por outros empreendimentos no entorno do aterro.

\subsubsection{Antigo Lixão}

\subsubsection{1 Água subterrânea}

Conforme Apêndice D5, foram coletadas amostras de água nos poços de monitoramento do antigo lixão de São Carlos nos dias 09/03/2004, 01/07/2004, 08/11/2004 e 10/02/2005.

As amostras de água subterrânea do antigo lixão de São Carlos apresentaram pH entre 4,28 e 6,0. As amostras dos poços PM e PJ1 e três amostras do PJ2 e PJ3 apresentaram valores abaixo do valor mínimo recomendado pela Portaria 518/2004 durante as quatro coletas. Porém, esta é uma característica natural das águas subterrâneas da região. O antigo lixão de São Carlos está localizado em área de afloramento do Aqüífero Guarani. Segundo CETESB (2004, p.98), o pH do Sistema Aqüífero Guarani é mais ácido na porção livre. No monitoramento realizado por CETESB (2004, p.57), o pH da porção livre do Aqüífero Botucatu variou entre 4,6 e 7,8. Segundo CETESB (2007e, p.74), dos 11 pontos do Sistema Aqüífero Guarani na UGRHI-13 analisados entre 2004 e 2006, o pH variou entre 5 e 9,52 .

A Temperatura das amostras variou entre 22,9 e $26,7^{\circ} \mathrm{C}$. A variação foi de $3,8^{\circ} \mathrm{C}$. Os valores estão dentro ao intervalo de 22 a $34,5^{\circ} \mathrm{C}$, apresentado pelas águas subterrâneas da porção livre do Aqüífero Botucatu pertencente ao Sistema Aqüífero Guarani, conforme 
CETESB (2004, p.57). No monitoramento realizado por CETESB (2007e, p.74) no Sistema Aqüífero Guarani na UGRHI-13, os valores variaram entre 16 e $28^{\circ} \mathrm{C}$.

Três amostras do PM e PJ2, todas do PJ1 e PJ2 e duas do PJ3 apresentaram Cor Aparente acima de 15UC, limite máximo recomendado pela Portaria 518/2004. Os valores variaram de 4 a 925UC. A segunda amostra do PM e a segunda amostra do PJ1 apresentaram os maiores valores, 925 e $825 \mathrm{UC}$ respectivamente.

Conforme a Cor, três amostras do PM e PJ2, todas do PJ1 e PJ2 e duas do PJ3 apresentaram valores de Turbidez acima de 5UT, limite máximo recomendado pela legislação. Foram obtidos valores entre 1,68 e 271UT. A segunda amostra do PM e a segunda amostra do PJ1 apresentaram os maiores valores, 271 e 258UT respectivamente.

As amostras apresentaram concentrações de Sólidos Totais Dissolvidos entre $61 \mathrm{e}$ $1871 \mathrm{mg} / \mathrm{L}$. A quarta amostra do PJ2 superou o limite máximo de $1.000 \mathrm{mg} / \mathrm{L}$, estabelecido pela Portaria 518/2004, bem como a concentração média de STD no esgoto sanitário que é de 700mg/L (Von Sperling, 2005, p.112). As concentrações no PJ2 variaram entre 71 e $1871 \mathrm{mg} / \mathrm{L}$. Uma amostra do PJ1 e do PJ2 apresentou concentração acima de 252mg/L, valor máximo obtido por CETESB (2007e, p.74) em águas subterrâneas do Aqüífero Guarani na UGRHI-13. Concentrações acima de $96 \mathrm{mg} / \mathrm{L}$, valor máximo obtido por CETESB (2004, p.57) em águas subterrâneas da porção livre do Aqüífero Botucatu, foram obtidas por uma amostra do PM, duas do PJ1, três do PJ2 e uma do PJ3. Uma amostra do PM e PJ1 e duas do PJ2 apresentaram concentrações acima de $260 \mathrm{mg} / \mathrm{L}$ para Sólidos Totais, valor máximo obtido por CETESB (2007e, p.74).

Todas as amostras dos poços apresentaram teores de Oxigênio Dissolvido abaixo de 5mg/L, concentração típica de águas subterrâneas não contaminadas (FUNPEC, 2004, p.76), com exceção da última amostra do PM. Os teores variaram entre 0,16 e 5,06mg/L.

Foram obtidas concentrações de Sulfato entre $<1$ e $6 \mathrm{mg} / \mathrm{L}$, dessa forma nenhuma amostra ultrapassou o limite máximo de $250 \mathrm{mg} / \mathrm{L}$, estabelecido pela Portaria 518/2004. A maior concentração foi obtida na primeira amostra do PJ1. Conforme CETESB (2007e, p.74), a concentração máxima obtida foi $<10 \mathrm{mg} / \mathrm{L}$ em amostras de água subterrânea do Aqüífero Guarani na UGRHI-13.

As concentrações de Fluoreto nas amostras variaram entre <0,01 e 0,46mg/L. Portanto, nenhuma amostra ultrapassou o limite de $1,5 \mathrm{mg} / \mathrm{L}$, estabelecido pela Portaria $518 / 2004$, bem como não superou a concentração máxima de $0,5 \mathrm{mg} / \mathrm{L}$, obtida por CETESB (2007e, p.74) em amostras de água subterrânea do Aqüífero Guarani na UGRHI-13.

As concentrações de Cloreto nas amostras variaram entre 0,5 e $51 \mathrm{mg} / \mathrm{L}$. Assim, nenhuma amostra ultrapassou o limite máximo de $250 \mathrm{mg} / \mathrm{L}$, estabelecido pela Portaria 518/2004. A maior concentração foi obtida na terceira amostra do PJ2. Uma amostra do PJ1 e três amostras do PJ2 superaram a concentração máxima de 11,5mg/L, encontrada por 
CETESB (2004, p.57) em águas subterrâneas da porção livre do Aqüífero Botucatu. Duas amostras do PJ1 e três do PJ2 superaram a concentração máxima de $4,7 \mathrm{mg} / \mathrm{L}$, obtida por CETESB (2007e, p.74) em amostras de água subterrânea do Aqüífero Guarani na UGRHI13.

Os valores de Condutividade Elétrica das amostras variaram de 28 a $238 \mu \mathrm{S} / \mathrm{cm}$. Duas amostras do PJ1 e todas as amostras do PJ2 superaram o valor máximo de $136 \mu \mathrm{S} / \mathrm{cm}$ encontrado por CETESB (2004, p.57) em águas subterrâneas da porção livre do Aqüífero Botucatu. Os poços PJ1 e PJ2 apresentaram valores médios de 154 e $191 \mu \mathrm{S} / \mathrm{cm}$, respectivamente. Com base no monitoramento realizado durante fevereiro a julho de 1996 por Contin Neto et al (1997, p.559), os poços L30 (PJ1) e L26 (PJ2) apresentaram valores de 140 e $283 \mu \mathrm{S} / \mathrm{cm}$, respectivamente. Uma amostra do PJ1 e duas do PJ2 superaram o

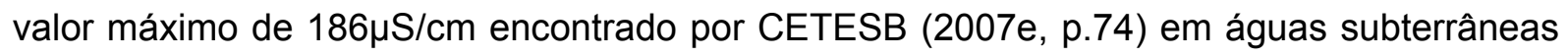
do Aqüífero Guarani na UGRHI-13.

Os valores de Coliformes Totais variaram entre $1,75 \times 10^{2}$ e $3,0 \times 10^{5} \mathrm{UFC} / 100 \mathrm{~mL}$. Os números foram elevados, acima do limite máximo de $5000 \mathrm{UFC} / 100 \mathrm{~mL}$, em uma amostra do PM, PJ1 e PJ2. Nenhuma amostra atingiu o limite máximo de $1.000 \mathrm{FC} / 100 \mathrm{~mL}$ de Coliformes Termotolerantes, recomendado pela CONAMA 357/2005 para águas

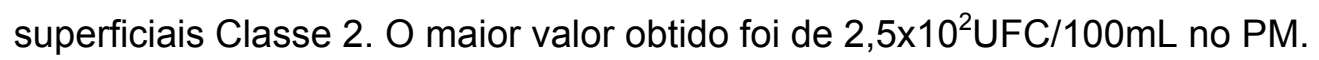

Bossolan (1993, p.62 e 86) constatou forte influência de Coliformes Totais e Termotolerantes na água subterrânea do antigo lixão. Os indicadores bacteriológicos de poluição Termotolerante estavam acima do permitido pela legislação, impossibilitando o consumo de água sem tratamento. Porém, a autora ressalta que os resultados podem não terem sido influenciados exclusivamente pelo lixão, a matéria orgânica gerada pela pastagem de gado próxima ao local pode ter contribuído.

Segundo CETESB (2007e, p.74), em águas subterrâneas do Aqüífero Guarani na UGRHI-13 foi obtido <1P/A/100mL para Coliformes Totais e não foram detectados Coliformes Termotolerantes. Em águas subterrâneas da porção livre do Aqüífero Botucatu, o valor máximo encontrado foi $9 \mathrm{NCMF} / 100 \mathrm{mg} / \mathrm{L}$ de Coliformes Totais e não foram detectados Coliformes Termotolerantes (CETESB, 2004, p.58).

As concentrações de DBO variaram entre $<1$ e $17 \mathrm{mg} / \mathrm{L}$. Uma amostra do PM, PJ1 e PJ2 apresentaram DBO acima de $5 \mathrm{mg} / \mathrm{L}$, limite máximo recomendado pela Resolução CONAMA 357/2005 para águas superficiais Classe 2. Apenas uma amostra do PJ1 superou $10 \mathrm{mg} / \mathrm{L}$, indicando descarga efluente, segundo EMBRAPA (2004, p.27).

As concentrações de DQO variaram entre 6 e 56mg/L. Três amostras do PM e todas as amostras dos outros poços superaram $5 \mathrm{mg} / \mathrm{L}$, concentração encontrada por Valente et al (1997) em águas limpas. Três amostras do PM e PJ1, todas as amostras do PJ2 e duas do PJ3 superaram 10mg/L, concentração máxima indicada por Von Sperling (2006) para a 
água natural não poluída. A maior concentração foi obtida no PM, adotado como poço controle por estar localizado a montante do antigo depósito de resíduos, onde as amostras deveriam apresentar as menores concentrações.

A relação DQO/DBO foi elevada (maior que 4) em todas as amostras coletadas, indicando fração inerte elevada (Von Sperling, 2005, p.94).

As amostras apresentaram concentrações de Carbono Orgânico Total entre 0,634 e 10,39mg/L. Segundo Libânio (2005, p.35), as águas subterrâneas podem apresentar concentração de COT entre 0,1 e 2,0mg/L. Uma amostra do PM, duas do PJ1, três do PJ2 e uma do PJ3 superaram 2,0mg/L. Segundo Baccini et al (1987) citado por Belevi e Baccini (1989, p.396-397), com base em dados de quatro aterros na Suíça, após dez anos o aterro é hidrologicamente estabilizado, acima deste período os compostos orgânicos podem ser os mais críticos, pois vários séculos podem ser necessários para que estes compostos, presentes no lixiviado, atinjam o nível das águas superficiais.

Todas as amostras dos poços PJ1 e PJ2 apresentaram concentrações elevadas de Nitrogênio Amoniacal, superando o limite máximo de $1,5 \mathrm{mg} / \mathrm{L}$ recomendado pela legislação, indicando que pode estar ocorrendo contaminação nestes poços. As mesmas amostras apresentaram concentrações superiores a $0,5 \mathrm{mg} / \mathrm{L}$, valor máximo obtido por CETESB (2007e, p.74) em águas subterrâneas do Aqüífero Guarani na UGRHI-13. A maior concentração obtida foi $3,26 \mathrm{mg} / \mathrm{L}$ na terceira coleta do poço PJ2, duas vezes o limite da Portaria 518/2004.

As amostras apresentaram concentrações de Nitrogênio Total entre 0,33 e 16,3mg/L. A concentração máxima encontrada por CETESB (2004, p.59) em águas subterrâneas do Aqüífero Guarani foi $1,01 \mathrm{mg} / \mathrm{L}$, bem como na porção livre do Aqüífero Botucatu. As amostras do PJ1 e PJ2 apresentaram concentrações acima deste valor, bem como superiores a 0,6mg/L, concentração máxima obtida por CETESB (2007e, p.74) em águas subterrâneas do Aqüífero Guarani na UGRHI-13.

As amostras apresentaram concentrações de Fósforo Total entre 0,0126 e 2,4mg/L. Segundo EMBRAPA (2004, p.29), as águas subterrâneas apresentam concentrações médias de 0,02mg/L. Três amostras do PM e PJ3, uma do PJ1 e duas do PJ2 apresentaram concentrações acima de 0,02mg/L. A maior concentração foi obtida no PM, 120 vezes o valor recomendado pela EMBRAPA. Conforme Tandel (1998, p.91), o lixiviado é rico em Fósforo. Com base em Baccini (1987) citado por Belevi e Baccini (1989, p.395), a concentração média de Fósforo em lixiviado de aterros com dez anos é de 6,8mg/L.

De acordo com a análise de metais, foram obtidas concentrações entre 0,12 e 14,69mg/L de Ferro. As amostras do PM e PJ1, três do PJ2 e duas do PJ3 superaram o limite máximo de 0,3mg/L recomendado pela Portaria 518/2004. O Manganês variou entre $<0,003$ e $0,37 \mathrm{mg} / \mathrm{L}$. Todas as amostras do PJ1 e três do PJ2 superaram o limite máximo de 
0,1 mg/L recomendado pela legislação. A primeira amostra do PJ3 apresentou concentração de Cromo Total superior ao limite máximo permissível de 0,05mg/L estabelecido pela Portaria 518/2004. Os demais parâmetros não atingiram valores preocupantes.

Conforme CETESB (2007e, p.74), foram obtidas concentrações máximas de 0,18 de Ferro, 0,18 de Manganês, 0,01 de Cromo Total e 0,15 de Alumínio em águas subterrâneas do Aqüífero Guarani na UGRHI-13. Todas as amostras do PM e do PJ1 e três do PJ2 e do PJ3 superaram a concentração do Ferro; duas amostras do PJ1 e PJ2 superaram a concentração do Manganês; uma amostra do PJ3 superou a concentração do Cromo.

Com base nos ensaios ecotoxicológicos (Apêndice F), na coleta de 09/03/2004, as amostras dos poços PJ1 e PJ2 apresentaram toxicidade aguda, as primeiras causaram imobilidade em $100 \%$ dos organismos e as segundas causaram imobilidade em $95 \%$ dos organismos. As amostras do PM e PJ3 não apresentaram efeito tóxico. Na coleta de 08/11/2004, as amostras dos poços PJ1 e PJ2 apresentaram toxicidade aguda, as primeiras causaram imobilidade em $90 \%$ dos organismos e as segundas causaram imobilidade em $100 \%$ dos organismos. As amostras do PJ3 apresentaram indício de toxicidade aguda, provocando imobilidade em $30 \%$ dos organismos.

Com base no monitoramento realizado, o antigo lixão apresentou uma tendência à estabilização, apresentando concentrações inferiores ao aterro que está em funcionamento em São Carlos, onde os valores de Condutividade Elétrica, Coliformes Termotolerantes, Salinidade, Cloreto, Fósforo, Nitrogênio Amoniacal, Nitrogênio Total, DBO, DQO, COT, Ferro e Manganês foram mais elevados. Por outro lado, no antigo lixão as concentrações de Nitrogênio Nitrato foram mais elevadas em relação ao aterro, indicando uma contaminação mais antiga. A atenuação de alguns valores foram constatados, conforme mostra a Tabela 32. 
Tabela 32 - Monitoramento da água subterrânea no antigo lixão de São Carlos

\begin{tabular}{|c|c|c|c|c|c|c|c|c|c|c|c|c|c|c|c|c|}
\hline \multirow{3}{*}{ PARÂMETROS } & \multirow{3}{*}{ Pesquisadores } & \multirow{2}{*}{\multicolumn{2}{|c|}{ Poço L5 }} & \multirow{2}{*}{\multicolumn{2}{|c|}{ Poço L12 }} & \multirow{2}{*}{\multicolumn{2}{|c|}{ Poço L14 }} & \multirow{2}{*}{\multicolumn{2}{|c|}{$\begin{array}{c}\text { PM } \\
\text { Poço L20 }\end{array}$}} & \multirow{2}{*}{\multicolumn{2}{|c|}{$\begin{array}{c}\text { PJ2 } \\
\text { Poço L26 }\end{array}$}} & \multirow{2}{*}{\multicolumn{2}{|c|}{$\begin{array}{c}\text { PJ3 } \\
\text { Poço L27 }\end{array}$}} & \multirow{2}{*}{\multicolumn{2}{|c|}{$\begin{array}{c}\text { PJ1 } \\
\text { Poço L30 }\end{array}$}} & \multirow{3}{*}{$\begin{array}{c}\text { Portaria } 518^{*} \\
\text { VMP }\end{array}$} \\
\hline & & & & & & & & & & & & & & & & \\
\hline & & $\operatorname{Max}$ & Med & $\operatorname{Max}$ & Med & $\operatorname{Max}$ & Med & $\operatorname{Max}$ & Med & $\operatorname{Max}$ & Med & $\operatorname{Max}$ & Med & $\operatorname{Max}$ & Med & \\
\hline \multirow{4}{*}{$\mathrm{pH}$} & CONTIN NETO et al (1995) & 4,70 & 3,80 & 7,00 & 6,90 & 6,10 & 5,90 & - & - & - & - & - & - & - & - & \multirow{4}{*}{$6,0-9,5$} \\
\hline & BOSSOLAN (1993) & - & 4,90 & - & 6,90 & - & 5,40 & - & - & - & - & - & - & - & - & \\
\hline & GADOTTI (1997) & - & - & - & - & - & - & - & - & 5,70 & 5,10 & 6,20 & 5,80 & 6,70 & 6,00 & \\
\hline & LOPES (2007) & - & - & - & - & - & - & 5,67 & 4,93 & 5,56 & 4,84 & 5,52 & 4,96 & 6,00 & 5,46 & \\
\hline & & - & - & - & - & - & - & 24,4 & 24,1 & 25,6 & 23,925 & 25,3 & 23,775 & 26,7 & 24,425 & \\
\hline Temperatura $\left({ }^{\circ} \mathrm{C}\right)$ & CONTIN NETO et al (1995) & 25,0 & 23,0 & 27,0 & 25,0 & 24,0 & 21,0 & - & - & - & - & - & - & - & - & - \\
\hline & BOSSOLAN (1993) & 30 & 23,5 & 28,5 & 22,5 & 33 & 24,9 & - & - & - & - & - & - & - & - & \\
\hline & & - & 15,50 & - & 0,40 & - & 6,10 & - & - & - & - & - & - & - & - & \\
\hline Oxigênio Dissolvido (mg/L) & GADOTTI (1997) & - & - & - & - & - & - & - & - & 1,50 & 0,50 & 4,10 & 2,50 & 0,00 & 0,00 & - \\
\hline & LOPES (2007) & - & - & - & - & - & - & 5,06 & 4,21 & 2,89 & 1,13 & 3,19 & 1,76 & 2,18 & 0,99 & \\
\hline & & - & - & - & - & - & - & 41 & 34 & 211 & 191 & 48 & 39 & 238 & 154 & \\
\hline Condutividade Flétrica $(\mathrm{\mu S} / \mathrm{cm})$ ) & CONTIN NETO et al (1997) & 162 & 73 & 5984 & 3826 & 598 & 530 & - & - & - & 283 & - & - & - & 140 & - \\
\hline 位) & GADOTTI (1997) & - & - & - & - & - & - & - & - & 342 & 282 & 79 & 49 & 214 & 139 & \\
\hline & BOSSOLAN (1993) & - & 28 & - & 2000 & - & 446 & - & - & - & - & - & - & - & - & \\
\hline Cloreto (mg/L) & GADOTTI (1997) & - & - & - & - & - & - & - & - & 115,0 & 61,5 & 4,0 & 1,9 & 16,0 & 5,7 & 250 \\
\hline & LOPES (2007) & - & - & - & - & - & - & 2,8 & 2,0 & 1,0 & 0,8 & 51,0 & 30,2 & 37,0 & 11,5 & 200 \\
\hline Coliformes Totais (NMP/100mL) & BOSSOLAN (1993) & 460 & 75 & $>2400$ & 1475 & 93 & 13 & - & - & - & - & - & - & - & - & \\
\hline (a) & LOPES (2007) & - & - & - & - & - & - & 8500 & 3910 & $3, \mathrm{E}+05$ & 75366 & 3000 & 1027 & $3, \mathrm{E}+04$ & 8398 & ausência \\
\hline Coliformes Termotolerantes (NMP/100mL) & & - & - & - & - & - & - & & & 62 & 45 & 33 & 16 & & 71 & \\
\hline 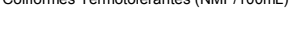 & BOSSOLAN (1993) & 15 & 3 & 460 & 133 & 7 & 3 & - & - & - & - & - & - & - & - & \\
\hline $\mathrm{DQO}(\mathrm{mg} / \mathrm{L})$ & GADOTTI (1997) & - & - & - & - & - & - & - & - & 63 & 29 & 56 & 26 & 75 & 47 & - \\
\hline UQ (might) & LOPES (2007) & - & - & - & - & - & - & 56 & 28 & 49 & 30 & 24 & 14 & 53 & 25 & \\
\hline Nitrogênio Nitrato (ma/l) & GADOTTI (1997) & - & - & - & - & - & - & - & - & 8,40 & 7,50 & 1,30 & 0,90 & 1,10 & 0,70 & 10 \\
\hline 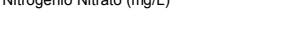 & LOPES (2007) & - & - & - & - & - & - & 1,1462 & 0,9987 & 9,5500 & 4,9272 & 0,4657 & 0,3565 & 4,4295 & 1,2657 & 10 \\
\hline Nitrogênio Total $(\mathrm{mg} / \mathrm{L})$ & GADOTTI (1997) & - & - & - & - & - & - & - & - & 15,96 & 6,27 & 9,24 & 3,78 & 12,82 & 6,26 & 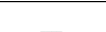 \\
\hline (Nitrogenio tolal(migh) & LOPES (2007) & - & - & - & - & - & - & 0,47 & 0,47 & 16,30 & 14,60 & 0,46 & 0,40 & 15,40 & 11,66 & \\
\hline 7 incr $(m a / 1)$ & BOSSOLAN (1993) & 0,35 & 0,28 & 1,4 & 0,81 & - & - & - & - & - & - & - & - & - & - & 50 \\
\hline Linco (migh) & LOPES (2007) & - & - & - & - & - & - & 0,15 & 0,09 & 1,55 & 0,45 & 1,50 & 0,46 & 1,79 & 0,54 & 3,0 \\
\hline Chumbo (mg/L) & & - & - & - & - & - & - & 0,00 & 0,00 & 0,00 & 0,00 & 0,00 & 0,00 & 0,00 & 0,00 & 0010 \\
\hline & BOSSOLAN (1993) & 0,218 & 0,159 & 0,279 & 0,231 & - & - & - & - & - & - & - & - & - & - & 0,010 \\
\hline Cádmio (mg/L) & & 0,0010 & - & 0,0130 & 0,0125 & - & - & - & - & - & - & - & - & - & - & 0005 \\
\hline & LOPES (2007) & - & - & - & - & - & - & 0,00 & 0,00 & 0,00 & 0,00 & 0,00 & 0,00 & 0,00 & 0,00 & ( \\
\hline Niquel $(\mathrm{mg} / \mathrm{L})$ & & - & - & - & - & - & - & 0,00 & 0,00 & 0,00 & 0,00 & 0,00 & 0,00 & 0,00 & 0,00 & - \\
\hline & BOSSOLAN (1993) & 0,0800 & 0,0400 & 0,0639 & 0,0319 & - & - & - & - & - & - & - & - & - & - & \\
\hline & & 1,67 & 1,65 & 22,75 & 14,19 & - & - & - & - & - & - & - & - & - & - & \\
\hline Ferro (mg/L) & CONTIN NETO et al (1995) & 0,10 & 0,09 & 0,18 & 0,14 & 0,01 & 0,01 & - & - & - & - & - & - & - & - & 0.3 \\
\hline (l) & GADOTTI (1997) & - & - & - & - & - & - & - & - & 0,30 & 0,20 & 4,70 & 1,44 & 8,00 & 2,60 & \\
\hline & LOPES (2007) & - & - & - & - & - & - & 7,28 & 2,01 & 33,00 & 8,51 & 0,25 & 0,12 & 14,69 & 6,72 & \\
\hline & 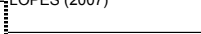 & - & - & - & - & - & - & 0,02 & 0,01 & 0,37 & 0,22 & 0,02 & 0,01 & 0,25 & 0,19 & \\
\hline Manganês (mg/L) & GADOTTI (1997) & - & - & - & - & - & - & - & - & 0,20 & 0,20 & 0,03 & 0,03 & 0,50 & 0,42 & 0,1 \\
\hline & CONTIN NETO et al (1995) & 0,42 & 0,16 & 0,14 & 0,06 & 0,9 & 0,74 & - & - & - & - & - & - & - & - & \\
\hline & BOSSOLAN (1993) & 0,32 & 0,29 & 1,03 & 0,65 & - & - & - & - & - & - & - & - & - & - & \\
\hline Cobre (mg/L) & & 0,04 & 0,03 & 0,09 & 0,45 & - & - & - & - & - & - & - & - & - & - & 20 \\
\hline & LOPES (2007) & - & - & - & - & - & - & 0,07 & 0,04 & 1,48 & 0,40 & 1,32 & 0,35 & 1,10 & 0,34 & 2,0 \\
\hline Cromo (mg/L) & & - & - & - & - & - & - & 0,00 & 0,00 & 0,00 & 0,00 & 0,15 & 0,04 & 0,00 & 0,00 & 0.05 \\
\hline & BOSSOLAN (1993) & 0,03 & 0,03 & 1,02 & 0,73 & - & - & - & - & - & - & - & - & - & - & \\
\hline Aluminio (mg/L) & BOSSOLAN (1993) & 1,32 & 0,97 & 3,57 & 2,68 & - & - & - & - & - & - & - & - & - & - & 0,2 \\
\hline & LOPES (2007) & - & - & - & - & - & - & 0,01 & 0,00 & 0,05 & 0,02 & 0,03 & 0,02 & 0,08 & 0,02 & \\
\hline$\square$ Valores abaixo dos limites recomer & pela legislação vigente & & & & & & & & & & & & & $\overline{V M P:}$ & Valor $\mathrm{Mà}$ & áximo Permitido \\
\hline$\square$ Valores acima dos limites rec & pela legislação vigente & & & & & & & & & & & & & & & \\
\hline " Portaria $n^{\circ} 518,25$ de março de 2004.1 & rio da Saúde. Padröes de & tabilidade & & & & & & & & & & & & & & \\
\hline BOSSOLAN, N. R. S. 1993. Aspectos eco & s das populaçōes bacteria & em ág & uhter & sot & to $d$ & ater & (nte & - Sã & rlos, & Disse & $(\mathrm{M}$ & o). $s$ & arlos & UFSCa & ar. 98p. & \\
\hline CONTIN NETO, D.; MENEZES, D. B.; FREI & S, A. L. S de. 1995. Alteraçōe & $s$ na qualii & ade da á & a subterrâr & ea e supe & rficial por & depositt & to de resid & Iuos. $x I S$ & mpósio B & sileiro & Recur: & Hidric & p. 153-15 & & \\
\hline $\begin{array}{l}\text { CONTIN NETO, D.; MATSUZAKI, S. S.; GA } \\
\text { Simposio Internazionale di Ingegneria Sanit }\end{array}$ & $\begin{array}{l}\text { TI, R. F.; FREITAS, A. L. } \\
\text { Ambientale. Ravello, Villa }\end{array}$ & $\begin{array}{l}\text { de; BARBC } \\
\text { ufolo. } 3 \text { a }\end{array}$ & ugno $D$. & $\begin{array}{l}\text { 7. Ava } \\
-563 .\end{array}$ & o da & ção & (a) & naçã & ág & uperfic & sut & neas & ogiã & aterro & trol & \\
\hline
\end{tabular}

Gadotti (1997) encontrou concentrações de Oxigênio Dissolvido mais elevadas no poço L27 (PJ3), enquanto que o presente estudo obteve teores mais elevados no poço L20 (PM). Vale destacar que Bossolan (1993) encontrou valores superiores no poço L5.

Quanto a Condutividade Elétrica, Gadotti (1997) encontrou o maior valor no poço L26 (PJ2) e a média neste poço se equiparou ao valor médio encontrado por Contin Neto et al 
(1995). Os valores encontrados por Gadotti (1997) no poço L27 (PJ3) foram superiores aos encontrados por este estudo, que obteve os maiores valores no L30 (PJ1). Gadotti (1997) encontrou concentrações mais elevadas de Cloreto no poço L26 (PJ2), enquanto que a presente pesquisa obteve as maiores concentrações no poço L27 (PJ3).

Bossolan (1993) detectou Coliformes Totais e Termotolerantes nos poços L5, L12 e L14, considerando que o L12 apresentou os maiores valores. O valor máximo de Coliformes Termotolerantes obtido no L12 superou o valor máximo obtido pela presente pesquisa no L20 (PM).

Gadotti (1997) obteve DQO mais elevada em relação ao presente estudo. Quanto ao Nitrogênio Nitrato, o autor obteve concentrações mais elevadas no L26, conforme este estudo, sendo que as concentrações no L27 (PJ3) foram superiores às obtidas pela presente pesquisa. O mesmo ocorreu com o Nitrogênio Total.

Bossolan (1993) detectou presença de Chumbo, Cádmio e Níquel nas amostras analisadas, o que não ocorreu durante esta pesquisa. As concentrações de Alumínio encontradas pela autora superaram o limite da Portaria 518/2004, o que não ocorreu no presente estudo. O Cromo foi detectado em concentrações superiores a recomendada pela Portaria 518/2004 em amostras do poço L12 analisadas por Bossolan (1993) e pelo presente estudo no poço L27.

Assim como o presente estudo, Bossolan (1993) e Gadotti (1997) obtiveram concentrações de Ferro acima do limite máximo estabelecido pela Portaria 518/2004. O Manganês foi encontrado em concentrações superiores ao limite máximo recomendado pela legislação por Bossolan (1993) e Contin Neto et al (1995), bem como por Gadotti (1997) nos poços L26 e L30, conforme esta pesquisa.

Os valores elevados de Cor, Turbidez, Fósforo, Coliformes Totais e Termotolerantes, DBO, DQO e COT no poço PM podem ter ocorrido devido a fatores externos ou devido a alterações no fluxo freático, provocadas durante o aterramento dos resíduos na antiga erosão. Por isso, o poço PM merece atenção e recomenda-se que novos estudos sejam realizados no local e no seu entorno, a fim de se encontrar as causas da alteração da qualidade das águas subterrâneas.

Mesmo com as atividades paralisadas e apesar da fração inerte ter sido elevada em todas as amostras, provavelmente ainda deve ocorrer degradação dos resíduos e formação de lixiviado no antigo lixão devido aos elevados valores de Condutividade Elétrica, Coliformes Totais e Termotolerantes, Nitrogênio Amoniacal, Nitrogênio Total, DBO, DQO, COT, STD, Ferro e Manganês no PJ1 (L30) e PJ2 (L26). Foi constatado contaminação destes poços por Nitrogênio Amoniacal e suas amostras apresentaram efeito tóxico. Estas constatações indicam que a pluma de contaminantes se move principalmente em direção aos mesmos. 
Assim, com base no monitoramento realizado, conclui-se que o sentido preferencial do fluxo subterrâneo no antigo lixão de São Carlos é para noroeste, ou seja, na direção do fluxo do córrego São José. Porém, para uma conclusão mais confiável, é necessário que todos os poços existentes na área sejam monitorados por um período de tempo maior.

Estudos anteriores foram realizados na área e as conclusões sobre o sentido do fluxo subterrâneo foram distintas, porém complementares à presente pesquisa. Isso pode ter ocorrido devido à falta de esclarecimento sobre o ponto de referência adotado pelos autores e devido à distinção entre os poços de referência monitorados.

De acordo com métodos geofísicos realizados por Ellert et al (1990, p.88), foi detectada uma nuvem (pluma) poluente rumando no sentido oeste-sudeste.

Gonçalves et al (1993) e Bossolan (1993, p.34) determinaram a direção do fluxo freático no antigo lixão para noroeste por meio do monitoramento de 10 poços.

Gadotti (1997, p.138) indicou o sentido do fluxo subterrâneo para sudoeste por meio de eletrorresistividade e monitoramento de 15 poços.

Contin Neto et al (1997) construíram 17 poços de monitoramento no local. Foram efetuados levantamentos geofísicos, monitoramento da água, bem como modelagem matemática usando o cloreto para o modelo de transporte de soluto, devido a sua alta mobilidade. A geofísica apontou a região central do antigo lixão como a parte mais afetada. Assim, conforme os autores, os poços de L30 (PJ1) e de L26 (PJ2), monitorados por este estudo, estão na zona de contaminação. Com base no cruzamento de dados, os autores concluíram que o fluxo de água subterrânea caminha na direção nordeste-noroeste.

\subsubsection{2 Água superficial}

Conforme Apêndice E7, foram coletadas amostras de água no córrego São José na área de influência do Antigo Lixão de São Carlos nos dias 09/03/2004, 01/07/2004, 08/11/2004 e 10/02/2005.

Com base nas análises realizadas, foram obtidos valores de pH entre 5,75 e 6,74. A primeira amostra do ponto PM apresentou valor inferior ao mínimo recomendado pela Resolução CONAMA 357/2005 para águas superficiais Classe 2. A Temperatura das amostras variou entre 18,9 e $25,4^{\circ} \mathrm{C}$. A variação foi de $6,5^{\circ} \mathrm{C}$.

As amostras apresentaram valores de Cor Aparente entre 24 e 231UC. Duas amostras do PM e todas do PJ apresentaram valores superiores a 75UC, limite máximo recomendado pela Resolução CONAMA 357/2005 para águas superficiais Classe 2. O maior valor foi obtido na segunda amostra do PJ, três vezes o limite da CONAMA. A Turbidez das amostras variou entre 2,96 e 68,6UT. Conforme a Cor, o maior valor foi obtido 
na segunda amostra do PJ. Porém, nenhuma amostra ultrapassou o limite máximo de 100UT, recomendado pela Resolução CONAMA 357/2005.

As amostras não atingiram o limite máximo de $500 \mathrm{mg} / \mathrm{L}$ para os Sólidos Totais Dissolvidos, estabelecido pela Resolução CONAMA 357/2005. As concentrações variaram entre 25 e 196mg/L. A maior concentração foi obtida na segunda amostra do PJ.

As amostras apresentaram teores de Oxigênio Dissolvido entre 2,82 e 8,62mg/L. Três amostras do PJ apresentaram teores inferiores a $5 \mathrm{mg} / \mathrm{L}$, contrário às recomendações da Resolução CONAMA 357/2005 e do Decreto 8468/1976 do Estado de São Paulo para águas Classe 2.

As concentrações de Fluoreto nas amostras variaram entre <0,01 e 0,15mg/L. Nenhuma amostra ultrapassou o limite máximo de $1,4 \mathrm{mg} / \mathrm{L}$, estabelecido pela Resolução CONAMA 357/2005.

As amostras apresentaram concentrações de Cloreto entre 0,4 e 4,3mg/L, não atingindo o limite máximo de 250mg/L, recomendado pela Resolução CONAMA 357/2005.

Os valores de Condutividade Elétrica das amostras variaram entre 26 e $72 \mu \mathrm{S} / \mathrm{cm}$. Conforme CETESB (2005a, p.16), valores acima de $100 \mu \mathrm{S} / \mathrm{cm}$ representam ambientes impactados. Portanto, nenhuma amostra superou este valor.

As amostras apresentaram valores entre $1,6 \times 10^{3}$ e $1,2 \times 10^{4} \mathrm{UFC} / 100 \mathrm{~mL}$ de Coliformes Totais. Uma amostra do ponto PM e todas as amostras do PJ superaram 5000UFC/100mL, limite máximo recomendado pelo Decreto 8468/1976 do Estado de São Paulo. Para os Coliformes Termotolerantes, a Resolução CONAMA 357/2005 e o Decreto 8468/1976 recomendam o limite máximo de 1000UFC/100mL para águas superficiais Classe 2. As amostras apresentaram valores entre 7 e 1890 UFC/100mL. Duas amostras do PJ superaram o limite das legislações.

A Resolução CONAMA 357/2005 e o Decreto 8468/1976 do Estado de São Paulo recomendam concentrações inferiores a $5 \mathrm{mg} / \mathrm{L}$ para a DBO das águas superficiais Classe 2 . A segunda amostra do ponto PJ superou este valor. As concentrações variaram entre $<1$ e 9mg/L. As legislações não estabelecem limite para a DQO, porém, segundo Von Sperling (2006), a água natural não poluída não deve superar $10 \mathrm{mg} / \mathrm{L}$. Duas amostras do PM e três do PJ superaram este valor. As amostras apresentaram concentrações entre 0,1 e 47mg/L. Assim como a DBO, a maior concentração foi detectada na segunda coleta do ponto PJ. Conforme Valente et al (1997), em trechos de água limpa a DQO não ultrapassa 5mg/L. Com base nesta informação, três amostras do PM e todas do PJ superaram este valor.

A relação DQO/DBO foi elevada (superior a 4) em três amostras do ponto PM e em todas as amostras do ponto $\mathrm{PJ}$, indicando fração inerte elevada. Uma amostra do PM apresentou relação DQO/DBO baixa (inferior a 2,5), indicando fração biodegradável elevada (Von Sperling, 2005, p.94). 
As concentrações de Carbono Orgânico Total variaram entre 1,011 e 4,412mg/L. A primeira amostra do PM apresentou a concentração mais elevada. Segundo Libânio (2005, p.35), as águas superficiais podem apresentar COT entre 1 e $20 \mathrm{mg} / \mathrm{L}$. Portanto, nenhuma amostra superou este valor.

Todas as amostras do PJ ultrapassaram 0,5mg/L, limite máximo estabelecido pelo Decreto 8468/1976 para o Nitrogênio Amoniacal. Porém, nenhuma amostra ultrapassou $3,7 \mathrm{mg} / \mathrm{L}$, limite máximo recomendado pela CONAMA 357/2005. As concentrações variaram entre 0,03 e 2,59mg/L. A maior concentração foi obtida na terceira amostra do PJ.

A Resolução CONAMA 357/2005 recomenda o limite máximo de 2,18mg/L de Nitrogênio Total para ambientes lóticos de águas Classe 2. As amostras do ponto PJ superaram este valor. As concentrações variaram entre 0,57 e 12,96mg/L. Conforme o Nitrogênio Amoniacal, a maior concentração foi registrada na terceira coleta no PJ.

Uma amostra do PM e duas amostras do PJ apresentaram concentração de Fósforo Total acima do limite máximo de 0,05mg/L, recomendado pela CONAMA 357/2005 para ambientes lóticos de águas Classe 2. As concentrações variaram entre 0,0126 e 0,0757mg/L. A maior concentração foi obtida na terceira amostra do PJ.

De acordo com as análises de metais, foram obtidas concentrações de Zinco acima de 0,18mg/L, limite máximo recomendado pela Resolução CONAMA 357/2005, em duas amostras do PM e em uma do PJ. As concentrações variaram entre <0,002 e 1,82mg/L. A maior concentração foi obtida na terceira amostra do PM, cerca de dez vezes o limite da CONAMA. Segundo CETESB (2005a), nas águas superficiais as concentrações variam entre $<0,001$ e $0,10 \mathrm{mg} / \mathrm{L}$.

Foram obtidas concentrações de Ferro acima do limite máximo de 0,3mg/L, estabelecido pela CONAMA 357/2005, em três amostras de cada ponto. As concentrações variaram entre 0,13 e 2,33mg/L. A maior concentração foi obtida na terceira amostra do $P J$, 7,76 vezes o limite da CONAMA. A mesma amostra do PJ apresentou concentração de Manganês acima do limite máximo de $0,1 \mathrm{mg} / \mathrm{L}$ da CONAMA 357/2005. As concentrações variaram entre $<0,003$ e $0,77 \mathrm{mg} / \mathrm{L}$. A maior concentração obtida foi 7,7 vezes o limite da CONAMA.

Foram obtidas concentrações de Cobre acima do limite máximo de 0,009mg/L da CONAMA 357/2005 em três amostras de cada ponto. As concentrações variaram entre $<0,005$ e 3,83mg/L. A maior concentração foi obtida na terceira amostra do PM, cerca de 425 vezes o limite da CONAMA. Segundo CETESB (2005a), o Cobre está presente nas águas, naturalmente, em concentrações inferiores a $20 \mu \mathrm{g} / \mathrm{L}$. Os outros parâmetros não superaram os limites das legislações.

Conforme os ensaios ecotoxicológicos (Apêndice F), as amostras coletadas em 09/03/2004 não apresentaram efeito tóxico. Na coleta realizada em 08/11/2004, a amostra 
do PM apresentou toxicidade crônica com efeito na sobrevivência e a amostra do PJ não apresentou efeito tóxico.

As análises de Substâncias Orgânicas constataram presença de organoclorados e organofosforados tanto no PM quanto no PJ, acima dos limites recomendados pela CONAMA 357/2005 (Apêndice G7). Ressalta-se que o córrego atravessa propriedades agrícolas com plantação de goiaba e pasto.

Com base no IQA calculado para o período de 2004 a 2005 (Apêndice E7), em média as amostras do PM apresentaram qualidade Ótima e as amostras do PJ apresentaram qualidade Boa.

A Tabela 33 mostra o monitoramento realizado por diversos pesquisadores no córrego São José, na área de influência do antigo lixão. Com base nesta tabela, constata-se que a maioria dos parâmetros apresentou maiores concentrações, bem como menor teor de Oxigênio Dissolvido no ponto a jusante do antigo lixão de São Carlos.

Gadotti (1997) obteve DQO mais elevada no ponto a montante, ao contrário do presente estudo. $\mathrm{O}$ autor obteve concentrações de Cloreto superiores às obtidas por esta pesquisa nos dois pontos. Contin Neto et al (1995) obtiveram os maiores valores de Condutividade Elétrica no ponto de montante e Gadotti no ponto de jusante. Ambos encontraram valores superiores aos obtidos por este estudo.

As maiores concentrações de Nitrogênio Nitrato e Nitrogênio Total foram obtidas por Gadotti (1997) no ponto a montante, ao contrário deste estudo e da pesquisa realizada por Rios (1993).

Por meio do presente estudo foram detectadas concentrações de Zinco superiores às obtidas por Bossolan (1993) a jusante do lixão. No entanto, a autora detectou concentrações de Chumbo, Cádmio e Níquel em suas amostras, o que não ocorreu neste estudo.

Assim como a presente pesquisa, as demais apresentaram concentrações de Ferro superiores às recomendadas pela legislação. Bossolan (1993) detectou as maiores concentrações.

Contin Neto et al (1995) obtiveram maiores concentrações de Manganês nas amostras de montante, ao contrário das outras pesquisas.

O presente estudo obteve maiores concentrações de Cobre, ao contrário de Bossolan (1993) que obteve as maiores concentrações de Cromo e Alumínio, superando o limite máximo estabelecido pela Portaria 518/2004.

Os resultados permitem inferir que os baixos teores de Oxigênio Dissolvido, bem como os elevados valores de Turbidez, Fósforo, Nitrogênio Total, Coliformes, DQO e DBO obtidos nas amostras de jusante do córrego São José se devem, provavelmente, à pastagem de animais e aplicação de produtos agrícolas no entorno. Não se pode afirmar 
que a alteração da qualidade da água se deve, exclusivamente, à proximidade com o antigo lixão, pois o mesmo está desativado desde 1996.

Tabela 33 - Monitoramento do córrego São José na área do antigo lixão de São Carlos

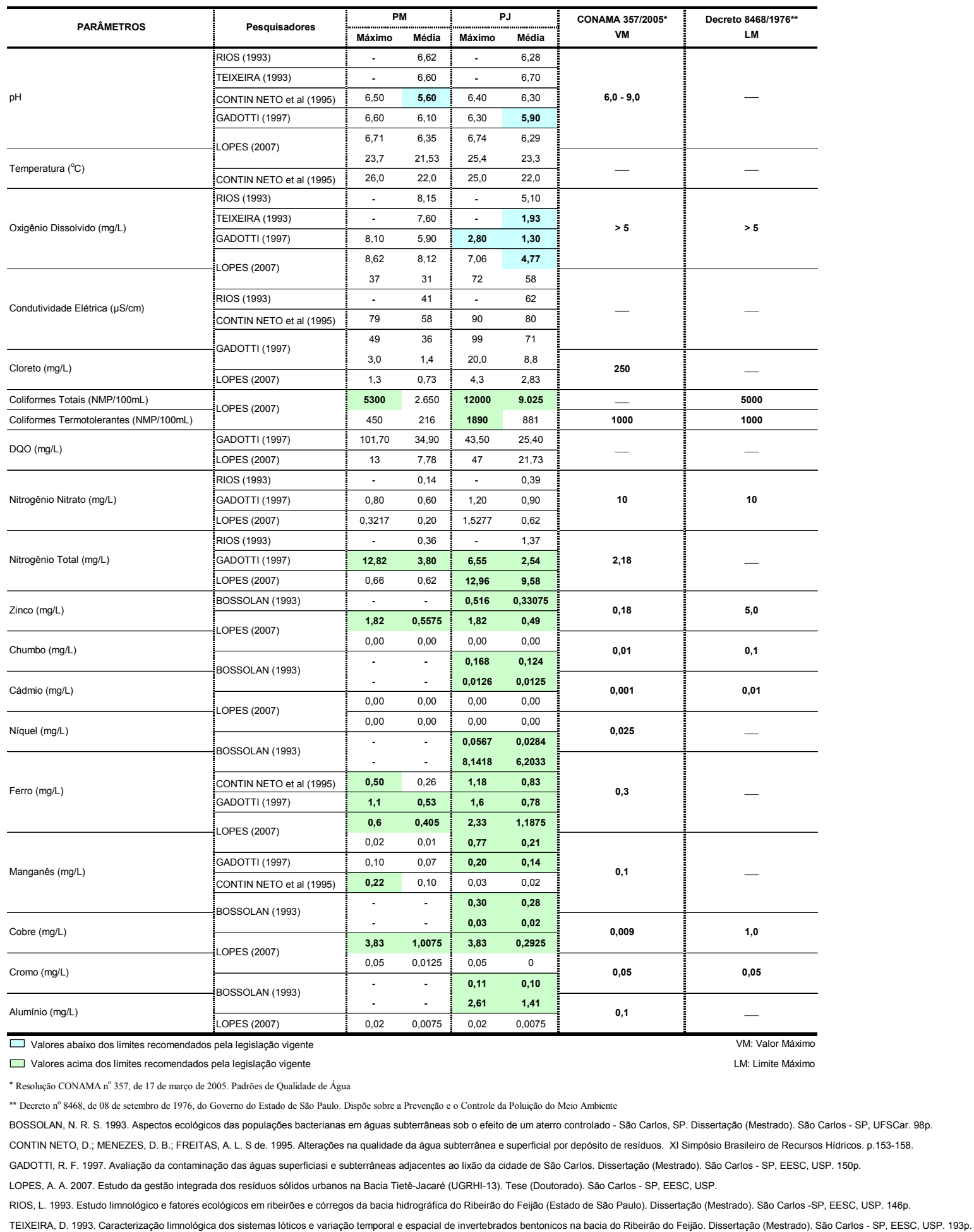




\subsection{Comparação entre os valores médios obtidos nos poços de monitoramento}

A comparação entre os aterros é complexa, pois cada área de disposição possui características distintas: como quantidade e tipo de resíduo descartado, idade e sistema operacional (recirculação de chorume, impermeabilização das células e lagoas, etc). Todos estes fatores somados às características naturais de cada local, podem influenciar os resultados.

Os valores médios obtidos nos poços de monitoramento das cinco áreas de disposição final de resíduos sólidos monitoradas estão apresentados na Tabela 34. As concentrações obtidas na água subterrânea foram comparadas às concentrações recomendadas pela Portaria 518/2004 e as obtidas no lixiviado.

As amostras de todos os aterros apresentaram valores médios de $\mathrm{pH}$ abaixo do intervalo recomendado pela Portaria 518/2004, bem como apresentaram valores médios de Cor, Turbidez, Ferro e Manganês acima do valor estabelecido pela legislação. Os aterros de Araraquara e São Carlos e o lixão de Jaú apresentaram concentrações médias de Nitrogênio Amoniacal superiores ao estabelecido pela legislação.

O lixão de Jaú apresentou também concentração média de Chumbo e Cromo Total superior ao limite máximo estabelecido pela legislação. Suas amostras apresentaram valores médios de Cor, Turbidez, Coliformes Totais, COT, DBO, DQO, Nitrogênio Amoniacal, Nitrogênio Total e Sólidos mais elevados que os demais aterros, o que pode indicar maior quantidade de matéria orgânica na água.

O aterro de São Carlos apresentou concentrações de DBO, DQO e Nitrogênio Total semelhantes às encontradas no lixão de Jaú, o que pode demonstrar falhas no seu sistema de impermeabilização, provavelmente das antigas lagoas de lixiviado. $O$ aterro apresentou concentração média de Alumínio superior à máxima estabelecida pela legislação. Além disso, o aterro apresentou valores médios mais elevados de Condutividade Elétrica, Cloreto, Salinidade, Fósforo e Coliformes Termotolerantes em relação aos outros aterros, o que indica elevada quantidade de matéria orgânica e sais na água. 
Tabela 34 - Valores médios obtidos nos poços de monitoramento

\begin{tabular}{|c|c|c|c|c|c|c|c|c|c|c|}
\hline \multirow{3}{*}{ PARÂMETROS } & \multicolumn{5}{|c|}{ Valores médios na água subterrânea } & \multirow{4}{*}{$\begin{array}{c}\text { Portaria } 518^{*} \\
\text { VMP }\end{array}$} & \multirow{4}{*}{$\begin{array}{l}\text { Limite de } \\
\text { Detecção }\end{array}$} & \multirow{4}{*}{ Ehrig $^{\star *}$} & \multirow{4}{*}{ Contrera $^{* \star \star}$} & \multirow{4}{*}{ Williams $^{* \star \star *}$} \\
\hline & Aterro 1 & Aterro 2 & Aterro 3 & Aterro 4 & Aterro 5 & & & & & \\
\hline & Araraquara & Bauru & Jaú & São Carlos & $\begin{array}{c}\text { Antigo Lixão } \\
\text { São Carlos }\end{array}$ & & & & & \\
\hline Nível Estático dos Poços (metro) & 11,20 & 15,02 & 15,55 & 24,12 & 9,26 & & & & & \\
\hline $\mathrm{pH}$ & 4,39 & 5,70 & 5,07 & 4,73 & 5,05 & $6,0-9,5$ & 0,00 & 7,05 & 8,12 & 7,12 \\
\hline Cor Aparente (uC) & 430 & 396 & 572 & 300 & 268 & 15 & 1 & - & - & - \\
\hline Turbidez (UT) & 103,48 & 110,72 & 155,58 & 67,49 & 77,05 & 5 & 0,01 & - & - & - \\
\hline Condutividade Elétrica ( $\mu \mathrm{S} / \mathrm{cm})$ & 149 & 238 & 381 & 900 & 104 & - & 0 & - & - & 14212 \\
\hline Temperatura $\left({ }^{\circ} \mathrm{C}\right)$ & 24,7 & 24,6 & 24,6 & 23,3 & 24,1 & - & 0,0 & - & - & - \\
\hline Salinidade (\%) & 0 & 0 & 2 & 4 & 0 & - & 0 & - & - & - \\
\hline Oxigênio Dissolvido (mg/L) & 1,94 & 1,88 & 2,35 & 1,82 & 2,02 & - & 0,00 & - & - & - \\
\hline Cloreto (mg Cl'/L) & 21,5 & 17,4 & 30,2 & 164,7 & 11,1 & 250 & 0,1 & 2100,0 & - & 1939,5 \\
\hline Fósforo Total (mg P/L) & 0,0232 & 0,0796 & 0,0669 & 0,8415 & 0,2525 & - & 0,0001 & 6,00 & - & 4,65 \\
\hline Fluoreto (mg F/L) & 0,07 & 0,05 & 0,07 & 0,12 & 0,16 & 1,5 & 0,01 & - & - & - \\
\hline Coliformes Totais (UFC/100mL) & $2,90 E+03$ & $3,97 \mathrm{E}+07$ & $4,38 \mathrm{E}+11$ & $1,83 \mathrm{E}+04$ & $2,22 E+04$ & ausência & 1 & 一 & $2,10 E+06$ & - \\
\hline Coliformes Termotolerantes (UFC/100mL) & 172 & 47 & 17 & 211 & 55 & ausência & 1 & - & $1,32 \mathrm{E}+09$ & - \\
\hline Demanda Quimica de Oxigênio $\left(\mathrm{mg} \mathrm{O}_{2} / \mathrm{L}\right)$ & 29 & 26 & 67 & 66 & 24 & - & 1 & 12500 & 4539 & 19562 \\
\hline Demanda Bioquímica de Oxigênio $\left(\mathrm{mg} \mathrm{O}_{2} / \mathrm{L}\right)$ & 8 & 4 & 12 & 13 & 5 & - & 1 & 6590 & 2656 & 9503 \\
\hline Nitrogênio Amoniacal (mg N/L) & 1,86 & 0,20 & 4,52 & 1,93 & 1,21 & 1,5 & 0,01 & - & 979 & 905,5 \\
\hline Nitrogênio Nitrato (mg N/L) & 0,3998 & 0,2722 & 1,1879 & 1,3799 & 1,8870 & 10 & 0,0001 & 3,00 & - & 1,33 \\
\hline Nitrogênio Nitrito (mg N/L) & 0,0064 & 0,0062 & 0,0071 & 0,0034 & 0,0048 & 1 & 0,0001 & 0,50 & - & 0,18 \\
\hline Nitrogênio Total (mg N/L) & 8,18 & 0,63 & 12,54 & 11,42 & 6,78 & 一 & 0,01 & 1250,00 & 1193,75 & - \\
\hline Carbono Orgânico Total (mg C/L) & 2,999 & 2,592 & 11,240 & 8,766 & 2,936 & - & 0,001 & - & - & 6475 \\
\hline Sulfato ( $\left.\mathrm{mg} \mathrm{SO}_{4}{ }^{2-} / \mathrm{L}\right)$ & 0 & 3 & 2 & 1 & 1 & 250 & 1 & 290 & - & 372 \\
\hline Sulfeto (mg S'/L) & $<0,001$ & $<0,001$ & $<0,001$ & $<0,001$ & $<0,001$ & 0,05 & 0,001 & - & - & - \\
\hline Sólidos Totais (mg/L) & 229,88 & 450,56 & $2.005,56$ & 531,75 & 299,06 & - & 0,0001 & - & 7351,72 & - \\
\hline Sólidos Totais Fixos (mg/L) & 145,94 & 436,25 & $1.609,71$ & 320,38 & 191,23 & - & 0,0001 & - & 5478,94 & - \\
\hline Sólidos Totais Voláteis (mg/L) & 83,94 & 190,63 & 395,85 & 211,13 & 106,58 & - & 0,0001 & - & 1872,94 & - \\
\hline Sólidos Totais Dissolvidos (mg/L) & 142,44 & 294,88 & 428,98 & 368,13 & 232,71 & 1000 & 0,0001 & - & - & 一 \\
\hline Zinco (mg/L) & 0,519 & 0,678 & 2,424 & 0,291 & 0,520 & 5 & 0,002 & 2,800 & 0,254 & 9,255 \\
\hline Chumbo (mg/L) & 0,00 & 0,00 & 0,09 & 0,00 & 0,00 & 0,01 & 0,02 & 0,09 & 0,16 & 0,24 \\
\hline Cádmio (mg/L) & 0,0000 & 0,0000 & 0,0000 & 0,0000 & 0,0000 & 0,005 & 0,0006 & 0,0060 & 0,0117 & 0,0175 \\
\hline Níquel (mg/L) & 0,000 & 0,000 & 0,048 & 0,000 & 0,000 & - & 0,008 & 0,200 & 0,168 & 0,295 \\
\hline Ferro Solúvel (mg/L) & 1,069 & 1,047 & 4,639 & 12,894 & 1,070 & 0,3 & 0,005 & 397,500 & 12,467 & 340,600 \\
\hline Manganês Solúvel (mg/L) & 0,348 & 0,171 & 3,025 & 0,414 & 0,350 & 0,1 & 0,003 & 12,850 & 0,541 & 16,700 \\
\hline Cobre (mg/L) & 0,227 & 0,521 & 0,279 & 0,211 & 0,230 & 2 & 0,005 & 0,080 & 0,010 & 0,150 \\
\hline Cromo Total (mg/L) & 0,009 & 0,019 & 0,090 & 0,013 & 0,010 & 0,05 & 0,005 & 0,300 & 0,030 & 0,110 \\
\hline Cromo Hexavalente (mg/L) & 0,000 & 0,000 & 0,000 & 0,000 & 0,000 & - & 0,001 & - & - & - \\
\hline Alumínio (mg/L) & 0,02 & 0,01 & 0,01 & 0,26 & 0,02 & 0,2 & 0,01 & - & - & - \\
\hline
\end{tabular}

$\square$ Valores abaixo dos limites recomendados pela legislação vigente

$\square$ Valores acima dos limites recomendados pela legislação vigente

VMP: Valor Máximo Permitido

* Portaria n 518,25 de março de 2004. Ministério da Saúde. Padrões de Potabilidade

** Ehrig, Hans-Jürgen. Leachate Quality. In: Christensen, T. H. et al. Sanitary Landfilling: Process, Technology and Environmental Impact. Academic Press. London. p.216 e 218. 1989. (Média de 15 aterros da Alemanha).

*** Contrera, R. C. 2003. Tratamento biológico de líquidos percolados de aterros sanitários utilizando reator anaeróbio horizontal de leito fixo (RAHLF).

Dissertação (Mestrado). São Carlos, Escola de Engenharia de São Carlos, Universidade de São Paulo. 149p. 2003. (Média dos aterros de Bauru e Rio Claro, Brasil)

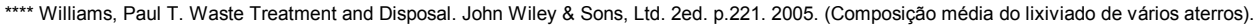


Ao contrário das outras áreas monitoradas, nenhuma amostra do antigo lixão de São Carlos apresentou Salinidade. Assim, pode-se inferir que a Salinidade está relacionada com a disposição recente dos resíduos sólidos.

A concentração média de Zinco obtida no lixão de Jaú equivale à encontrada por Ehrig (1989) em lixiviados de aterros da Alemanha. As amostras do lixão de Jaú também apresentaram concentração média de Cromo Total superior à encontrada por Contrera (2003) em lixiviados dos aterros de Bauru e Rio Claro, no Brasil. As amostras de água do aterro de São Carlos apresentaram concentrações médias de Ferro e Manganês próximas às encontradas pelo pesquisador e as amostras de Bauru e Jaú superaram o número de Coliformes Totais.

As análises físico-químicas (Apêndices D1 a D5) demonstraram variações de Sulfato, $\mathrm{pH}$, Nitrogênio Amoniacal, Cor, Turbidez, DBO, DQO, Condutividade Elétrica, Cloreto, COT e Sólidos Totais Dissolvidos na água subterrânea, em área de influência dos aterros monitorados (Figura 125 a Figura 144).

Os maiores valores de Cor e Turbidez foram obtidos nas amostras do PJ2 de Araraquara e PJ1 de Bauru (Figura 129 e 130). O aterro de Bauru apresentou também as maiores concentrações de Cobre (Figura 144) e Sulfato nas amostras do PJ1 (Figura 128).

As concentrações de COT, Nitrogênio Amoniacal e Manganês mais elevadas foram obtidas nas amostras do PJ3 do lixão de Jaú (Figura 135, Figura 126 e Figura 142), que apresentou as maiores concentrações de Zinco, Cromo Total, Níquel e Chumbo.

Os valores mais elevados de Condutividade Elétrica, Cloreto, DBO, DQO, STD e Ferro foram obtidos nas amostras do PJ2 do aterro de São Carlos (Figura 133, Figura 134, Figura 131, Figura 132, Figura 136 e Figura 141), que apresentou a concentração mais elevada de Alumínio nas amostras do PJ1 (Figura 143).

Elevados valores de Condutividade Elétrica em algumas amostras (Figura 133) podem ter ocorrido devido ao contato da água subterrânea com o solo e rochas, que contêm uma variedade de minerais. A água subterrânea naturalmente contém íons inorgânicos dissolvidos que podem ter sido liberados, indicados pela presença de Cloreto, Fluoreto, Fosfato, Nitrato, Sulfato e Sólidos Totais Dissolvidos. 


\begin{tabular}{|c|c|c|}
\hline Araraquara & B auru & Jaú \\
\hline São Carlos & $\square$ Antigo Lixão de São Carlos & - - - - Portaria 518/2004 \\
\hline
\end{tabular}

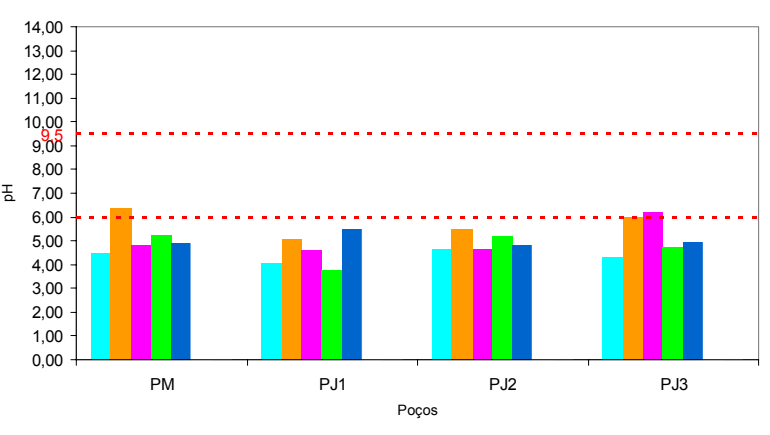

Figura 125 - Valores médios de pH na água subterrânea

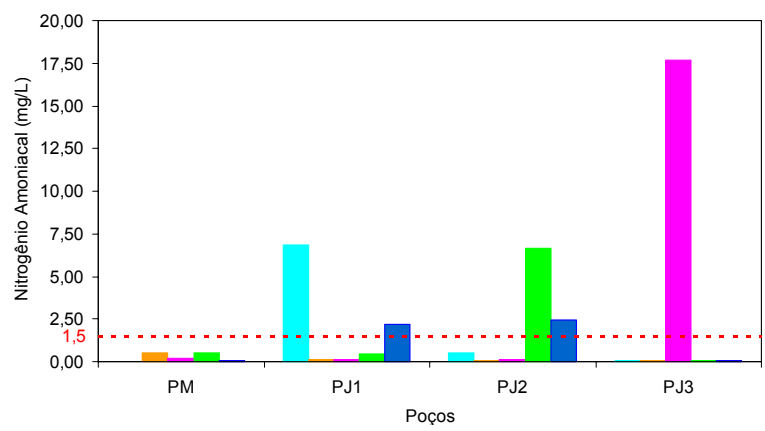

Figura 126 - Valores médios de Nitrogênio Amoniacal na água subterrânea

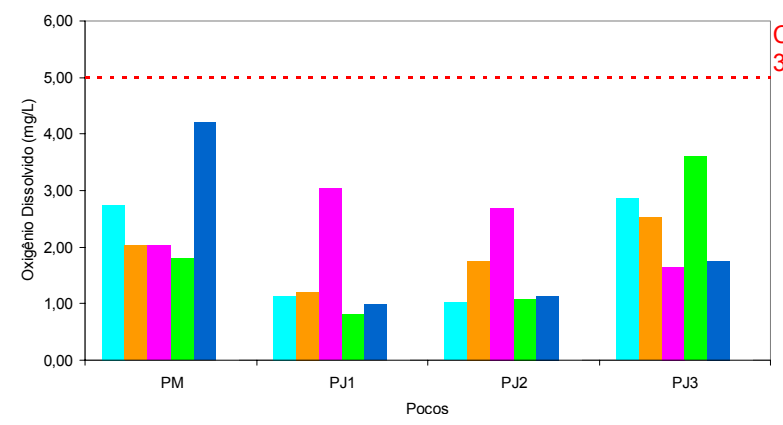

Figura 127 - Valores médios de Oxigênio Dissolvido na água subterrânea

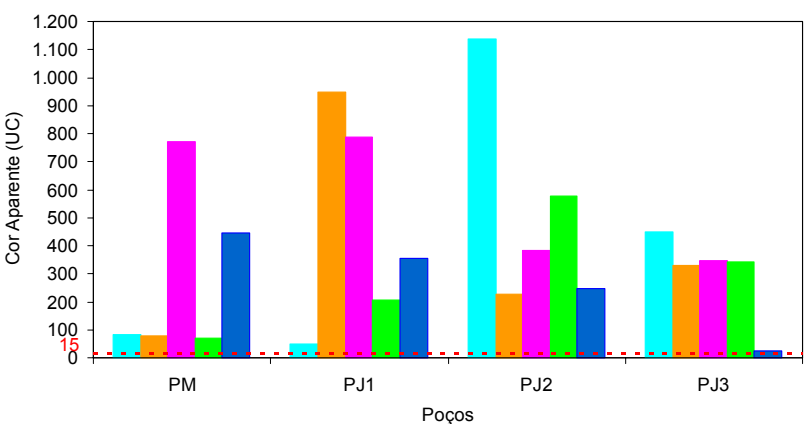

Figura 129 - Valores médios de Cor Aparente na água subterrânea

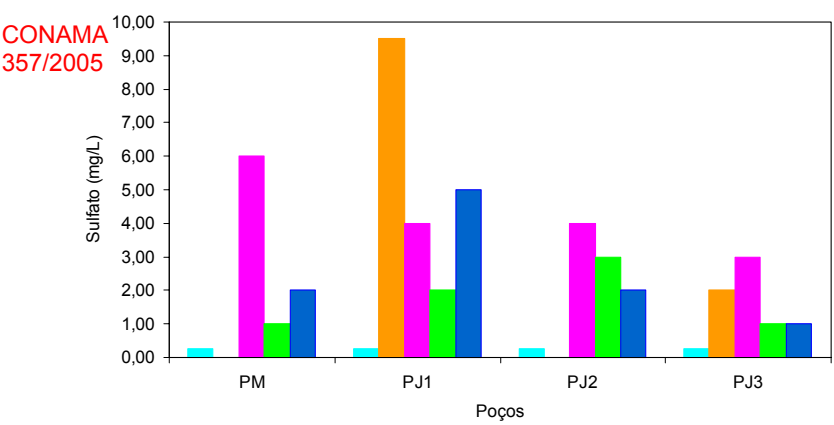

Figura 128 - Valores médios de Sulfato na água subterrânea

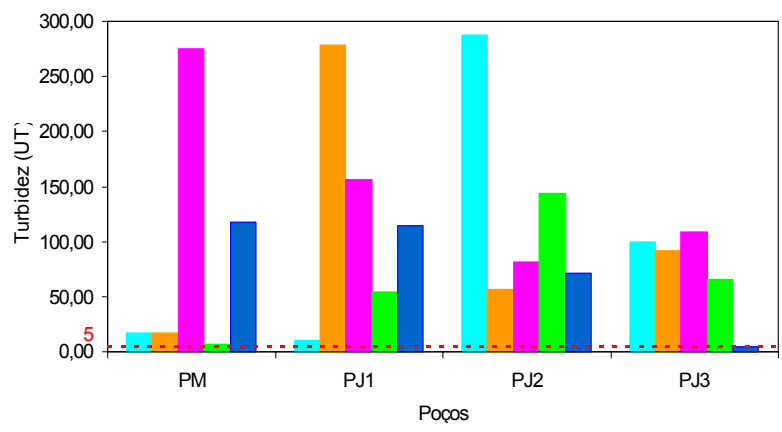

Figura 130 - Valores médios de Turbidez na água subterrânea 


\begin{tabular}{|c|c|c|}
\hline Araraquara & B auru & Jaú \\
\hline São Carlos & Antigo Lixão de São Carlos & - - - Portaria 518/2004 \\
\hline
\end{tabular}

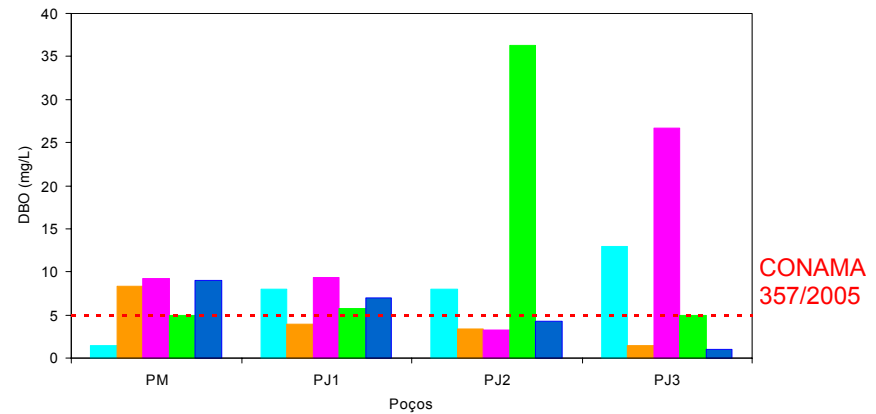

Figura 131 - Valores médios de Demanda Bioquímica de Oxigênio na água subterrânea

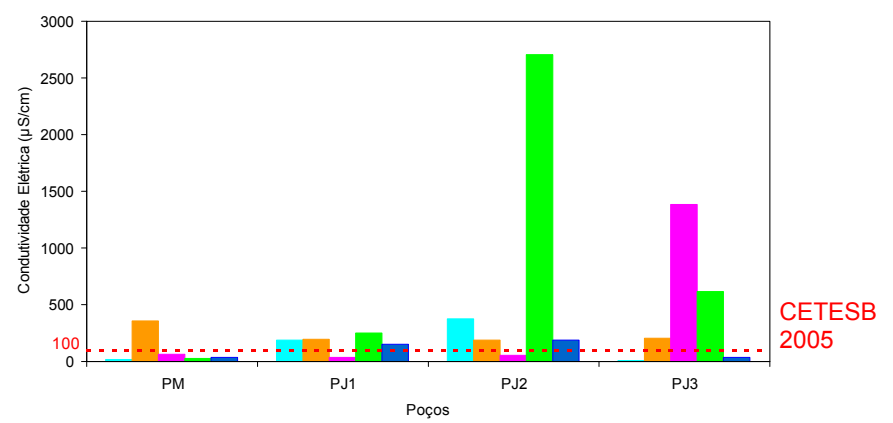

Figura 133 - Valores médios de Condutividade Elétrica na água subterrânea

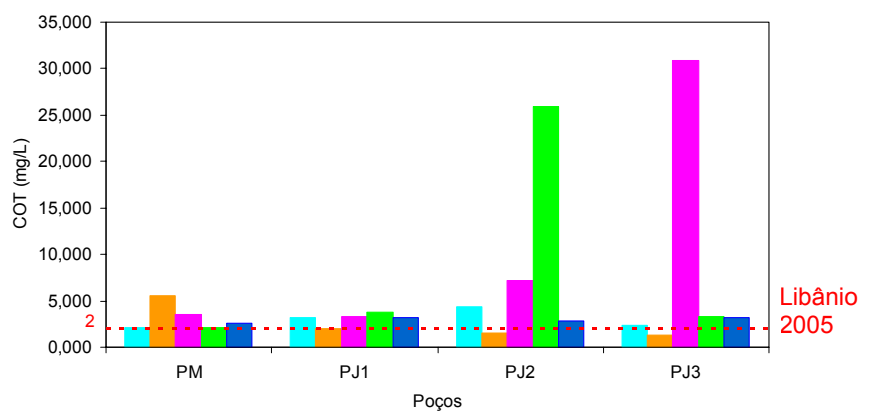

Figura 135 - Valores médios de Carbono Orgânico Total na água subterrânea

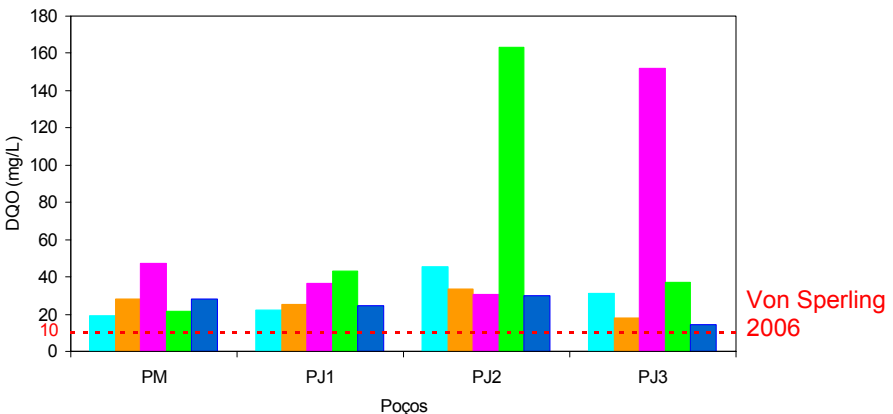

Figura 132 - Valores médios de Demanda Química de Oxigênio na água subterrânea

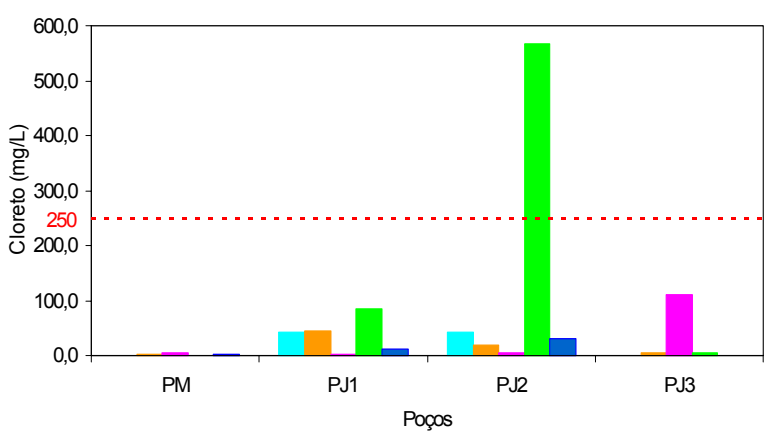

Figura 134 - Valores médios de Cloreto na água subterrânea

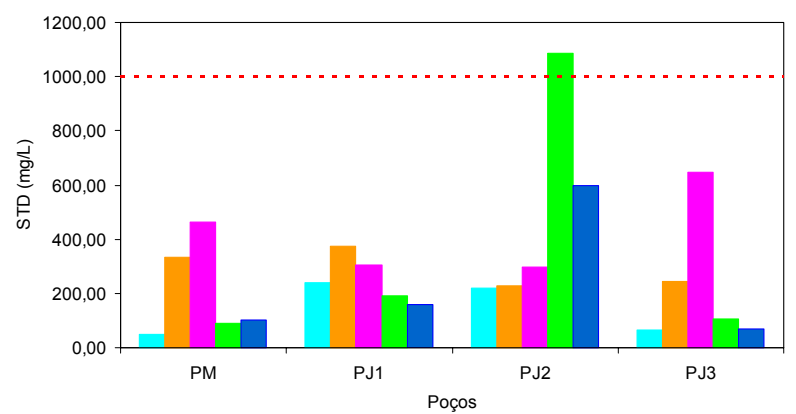

Figura 136 - Valores médios de Sólidos Totais Dissolvidos na água subterrânea 


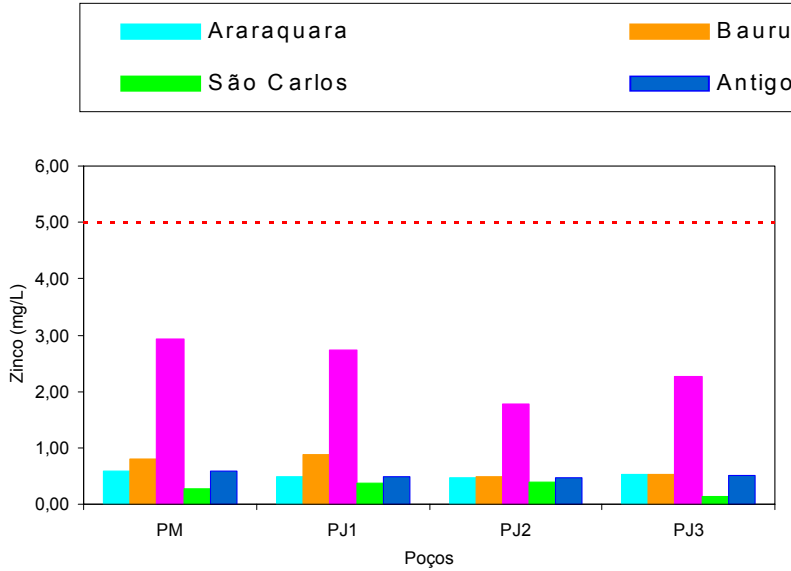

Figura 137 - Valores médios de Zinco na água subterrânea

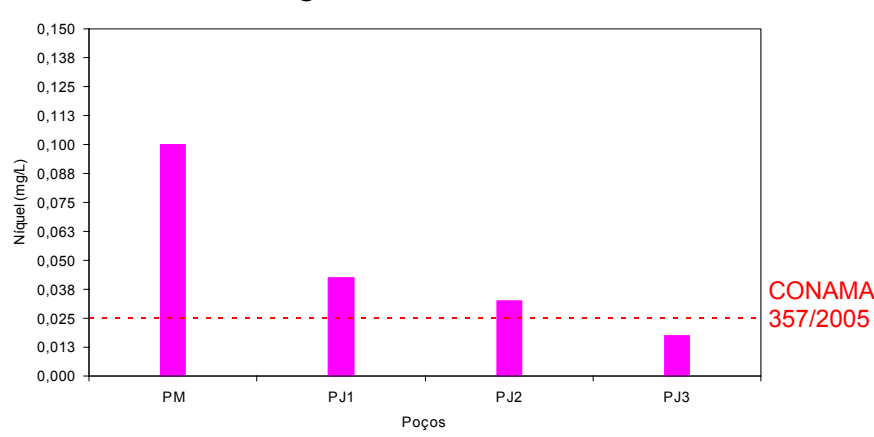

Figura 139 - Valores médios de Níquel na água subterrânea

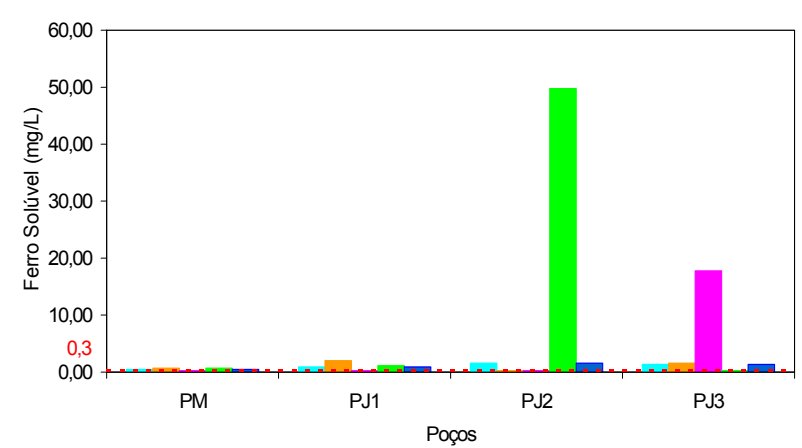

Figura 141 - Valores médios de Ferro na água subterrânea

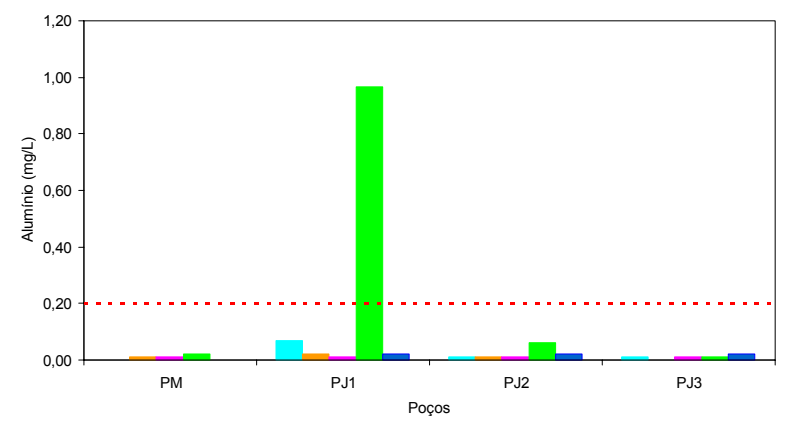

Figura 143 - Valores médios de Alumínio na água subterrânea

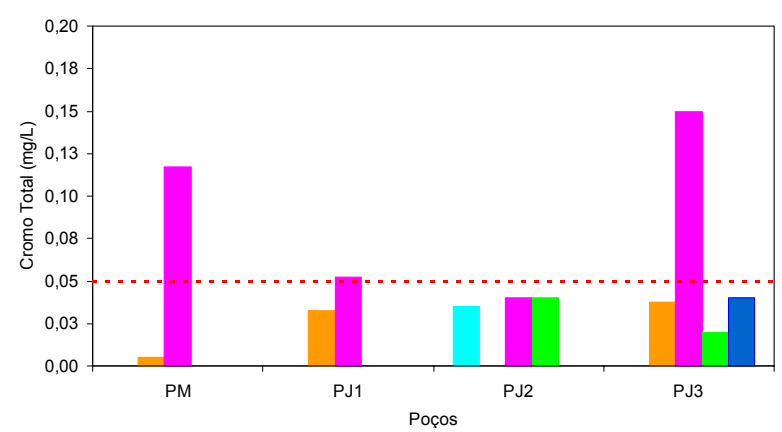

Figura 138 - Valores médios de Cromo Total na água subterrânea

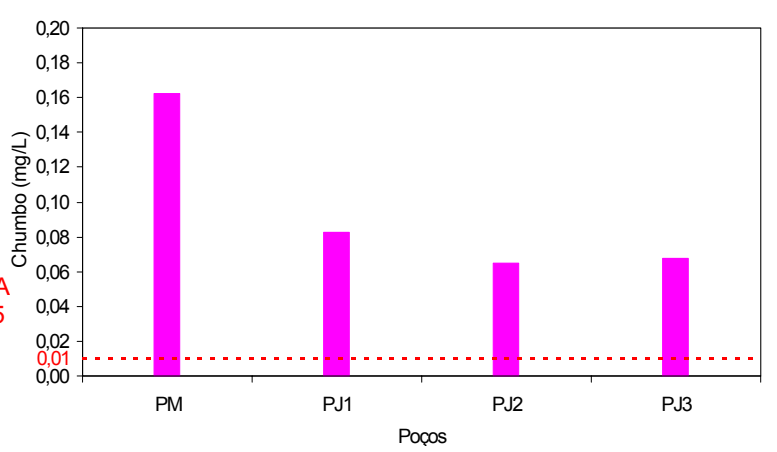

Figura 140 - Valores médios de Chumbo na água subterrânea

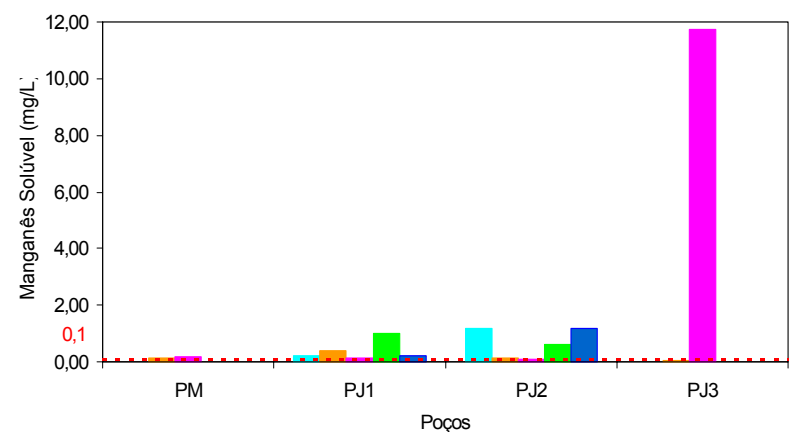

Figura 142 - Valores médios de Manganês na água subterrânea

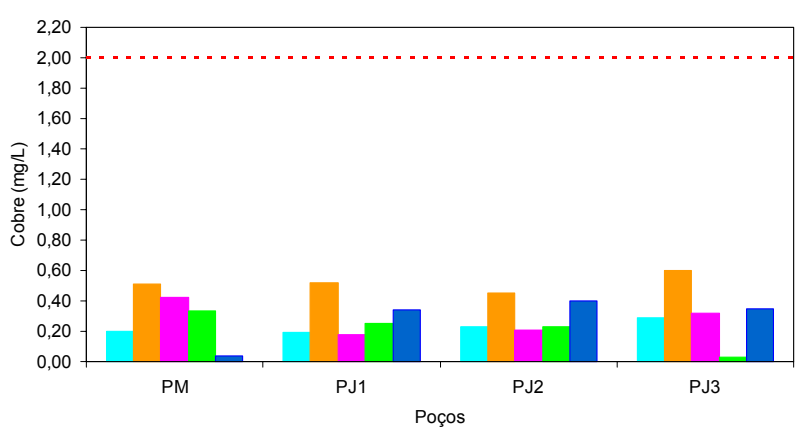

Figura 144 - Valores médios de Cobre na água subterrânea 


\subsection{Comparação entre os valores médios obtidos nos córregos}

Cada corpo d'água possui suas características naturais (volume de água, tipo de solo-leito, presença ou ausência de vegetação nas suas margens), além destas a qualidade de suas águas pode ser influenciada pelo uso do solo no seu entorno.

Os valores médios obtidos nos sete córregos monitorados estão apresentados na Tabela 35. As concentrações obtidas na água superficial foram comparadas às concentrações recomendadas pela Resolução CONAMA 357/2005 e pelo Decreto 8468/1976 do Estado de São Paulo.

As amostras dos córregos do Pinheirinho, da Cachoeira Grande e do Tamanduá apresentaram valores médios de $\mathrm{pH}$ abaixo do intervalo recomendado pela CONAMA $357 / 2005$.

Os córregos da Gabiroba, do Tamanduá, do Galdino, São José e o Ribeirão do Matão apresentaram valores médios de Cor acima do estabelecido pela legislação.

Os córregos da Gabiroba e do Tamanduá apresentaram teores médios de Oxigênio Dissolvido abaixo de $5 \mathrm{mg} / \mathrm{L}$, valor mínimo recomendado pelas legislações.

Todos os córregos, exceto o do Pinheirinho, apresentaram números de Coliformes Totais acima do limite máximo recomendado pelo Decreto Estadual, considerando que os córregos da Gabiroba e da Cachoeira Grande também apresentaram números de Coliformes Termotolerantes acima do limite máximo recomendado pela CONAMA 357/2005 e pelo Decreto Estadual.

Os córregos da Gabiroba, do Galdino e São José apresentaram concentrações médias de Nitrogênio Total superiores ao estabelecido pela legislação.

Todos os córregos apresentaram concentrações médias de Zinco, Ferro e Cobre acima do limite máximo recomendado pela CONAMA 357/2005.

Os córregos da Gabiroba e São José e o ribeirão do Matão apresentaram concentrações médias de Manganês acima do limite máximo recomendado pela CONAMA $357 / 2005$.

Apenas o córrego da Gabiroba apresentou concentrações de Fluoreto, DBO, Nitrogênio Amoniacal e STD acima do limite máximo recomendado pela CONAMA 357/2005. Este córrego foi o único que apresentou Salinidade. Com exceção do pH, Oxigênio Dissolvido, Coliformes Totais, Zinco e Cromo Total, este córrego apresentou as maiores concentrações, principalmente na primeira e última coleta, conforme Figura 145 a Figura 164. 
Tabela 35 - Valores médios obtidos nos córregos

\begin{tabular}{|c|c|c|c|c|c|c|c|c|c|c|}
\hline \multirow{4}{*}{ PARÂMETROS } & \multicolumn{7}{|c|}{ Valores médios na água superficial } & \multirow{3}{*}{$\begin{array}{c}\text { CONAMA } 357 / 2005^{*} \\
\text { VM }\end{array}$} & \multirow{3}{*}{$\begin{array}{c}\text { Decreto } 8468 / 1976^{\text {t* }} \\
\text { LM }\end{array}$} & \multirow{4}{*}{$\begin{array}{l}\text { Limite de } \\
\text { Detecção }\end{array}$} \\
\hline & \multirow{3}{*}{$\begin{array}{l}\text { Cómrego } 1 \\
\text { Araraquara }\end{array}$} & \multirow{3}{*}{$\begin{array}{c}\text { Cómego 2 } \\
\text { Bauru }\end{array}$} & \multirow{3}{*}{$\begin{array}{c}\text { Córrego } 3 \\
\text { Brotas }\end{array}$} & \multirow{3}{*}{$\begin{array}{c}\text { Córrego } 4 \\
\text { Jaú }\end{array}$} & \multirow{3}{*}{$\begin{array}{c}\text { Córrego } 5 \\
\text { Ribeirão Bonito }\end{array}$} & \multirow{3}{*}{$\begin{array}{l}\text { Córrego } 6 \\
\text { São Carlos }\end{array}$} & \multirow{3}{*}{\begin{tabular}{|c|} 
Cómrego 7 \\
São Carlos
\end{tabular}} & & & \\
\hline & & & & & & & & & & \\
\hline & & & & & & & & \multicolumn{2}{|c|}{ Água Classe 2} & \\
\hline $\mathrm{pH}$ & 5,31 & 6,89 & 5,54 & 6,92 & 5,99 & 6,04 & 6,32 & $6,0-9,0$ & - & 0 \\
\hline Cor Aparente (UC) & 22,9 & 546,1 & 70,4 & 116,3 & 138,2 & 303,5 & 121,6 & 75 & - & 1 \\
\hline Turbidez (UT) & 35,23 & 73,49 & 6,87 & 15,52 & 14,33 & 35,11 & 19,88 & 100 & - & 0,01 \\
\hline Condutividade 日étrica $(\mu \mathrm{S} / \mathrm{cm})$ & 15 & 880 & 20 & 98 & 17 & 38 & 45 & - & - & 0 \\
\hline Temperatura $\left({ }^{\circ} \mathrm{C}\right)$ & 23,6 & 26,2 & 24,4 & 22,2 & 21,0 & 21,6 & 22,4 & - & - & 0 \\
\hline Salinidade (\%) & 0 & 4 & 0 & 0 & 0 & 0 & 0 & - & - & 0 \\
\hline Oxigênio Dissolvido (mglL) & 6,51 & 4,48 & 5,33 & 5,02 & 4,01 & 5,20 & 6,44 & $>5$ & $>5$ & 0 \\
\hline Coreto (mg Q/l/L) & 0,49 & 96,48 & 0,36 & 10,09 & 0,54 & 2,33 & 1,78 & 250 & - & 0,1 \\
\hline Fósforo Total (mg PlL) & 0,0532 & 0,4683 & 0,0342 & 0,0225 & 0,0262 & 0,0481 & 0,0469 & 0,05 & - & 0,001 \\
\hline Fuoreto (mg F/L) & 0,12 & 1,72 & 0,04 & 0,09 & 0,06 & 0,07 & 0,07 & 1,4 & - & 0,01 \\
\hline Coliformes Totais (UFC100mL) & 559 & $5,00 \mathrm{E}+08$ & $1,01 E+09$ & $1,80 E+09$ & 11094 & 5429 & 5838 & - & 5.000 & $<1$ \\
\hline Coliformes Temmotolerantes (UFC100mL) & 23 & 14026 & 1674 & 88 & 54 & 702 & 549 & 1.000 & 1.000 & $<1$ \\
\hline Demanda Química de Oxigênio ( $\mathrm{mg} \mathrm{O}_{2} / \mathrm{L}$ ) & 20 & 612 & 9 & 13 & 16 & 26 & 15 & - & - & 1 \\
\hline Demanda Bioquímica de Oxigênio ( $m g$ O/L) & 0 & 378 & 1 & 1 & 1 & 1 & 1 & $<5$ & $<5$ & 1 \\
\hline Nitrogênio Amoniacal (mg NL) & 0,05 & 20,75 & 0,13 & 0,20 & 0,07 & 0,90 & 0,80 & 3,7 & - & 0,01 \\
\hline Nitrogênio Nitrato (mg NL) & 0,0910 & 6,5932 & 0,5117 & 1,0605 & 0,2000 & 0,6614 & 0,4116 & 10 & 10 & 0,01 \\
\hline Nitrogênio Nitrito (mg NL) & 0,0000 & 0,6782 & 0,0000 & 0,0050 & 0,0000 & 0,0000 & 0,0113 & 1 & 1 & 0,001 \\
\hline Nitrogênio Total (mg NL) & 0,38 & 63,50 & 0,70 & 0,98 & 0,29 & 8,87 & 5,10 & 2,18 & - & 0,1 \\
\hline Carbono Orgânico Total (mg CL) & 1,544 & 165,069 & 1,791 & 1,387 & 1,873 & 6,464 & 2,387 & - & - & 0,1 \\
\hline Sulfato ( $\left.\mathrm{mg} \mathrm{SO}_{4}^{2-} \mathrm{L}\right)$ & 0 & 22 & $<1$ & 1 & $<1$ & 1 & 0 & 250 & - & 1 \\
\hline Sulfeto (mg SO $\mathrm{O}^{2} \mathrm{~L}$ ) & $<0,01$ & $<0,01$ & $<0,01$ & $<0,01$ & $<0,01$ & $<0,01$ & $<0,01$ & 0,002 & - & 0,01 \\
\hline Sólidos Totais (mglL) & 47,63 & $1.164,38$ & 109,13 & 119,75 & 75,46 & 103,38 & 103,13 & - & - & 0,1 \\
\hline Sólidos Totais Fixos (mg/L) & 11,88 & 517,63 & 42,63 & 58,25 & 30,42 & 35,83 & 44,88 & - & - & 0,1 \\
\hline Sólidos Totais Voláteis (mglL) & 35,75 & 650,50 & 66,50 & 61,50 & 45,04 & 62,79 & 58,25 & - & - & 0,1 \\
\hline Sólidos Totais Dissolvidos (mgll) & 41,00 & 1082,75 & 97,50 & 105,38 & 54,46 & 63,42 & 78,75 & 500 & - & 0,1 \\
\hline Znœ (mg/L) & 0,52 & 1,01 & 1,15 & 0,43 & 1,01 & 0,19 & 0,52 & 0,18 & 5,000 & 0,002 \\
\hline Chumbo (mgl) & 0,00 & 0,00 & 0,00 & 0,00 & 0,00 & 0,01 & 0,00 & 0,01 & 0,100 & 0,02 \\
\hline Cádmio (mglL) & 0,0000 & 0,0000 & 0,0000 & 0,0000 & 0,0000 & 0,0000 & 0,0000 & 0,001 & 0,010 & 0,0006 \\
\hline Niquel (mglL) & 0,000 & 0,000 & 0,000 & 0,000 & 0,000 & 0,000 & 0,000 & 0,025 & - & 0,008 \\
\hline Ferro Solúvel (mg/L) & 0,394 & 3,893 & 0,623 & 0,753 & 0,880 & 1,190 & 0,796 & 0,3 & - & 0,005 \\
\hline Manganês Solível (mg/L) & 0,004 & 0,413 & 0,018 & 0,263 & 0,068 & 0,068 & 0,110 & 0,1 & - & 0,003 \\
\hline Cobre (mgll) & 0,193 & 0,644 & 0,270 & 0,158 & 0,099 & 0,224 & 0,650 & 0,009 & 1,000 & 0,005 \\
\hline Cromo Total (mg/L) & 0,040 & 0,029 & 0,000 & 0,000 & 0,000 & 0,000 & 0,006 & 0,05 & 0,050 & 0,005 \\
\hline Cromo Hexavalente (mglL) & 0,000 & 0,000 & 0,000 & 0,000 & 0,000 & 0,000 & 0,000 & 0,05 & - & 0,001 \\
\hline Alumínio (mglL) & 0,01 & 0,03 & 0,00 & 0,01 & 0,01 & 0,02 & 0,01 & 0,1 & - & 0,01 \\
\hline$\square$ Valores abaixo dos limites recomendados & ela legislação vi & & & & & & & & & Valor Máximo \\
\hline$\square$ Valores acima dos limites recomendados & la legislação vic & & & & & & & & & imite Máximo \\
\hline * Resolução CONAMAn 357 , de 17 de março & 2005. Padrões & de Qualidade c & & & & & & & & \\
\hline${ }^{\star *}$ Decreto n ${ }^{\circ} 8468$, de 08 de setembro de 197 & Governo do & stado de São F & ulo. Dispõe sc & e a Prevenção & o Controle da Poluic & do Meio Am & & & & \\
\hline Córego 1: Pinheirinho, Araraquara & & & & & & & & & & \\
\hline Córrego 2: Gabiroba, Bauru & & & & & & & & & & \\
\hline Córego 3: Cachoeira Grande, Brotas & & & & & & & & & & \\
\hline Córrego 4: Ribeirão do Matão, Jaú & & & & & & & & & & \\
\hline Córego 5: Tamanduá, Ribeirão Bonito & & & & & & & & & & \\
\hline Córego 6: Galdino, São Carlos & & & & & & & & & & \\
\hline Córego 7: São José, São Carlos & & & & & & & & & & \\
\hline
\end{tabular}

Com base na Tabela 35, as concentrações médias mais elevadas de Zinco foram obtidas no córrego da Cachoeira Grande e as concentrações médias mais elevadas de Cromo Total foram obtidas no córrego do Pinheirinho.

Da Figura 145 a Figura 164 estão apresentadas as variações dos parâmetros nas amostras de água superficial, com base nos Apêndices E1 a E7. 
As maiores concentrações de Zinco foram obtidas na primeira coleta do córrego da Cachoeira Grande e na primeira coleta no córrego do Tamanduá (Figura 159).

As maiores concentrações de Cobre foram obtidas na terceira coleta do córrego São José e na segunda coleta do córrego da Gabiroba (Figura 160).

As maiores concentrações de Ferro e Manganês foram obtidas na quarta coleta do córrego da Gabiroba (Figura 161 e Figura 162).

As maiores concentrações de Cromo foram obtidas na terceira coleta do córrego do Pinheirinho e na quarta coleta do córrego da Gabiroba (Figura 163).

As maiores concentrações de Alumínio foram obtidas na quarta coleta do córrego da Gabiroba e na terceira coleta do córrego do Pinheirinho (Figura 164). 


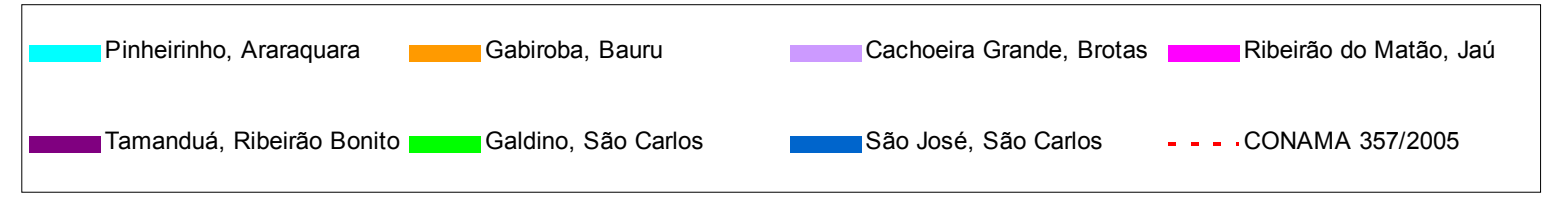

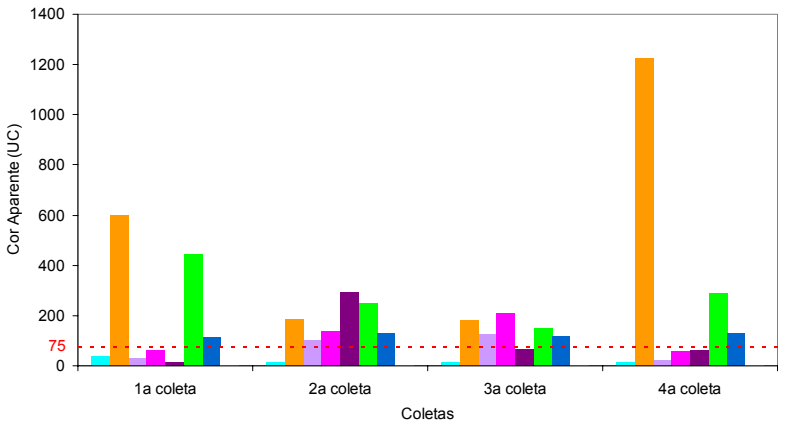

Figura 145 - Valores médios de Cor Aparente na água superficial

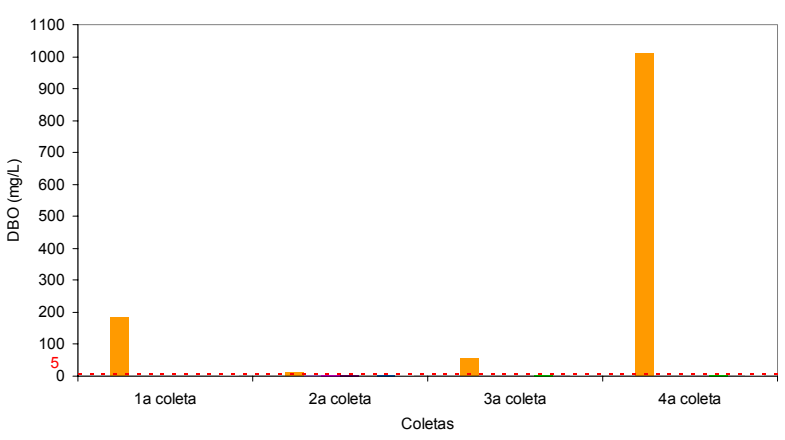

Figura 147 - Valores médios de Demanda Bioquímica de Oxigênio na água superficial

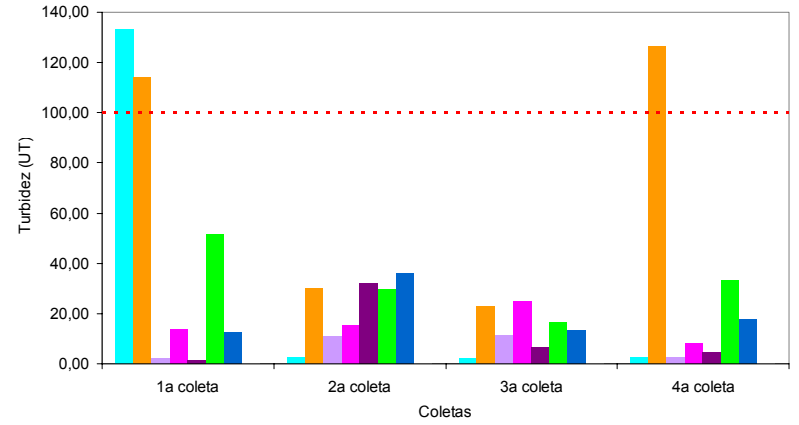

Figura 146 - Valores médios de Turbidez na água superficial

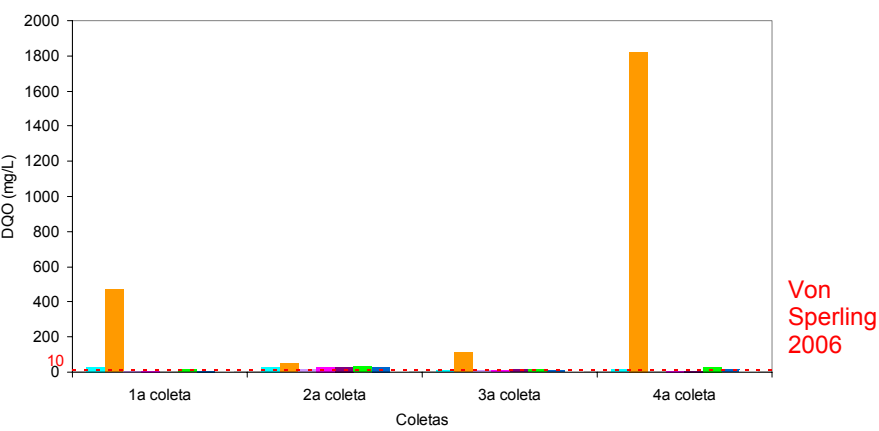

Figura 148 - Valores médios de Demanda Química de Oxigênio na água superficial

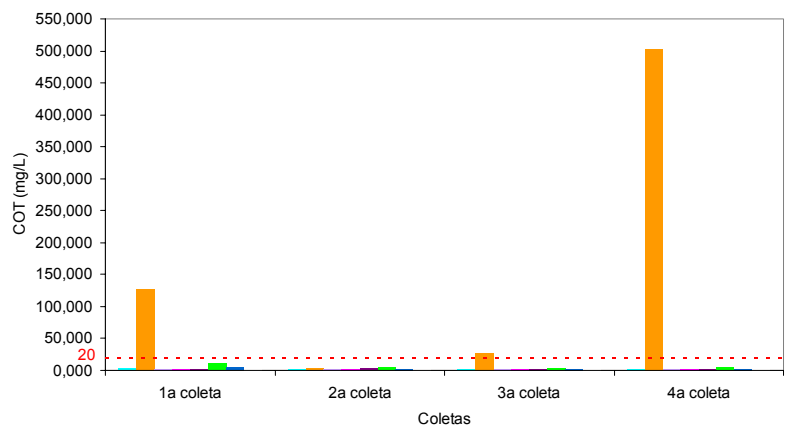

Figura 149 - Valores médios de Carbono Orgânico Total na água superficial

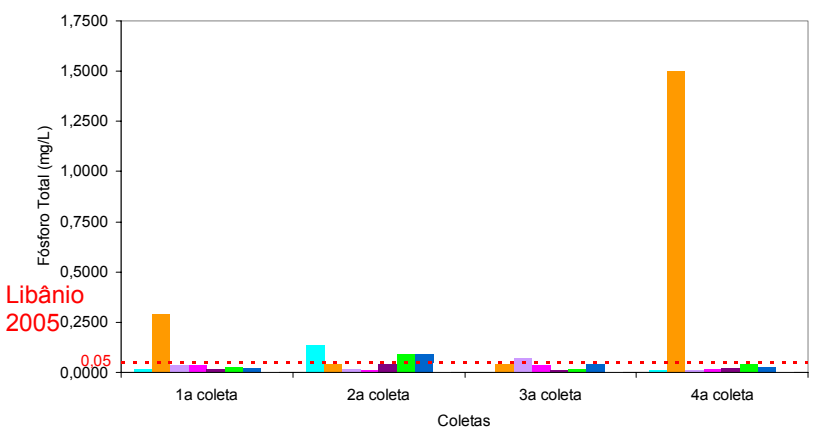

Figura 150 - Valores médios de Fósforo Total na água superficial 


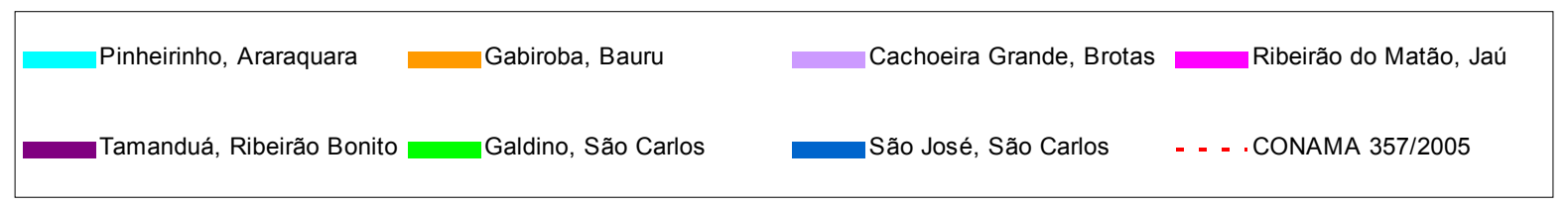

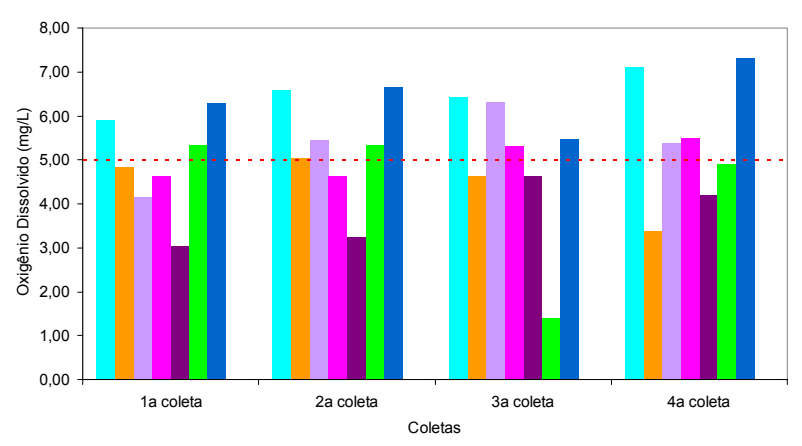

Figura 151 - Valores médios de Oxigênio Dissolvido na água superficial

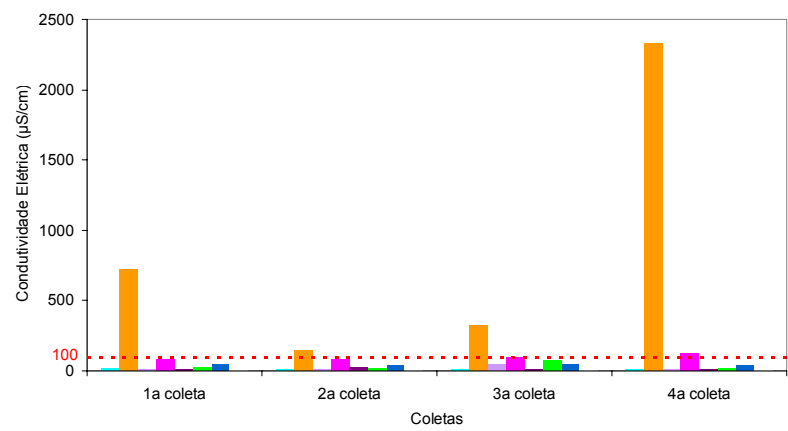

Figura 153 - Valores médios de Condutividade Elétrica na água superficial

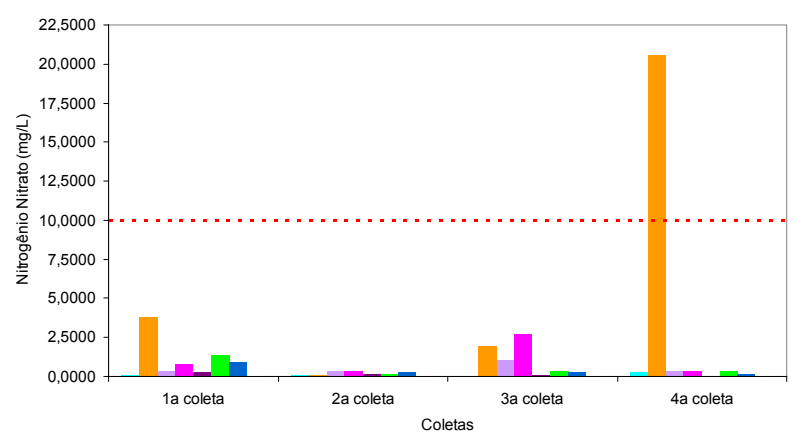

Figura 155 - Valores médios de Nitrogênio Nitrato na água superficial

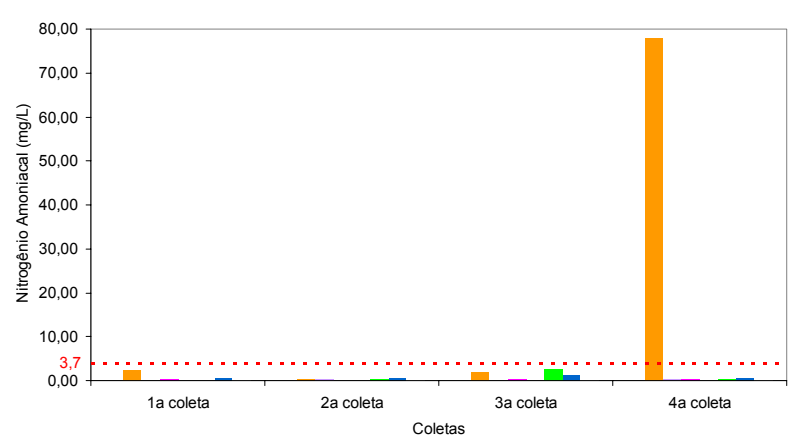

Figura 157 - Valores médios de Nitrogênio Amoniacal na água superficial

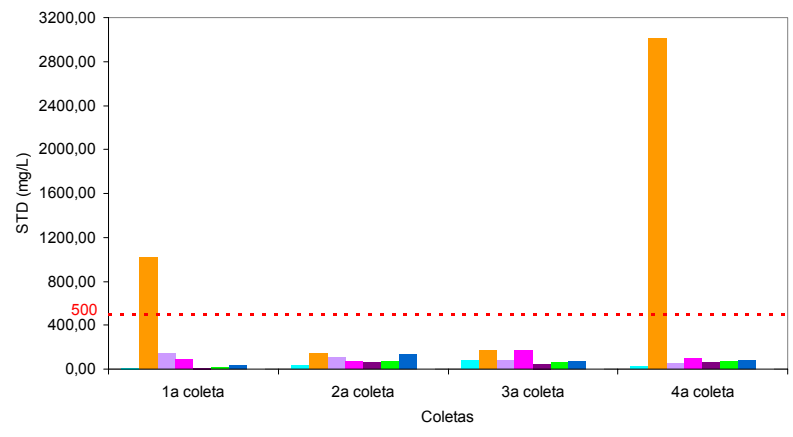

Figura 152 - Valores médios de Sólidos Totais Dissolvidos na água superficial

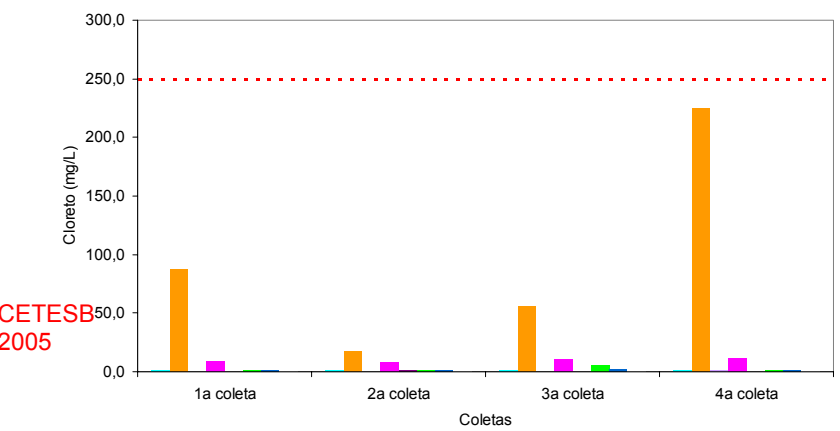

Figura 154 - Valores médios de Cloreto na água superficial

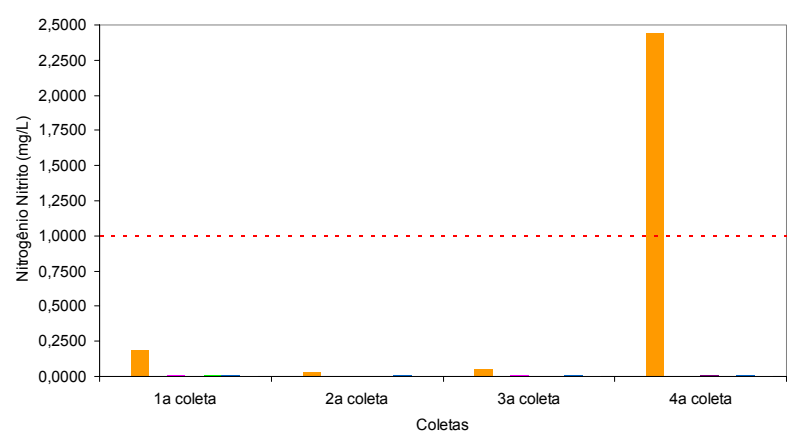

Figura 156 - Valores médios de Nitrogênio Nitrito na água superficial

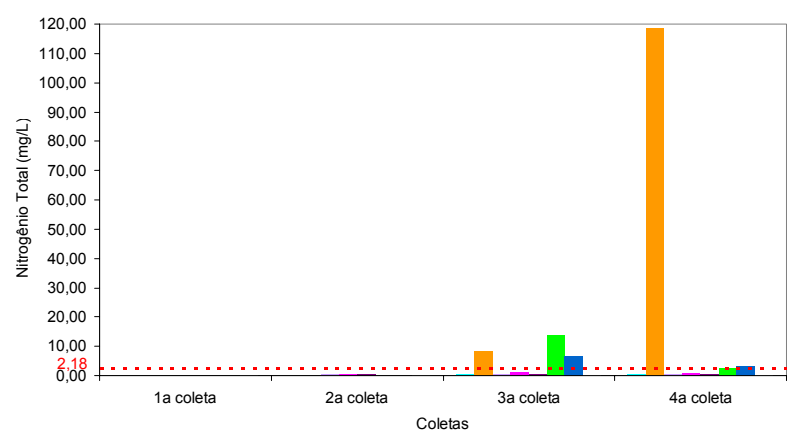

Figura 158 - Valores médios de Nitrogênio Total na água superficial 


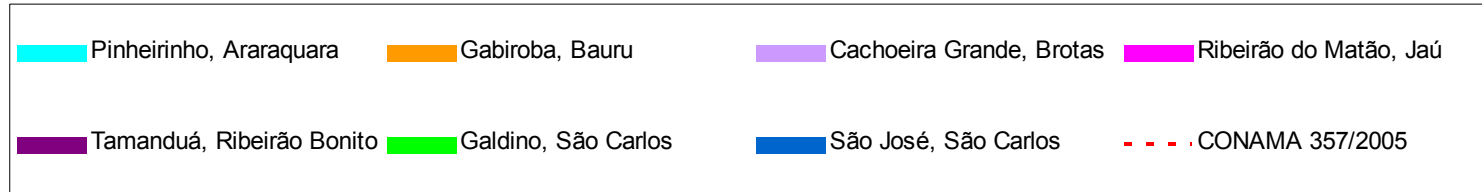

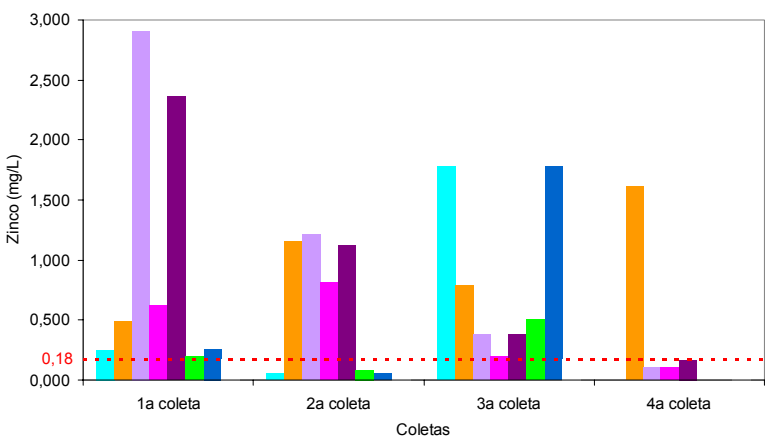

Figura 159 - Valores médios de Zinco na água superficial

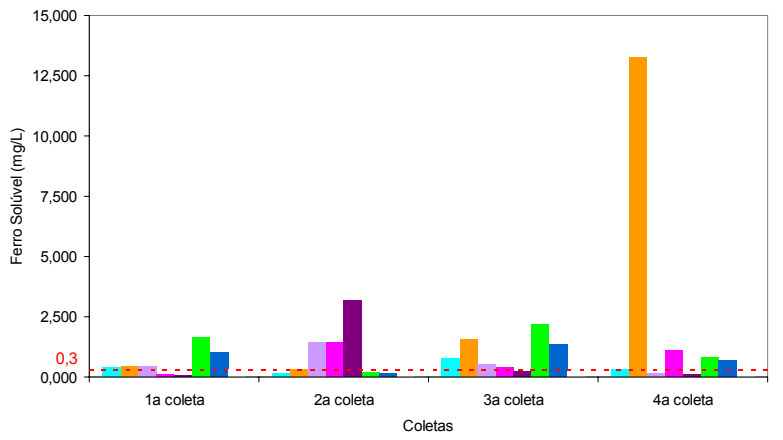

Figura 161 - Valores médios de Ferro Solúvel na água superficial

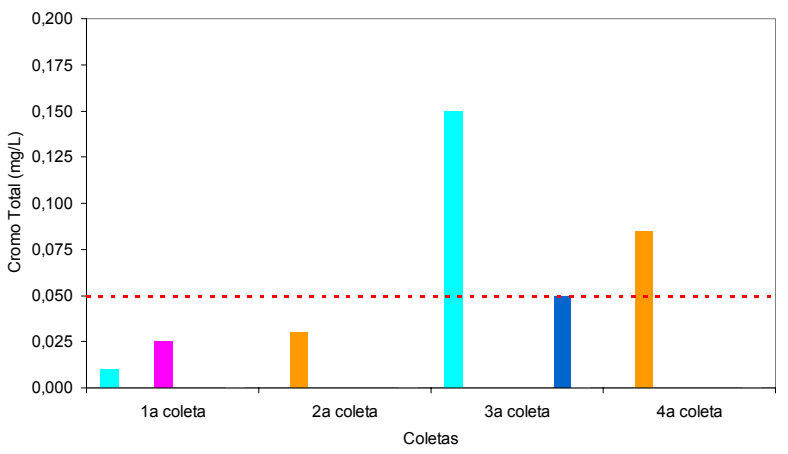

Figura 163 - Valores médios de Cromo Total na água superficial

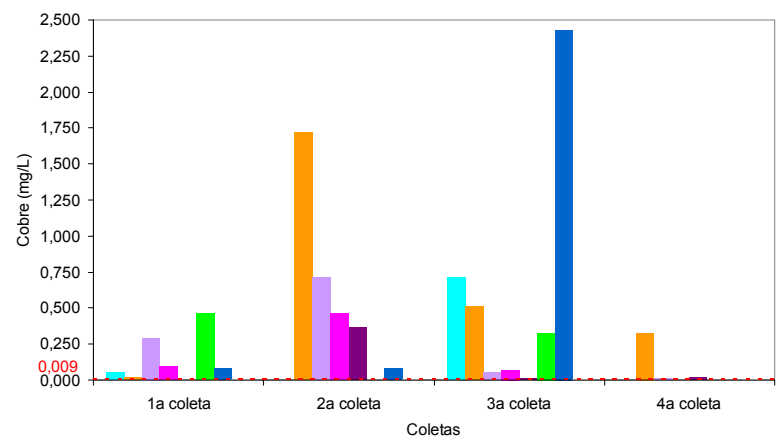

Figura 160 - Valores médios de Cobre na água superficial

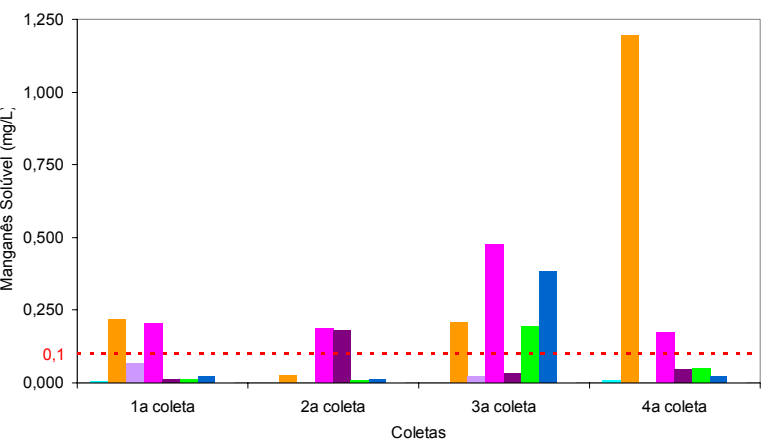

Figura 162 - Valores médios de Manganês Solúvel na água superficial

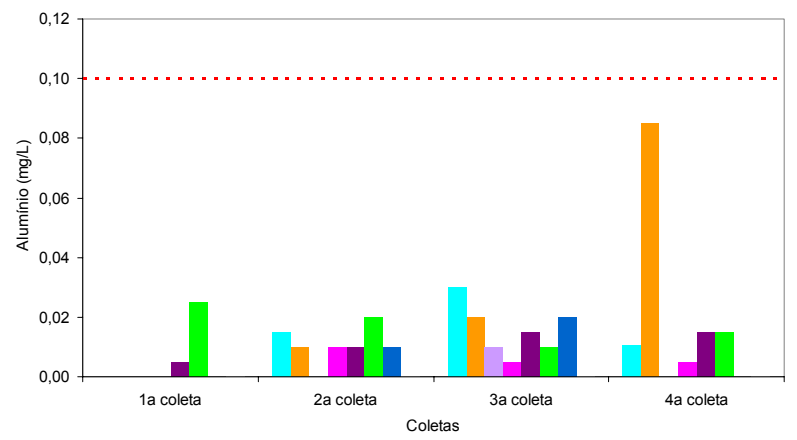

Figura 164 - Valores médios de Alumínio na água superficial 


\subsection{Análise das amostras de solo do lixão de Jaú}

Foi realizado análise de metais com amostras de solo do lixão de Jaú, a fim de verificar se estava ocorrendo percolação de chorume. O estudo procurou constatar se as camadas mais profundas do solo a montante e jusante do lixão estavam apresentando qualidade alterada. Os resultados foram comparados aos valores orientadores para solo no Estado de São Paulo (CETESB 2005b).

De acordo com a Tabela 36, as concentrações de metais nas amostras de solo do furo do poço a jusante PJ3 foram, na maioria, mais elevadas que as do furo do poço a montante PM, com exceção do Ferro e Manganês. Com base em CETESB (2005b), nenhuma das amostras superou os Valores de Prevenção e Intervenção, apenas a concentração de Cromo Total no PJ3 superou o Valor de Referência de Qualidade (VRQ), provavelmente devido à disposição de resíduos da indústria de artefatos de couro no lixão.

Tabela 36 - Análise de metais com amostras de solo do lixão de Jaú

\begin{tabular}{|c|c|c|c|c|c|c|}
\hline \multirow{2}{*}{$\begin{array}{l}\text { Parâmetros } \\
\text { (mg/kg) }\end{array}$} & \multicolumn{2}{|c|}{ Lixão de Jaú } & \multirow{2}{*}{$\begin{array}{l}\text { Limite de } \\
\text { Detecção }\end{array}$} & \multicolumn{3}{|c|}{$\begin{array}{l}\text { Valores orientadores para solo e água } \\
\text { subterrânea no Estado de São Paulo* }\end{array}$} \\
\hline & $\begin{array}{c}\text { PM } \\
(15 \mathrm{~m})\end{array}$ & $\begin{array}{l}\text { PJ3 } \\
\text { (8m) }\end{array}$ & & $\begin{array}{c}\text { Valores de } \\
\text { Referência de } \\
\text { Qualidade }^{* *}\end{array}$ & $\begin{array}{l}\text { Valores de } \\
\text { Prevenção** }\end{array}$ & $\begin{array}{l}\text { Valores de } \\
\text { Intervenção } \\
\text { (Agrícola) }^{* *}\end{array}$ \\
\hline Zinco & 16,00 & 35,34 & 0,699 & 60 & 300 & 450 \\
\hline Chumbo & 12,09 & 14,95 & 0,081 & 17 & 72 & 180 \\
\hline Cádmio & $<0,00062$ & $<0,00062$ & 0,00062 & $<0,5$ & 1,3 & 3 \\
\hline Níquel & 9,64 & 12,52 & 0,040 & 13 & 30 & 70 \\
\hline Ferro & 18262,90 & 10904,94 & 9,429 & - & - & - \\
\hline Manganês & 66,51 & 36,13 & 0,013 & - & - & - \\
\hline Cobre & $<0,009$ & 1,93 & 0,009 & 35 & 60 & 200 \\
\hline Cromo Total & 4,87 & 43,79 & 0,019 & 40 & 75 & 150 \\
\hline Alumínio & 3625,25 & 33145,13 & - & - & - & - \\
\hline
\end{tabular}

$\square$ Valor acima dos Valores de Referência de Qualidade (VRQ)

* CETESB. 2004. Relatório de Qualidade das Águas Subterrâneas no Estado de São Paulo 2001-2003

** CETESB. 2005b. Decisão da Diretoria n 195-2005-E, de 23 de novembro de 2005

Os Valores de Referência de Qualidade indicam o grau de qualidade de um solo considerado limpo e devem ser empregados para ações de prevenção à poluição, bem como para o controle de áreas contaminadas. Os Valores de Prevenção expressam a concentração acima da qual podem ocorrer alterações prejudiciais à qualidade do solo e águas subterrâneas. Quando ultrapassada, recomenda-se o monitoramento dos impactos. Os Valores de Intervenção indicam "riscos potenciais, diretos ou indiretos, à saúde humana" e, portanto, necessidade de ações para resguardar os receptores de risco. Quando ultrapassados estes limites, a área será classificada como "Área Contaminada" (CETESB, 2005b). 
Com base em CETESB (2004 e 2005b), não há valores recomendados para os metais Ferro, Manganês e Alumínio, porém constataram-se concentrações elevadas de Ferro e Alumínio nas amostras de solo do lixão de Jaú. Segundo CETESB (2002, p.165) o Alumínio e o Manganês são substâncias essenciais do solo. Conforme Braga et al (2005, p.136), Latossolos possuem elevados teores de óxidos de Ferro e Alumínio. Deduz-se que parte desses valores pode corresponder às características naturais do solo (substrato geológico), bem como à adsorção de metais presentes no lixiviado. Por comparação, Almeida (2005, p.65) encontrou $5500 \mathrm{mg} / \mathrm{kg}$ de Ferro em amostras de solo do aterro de São Carlos. Os valores obtidos nas amostras de solo do lixão de Jaú foram, no mínimo, cerca de duas vezes superior.

Com base nos resultados pode-se afirmar que houve indícios da percolação de lixiviado, devido às concentrações de Zinco, Chumbo, Níquel, Cobre, Cromo Total e Aumínio mais elevadas nas amostras de solo do PJ3. Por isso, recomendam-se estudos mais aprofundados com amostras de solo coletadas em vários pontos do local, a fim de verificar as concentrações de metais nas camadas superficiais, onde espera-se que os valores sejam mais elevados.

\subsection{Análise estatística dos parâmetros físico-químicos}

\subsubsection{Araraquara}

\subsubsection{1 Águas subterrâneas}

Com base no Apêndice D1, das vinte e duas variáveis físico-químicas analisadas, sete explicaram $90,65 \%$ dos resultados, ou seja, apresentaram variação significativa para o aterro durante as quatro coletas. A Tabela 37 apresenta as variáveis que explicaram o conjunto de dados do aterro por ordem de importância. 
Tabela 37 - PCA do aterro de Araraquara

\begin{tabular}{lrrr}
\hline Component loadings & 1 & 2 & \multicolumn{1}{c}{3} \\
SO4 & -0.145 & $\mathbf{0 . 8 7 7}$ & -0.413 \\
TURB & 0.503 & 0.464 & 0.707 \\
OD & -0.832 & -0.075 & 0.432 \\
STD & 0.851 & -0.357 & -0.188 \\
STV & 0.813 & -0.365 & 0.074 \\
STF & 0.828 & 0.415 & 0.064 \\
ST & 0.987 & 0.090 & -0.009 \\
Percent of Total Variance Explained & \\
& 1 & 2 & 3 \\
& 57.329 & 20.436 & 12.893 \\
\hline
\end{tabular}

- $\quad 1^{\circ}$ eixo: ST, STD, OD, STF, STV (explicaram cerca de $57 \%$ dos resultados);

- $2^{\circ}$ eixo: $\mathrm{SO}_{4}$;

- $3^{\circ}$ eixo: TURB.

Esse resultado indica a presença de sólidos na água, proveniente da matéria orgânica, responsável pela diminuição dos teores de $O D$, bem como da transparência da água. Constata-se também a presença de sais, expressa pela variação de Sulfatos.

\subsubsection{2 Águas superficiais}

Com base no Apêndice E1, das vinte e duas variáveis físico-químicas analisadas, doze explicaram $89,44 \%$ dos resultados, ou seja, apresentaram variação significativa para o córrego do Pinheirinho durante as quatro coletas. A Tabela 38 apresenta as variáveis que explicaram o conjunto de dados do córrego por ordem de importância.

Tabela 38 - PCA do córrego do Pinheirinho

\begin{tabular}{lrrr}
\hline Component loadings & \multicolumn{1}{c}{} \\
P & 1 & 2 & 3 \\
TEMP & 0.105 & -0.928 & 0.164 \\
NNO2 & 0.019 & 0.920 & 0.229 \\
STF & -0.084 & 0.118 & -0.959 \\
STD & 0.856 & 0.096 & 0.489 \\
STV & -0.852 & -0.147 & 0.476 \\
DQO & -0.851 & -0.043 & 0.336 \\
NT & 0.754 & -0.556 & -0.199 \\
COT & -0.805 & 0.452 & -0.192 \\
SO4 & 0.955 & 0.204 & 0.132 \\
PH & 0.866 & 0.414 & 0.053 \\
CE & -0.796 & 0.309 & 0.031 \\
Percent of Total Variance Explained & 0.419 & 0.023 \\
& 0.769 & 2 & \\
& 1 & 22.938 & 13.966 \\
\hline
\end{tabular}


- $\quad 1^{\circ}$ eixo: COT, $\mathrm{SO}_{4}, \mathrm{STF}, \mathrm{STD}, \mathrm{STV}, \mathrm{NT}, \mathrm{pH}, \mathrm{CE}, \mathrm{DQO}$ (explicaram cerca de $52 \%$ dos resultados);

- $\quad 2^{\circ}$ eixo: P, TEMP;

- $3^{\circ}$ eixo: $\mathrm{NNO}_{2}$.

\subsubsection{Bauru}

\subsubsection{1 Águas subterrâneas}

Com base no Apêndice D2, das vinte e duas variáveis físico-químicas analisadas, quatorze explicaram $81,01 \%$ da variação dos resultados. A Tabela 39 apresenta as variáveis mais significativas, por ordem de importância, para o aterro de Bauru.

Tabela 39 - PCA do aterro de Bauru

\begin{tabular}{|c|c|c|c|}
\hline \multicolumn{4}{|c|}{ Component loadings } \\
\hline & 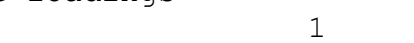 & 2 & 3 \\
\hline $\mathrm{NNO} 2$ & 0.189 & 0.211 & -0.855 \\
\hline $\mathrm{COT}$ & 0.446 & 0.363 & -0.753 \\
\hline $\mathrm{P}$ & 0.074 & 0.756 & 0.473 \\
\hline STV & 0.743 & -0.209 & -0.336 \\
\hline $\mathrm{DQO}$ & 0.701 & 0.215 & 0.335 \\
\hline TURB & 0.825 & -0.124 & 0.242 \\
\hline $\mathrm{STF}$ & 0.836 & 0.258 & 0.241 \\
\hline $\mathrm{COR}$ & 0.882 & -0.208 & 0.225 \\
\hline STD & 0.734 & 0.309 & -0.192 \\
\hline TEMP & 0.239 & -0.876 & -0.035 \\
\hline $\mathrm{ST}$ & 0.965 & 0.073 & 0.028 \\
\hline $\mathrm{PH}$ & -0.245 & 0.922 & 0.008 \\
\hline $\mathrm{CL}$ & 0.376 & -0.886 & 0.008 \\
\hline $\mathrm{CE}$ & 0.368 & 0.783 & -0.006 \\
\hline \multicolumn{4}{|c|}{ Percent of Total Variance Explained } \\
\hline & 1 & 2 & 3 \\
\hline & 37.913 & 29.147 & 13.956 \\
\hline
\end{tabular}

$1^{\circ}$ eixo: ST, COR, STF, TURB, STV, STD, DQO (explicaram cerca de $37 \%$ dos resultados); $2^{\circ}$ eixo: $\mathrm{pH}, \mathrm{Cl}, \mathrm{TEMP}, \mathrm{CE}, \mathrm{P}$;

$3^{\circ}$ eixo: $\mathrm{NNO}_{2}$ e COT.

A análise estatística indica a influência dos sólidos na água, devido à presença de matéria orgânica, responsável pela alteração na coloração e diminuição da transparência da água. A variação de $\mathrm{pH}$ também pode estar associada aos sólidos, bem como à oxidação da matéria orgânica. Os cloretos são provenientes da dissolução de sais e confere sabor salgado à água. A presença de sais deve ter provocado a alteração dos valores de 
condutividade elétrica. A variação da temperatura da água e das concentrações de Fósforo e Nitrogênio pode ter ocorrido devido à migração de lixiviado.

\subsubsection{2 Águas superficiais}

Com base no Apêndice E2, das vinte e duas variáveis físico-químicas analisadas, vinte explicaram $91,26 \%$ dos resultados, ou seja, apresentaram variação significativa para o córrego da Gabiroba durante as quatro coletas. A Tabela 40 apresenta as variáveis que explicaram o conjunto de dados do córrego por ordem de importância.

Tabela 40 - PCA do córrego da Gabiroba

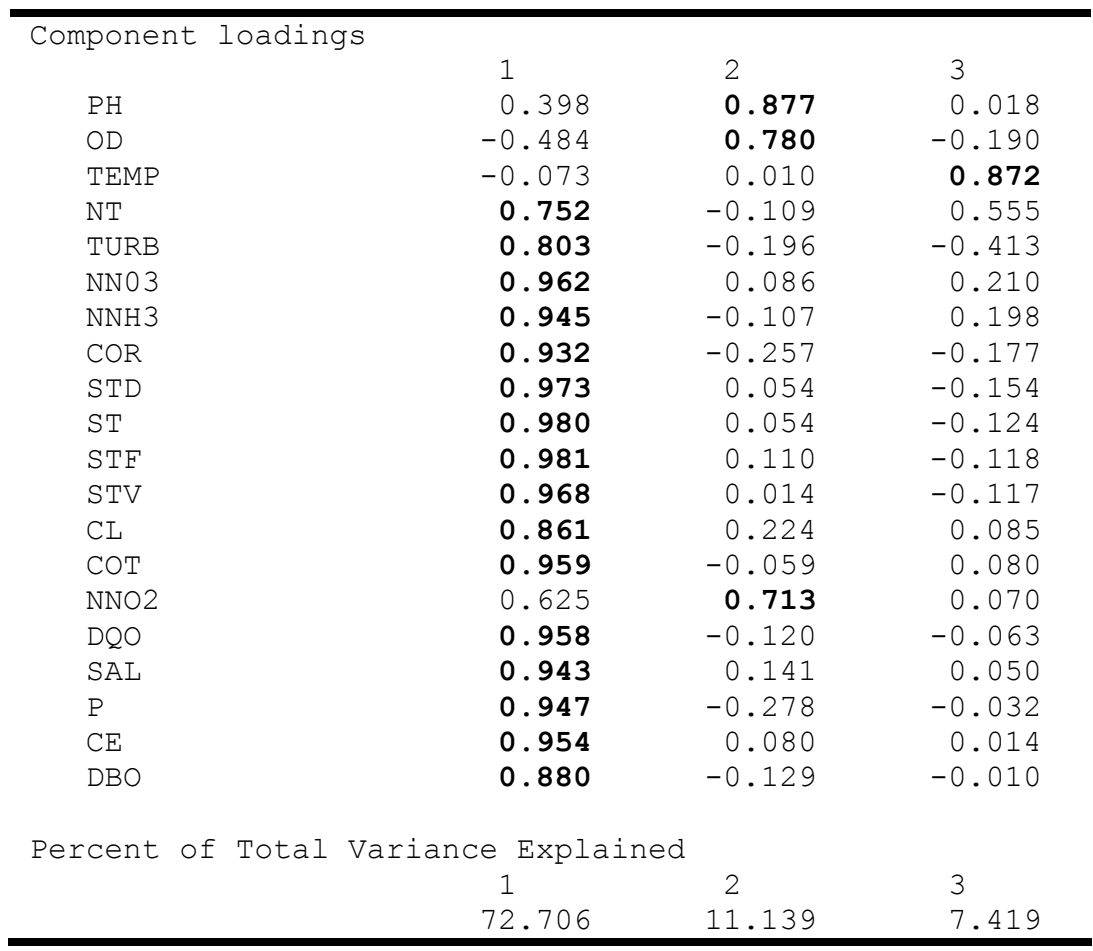

- $\quad 1^{\circ}$ eixo: STF, ST, STD, STV, $\mathrm{NNO}_{3}, \mathrm{COT}, \mathrm{DQO}, \mathrm{CE}, \mathrm{P}, \mathrm{NNH}_{3}, \mathrm{SAL}, \mathrm{COR}, \mathrm{DBO}, \mathrm{CL}$, TURB, NT (explicaram cerca de $72 \%$ dos resultados);

- $\quad 2^{\circ}$ eixo: $\mathrm{pH}, \mathrm{OD}, \mathrm{NNO}_{2}$;

- $\quad 3^{\circ}$ eixo: TEMP. 


\subsubsection{Brotas}

\subsubsection{1 Águas superficiais}

Conforme Apêndice E3, das vinte e duas variáveis físico-químicas analisadas, oito explicaram 93,09\% dos resultados, ou seja, apresentaram variação significativa para o córrego da Cachoeira Grande durante as quatro coletas. A Tabela 41 apresenta as variáveis que explicaram o conjunto de dados do córrego por ordem de importância.

Tabela 41 - PCA do córrego da Cachoeira Grande

\begin{tabular}{lrrr}
\hline Component loadings & \multicolumn{1}{c}{} \\
DQO & $\mathbf{0 . 9 8 7}$ & -0.082 & 3 \\
TEMP & 0.311 & $-\mathbf{0 . 8 4 7}$ & 0.005 \\
CL & -0.205 & 0.821 & 0.282 \\
NNH3 & 0.273 & 0.349 & 0.843 \\
ST & 0.377 & -0.732 & 0.446 \\
COR & 0.932 & 0.170 & -0.291 \\
TURB & 0.929 & 0.244 & -0.214 \\
COT & 0.905 & 0.339 & 0.073 \\
Percent of Total Variance Explained & \\
& 1 & 2 & 3 \\
& 48.526 & 28.260 & 16.309 \\
\hline
\end{tabular}

- $\quad 1^{\circ}$ eixo: DQO, COR, TURB, COT (explicaram cerca de $48 \%$ dos resultados);

- $\quad 2^{\circ}$ eixo: TEMP, CL, ST;

- $3^{\circ}$ eixo: $\mathrm{NNH}_{3}$.

\subsubsection{Jaú}

\subsubsection{1 Águas subterrâneas}

Com base no Apêndice D3, das vinte e duas variáveis físico-químicas analisadas, quatorze explicaram $89,54 \%$ dos resultados, ou seja, apresentaram variação significativa para o lixão durante as quatro coletas. A Tabela 42 apresenta as variáveis que explicaram o conjunto de dados do lixão por ordem de importância. 
Tabela 42 - PCA do lixão de Jaú

\begin{tabular}{lrrr}
\hline Component loadings & \multicolumn{1}{c}{} \\
SO4 & -0.286 & \multicolumn{1}{c}{0.246} & 3 \\
OD & 0.168 & $\mathbf{0 . 8 3 5}$ \\
STF & $\mathbf{0 . 8 4 0}$ & 0.443 & 0.389 \\
CE & $\mathbf{0 . 8 2 0}$ & -0.525 & -0.213 \\
NNH3 & $\mathbf{0 . 7 6 1}$ & -0.608 & 0.182 \\
PH & $\mathbf{0 . 8 4 7}$ & 0.173 & 0.161 \\
SAL & $\mathbf{0 . 7 4 8}$ & -0.629 & 0.158 \\
ST & $\mathbf{0 . 8 4 4}$ & 0.481 & -0.135 \\
DBO & $\mathbf{0 . 9 0 0}$ & 0.106 & -0.087 \\
STV & $\mathbf{0 . 8 4 1}$ & 0.486 & -0.047 \\
NN03 & $\mathbf{0 . 8 4 2}$ & -0.333 & 0.044 \\
CL & $\mathbf{0 . 9 2 5}$ & -0.337 & 0.031 \\
DQO & $\mathbf{0 . 9 0 9}$ & 0.167 & -0.017 \\
STD & $\mathbf{0 . 9 0 4}$ & 0.359 & 0.003 \\
Percent of Total Variance Explained & & \\
& 1 & 2 & 3 \\
\hline
\end{tabular}

- $\quad 1^{\circ}$ eixo: $\mathrm{Cl}, \mathrm{DQO}, \mathrm{STD}, \mathrm{DBO}, \mathrm{pH}, \mathrm{ST}, \mathrm{NNO}_{3}, \mathrm{STV}, \mathrm{STF}, \mathrm{CE}, \mathrm{NNH}_{3}, \mathrm{SAL}$ (explicaram cerca de $62 \%$ dos resultados);

- $\quad 2^{\circ}$ eixo: OD;

- $\quad 3^{\circ}$ eixo: $\mathrm{SO}_{4}$.

Os resultados mostram a variação significativa de Cloretos, Condutividade Elétrica e Salinidade no primeiro eixo e Sulfatos no terceiro eixo, indicando presença de sais na água, bem como de matéria orgânica, devido à variação de sólidos, DQO, DBO, pH e Nitrogênio. Os sais e a decomposição da matéria orgânica foram os responsáveis pela redução nos teores de OD. A combinação desses parâmetros pode indicar a migração de lixiviado.

\subsubsection{2 Águas superficiais}

Com base no Apêndice E4, das vinte e duas variáveis físico-químicas analisadas, dezesseis explicaram $87,72 \%$ dos resultados, ou seja, apresentaram variação significativa para o ribeirão do Matão durante as quatro coletas. A Tabela 43 apresenta as variáveis que explicaram o conjunto de dados do ribeirão por ordem de importância. 
Tabela 43 - PCA do ribeirão do Matão

\begin{tabular}{lrrr}
\hline Component loadings & \multicolumn{1}{r}{} & \multicolumn{1}{c}{3} \\
CE & 0.096 & -0.513 & 0.713 \\
P & $\mathbf{0 . 7 2 7}$ & 0.280 & -0.470 \\
STV & $\mathbf{0 . 8 8 3}$ & 0.021 & 0.439 \\
NNO3 & $\mathbf{0 . 7 6 2}$ & 0.446 & -0.377 \\
DBO & -0.119 & $-\mathbf{0 . 8 9 0}$ & -0.375 \\
SO4 & $\mathbf{0 . 7 7 0}$ & 0.416 & 0.370 \\
NT & $\mathbf{0 . 7 3 9}$ & 0.197 & 0.317 \\
NNO2 & $\mathbf{0 . 8 7 6}$ & 0.376 & -0.280 \\
NNH3 & $\mathbf{0 . 8 8 1}$ & -0.097 & -0.260 \\
OD & -0.373 & $\mathbf{0 . 8 5 5}$ & 0.211 \\
CL & $\mathbf{0 . 8 0 6}$ & -0.451 & 0.124 \\
DQO & 0.118 & -0.778 & -0.070 \\
STD & $\mathbf{0 . 9 8 7}$ & 0.017 & 0.065 \\
TURB & $\mathbf{0 . 8 8 6}$ & -0.408 & -0.036 \\
COR & $\mathbf{0 . 8 7 5}$ & -0.246 & 0.034 \\
ST & $\mathbf{0 . 9 9 5}$ & 0.006 & 0.009 \\
Percent of Total Variance Explained & & \\
& 1 & 2 & 3 \\
\hline
\end{tabular}

- $\quad 1^{\circ}$ eixo: ST, STD, TURB, STV, $\mathrm{NNH}_{3}, \mathrm{COR}, \mathrm{NNO}_{2}, \mathrm{CL}, \mathrm{SO}_{4}, \mathrm{NNO}_{3}, \mathrm{NT}, \mathrm{P}$, (explicaram cerca de $55 \%$ dos resultados);

- $\quad 2^{\circ}$ eixo: DBO, OD, DQO;

- $\quad 3^{\circ}$ eixo: $\mathrm{CE}$.

\subsubsection{Ribeirão Bonito}

\subsubsection{1 Águas superficiais}

Conforme Apêndice E5, das vinte e duas variáveis físico-químicas analisadas, dezenove explicaram $90,79 \%$ dos resultados, ou seja, apresentaram variação significativa para o córrego do Tamanduá durante as quatro coletas. A Tabela 44 apresenta as variáveis que explicaram o conjunto de dados do córrego por ordem de importância. 
Tabela 44 - PCA do córrego do Tamanduá

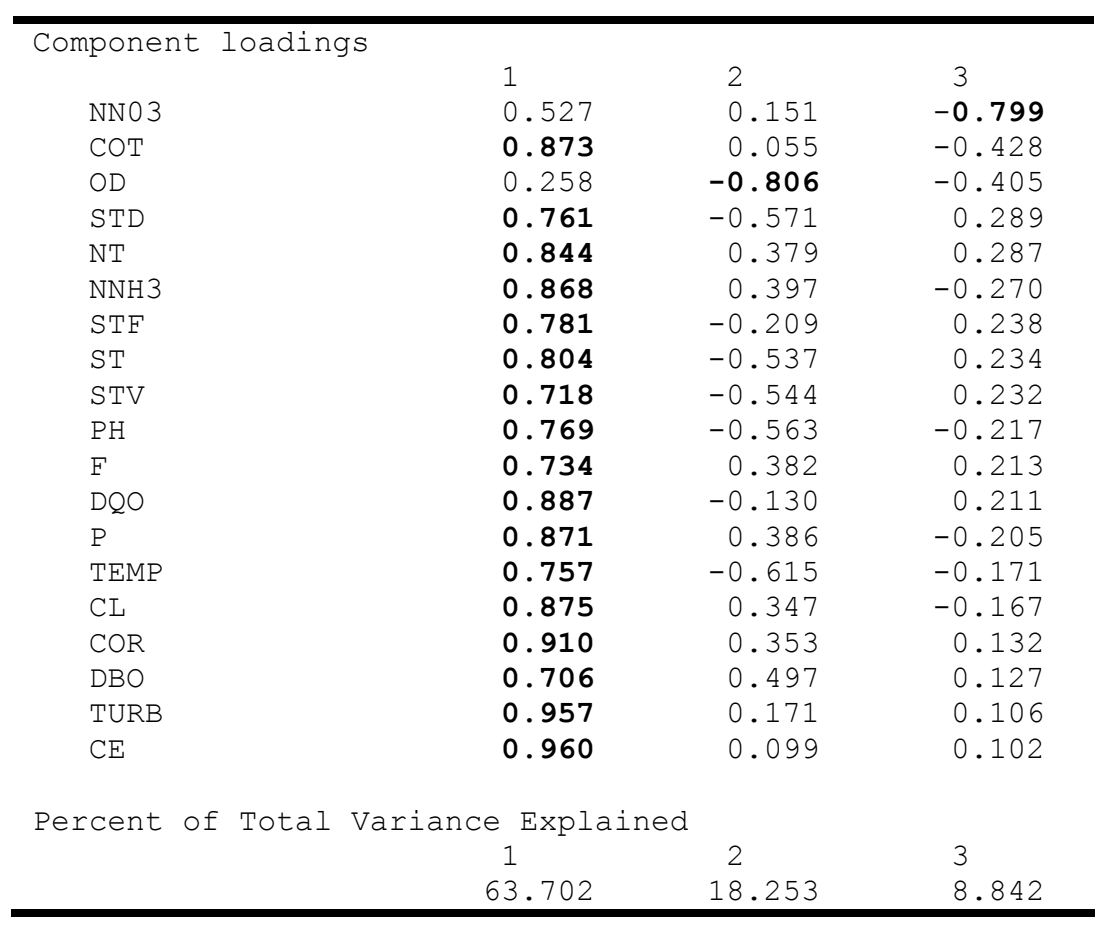

- $\quad 1^{\circ}$ eixo: CE, TURB, COR, DQO, CL, COT, P, NNH $\mathrm{N}_{3}, \mathrm{NT}, \mathrm{ST}, \mathrm{STF}, \mathrm{pH}, \mathrm{STD}, \mathrm{TEMP}, \mathrm{F}$, STV, DBO (explicaram cerca de $63 \%$ dos resultados);

- $\quad 2^{\circ}$ eixo: OD;

- $\quad 3^{\circ}$ eixo: $\mathrm{NNO}_{3}$.

\subsubsection{São Carlos}

\subsubsection{Aterro}

\subsubsection{1 Águas subterrâneas}

Com base no Apêndice D4, das vinte e duas variáveis físico-químicas analisadas, dezoito explicaram $77,27 \%$ dos resultados, ou seja, apresentaram variação significativa para o aterro durante as quatro coletas. A Tabela 45 apresenta as variáveis que explicaram o conjunto de dados do aterro por ordem de importância. 
Tabela 45 - PCA do aterro de São Carlos

\begin{tabular}{llr}
\hline Component loadings & & \\
& 1 & 2 \\
OD & 0.359 & 0.790 \\
F & 0.155 & 0.762 \\
P & 0.133 & 0.711 \\
PH & 0.748 & 0.482 \\
SAL & 0.734 & -0.481 \\
CL & 0.829 & -0.428 \\
TEMP & 0.785 & 0.417 \\
CE & 0.833 & -0.363 \\
COT & 0.892 & -0.265 \\
DBO & 0.861 & -0.175 \\
NNO3 & 0.800 & -0.168 \\
STV & 0.890 & 0.135 \\
ST & 0.926 & 0.120 \\
STD & 0.892 & 0.093 \\
DQO & 0.959 & 0.059 \\
COR & 0.752 & -0.053 \\
STF & 0.946 & 0.021 \\
TURB & 0.898 & -0.004 \\
PerCent of Total Variance Explained & \\
& 1 & 2 \\
\hline
\end{tabular}

- $1^{\circ}$ eixo: DQO, STF, ST, TURB, COT e STD, STV, DBO, CE, CI, NNO $\mathrm{N}_{3}, \mathrm{TEMP}, \mathrm{COR}$, $\mathrm{pH}, \mathrm{SAL}$ (explicaram cerca de $61 \%$ dos resultados);

- $\quad 2^{\circ}$ eixo: OD, $F, P$.

Os resultados indicam a migração de lixiviado para as águas subterrâneas, devido à combinação dos parâmetros que mais variaram, principalmente no primeiro eixo, os quais indicam a variação de matéria orgânica, sais e Nitrogênio. Estas variáveis contribuíram para coloração, redução da transparência da água e dos teores de OD. A variação de Fósforo também pode indicar a percolação do lixiviado.

\subsubsection{2 Águas superficiais}

Conforme Apêndice E6, das vinte e duas variáveis físico-químicas analisadas, dezesseis explicaram $87,17 \%$ dos resultados, ou seja, apresentaram variação significativa para o córrego do Galdino durante as quatro coletas. A Tabela 46 apresenta as variáveis que explicaram o conjunto de dados do córrego por ordem de importância. 
Tabela 46 - PCA do córrego do Galdino

\begin{tabular}{llr}
\hline Component loadings & 1 & 2 \\
NT & 0.533 & -0.818 \\
NNH3 & 0.569 & -0.785 \\
DBO & 0.540 & -0.701 \\
CL & 0.755 & -0.621 \\
CE & 0.817 & -0.517 \\
STF & 0.860 & 0.384 \\
COT & 0.885 & 0.366 \\
TURB & 0.907 & 0.320 \\
TEMP & 0.936 & 0.300 \\
COR & 0.805 & 0.299 \\
ST & 0.941 & 0.283 \\
DQO & 0.881 & 0.245 \\
PH & 0.899 & 0.188 \\
STV & 0.903 & 0.099 \\
F & 0.839 & -0.084 \\
STD & 0.873 & 0.021 \\
Percent of Total Variance Explained \\
\end{tabular}

- $1^{\circ}$ eixo: ST, TEMP, TURB, STV, pH, COT, DQO, STD, STF, F, CE, COR, CL, (explicaram cerca de $67 \%$ dos resultados);

- $\quad 2^{\circ}$ eixo: $\mathrm{NT}, \mathrm{NNH}_{3}, \mathrm{DBO}$.

\subsubsection{Antigo Lixão}

\subsubsection{1 Águas subterrâneas}

Conforme Apêndice D5, das vinte e duas variáveis físico-químicas analisadas, onze explicaram $86,07 \%$ dos resultados, ou seja, apresentaram variação significativa para o antigo lixão durante as quatro coletas. A Tabela 47 apresenta as variáveis que explicaram o conjunto de dados do antigo lixão por ordem de importância. 
Tabela 47 - PCA do antigo lixão de São Carlos

\begin{tabular}{lrrr}
\hline Component loadings & \multicolumn{1}{c}{} \\
P & 1 & 2 & \multicolumn{1}{l}{3} \\
F & 0.235 & -0.864 & 0.210 \\
SO4 & 0.154 & -0.846 & 0.122 \\
CE & 0.286 & -0.521 & -0.739 \\
PH & 0.722 & 0.352 & -0.486 \\
TEMP & 0.824 & 0.134 & 0.205 \\
STF & 0.902 & 0.051 & 0.203 \\
STD & 0.910 & -0.044 & -0.178 \\
STV & 0.929 & 0.208 & 0.159 \\
DQO & 0.966 & 0.031 & 0.107 \\
ST & 0.872 & -0.149 & 0.068 \\
Percent of Total Variance Explained & 0.018 & -0.006 \\
& 0.983 & 2 & 3 \\
& 1 & 17.698 & 9.068 \\
\hline
\end{tabular}

- $1^{\circ}$ eixo: ST, STV, STD, STF, TEMP, DQO, pH, CE (explicaram cerca de $59 \%$ dos resultados);

- $2^{\circ}$ eixo: $P, F$;

- $3^{\circ}$ eixo: $\mathrm{SO}_{4}$.

A análise estatística indica a variação de matéria orgânica e sais na água, que podem ser resultantes da migração de lixiviado, o que pode ter alterado a temperatura da água. A variação de Fósforo reforça esta hipótese. Elevados valores de Condutividade Elétrica, DQO e Sólidos também podem ser resultantes do lixiviado.

Foram constatadas variações de Fluoreto nas águas do aterro e do antigo lixão de São Carlos. De acordo com CETESB (2005a, p.30), normalmente os Fluoretos são encontrados em águas naturais, concentrações elevadas geralmente estão associadas a fontes subterrâneas e podem estar disponíveis biologicamente, dependendo das condições do solo. "Estudos hidroquímicos sobre concentrações naturais de flúor em águas subterrâneas no Estado de São Paulo têm reportado a ocorrência de fluoreto, acima do padrão de potabilidade, nas águas subterrâneas dos Sistemas Aqüíferos Serra Geral e Guarani”, porém invesigações sobre a origem do Fluoreto nas águas subterrâneas de algumas UGRHIs devem ser realizadas, pois sua origem pode ser industrial (CETESB, 2004, p.90).

\subsubsection{2 Águas superficiais}

Conforme Apêndice E7, das vinte e duas variáveis físico-químicas analisadas, dezesseis explicaram $90,38 \%$ dos resultados, ou seja, apresentaram variação significativa 
para o córrego São José durante as quatro coletas. A Tabela 48 apresenta as variáveis que explicaram o conjunto de dados do córrego por ordem de importância.

Tabela 48 - PCA do córrego São José

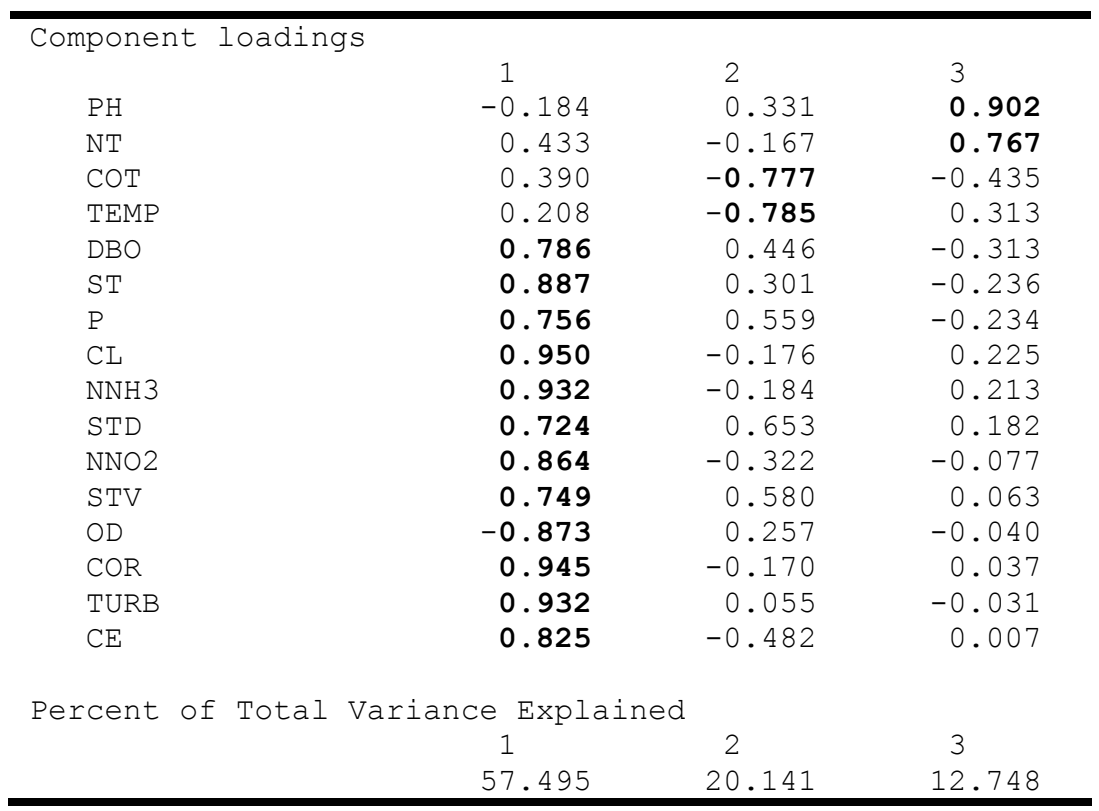

- $\quad 1^{\circ}$ eixo: $\mathrm{CL}, \mathrm{COR}, \mathrm{NNH}_{3}$ e TURB, ST, OD, $\mathrm{NNO}_{2}, \mathrm{CE}, \mathrm{DBO}, \mathrm{P}, \mathrm{STV}, \mathrm{STD}$ (explicaram cerca de $57 \%$ dos resultados);

- $\quad 2^{\circ}$ eixo: TEMP, COT;

- $\quad 3^{\circ}$ eixo: $\mathrm{pH}, \mathrm{NT}$.

\subsubsection{Cluster das águas subterrâneas}

$\mathrm{Na}$ análise de cluster das médias, o coeficiente de correlação cofenético (CF) foi igual a 0,98 . Quanto mais próximo de 1,0 for o CF significa que os dados agrupados são mais fiéis à realidade. Dessa forma, a análise estatística apontou uma boa avaliação dos dados.

As variáveis significativas comuns entre os aterros, apontadas pela PCA, foram: (1) Turbidez, (2) Oxigênio Dissolvido, (3) Sulfatos, (4) Sólidos Totais, (5) Sólidos Totais Fixos, (6) Sólidos Totais Voláteis e (7) Sólidos Totais Dissolvidos.

Os aterros foram denominados da seguinte forma: 
- Aterro 1 = Araraquara;

- Aterro 2 = Bauru;

- Aterro 3 = Lixão de Jaú;

- Aterro 4 = São Carlos e

- Aterro 5 = Antigo Lixão de São Carlos.

Com base no tratamento das médias de cada aterro foi gerado o gráfico apresentado na Figura 165.

\section{Cluster Tree}

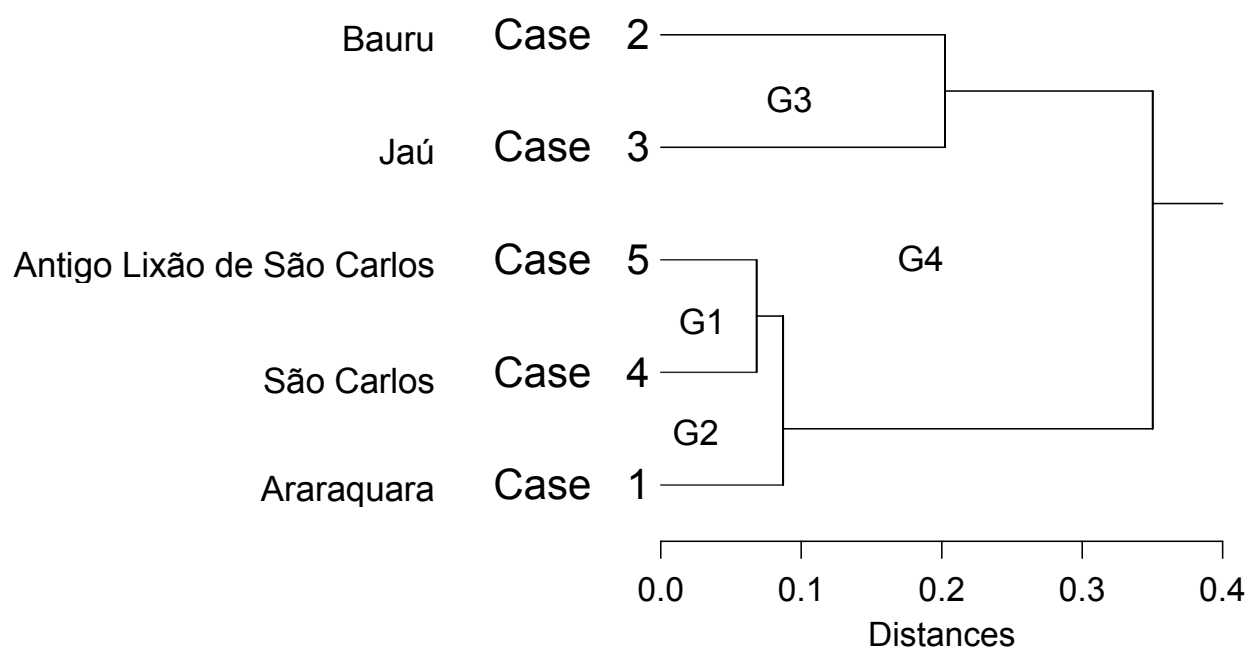

Figura 165 - Cluster das médias dos aterros

De acordo com a Figura 165, por similaridade, os aterros mais parecidos foram:

- Grupo 1 (G1) = Aterro de São Carlos + Antigo Lixão de São Carlos;

- Grupo $2(\mathrm{G} 2)$ = Grupo 1 + Aterro de Araraquara;

- Grupo $3(\mathrm{G} 3)$ = Aterro de Bauru + Lixão de Jaú;

- Grupo 4 (G4) = Grupo 2 + Grupo 3.

O cluster indicou que as águas subterrâneas do Aterro de São Carlos possuem qualidade mais parecida com as águas do Antigo Lixão de São Carlos e, em seguida, as águas desses dois aterros possuem qualidade parecida com as águas do Aterro de 
Araraquara. Isso pode significar que as características do solo e da geologia da região podem ter influenciado os resultados.

\subsubsection{Cluster das águas superficiais}

$\mathrm{Na}$ análise de cluster das médias, o coeficiente de correlação cofenético (CF) foi igual a 0,9821 . Quanto mais próximo de 1,0 for o CF significa que os dados agrupados são mais fiéis à realidade. Dessa forma, a análise estatística apontou uma boa avaliação dos dados.

As variáveis significativas mais comuns entre os córregos, apontadas pela PCA, foram: (1) Demanda Química de Oxigênio, (2) Temperatura, (3) Cloretos, (4) Nitrogênio Amoniacal, (5) Sólidos Totais, (6) Cor, (7) Turbidez e (8) Carbono Orgânico Total.

Os córregos foram denominados da seguinte forma:

- Córrego 1 = córrego do Pinheirinho, Araraquara;

- Córrego 2 = córrego da Gabiroba, Bauru;

- Córrego 3 = córrego da Cachoeira Grande, Brotas;

- Córrego 4 = ribeirão do Matão, Jaú;

- Córrego 5 = córrego do Tamanduá, Ribeirão Bonito;

- Córrego 6 = córrego do Galdino, São Carlos (aterro) e

- Córrego 7 = córrego São José, São Carlos (antigo lixão).

Com base no tratamento das médias de cada córrego foi gerado o gráfico apresentado na Figura 166. 


\section{Cluster Tree}

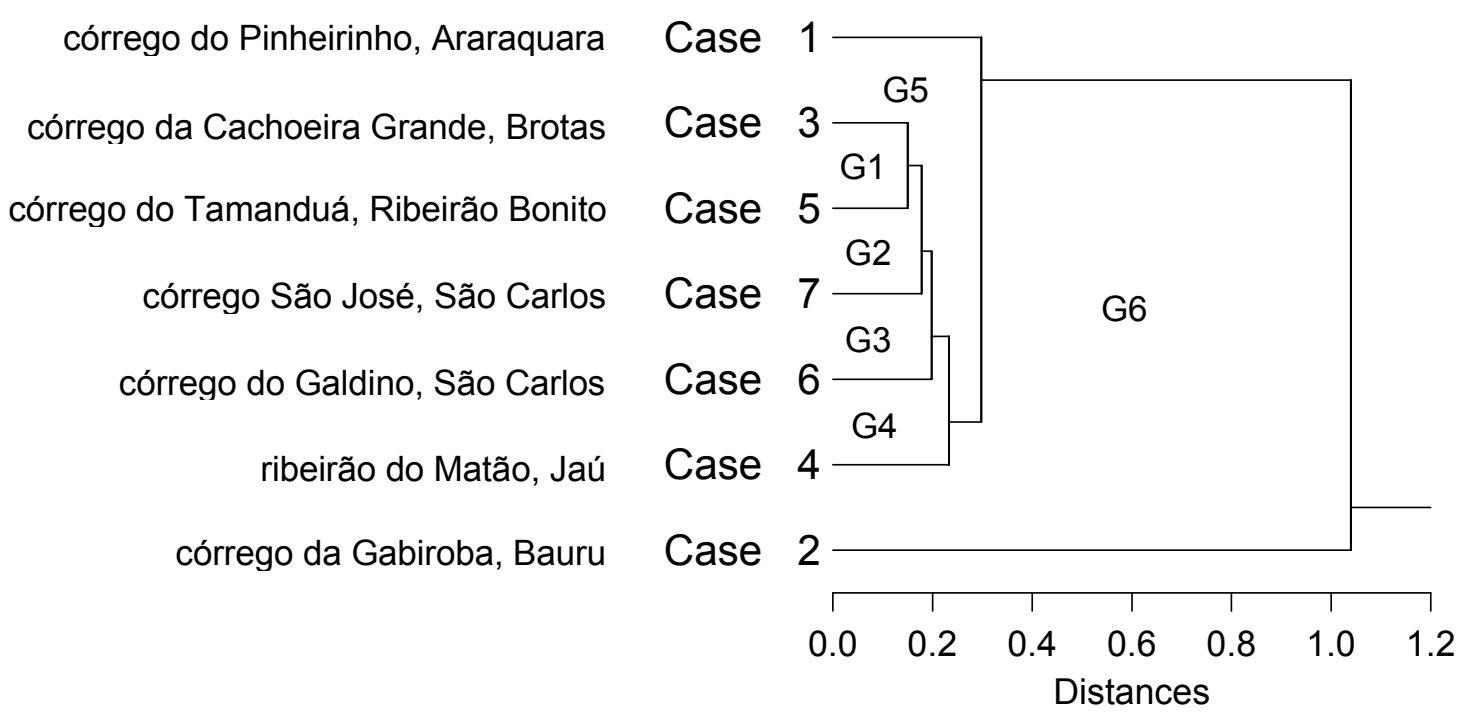

Figura 166 - Cluster das médias dos córregos

De acordo com a Figura 166, os córregos mais parecidos foram:

- Grupo $1(\mathrm{G} 1)$ = Brotas + Ribeirão Bonito;

- Grupo 2 (G2) = Grupo 1 + São Carlos (São José);

- Grupo 3 (G3) = Grupo 2 + São Carlos (Galdino);

- Grupo $4(\mathrm{G} 4)$ = Grupo 3 + Jaú;

- Grupo 5 (G5) = Grupo 4 + Araraquara;

- Grupo $6(\mathrm{G} 6)$ = Bauru.

O cluster indicou que o córrego da Gabiroba em Bauru possui características distintas comparado aos outros córregos, ao contrário dos córregos da Cachoeira Grande em Brotas e do Tamanduá em Ribeirão Bonito que apresentaram características semelhantes, conforme ensaios laboratoriais. 


\subsection{Análise estatística de metais}

\subsubsection{Araraquara}

\subsubsection{1 Águas subterrâneas}

Conforme Apêndice D1, dos dez metais analisados, cinco explicaram 90,58\% dos resultados, ou seja, apresentaram variação significativa para o aterro durante as quatro coletas. A Tabela 49 apresenta as variáveis que explicaram o conjunto de dados do aterro por ordem de importância.

Tabela 49 - PCA do aterro de Araraquara

\begin{tabular}{crrr}
\hline Component loadings & & & \\
& 1 & 2 & 3 \\
ZN & 0.943 & 0.030 & 0.182 \\
FE & 0.897 & 0.119 & 0.132 \\
CU & 0.872 & -0.140 & 0.054 \\
AL & -0.166 & 0.902 & 0.382 \\
CR & -0.323 & -0.423 & $\mathbf{0 . 8 4 6}$ \\
Percent of Total Variance Explained & \\
& 1 & 2 & 3 \\
& 51.731 & 20.544 & 18.305 \\
\hline
\end{tabular}

- $\quad 1^{\circ}$ eixo: Zinco, Ferro, Cobre (explicaram cerca de $51 \%$ dos resultados);

- $\quad 2^{\circ}$ eixo: Alumínio;

- $\quad 3^{\circ}$ eixo: Cromo.

\subsubsection{2 Águas superficiais}

Conforme Apêndice E1, dos dez metais analisados, cinco explicaram 89,04\% dos resultados, ou seja, apresentaram variação significativa para o córrego do Pinheririnho durante as quatro coletas. A Tabela 50 apresenta as variáveis que explicaram o conjunto de dados do córrego por ordem de importância. 
Tabela 50 - PCA do córrego do Pinheirinho

\begin{tabular}{crr}
\hline Component loadings & \multicolumn{3}{c}{} \\
CU & 0.990 & 0.016 \\
ZN & 0.983 & 0.051 \\
MN & -0.302 & -0.936 \\
FE & 0.814 & -0.435 \\
CR & 0.828 & 0.008 \\
Percent of Total Variance Explained \\
\end{tabular}

- $1^{\circ}$ eixo: Cobre, Zinco, Cromo, Ferro (explicaram cerca de $67 \%$ dos resultados);

- $\quad 2^{\circ}$ eixo: Manganês.

\subsubsection{Bauru}

\subsubsection{1 Águas subterrâneas}

Conforme Apêndice D2, dos dez metais analisados, cinco explicaram 79,08\% dos resultados, ou seja, apresentaram variação significativa para o aterro durante as quatro coletas. A Tabela 51 apresenta as variáveis que explicaram o conjunto de dados do aterro por ordem de importância.

Tabela 51 - PCA do aterro de Bauru

\begin{tabular}{crr}
\hline Component loadings & \multicolumn{1}{c}{} \\
CU & $\mathbf{0 . 9 5 9}$ & -0.058 \\
ZN & $\mathbf{0 . 8 8 5}$ & 0.296 \\
$\mathrm{CR}$ & $\mathbf{0 . 8 3 1}$ & -0.255 \\
$\mathrm{FE}$ & -0.035 & $\mathbf{0 . 8 7 3}$ \\
$\mathrm{AL}$ & 0.045 & $\mathbf{0 . 7 9 9}$ \\
Percent of Total Variance Explained \\
\\
\end{tabular}

- $1^{\circ}$ eixo: Cobre, Zinco, Cromo (explicaram cerca de $47 \%$ dos resultados);

- $\quad 2^{\circ}$ eixo: Ferro e Alumínio. 


\subsubsection{2 Águas superficiais}

Conforme Apêndice E2, dos dez metais analisados, seis explicaram 88,94\% dos resultados, ou seja, apresentaram variação significativa para o córrego da Gabiroba durante as quatro coletas. A Tabela 52 apresenta as variáveis que explicaram o conjunto de dados do córrego por ordem de importância.

Tabela 52 - PCA do córrego da Gabiroba

\begin{tabular}{|c|c|c|}
\hline \multicolumn{3}{|c|}{ Component loadings } \\
\hline & 1 & 2 \\
\hline AL & 0.967 & 0.219 \\
\hline $\mathrm{ZN}$ & 0.423 & 0.880 \\
\hline $\mathrm{CU}$ & -0.198 & 0.761 \\
\hline $\mathrm{CR}$ & 0.654 & 0.708 \\
\hline $\mathrm{FE}$ & 0.705 & -0.629 \\
\hline MN & 0.803 & -0.563 \\
\hline \multicolumn{3}{|c|}{ Percent of Total Variance Explained } \\
\hline & 1 & 2 \\
\hline & & 43.571 \\
\hline
\end{tabular}

- $1^{\circ}$ eixo: Alumínio, Manganês, Ferro (explicaram cerca de $45 \%$ dos resultados);

- $\quad 2^{\circ}$ eixo: Zinco, Cobre, Cromo.

\subsubsection{Brotas}

\subsubsection{1 Águas superficiais}

Conforme Apêndice E3, dos dez metais analisados, cinco explicaram $88,54 \%$ dos resultados, ou seja, apresentaram variação significativa para o córrego da Cachoeira Grande durante as quatro coletas. A Tabela 53 apresenta as variáveis que explicaram o conjunto de dados do córrego por ordem de importância.

Tabela 53 - PCA do córrego da Cachoeira Grande

\begin{tabular}{lrrr}
\hline Component loadings & \multicolumn{3}{c}{} \\
& 1 & 2 & 3 \\
CU & 0.846 & -0.268 & 0.072 \\
FE & 0.815 & -0.434 & -0.339 \\
ZN & 0.736 & 0.473 & 0.071 \\
MN & 0.299 & 0.898 & 0.093 \\
AL & -0.143 & 0.258 & -0.952 \\
Percent of Total Variance Explained & \\
& 1 & 2 & 3 \\
& 40.617 & 27.136 & 20.788 \\
\hline
\end{tabular}


- $1^{\circ}$ eixo: Cobre, Ferro, Zinco (explicaram cerca de $40 \%$ dos resultados);

- $\quad 2^{\circ}$ eixo: Manganês;

- $\quad 3^{\circ}$ eixo: Alumínio.

\subsubsection{Jaú}

\subsubsection{1 Águas subterrâneas}

Conforme Apêndice D3, dos dez metais analisados, oito explicaram 89,49\% dos resultados, ou seja, apresentaram variação significativa para o lixão durante as quatro coletas. A Tabela 54 apresenta as variáveis que explicaram o conjunto de dados do lixão por ordem de importância.

Tabela 54 - PCA do lixão de Jaú

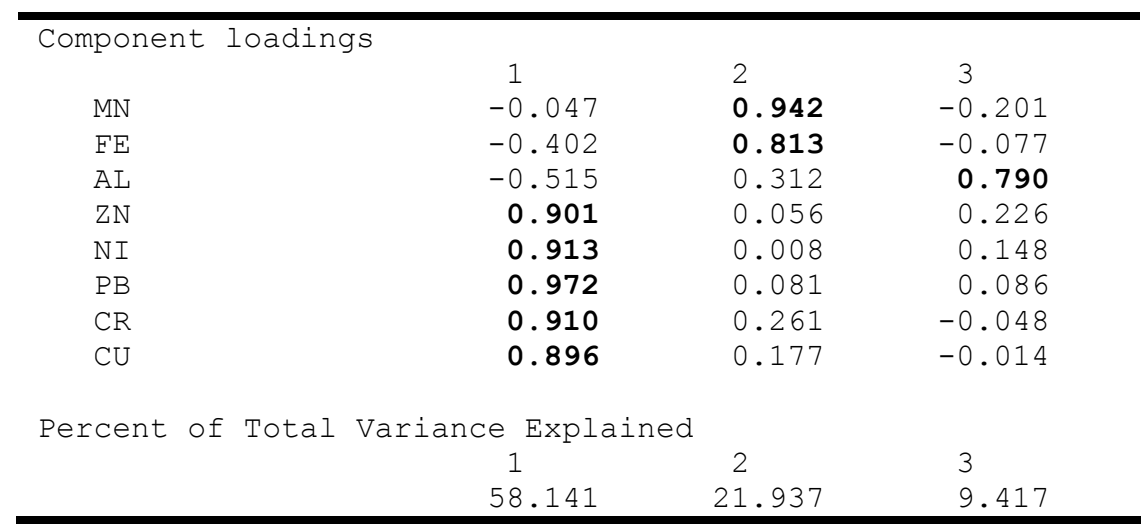

- $1^{\circ}$ eixo: Chumbo, Níquel, Cromo, Zinco, Cobre (explicaram cerca de $58 \%$ dos resultados);

- $\quad 2^{\circ}$ eixo: Manganês, Ferro;

- $\quad 3^{\circ}$ eixo: Alumínio.

\subsubsection{2 Águas superficiais}

Conforme Apêndice E4, dos dez metais analisados, cinco explicaram 93,67\% dos resultados, ou seja, apresentaram variação significativa para o ribeirão do Matão durante as quatro coletas. A Tabela 55 apresenta as variáveis que explicaram o conjunto de dados do ribeirão por ordem de importância. 
Tabela 55 - PCA do ribeirão do Matão

\begin{tabular}{lrrr}
\hline Component loadings & \multicolumn{1}{c}{} \\
& 1 & 2 & \multicolumn{1}{c}{3} \\
ZN & $\mathbf{0 . 9 4 7}$ & 0.287 & -0.027 \\
CU & $\mathbf{0 . 9 2 4}$ & -0.232 & 0.110 \\
CR & 0.437 & 0.796 & -0.308 \\
AL & 0.469 & -0.759 & 0.262 \\
MN & -0.081 & 0.600 & 0.795 \\
Percent of Total Variance Explained & \\
& 1 & 2 & 3 \\
& 43.371 & 34.116 & 16.185 \\
\hline
\end{tabular}

- $\quad 1^{\circ}$ eixo: Zinco, Cobre (explicaram cerca de $43 \%$ dos resultados);

- $\quad 2^{\circ}$ eixo: Cromo, Alumínio;

- $\quad 3^{\circ}$ eixo: Manganês.

\subsubsection{Ribeirão Bonito}

\subsubsection{1 Águas superficiais}

Conforme Apêndice E5, dos dez metais analisados, quatro explicaram 96,49\% dos resultados, ou seja, apresentaram variação significativa para o córrego do Tamanduá o durante as quatro coletas. A Tabela 56 apresenta as variáveis que explicaram o conjunto de dados do córrego por ordem de importância.

Tabela 56 - PCA do córrego do Tamanduá

\begin{tabular}{ccr}
\hline Component loadings & 1 & 2 \\
FE & 0.989 & 0.103 \\
CU & 0.975 & 0.029 \\
MN & 0.958 & -0.050 \\
AL & -0.083 & $\mathbf{0 . 9 9 6}$ \\
Percent of Total Variance Explained \\
& 1 & 2 \\
& 71.342 & 25.157 \\
\hline
\end{tabular}

- $\quad 1^{\circ}$ eixo: Ferro, Cobre, Manganês (explicaram cerca de $71 \%$ dos resultados);

- $\quad 2^{\circ}$ eixo: Alumínio. 


\subsubsection{São Carlos}

\subsubsection{Aterro}

\subsubsection{1 Águas subterrâneas}

Conforme Apêndice D4, dos dez metais analisados, três explicaram 97,26\% dos resultados, ou seja, apresentaram variação significativa para o aterro durante as quatro coletas. A Tabela 57 apresenta as variáveis que explicaram o conjunto de dados do aterro por ordem de importância.

Tabela 57 - PCA do aterro de São Carlos

\begin{tabular}{ccc}
\hline Component loadings & 1 & 2 \\
ZN & 0.976 & 0.082 \\
CU & 0.967 & 0.159 \\
FE & 0.242 & $-\mathbf{0 . 9 7 0}$ \\
Percent of Total Variance Explained \\
& 1 & 2 \\
& 64.813 & 32.452 \\
\hline
\end{tabular}

- $\quad 1^{\circ}$ eixo: Zinco, Cobre (explicaram cerca de $64 \%$ dos resultados);

- $\quad 2^{\circ}$ eixo: Ferro.

\subsubsection{2 Águas superficiais}

Conforme Apêndice E6, dos dez metais analisados, seis explicaram 96,27\% dos resultados, ou seja, apresentaram variação significativa para o córrego do Galdino durante as quatro coletas. A Tabela 58 apresenta as variáveis que explicaram o conjunto de dados do córrego por ordem de importância.

Tabela 58 - PCA do córrego do Galdino

\begin{tabular}{crrr}
\hline Component loadings & & & \\
& 1 & 2 & 3 \\
FE & $\mathbf{0 . 9 7 8}$ & 0.014 & -0.125 \\
AL & 0.474 & $\mathbf{0 . 8 4 4}$ & -0.162 \\
PB & -0.445 & 0.538 & 0.713 \\
MN & $\mathbf{0 . 8 0 6}$ & -0.373 & 0.414 \\
ZN & $\mathbf{0 . 9 0 5}$ & -0.113 & 0.385 \\
CU & $\mathbf{0 . 8 9 9}$ & 0.254 & -0.184 \\
Percent of Total Variance Explained & & \\
& 1 & 2 & 3 \\
& 60.907 & 20.310 & 15.055 \\
\hline
\end{tabular}


- $\quad 1^{\circ}$ eixo: Ferro, Zinco, Cobre, Manganês (explicaram cerca de $60 \%$ dos resultados);

- $\quad 2^{\circ}$ eixo: Alumínio;

- $\quad 3^{\circ}$ eixo: Chumbo.

\subsubsection{Antigo Lixão}

\subsubsection{1 Águas subterrâneas}

Conforme Apêndice D5, dos dez metais analisados, cinco explicaram 90,57\% dos resultados, ou seja, apresentaram variação significativa para o antigo lixão durante as quatro coletas. A Tabela 59 apresenta as variáveis que explicaram o conjunto de dados do antigo lixão por ordem de importância.

Tabela 59 - PCA do antigo lixão de São Carlos

\begin{tabular}{lrrr}
\hline Component loadings & & & \\
& 1 & 2 & 3 \\
ZN & $\mathbf{0 . 9 4 3}$ & 0.030 & 0.182 \\
$\mathrm{FE}$ & $\mathbf{0 . 8 9 7}$ & 0.119 & 0.132 \\
$\mathrm{CU}$ & $\mathbf{0 . 8 7 2}$ & -0.140 & 0.054 \\
$\mathrm{AL}$ & -0.166 & $\mathbf{0 . 9 0 2}$ & 0.382 \\
$\mathrm{CR}$ & -0.324 & -0.423 & $\mathbf{0 . 8 4 6}$ \\
Percent of Total Variance Explained & \\
& 1 & 2 & 3 \\
& 51.732 & 20.544 & 18.300 \\
\hline
\end{tabular}

- $\quad 1^{\circ}$ eixo: Zinco, Ferro, Cobre (explicaram cerca de $51 \%$ dos resultados);

- $\quad 2^{\circ}$ eixo: Alumínio;

- $3^{\circ}$ eixo: Cromo.

\subsubsection{2 Águas superficiais}

Conforme Apêndice E7, dos dez metais analisados, seis explicaram 90,84\% dos resultados, ou seja, apresentaram variação significativa para o córrego São José durante as quatro coletas. A Tabela 60 apresenta as variáveis que explicaram o conjunto de dados do córrego por ordem de importância. 
Tabela 60 - PCA do córrego São José

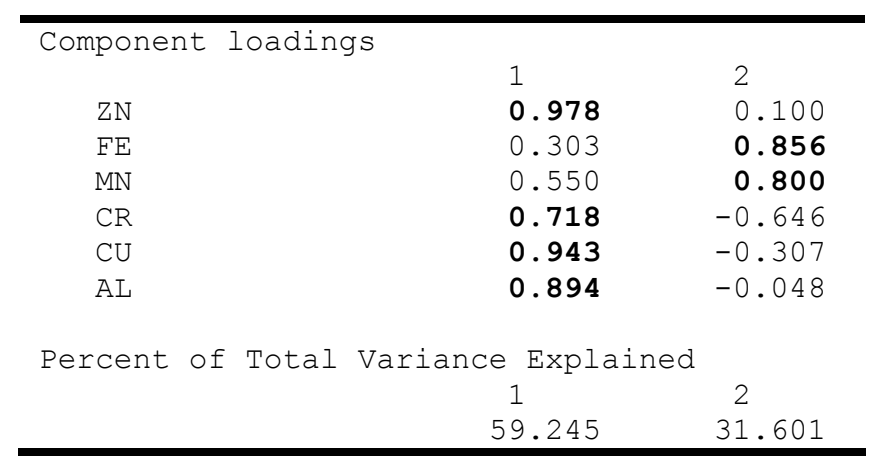

- $\quad 1^{\circ}$ eixo: Zinco, Cobre, Alumínio, Cromo (explicaram cerca de 59\% dos resultados);

- $\quad 2^{\circ}$ eixo: Ferro, Manganês.

\subsubsection{Cluster dos metais das águas subterrâneas}

$\mathrm{Na}$ análise de cluster das médias, o coeficiente de correlação cofenético (CF) foi igual a 0,9278. Quanto mais próximo de 1,0 for o CF significa que os dados agrupados são mais fiéis à realidade. Dessa forma, a análise estatística apontou uma boa avaliação dos dados.

As variáveis significativas mais comuns entre os aterros, apontadas pela PCA, foram: (1) Zinco, (2) Cobre e (3) Ferro.

Os aterros foram denominados da seguinte forma:

- Aterro 1 = Araraquara;

- Aterro 2 = Bauru;

- Aterro 3 = Lixão de Jaú;

- Aterro 4 = São Carlos e

- Aterro 5 = Antigo Lixão de São Carlos.

Com base no tratamento das médias de cada aterro foi gerado o gráfico apresentado na Figura 167. 


\section{Cluster Tree}

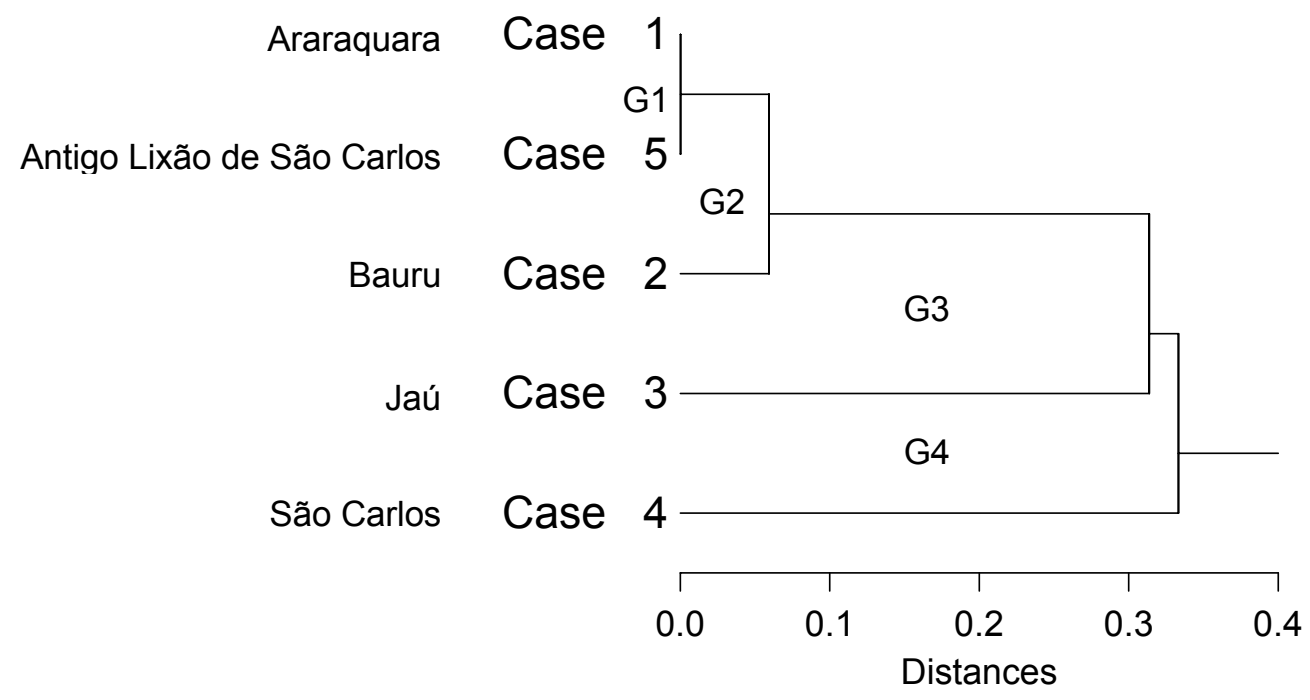

Figura 167 - Cluster das médias dos metais dos aterros

De acordo com a Figura 167, por similaridade, os aterros mais parecidos com relação aos metais na água subterrânea foram:

- Grupo $1(\mathrm{G} 1)$ = Aterro de Araraquara + Antigo Lixão de São Carlos;

- Grupo $2(\mathrm{G} 2)$ = Grupo 1 + Aterro de Bauru;

- Grupo 3 (G3) = Lixão de Jaú;

- Grupo 4 (G4) = Aterro de São Carlos.

O cluster indicou que nas águas subterrâneas do Aterro de São Carlos apenas três metais influenciam sua qualidade, apresentando qualidade superior aos demais aterros. Já nas águas do Lixão de Jaú, oito metais influenciaram os resultados, apresentando qualidade inferior.

\subsubsection{Cluster dos metais das águas superficiais}

$\mathrm{Na}$ análise de cluster das médias, o coeficiente de correlação cofenético (CF) foi igual a 0,9525 . Quanto mais próximo de 1,0 for o CF significa que os dados agrupados são mais fiéis à realidade. Dessa forma, a análise estatística apontou uma boa avaliação dos dados. 
As variáveis significativas mais comuns entre os córregos, apontadas pela PCA, foram: (1) Ferro, (2) Cobre, (3) Manganês e (4) Alumínio.

Os córregos foram denominados da seguinte forma:

- Córrego 1 = córrego do Pinheirinho, Araraquara;

- Córrego 2 = córrego da Gabiroba, Bauru;

- Córrego 3 = córrego da Cachoeira Grande, Brotas;

- Córrego 4 = ribeirão do Matão, Jaú;

- Córrego 5 = córrego do Tamanduá, Ribeirão Bonito;

- Córrego 6 = córrego do Galdino, São Carlos (aterro) e

- Córrego 7 = córrego São José, São Carlos (antigo lixão).

Com base no tratamento das médias de cada córrego foi gerado o gráfico apresentado na Figura 168.

\section{Cluster Tree}

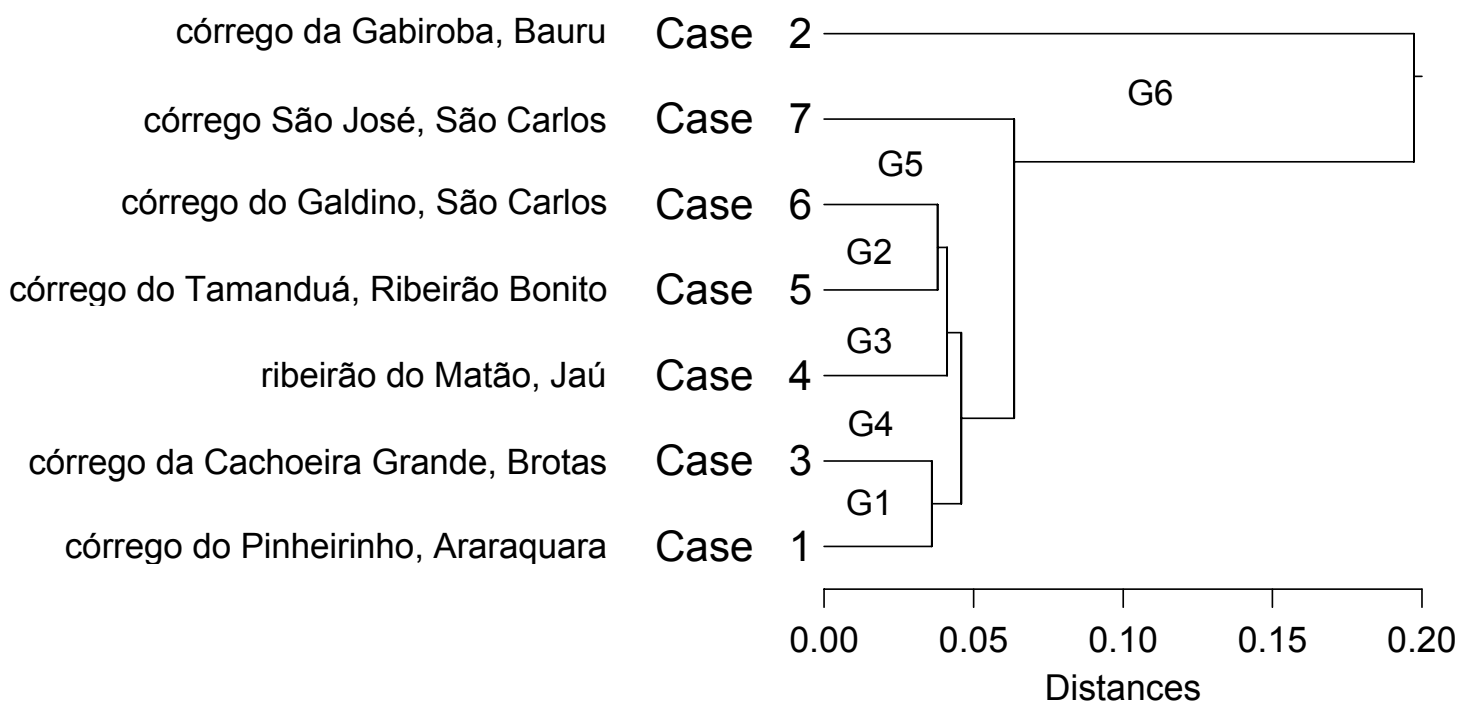

Figura 168 - Cluster das médias dos metais dos córregos

De acordo com a Figura 168, por qualidade da água, os córregos mais parecidos foram: 
- Grupo $1(\mathrm{G} 1)$ = Araraquara + Brotas;

- Grupo 2 (G2) = Ribeirão Bonito + São Carlos (Galdino);

- Grupo $3(\mathrm{G} 3)$ = Grupo 2 + Jaú;

- Grupo 4 (G4) = Grupo 1 + Grupo 3;

- Grupo 5 (G5) = Grupo 4 + São Carlos (São José);

- Grupo $6(\mathrm{G} 6)$ = Bauru.

O cluster indicou que no afluente do córrego da Gabiroba em Bauru uma quantidade maior de metais influenciou suas características em relação aos outros córregos, ao contrário do córrego do Tamanduá em Ribeirão Bonito, indicando que este apresentou qualidade superior. Vale ressaltar que o tipo de solo pode ter influenciado os resultados. 


\section{CONCLUSÕES}

A realização do presente estudo permitiu uma prévia avaliação das condições das áreas de disposição final de resíduos sólidos e córregos monitorados.

Com base no monitoramento da água subterrânea foi constatado alteração das suas características naturais, indicando poluição e contaminação em algumas amostras devido, provavelmente, à migração de lixiviado, resultado de falhas na construção e operação dos aterros. Cabe ressaltar que a presença de coliformes totais e termotolerantes nas águas subterrâneas, associada às elevadas concentrações de alguns parâmetros, além da toxicidade das amostras permite fazer essa afirmação.

Das 76 amostras de água subterrânea analisadas, 86,84\% apresentaram pH inferior ao intervalo estabelecido pela Portaria 518/2004 e 11 parâmetros apresentaram concentrações acima dos valores recomendados pela legislação: $90,78 \%$ Cor; $85,52 \%$ Turbidez; 26,31\% Nitrogênio Amoniacal; 6,57\% Sólidos Totais Dissolvidos; 5,26\% Cloretos; 59,21\% Ferro; 52,63\% Manganês; 10,52\% Cromo; 5,26\% Zinco e Chumbo; 1,31\% Alumínio. Vale destacar que estes resultados podem ter sido influenciados pelas características naturais do próprio local. Assim, considerando os pontos de montante e jusante de cada aterro, a quantidade de amostras fora dos limites recomendados pela legislação está apresentada no Apêndice H1.

Nesse sentido, destaca-se que $100 \%$ das amostras dos poços de montante apresentaram $\mathrm{pH}$ inferior ao intervalo estabelecido pela Portaria 518/2004, exceto no aterro de Bauru, onde todas as amostras apresentaram valores dentro do intervalo recomendado pela legislação.

A análise estatística das amostras de água subterrânea indicou dez parâmetros comuns que mais variaram: (1) Turbidez, (2) Oxigênio Dissolvido, (3) Sulfatos, (4) Sólidos Totais, (5) Sólidos Totais Fixos, (6) Sólidos Totais Voláteis, (7) Sólidos Totais Dissolvidos, (8) Zinco, (9) Cobre e (10) Ferro.

Com base nos ensaios ecotoxicológicos, das 41 amostras de poços analisadas, $53,65 \%$ apresentaram toxicidade aguda, 26,82\% toxicidade crônica, $17,07 \%$ indício de toxicidade aguda e $9,75 \%$ não apresentaram efeito tóxico.

Foi confirmada a redução das concentrações de alguns compostos com o passar do tempo, comparando-se os resultados obtidos nas amostras de água subterrânea do aterro e do antigo lixão de São Carlos.

A presença dos metais Ferro, Manganês e Cromo Total nas amostras de água subterrânea pode ter sido proveniente da interação água-solo-rocha, do tipo de argila utilizada ou do vazamento de lixiviado dos aterros. A presença de Ferro e Manganês na 
água pode ter influenciado a cor, turbidez e condutividade elétrica das amostras de água. Os solos da região contêm óxidos de $\mathrm{Fe}$, promovendo coloração avermelhada às amostras de água. A detecção de Cromo Total em algumas amostras de água subterrânea dos aterros de Araraquara e São Carlos, no lixão de Jaú e no antigo lixão de São Carlos pode ter ocorrido devido ao aterramento de algum tipo de resíduo que continha cromo. No caso do lixão de Jaú foram enterrados artefatos de couro até 2004.

Há trabalhos que apontam a possibilidade do cromo ter origem natural, associado aos sedimentos da Formação Adamantina (CETESB, 2007, p.136). "Em áreas onde ocorrem depósitos significativos de cromo, as fontes de água podem apresentar concentrações superiores a $0,05 \mathrm{mg} / \mathrm{L}$, valores que ultrapassam os padrões nacionais e internacionais para água potável" (WHO, 1988 citado por CETESB, 2004, p.84). Assim, a CETESB alerta para a necessidade de novas pesquisas sobre a origem do cromo nas águas subterrâneas, em função da atividade agrícola e curtumes, que dispõem seus resíduos no solo.

Ressalta-se que amostras do córrego Pinheirinho em Araraquara, do afluente do córrego da Gabiroba em Bauru, do ribeirão do Matão em Jaú e do córrego São José em São Carlos também apresentaram traços deste metal. Para confirmar estas informações são necessárias análises das amostras de solo dos locais monitorados.

Os resultados do monitoramento das águas superficiais não permitem afirmar que algumas alterações na qualidade dessas águas são provenientes exclusivamente dos aterros, devido à distância e ao uso do solo no entorno dos corpos d'água, que é predominantemente agrícola, comprovado pela alta concentração de algumas substâncias utilizadas na composição de agrotóxicos. Além disso, foi constatado presença de matéria orgânica e coliformes em algumas amostras, devido provavelmente à pastagem de gado.

Das 54 amostras de água superficial analisadas, 40,74\% apresentaram $\mathrm{pH}$ e 37,03\% Oxigênio Dissolvido inferior ao intervalo da CONAMA 357/2005, enquanto que dezoito parâmetros apresentaram concentrações superiores aos valores recomendados pela legislação: $57,40 \%$ Cor; 46,29\% Coliformes Totais; 22,22\% Fósforo; 16,66\% Nitrogênio Total; 14,81\% Coliformes Fecais e Demanda Biológica de Oxigênio; 5,55\% Turbidez, Nitrogênio Amoniacal e Sólidos Totais Dissolvidos; 3,70\% Nitrogênio Nitrato e Fluoreto; 1,85\% Cloreto; 70,37\% Cobre; 68,51\% Ferro; 57,40\% Zinco; 24,07\% Manganês; 3,70\% Cromo; $1,85 \%$ Alumínio. Assim, considerando os pontos de montante e jusante de cada córrego, a quantidade de amostras fora dos limites recomendados pelas legislações está apresentada no Apêndice $\mathrm{H} 2$.

De acordo com a análise estatística das amostras de água superficial, os 12 parâmetros que mais variaram foram: (1) Demanda Química de Oxigênio, (2) Temperatura, (3) Cloretos, (4) Nitrogênio Amoniacal, (5) Sólidos Totais, (6) Cor, (7) Turbidez, (8) Carbono Orgânico Total, (9) Ferro, (10) Cobre, (11) Manganês e (12) Alumínio. 
Conforme os ensaios ecotoxicológicos, das 28 amostras de córregos analisadas, $64,28 \%$ não apresentaram efeito tóxico, 28,57\% apresentaram toxicidade crônica e $7,14 \%$ toxicidade aguda.

O efeito tóxico nas amostras de água subterrânea e superficial pode ter sido provocado pela presença de metais devido à sensibilidade dos organismos aquáticos, mesmo em concentrações inferiores às estabelecidas pelas legislações vigentes.

Com base nas informações levantadas e resultados obtidos, conclui-se que não há gestão integrada dos resíduos sólidos urbanos na Bacia Tietê-Jacaré (UGRHI-13), conforme hipótese inicial. As decisões são segmentadas e a qualidade das águas na área de influência dos aterros está sendo alterada. Além disso, as informações sobre os resíduos sólidos não estão totalmente disponíveis e não são compartilhadas entre os órgãos públicos e com toda a sociedade. Recomenda-se a criação de páginas na internet com informações sobre os resíduos sólidos nos sites das prefeituras.

Os aterros municipais estão melhorando gradativamente, a fim de atenderem as exigências dos órgãos ambientais, porém nota-se que as medidas são emergenciais e corretivas. Falta investimento da administração pública no que se refere à prevenção dos impactos negativos, uma vez que técnicas de remediação (contenção, remoção e tratamento) podem ser onerosas.

Porém, ressalta-se que foram constatados avanços na área de resíduos sólidos em alguns municípios da UGRHI-13, principalmente Araraquara e São Carlos (Quadro 13). Durante o período de 2003 a 2007, o município de Araraquara merece destaque, uma vez que a gestão dos resíduos está mais integrada. Em Araraquara foram implantados poços de monitoramento de águas subterrâneas e incinerador de Resíduos de Serviços de Saúde (RSS) no aterro, central de recebimento de embalagens de agrotóxicos e Área de Transbordo e Triagem (ATT) de Resíduos da Construção Civil (RCC). Em São Carlos foram implantados o programa piloto de compostagem, o aterro e a usina de reciclagem de RCC, além de nova célula de RSU e nova lagoa para armazenamento do lixiviado no aterro, ambas impermeabilizadas. Porém, foi constatado que a gestão dos diferentes tipos de resíduos sólidos é segmentada, o que ocorre em outros municípios da bacia Tietê-Jacaré. 
Quadro 13 - Aspectos relacionados aos resíduos sólidos nos municípios monitorados

\begin{tabular}{|c|c|c|c|c|c|c|}
\hline Categoria & Araraquara & Bauru & Brotas & Jaú & $\begin{array}{c}\text { Ribeirão } \\
\text { Bonito }\end{array}$ & $\begin{array}{l}\text { São } \\
\text { Carlos }\end{array}$ \\
\hline \multicolumn{7}{|l|}{\begin{tabular}{l|l} 
Aterro Controlado \\
\end{tabular}} \\
\hline \multicolumn{7}{|l|}{2 Aterro Industrial } \\
\hline 3 Aterro Sanitário & & & 1 & & 1 & \\
\hline \multicolumn{7}{|l|}{4 ATT e Aterro de RCC } \\
\hline \multicolumn{7}{|l|}{5 Bolsão de RCC } \\
\hline \multicolumn{7}{|l|}{$6 \begin{array}{l}\text { Central de Recebimento } \\
\text { de Embalagens de } \\
\text { Agrotóxicos }\end{array}$} \\
\hline 7 Central de Triagem & & * & * & & & \\
\hline 8 Coleta Seletiva & 2 & 2 & 3 & 4 & & 2 \\
\hline 9 Compostagem & & & & & & 5 \\
\hline 10 Lixão & & & & & & 6 \\
\hline \multicolumn{7}{|l|}{\begin{tabular}{l|l}
11 & $\begin{array}{l}\text { Pneus encaminhados } \\
\text { para reciclagem }\end{array}$
\end{tabular}} \\
\hline $12 \begin{array}{l}\text { Poços para o } \\
\text { monitoramento de água } \\
\text { subterrânea no aterro } \\
\text { ou lixão }\end{array}$ & & & ** & & ** & \\
\hline \multicolumn{7}{|l|}{$13 \begin{array}{l}\text { Programa de Educação } \\
\text { Ambiental voltado para } \\
\text { resíduos sólidos }\end{array}$} \\
\hline \multicolumn{7}{|l|}{$14 \mid \begin{array}{l}\text { Tratamento de } \\
\text { Lâmpadas } \\
\text { Fluorescentes }\end{array}$} \\
\hline 15 Tratamento de Lixiviado & 7 & & 8 & & & 7 \\
\hline 16 Tratamento de RSS & & & 9 & 9 & 10 & 10 \\
\hline \multicolumn{7}{|l|}{$17 \begin{array}{l}\text { Usina de reciclagem de } \\
\text { RCC }\end{array}$} \\
\hline \multicolumn{7}{|l|}{18 Valas sépticas } \\
\hline $\begin{aligned} & \square \text { Possui } \\
& * \text { Local de separação de recicl } \\
& * * \text { Não foi encontrado lençol fre } \\
& 1 \text { Aterro Sanitário em Trincheir } \\
& 2 \text { Coleta Seletiva parcial, não a } \\
& 3 \text { Coleta Seletiva realizada pel } \\
& 4 \text { Coleta Seletiva realizada pel } \\
& 5 \text { Projeto Piloto "ABC da Comp } \\
& 6 \text { Lixão desativado } \\
& 7 \text { Encaminhado para a ETE de } \\
& 8 \text { Encaminhado para a ETE de } \\
& 9 \text { Em Paulínia } \\
& 10 \text { Em Campinas }\end{aligned}$ & $\begin{array}{l}\text { áveis em situas } \\
\text { ático no aterro } \\
\text { as } \\
\text { tende } 100 \% \text { dd } \\
\text { a APAE de Bro } \\
\text { a ACAP de Jaú } \\
\text { ostagem" } \\
\text { Araraquara } \\
\text { Brotas }\end{array}$ & $\begin{array}{l}\text { ão precár } \\
\text { municípi } \\
\text { as }\end{array}$ & & & & \\
\hline
\end{tabular}


Quanto ao planejamento territorial, os Planos Diretores dos municípios de Bariri (Art. 73), Matão (Art. 35) e São Carlos (Art. 39 e 45) ainda são limitados no que se refere aos resíduos sólidos. Em geral, estes planos dispõem que os resíduos sólidos devem receber coleta, tratamento e disposição final adequada (como a Lei Orgânica da maioria dos municípios), dispõem sobre a implantação de aterro sanitário ou sobre o controle ambiental das áreas de aterros e lixões, porém não apresentam propostas e diretrizes para implantação de futuras áreas onde estas atividades poderão ser desenvolvidas, com vistas ao menor impacto negativo possível. Sobre este aspecto tratam o Plano Diretor de Araraquara (Art. 70), Bauru (Art. 155), Brotas (Art. 8), Jaú (Art. 63) e Pederneiras (Art. 14). Além disso, ressalta-se que alguns municípios da Bacia Tietê-Jacaré com mais de 20.000 habitantes ainda não possuem Plano Diretor, conforme determina o Artigo 182 da Constituição Federal. Dos 37 municípios com território na UGRHI-13, apenas oito possuem Plano Diretor.

Para um diagnóstico completo da UGRHI-13 quanto à gestão dos resíduos sólidos, recomendam-se visitas aos municípios, além do monitoramento dos aterros e lixões localizados na bacia Tietê-Jacaré para o controle dos impactos causados. Porém, para isso é necessária a formação de uma equipe multidisciplinar para coleta e análise dos dados e amostras. Além disso, é necessário que todas as prefeituras dos municípios com território na UGRHI-13 disponibilizem informações sobre os resíduos sólidos e permitam acesso as suas áreas de disposição final.

A escolha de áreas dentro da UGRHI-13 representou o monitoramento da BHTJ por amostragem. Os municípios selecionados são de pequeno e médio porte, retratando a realidade da UGRHI. Com base nas informações levantadas e no monitoramento realizado na região, conclui-se que há muito para se fazer na área de resíduos sólidos. A coleta seletiva não atende a demanda atual, ainda há lixões e aterros "controlados" (sem impermeabilização), há pouco investimento na reciclagem dos RCC, bem como no tratamento de outros tipos de resíduos. 


\section{PROPOSTAS DE GESTÃO INTEGRADA DE RESÍDUOS SÓLIDOS URBANOS PARA OS MUNICÍPIOS MONITORADOS}

As propostas foram elaboradas com base nas visitas realizadas nos municípios monitorados, bem como nas informações obtidas por meio dos questionários e fornecidas pelos responsáveis pela limpeza urbana.

\subsection{Araraquara}

a) ampliar a coleta seletiva, a fim de minimizar a quantidade de material reciclável destinada ao aterro;

b) implantar queimadores de gases e impermeabilizar as futuras células do aterro;

c) implantar um programa de compostagem "piloto", a fim de aproveitar os resíduos orgânicos e os de poda e capina que atualmente são dispostos no aterro;

d) realizar estudos para a escolha de áreas adequadas de onde possa ser retirado solo para cobertura dos resíduos no aterro, buscando respeitar a capacidade suporte do ambiente local. Estas áreas devem estar nas proximidades do aterro, preferencialmente. É importante prever a recuperação destas áreas;

e) realizar estudos para a escolha de uma área adequada para construção de um novo aterro sanitário, pois a vida útil do aterro atual já está se esgotando;

f) investir em programas de conscientização dos moradores sobre a importância da separação "responsável" dos resíduos sólidos, com o objetivo de orientar a separação (1) da matéria orgânica para a reativação da usina de compostagem e produção de um composto de boa qualidade e (2) dos materiais recicláveis secos para contribuir com o trabalho dos catadores, uma vez que recicláveis contaminados ou muito sujos não podem ser vendidos pelas cooperativas e são destinados ao aterro. Vale destacar que a compostagem deve ser incentivada, pois é válida do ponto de vista ambiental, que deve prevalecer sobre o financeiro.

\subsection{Bauru}

a) ampliar e melhorar a coleta seletiva, investindo na conscientização dos moradores, a fim de aumentar sua participação, que é fundamental para a mesma continuar funcionando, uma vez que constatou-se grande quantidade de material reciclável no aterro; 
b) realizar estudos para a escolha de uma área adequada para implantação de um aterro de resíduos da construção civil (RCC) no município, onde os resíduos que não podem ser reaproveitados ou reciclados possam ser dispostos adequadamente;

c) construir uma usina de reciclagem de RCC, a fim de que artefatos de cimento possam ser produzidos para construção de condomínios populares; calçamento e construção de guias e sarjetas na área urbana, entre outras aplicações. Esta usina poderá ser instalada ao lado do aterro de RCC e poderá receber os RCC de municípios vizinhos. Ao lado da usina pode ser instalada uma central de triagem de materiais recicláveis, visto que estes são descartados indevidamente nas caçambas;

d) definir áreas dentro do território municipal para o armazenamento temporário dos RCC até que sejam transportados para a usina de reciclagem ou para o aterro de RCC. Atualmente estes resíduos são descartados na periferia da cidade ou em vazios urbanos. Junto às áreas de armazenamento temporário de RCC podem ser implantados contêineres para o descarte de materiais recicláveis de origem doméstica, os quais muitas vezes são misturados aos RCC;

e) tratar os resíduos de serviços de saúde (RSS), por meio da aquisição de um equipamento adequado que pode ser instalado no próprio aterro, a fim de evitar que esses resíduos continuem sendo enterrados em valas sépticas, que ocupam uma área considerável do aterro e de onde podem ocorrer vazamentos. Segundo Bidone e Povinelli (1999, p.88), estudos realizados pela CETESB constataram a ineficiência da cal, usada em valas sépticas, para a eliminação de organismos patogênicos;

f) realizar estudos para a implantação de um programa de compostagem "piloto" que possa ser ampliado gradativamente conforme a adesão dos moradores, com vistas à produção de um composto de boa qualidade e redução da quantidade de matéria orgânica descartada no aterro;

g) continuar investindo em programas de conscientização dos moradores sobre a importância da separação "responsável", com o objetivo de orientar a separação da matéria orgânica para a implantação de um programa de compostagem e dos materiais recicláveis secos para contribuir com o trabalho dos catadores, uma vez que recicláveis contaminados ou sujos não podem ser vendidos pelas cooperativas e são destinados ao aterro;

h) transportar o lixiviado do aterro para a ETE mais próxima em caso de vazamentos que possam comprometer o ecossistema local, até a implantação de um sistema de tratamento;

i) em relação ao córrego da Gabiroba, situado a jusante do aterro, tratar o esgoto sanitário gerado na penitenciária antes do seu lançamento nas águas superficiais. 


\subsection{Brotas}

a) implantar um programa de coleta seletiva no município, buscando auxiliar e integrar os catadores existentes na cidade, o que evitaria a invasão ao aterro, bem como o descarte de material reciclável, o que aumentaria a vida útil do aterro;

b) auxiliar e orientar o trabalho dos catadores existentes na cidade, conscientizando a população sobre a importância da separação;

c) proibir a entrada de catadores no aterro, por meio de avisos no próprio aterro, orientação dos funcionários que trabalham no local e de palestras e reuniões com os próprios catadores;

d) cobrir os resíduos dispostos no aterro ao final de cada dia, a fim de evitar o espalhamento de resíduos pelo vento e a atração de vetores, minimizar a infiltração de água de chuva dentro das valas e, conseqüentemente, minimizar a formação de lixiviado;

e) realizar estudos para a escolha de uma área adequada para implantação de um aterro de RCC no município, onde os resíduos que não podem ser reaproveitados ou reciclados possam ser dispostos adequadamente, em conformidade com a Resolução CONAMA 307/2002;

f) definir áreas dentro do território municipal e licenciá-las para o armazenamento temporário dos RCC até que sejam transportados para o aterro de RCC, a fim de evitar que sejam descartados na periferia da cidade ou em vazios urbanos. Junto às áreas de armazenamento temporário de RCC podem ser implantados contêineres para o descarte de materiais recicláveis de origem doméstica, os quais muitas vezes são misturados aos RCC;

g) destinar os RCC recicláveis para a usina de reciclagem mais próxima, os quais podem ser separados em área contígua ao aterro. Os artefatos de cimento produzidos na usina do município vizinho, referente à quantidade de RCC enviada, podem ser transportados e empregados em obras no próprio município de Brotas. Isso pode ser feito por meio de acordos entre municípios ou consórcios intermunicipais.

\subsection{Jaú}

a) implantar um programa de coleta seletiva no município, buscando integrar os catadores existentes na cidade, o que evitaria a presença dos mesmos no lixão, bem como o descarte de material reciclável no lixão;

b) cobrir os resíduos dispostos no lixão ao final de cada dia, a fim de evitar o espalhamento de resíduos pelo vento e a atração de vetores, minimizar a infiltração de água de chuva na massa de resíduos e, conseqüentemente, minimizar a formação de lixiviado; 
c) proibir a queimada dos resíduos dispostos no lixão, a fim de evitar a formação de substâncias tóxicas como as dioxinas, geradas pela queima do plástico, evitando a contaminação do ar;

d) desativar o lixão com as medidas de proteção ambiental adequadas (impermeabilização da cobertura, construção de um sistema de drenagem de águas pluviais, plantação de gramínea para evitar a formação de processos erosivos e minimizar a infiltração de água de chuva, recuperação da área degradada, entre outras);

e) iniciar as obras do aterro sanitário, cujo projeto já foi aprovado, e ativá-lo o mais rápido possível;

f) realizar estudos para a escolha de uma área adequada para implantação de um aterro de RCC no município, onde os resíduos que não podem ser reaproveitados ou reciclados possam ser dispostos adequadamente, conforme Resolução CONAMA 307/2002;

g) definir áreas dentro do território municipal e licenciá-las para o armazenamento temporário dos RCC até que sejam transportados para a usina ou para o aterro de RCC, a fim de evitar que sejam descartados na periferia da cidade ou em vazios urbanos. Junto às áreas de armazenamento temporário de RCC podem ser implantados contêineres para o descarte de materiais recicláveis de origem doméstica, os quais muitas vezes são misturados aos RCC;

h) destinar os RCC recicláveis para a usina de reciclagem mais próxima, os quais podem ser separados em área contígua ao aterro. Os artefatos de cimento produzidos na usina do município vizinho, referente à quantidade de RCC enviada, podem ser transportados e empregados em obras no próprio município de Jaú. Isso pode ser feito por meio de acordos entre municípios ou consórcios intermunicipais. Essa medida pode ser tomada até que a usina de reciclagem de RCC de Jaú seja construída;

i) construir uma usina de reciclagem de RCC, a fim de que artefatos de cimento possam ser produzidos para construção de condomínios populares; calçamento e construção de guias e sarjetas na área urbana, entre outras aplicações. Esta usina poderá ser instalada ao lado do aterro de RCC e poderá receber os RCC de municípios vizinhos. Ao lado da usina pode ser instalada uma central de triagem de materiais recicláveis, visto que estes são descartados indevidamente nas caçambas.

\subsection{Ribeirão Bonito}

a) implantar um programa de coleta seletiva no município, buscando integrar os catadores existentes na cidade, o que evitaria o descarte de material reciclável no aterro;

b) construir drenos para coleta do lixiviado e impermeabilizar as futuras valas do aterro; 
c) transportar o lixiviado gerado no aterro para a ETE mais próxima e estudar métodos para o tratamento do líquido no local;

d) cobrir os resíduos dispostos no aterro ao final de cada dia, a fim de evitar o espalhamento de resíduos pelo vento e a atração de vetores, minimizar a infiltração de água de chuva na massa de resíduos e, conseqüentemente, minimizar a formação de lixiviado;

e) realizar estudos para a escolha de uma área adequada para implantação de um aterro de RCC no município, onde os resíduos que não podem ser reaproveitados ou reciclados possam ser dispostos adequadamente, conforme Resolução CONAMA 307/2002;

f) definir áreas dentro do território municipal e licenciá-las para o armazenamento temporário dos RCC até que sejam transportados para o aterro de RCC, a fim de evitar que sejam descartados na periferia da cidade ou em vazios urbanos. Junto às áreas de armazenamento temporário de RCC podem ser implantados contêineres para o descarte de materiais recicláveis de origem doméstica, os quais muitas vezes são misturados aos RCC;

g) destinar os RCC recicláveis para a usina de reciclagem mais próxima, os quais podem ser separados em área contígua ao aterro. Os artefatos de cimento produzidos na usina do município vizinho, referente à quantidade de RCC enviada, podem ser transportados e empregados em obras no próprio município de Ribeirão Bonito. Isso pode ser feito por meio de acordos entre municípios ou consórcios intermunicipais;

h) destinar os RSS para o município mais próximo que possua equipamento para o tratamento adequado.

\subsection{São Carlos}

a) ampliar a coleta seletiva, a fim de minimizar a quantidade de material reciclável destinada ao aterro;

b) realizar estudos para a escolha de áreas adequadas de onde possa ser retirado solo para cobertura dos resíduos no aterro, buscando respeitar a capacidade suporte do ambiente local. Estas áreas devem estar nas proximidades do aterro, preferencialmente. É importante prever a recuperação destas áreas;

c) realizar estudos para a escolha de áreas adequadas para construção de um novo aterro sanitário e de um novo aterro de RCC, com vida útil estimada superior a 20 anos, a fim de evitar gastos constantes com projetos, ampliações e medidas emergenciais, bem como evitar constantes solicitações de licenças ambientais, pois os trâmites burocráticos demandam tempo até a aprovação. Esta é uma medida preventiva, pois minimiza os riscos de impactos ambientais negativos; 
d) ampliar gradativamente o programa de compostagem "piloto", conforme a adesão da sociedade, a fim de desviar os resíduos orgânicos dispostos no aterro sanitário e os de poda e capina dispostos no aterro de RCC, com vistas à produção de um composto de boa qualidade;

e) continuar investindo em programas de conscientização dos moradores sobre a importância da separação "responsável", com o objetivo de orientar a separação (1) da matéria orgânica para a implantação de um programa de compostagem e (2) dos materiais recicláveis secos para contribuir com o trabalho dos catadores, uma vez que materiais contaminados ou sujos não podem ser vendidos pelas cooperativas e são destinados ao aterro;

f) adquirir equipamentos adequados para o tratamento dos RSS, evitando gastos com o transporte e tratamento dos mesmos em outro município;

g) ampliar a capacidade da usina de reciclagem de RCC, a fim de minimizar a quantidade de material reciclável destinada ao aterro de RCC;

h) investir em estudos, fornecer infra-estrutura adequada e adquirir equipamentos para o tratamento do lixiviado, que poderá ocorrer na própria área do aterro. O tratamento do lixiviado poderá evitar a construção de novas lagoas no aterro. Está previsto o encaminhamento do lixiviado gerado no aterro para a ETE que está sendo construída no município, porém as ETEs não são dimensionadas para tratar este tipo de líquido que possui DBO e DQO superiores às do esgoto sanitário. 


\section{DIRETRIZES PARA IMPLANTAÇÃO DE UM PLANO DE GESTÃO INTEGRADA DE RESÍDUOS SÓLIDOS URBANOS}

Alguns pontos importantes que permeiam a área de resíduos sólidos podem ser destacados para a implantação de um plano integrado:

- Elaborar propostas para os diferentes tipos de resíduos sólidos em conjunto com diversos setores da sociedade: Organizações Não Governamentais (ONGs), órgãos públicos e privados, universidades, Comitês de Bacia, sociedade civil, entre outros;

- Elaborar o Plano Diretor Municipal para auxiliar no estudo da vocação (escolha) das áreas para implantação de aterros sanitários, indústrias, loteamentos, conjuntos habitacionais, hospitais, universidades, rodovias, aeroportos, entre outras, a fim de evitar a proximidade de usos conflitantes;

- Estudar a geologia, pedologia e hidrologia local para escolha de áreas adequadas para implantação de aterros e unidades de tratamento, com o intuito de evitar a localização em solos muito permeáveis ou alagáveis, em áreas de afloramento, em áreas de preservação permanente, próximos a corpos d'água ou em locais com nível do aqüífero freático próximo à superfície do terreno;

- Estudar o regime de chuvas, a fim de adotar medidas preventivas no que se refere à geração de lixiviado no aterro, o que acarreta custos para armazenamento, transporte e tratamento;

- Promover eventos e divulgar informações para conscientizar a população sobre sua co-responsabilidade na gestão ambiental (especificamente no caso deste trabalho na gestão dos resíduos sólidos e da água) com a finalidade de motivar a participação popular e a cooperação, promovendo assim a gestão compartilhada com toda a sociedade;

- Difundir metodologias que visam à prevenção e ao controle da poluição, à substituição de materiais tóxicos por materiais menos impactantes (mais facilmente degradáveis), ao aproveitamento (reúso) de resíduos, entre outras;

- Implantar programas de compostagem com o objetivo de reduzir a quantidade de resíduos orgânicos encaminhada ao aterro e empregá-los como condicionador de solos, bem como reduzir o volume de lixiviado nos aterros;

- Elaborar políticas públicas que auxiliem na gestão integrada dos resíduos sólidos do município e da região, tratando de questões relacionadas à localização de futuros aterros sanitários; implantação de coleta seletiva; organização, 
capacitação e integração dos catadores (inserção sócio-ambiental e econômica) no programa de coleta seletiva e no mercado de recicláveis; transporte, tratamento e disposição final adequada dos diferentes tipos de resíduos; emprego de técnicas adequadas e viáveis; exigência do monitoramento ambiental, parcerias entre municípios via consórcios inter-municipais, entre outras;

- Elaborar políticas públicas que auxiliem na gestão integrada dos recursos hídricos do município e da região, com a finalidade de definir diretrizes para os diferentes tipos de uso das águas superficiais e subterrâneas, com vistas a preservar sua potabilidade para que atenda ao uso mais importante que é o abastecimento público. 


\section{SUGESTÕES PARA TRABALHOS FUTUROS}

Como proposta para o avanço de pesquisas semelhantes ou complementares, recomenda-se:

- Entrar em contato com a agência ambiental fiscalizadora e com o Comitê de Bacia Hidrográfica na tentativa de estabelecer parceria para obter informações sobre os resíduos sólidos gerados nos municípios;

- Dar continuidade ao monitoramento das águas nas áreas de influência dos aterros sanitários, a fim de verificar o comportamento e a variação dos parâmetros ao longo do tempo;

- Realizar análise de substâncias orgânicas nas amostras de água subterrânea e no lixiviado;

- Ampliar o número de ensaios ecotoxicológicos (realizar no mínimo quatro análises no período de um ano), a fim de verificar os efeitos das amostras de água na reprodução e sobrevivência dos organismos aquáticos durante os diferentes períodos climáticos. Pode ser adotado outro organismo como indicador, pois as respostas podem ser distintas;

- Analisar o solo dos aterros monitorados para obter dados sobre permeabilidade (teor de argila, condutividade hidráulica), geologia, metais, entre outros. Recomenda-se análise de amostras da camada superficial e mais profunda do solo para fins de comparação (verificar a da retenção de substâncias);

- Medir a vazão de referência dos córregos monitorados, a fim de analisar a variação de alguns compostos conforme o volume do corpo d'água nos diferentes períodos climáticos;

- Realizar estudos geofísicos para determinação da geometria e espessura dos aterros, determinação da espessura dos diferentes materiais litológicos entre o aterro e o aqüífero freático e sua identificação, definição do fluxo subterrâneo, mapeamento vertical e horizontal e evolução da pluma de contaminação. 


\section{REFERÊNCIAS BIBLIOGRÁFICAS}

ABNT. NBR 8849: Apresentação de projetos de aterros controlados de resíduos sólidos urbanos. Associação Brasileira de Normas Técnicas. Rio de Janeiro. 1985a.

ABNT. NBR 9190: Sacos plásticos para acondicionamento de lixo - Classificação. Associação Brasileira de Normas Técnicas. Rio de Janeiro. dez. 1985b.

ABNT. NBR 7500: Símbolo de risco e manuseio para o armazenamento de material Simbologia. Associação Brasileira de Normas Técnicas. Rio de Janeiro. dez. 1987a.

ABNT. NBR 10157: Aterros de resíduos perigosos - Critérios para projeto, construção e operação. Associação Brasileira de Normas Técnicas. Rio de Janeiro. 22p. dez. 1987b.

ABNT. NBR 8419. Apresentação de projetos de aterros sanitários de resíduos sólidos urbanos: Procedimento. Projeto NB-843/1983. Associação Brasileira de Normas Técnicas. Rio de Janeiro. 7p. 1992.

ABNT. NBR 13896. Aterros de resíduos não perigosos - Critérios para projeto, implantação e operação: Procedimento. Projeto 01:603.06-006/1993. Associação Brasileira de Normas Técnicas. Rio de Janeiro. 12p. 1997a.

ABNT. NBR 13895. Construção de poços de monitoramento e amostragem: Procedimento. Projeto 01:603.06-003/1993. Associação Brasileira de Normas Técnicas. Rio de Janeiro. 21p. 1997b.

ABNT. NBR 10004. Resíduos Sólidos - Classificação. Associação Brasileira de Normas Técnicas. Rio de Janeiro. 71p. 2004a.

ABNT. NBR 12713. Ecotoxicologia aquática - Toxicidade aguda - Método de ensaio com Daphnia spp (Cladocera, Crustacea). Associação Brasileira de Normas Técnicas, Rio de Janeiro. 17p. 2004b.

ABNT. Projeto NBR 13373. Ecotoxicologia aquática - Toxicidade crônica - Método de ensaio com Ceriodaphnia spp (Crustacea, Cladocera). Comissão de Estudo Especial Temporária de Análises Ecotoxicológicas. Associação Brasileira de Normas Técnicas Rio de Janeiro. 12p. 2005.

ABNT. NBR 15495-1. Poços de monitoramento de águas subterrâneas em aqüíferos granulares - Parte 1: Projeto e construção. Associação Brasileira de Normas Técnicas, Rio de Janeiro. 25p. 2007a. 
ABNT. NBR 15492. Sondagem de reconhecimento para fins de qualidade ambiental Procedimento. Associação Brasileira de Normas Técnicas, Rio de Janeiro. 31p. 2007b.

ABRELPE. Panorama dos resíduos sólidos no Brasil. 180p. 2005.

AGUIAR, R. L. Mapeamento geotécnico da área de expansão de São Carlos - SP. Dissertação (Mestrado). São Carlos, Escola de Engenharia de São Carlos, Universidade de São Paulo. 127p. 1989.

ALLAN, R. J. Os pesticidas orgânicos em meio ambiente aquático, com ênfase em sua origem e destino nos grandes lagos. In: Matsui, S. (ed). Diretrizes para o gerenciamento de lagos. ILEC and IIE. Japan. p.95-121. 2002.

ALMEIDA, T. L. de. Estudo da atenuação dos contaminantes de líquidos percolados no solo. São Carlos. 126p. Dissertação (Mestrado) - Escola de Engenharia de São Carlos, Universidade de São Paulo. 2005.

ALVAREZ, P. J. Princípios e aplicações da biorremediação de BTEX. In: MOERI, E.; COELHO, R.; MARKER, A. (eds.). Remediação e revitalização de áreas contaminadas: aspectos técnicos, legais e financeiros. Instituto Ekos Brasil. São Paulo: Signus Editora. p.93-107. 2004

ALVES, F.; ARAÚJO, L. Áreas Contaminadas: número de casos aumenta, mas remediação avança pouco. Saneamento ambiental. Ano XVI, n.119. Mar/Abr. p.24-27. 2006.

ANDREOTTOLA, G.; CANNAS, P. Chemical and Biological Characteristics of Landfill Leachate. In: CHRISTENSEN, T. H.; COSSU, R.; STEGMANN, R. (eds). Landfilling of waste: leachate. E \& FN SPON. London. p.81-82. 1992.

ANVISA. Mesa livre de veneno. In: Agência Nacional de Vigilância Sanitária. Agrotóxicos: programa monitora resíduos em alimentos. Boletim informativo, ed.60. p.6-8. 2005.

APHA. Standard methods for the examination of water and wastewater. American Public Health Association, American Water Works Association, Water Environmental Federation, $20^{\text {th }}$ ed. Washington. 1998.

AWWA. Water quality and treatment: a handbook of community water supplies. Pontius, F. W. (ed.). United States. American Water Works Association, $4^{\text {th }}$ ed., McGraw-Hill, Inc., 1.194p. 1990.

BACCINI, P.; HENSELER, G.; FIGI, R.; BELEVI, H. Water and element balances of municipal solid waste landfills. Waste Management and Research, 5, 483-499. 1987. 
BELEVI, H.; BACCINI, P. Long-term leachate emissions from municipal solid waste landfills. In: CHRISTENSEN, T. H. COSSU, R.; STEGMANN, R. (eds.). Landfilling of waste: leachate. E \& F. N. Spon, London. p.431-440. 1992.

BERNARDI FILHO, N. A. Subsídios bibliográficos para utilização de lixão desativado para disposição final de resíduos sólidos gerados no setor calçadista do município de Jaú - SP. São Carlos-SP. 95p. Dissertação (Mestrado). Escola de Engenharia de São Carlos, Universidade de São Paulo. 2005.

BIDONE, F. R. A.; POVINELLI, J. Conceitos básicos de resíduos sólidos. São Carlos: EESC/USP, Projeto REENGE. 120p. 1999.

BOSCARDIN BORGHETTI, N. R.; BORGHETTI, J. R.; ROSA FILHO, E. F. Aqüífero Guarani: a verdadeira integração dos países do Mercosul. Grupo Integrado de Aqüicultura e Estudos Ambientais (GIA). Maxigráfica: Curitiba, PR. 214p. 2004.

BRAGA, B.; HESPANHOL, I.; CONEJO, J. G. L.; MIERZWA, J. C.; BARROS, M. T. L. de; SPENCER, M.; PORTO, M.; NUCCI, N.; JULIANO, N.; EIGER, S. Introdução à Engenharia Ambiental: o desafio do desenvolvimento sustentável. 2ed. São Paulo: Pearson Prentice Hall. 318p. 2005.

BRASIL. Portaria $n^{\circ}$ 518, de 25 de março de 2004. Padrões de Potabilidade. Ministério da Saúde. 2004.

BUSS, S. R.; HERBERT, A. W.; MORGAN, P.; THORNTON, S. F.; SMITH, J. W. N. A review of ammonium attenuation in soil and groundwater. Quaterly Journal of Engineering Geology and Hydrogeology, 37, p.347-359. Geological Society of London. 2004.

CALVO, F., MORENO, B., ZAMORANO, M., SZANTO, M. Environmental diagnosis methodology for municipal waste landfills, Waste Management, n.25, p.768-779. 2005.

CÂMARA NETO, H. F.; AUGUSTO, L. G. da S. Condições sanitárias do ambiente urbano e o uso de pesticida doméstico: implicações para a saúde. In: XXVII CONGRESSO INTERAMERICANO DE ENGENHARIA SANITÁRIA E AMBIENTAL. Anais... Porto AlegreRS: ABES, VII-019, 63p. 2000.

CAMPOS, J. de O. Resíduos sólidos - inventário e plano de manejo para a cidade de São Carlos. Projeto Cátedras de São Carlos. Prefeitura Municipal de São Carlos. Secretaria Municipal de Ciência, Tecnologia e Desenvolvimento Econômico. CNPq. 142p. 2000.

CASTRO, M. C. A. A. de. Avaliação de um sistema australiano de lagoas no tratamento conjunto de esgoto sanitário e líquidos percolados gerados em aterro sanitário. São Carlos. 248p. Tese (Doutorado) - Escola de Engenharia de São Carlos, Universidade de São Paulo. 2001. 
CATAPRETA, C. A. A.; BATISTA, H. P.; SILVA, A. L. da; SIMÕES, G. F. Geração de biogás no aterro sanitário de Belo Horizonte - monitoramento e resultados. In: RESILIMP 2006 SEMINÁRIO INTERNACIONAL DE RESÍDUOS SÓLIDOS E LIMPEZA PÚBLICA. Anais... São Paulo-SP: Abrelpe, p.1-12. 2006.

$\mathrm{CBH}$ - TJ. Estatuto do Comitê de Bacia Hidrográfica do Tietê - Jacaré. Disponível em: <http://www.sigrh.sp.gov.br/sigrh/ARQS/RELATORIO/CRH/CBH-TJ/880/estatuto2.htm>. 1999.

CETESB. Poluição das águas subterrâneas no Estado de São Paulo. Estudo preliminar. São Paulo: Companhia de Tecnologia de Saneamento Ambiental. 88p. 1977.

CETESB. Guia de coleta e preservação de amostras de água. 1ed. São Paulo: Companhia de Tecnologia de Saneamento Ambiental. 150p. 1987.

CETESB. Amostragem e monitoramento das águas subterrâneas 6410. Construção de poços de monitoramento de aqüífero freático: Procedimento. Projeto CETESB-GTZ. São Paulo: Companhia de Tecnologia de Saneamento Ambiental, 32p. 1988, atualizada em novembro de 1999.

CETESB. Manual de gerenciamento de áreas contaminadas. Projeto GTZ. 2ed. São Paulo: Companhia de Tecnologia de Saneamento Ambiental. 389p. 2001a.

CETESB. Relatório de qualidade das águas subterrâneas no Estado de São Paulo 1998 - 2000. São Paulo: Companhia de Tecnologia de Saneamento Ambiental, 96p. 2001b.

CETESB. Inventário estadual de resíduos sólidos domiciliares. Relatório de 2000. São Paulo: Companhia de Tecnologia de Saneamento Ambiental. Diretoria de Controle de Poluição Ambiental. v.1. 95p. 2001c.

CETESB. Relatório de qualidade das águas interiores do Estado de São Paulo 2001. São Paulo: Companhia de Tecnologia de Saneamento Ambiental. v.1. 227p. 2002.

CETESB. Relatório de qualidade das águas subterrâneas no Estado de São Paulo 2001 - 2003. São Paulo: Companhia de Tecnologia de Saneamento Ambiental. 103p. 2004.

CETESB. Relatório de qualidade das águas interiores do Estado de São Paulo 2004. São Paulo: Companhia de Tecnologia de Saneamento Ambiental. v.1. 307p. 2005a.

CETESB. Decisão da Diretoria $\mathbf{n}^{\circ}$ 195-2005-E, de 23 de novembro de 2005. Dispõe sobre a aprovação dos Valores Orientadores para Solos e Águas Subterrâneas no Estado de São Paulo - 2005, em substituição aos Valores Orientadores de 2001, e dá outras providências. São Paulo: Companhia de Tecnologia de Saneamento Ambiental. 4p. 2005b. 
CETESB. Inventário estadual de resíduos sólidos domiciliares. Relatório de 2006. São Paulo: Companhia de Tecnologia de Saneamento Ambiental. 98p. (Série relatórios). 2007a.

CETESB. Relação de áreas contaminadas. Disponível em: $<$ http://hww.cetesb.sp.gov.br/Solo/areas_contaminadas/relacao_areas.asp>. Acesso em 13 fev. 2007. 2007b.

CETESB. Relatório de qualidade das águas interiores no Estado de São Paulo - 2006. São Paulo: Companhia de Tecnologia de Saneamento Ambiental. 2v. 327p. 2007c.

CETESB. Procedimento para amostragem de água subterrânea. Cód: S704V01. 02/02/2007. Companhia de Tecnologia de Saneamento Ambiental. 2p. 2007d.

CETESB. Relatório de qualidade das águas subterrâneas no Estado de São Paulo 2004-2006. São Paulo: Companhia de Tecnologia de Saneamento Ambiental. 199 p. 2007e.

CHRISTENSEN, T. H. Attenuation of leachate polutants in groundwater. In: CHRISTENSEN, T. H. COSSU, R.; STEGMANN, R. (eds.). Landfilling of waste: leachate. E \& F. N. Spon, London. p.441-484. 1992.

COMISSÃO EUROPÉIA. Outras substâncias: proteção das águas subterrâneas. Disponível em: <http://europa.eu.int/scadplus/leg/pt/lvb/l28017b.htm>. Acesso em: 29 jan. 2004.

CONTIN NETO, D.; MENEZES, D. B.; FREITAS, A. L. S. de. Alterações na qualidade da água subterrânea e superficial por depósitos de resíduos. In: XI SIMPÓSIO BRASILEIRO DE RECURSOS HÍDRICOS E II SIMPÓSIO DE HIDRÁULICA E RECURSOS HÍDRICOS DOS PAÍSES DE LÍNGUA OFICIAL PORTUGUESA. Anais... Recife-PE: Associação Brasileira de Recursos Hídricos, 5-9 nov. v.2, 153-158. 1995.

CONTIN NETO, D.; MATSUZAKI, S. S.; GADOTTI, R. F.; FREITAS, A. L. S. DE; BARBOSA, D. O. Avaliação da poluição e da contaminação das águas superficiais e subterrâneas em região de aterro controlado. In: SIMPOSIO INTERNAZIONALE DI INGEGNERIA SANITARIA AMBIENTALE - SIDISA. Anais... Ravello, Villa Rufolo: ABES, 3-7 giugno, 556-563. 1997.

CONTRERA, R. C. Tratamento biológico de líquidos percolados de aterros sanitários utilizando reator anaeróbio horizontal de leito fixo (RAHLF). São Carlos. 149p. Dissertação (Mestrado) - Escola de Engenharia de São Carlos, Universidade de São Paulo. 2003.

DAAE. Aqüífero Guarani. Departamento Autônomo de Água e Esgoto de Araraquara. Disponível em: <http://www.daaeararaquara.com.br>. Acesso em: 22 maio 2003.

DANIEL, L. A. (coord.). Processos de desinfecção e desinfetantes alternativos na produção de água potável. Projeto PROSAB. Rio de Janeiro: Rima, ABES, 139p. 2001. 
EHRIG, H. J. Leachate quality. In: CHRISTENSEN, T. H. et al. Sanitary landfilling: process, technology and environmental impact. Academic Press. London. p.216-218. 1989.

EIGENHEER, E. M. (org.). Coleta seletiva de lixo: experiências brasileiras. n.3. Universidade Federal Fluminense. Rio de Janeiro. 80p. 1999.

ELLERT, N.; ROSS, S.; MENDES, J. M. B.; MARTIN, E. Mapeamento geofísico do lixão de São Carlos. In: $6^{\circ}$ CONGRESSO BRASILEIRO DE ÁGUA SUBTERRÂNEA. Anais... Porto Alegre-RS, 43, 82-88. 1990.

EMBRAPA. Avaliação da qualidade das águas: manual prático. Hermes, L. C.; Silva, A. de S. Empresa Brasileira de Pesquisa Agropecuária. Brasília, DF: Embrapa Informação Tecnológica. 55p. 2004.

ENGER, E. D.; SMITH, B. F. Environmental Science: a study of interralationships. McGraw-Hill, New York. 9ed. 477p. 2004.

ENVIRONMENT AGENCY. Evaluation of the extend and character of groundwater pollution from point sources in England and Wales. Environment Agency, Bristol. 1996.

EPA Method Study 20 Method 610 (PNA's). EPA 600/4-84-063. National Technical Information Service. PB84-211614. Springfield, Virginia 22161. 24p. jun. 1984a.

EPA. Method Study 18 Method 608. Organochlorine Pesticides and PCBs. EPA 600/484-061. National Technical Information Service. PB84-211358. Springfield, Virginia 22161. 32p. jun. 1984b.

EPA. Test methods for Headspace 3810. United States Environmental Protection Agency. CD-ROM. 5p. sep. 1986a.

EPA. Test methods for Polynuclear Aromatic Hydrocarbons 8310. United States Environmental Protection Agency. CD-ROM. 13p. sep. 1986b.

EPA. Test methods for organophosphorus compounds by gas chromatography: capillary column technique 8141A. United States Environmental Protection Agency. CDROM, 35p. sep. 1994.

EPA. Test methods for Halogenated and Aromatic Volatile Organic Compounds (VOCs) by gas chromatography. SW-846 Methods 8010A and 8020A or Method 8021A. 6p. dez. 1999.

ESTEVES, F. de A. Fundamentos de Limnologia. Rio de Janeiro: Editora Interciência: FINEP, 575p. 1988. 
EUROPA. Ambiente: gestão dos resíduos. Atividades da União Européia. Disponível em: <http://europa.eu/scadplus/leg/pt/s15002.htm>. Acesso em julho de 2007.

EUROPEAN COMMISSION. Waste generated and treated in Europe. Office for official publications of the european communities, Luxembourg. 2003.

FERNANDES, L. A. Mapa litoestratigráfico da parte oriental da bacia Bauru (PR, SP, MG). Escala 1:1.000.000. Boletim Paranaense de Geociências, n.55, p.53-66, Editora UFPR. 2004.

FERNANDEZ, J. A. B. Análise da geração de resíduos perigosos de origem domiciliar na coleta seletiva do município de São Carlos/SP. In: VIII SIMPÓSIO ÍTALO BRASILEIRO DE ENGENHARIA SANITÁRIA E AMBIENTAL - SIBESA. Anais... Fortaleza-CE: ABES, p.1-6. 2006.

FERRAZ, M. C. C.; BASSO, H. C. Resíduos sólidos formados por lixo eletrônico: riscos ambientais e política de reaproveitamento. In: $1^{\circ}$ FÓRUM DAS UNIVERSIDADES PUBLICAS PAULISTAS: CIÊNCIA E TECNOLOGIA EM RESÍDUOS. Anais... São Pedro-SP, 18-20 mai, p.286-292. 2003.

FIORATTI, G. SP não reaproveita lixo que produz todos os dias. Folha de São Paulo, domingo, C22, 15 de julho de 2007.

FIPAI. Aterro sanitário da cidade de Bauru - SP, EIA-RIMA (Estudo de Impacto Ambiental - Relatório de Impacto do Meio Ambiente). Fundação para o Incremento da Pesquisa e do Aperfeiçoamento Industrial. 5v. São Carlos - SP. 1992.

FREITAS, A. L. S. Caracterização do Aqüífero Botucatu na região de São Carlos. São Carlos. 205p. Dissertação (Mestrado) - Escola de Engenharia e São Carlos, Universidade de São Carlos. 1996.

FREITAS, P. N. P. de. Levantamento e pré-caracterizaçao dos resíduos de construção e demolição no município de Bauru. Bauru-SP: Departamento de Engenharia Civil, Universidade Estadual Paulista, Júlio de Mesquita Filho, 10/03/2007. (Relatório de iniciação científica, Processo FAPESP 04/15219-9).

FRÉSCA, F. R. C. Estudo da geração de resíduos sólidos domiciliares no município de São Carlos, SP, a partir da caracterização física. In: VIII SIMPÓSIO ÍTALO BRASILEIRO DE ENGENHARIA SANITÁRIA E AMBIENTAL - SIBESA. Anais... Fortaleza-CE: ABES, III-040, p.1-9. 2006.

FUNPEC. Métodos geofísicos, hidrogeológicos e hidroquímicos aplicados ao Zoneamento Ecológico-Econômico do Rio Grande do Norte: Caiçara do Norte e São Bento do Norte. Relatório Final. Laboratório de Geofísica de Prospecção e Sensoriamento Remoto, Fundação Norte Rio-Grandense de Pesquisa e Cultura. Natal, RN. 2004 
GADOTTI, R. F. Avaliação da contaminação das águas superficiais e subterrâneas adjacentes ao lixão da cidade de São Carlos. São Carlos. 150p. Dissertação (Mestrado) Escola de Engenharia de São Carlos, Universidade de São Paulo. 1997.

GANZELI, J. P. Aspectos ambientais do planejamento dos recursos hídricos: a bacia do rio Piracicaba. In: TAUK, S. M. (org.). Análise ambiental: uma visão multidisciplinar. São Paulo: Editora da Universidade Estadual Paulista. 2ed. Cap.6, p.134-140. 1995.

GOMES, L. P. Estudo da caracterização física e da biodegradabilidade dos resíduos sólidos urbanos em aterro sanitário. São Carlos/SP. São Carlos. Dissertação (Mestrado) - Escola de Engenharia de São Carlos. Universidade de São Paulo. 1989.

GOMES, L. P.; COELHO, O. W.; ERBA, D. A.; VERONEZ, M. Critérios de seleção de áreas para disposição final de resíduos sólidos. In: ANDREOLI, C. V. (coord.). Resíduos sólidos do saneamento: processamento, reciclagem e disposição final. Programa de Pesquisa em Saneamento Básico - PROSAB 2. Cap.6, p.145-163. 2003.

GONÇALVES, A. R. L. Geologia ambiental da área de São Carlos. São Paulo. 138p. Tese (Doutorado) - Instituto de Geociências, Universidade de São Paulo. 1986.

GONÇALVES, A. R. L.; BOSSOLAN, N. R. S.; ORLANDO, M. J. G. Determinação da direção do fluxo de freático no aterro sanitário de São Carlos. In: $7^{\circ}$ CONGRESSO BRASILEIRO DE ÁGUAS SUBTERRÂNEAS. Anais... Belo Horizonte-MG, p.114-118. 1993.

GRIMSKI, D. Revitalização de áreas degradadas e contaminadas na Alemanha e Europa. In: MOERI, E.; COELHO, R.; MARKER, A. (eds.). Remediação e revitalização de áreas contaminadas: aspectos técnicos, legais e financeiros. Instituto Ekos Brasil. São Paulo: Signus Editora. p.3-15. 2004.

HACH Company. Water Analysis Handbook. 2ed., Loveland, Colorado, United States. 1992.

HASSUDA, S. Critérios para a gestão de áreas suspeitas ou contaminadas por resíduos sólidos: estudo de caso na região metropolitana de São Paulo. São Paulo. 142p. Tese (Doutorado) - Instituto de Geociências, Universidade de São Paulo. 1997.

HEITZMANN JUNIOR, J. F. Alterações na composição do solo nas proximidades de depósitos de resíduos domésticos na bacia do rio Piracicaba, São Paulo, Brasil. São Paulo: Associação Brasileira de Geologia de Engenharia. (Série síntese de tese). 1999.

HAMILTON, M.; RUSSO, R. C.; THURSTON, R. V. Trimmed Spearman-Karber method for estimating median lethal concentrations in toxicity bioassays. Environmental Science Technology, v.11, n.7, p.714-719. 1978. 
IBGE. Pesquisa Nacional de Saneamento Básico 2000. Instituto Brasileiro de Geografia e Estatística. Ministério do Planejamento, Orçamento e Gestão. Brasil. Disponível em: <http://www.ibge.gov.br/home/presidencia/noticias/27032002pnsb.shtm>. Acesso em: 25 jul. 2004.

IBGE. Perfil dos Municípios Brasileiros - Finanças Públicas. Comunicação Social, 26 de outubro de 2004. Instituto Brasileiro de Geografia e Estatística. Disponível em: <http://www.ibge.gov.br/home/presidencia/noticias/noticia_impressao.php?id_noticia=243>. Acesso em: 01 nov. 2004.

IBGE. 2007. População estimada em 14/11/2007. Instituto Brasileiro de Geografia e Estatística. Disponível em: <http://www.ibge.gov.br/cidadesat/default.php>. Acesso em: 26 nov. 2007.

IGC. Mapa das Unidades Hidrográficas de Gerenciamento de Recursos Hídricos UGRHI. Plano Cartográfico do Estado de São Paulo. Governo do Estado de São Paulo. Conselho Estadual de Recursos Hídricos. Instituto Geográfico e Cartográfico. Departamento de Águas e Energia Elétrica. Edição revisada 1996.

IPT. Mapa Geológico do Estado de São Paulo. Escala 1:500.000. v.ll. Divisão de Minas e Geologia Aplicada. Instituto de Pesquisas Tecnológicas: São Paulo. Publicação n 1184. 1981.

IPT. Mapa Geológico da Folha Campinas. Escala: 1:250.000. Instituto de Pesquisas Tecnológicas: São Paulo. 1993a.

IPT. Mapa Geológico da Folha de Ribeirão Preto. Escala: 1:250.000. Instituto de Pesquisas Tecnológicas: São Paulo. 1993b.

IPT. Relatório N. 40.674: Diagnóstico da situação atual dos recursos hídricos e estabelecimento de diretrizes técnicas para a elaboração do Plano da Bacia Hidrográfica do Tietê/Jacaré - Relatório Final. Instituto de Pesquisas Tecnológicas do Estado de São Paulo S/A. Comitê da Bacia Hidrográfica do Tietê/Jacaré, Fundo Estadual de Recursos Hídricos. 3v. 528p. 2000.

LAGO, A. L. Aplicação integrada de métodos geofísicos em área de disposição de resíduos sólidos urbanos em Bauru - SP. São Paulo. Dissertação (Mestrado) - Instituto de Astronomia, Geofísica e Ciências Atmosféricas, Universidade de São Paulo. 2004.

LEGENDRE, L. Measures of ecological resemblance. In: LEGENDRE, L.; LEGENDRE, P. Numerical Ecology. Elsevier Scientific Publishing Company. Amsterdan. 317p. (Developments in Environmental Modeling, n.3). 1983.

LEITE, W. C. A. Estudo do comportamento da temperatura, pH e teor de umidade na decomposição de resíduos sólidos urbanos em aterros sanitários. São Carlos. Dissertação (Mestrado) - Escola de Engenharia de São Carlos, Universidade de São Paulo. 1991. 
LEITE, W. C. A. Estudo da gestão de resíduos sólidos: uma proposta de modelo tomando a Unidade de Gerenciamento de Recursos Hídricos (UGRHI - 5) como referência. São Carlos. 270p. Tese (Doutorado) - Escola de Engenharia de São Carlos, Universidade de São Paulo. 1997.

LIBÂNIO, M. Fundamentos de qualidade e tratamento de água. Editora Átomo: Campinas-SP. 1ed. 444p. 2005.

LIMA, J. D. de. Gestão de resíduos sólidos urbanos no Brasil. Associação Brasileira de Engenharia Sanitária e Ambiental. Paraíba: Inspira Comunicação e Design. 267p. 2003.

LOPES, C. V. M.; KRÜGER, V. (org.). Propostas para o ensino de química: poluição do ar e lixo. Porto Alegre: Secretaria Estadual da Educação do Rio Grande do Sul, Centro de Ciências do Rio Grande do Sul. p.156-157. 1997.

LOPES, A. A. Estudo da gestão e do gerenciamento integrado dos resíduos sólidos urbanos no município de São Carlos (SP). São Carlos. 178p. Dissertação (Mestrado) Escola de Engenharia de São Carlos, Universidade de São Paulo. 2003.

MACHADO, C. J. S. Mudanças conceituais na administração pública do meio ambiente. Ciência e Cultura: Gestão das Águas. Ano 55, n.4, out.-nov.-dez. p.24-26. 2003.

MAGALHÃES, V. S. Hidroquímica e qualidade das águas superficiais e subterrâneas em áreas sob influência de lavras pegmatíticas nas bacias dos córregos Água Santa e Palmeiras, município de Coronel Murta (MG). Belo Horizonte. Dissertação (Mestrado) Instituto de Geociências, Universidade Federal de Minas Gerais. 2006.

MANCINI, P. J. P. Uma avaliação do sistema de coleta informal de resíduos sólidos recicláveis no município de São Carlos, SP. São Carlos. 150p. Dissertação (Mestrado) Escola de Engenharia de São Carlos, Universidade de São Paulo. 1999.

MARCONDES, M. J. de A. Cidade e natureza: proteção dos mananciais e exclusão social. São Paulo: Studio Nobel: Editora da Universidade de São Paulo: Fapesp. (Coleção cidade aberta). 238p. 1999.

MARQUES NETO, J. da C. Diagnóstico para estudo de gestão dos resíduos de construção e demolição do município de São Carlos - SP. São Carlos. 155p. Dissertação (Mestrado) - Escola de Engenharia de São Carlos, Universidade de São Paulo. 2003.

MARSH, W. M.; GROSSA JUNIOR, J. M. Environmental geography science, land use, and earth systems. John Wiley \& Sons, Inc., United States. p.231-232. 1996.

MASSUKADO, L. M. Compostagem de resíduos orgânicos em São Carlos. Informações pessoais. 2007. 
MATOS, T. F. L. Diagnóstico dos resíduos poliméricos presentes nos resíduos sólidos domiciliares gerados em São Carlos, SP. São Carlos. 175p. Dissertação (Mestrado). EESC/USP. 2006.

MATTOS, A. Método de previsão de estiagens em rios perenes (usando poucos dados de vazão e longas séries de precipitação). São Carlos. Tese (Doutorado). EESC/USP. 1982.

MENDES, J. O uso racional da água. Jornal da Ciência, e-mail: 2406, 12 nov. 2003.

MENEZES, D. B. Diagnóstico dos impactos do lixão de São Carlos (SP) no meio físico. São Carlos. 101p. Dissertação (Mestrado) - Escola de Engenharia de São Carlos, Universidade de São Paulo. 1995.

METCALF; EDDY, Inc. Wastewater engineering: treatment and reuse. McGraw Hill. 4th ed. 1819p. 2003.

MONDELLI, G. Investigação geoambiental em áreas de disposição de resíduos sólidos urbanos utilizando a tecnologia do piezocone. Dissertação (Mestrado). São Paulo, Escola Politécnica, Universidade de São Paulo. 264p. 2004.

MONDELLI, G.; ZUQUETTE, L. V.; GIACHETI, H. L.; HAMADA, J.; ELIS, V. R. Considerações sobre a implantação de sistemas de monitoramento de águas subterrâneas em aterros de resíduos sólidos urbanos: um estudo de caso. In: XIII CONGRESSO BRASILEIRO DE MECÂNICA DOS SOLOS E ENGENHARIA GEOTÉCNICA. Anais... Curitiba-PR, v.1, 6p. 2006.

MONDELLI, G. Informações pessoais. Tese de Doutorado (em desenvolvimento). 2007.

MOTA, S. Urbanização e meio ambiente. Rio de Janeiro-RJ: ABES. 352p. 1999.

MOTA, S. Introdução à Engenharia Ambiental. 4ed. Rio de Janeiro: ABES. 388p. 2006.

MOTULSKY, H. Intuitive Biostastic. New York. Oxford University Press. 1995.

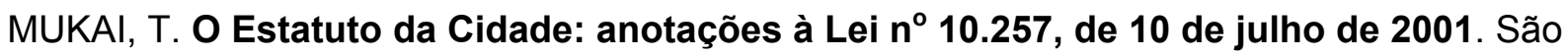
Paulo: Saraiva, p.40-49. 2001.

MÜLLER-PLANTENBERG, C.; AB'SABER, A. N. (orgs.). Previsão de impactos: o Estudo de Impacto Ambiental no Leste, Oeste e Sul. Experiências no Brasil, na Rússia e na Alemanha. São Paulo: Editora da Universidade de São Paulo. 569p. 1994. 
NASCIMENTO, M. C. B. do. Seleção de sítios visando à implantação de aterros sanitários com base em critérios geológicos, geomorfológicos e hidrológicos. São Paulo. Dissertação (Mestrado). Instituto de Geociências. 137p. 2001.

NAZAROFF, W. W.; ALVAREZ-COHEN, L. Environmental engineering science. New York, United States. John Wiley \& Sons, Inc. 690p. 2001.

NEDER, L. T. C. Reciclagem de resíduos sólidos de origem domiciliar: análise da implantação e da evolução de programas institucionais de coleta seletiva em alguns municípios brasileiros. Ciência Ambiental: primeiros mestrados. São Paulo: Annablume: FAPESP. Programa de Pós-graduação, Universidade de São Paulo. p.155-186. 1998.

O'CONNELL, K. A. Governments and the solid waste industry are making a push to recycle electronic products. Waste Age, p.88-92. apr. 2007.

OLIVEIRA JUNIOR, R. S. Introdução ao controle químico. In: OLIVEIRA JUNIOR, R. S.; CONSTANTIM, J. (ed.). Plantas daninhas e seu manejo. Guaíba: Agropecuária. p.187-204. 2001.

OTERO D'ALMEIDA, M. L.; VILHENA, A. (coord.). Lixo Municipal: manual de gerenciamento integrado. 2ed. São Paulo: IPT/CEMPRE. 2000.

PINHEIRO PEDRO, A. F. Taxa de lixo domiciliar em São Paulo: aspectos tributários constitucionais. Gerenciamento Ambiental: Saneamento em primeiro plano. BJ Moura Editora: São Paulo-SP. Ano 5. n.24. mar.-abr. p.30-33. 2003.

PIVATO, A.; RAGA, R. Tests for the evaluation of ammonium attenuation in MSW landfill leachate by adsorption into bentonite in a landfill liner, Waste Management, n.26, p.123132. 2006.

PLANO DIRETOR DE SÃO CARLOS. Anotações sobre o Projeto de Lei. Parte I Diagnóstico da Cidade. Câmara Municipal de São Carlos. Comissão de Urbanização, Transportes e Habitação. 2004.

PLANO DIRETOR PARTICIPATIVO DO MUNICÍPIO DE BAURU. Mapa 05: Áreas de interesse ambiental. DAE Geoprocessamento. Prefeitura Municipal de Bauru-SP. 66p. 2006.

POLAZ, C. N. M. Análise de populações bacterianas em área de recarga do Aqüífero Guarani (São Carlos/SP): efeito de antigos aterros e o isolamento de bactérias produtoras de exopolissacarídeos. São Carlos. 64p. Monografia (graduação) Universidade Federal de São Carlos. 2004.

POMPEU, C. T. O papel do Conselho Nacional de Recursos Hídricos - CNRH. Ciência e Cultura: Gestão das Águas. Ano 55, n.4, out.-nov.-dez. p.42-44. 2003. 
POVINELLI, J. Ação dos metais pesados nos processos biológicos de tratamento de águas residuárias. São Carlos. 285p. Tese (Livre Docência) - Escola de Engenharia de São Carlos, Universidade de São Paulo. 1987.

PREFEITURA MUNICIPAL DE SÃO CARLOS. Projeto executivo: aterro sanitário de resíduos sólidos urbanos, Fazenda Guaporé. Filsan Engenharia e Serviços S/A. Departamento de Estudos e Projetos Ambientais. v1. jan. 1989.

PREFEITURA MUNICIPAL DE SÃO CARLOS. Relatório Ambiental Preliminar do projeto de ampliação do aterro sanitário de São Carlos - SP. Secretaria de Ciência, Tecnologia e Desenvolvimento Sustentável, São Carlos. 112p. dez. 2001.

PREFEITURA MUNICIPAL DE SÃO CARLOS. Relatório Ambiental Preliminar: Ampliação do aterro sanitário de São Carlos. Projeto da $4^{a}$ lagoa de armazenamento de chorume. Secretaria de Ciência, Tecnologia e Desenvolvimento Sustentável, São Carlos. jul. 2005.

REBOUÇAS, A. da C. Impactos ambientais nas águas subterrâneas. In: $7^{\circ}$ CONGRESSO BRASILEIRO DE ÁGUAS SUBTERRÂNEAS. Anais... Belo Horizonte-MG: Associação Brasileira de Águas Subterrâneas, p.11-17. 1992.

RIBEIRO, L. C. de Q.; CARDOSO, A. L. Da cidade à nação: gênese e evolução do urbanismo no Brasil. In: RIBEIRO, L. C. de Q.; PECHMAN, R. (orgs.). Cidade, povo e nação: gênese do urbanismo moderno. Rio de Janeiro: Editora Civilização Brasileira. Cap.3, p.53-78. 1996.

RIOS, L. Estudo limnológico e fatores ecológicos em ribeirões e córregos da bacia hidrográfica do ribeirão do Feijão (Estado de São Paulo). São Carlos. 146p. Dissertação (Mestrado) - Escola de Engenharia de São Carlos, Universidade de São Paulo. 1993.

ROCHA, J. A. M. R. GPS: uma abordagem prática. 4ed. Edições Bagaço, Recife. 2003.

ROGERS, D. S.; TIBBEN-LEMBKE, R. S. Going backwards: reverse logistics trends and practices. University of Nevada, Reno, Center for Logistics Management. Reverse Logistics Executive Council. Cap.4, p.101-136. 1998.

SANCHEZ, L. E. Desengenharia: o passivo ambiental na desativação de empreendimentos industriais. São Paulo: Editora da Universidade de São Paulo, 254p. 2001.

SANTOS FILHO, M. G. dos. O impacto na qualidade das águas subterrâneas gerado pela disposição inadequada de resíduos sólidos no município de Tatuí (SP). São Paulo. 93p. Dissertação (Mestrado) - Instituto de Geociências, USP. 2001. 
SÃO PAULO. Mapeamento da vulnerabilidade e risco de poluição das águas subterrâneas no Estado de São Paulo. HIRATA, R. C. A.; BASTOS, C. R. de A.; ROCHA, G. A. (coord.). São Paulo: Instituto Geológico: CETESB - Série Documentos, v.1, 144p. 1997.

SÃO PAULO. Resíduos urbanos: um problema global. Secretaria do Meio Ambiente, Governo do Estado de São Paulo. São Paulo, 64p. 1998.

SÃO PAULO. Meio ambiente: caracterização, segundo Unidades de Gerenciamento de Recursos Hídricos. Secretaria de Recursos Hídricos, Saneamento e Obras; Secretaria de Estado de Meio Ambiente/Departamento Estadual de Proteção de Recursos Naturais; Fundação Sistema Estadual de Análise de Dados. 3p. 2001.

SCHALCH, V. Produção e características do chorume em processo de decomposição de lixo urbano. São Carlos. 103p. Dissertação (Mestrado) - Escola de Engenharia de São Carlos, Universidade de São Paulo. 1984.

$\mathrm{SCHALCH}, \mathrm{V}$. Análise comparativa do comportamento de dois aterros sanitários semelhantes e correlações dos parâmetros do processo de digestão anaeróbia. São Carlos. 220p. Tese (Doutorado) - Escola de Engenharia de São Carlos, Universidade de São Paulo. 1992.

SCHALCH, V.; LEITE, W. C. de A.; FERNANDES JUNIOR, J. L.; CASTRO, M. C. A. A. Gerenciamento de resíduos sólidos. Disciplina: Gerenciamento de Resíduos Sólidos. Departamento de Hidráulica e Saneamento. Escola de Engenharia de São Carlos. Universidade de São Paulo. 169p. 2000. (Apostila).

SCHIANETZ, B. Passivos ambientais: levantamento histórico, avaliação da periculosidade, ações de recuperação. Curitiba-PR: SENAI. 200p. 1999.

SETTI, A. A. et al. Introdução ao gerenciamento de recursos hídricos. Brasília: Agência Nacional de Energia Elétrica; Agência Nacional de Águas. 328p. 2001.

SILVA, A. C. Tratamento do lixiviado de aterro sanitário e avaliação da toxicidade do efluente bruto e tratado. Rio de Janeiro. 126p. Dissertação (Mestrado), Universidade Federal do Rio de Janeiro. 2002.

SILVA, R. S. M.; COTTA, J. A. de O. Caracterização física e química e determinação de metais em solo. In: $12^{\circ}$ SIMPÓSIO INTERNACIONAL DE INICIAÇÃO CIENTÍFICA DA UNIVERSIDADE DE SÃO PAULO. Área: Engenharia e Exatas. Anais... Escola Politécnica da Universidade de São Paulo, São Paulo-SP, 25-26 nov., 2004.

SILVA, C. M. M. de S.; FAY, E. F. Agrotóxicos e ambiente. Brasília, DF: Embrapa. 400p. 2004. 
SISINNO, C. L. S. Destino dos resíduos sólidos urbanos e industriais no Estado do Rio de Janeiro: avaliação da toxicidade dos resíduos e suas implicações para o ambiente e para a saúde humana. Rio de Janeiro. 102p. Tese (Doutorado), Fundação Oswaldo Cruz, Escola Nacional de Saúde Pública. 2002.

SMA. Normas básicas sobre licenciamento ambiental e estudo de impacto ambiental. Documentos Ambientais. Secretaria de Estado do Meio Ambiente. Governo do Estado de São Paulo. 92p. 1995.

SNIS. Diagnóstico dos serviços de água e esgotos. Série histórica 1995-2003. Sistema Nacional de Informações sobre Saneamento. Santos. 2003.

SOUZA, M. P. de. Instrumentos de gestão ambiental: fundamentos e prática. São Carlos: Editora Riani Costa. 112p. 2000.

TANDEL, R. Y. Contribuição ao estudo da poluição provocada no aqüífero freático e no solo pelo aterro controlado da cidade de Rio Claro, SP. São Paulo. 144p. Tese (Doutorado) - Instituto de Geociências, Universidade de São Paulo. 1998.

TARDENT, J. L. Plano de remediação para o depósito de resíduos perigosos de Koelliken. In: MOERI, E.; RODRIGUES, D. (eds.). Áreas contaminadas: remediação e redesenvolvimento. Instituto Ekos Brasil. São Paulo: Signus Editora. p.11-18. 2005.

TCHOBANOGLOUS, G. Integrated solid waste: engineering principles and management issues. McGraw-Hill, International Editions, Civil Engineering Series, 978p. 1993.

TEIXEIRA, D. Caracterização limnológica dos sistemas lóticos e variação temporal e espacial de invertebrados bentônicos na bacia do ribeirão do Feijão. São Carlos. 193p. Dissertação (Mestrado) - Escola de Engenharia de São Carlos, Universidade de São Paulo. 1993.

TRUSSEL, R. P. The percent un-ionized ammonian aqueous ammonia solutions at diferent pH levels and temperature. J. Fish. Res. Board. Can., 29: p.1505-1507. 1972.

UNESCO. Disponibilidade da água na Terra. Organização das Nações Unidas para a Educação, a Ciência e a Cultura. Disponível em: <http://www.castelobranco.br/redepea/noticia200211221159.php>. 2004.

USEPA. Appendix A: Glossary. EPA's recycling guide for native american nations (EPA530-K-95-006). Environmental Protection Agency. United States. Disponível em: $<w w w . e p a . g o v / e p a o s w e r / n o n-h w / t r i b a l / p d f t x t / n t v e r e c y . p d f>$. Acesso em: 16 maio 2004. 2001.

VALENTE, J. P. S.; PADILHA, P. M.; SILVA, A. M. M. Oxigênio dissolvido (OD), demanda bioquímica de oxigênio (DBO) e demanda química de oxigênio (DQO) como parâmetros de poluição no ribeirão Lavapés/Botucatu - SP, Eclética Química, São Paulo, v.22, p.49-66. 1997. 
VILLAÇA, F. Uma contribuição para a história do planejamento urbano no Brasil. In: Schiffer, S. T. R.; Deák, C. (orgs.). O processo de urbanização no Brasil. São Paulo: EDUSP. Cap.6. p.169-243. 1999.

VON SPERLING, M. Introdução à qualidade das águas e ao tratamento de esgotos. 3ed. $1^{\circ}$ vol, Belo Horizonte: Departamento de Engenharia Sanitária e Ambiental (DESA). Universidade Federal de Minas Gerais, 452p. 2005.

VON SPERLING, M., 2006. DQO da água natural. Informações pessoais, 31 jul. 2006.

WASTE AGE. Measuring Michigan: Canadian imports up, but landfill disposal drops overall. p.14-15, apr. 2007.

WHO. Environmental Health Criteria, 61: Chromium. World Health Organization. Genebra. 197p. 1988.

WILLIAMS, P. T. Waste treatment and disposal. Second edition. John Wiley \& Sons, Ltd. England. 380p. 2005.

ZAGATTO, P. A.; BERTOLETTI, E. (eds). Ecotoxicologia aquática: princípios e aplicações. Rima editora, São Carlos-SP. 478p. 2006. 


\title{
APÊNDICES
}

\section{Apêndice A - Questionário 1}

\author{
UNIVERSIDADE DE SÃO PAULO \\ ESCOLA DE ENGENHARIA DE SÃO CARLOS \\ DEPARTAMENTO DE HIDRÁULICA E SANEAMENTO \\ CENTRO DE RECURSOS HÍDRICOS E ECOLOGIA APLICADA \\ Aluna: Adriana Antunes Lopes \\ Orientador: Prof. Dr. Valdir Schalch
}

Projeto: Estudo da gestão integrada dos resíduos sólidos urbanos na bacia Tietê-Jacaré (UGRHI-13)

\section{Questionário}

Prefeitura:

Entrevistado:

Cargo:

Departamento/Secretaria:

Data:

1. Quais serviços a prefeitura presta ao município atualmente?

) Coleta regular

) Coleta seletiva

) Coleta de resíduos de serviços de saúde

) Coleta de resíduos sólidos industriais

) Pintura de faixas, guias, outros
) Triagem de materiais recicláveis

) Operação do aterro ou lixão

) Limpeza de parques, jardins

) Compostagem

) Reciclagem

2. Quem é responsável pela coleta regular do lixo no município atualmente?

3. Quantos caminhões e funcionários realizam a coleta regular no município?

4. Quantos bairros do município são atendidos pela coleta regular? E em porcentagem?

5. Como os setores são divididos para a coleta? Qual o critério utilizado para essa divisão: proximidade de bairros, melhor trajeto ou outro?

6. Qual a quantidade de resíduos gerada por bairros ou por setores do município? Quando essa estimativa foi levantada? 
7. Qual a composição média do lixo gerado no município (\% de vidro, plástico, metal, papel e papelão)? Quando essa estimativa foi realizada? vidro papel papelão plásticos metal tetrapak

8. Qual a geração diária (toneladas por dia) dos resíduos (domiciliares, comerciais, de serviços, industriais, RSS, de varrição, de poda e capina, volumosos, da construção civil) no município?

$\begin{array}{ll} & \text { domiciliar (RSD) } \\ & \text { comerciais } \\ & \text { varrição } \\ & \text { poda e capina }\end{array}$
industriais (RSI), Classe II serviços de saúde (RSS) volumosos (Ex: móveis) construção civil (RCC)

9. Qual a quantidade de resíduos sólidos proveniente de postos de gasolina?

10. Qual a quantidade de resíduos sólidos domiciliares gerada no final do ano?

11. Quantas e quais empresas estão autorizadas para coletar e descartar os RCC no município?

12. Onde estão localizadas as áreas autorizadas para o descarte dos RCC?

13. Qual a quantidade de resíduos volumosos descartados freqüentemente?

14. Qual a quantidade diária descartada de resíduo (orgânico e reciclável seco) proveniente dos refeitórios e escritórios das indústrias?

15. A prefeitura presta serviços às indústrias? Quais serviços?

16. Qual o custo desses serviços? 
17. Existem empresas que prestam esses tipos de serviços? Quais empresas?

18. Qual a geração diária (toneladas por dia) de resíduos sólidos industriais (RSI) perigosos (Classe I)?

19. As empresas enviam seus resíduos perigosos (Classe I) para qual aterro? Em qual município este aterro está localizado?

20. Existe previsão para instalação de algum aterro industrial no município ou na região? Qual é a previsão?

21. Todas as indústrias cadastradas na prefeitura depositam seus RSI no mesmo local?

22. Os RSI são identificados antes de serem descartados? Por quem?

23. A quantos estabelecimentos comerciais e industriais a prefeitura presta serviço?

24. Há previsão para a exigência do Certificado de Autorização e Destinação de Resíduos Industriais (CADRI) ou já está sendo exigida alguma taxa das empresas para identificação e disposição final dos resíduos Classe II?

25. Existem locais autorizados para recebimento de pilhas e baterias usadas no município? Onde?

26. A prefeitura é responsável pelo gerenciamento dos Resíduos de Serviços de Saúde (RSS) gerados no município? Quais os serviços prestados?

27. Há tratamento dos RSS na cidade? Qual o custo/tonelada para tratar estes resíduos?

28. O município trata os RSS provenientes de outras localidades? De quais municípios?

29. A prefeitura coleta o lixo da área rural? Qual a quantidade (toneladas por dia) gerada nesta área? 
30. A cidade possui coleta seletiva? Por quem é realizada?

31. A cidade possui central de triagem? Quantas? Onde estão localizadas?

32. Qual a quantidade de lixo desviada pelos catadores (coleta informal)?

33. Quantas toneladas por dia de lixo são recicladas no município atualmente?

34. Quais os materiais recicláveis que estão tendo um bom mercado no município?

35. Para onde os materiais recicláveis estão sendo vendidos?

36. A prefeitura investe ou pretende investir na compostagem e aproveitamento dos resíduos orgânicos e de poda e capina? Qual a previsão?

37. Já existe algum planejamento ou estudo de parcerias (com universidades, empresas, outros municípios, entre outros) sobre essa questão?

38. Há algum estudo voltado para a reciclagem do entulho (RCC) ou pneu?

39. Quem é o responsável por esses estudos?

40. Qual o custo de cada um desses serviços?

\begin{tabular}{|c|c|}
\hline Coleta regular & - Triagem de materiais recicláveis \\
\hline Coleta seletiva & Operação do aterro ou lixão \\
\hline Coleta de resíduos de serviços de saúde & Limpeza de parques, jardins \\
\hline Coleta de resíduos sólidos industriais & Compostagem \\
\hline Pintura de faixas, guias, outros & Reciclagem \\
\hline
\end{tabular}

41. Qual o custo total pago pela prefeitura (por mês, por ano ou por tonelada de lixo) para o gerenciamento dos resíduos sólidos?

42. A prefeitura coleta resíduos descartados por supermercados, restaurantes e lanchonetes? De quantos estabelecimentos? 
43. Qual o destino desses resíduos?

44. Há informação sobre entidades beneficiadas com a doação de produtos de restaurantes, lanchonetes ou supermercados (prazo de validade prestes a vencer)? Quais?

45. A prefeitura colabora com campanhas ou instituições no município ou região? Quais?

46. Há informação sobre o funcionamento de algum Bolsão de Resíduos na região? Onde?

47. A cidade possui aterro ou lixão? O aterro é considerado controlado ou sanitário?

48. A área possui poços para o monitoramento da água subterrânea? Quantos?

49. Quem é responsável pelo monitoramento desses poços? Eles são monitorados com qual freqüência?

50. Há intenção em remediar ou transformar algum lixão em aterro? Qual a previsão?

51. Qual a área total do aterro ou lixão e há quanto tempo ele funciona?

52. Qual a vida útil estimada para essa área? Quando esse cálculo foi previsto?

53. A quem pertence o terreno onde funciona o aterro ou lixão?

54. A área corre risco de desapropriação?

55. É paga alguma taxa (aluguel) pela prefeitura para o uso da área? Qual o valor por mês ou por ano?

56. A área recebe resíduos de outros municípios? De quais?

57. Quem são os responsáveis pelo funcionamento (operação) da área? 
58. Os serviços são acompanhados pela prefeitura? Por qual Departamento/Secretaria? Com qual freqüência?

59. Há fiscalização da área por algum órgão ambiental? Qual? Com qual freqüência?

60. Há alguma restrição ambiental ou legal quanto à localização da área?

61. Qual é o maior problema dessa área? Qual a estratégia para solucionar esse problema e para a área se enquadrar nas exigências dos órgãos ambientais?

62. Qual foi a última avaliação da Companhia de Tecnologia e Saneamento Ambiental (CETESB) para a área, referente ao Índice de Qualidade de Aterro de Resíduos (IQR)?

63. Quantas células para a disposição de resíduos são viáveis nesta área?

64. Qual a área, capacidade de resíduos e tempo de vida útil previstos para cada célula?

65. Qual o custo para "construção" e funcionamento de cada nova célula?

66. A área já foi ampliada? Quando? Qual empresa encarregada pelo projeto de ampliação?

67. Foi solicitado pela CETESB o Relatório Ambiental Preliminar (RAP) e/ou Termo de Ajuste de Conduta (TAC) para ampliação da área (construção de novas células)? Quando?

68. Qual a previsão para a(s) nova(s) célula(s) funcionar(em)?

69. Há algum processo de licenciamento ambiental em andamento? De qual área? Qual o prazo previsto?

70. A CETESB exigiu o Projeto de Recuperação de Áreas Degradadas (PRAD) para o selamento do aterro ou lixão? Quando está previsto para ser executado e qual o custo? 


\section{Apêndice B - Questionário 2}

Prezados(as) senhores(as),

Solicitamos a gentileza do preenchimento do quadro abaixo com um $\mathbf{X}$ nos itens contemplados pelo município, a fim de atualizarmos os dados fornecidos pelo Comitê da Bacia Hidrográfica do Tietê-Jacaré (UGRHI-13). Se possível, identificar as leis ambientais do município relacionadas aos resíduos sólidos e recursos hídricos na folha seguinte.

\begin{tabular}{|c|c|c|c|c|c|c|c|}
\hline & Municípios & Plano Diretor & \begin{tabular}{|l|} 
Lei de Uso e \\
Ocupação do
\end{tabular} & Lei Orgânica & $\begin{array}{l}\text { Código de } \\
\text { Obras }\end{array}$ & $\begin{array}{l}\text { Código de } \\
\text { Posturas }\end{array}$ & $\begin{array}{c}\text { Leis } \\
\text { Ambientais }\end{array}$ \\
\hline 1 & Agudos & & & & & & \\
\hline 2 & Analândia & & & & & & \\
\hline 3 & Araraquara & & & & & & \\
\hline 4 & Arealva & & & & & & \\
\hline 5 & Areiópolis & & & & & & \\
\hline 6 & Bariri & & & & & & \\
\hline 7 & Barra Bonita & & & & & & \\
\hline 8 & Bauru & & & & & & \\
\hline 9 & Boa Esperança do Sul & & & & & & \\
\hline 10 & Bocaina & & & & & & \\
\hline 11 & Boracéia & & & & & & \\
\hline 12 & Borebi & & & & & & \\
\hline 13 & Brotas & & & & & & \\
\hline 14 & Dois Córregos & & & & & & \\
\hline 15 & Dourado & & & & & & \\
\hline 16 & Gavião Peixoto & & & & & & \\
\hline 17 & lacanga & & & & & & \\
\hline 18 & Ibaté & & & & & & \\
\hline 19 & Ibitinga & & & & & & \\
\hline 20 & Igaraçu do Tietê & & & & & & \\
\hline 21 & Itaju & & & & & & \\
\hline 22 & Itapuí & & & & & & \\
\hline 23 & Itirapina & & & & & & \\
\hline 24 & Jaú & & & & & & \\
\hline 25 & Lençóis Paulista & & & & & & \\
\hline 26 & Macatuba & & & & & & \\
\hline 27 & Matão & & & & & & \\
\hline 28 & Mineiros do Tietê & & & & & & \\
\hline 29 & Nova Europa & & & & & & \\
\hline 30 & Pederneiras & & & & & & \\
\hline 31 & Ribeirão Bonito & & & & & & \\
\hline 32 & São Carlos & & & & & & \\
\hline 33 & São Manuel & & & & & & \\
\hline 34 & São Pedro & & & & & & \\
\hline 35 & Tabatinga & & & & & & \\
\hline 36 & Torrinha & & & & & & \\
\hline 37 & Trabiju & & & & & & \\
\hline
\end{tabular}


IDENTIFICAÇÃO DAS LEIS AMBIENTAIS

Resíduos Sólidos:

Recursos Hídricos: 
Apêndice C - Resíduos sólidos nos municípios da Bacia Tietê-Jacaré (UGRHI-13)

\begin{tabular}{|c|c|c|c|c|c|c|c|c|c|c|c|c|c|c|c|c|}
\hline \multirow{2}{*}{\multicolumn{2}{|c|}{ Municípios }} & \multirow{2}{*}{$\begin{array}{l}\text { Área } \\
\left(\mathrm{Km}^{2}\right)\end{array}$} & \multirow{2}{*}{$\begin{array}{c}\text { População }{ }^{2} \\
\text { (hab) }\end{array}$} & \multirow{2}{*}{$\begin{array}{l}\text { RCC* } \\
\text { (t/dia) }\end{array}$} & \multirow{2}{*}{$\begin{array}{l}\text { RSS }^{* *} \\
\text { (t/dia) }\end{array}$} & \multirow{2}{*}{$\begin{array}{l}\mathrm{RSI} I^{* * *} \\
\text { (t/dia) }\end{array}$} & \multicolumn{2}{|c|}{$\mathrm{RSD}^{\star * * *}$ (t/dia) } & \multirow{2}{*}{$\begin{array}{l}\text { Disposição } \\
\text { Final RSD }\end{array}$} & \multicolumn{3}{|c|}{ Aterro } & \multirow{2}{*}{$\begin{array}{l}\text { Coleta } \\
\text { RSD }\end{array}$} & \multirow{2}{*}{\multicolumn{2}{|c|}{$\begin{array}{l}\text { IQR } \\
2006\end{array}$}} & \multirow{2}{*}{$\begin{array}{c}\text { Plano } \\
\text { Diretor } \\
\left(\mathbf{N}^{\circ} \text { Lei/Ano) }\right.\end{array}$} \\
\hline & & & & & & & CETESB $^{3}$ & Quest & & $\begin{array}{l}\text { Ano } \\
\text { Oper }\end{array}$ & $\begin{array}{c}\text { Área } \\
\left(m^{2}\right)\end{array}$ & PM & & & & \\
\hline & Agudos & 968 & 34.221 & - & - & - & 12,9 & - & - & - & - & - & - & 7,2 & $\mathrm{C}$ & - \\
\hline & Analândia & 327 & 4.166 & - & - & - & 1,2 & - & - & - & - & - & - & 4,1 & $\mathrm{I}$ & - \\
\hline 3 & Araraquara & 1.006 & 195.815 & 388,00 & 1,24 & - & 94,9 & 165,00 & $A C$ & 1975 & 80.000 & 4 & Ter & 8,5 & $\mathrm{~A}$ & $350 / 2005$ \\
\hline 4 & Arealva & 506 & 7.504 & - & - & - & 2,2 & - & - & - & - & - & - & 8,9 & $\mathrm{~A}$ & - \\
\hline & Areiópolis & 86 & 10.630 & - & - & - & 3,5 & - & - & - & - & - & - & 8,3 & $\mathrm{~A}$ & - \\
\hline 6 & Bariri & 441 & 30.995 & 7,60 & - & - & 11,4 & 11,20 & Valas & - & 36.300 & - & Ter & 6,0 & $\mathrm{I}$ & 039/2006 \\
\hline & Barra Bonita & 150 & 35.090 & - & - & - & 15,1 & 16,00 & $A C$ & 2001 & 12.000 & - & Pref & 5,4 & $\mathrm{I}$ & - \\
\hline 8 & Bauru & 673 & 347.601 & 600 & 1,80 & - & 211,7 & 200,00 & AS & 1993 & 300.000 & 16 & Pref/Ter & 8,7 & $\mathrm{~A}$ & $75 / 2006$ \\
\hline 9 & $\begin{array}{l}\text { Boa Esperança } \\
\text { do Sul }\end{array}$ & 691 & 13.208 & - & - & - & 4,8 & - & - & - & - & - & - & 8,9 & A & - \\
\hline 10 & Bocaina & 364 & 10.299 & - & - & - & 4,1 & - & - & - & - & - & - & 7,4 & $\mathrm{C}$ & - \\
\hline $11 \mid$ & Boracéia & 121 & 4.128 & - & - & - & 1,4 & - & - & - & - & - & - & 8,0 & $\mathrm{C}$ & - \\
\hline 12 & Borebi & 348 & 2.172 & - & - & - & 0,7 & - & - & - & - & - & - & 9,8 & $\mathrm{~A}$ & - \\
\hline 13 & Brotas & 1.101 & 20.996 & 1,28 & 0,06 & - & 7,7 & 9,44 & Trincheiras & 2004 & 53.753 & - & Pref & 7,5 & C & $12 / 2006$ \\
\hline 14 & Dois Córregos & 633 & 24.384 & - & 0,08 & - & 9,0 & 10,00 & Valas & - & 48.400 & - & Pref & 8,8 & $\mathrm{~A}$ & - \\
\hline 15 & Dourado & 206 & 8.751 & - & - & - & 3,4 & - & - & - & - & - & - & 6,2 & $\mathrm{C}$ & - \\
\hline 16 & Gavião Peixoto & 244 & 4.103 & - & - & - & 1,1 & - & - & - & - & - & - & 6,1 & $\mathrm{C}$ & - \\
\hline 17 & lacanga & 548 & 9.074 & - & - & - & 3,0 & - & - & - & - & - & - & 8,5 & A & - \\
\hline 18 & Ibaté & 290 & 28.040 & - & - & - & 12,6 & - & - & - & - & - & - & 7,9 & $\mathrm{C}$ & - \\
\hline 19 & Ibitinga & 689 & 49.951 & - & - & - & 20 & - & - & - & - & - & - & 6,3 & $\mathrm{C}$ & - \\
\hline 20 & Igaraçu do Tietê & 97 & 23.085 & - & - & - & 9,4 & - & - & - & - & - & - & 8,5 & $\mathrm{~A}$ & - \\
\hline 21 & Itaju & 229 & 2.624 & - & - & - & 0,7 & - & - & - & - & - & - & 9,5 & $\mathrm{~A}$ & - \\
\hline 22 & Itapuí & 140 & 11.605 & - & - & - & 4,2 & - & - & - & - & - & - & 4,7 & $\mathrm{I}$ & - \\
\hline 23 & Itirapina & 564 & 13.889 & 20,00 & 0,015 & 5,00 & 5,3 & 9,80 & Trincheira & 2004 & - & 3 & Pref & 7,4 & C & - \\
\hline 24 & Jaú & 688 & 125.469 & 40,00 & 0,30 & 18,00 & 60,2 & 115,00 & Lixão & 1992 & 48.400 & 4 & Pref & 5,5 & 1 & $277 / 2006$ \\
\hline
\end{tabular}

Continua na próxima página 
Apêndice C - Resíduos sólidos nos municípios da Bacia Tietê-Jacaré (UGRHI-13) (continuação)

\begin{tabular}{|c|c|c|c|c|c|c|c|c|c|c|c|c|c|c|c|c|}
\hline & \multirow[b]{2}{*}{ Municípios } & \multirow{2}{*}{$\begin{array}{l}\text { Área } \\
\left(\mathrm{Km}^{2}\right)\end{array}$} & \multirow{2}{*}{$\begin{array}{c}\text { População } \\
\text { (hab) }\end{array}$} & \multirow{2}{*}{$\begin{array}{l}\text { RCC* } \\
\text { (t/dia) }\end{array}$} & \multirow{2}{*}{$\begin{array}{l}R^{R S} S^{* *} \\
\text { (t/dia) }\end{array}$} & \multirow{2}{*}{$\begin{array}{l}\text { RSI } I^{* * *} \\
\text { (t/dia) }\end{array}$} & \multicolumn{2}{|c|}{$\mathrm{RSD}^{* * * *}$ (t/dia) } & \multirow{2}{*}{$\begin{array}{l}\text { Disposição } \\
\text { Final RSD }\end{array}$} & \multicolumn{3}{|c|}{ Aterro } & \multirow{2}{*}{$\begin{array}{c}\text { Coleta } \\
\text { RSD }\end{array}$} & \multirow{2}{*}{\multicolumn{2}{|c|}{$\begin{array}{l}I^{1 Q R} R^{3} \\
2006\end{array}$}} & \multirow{2}{*}{$\begin{array}{c}\text { Plano } \\
\text { Diretor } \\
\text { (N. Lei/Ano) }\end{array}$} \\
\hline & & & & & & & CETESB $^{3}$ & Quest & & $\begin{array}{l}\text { Ano } \\
\text { Oper }\end{array}$ & $\begin{array}{c}\text { Área } \\
\left(\mathrm{m}^{2}\right)\end{array}$ & PM & & & & \\
\hline 25 & Lençóis Paulista & 804 & 59.366 & - & - & - & 24,0 & - & - & - & - & - & - & 8,4 & $\mathrm{~A}$ & - \\
\hline 26 & Macatuba & 226 & 16.173 & - & - & - & 6,7 & - & - & - & - & - & - & 4,3 & $\mathrm{I}$ & - \\
\hline 27 & Matão & 527 & 74.407 & - & - & - & 30,0 & - & - & - & - & - & - & 7,4 & $\mathrm{C}$ & $3800 / 2006$ \\
\hline 28 & $\begin{array}{l}\text { Mineiros do } \\
\text { Tietê }\end{array}$ & 212 & 11.760 & - & - & - & 5,0 & - & - & - & - & - & - & 8,8 & $A$ & - \\
\hline 29 & Nova Europa & 161 & 9.047 & - & - & - & 3,2 & - & - & - & - & - & - & 8,2 & $\mathrm{~A}$ & - \\
\hline 30 & Pederneiras & 729 & 40.270 & - & - & - & 14,9 & - & - & - & - & - & - & 7,4 & $\mathrm{C}$ & $2523 / 2006$ \\
\hline 31 & Ribeirão Bonito & 472 & 11.383 & 1,43 & 0,02 & - & 4,2 & 10,00 & Valas & 2004 & 40.000 & - & Pref & 7,6 & $\mathrm{C}$ & - \\
\hline 32 & São Carlos & 1.141 & 212.956 & 500,00 & 0,66 & 500,00 & 125,8 & 150,00 & AS & 1996 & 100.000 & 5 & Ter & 9,0 & $\mathrm{~A}$ & $13691 / 2005$ \\
\hline 33 & São Manuel & 651 & 37.797 & - & - & - & 14,8 & - & - & - & - & - & - & 8,9 & $\mathrm{~A}$ & - \\
\hline 34 & São Pedro & 618 & 29.733 & - & - & - & 11,1 & - & - & - & - & - & - & 7,4 & $\mathrm{C}$ & - \\
\hline 35 & Tabatinga & 366 & 13.965 & - & - & - & 4,6 & - & - & - & - & - & - & 8,0 & $\mathrm{C}$ & - \\
\hline 36 & Torrinha & 311 & 8.918 & - & - & - & 3,2 & - & - & - & - & - & - & 7,7 & $\mathrm{C}$ & - \\
\hline 37 & Trabiju & 63 & 1.441 & - & - & - & 0,5 & - & - & - & - & - & - & 9,2 & $A$ & - \\
\hline \multicolumn{2}{|c|}{ Total } & 17.391 & 1.545 .016 & & & & 748,5 & & & & & & & & & \\
\hline
\end{tabular}

${ }^{1}$ e ${ }^{2}$ Fonte: IBGE (2007). População estimada em 14/11/2007. Disponível em: <http://www.ibge.gov.br/cidadesat/default.php>. Acesso em: 26 nov. 2007

${ }^{1}$ Apenas 15 municípios possuem $100 \%$ de seus territórios dentro da UGRHI-13

${ }^{3}$ CETESB (2007). Inventário Estadual de Resíduos Sólidos Domiciliares. Relatório de 2006. IQR: Índice de Qualidade de Aterro de Resíduos

A: Condições Adequadas; C: Condições Controladas; I: Condições Inadequadas

${ }^{*}$ RCC: Resíduo de Construção Civil

${ }^{* *}$ RSS: Resíduo de Serviços de Saúde

*** RSI: Resíduo Sólido Industrial

****RSD: Resíduo Sólido Domiciliar

AC: Aterro Controlado

AS: Aterro Sanitário

PM: Poços de Monitoramento

Pref: Prefeitura

Ter: Terceirizada

Oper: Operação

Quest: Questionário 


\section{Apêndice D - Resultados dos ensaios físico-químicos e microbiológicos com amostras de água subterrânea}

\section{D.1 Aterro de Araraquara}

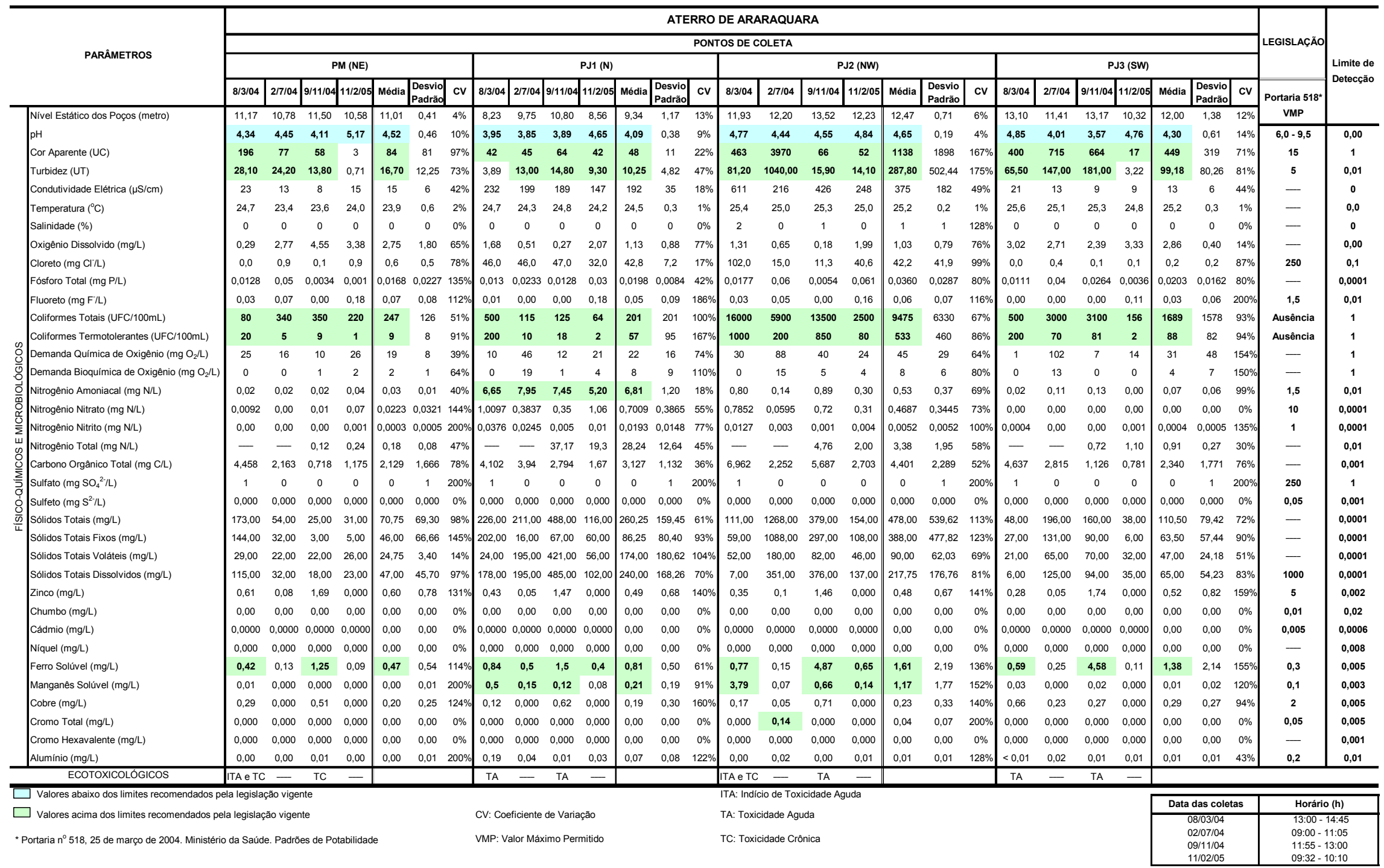




\section{D.2 Aterro de Bauru}

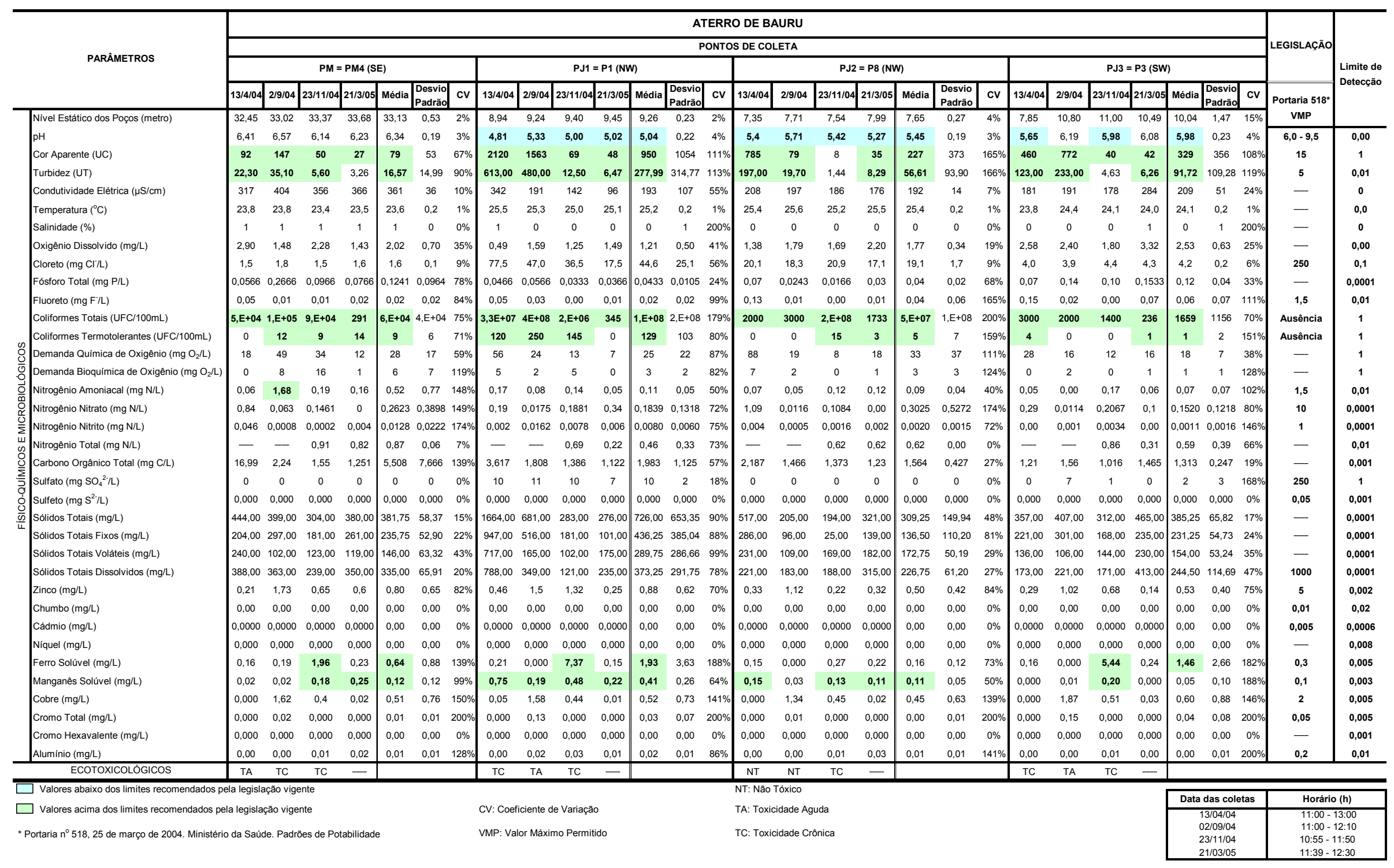




\section{D.3 Lixão de Jaú}

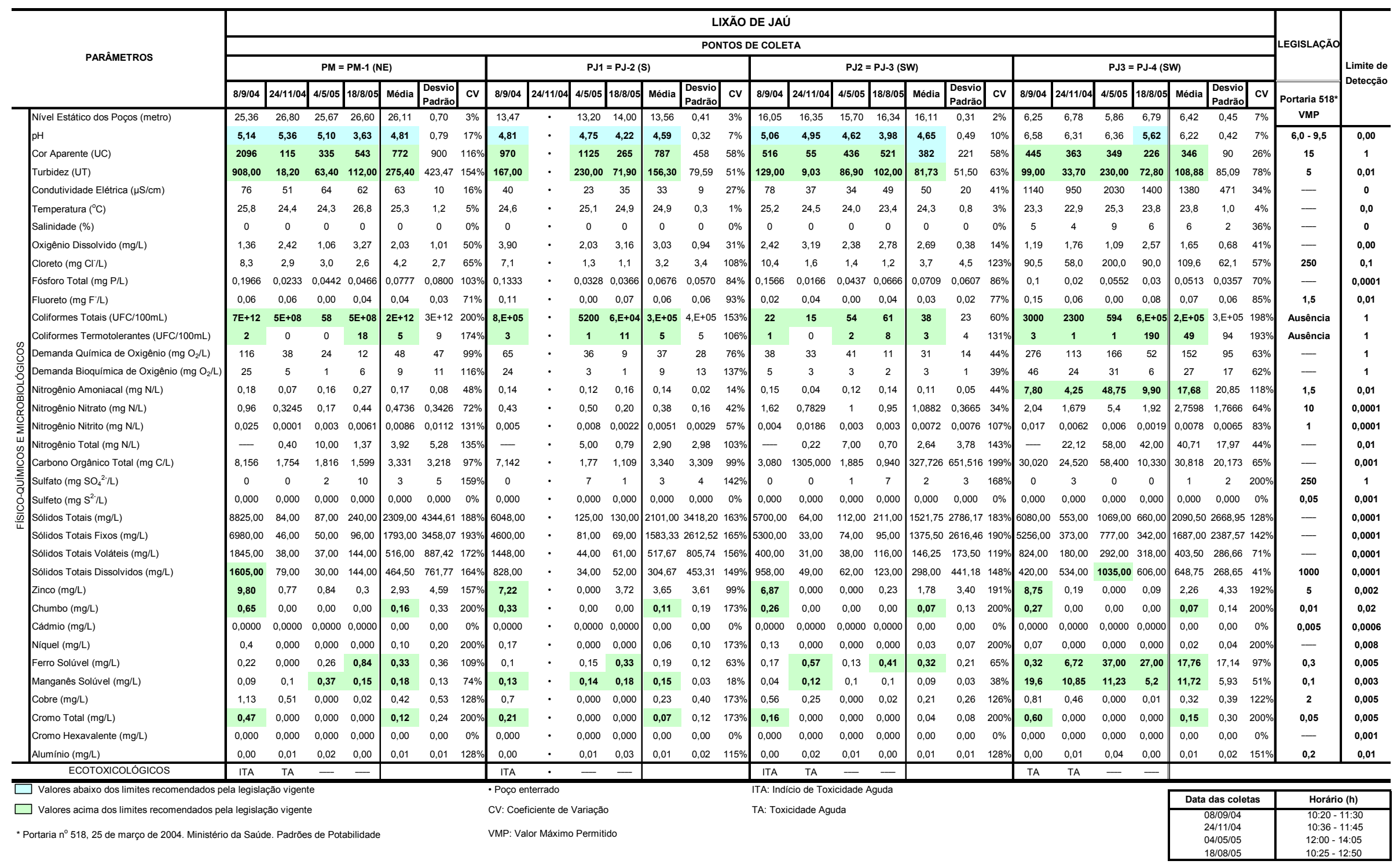




\section{D.4 Aterro de São Carlos}

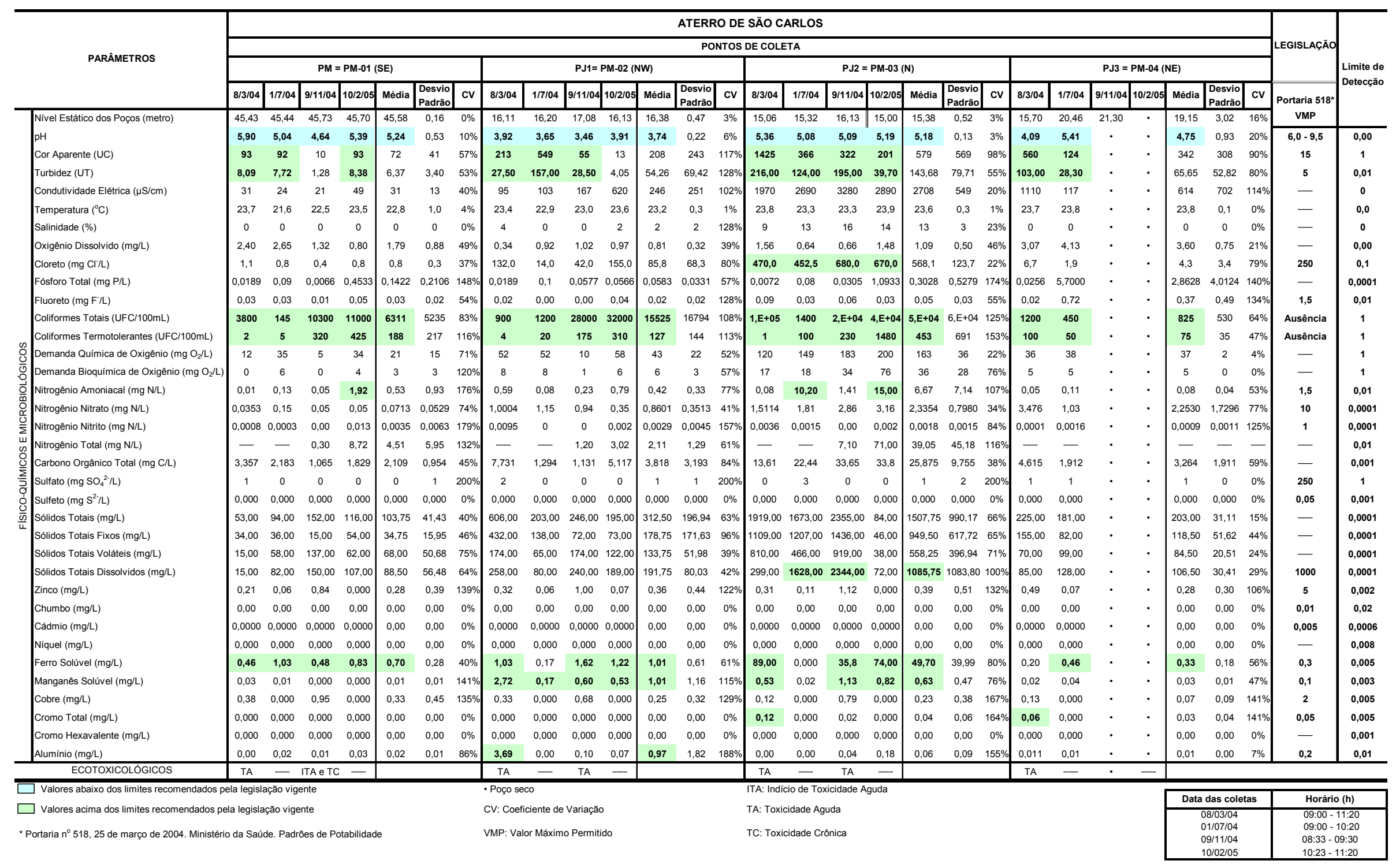




\section{D.5 Antigo Lixão de São Carlos}

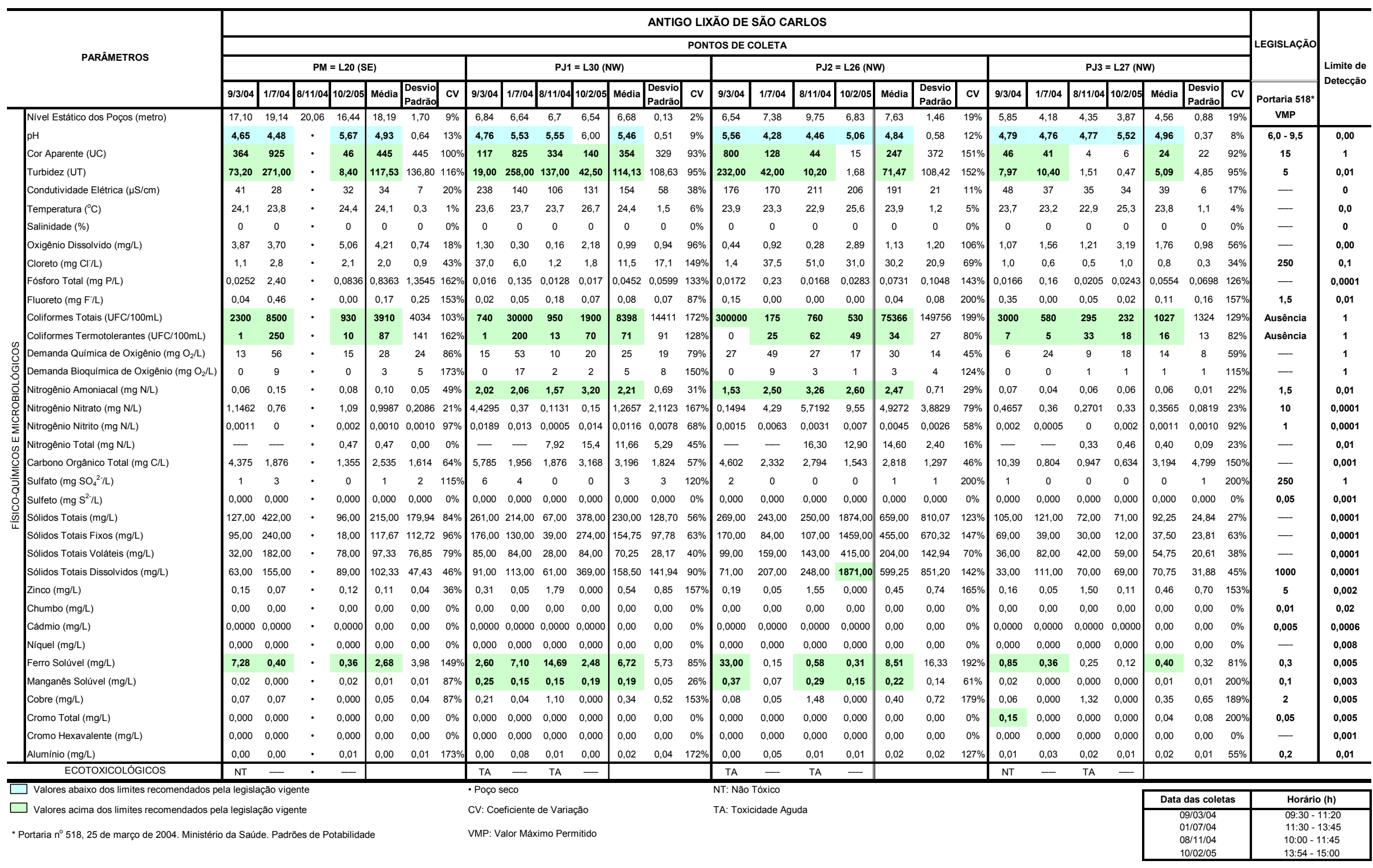


Apêndice E - Resultados dos ensaios físico-químicos e microbiológicos com amostras de água superficial E.1 Córrego do Pinheirinho, Araraquara

\begin{tabular}{|c|c|c|c|c|c|c|c|c|c|c|c|c|c|c|c|c|c|}
\hline \multirow{4}{*}{ PARÁMETROS } & \multicolumn{14}{|c|}{ CÓRREGO DO PINHEIRINHO, ARARAQUARA } & \multirow{2}{*}{\multicolumn{2}{|c|}{ LEGISLAÇÖES }} & \multirow{4}{*}{$\begin{array}{l}\text { Limite dé } \\
\text { Detecçăc }\end{array}$} \\
\hline & \multicolumn{14}{|c|}{ PONTOS DE COLETA } & & & \\
\hline & \multicolumn{7}{|c|}{ Montante (PM) } & \multicolumn{7}{|c|}{ Jusante (PJ) } & \multicolumn{2}{|c|}{ Agua Classe 2} & \\
\hline & $\begin{array}{l}8 / 3 / 04 \\
15: 00\end{array}$ & \begin{tabular}{|l|}
$2 / 7104$ \\
$11: 20$
\end{tabular} & $\begin{array}{c}\text { 9/11/04 } \\
13: 13\end{array}$ & \begin{tabular}{c|c}
$11 / 2 / 05$ \\
$10: 29$
\end{tabular} & Média & \begin{tabular}{|l|} 
Desvio \\
Padrão
\end{tabular} & \begin{tabular}{|l|}
$\begin{array}{l}\text { Coeficiente } \\
\text { de Variaçāo }\end{array}$ \\
\end{tabular} & $\begin{array}{l}8 / 3 / 04 \\
16: 00\end{array}$ & \begin{tabular}{|l|l|l|l|l}
$2 / 7104$ \\
$11: 45$
\end{tabular} & \begin{tabular}{|l|l} 
9/11/104 \\
$13: 30$
\end{tabular} & $\begin{array}{c}11 / 2 / 105 \\
10: 45\end{array}$ & Média & \begin{tabular}{|l|} 
Desvio \\
Padräo
\end{tabular} & $\begin{array}{l}\begin{array}{l}\text { Coeficiente } \\
\text { de Variação }\end{array} \\
\end{array}$ & $\begin{array}{l}\text { CONAMA 357/2005* } \\
\text { VM }\end{array}$ & \begin{tabular}{|c|} 
Decreto $8468 / 1976^{\text {t*t }}$ \\
LM
\end{tabular} & \\
\hline $\mathrm{pH}$ & 4,57 & 4,88 & 5,55 & 5,56 & 5,33 & 0,50 & $9 \%$ & 5,00 & 5,43 & 5,98 & 5,50 & 5,48 & 0,40 & $7 \%$ & $6,0-9,0$ & - & 0,00 \\
\hline Cor Aparente (uC) & 35 & 6 & 6 & 13 & 15 & 14 & $92 \%$ & 47 & 27 & 28 & 21 & 31 & 11 & $37 \%$ & 75 & - & 1 \\
\hline Turbidez (uT) & 262,00 & 1,60 & 1,19 & 1,95 & 66,68 & 130,21 & $195 \%$ & 4,87 & 3,73 & 3,30 & 3,21 & 3,77 & 0,76 & $20 \%$ & 100 & - & 0,01 \\
\hline Condutividade Elétrica $(\mu \mathrm{S} / \mathrm{cm})$ & 17 & 12 & 12 & 13 & 13 & 2 & $16 \%$ & 20 & 17 & 15 & 15 & 17 & 2 & $12 \%$ & - & - & 0 \\
\hline Temperatura $\left({ }^{\circ} \mathrm{C}\right)$ & 24,4 & 21,5 & 24,5 & 23,3 & 23,4 & 1,4 & $6 \%$ & 25,3 & 21,2 & 25,6 & 23,3 & 23,9 & 2,0 & $9 \%$ & - & - & 0,0 \\
\hline Salinidade (\%) & 0 & 0 & 0 & 0 & 0 & 0 & $0 \%$ & 0 & 0 & 0 & 0 & 0 & 0 & $0 \%$ & - & - & 0 \\
\hline Oxigênio Dissolvido (mg/L) & 5,70 & 6,32 & 5,79 & 6,73 & 6,13 & 0,48 & $8 \%$ & 6,08 & 6,88 & 7,07 & 7,48 & 6,87 & 0,59 & $9 \%$ & $>5$ & $>5$ & 0,00 \\
\hline Cloreto (mg Cl/L) & 0,5 & 0,6 & 0,6 & 0,5 & 0,6 & 0,1 & $10 \%$ & 0,5 & 0,5 & 0,3 & 0,4 & 0,4 & 0,1 & $23 \%$ & 250 & - & 0,1 \\
\hline Fósforo Total (mg P/L) & 0,0146 & 0,2000 & 0,0000 & 0,0100 & 0,0562 & 0,0961 & $171 \%$ & 0,0128 & 0,0750 & 0,0000 & 0,0066 & 0,0236 & 0,0347 & $147 \%$ & 0,050 & - & 0,0001 \\
\hline Fluoreto (mg F/L) & 0,02 & 0,00 & 0,00 & 0,19 & 0,0525 & 0,0922 & $176 \%$ & 0,02 & 0,36 & 0,00 & 0,18 & 0,14 & 0,17 & $120 \%$ & 1,4 & - & 0,01 \\
\hline Coliformes Totais (UFC/100mL) & 600 & 730 & 780 & 883 & 748 & 102 & $14 \%$ & 150 & 450 & 432 & 450 & 370 & 128 & $34 \%$ & - & 5000 & 1 \\
\hline Coliformes Termotolerantes (UFC/100mL) & 13 & 35 & 42 & 2 & 23 & 19 & $81 \%$ & 34 & 15 & 22 & 18 & 22 & 7 & $33 \%$ & 1000 & 1000 & 1 \\
\hline of Demanda Química de Oxigênio ( $\mathrm{mg} \mathrm{O}_{2} \mathrm{~L}$ ) & 20 & 28 & 11 & 16 & 19 & 7 & $38 \%$ & 31 & 33 & 6 & 14 & 21 & 13 & $63 \%$ & - & - & 1 \\
\hline Demanda Bioquímica de Oxigênio ( $\mathrm{mg} \mathrm{O}_{2} / \mathrm{L}$ ) & 0 & 0 & 1 & 0 & 0 & 1 & $200 \%$ & 0 & 0 & 0 & 0 & 0 & 0 & $0 \%$ & $<5$ & $<5$ & 1 \\
\hline Nitrogênio Amoniacal (mg N/L) & 0,05 & 0,02 & 0,07 & 0,02 & 0,04 & 0,02 & $61 \%$ & 0,05 & 0,06 & 0,06 & 0,06 & 0,05 & 0,01 & $10 \%$ & 3,7 & 0,500 & 0,01 \\
\hline Nitrogênio Nitrato (mg N/L) & 0,1070 & 0,0567 & 0,0100 & 0,3700 & 0,1350 & 0,161 & $119 \%$ & 0,0884 & 0,0157 & 0,0100 & 0,0700 & 0,0460 & 0,039 & $85 \%$ & 10 & 10,000 & 0,0001 \\
\hline Nitrogênio Nitrito (mg N/L) & 0,0005 & 0,0005 & 0,0000 & 0,0020 & 0,0008 & 0,0009 & $115 \%$ & 0,0008 & 0,0000 & 0,0000 & 0,0020 & 0,0007 & 0,0009 & $135 \%$ & 1 & 1,000 & 0,0001 \\
\hline Nitrogênio Total (mg N/L) & - & - & 0,40 & 0,20 & 0,30 & 0,14 & $47 \%$ & - & - & 0,36 & 0,57 & 0,46 & 0,15 & $32 \%$ & 2,18 & - & 0,01 \\
\hline Carbono Orgânico Total (mg C/L) & 2,739 & 1,197 & 0,867 & 0,775 & 1,394 & 0,91 & $66 \%$ & 3,819 & 1,305 & 0,812 & 0,834 & 1,69 & 1,44 & $85 \%$ & - & - & 0,001 \\
\hline Sulfato $\left(\mathrm{mg} \mathrm{SO}_{4}{ }^{2} \cdot \mathrm{L}\right)$ & 1 & 0 & 0 & 0 & 0 & 1 & $200 \%$ & 2 & 0 & 0 & 0 & 1 & 1 & $200 \%$ & 250 & - & 1 \\
\hline Sulfeto $\left(\mathrm{mg} \mathrm{s}^{2} \cdot \mathrm{L}\right)$ & 0,000 & 0,000 & 0,000 & 0,000 & 0,000 & 0,000 & $0 \%$ & 0,000 & 0,000 & 0,000 & 0,000 & 0,000 & 0,000 & $0 \%$ & 0,002 & - & 0,001 \\
\hline \begin{tabular}{l|l}
$\frac{8}{0}$ & Sólidos Totais $(\mathrm{mg} / \mathrm{L})$
\end{tabular} & 25,00 & 56,00 & 82,00 & 24,00 & 46,75 & 27,80 & $59 \%$ & 33,00 & 29,00 & 94,00 & 38,00 & 48,50 & 30,56 & $63 \%$ & - & - & 0,0001 \\
\hline 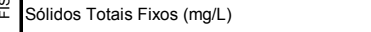 & 21,00 & 10,00 & 8,00 & 5,00 & $\mid 11,00$ & 6,98 & $63 \%$ & 21,00 & 14,00 & 10,00 & 6,00 & 12,75 & 6,40 & $50 \%$ & - & - & 0,0001 \\
\hline Sólidos Totais Voláteis (mg/L) & 4,00 & 46,00 & 74,00 & 19,00 & 35,75 & 30,86 & $86 \%$ & 12,00 & 15,00 & 84,00 & 32,00 & 35,75 & 33,35 & $93 \%$ & - & - & 0,0001 \\
\hline Sólidos Totais Dissolvidos (mg/L) & 17,00 & 53,00 & 80,00 & 22,00 & 43,00 & 29,36 & $68 \%$ & 9,00 & 26,00 & 88,00 & 33,00 & 39,00 & 34,19 & $88 \%$ & 500 & - & 0,0001 \\
\hline Zinco (mg/L) & 0,320 & 0,050 & 2,130 & 0,000 & 0,625 & 1,01 & $162 \%$ & 0 & 0,070 & 1,430 & 0,000 & 0,423 & 0,68 & $160 \%$ & 0,18 & 5,000 & 0,002 \\
\hline Chumbo (mg/L) & 0,00 & 0,00 & 0,00 & 0,00 & 0,00 & 0,00 & $0 \%$ & 0,00 & 0,00 & 0,00 & 0,00 & 0,00 & 0,00 & $0 \%$ & 0,01 & 0,100 & 0,02 \\
\hline Cádmio (mg/L) & 0,0000 & 0,0000 & 0,0000 & 0,0000 & 0,0000 & 0,00 & $0 \%$ & 0,0000 & 0,0000 & 0,0000 & 0,0000 & 0,0000 & 0,00 & $0 \%$ & 0,001 & 0,010 & 0,0006 \\
\hline Niquel $(\mathrm{mg} / \mathrm{L})$ & 0,000 & 0,000 & 0,000 & 0,000 & $\mid 0,000$ & 0,00 & $0 \%$ & 0,000 & 0,000 & 0,000 & 0,000 & 0,000 & 0,00 & $0 \%$ & 0,025 & - & 0,008 \\
\hline Ferro Solível (mg/L) & 0,250 & 0,000 & 0,730 & 0,230 & 0,303 & 0,31 & $101 \%$ & 0,550 & 0,240 & 0,800 & 0,350 & 0,485 & 0,25 & $51 \%$ & 0,3 & - & 0,005 \\
\hline Manganês Solúvel (mg/L) & 0,000 & 0,000 & 0,000 & 0,000 & $0,0,000$ & 0,00 & $0 \%$ & 0,010 & 0,000 & 0,000 & 0,020 & 0,008 & 0,01 & $128 \%$ & 0,1 & - & 0,003 \\
\hline Cobre (mg/L) & 0,060 & 0,000 & 0,880 & 0,000 & \begin{tabular}{|l|}
0,235 \\
\end{tabular} & 0,43 & $183 \%$ & 0,050 & 0,000 & 0,550 & 0,000 & 0,150 & 0,27 & $178 \%$ & 0,009 & 1,000 & 0,005 \\
\hline Cromo Total (mg/L) & 0,000 & 0,000 & 0,300 & 0,000 & 0,075 & 0,15 & $200 \%$ & 0,020 & 0,000 & 0,000 & 0,000 & 0,005 & 0,01 & $200 \%$ & 0,05 & 0,050 & 0,005 \\
\hline Cromo Hexavalente (mg/L) & 0,000 & 0,000 & 0,000 & 0,000 & $\mid 0,000$ & 0,00 & $0 \%$ & 0,000 & 0,000 & 0,000 & 0,000 & 0,000 & 0,00 & $0 \%$ & 0,05 & - & 0,001 \\
\hline Aluminio (mg/L) & 0,00 & 0,01 & 0,02 & 0,001 & 0,01 & 0,01 & $120 \%$ & 0,00 & 0,02 & 0,04 & 0,02 & 0,02 & 0,02 & $82 \%$ & 0,1 & - & 0,01 \\
\hline ECOTOXICOLÓGICOS & NT & 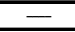 & $\mathrm{TC}$ & & & & & NT & & TC & 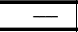 & & & & & & \\
\hline & 55,20 & 70,70 & 74,60 & \begin{tabular}{ll|}
83,66 \\
\end{tabular} & 71,04 & & & 77,55 & 78,37 & 87,32 & \begin{tabular}{ll|}
78,99 \\
\end{tabular} & 80,56 & & & & & \\
\hline (CETESB, 2007) & Boa & Boa & Boa & Ótima & Boa & & & Boa & Boa & Ótima & Boa & Ótima & & & & & \\
\hline \multirow{2}{*}{\multicolumn{11}{|c|}{$\square$ Valores abaixo dos limites recomendados pelas legislaçōes vigentes }} & \multirow{3}{*}{\multicolumn{4}{|c|}{$\begin{array}{l}\text { NT: Nấo Toxico } \\
\text { TC: Toxicidadade Crôn }\end{array}$}} & \multirow{2}{*}{\multicolumn{2}{|c|}{ IQA }} & \\
\hline & & & & & & & & & & & & & & & & & \\
\hline \multirow{2}{*}{\multicolumn{11}{|c|}{$\begin{array}{l}\text { "Resoluçāo CONAMA } 357,17 \text { de março de 2005. Padrōes de Qualidade de Água } \\
\text { " Depreto } 8468,08 \text { de setembro de } 1976 \text { Governo do Estado de São Paulo. Prevencão e }\end{array}$}} & \multirow{5}{*}{\multicolumn{4}{|c|}{$\begin{array}{l}\text { VM: Valor Máximo } \\
\text { LM: Limite Máximo }\end{array}$}} & Ótima & 80 a 100 & \\
\hline & & & & & enção e o & o Controle & (a) & do Meio & & & & & & & Boa & 52 a 79 & \\
\hline \multirow{3}{*}{\multicolumn{11}{|c|}{ 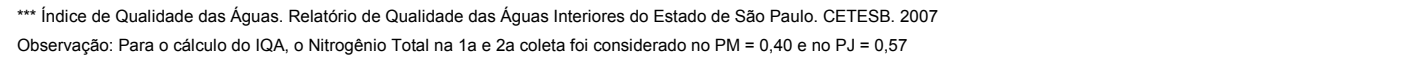 }} & & & & & Regular & 37 a 51 & \\
\hline & & & & & & & & & & & & & & & Ruim & 20 a 36 & \\
\hline & & & & & & & & & & & & & & & Péssima & o a 19 & \\
\hline
\end{tabular}




\section{E.2 Córrego da Gabiroba, Bauru}

\begin{tabular}{|c|c|c|c|c|c|c|c|c|c|c|c|c|c|c|c|c|c|}
\hline \multirow{4}{*}{ PARÂMETROS } & \multicolumn{14}{|c|}{ CÓRREGO DA GABIROBA, BAURU } & \multirow{3}{*}{\multicolumn{2}{|c|}{$\begin{array}{l}\text { LEGISLAÇōES } \\
\text { Agua Classe } 2\end{array}$}} & \multirow{4}{*}{$\begin{array}{l}\text { Limite de } \\
\text { Deteç̧ão }\end{array}$} \\
\hline & \multicolumn{14}{|c|}{ PONTOS DE COLETA } & & & \\
\hline & \multicolumn{7}{|c|}{ Montante (PM) } & \multicolumn{7}{|c|}{ Jusante (PJ) } & & & \\
\hline & $\begin{array}{c}13 / 04 / 04 \\
13: 15\end{array}$ & \begin{tabular}{c|c}
$02 / 09 / 04$ \\
$10: 15$
\end{tabular} & \begin{tabular}{c|c}
$23 / 11 / 04$ \\
$12: 05$
\end{tabular} & $\begin{array}{c}21 / 03 / 05 \\
12: 47\end{array}$ & Média & \begin{tabular}{l|l} 
Desvio \\
Padrão
\end{tabular} & \begin{tabular}{c|c} 
Coeficiente \\
de Varią̧ăo
\end{tabular} & $\begin{array}{c}13 / 04 / 04 \\
14: 00\end{array}$ & $\begin{array}{c}02 / 09 / 04 \\
10: 30\end{array}$ & $\begin{array}{c}23 / 11 / 04 \\
12: 20\end{array}$ & $\begin{array}{c}21 / 03 / 05 \\
12: 40\end{array}$ & Média & $\begin{array}{l}\text { Desvio } \\
\text { Padrão }\end{array}$ & $\begin{array}{l}\text { Coeficiente } \\
\text { de Variação }\end{array}$ & $\begin{array}{l}\text { CONAMA } 357 / 2005^{*} \\
\text { VM }\end{array}$ & \begin{tabular}{|c|} 
Decreto $8468 / 1976^{* \star *}$ \\
LM
\end{tabular} & \\
\hline $\mathrm{pHH}$ & 7,22 & 6,65 & 6,70 & 7,97 & 7,14 & 0,61 & $9 \%$ & 7,10 & 6,44 & 6,79 & 6,26 & 6,65 & 0,37 & $6 \%$ & $6,0-9,0$ & - & 0,00 \\
\hline Cor Aparente (uC) & 950 & 136 & 150 & 882 & 530 & 447 & $84 \%$ & 247 & 228 & 210 & 1566 & 563 & 669 & $119 \%$ & 75 & - & 1 \\
\hline Turbidez (uT) & 186,00 & 23,40 & 15,90 & 81,20 & 76,63 & 78,54 & $102 \%$ & 42,00 & 37,00 & 30,40 & 172,00 & 70,35 & 67,93 & $97 \%$ & 100 & - & 0,01 \\
\hline Condutividade Elétrica ( $(\mathrm{S} / \mathrm{cm})$ & 1250 & 151 & 151 & 2700 & 1063 & 1046 & $98 \%$ & 188 & 140 & 490 & 1970 & 697 & 863 & $124 \%$ & - & - & 0 \\
\hline Temperatura $\left({ }^{\circ} \mathrm{C}\right)$ & 25,6 & 23,6 & 29,7 & 25,5 & 26,1 & 2,6 & $10 \%$ & 26,8 & 23,6 & 29,2 & 25,8 & 26,4 & 2,3 & $9 \%$ & - & - & 0,0 \\
\hline Salinidade $(\%)$ & 5 & 0 & 0 & 13 & 5 & 6 & $136 \%$ & 0 & 0 & 2 & 9 & 3 & 4 & $155 \%$ & - & - & 0 \\
\hline Oxigênio Dissolvido (mg/L) & 5,10 & 4,52 & 5,08 & 4,85 & 4,89 & 0,27 & $6 \%$ & 4,61 & 5,60 & 4,15 & 1,90 & 4,07 & 1,57 & $38 \%$ & $>5$ & $>5$ & 0,00 \\
\hline Cloreto (mg Cl/L) & 162,5 & 27,5 & 103,0 & 335,0 & 157,0 & 130,9 & $83 \%$ & 11,7 & 8,1 & 9,0 & 115,0 & 36,0 & 52,7 & $147 \%$ & 250 & - & 0,1 \\
\hline Fósforo Total (mg P/L) & 0,5333 & 0,0400 & 0,0533 & 1,0666 & 0,4233 & 0,4864 & $115 \%$ & 0,0466 & 0,0433 & 0,0300 & 1,9333 & 0,5133 & 0,9467 & $184 \%$ & 0,050 & - & 0,0001 \\
\hline Fluoreto (mg F/L) & 6,40 & 0,52 & 1,25 & 4,85 & 3,26 & 2,82 & $87 \%$ & 0,08 & 0,00 & 0,06 & 0,41 & 0,14 & 0,18 & $134 \%$ & 1,4 & - & 0,01 \\
\hline Coliformes Totais (UFC/100mL) & $4,00 E+08$ & $6,00 E+08$ & $8,00 E+05$ & $2,00 E+06$ & $2,51 E+08$ & $2,99 \mathrm{E}+08$ & $119 \%$ & $3,00 E+04$ & $5,00 E+04$ & $6,00 E+04$ & $6,50 \mathrm{E}+05$ & $1,98 \mathrm{E}+05$ & $3,02 E+05$ & $153 \%$ & - & 5000 & 1 \\
\hline Coliformes Termotolerantes (UFC/100mL) & 0 & 20 & 5 & $8,00 E+04$ & $2,00 \mathrm{E}+04$ & $4,00 E+04$ & $200 \%$ & 30 & 85 & 93 & 32000 & 8052 & 13826 & $172 \%$ & 1000 & 1000 & 1 \\
\hline so Demanda Quimica de Oxigênio $\left(\mathrm{mg} \mathrm{O}_{2} / \mathrm{L}\right)$ & 896 & 46 & 196 & 1092 & 558 & 514 & $92 \%$ & 39 & 53 & 23 & 2552 & 667 & 1257 & $189 \%$ & - & - & 1 \\
\hline 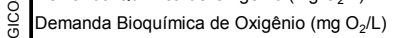 & 366 & 10 & 105 & 526 & 252 & 237 & $94 \%$ & 0 & 14 & 3 & 1498 & 379 & 746 & $197 \%$ & $<5$ & $<5$ & 1 \\
\hline 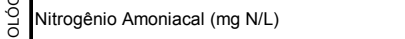 & 3,70 & 0,20 & 3,20 & 66,00 & 18,28 & 31,85 & $174 \%$ & 1,16 & 0,71 & 1,03 & 90,00 & 23,23 & 44,52 & $192 \%$ & 3,7 & 0,500 & 0,01 \\
\hline \begin{tabular}{l|l} 
产 Nitrogênio Nitrato (mg N/L) \\
\end{tabular} & 6,3400 & 0,0820 & 2,0531 & 25,4300 & 8,4763 & 11,6005 & $137 \%$ & 1,3500 & 0,0390 & 1,8313 & 15,6200 & 4,7101 & 7,31 & $155 \%$ & 10 & 10,000 & 0,0001 \\
\hline Nitrogênio Nitrito (mg N/L) & 0,3400 & 0,0230 & 0,0898 & 4,8600 & 1,3282 & 2,3585 & $178 \%$ & 0,0400 & 0,0270 & 0,0227 & 0,0230 & 0,0282 & 0,0081 & $29 \%$ & 1 & 1,000 & 0,0001 \\
\hline 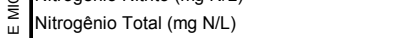 & - & - & 12,00 & 113,00 & 62,50 & 71,42 & $114 \%$ & - & - & 5,00 & 124,00 & 64,50 & 84,15 & $130 \%$ & 2,18 & - & 0,01 \\
\hline \begin{tabular}{l|l} 
: & Carbono Orgânico Total (mg C/L)
\end{tabular} & 247,90 & 2,734 & 52,25 & 337,10 & 159,996 & 158,570 & $99 \%$ & 7,527 & 2,743 & 3,678 & 666,6 & 170,137 & 330,982 & $195 \%$ & - & - & 0,001 \\
\hline Sulfato $\left(\mathrm{mg} \mathrm{SO}_{4}{ }^{2} / \mathrm{L}\right)$ & 75 & 0 & 12 & 42 & 32 & 34 & $104 \%$ & 0 & 0 & 0 & 0 & 0 & 0 & $0 \%$ & 250 & - & 1 \\
\hline Sulfeto ( $\mathrm{mg} \mathrm{s}^{2} / \mathrm{L}$ ) & 0,000 & 0,000 & 0,000 & 0,000 & 0,000 & 0,000 & $0 \%$ & 0,000 & 0,000 & 0,000 & 0,000 & 0,000 & 0,000 & $0 \%$ & 0,002 & - & 0,001 \\
\hline 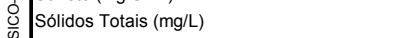 & 1947,00 & 152,00 & 304,00 & 3489,00 & 1473 & 1570,62 & $107 \%$ & 306,00 & 171,00 & 111,00 & 2835,00 & 855,75 & 1322,02 & $154 \%$ & - & - & 0,0001 \\
\hline Sólidos Totais Fixos (mg/L) & 699,00 & 91,00 & 155,00 & 1859,00 & 701 & 818,78 & $117 \%$ & 119,00 & 96,00 & 53,00 & 1069,00 & 334,25 & 490,60 & $147 \%$ & - & - & 0,0001 \\
\hline Sólidos Totais Voláteis (mg/L) & 1278,00 & 61,00 & 149,00 & 1630,00 & 779,5 & 792,81 & $102 \%$ & 187,00 & 75,00 & 58,00 & 1766,00 & 521,50 & 831,64 & $159 \%$ & - & - & 0,0001 \\
\hline Sólidos Totais Dissolvidos (mg/L) & 1787,00 & 134,00 & 263,00 & 3327,00 & 1377,75 & 1500,74 & $109 \%$ & 248,00 & 145,00 & 69,00 & 2689,00 & 787,75 & 1269,62 & $161 \%$ & 500 & - & 0,0001 \\
\hline Zinco (mg/L) & 0,770 & 1,170 & 0,980 & 2,930 & 1,463 & 0,99 & $68 \%$ & 0,210 & 1,150 & 0,590 & 0,290 & 0,560 & 0,43 & $76 \%$ & 0,18 & 5,000 & 0,002 \\
\hline Chumbo (mg/L) & 0,00 & 0,00 & 0,00 & 0,00 & 0,00 & 0,00 & $0 \%$ & 0,00 & 0,00 & 0,00 & 0,00 & 0,00 & 0,00 & $0 \%$ & 0,01 & 0,100 & 0,02 \\
\hline Cádmio (mg/L) & 0,0000 & 0,0000 & 0,0000 & 0,0000 & 0,0000 & 0,00 & $0 \%$ & 0,0000 & 0,0000 & 0,0000 & 0,0000 & 0,0000 & 0,00 & $0 \%$ & 0,001 & 0,010 & 0,0006 \\
\hline Niquel (mg/L) & 0,000 & 0,000 & 0,000 & 0,000 & 0,000 & 0,00 & $0 \%$ & 0,000 & 0,000 & 0,000 & 0,000 & 0,000 & 0,00 & $0 \%$ & 0,025 & - & 0,008 \\
\hline Ferro Solúvel (mg/L) & 0,500 & 0,270 & 1,480 & 1,840 & 1,023 & 0,76 & $74 \%$ & 0,380 & 0,310 & 1,660 & 24,700 & 6,763 & 11,97 & $177 \%$ & 0,3 & - & 0,005 \\
\hline Manganês Solúvel (mg/L) & 0,300 & 0,020 & 0,260 & 0,600 & 0,295 & 0,24 & $81 \%$ & 0,140 & 0,030 & 0,160 & 1,790 & 0,530 & 0,84 & $159 \%$ & 0,1 & - & 0,003 \\
\hline Cobre (mg/L) & 0,040 & 1,930 & 0,700 & 0,610 & 0,820 & 0,80 & $97 \%$ & 0,000 & 1,510 & 0,320 & 0,040 & 0,468 & 0,71 & $152 \%$ & 0,009 & 1,000 & 0,005 \\
\hline Cromo Total (mg/L) & 0,000 & 0,040 & 0,000 & 0,170 & 0,053 & 0,08 & $153 \%$ & 0,000 & 0,020 & 0,000 & 0,000 & 0,005 & 0,01 & $200 \%$ & 0,05 & 0,050 & 0,005 \\
\hline Cromo Hexavalente (mg/L) & 0,000 & 0,000 & 0,000 & 0,000 & 0,000 & 0,00 & $0 \%$ & 0,000 & 0,000 & 0,000 & 0,000 & 0,000 & 0,00 & $0 \%$ & 0,05 & - & 0,001 \\
\hline Alumínio (mg/L) & 0,00 & 0,01 & 0,02 & 0,11 & 0,04 & 0,05 & $145 \%$ & 0,00 & 0,01 & 0,02 & 0,06 & 0,02 & 0,03 & $117 \%$ & 0,1 & - & 0,01 \\
\hline ECOTOXICOLOGICOS & TA & NT & TC & $=$ & & & & NT & NT & NT & $=$ & & & & & & \\
\hline & 26,63 & 42,15 & 35,52 & 15,47 & 29,94 & & & 46,32 & 42,47 & 70,54 & 11,72 & 42,76 & & & & & \\
\hline (CETESB, 2007) & Ruim & Regular & Ruim & Péssima & Ruim & & & Regular & Regular & Boa & Péssima & Regular & & & & & \\
\hline \multicolumn{11}{|c|}{$\square$ Valores abaixo dos limites recomendados pelas legislaçōes vigentes } & & \multirow{2}{*}{\multicolumn{2}{|c|}{ IQA }} & \\
\hline \multirow{2}{*}{\multicolumn{11}{|c|}{$\begin{array}{l}\square \text { Valores acima dos limites recomendados pelas legislaçōes vigentes } \\
\text { * Resoluçäo CONAMA } 357,17 \text { de março de 2005. Padröes de Qualidade de Água }\end{array}$}} & \multirow{2}{*}{\multicolumn{4}{|c|}{ 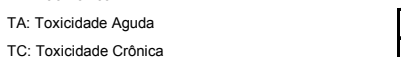 }} & & & \\
\hline \multirow{3}{*}{\multicolumn{15}{|c|}{$\begin{array}{l}\text { * " ecreto 8468, } 08 \text { de setembro de 1976, Governo do Estado de São Paulo. Prevenção e o Controle da Poluição do Meio Ambiente } \\
* * \text { Indice de Qualidade das Aguas. Relatório de Qualidade das Aguas Interiores do Estado de Săo Paulo. CETESB. } 2007\end{array}$}} & Ótima & 80 a 100 & \\
\hline & & & & & & & & & & & & & & & Boa & 52 a 79 & \\
\hline & & & & & & & & & & & & & & & Regular & 37 a 51 & \\
\hline \multirow{2}{*}{\multicolumn{15}{|c|}{ Observaçăo: Para o cálculo do IQA, o Nitrogênio Total na 1a e 2a coleta foi considerado no PM $=113,0$ e no PJ $=124,0$}} & Ruim & 20 a 36 & \\
\hline & & & & & & & & & & & & & & & Péssima & 0 a 19 & \\
\hline
\end{tabular}




\section{E.3 Córrego da Cachoeira Grande, Brotas}

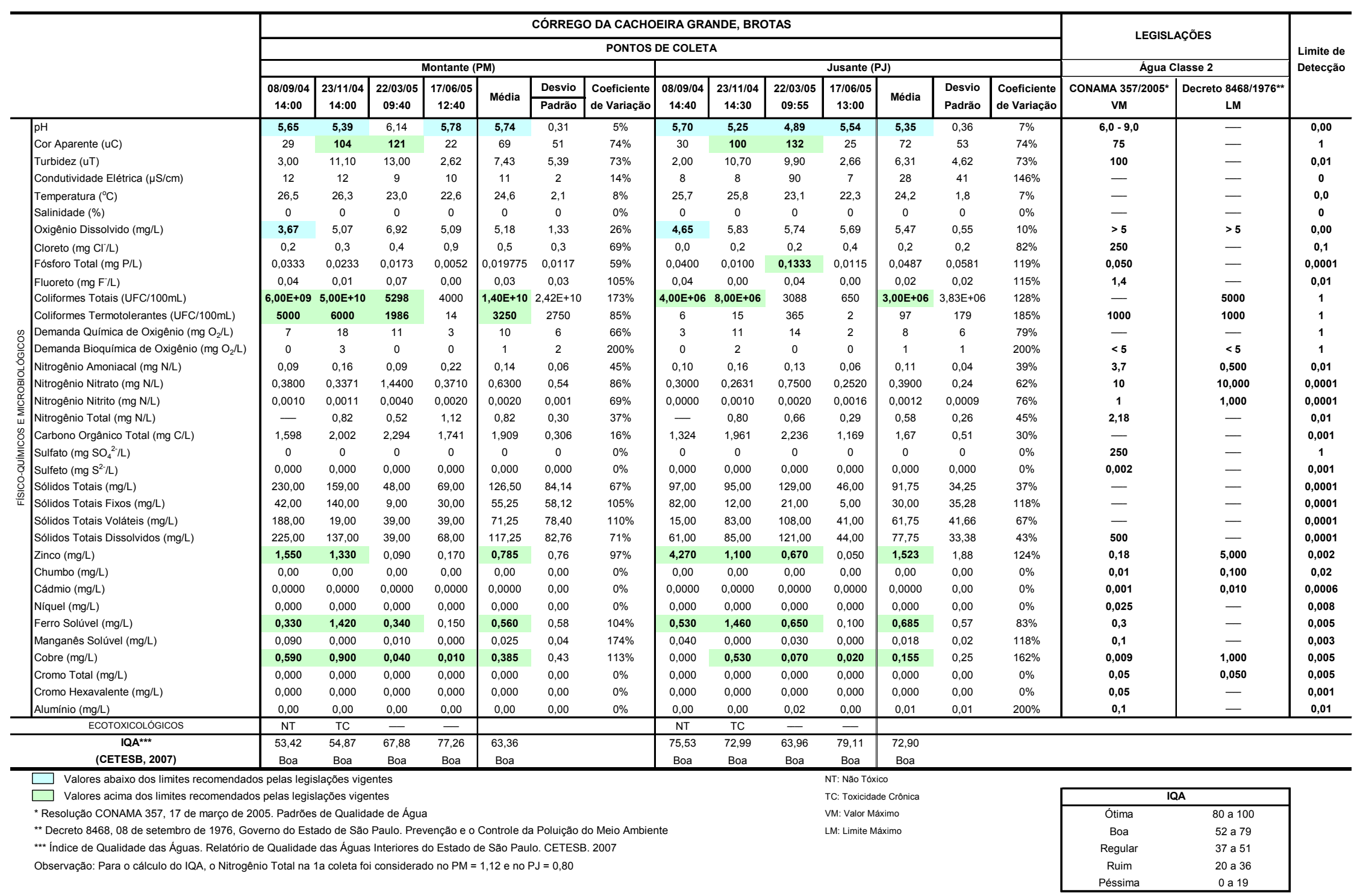




\section{E.4 Ribeirão do Matão, Jaú}

\begin{tabular}{|c|c|c|c|c|c|c|c|c|c|c|c|c|c|c|c|c|c|}
\hline \multirow{4}{*}{ PARÂMETROS } & \multicolumn{14}{|c|}{ RIBEIRÃO DO MATÃO, JAÚ } & \multirow{2}{*}{\multicolumn{2}{|c|}{ LEGISLAÇŌES }} & \multirow{4}{*}{$\begin{array}{l}\text { Limite de } \\
\text { Deteç̧ăo }\end{array}$} \\
\hline & \multicolumn{14}{|c|}{ PONTOS DE COLETA } & & & \\
\hline & \multicolumn{7}{|c|}{ Montante (PM) } & \multicolumn{7}{|c|}{ Jusante (PJ) } & \multicolumn{2}{|c|}{ Agua Classe 2} & \\
\hline & 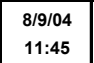 & \begin{tabular}{|c|}
$24 / 11 / 04$ \\
$12: 00$
\end{tabular} & \begin{tabular}{c|c|c|c|c|}
$22 / 3105$ \\
$12: 00$
\end{tabular} & $\begin{array}{ll}18 / 8 / 05 \\
14: 20\end{array}$ & Média & \begin{tabular}{l|l} 
Desvio \\
Padrão
\end{tabular} & \begin{tabular}{|l|} 
Coeficiente \\
de Variação
\end{tabular} & $\begin{array}{l}8 / 9 / 04 \\
12: 10\end{array}$ & \begin{tabular}{c|c|c|}
$24 / 11 / 04$ \\
$12: 35$
\end{tabular} & $\begin{array}{c}22 / 3 / 05 \\
12: 35\end{array}$ & 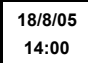 & Média & $\begin{array}{l}\text { Desvio } \\
\text { Padrão }\end{array}$ & \begin{tabular}{l|} 
Coeficiente \\
de Variação
\end{tabular} & $\begin{array}{l}\text { CONAMA } 357 / 2005^{*} \\
\text { VM }\end{array}$ & \begin{tabular}{|c|} 
Decreto $8468 / 1976^{\star *}$ \\
LM
\end{tabular} & \\
\hline $\mathrm{pH}$ & 6,86 & 6,79 & 6,80 & 6,80 & 6,81 & 0,03 & $0 \%$ & 6,86 & 6,69 & 6,91 & 7,62 & 7,02 & 0,41 & $6 \%$ & $6,0-9,0$ & - & 0,00 \\
\hline Cor Aparente (uC) & 37 & 21 & 342 & 105 & 126 & 148 & $118 \%$ & 91 & 251 & 70 & 13 & 106 & 102 & $96 \%$ & 75 & - & 1 \\
\hline Turbidez (uT) & 3,83 & 2,74 & 44,00 & 15,30 & 16,47 & 19,21 & $117 \%$ & 23,50 & 27,40 & 6,06 & 1,32 & 14,57 & 12,81 & $88 \%$ & 100 & - & 0,01 \\
\hline Condutividade Elétrica ( $\mathrm{\mu S} / \mathrm{cm})$ & 42 & 48 & 43 & 185 & 80 & 70 & $89 \%$ & 127 & 122 & 147 & 72 & 117 & 32 & $27 \%$ & - & - & 0 \\
\hline Temperatura $\left({ }^{\circ} \mathrm{C}\right)$ & 20,8 & 22,9 & 22,9 & 21,8 & 22,1 & 1,0 & $5 \%$ & 21,8 & 23,8 & 23,9 & 19,6 & 22,3 & 2,0 & $9 \%$ & - & - & 0,0 \\
\hline Salinidade (\%) & 0 & 0 & 0 & 0 & 0 & 0 & $0 \%$ & 0 & 0 & 0 & 0 & 0 & 0 & $0 \%$ & - & - & 0 \\
\hline Oxigênio Dissolvido (mg/L) & 5,69 & 5,18 & 5,14 & 4,82 & 5,21 & 0,36 & $7 \%$ & 3,58 & 4,07 & 5,48 & 6,16 & 4,82 & 1,20 & $25 \%$ & $>5$ & $>5$ & 0,00 \\
\hline Cloreto (mg Cl/L) & 0,8 & 1,1 & 20,0 & 21,9 & 11,0 & 11,6 & $106 \%$ & 18,2 & 15,0 & 1,3 & 2,4 & 9,2 & 8,6 & $94 \%$ & 250 & - & 0,1 \\
\hline Fósforo Total (mg P/L) & 0,0300 & 0,0100 & 0,0500 & 0,0200 & 0,0275 & 0,02 & $62 \%$ & 0,0400 & 0,0066 & 0,0166 & 0,0066 & 0,0175 & 0,0158 & $90 \%$ & 0,050 & - & 0,0001 \\
\hline Fluoreto (mg F/L) & 0,18 & 0,06 & 0,06 & 0,05 & 0,09 & 0,06 & $71 \%$ & 0,10 & 0,08 & 0,11 & 0,05 & 0,085 & 0,026 & $31 \%$ & 1,4 & - & 0,01 \\
\hline Coliformes Totais (UFC/100mL) & $9,00 E+09$ & $7,00 E+07$ & 3200 & 2277 & $2,27 E+09$ & 4,49E+09 & $198 \%$ & $4,00 E+08$ & $6,00 E+09$ & 2778 & 3293 & $1,60 \mathrm{E}+09$ & $2,939 E+09$ & $184 \%$ & - & 5000 & 1 \\
\hline Coliformes Termotolerantes (UFC/100mL) & 16 & 21 & 285 & 26 & 87 & 132 & $152 \%$ & 12 & 25 & 23 & 299 & 90 & 140 & $156 \%$ & 1000 & 1000 & 1 \\
\hline D. Demanda Química de Oxigênio $\left(\mathrm{mg} \mathrm{O}_{2} / \mathrm{L}\right)$ & 2 & 28 & 9 & 7 & 12 & 11 & $99 \%$ & 12 & 32 & 8 & 4 & 14 & 12 & $88 \%$ & - & - & 1 \\
\hline 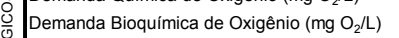 & 0 & 3 & 0 & 0 & 1 & 2 & $200 \%$ & 3 & 5 & 0 & 0 & 2 & 2 & $122 \%$ & $<5$ & $<5$ & 1 \\
\hline $\begin{array}{l}\text { Nitrogênio Amoniacal (mg N/L) } \\
\text { (m) }\end{array}$ & 0,06 & 0,06 & 0,51 & 0,24 & 0,22 & 0,21 & $98 \%$ & 0,41 & 0,16 & 0,04 & 0,13 & 0,19 & 0,16 & $86 \%$ & 3,7 & 0,500 & 0,01 \\
\hline 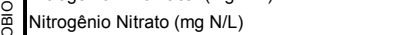 & 0,6300 & 0,5230 & 4,5700 & 0,3300 & 1,5133 & 2,04 & $135 \%$ & 1,0300 & 0,1713 & 0,8100 & 0,4200 & 0,6078 & 0,3851 & $63 \%$ & 10 & 10,000 & 0,0001 \\
\hline 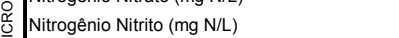 & 0,0030 & 0,0000 & 0,0230 & 0,0040 & 0,0075 & 0,0105 & $140 \%$ & 0,0070 & 0,0000 & 0,0020 & 0,0019 & 0,0027 & 0,0030 & $110 \%$ & 1 & 1,000 & 0,0001 \\
\hline \begin{tabular}{l|l}
$\bar{\Sigma}$ & Nitrogênio Total (mg N/L)
\end{tabular} & - & 0,32 & 2,60 & 1,31 & 1,41 & 1,14 & $81 \%$ & - & 0,76 & 0,25 & 0,66 & 0,56 & 0,27 & $49 \%$ & 2,18 & - & 0,01 \\
\hline $\begin{array}{l}\text { o. Carbono Orgânico Total (mg C/L) } \\
0\end{array}$ & 1,112 & 1,44 & 1,425 & 1,255 & 1,308 & 0,155 & $12 \%$ & 1,708 & 1,436 & 1,673 & 1,046 & 1,466 & 0,305 & $21 \%$ & - & - & 0,001 \\
\hline $\begin{array}{l}\frac{U}{\Sigma} \\
\underline{e}\end{array}$ & 0 & 0 & 2 & 1 & 1 & 1 & $128 \%$ & 0 & 0 & 1 & 0 & 0 & 1 & $200 \%$ & 250 & - & 1 \\
\hline 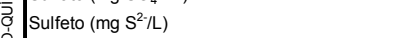 & 0,000 & 0,000 & 0,000 & 0,000 & 0,000 & 0,000 & $0 \%$ & 0,000 & 0,000 & 0,000 & 0,000 & 0,000 & 0,000 & $0 \%$ & 0,002 & - & 0,001 \\
\hline Sollidos Totais (mg/L) & 75,00 & 68,00 & 291,00 & 147,00 & 145,25 & 103,52 & $71 \%$ & 120,00 & 110,00 & 85,00 & 62,00 & 94,25 & 26,06 & $28 \%$ & - & - & 0,0001 \\
\hline \begin{tabular}{l|l}
$\frac{T}{L}$ & Solidos Totais Fixos (mg/L)
\end{tabular} & 56,00 & 46,00 & 133,00 & 46,00 & 70,25 & 42,10 & $60 \%$ & 78,00 & 58,00 & 14,00 & 35,00 & 46,25 & 27,77 & $60 \%$ & - & - & 0,0001 \\
\hline Sólidos Totais Voláteis (mg/L) & 19,00 & 22,00 & 158,00 & 101,00 & 75,00 & 67,11 & $89 \%$ & 42,00 & 52,00 & 71,00 & 27,00 & 48,00 & 18,46 & $38 \%$ & - & - & 0,0001 \\
\hline Sólidos Totais Dissolvidos (mg/L) & 66,00 & 55,00 & 257,00 & 141,00 & 129,75 & 93,04 & $72 \%$ & 104,00 & 93,00 & 77,00 & 50,00 & 81,00 & 23,45 & $29 \%$ & 500 & - & 0,0001 \\
\hline Zinco (mg/L) & 0,090 & 0,620 & 0,100 & 0,080 & 0,223 & 0,27 & $119 \%$ & 1,150 & 1,000 & 0,280 & 0,130 & 0,640 & 0,51 & $80 \%$ & 0,18 & 5,000 & 0,002 \\
\hline Chumbo (mg/L) & 0,00 & 0,00 & 0,00 & 0,00 & 0,00 & 0,00 & $0 \%$ & 0,00 & 0,00 & 0,00 & 0,00 & 0,00 & 0,00 & $0 \%$ & 0,01 & 0,100 & 0,02 \\
\hline Cádmio (mg/L) & 0,0000 & 0,0000 & 0,0000 & 0,0000 & 0,0000 & 0,00 & $0 \%$ & 0,0000 & 0,0000 & 0,0000 & 0,0000 & 0,0000 & 0,00 & $0 \%$ & 0,001 & 0,010 & 0,0006 \\
\hline Niquel (mg/L) & 0,000 & 0,000 & 0,000 & 0,000 & 0,000 & 0,00 & $0 \%$ & 0,000 & 0,000 & 0,000 & 0,000 & 0,000 & 0,00 & $0 \%$ & 0,025 & - & 0,008 \\
\hline Ferro Solúvel (mglL) & 0,160 & 0,390 & 0,460 & 1,800 & 0,703 & 0,74 & $106 \%$ & 0,010 & 2,460 & 0,310 & 0,430 & 0,803 & 1,12 & $139 \%$ & 0,3 & - & 0,005 \\
\hline Manganês Solúvel (mg/L) & 0,030 & 0,000 & 0,920 & 0,280 & 0,308 & 0,43 & $139 \%$ & 0,380 & 0,380 & 0,040 & 0,070 & 0,218 & 0,19 & $86 \%$ & 0,1 & - & 0,003 \\
\hline Cobre (mg/L) & 0,000 & 0,490 & 0,020 & 0,000 & 0,128 & 0,24 & $190 \%$ & 0,200 & 0,430 & 0,120 & 0,000 & 0,188 & 0,18 & $97 \%$ & 0,009 & 1,000 & 0,005 \\
\hline Cromo Total $(\mathrm{mg} / \mathrm{L})$ & 0,000 & 0,000 & 0,000 & 0,000 & 0,000 & 0,00 & $0 \%$ & 0,050 & 0,000 & 0,000 & 0,000 & 0,013 & 0,03 & $200 \%$ & 0,05 & 0,050 & 0,005 \\
\hline Cromo Hexavalente (mg/L) & 0,000 & 0,000 & 0,000 & 0,000 & 0,000 & 0,00 & $0 \%$ & 0,000 & 0,000 & 0,000 & 0,000 & 0,000 & 0,00 & $0 \%$ & 0,05 & - & 0,001 \\
\hline Alumínio (mg/L) & 0,00 & 0,01 & 0,00 & 0,01 & 0,01 & 0,01 & $115 \%$ & 0,00 & 0,01 & 0,01 & 0,00 & 0,01 & 0,01 & $115 \%$ & 0,1 & - & 0,01 \\
\hline ECOTOXICOLÓGICOS & NT & NT & - & - & & & & TA & $\mathrm{TC}$ & - & - & & & & & & \\
\hline & 83,48 & 80,06 & 68,2 & 48,09 & 69,96 & & & 69,29 & 67,67 & 83,81 & 78,19 & 74,74 & & & & & \\
\hline (CETESB, 2007) & Otima & Otima & Boa & Regular & Boa & & & Boa & Boa & Otima & Boa & Boa & & & & & \\
\hline \multicolumn{11}{|l|}{$\square$ Valores abaixo dos limites recomenda } & \multicolumn{4}{|c|}{ NT: Nầ Tóxico } & & & \\
\hline \multirow{2}{*}{\multicolumn{11}{|c|}{ 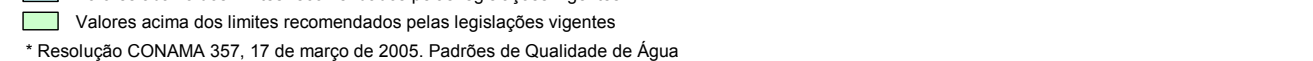 }} & \multirow{2}{*}{\multicolumn{4}{|c|}{ TA: Toxicidade Aguda }} & \multicolumn{2}{|c|}{ IQA } & \\
\hline & & & & & & & & & & & & & & & Ótima & 80 a 100 & \\
\hline \multirow{2}{*}{\multicolumn{15}{|c|}{$\begin{array}{l}\text { "* Decreto } 8468,08 \text { de setembro de 1976, Governo do Estado de São Paulo. Prevennção e o Controle da Poluição do Meio Ambiente } \\
* * * \text { Indice de Qualidade das Aguas. Relatório de Qualidade das Aguas Interiores do Estado de São Paulo. CETESB. } 2007\end{array}$}} & Boa & 52 a 79 & \\
\hline & & & & & & & & & & & LM: Limite N & & & & Regular & 37 a 51 & \\
\hline \multirow{2}{*}{\multicolumn{15}{|c|}{ 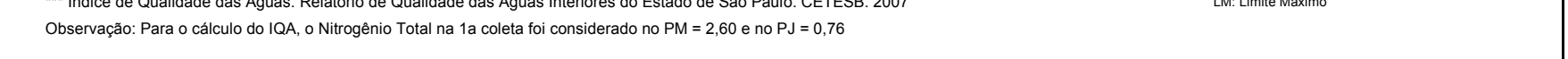 }} & Ruim & 20 a 36 & \\
\hline & & & & & & & & & & & & & & & Péssima & 0 a 19 & \\
\hline
\end{tabular}




\section{E.5 Córrego do Tamanduá, Ribeirão Bonito}

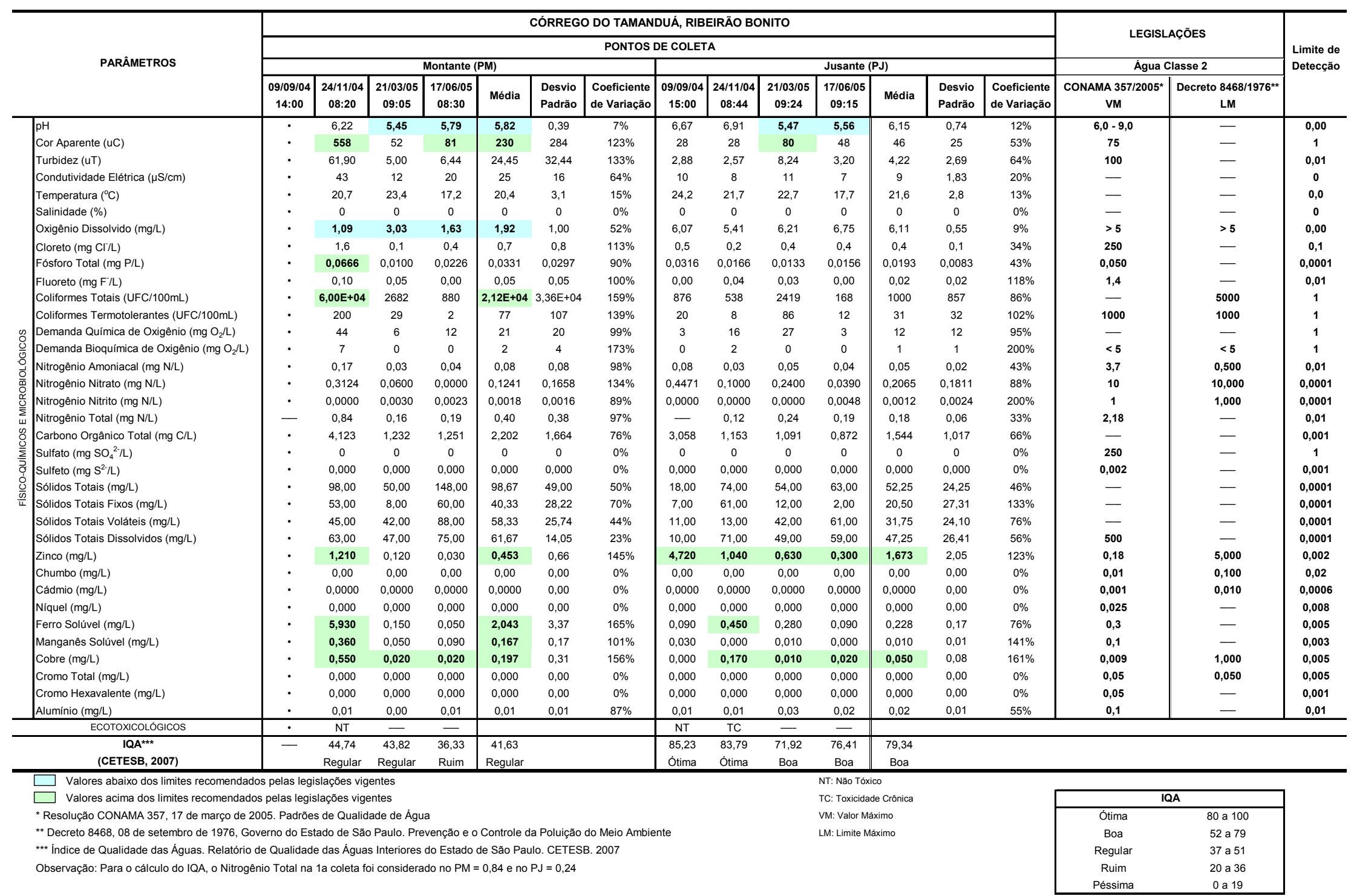




\section{E.6 Córrego do Galdino, São Carlos}

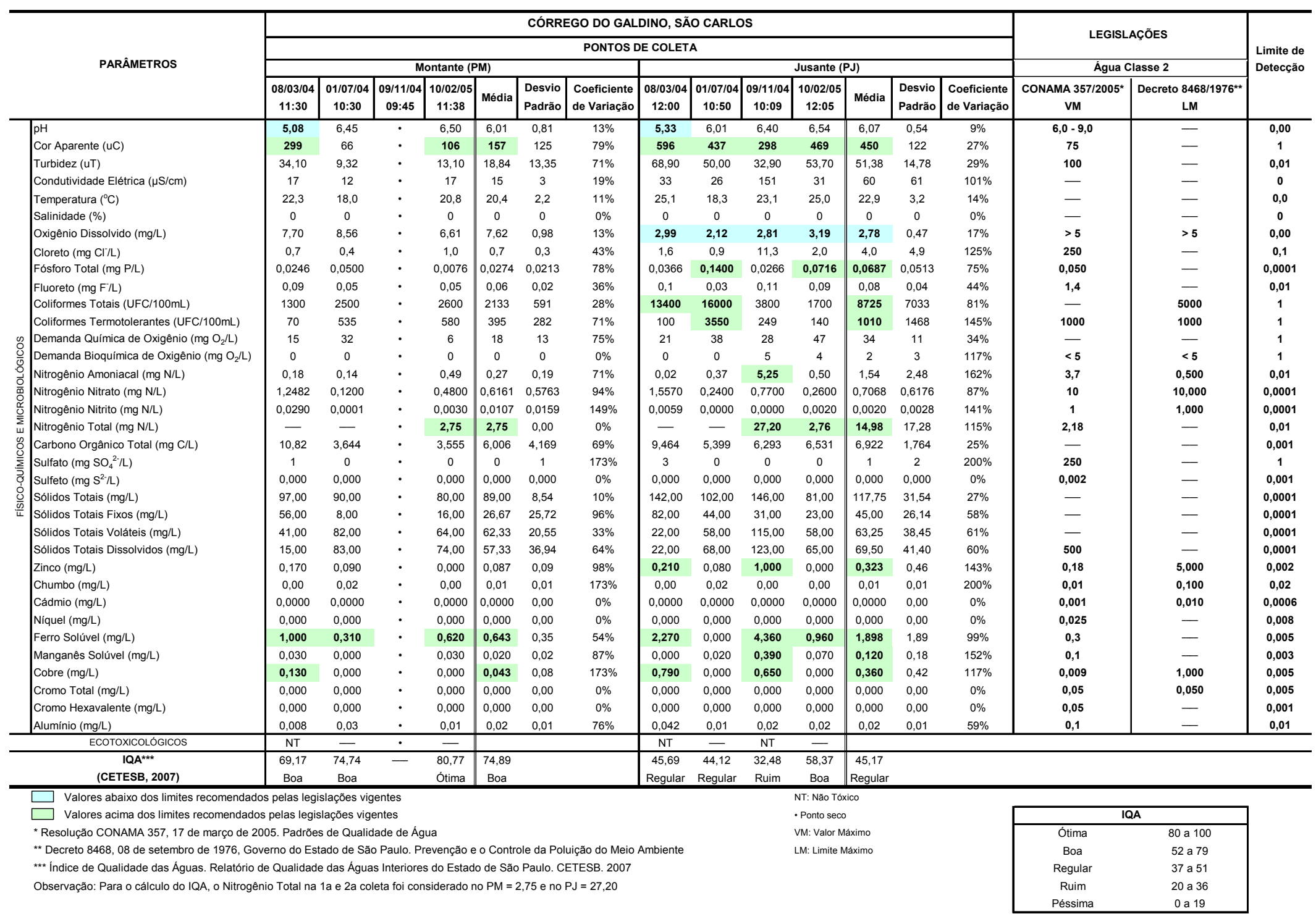




\section{E.7 Córrego São José, São Carlos}

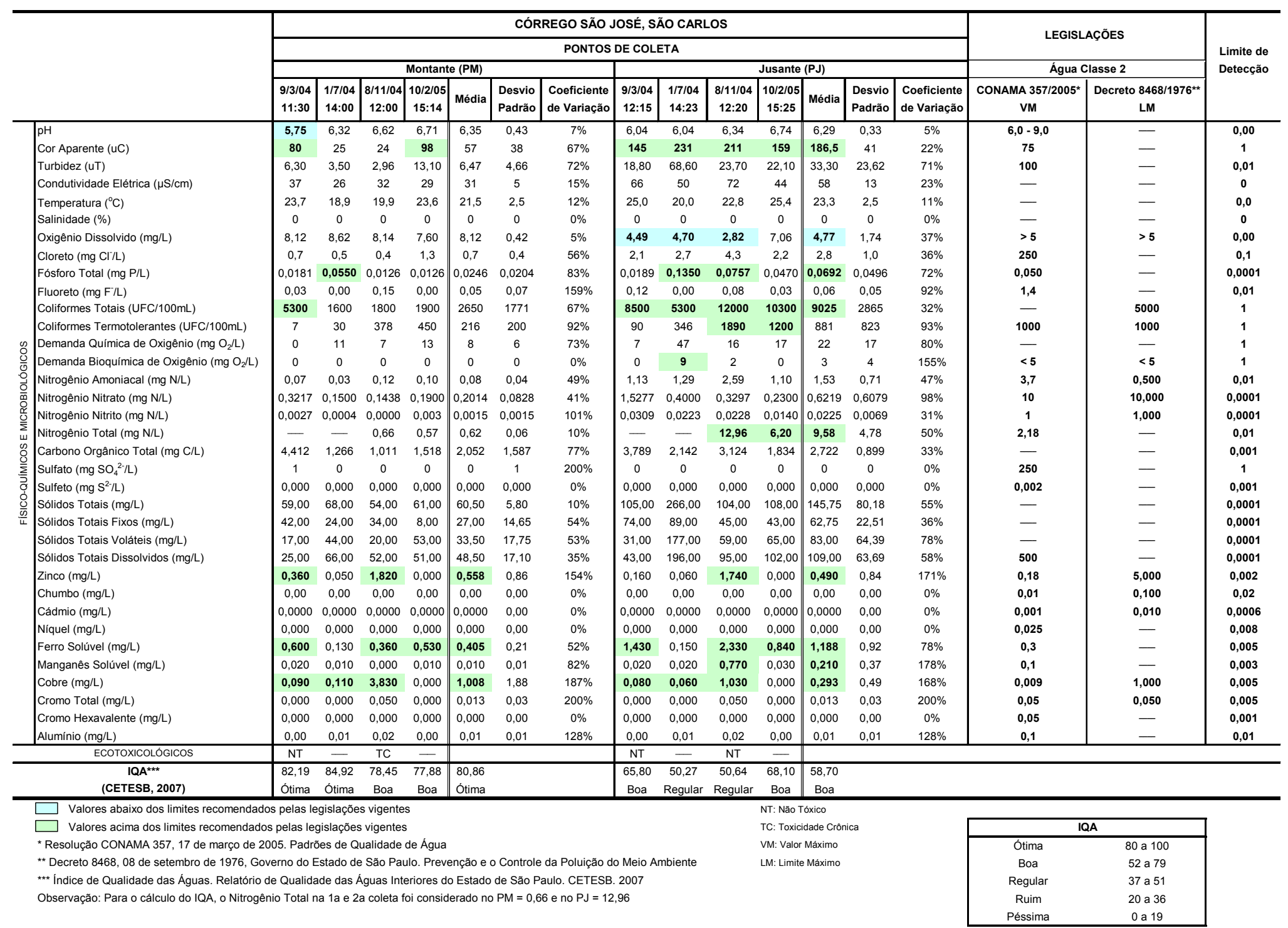


Apêndice F - Resultados dos ensaios ecotoxicológicos

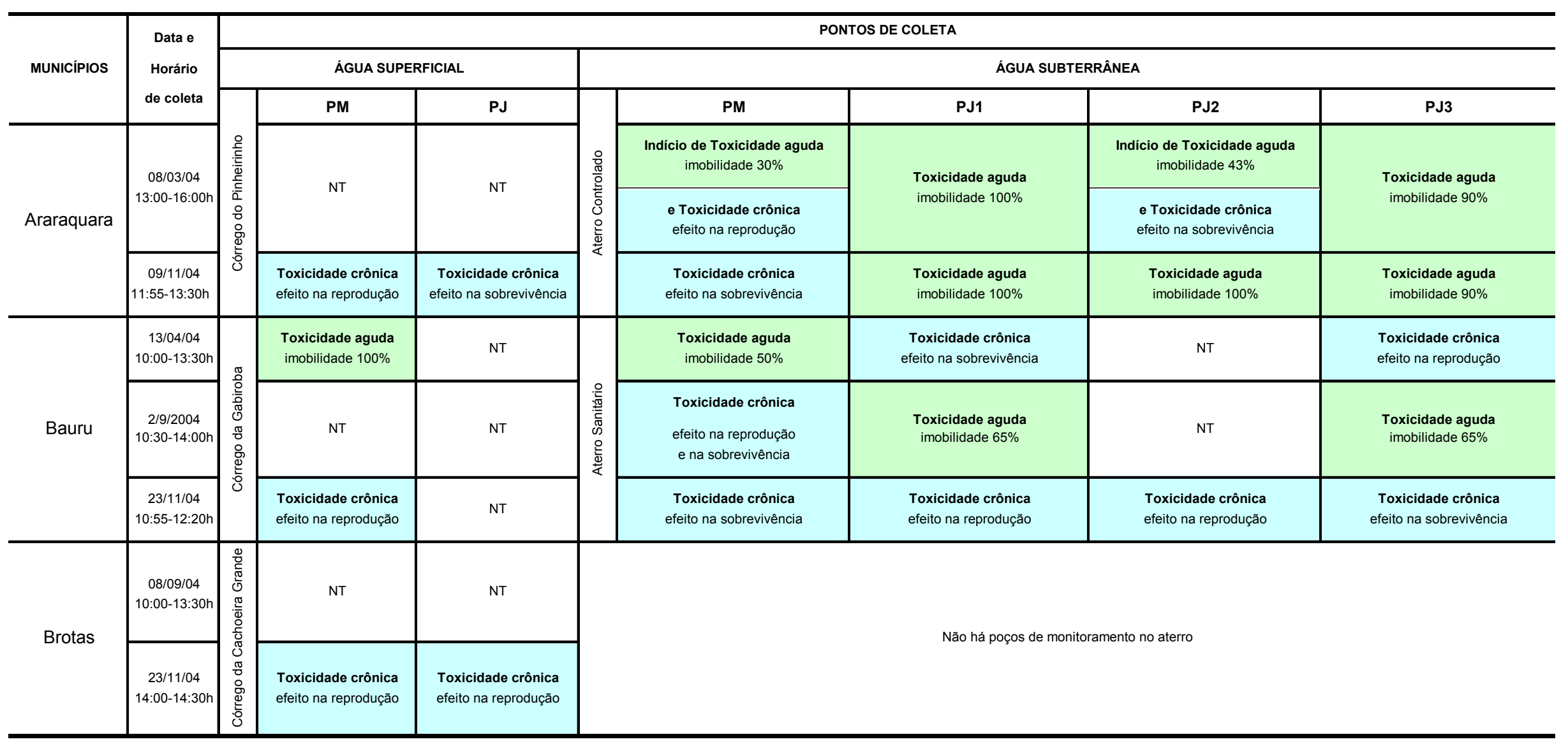

Toxicidade Crônica

$\square$ Toxicidade Aguda

NT: Não Tóxico

PM: Ponto a Montante

PJ: Ponto a Jusante 
Apêndice F - Resultados dos ensaios ecotoxicológicos (continuação)

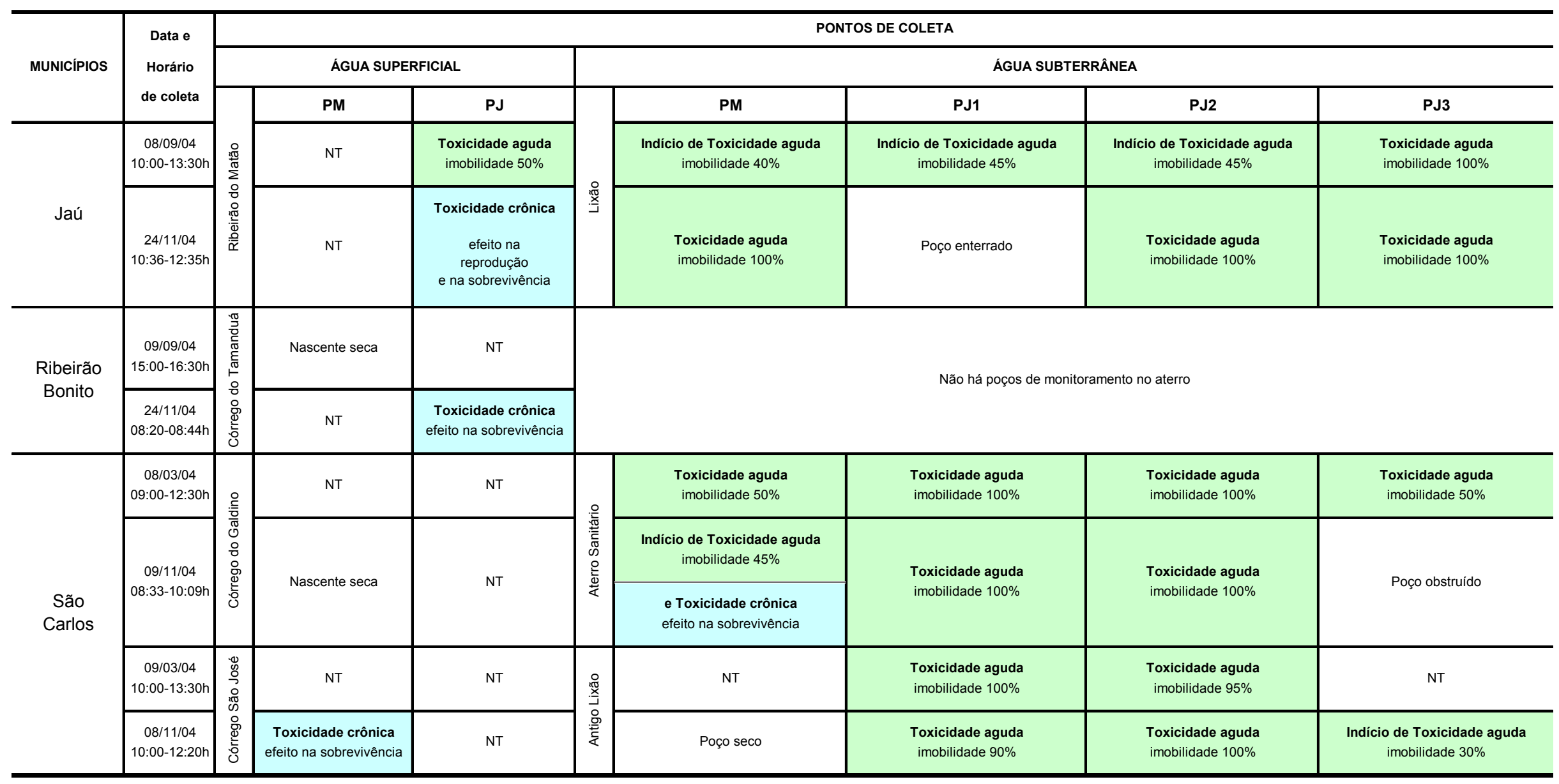

Toxicidade Crônica

$\square$ Toxicidade Aguda

NT: Não Tóxico

PM: Ponto a Montante

PJ: Ponto a Jusante 
Apêndice G - Resultados dos ensaios de extração e quantificação de substâncias orgânicas com amostras de água superficial G.1 Córrego do Pinheirinho, Araraquara

\begin{tabular}{|c|c|c|c|c|c|c|c|}
\hline & \multirow{4}{*}{$\begin{array}{l}\text { PARÂMETROS } \\
(\mu \mathrm{g} / \mathrm{L})\end{array}$} & \multicolumn{4}{|c|}{ CÓRREGO DO PINHEIRINHO, ARARAQUARA } & \multirow{3}{*}{ LEGISLAÇÃo } & \multirow{4}{*}{$\begin{array}{l}\text { Limite de } \\
\text { Deteç̧ão }\end{array}$} \\
\hline & & \multicolumn{4}{|c|}{ PONTOS DE COLETA } & & \\
\hline & & \multicolumn{2}{|c|}{ Montante (PM) } & \multicolumn{2}{|c|}{ Jusante (PJ) } & & \\
\hline & & $\begin{array}{l}\text { 9/11/04 } \\
13: 13\end{array}$ & $\begin{array}{c}11 / 2 / 05 \\
10: 29\end{array}$ & $\begin{array}{c}9 / 11 / 04 \\
13: 30\end{array}$ & $\begin{array}{c}11 / 2 / 05 \\
10: 45\end{array}$ & $\begin{array}{c}\text { CONAMA } 357 / 2005^{*} \\
\text { VM }\end{array}$ & \\
\hline \multirow{10}{*}{ 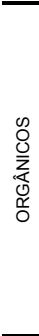 } & Benzeno & ND & ND & 0,05 & ND & 5 & 0,05 \\
\hline & Tolueno & ND & ND & 0,05 & ND & 2,0 & 0,05 \\
\hline & Etilbenzeno & ND & ND & 0,05 & ND & 90 & 0,05 \\
\hline & Xileno & ND & ND & 0,05 & ND & 300 & 0,05 \\
\hline & Benzo-a-pireno & 0,01 & ND & ND & 0,05 & 0,05 & 0,01 \\
\hline & 1,2 Dicloroetano & 1,871 & 2,021 & ND & ND & 10 & 0,05 \\
\hline & 1,1 Dicloroeteno & 0,05 & ND & ND & ND & 3 & 0,05 \\
\hline & Tricloroeteno & ND & ND & ND & ND & 30 & 0,05 \\
\hline & Tetracloreto de Carbono & ND & ND & ND & ND & 2 & 0,05 \\
\hline & Tetracloroeteno & $\mathrm{ND}$ & 0,076 & 0,076 & ND & 10 & 0,05 \\
\hline \multirow{14}{*}{$\begin{array}{l}0 \\
0 \\
0 \\
0 \\
0 \\
0 \\
0 \\
0 \\
0 \\
0 \\
0 \\
0\end{array}$} & Aldrin & 0,001 & 0,023 & $\mathrm{ND}$ & $\mathrm{ND}$ & 0,005 & 0,001 \\
\hline & Clordano & ND & ND & ND & ND & 0,04 & 0,001 \\
\hline & DDT & ND & ND & 0,001 & ND & 0,002 & 0,001 \\
\hline & Dieldrin & ND & ND & ND & 0,089 & 0,005 & 0,001 \\
\hline & Endossulfan & ND & ND & 0,001 & 0,067 & 0,056 & 0,001 \\
\hline & Metoxicloro & ND & ND & ND & 1,98 & 0,03 & 0,001 \\
\hline & Endrin & 0,001 & ND & ND & ND & 0,004 & 0,001 \\
\hline & Heptacloro & ND & ND & ND & ND & 0,01 & 0,001 \\
\hline & Heptacloro Epóxido & ND & ND & ND & ND & 0,01 & 0,001 \\
\hline & g-BHC (Lindano) & ND & ND & ND & ND & 0,02 & 0,001 \\
\hline & Toxafeno & ND & ND & ND & ND & 0,01 & 0,001 \\
\hline & Pentaclorofenol (PCP) & ND & ND & ND & ND & 0,009 & 0,005 \\
\hline & 2,4,6 Triclorofenol & ND & ND & ND & ND & 10 & 1 \\
\hline & PCBs totais & 0,0321 & ND & ND & ND & 0,001 & 0,001 \\
\hline \multirow{3}{*}{$\begin{array}{l}0 \\
0 \\
0 \\
0 \\
0 \\
0 \\
0 \\
0 \\
0 \\
0 \\
0 \\
0 \\
0 \\
0 \\
0\end{array}$} & Malation & 0,23 & 0,094 & ND & ND & 0,1 & 0,01 \\
\hline & Paration & 0,01 & ND & ND & ND & 0,04 & 0,01 \\
\hline & Gution & ND & ND & ND & ND & 0,005 & 0,001 \\
\hline
\end{tabular}

Valores acima dos limites recomendados pela legislação vigente

VM: Valor Máximo

ND: Não Detectado

* Resolução CONAMA 357, 17 de março de 2005. Padrões de Qualidade de Água 


\section{G.2 Córrego da Gabiroba, Bauru}

\begin{tabular}{|c|c|c|c|c|c|c|c|}
\hline & \multirow{4}{*}{$\begin{array}{c}\text { PARÂMETROS } \\
(\mu \mathrm{g} / \mathrm{L})\end{array}$} & \multicolumn{4}{|c|}{ CÓRREGO DA GABIROBA, BAURU } & \multirow{3}{*}{ LEGISLAÇÃO } & \multirow{4}{*}{$\begin{array}{l}\text { Limite de } \\
\text { Deteç̧ão }\end{array}$} \\
\hline & & \multicolumn{4}{|c|}{ PONTOS DE COLETA } & & \\
\hline & & \multicolumn{2}{|c|}{ Montante (PM) } & \multicolumn{2}{|c|}{ Jusante (PJ) } & & \\
\hline & & $\begin{array}{c}23 / 11 / 04 \\
12: 05\end{array}$ & $\begin{array}{c}21 / 03 / 05 \\
12: 47\end{array}$ & $\begin{array}{l}23 / 11 / 04 \\
12: 20\end{array}$ & $\begin{array}{l}21 / 03 / 05 \\
12: 40\end{array}$ & $\begin{array}{c}\text { CONAMA } 357 / 2005^{*} \\
\text { VM }\end{array}$ & \\
\hline \multirow{10}{*}{$\begin{array}{l}\text { on } \\
\text { U్ }\end{array}$} & Benzeno & ND & 0,719 & 0,05 & 0,609 & 5 & 0,05 \\
\hline & Tolueno & ND & 0,719 & ND & 0,609 & 2,0 & 0,05 \\
\hline & Etilbenzeno & ND & 0,719 & ND & 0,609 & 90 & 0,05 \\
\hline & Xileno & ND & 0,719 & ND & 0,609 & 300 & 0,05 \\
\hline & Benzo-a-pireno & ND & ND & ND & ND & 0,05 & 0,01 \\
\hline & 1,2 Dicloroetano & 0,05 & 2,021 & ND & 0,089 & 10 & 0,05 \\
\hline & 1,1 Dicloroeteno & ND & ND & ND & 1,301 & 3 & 0,05 \\
\hline & Tricloroeteno & 0,078 & ND & ND & ND & 30 & 0,05 \\
\hline & Tetracloreto de Carbono & ND & ND & ND & 2,871 & 2 & 0,05 \\
\hline & Tetracloroeteno & ND & 0,176 & ND & ND & 10 & 0,05 \\
\hline \multirow{14}{*}{ 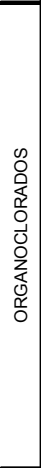 } & Aldrin & $\mathrm{ND}$ & $\mathrm{ND}$ & $\mathrm{ND}$ & 2,022 & 0,005 & $\overline{0,001}$ \\
\hline & Clordano & ND & ND & ND & ND & 0,04 & 0,001 \\
\hline & DDT & 0,001 & ND & 0,027 & ND & 0,002 & 0,001 \\
\hline & Dieldrin & ND & 0,019 & ND & 0,091 & 0,005 & 0,001 \\
\hline & Endossulfan & 0,001 & 0,06 & 0,012 & ND & 0,056 & 0,001 \\
\hline & Metoxicloro & 0,065 & 3,091 & ND & 0,039 & 0,03 & 0,001 \\
\hline & Endrin & ND & ND & ND & ND & 0,004 & 0,001 \\
\hline & Heptacloro & ND & 0,0031 & ND & ND & 0,01 & 0,001 \\
\hline & Heptacloro Epóxido & ND & ND & ND & ND & 0,01 & 0,001 \\
\hline & g-BHC (Lindano) & ND & 0,065 & ND & ND & 0,02 & 0,001 \\
\hline & Toxafeno & ND & ND & ND & 0,075 & 0,01 & 0,001 \\
\hline & Pentaclorofenol (PCP) & ND & ND & ND & 1,022 & 0,009 & 0,005 \\
\hline & 2,4,6 Triclorofenol & ND & ND & ND & 0,093 & 10 & 1 \\
\hline & PCBs totais & ND & ND & ND & 2,876 & 0,001 & 0,001 \\
\hline \multirow{3}{*}{ 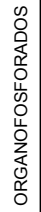 } & Malation & ND & 1,032 & ND & 0,19 & 0,1 & 0,01 \\
\hline & Paration & $\mathrm{ND}$ & 0,965 & $\mathrm{ND}$ & $\mathrm{ND}$ & 0,04 & 0,01 \\
\hline & Gution & ND & ND & $\mathrm{ND}$ & 1,62 & 0,005 & 0,001 \\
\hline
\end{tabular}

$\square$ Valores acima dos limites recomendados pela legislação vigente

VM: Valor Máximo

ND: Não Detectado

* Resolução CONAMA 357, 17 de março de 2005. Padrões de Qualidade de Água 


\section{G.3 Córrego da Cachoeira Grande, Brotas}

\begin{tabular}{|c|c|c|c|c|c|c|c|}
\hline & \multirow{4}{*}{$\begin{array}{c}\text { PARÂMETROS } \\
(\mu \mathrm{g} / \mathrm{L})\end{array}$} & \multicolumn{4}{|c|}{ CÓRREGO DA CACHOEIRA GRANDE, BROTAS } & \multirow{3}{*}{ LEGISLAÇÃo } & \multirow{4}{*}{$\begin{array}{l}\text { Limite de } \\
\text { Detecção }\end{array}$} \\
\hline & & \multicolumn{4}{|c|}{ PONTOS DE COLETA } & & \\
\hline & & \multicolumn{2}{|c|}{ Montante (PM) } & \multicolumn{2}{|c|}{ Jusante (PJ) } & & \\
\hline & & $\begin{array}{c}23 / 11 / 04 \\
14: 00\end{array}$ & $\begin{array}{c}22 / 03 / 05 \\
09: 40\end{array}$ & $\begin{array}{c}23 / 11 / 04 \\
14: 30\end{array}$ & $\begin{array}{c}22 / 03 / 05 \\
09: 55\end{array}$ & $\begin{array}{c}\text { CONAMA } 357 / 2005^{*} \\
\text { VM }\end{array}$ & \\
\hline \multirow{10}{*}{$\begin{array}{l}0 \\
0 \\
0 \\
0 \\
0 \\
0 \\
0\end{array}$} & Benzeno & ND & $\mathrm{ND}$ & 0,05 & 0,044 & 5 & 0,05 \\
\hline & Tolueno & ND & ND & ND & ND & 2,0 & 0,05 \\
\hline & Etilbenzeno & ND & ND & ND & ND & 90 & 0,05 \\
\hline & Xileno & ND & ND & ND & ND & 300 & 0,05 \\
\hline & Benzo-a-pireno & ND & ND & ND & ND & 0,05 & 0,01 \\
\hline & 1,2 Dicloroetano & ND & ND & ND & ND & 10 & 0,05 \\
\hline & 1,1 Dicloroeteno & ND & ND & ND & ND & 3 & 0,05 \\
\hline & Tricloroeteno & ND & ND & 0,05 & ND & 30 & 0,05 \\
\hline & Tetracloreto de Carbono & ND & ND & ND & ND & 2 & 0,05 \\
\hline & Tetracloroeteno & ND & ND & ND & ND & 10 & 0,05 \\
\hline \multirow{14}{*}{ 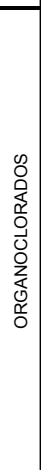 } & Aldrin & 0,098 & $\mathrm{ND}$ & $\mathrm{ND}$ & 0,022 & 0,005 & 0,001 \\
\hline & Clordano & ND & $\mathrm{ND}$ & $\mathrm{ND}$ & ND & 0,04 & 0,001 \\
\hline & DDT & ND & ND & $\mathrm{ND}$ & ND & 0,002 & 0,001 \\
\hline & Dieldrin & ND & 0,032 & ND & 0,019 & 0,005 & 0,001 \\
\hline & Endossulfan & 0,043 & ND & ND & ND & 0,056 & 0,001 \\
\hline & Metoxicloro & ND & ND & ND & ND & 0,03 & 0,001 \\
\hline & Endrin & ND & ND & ND & ND & 0,004 & 0,001 \\
\hline & Heptacloro & ND & 0,014 & ND & ND & 0,01 & 0,001 \\
\hline & Heptacloro Epóxido & ND & ND & ND & ND & 0,01 & 0,001 \\
\hline & g-BHC (Lindano) & ND & ND & ND & ND & 0,02 & 0,001 \\
\hline & Toxafeno & ND & ND & ND & ND & 0,01 & 0,001 \\
\hline & Pentaclorofenol (PCP) & ND & ND & ND & ND & 0,009 & 0,005 \\
\hline & 2,4,6 Triclorofenol & ND & ND & 0,021 & ND & 10 & 1 \\
\hline & PCBs totais & $\mathrm{ND}$ & $\mathrm{ND}$ & ND & ND & 0,001 & 0,001 \\
\hline \multirow{3}{*}{$\begin{array}{l} \\
0 \\
0 \\
0 \\
0 \\
0 \\
0 \\
0 \\
0 \\
0 \\
0 \\
0 \\
0 \\
0 \\
0 \\
0\end{array}$} & Malation & ND & ND & ND & ND & 0,1 & 0,01 \\
\hline & Paration & ND & $\mathrm{ND}$ & 0,01 & ND & 0,04 & 0,01 \\
\hline & Gution & ND & $\mathrm{ND}$ & $\mathrm{ND}$ & ND & 0,005 & 0,001 \\
\hline
\end{tabular}

$\square$ Valores acima dos limites recomendados pela legislação vigente

VM: Valor Máximo

ND: Não Detectado

* Resolução CONAMA 357, 17 de março de 2005. Padrões de Qualidade de Água 


\section{G.4 Ribeirão do Matão, Jaú}

\begin{tabular}{|c|c|c|c|c|c|c|c|}
\hline & \multirow{4}{*}{$\begin{array}{c}\text { PARÂMETROS } \\
(\mu \mathrm{g} / \mathrm{L})\end{array}$} & \multicolumn{4}{|c|}{ RIBEIRÃO DO MATÃO, JAÚ } & \multirow{3}{*}{ LEGISLAÇÃo } & \multirow{4}{*}{$\begin{array}{l}\text { Limite de } \\
\text { Detecção }\end{array}$} \\
\hline & & \multicolumn{4}{|c|}{ PONTOS DE COLETA } & & \\
\hline & & \multicolumn{2}{|c|}{ Montante (PM) } & \multicolumn{2}{|c|}{ Jusante (PJ) } & & \\
\hline & & $\begin{array}{c}24 / 11 / 04 \\
12: 00\end{array}$ & $\begin{array}{l}22 / 3 / 05 \\
12: 00\end{array}$ & $\begin{array}{c}24 / 11 / 04 \\
12: 35\end{array}$ & $\begin{array}{l}22 / 3 / 05 \\
12: 35\end{array}$ & $\begin{array}{c}\text { CONAMA } 357 / 2005^{*} \\
\text { VM }\end{array}$ & \\
\hline \multirow{10}{*}{$\begin{array}{l}\text { on } \\
0 \\
\text { ż } \\
0 \\
\text { of }\end{array}$} & Benzeno & ND & ND & ND & ND & 5 & 0,05 \\
\hline & Tolueno & ND & ND & ND & ND & 2,0 & 0,05 \\
\hline & Etilbenzeno & ND & ND & ND & ND & 90 & 0,05 \\
\hline & Xileno & ND & ND & ND & ND & 300 & 0,05 \\
\hline & Benzo-a-pireno & 0,054 & ND & ND & ND & 0,05 & 0,01 \\
\hline & 1,2 Dicloroetano & ND & ND & ND & ND & 10 & 0,05 \\
\hline & 1,1 Dicloroeteno & ND & ND & 0,067 & ND & 3 & 0,05 \\
\hline & Tricloroeteno & ND & ND & ND & ND & 30 & 0,05 \\
\hline & Tetracloreto de Carbono & ND & 3,221 & 1,67 & ND & 2 & 0,05 \\
\hline & Tetracloroeteno & ND & 0,765 & 0,05 & ND & 10 & 0,05 \\
\hline \multirow{14}{*}{ 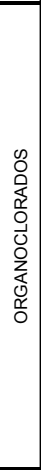 } & Aldrin & $\mathrm{ND}$ & 0,021 & $\mathrm{ND}$ & 0,044 & 0,005 & 0,001 \\
\hline & Clordano & ND & ND & ND & ND & 0,04 & 0,001 \\
\hline & DDT & 0,001 & ND & ND & ND & 0,002 & 0,001 \\
\hline & Dieldrin & ND & 0,0422 & ND & 0,033 & 0,005 & 0,001 \\
\hline & Endossulfan & ND & ND & ND & ND & 0,056 & 0,001 \\
\hline & Metoxicloro & ND & $\mathrm{ND}$ & ND & ND & 0,03 & 0,001 \\
\hline & Endrin & ND & ND & ND & ND & 0,004 & 0,001 \\
\hline & Heptacloro & 0,034 & ND & ND & ND & 0,01 & 0,001 \\
\hline & Heptacloro Epóxido & ND & ND & ND & ND & 0,01 & 0,001 \\
\hline & g-BHC (Lindano) & ND & ND & ND & ND & 0,02 & 0,001 \\
\hline & Toxafeno & ND & ND & ND & ND & 0,01 & 0,001 \\
\hline & Pentaclorofenol (PCP) & 0,65 & $\mathrm{ND}$ & ND & $\mathrm{ND}$ & 0,009 & 0,005 \\
\hline & 2,4,6 Triclorofenol & ND & $\mathrm{ND}$ & ND & ND & 10 & 1 \\
\hline & PCBs totais & $\mathrm{ND}$ & $\mathrm{ND}$ & ND & ND & 0,001 & 0,001 \\
\hline \multirow{3}{*}{$\begin{array}{l}0 \\
0 \\
0 \\
0 \\
0 \\
0 \\
0 \\
0 \\
0 \\
0 \\
0 \\
0 \\
0 \\
0 \\
0 \\
0\end{array}$} & Malation & ND & ND & ND & ND & 0,1 & 0,01 \\
\hline & Paration & $\mathrm{ND}$ & ND & 0,01 & ND & 0,04 & 0,01 \\
\hline & Gution & ND & ND & ND & ND & 0,005 & 0,001 \\
\hline
\end{tabular}

$\square$ Valores acima dos limites recomendados pela legislação vigente

VM: Valor Máximo

ND: Não Detectado

* Resolução CONAMA 357, 17 de março de 2005. Padrões de Qualidade de Água 


\section{G.5 Córrego do Tamanduá, Ribeirão Bonito}

\begin{tabular}{|c|c|c|c|c|c|c|c|}
\hline & \multirow{4}{*}{$\begin{array}{c}\text { PARÂMETROS } \\
(\mu \mathrm{g} / \mathrm{L})\end{array}$} & \multicolumn{4}{|c|}{ CÓRREGO DO TAMANDUÁ, RIBEIRÃO BONITO } & \multirow{3}{*}{ LEGISLAÇÃo } & \multirow{4}{*}{$\begin{array}{l}\text { Limite de } \\
\text { Detecção }\end{array}$} \\
\hline & & \multicolumn{4}{|c|}{ PONTOS DE COLETA } & & \\
\hline & & \multicolumn{2}{|c|}{ Montante (PM) } & \multicolumn{2}{|c|}{ Jusante (PJ) } & & \\
\hline & & $\begin{array}{c}24 / 11 / 04 \\
08: 20\end{array}$ & $\begin{array}{c}21 / 03 / 05 \\
09: 05\end{array}$ & $\begin{array}{c}24 / 11 / 04 \\
08: 44\end{array}$ & $\begin{array}{c}21 / 03 / 05 \\
09: 24\end{array}$ & $\begin{array}{c}\text { CONAMA } 357 / 2005^{*} \\
\text { VM }\end{array}$ & \\
\hline \multirow{10}{*}{$\begin{array}{l}0 \\
0 \\
0 \\
0 \\
0 \\
0 \\
0\end{array}$} & Benzeno & $\mathrm{ND}$ & $\mathrm{ND}$ & ND & 0,027 & 5 & 0,05 \\
\hline & Tolueno & ND & ND & ND & 0,027 & 2,0 & 0,05 \\
\hline & Etilbenzeno & ND & ND & ND & 0,027 & 90 & 0,05 \\
\hline & Xileno & ND & ND & ND & 0,027 & 300 & 0,05 \\
\hline & Benzo-a-pireno & ND & ND & 0,044 & 0,021 & 0,05 & 0,01 \\
\hline & 1,2 Dicloroetano & ND & ND & ND & ND & 10 & 0,05 \\
\hline & 1,1 Dicloroeteno & ND & ND & ND & 1,991 & 3 & 0,05 \\
\hline & Tricloroeteno & ND & 0,552 & ND & ND & 30 & 0,05 \\
\hline & Tetracloreto de Carbono & ND & ND & ND & ND & 2 & 0,05 \\
\hline & Tetracloroeteno & ND & ND & ND & ND & 10 & 0,05 \\
\hline \multirow{14}{*}{$\begin{array}{l}\infty \\
0 \\
0 \\
0 \\
0 \\
0 \\
0 \\
0 \\
0 \\
0 \\
0 \\
0\end{array}$} & Aldrin & $\mathrm{ND}$ & 0,031 & 0,031 & 0,071 & 0,005 & 0,001 \\
\hline & Clordano & ND & ND & ND & ND & 0,04 & 0,001 \\
\hline & DDT & ND & ND & $\mathrm{ND}$ & ND & 0,002 & 0,001 \\
\hline & Dieldrin & ND & 0,012 & ND & 0,012 & 0,005 & 0,001 \\
\hline & Endossulfan & ND & ND & ND & ND & 0,056 & 0,001 \\
\hline & Metoxicloro & ND & ND & 0,432 & ND & 0,03 & 0,001 \\
\hline & Endrin & ND & 0,032 & ND & ND & 0,004 & 0,001 \\
\hline & Heptacloro & 0,61 & ND & ND & ND & 0,01 & 0,001 \\
\hline & Heptacloro Epóxido & ND & 0,0211 & ND & ND & 0,01 & 0,001 \\
\hline & g-BHC (Lindano) & ND & 0,091 & ND & ND & 0,02 & 0,001 \\
\hline & Toxafeno & $\mathrm{ND}$ & ND & ND & 0,011 & 0,01 & 0,001 \\
\hline & Pentaclorofenol (PCP) & ND & ND & ND & ND & 0,009 & 0,005 \\
\hline & 2,4,6 Triclorofenol & ND & ND & ND & ND & 10 & 1 \\
\hline & PCBs totais & ND & ND & ND & ND & 0,001 & 0,001 \\
\hline \multirow{3}{*}{ 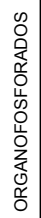 } & Malation & 0,01 & ND & $\mathrm{ND}$ & $\mathrm{ND}$ & 0,1 & 0,01 \\
\hline & Paration & ND & ND & ND & ND & 0,04 & 0,01 \\
\hline & Gution & ND & ND & ND & ND & 0,005 & 0,001 \\
\hline
\end{tabular}

dos limites recomendados pela legislação vigente

VM: Valor Máximo

ND: Não Detectado

* Resolução CONAMA 357, 17 de março de 2005. Padrões de Qualidade de Água 


\section{G.6 Córrego do Galdino, São Carlos}

\begin{tabular}{|c|c|c|c|c|c|c|c|}
\hline & \multirow{4}{*}{$\begin{array}{l}\text { PARÂMETROS } \\
(\mu \mathrm{g} / \mathrm{L})\end{array}$} & \multicolumn{4}{|c|}{ CÓRREGO DO GALDINO, SÃO CARLOS } & \multirow{3}{*}{ LEGISLAÇÃo } & \multirow{4}{*}{$\begin{array}{l}\text { Limite de } \\
\text { Deteç̧ão }\end{array}$} \\
\hline & & \multicolumn{4}{|c|}{ PONTOS DE COLETA } & & \\
\hline & & \multicolumn{2}{|c|}{ Montante (PM) } & \multicolumn{2}{|c|}{ Jusante (PJ) } & & \\
\hline & & $\begin{array}{c}09 / 11 / 04 \\
09: 45\end{array}$ & $\begin{array}{c}10 / 02 / 05 \\
11: 38\end{array}$ & $\begin{array}{c}09 / 11 / 04 \\
10: 09\end{array}$ & $\begin{array}{c}10 / 02 / 05 \\
12: 05\end{array}$ & $\begin{array}{c}\text { CONAMA } 357 / 2005^{*} \\
\text { VM }\end{array}$ & \\
\hline \multirow{10}{*}{$\begin{array}{l}\text { on } \\
0 \\
\text { ż } \\
0 \\
\text { of }\end{array}$} & Benzeno & ND & ND & ND & 0,035 & 5 & 0,05 \\
\hline & Tolueno & ND & ND & ND & ND & 2,0 & 0,05 \\
\hline & Etilbenzeno & ND & ND & ND & ND & 90 & 0,05 \\
\hline & Xileno & ND & ND & ND & ND & 300 & 0,05 \\
\hline & Benzo-a-pireno & ND & ND & ND & ND & 0,05 & 0,01 \\
\hline & 1,2 Dicloroetano & ND & ND & ND & ND & 10 & 0,05 \\
\hline & 1,1 Dicloroeteno & ND & ND & ND & ND & 3 & 0,05 \\
\hline & Tricloroeteno & ND & 0,012 & ND & ND & 30 & 0,05 \\
\hline & Tetracloreto de Carbono & ND & ND & ND & ND & 2 & 0,05 \\
\hline & Tetracloroeteno & ND & ND & ND & 0,028 & 10 & 0,05 \\
\hline \multirow{14}{*}{ 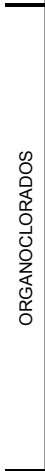 } & Aldrin & 0,027 & 0,109 & $\mathrm{ND}$ & $\mathrm{ND}$ & 0,005 & 0,001 \\
\hline & Clordano & ND & ND & $\mathrm{ND}$ & ND & 0,04 & 0,001 \\
\hline & DDT & ND & ND & 0,076 & 0,076 & 0,002 & 0,001 \\
\hline & Dieldrin & ND & 0,0034 & ND & 0,012 & 0,005 & 0,001 \\
\hline & Endossulfan & 0,001 & ND & ND & ND & 0,056 & 0,001 \\
\hline & Metoxicloro & ND & ND & ND & 0,034 & 0,03 & 0,001 \\
\hline & Endrin & ND & ND & ND & ND & 0,004 & 0,001 \\
\hline & Heptacloro & 0,023 & 0,0209 & ND & ND & 0,01 & 0,001 \\
\hline & Heptacloro Epóxido & ND & ND & ND & ND & 0,01 & 0,001 \\
\hline & g-BHC (Lindano) & ND & ND & ND & ND & 0,02 & 0,001 \\
\hline & Toxafeno & ND & ND & ND & ND & 0,01 & 0,001 \\
\hline & Pentaclorofenol (PCP) & ND & $\mathrm{ND}$ & ND & ND & 0,009 & 0,005 \\
\hline & 2,4,6 Triclorofenol & ND & $\mathrm{ND}$ & ND & ND & 10 & 1 \\
\hline & PCBs totais & ND & 0,012 & ND & ND & 0,001 & 0,001 \\
\hline \multirow{3}{*}{$\begin{array}{l}0 \\
0 \\
0 \\
0 \\
0 \\
0 \\
0 \\
0 \\
0 \\
0 \\
0 \\
0 \\
0 \\
0 \\
0 \\
0\end{array}$} & Malation & ND & ND & ND & ND & 0,1 & 0,01 \\
\hline & Paration & $\mathrm{ND}$ & 0,0298 & ND & ND & 0,04 & 0,01 \\
\hline & Gution & ND & ND & ND & ND & 0,005 & 0,001 \\
\hline
\end{tabular}

$\square$ Valores acima dos limites recomendados pela legislação vigente

VM: Valor Máximo

ND: Não Detectado

* Resolução CONAMA 357, 17 de março de 2005. Padrões de Qualidade de Água 


\section{G.7 Córrego São José, São Carlos}

\begin{tabular}{|c|c|c|c|c|c|c|c|}
\hline \multirow{4}{*}{\multicolumn{2}{|c|}{$\begin{array}{l}\text { PARÂMETROS } \\
(\mu \mathrm{g} / \mathrm{L})\end{array}$}} & \multicolumn{4}{|c|}{ CÓRREGO SÃO JOSÉ, SÃO CARLOS } & \multirow{3}{*}{ LEGISLAÇÃo } & \multirow{4}{*}{$\begin{array}{l}\text { Limite de } \\
\text { Detecção }\end{array}$} \\
\hline & & \multicolumn{4}{|c|}{ PONTOS DE COLETA } & & \\
\hline & & \multicolumn{2}{|c|}{ Montante (PM) } & \multicolumn{2}{|c|}{ Jusante (PJ) } & & \\
\hline & & $8 / 11 / 04$ & 10/2/05 & $8 / 11 / 04$ & 10/2/05 & CONAMA $357 / 2005^{*}$ & \\
\hline \multirow{10}{*}{$\begin{array}{l}\text { on } \\
0 \\
0 \\
0 \\
0 \\
0 \\
0\end{array}$} & Benzeno & ND & $\mathrm{ND}$ & $\mathrm{ND}$ & ND & 5 & 0,05 \\
\hline & Tolueno & ND & ND & ND & ND & 2,0 & 0,05 \\
\hline & Etilbenzeno & ND & ND & ND & ND & 90 & 0,05 \\
\hline & Xileno & ND & ND & ND & ND & 300 & 0,05 \\
\hline & Benzo-a-pireno & 0,01 & ND & ND & ND & 0,05 & 0,01 \\
\hline & 1,2 Dicloroetano & ND & ND & ND & ND & 10 & 0,05 \\
\hline & 1,1 Dicloroeteno & ND & ND & ND & ND & 3 & 0,05 \\
\hline & Tricloroeteno & ND & ND & ND & ND & 30 & 0,05 \\
\hline & Tetracloreto de Carbono & ND & 1,202 & ND & ND & 2 & 0,05 \\
\hline & Tetracloroeteno & 0,05 & 3,099 & ND & ND & 10 & 0,05 \\
\hline \multirow{14}{*}{$\begin{array}{l}0 \\
0 \\
0 \\
0 \\
0 \\
0 \\
0 \\
0 \\
0 \\
0 \\
0 \\
0\end{array}$} & Aldrin & $\mathrm{ND}$ & 0,65 & 0,017 & 0,018 & 0,005 & $\overline{0,001}$ \\
\hline & Clordano & ND & ND & ND & ND & 0,04 & 0,001 \\
\hline & DDT & ND & ND & ND & ND & 0,002 & 0,001 \\
\hline & Dieldrin & ND & ND & ND & 0,045 & 0,005 & 0,001 \\
\hline & Endossulfan & 1,984 & ND & ND & ND & 0,056 & 0,001 \\
\hline & Metoxicloro & ND & 0,034 & 0,004 & ND & 0,03 & 0,001 \\
\hline & Endrin & ND & ND & ND & ND & 0,004 & 0,001 \\
\hline & Heptacloro & ND & ND & ND & 0,056 & 0,01 & 0,001 \\
\hline & Heptacloro Epóxido & 0,001 & ND & ND & ND & 0,01 & 0,001 \\
\hline & g-BHC (Lindano) & ND & ND & ND & ND & 0,02 & 0,001 \\
\hline & Toxafeno & ND & ND & ND & ND & 0,01 & 0,001 \\
\hline & Pentaclorofenol (PCP) & 0,012 & 1,012 & ND & ND & 0,009 & 0,005 \\
\hline & 2,4,6 Triclorofenol & 1 & ND & ND & ND & 10 & 1 \\
\hline & PCBs totais & ND & $\mathrm{ND}$ & $\mathrm{ND}$ & ND & 0,001 & 0,001 \\
\hline \multirow{3}{*}{ 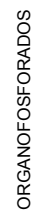 } & Malation & ND & ND & ND & ND & 0,1 & 0,01 \\
\hline & Paration & 0,56 & 0,098 & ND & 1,198 & 0,04 & 0,01 \\
\hline & Gution & ND & ND & ND & ND & 0,005 & 0,001 \\
\hline
\end{tabular}

$\square$ Valores acima dos limites recomendados pela legislação vigente

VM: Valor Máximo

ND: Não Detectado

*Resolução CONAMA 357, 17 de março de 2005. Padrões de Qualidade de Água 
Apêndice H1 - Quantidade de amostras de água subterrânea fora dos limites recomendados pela Portaria 518/2004 (\%)

\begin{tabular}{|c|c|c|c|c|c|c|c|c|c|c|c|c|c|c|c|}
\hline \multirow{3}{*}{ PARÂMETROS } & \multicolumn{5}{|c|}{ Poços de Montante (PM) } & \multicolumn{5}{|c|}{ Poços de Jusante (PJ) } & \multicolumn{5}{|c|}{ Total de amostras dos aterros } \\
\hline & Aterro 1 & Aterro 2 & Aterro 3 & Aterro 4 & Aterro 5 & Aterro 1 & Aterro 2 & Aterro 3 & Aterro 4 & Aterro 5 & Aterro 1 & Aterro 2 & Aterro 3 & Aterro 4 & Aterro 5 \\
\hline & $\begin{array}{c}\text { aterro de } \\
\text { Araraquara }\end{array}$ & $\begin{array}{l}\text { aterro de } \\
\text { Bauru }\end{array}$ & $\begin{array}{l}\text { lixão de } \\
\text { Jaú }\end{array}$ & $\begin{array}{l}\text { aterro de } \\
\text { São Carlos }\end{array}$ & $\begin{array}{l}\text { antigo lixão de } \\
\text { São Carlos }\end{array}$ & $\begin{array}{c}\text { aterro de } \\
\text { Araraquara }\end{array}$ & $\begin{array}{c}\text { aterro de } \\
\text { Bauru }\end{array}$ & $\begin{array}{l}\text { lixão de } \\
\text { Jaú }\end{array}$ & $\begin{array}{l}\text { aterro de } \\
\text { são Carlos }\end{array}$ & $\begin{array}{l}\text { antigo lixão de } \\
\text { São Carlos }\end{array}$ & $\begin{array}{c}\text { aterro de } \\
\text { Araraquara }\end{array}$ & $\begin{array}{c}\text { aterro de } \\
\text { Bauru }\end{array}$ & $\begin{array}{l}\text { lixão de } \\
\text { Jaú }\end{array}$ & $\begin{array}{l}\text { aterro de } \\
\text { São Carlos }\end{array}$ & $\begin{array}{l}\text { antigo lixão de } \\
\text { São Carlos }\end{array}$ \\
\hline $\mathrm{pH}$ & 100 & 0 & 100 & 100 & 100 & 100 & 83,33 & 72,72 & 100 & 91,66 & 100 & 62,50 & 80 & 100 & 93,33 \\
\hline Cor Aparente & 75 & 100 & 100 & 75 & 100 & 100 & 91,66 & 100 & 90 & 75 & 93,75 & 93,75 & 100 & 85,71 & 80 \\
\hline Turbidez & 75 & 75 & 100 & 75 & 100 & 83,33 & 83,33 & 100 & 90 & 75 & 81,25 & 81,25 & 100 & 85,71 & 80 \\
\hline Cloreto & 0 & 0 & 0 & 0 & 0 & 0 & 0 & 0 & 40 & 0 & 0 & 0 & 0 & 28,57 & 0 \\
\hline Nitrogênio Amoniacal & 0 & 25 & 0 & 25 & 0 & 33,33 & 0 & 36,36 & 20 & 66,66 & 25 & 6,25 & 26,66 & 21,42 & 53,33 \\
\hline Sólidos Totais Dissolvidos & 0 & 0 & 25 & 0 & 0 & 0 & 0 & 9,09 & 20 & 8,33 & 0 & 0 & 13,33 & 14,28 & 6,66 \\
\hline Zinco & 0 & 0 & 25 & 0 & 0 & 0 & 0 & 27,27 & 0 & 0 & 0 & 0 & 26,66 & 0 & 0 \\
\hline Chumbo & 0 & 0 & 25 & 0 & 0 & 0 & 0 & 27,27 & 0 & 0 & 0 & 0 & 26,66 & 0 & 0 \\
\hline Ferro Solúvel & 50 & 25 & 25 & 100 & 100 & 75 & 16,66 & 63,63 & 70 & 75 & 68,75 & 18,75 & 53,33 & 78,57 & 80 \\
\hline Manganês Solúvel & 0 & 50 & 50 & 0 & 0 & 50 & 66,66 & 72,72 & 70 & 58,33 & 37,50 & 62,50 & 66,66 & 50 & 46,66 \\
\hline Cromo Total & 0 & 0 & 25 & 0 & 0 & 8,33 & 0 & 27,27 & 10 & 8,33 & 6,25 & 0 & 26,66 & 7,14 & 6,66 \\
\hline Alumínio & 0 & 0 & 0 & 0 & 0 & 0 & 0 & 0 & 10 & 0 & 0 & 0 & 0 & 7,14 & 0 \\
\hline
\end{tabular}

$\square$ Amostras abaixo dos limites recomendados pela Portaria 518/2004
$\square$ Amostras acima dos limites recomendados pela Portaria 518/2004

* Portaria $n^{\circ}$ 518, 25 de março de 2004. Ministério da Saúde. Padrões de Potabilidade 
Apêndice H2 - Quantidade de amostras de água superficial fora dos limites recomendados pela CONAMA 357/2005 e pelo Decreto $8468 / 1976(\%)$

\begin{tabular}{|c|c|c|c|c|c|c|c|c|c|c|c|c|c|c|c|c|c|c|c|c|c|}
\hline \multirow{3}{*}{ PARÂMETROS } & \multicolumn{7}{|c|}{ Pontos de Montante (PM) } & \multicolumn{7}{|c|}{ Pontos de Jusante (PJ) } & \multicolumn{7}{|c|}{ Total de amostras dos córregos } \\
\hline & Córrego 1 & Córrego 2 & Córrego 3 & Córrego 4 & Córrego 5 & Córrego 6 & Córrego 7 & Córrego 1 & Córrego 2 & Córrego 3 & Córrego 4 & Córrego 5 & Córrego 6 & Córrego 7 & Córrego 1 & Córrego 2 & Córrego 3 & Córrego 4 & Córrego 5 & Córrego 6 & Córrego 7 \\
\hline & Araraquara & Bauru & Brotas & Jaú & R. Bonito & São Carlos & São Carlos & Araraquara & Bauru & Brotas & Jaú & R. Bonito & São Carlos & São Carlos & Araraquara & Bauru & Brotas & Jaú & R. Bonito & São Carlos & São Carlos \\
\hline $\mathrm{pH}$ & 100 & 0 & 75 & 0 & 66,66 & 33,33 & 25 & 100 & 0 & 100 & 0 & 50 & 25 & 0 & 100 & 0 & 87,50 & 0 & 57,14 & 28,57 & 12,50 \\
\hline Cor Aparente & 0 & 100 & 50 & 50 & 66,66 & 66,66 & 50 & 0 & 100 & 50 & 50 & 25 & 100 & 100 & 0 & 100 & 50 & 50 & 42,85 & 85,71 & 75 \\
\hline Turbidez & 25 & 25 & 0 & 0 & 0 & 0 & 0 & 0 & 25 & 0 & 0 & 0 & 0 & 0 & 12,50 & 25 & 0 & 0 & 0 & 0 & 0 \\
\hline Oxigênio Dissolvido & 0 & 50 & 25 & 25 & 100 & 0 & 0 & 0 & 75 & 25 & 50 & 0 & 100 & 75 & 0 & 62,50 & 25 & 37,50 & 42,85 & 57,14 & 37,50 \\
\hline Cloreto & 0 & 25 & 0 & 0 & 0 & 0 & 0 & 0 & 0 & 0 & 0 & 0 & 0 & 0 & 0 & 12,50 & 0 & 0 & 0 & 0 & 0 \\
\hline Fósforo Total & 25 & 50 & 0 & 0 & 33,33 & 0 & 25 & 25 & 25 & 25 & 0 & 0 & 50 & 50 & 25 & 37,50 & 12,50 & 0 & 14,28 & 28,57 & 37,50 \\
\hline Fluoreto & 0 & 50 & 0 & 0 & 0 & 0 & 0 & 0 & 0 & 0 & 0 & 0 & 0 & 0 & 0 & 25 & 0 & 0 & 0 & 0 & 0 \\
\hline Coliformes Totais & 0 & 100 & 75 & 50 & 33,33 & 0 & 25 & 0 & 100 & 50 & 50 & 0 & 50 & 100 & 0 & 100 & 62,50 & 50 & 14,28 & 28,57 & 62,50 \\
\hline Coliformes Termotolerantes & 0 & 25 & 75 & 0 & 0 & 0 & 0 & 0 & 25 & 0 & 0 & 0 & 25 & 50 & 0 & 25 & 37,50 & 0 & 0 & 14,28 & 25 \\
\hline Demanda Bioquímica de Oxigênio & 0 & 100 & 0 & 0 & 0 & 0 & 0 & 0 & 50 & 0 & 0 & 0 & 0 & 0 & 0 & 75 & 0 & 0 & 0 & 0 & 12,50 \\
\hline Nitrogênio Amoniacal & 0 & 25 & 0 & 0 & 0 & 0 & 0 & 0 & 25 & 0 & 0 & 0 & 25 & 0 & 0 & 25 & 0 & 0 & 0 & 14,28 & 0 \\
\hline Nitrogênio Nitrato & 0 & 25 & 0 & 0 & 0 & 0 & 0 & 0 & 25 & 0 & 0 & 0 & 0 & 0 & 0 & 25 & 0 & 0 & 0 & 0 & 0 \\
\hline Nitrogênio Total & 0 & 100 & 0 & 0 & 0 & 100 & 0 & 0 & 100 & 0 & 0 & 0 & 100 & 100 & 0 & 100 & 0 & 0 & 0 & 100 & 50 \\
\hline Sólidos Totais Dissolvidos & 0 & 50 & 0 & 0 & 0 & 0 & 0 & 0 & 25 & 0 & 0 & 0 & 0 & 0 & 0 & 37,50 & 0 & 0 & 0 & 0 & 0 \\
\hline Zinco & 50 & 100 & 50 & 25 & 33,33 & 0 & 50 & 50 & 100 & 75 & 75 & 100 & 50 & 25 & 50 & 100 & 62,50 & 50 & 71,42 & 28,57 & 37,50 \\
\hline Ferro Solúvel & 25 & 75 & 75 & 75 & 33,33 & 100 & 75 & 75 & 100 & 75 & 75 & 25 & 75 & 75 & 50 & 87,50 & 75 & 75 & 28,57 & 85,71 & 75 \\
\hline Manganês Solúvel & 0 & 75 & 0 & 50 & 33,33 & 0 & 0 & 0 & 75 & 0 & 50 & 0 & 25 & 25 & 0 & 75 & 0 & 50 & 14,28 & 14,28 & 12,50 \\
\hline Cobre & 50 & 100 & 100 & 50 & 100 & 33,33 & 75 & 50 & 75 & 75 & 75 & 75 & 50 & 75 & 50 & 87,50 & 87,50 & 62,50 & 85,71 & 42,85 & 75 \\
\hline Cromo Total & 25 & 25 & 0 & 0 & 0 & 0 & 0 & 0 & 0 & 0 & 0 & 0 & 0 & 0 & 12,50 & 12,50 & 0 & 0 & 0 & 0 & 0 \\
\hline Alumínio & 0 & 25 & 0 & 0 & 0 & 0 & 0 & 0 & 0 & 0 & 0 & 0 & 0 & 0 & 0 & 12,50 & 0 & 0 & 0 & 0 & 0 \\
\hline
\end{tabular}

Amostras abaixo dos limites recomendados pela CONAMA $n^{\circ} 357 / 2005$ e pelo Decreto $n^{\circ} 8468 / 1976$

$\square$ Amostras acima dos limites recomendados pela CONAMA $n^{\circ} 357 / 2005$ e pelo Decreto $n^{\circ} 8468 / 1976$

* Resolução CONAMA n ${ }^{\circ}$ 357, de 17 de março de 2005. Padrões de Qualidade de Água

** Decreto $n^{\circ}$ 8468, de 08 de setembro de 1976, do Governo do Estado de São Paulo. Dispõe sobre a Prevenção e o Controle da Poluição do Meio Ambiente

Córrego 1: Pinheirinho, Araraquara

Córrego 2: Gabiroba, Bauru

Córrego 3: Cachoeira Grande, Brotas

Córrego 4: Ribeirão do Matão, Jaú

Córrego 5: Tamanduá, Ribeirão Bonito

Córrego 6: Galdino, São Carlos

Córrego 7: São José, São Carlos 


\section{ANEXOS}

\section{Anexo 1 - Relatório de sondagem no aterro de Brotas}

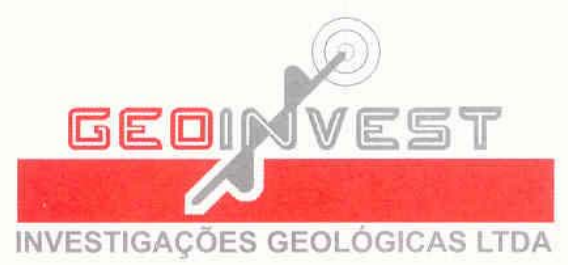

$\mathrm{AO}$

PROF. VALDIR SCHALCH

Av. Trabalhador São-carlense $\mathrm{n}^{\circ} 400$

São Carlos - SP

Ref:: RELATÓRIO DE SONDAGEM

Prezado Senhor

A Geoinvest Investigações Geológicas apresenta o resultados dos serviços de sondagem a trado, para caracterização das camadas do subsolo, realizadas no Aterro Sanitário Municipal de Brotas, no município de Brotas, SP.

\section{DADOS DA OBRA}

Tipo de serviço: Sondagem a trado

A sondagem a trado é executada por meio da cravação no solo, por meio de rotação, de um trado do tipo helicoidal que, após ser retirado, Descrição: $\quad$ possibilita a coleta de amostras deformadas sobre as quais são realizadas análises tátil-visuais para sua classificação textural possibilitando a montagem do perfil do subsolo no ponto perfurado.

Quantidade de furos:

02

Total de metros perfurados:

37.50

Amostras coletadas:

39

Diâmetro da perfuração (pol.) 4 (até 10.00 metros) e 2.5 (restante)

Data do inicio:

$04 / 08 / 04$

Data do término:

05/08/04

Anexos:

- Planta com a locação dos furos de sondagem (página 1)

- Perfil individual do subsolo dos furos executados (páginas 2 e 3)

Ribeirão Preto, 05 de Outubro de 2004

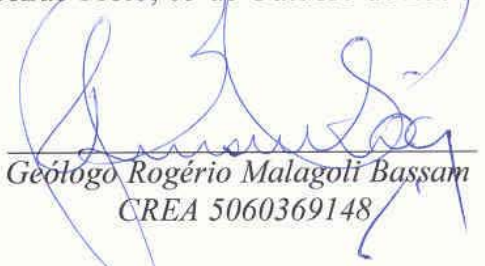

Rua General Osório n 1630 - Vila Seixas - CEP: 14.015-030 - Ribeirão Preto - SP Fonefax: (16) 3941-4616 - Email: geoinvest@uol.com.br 


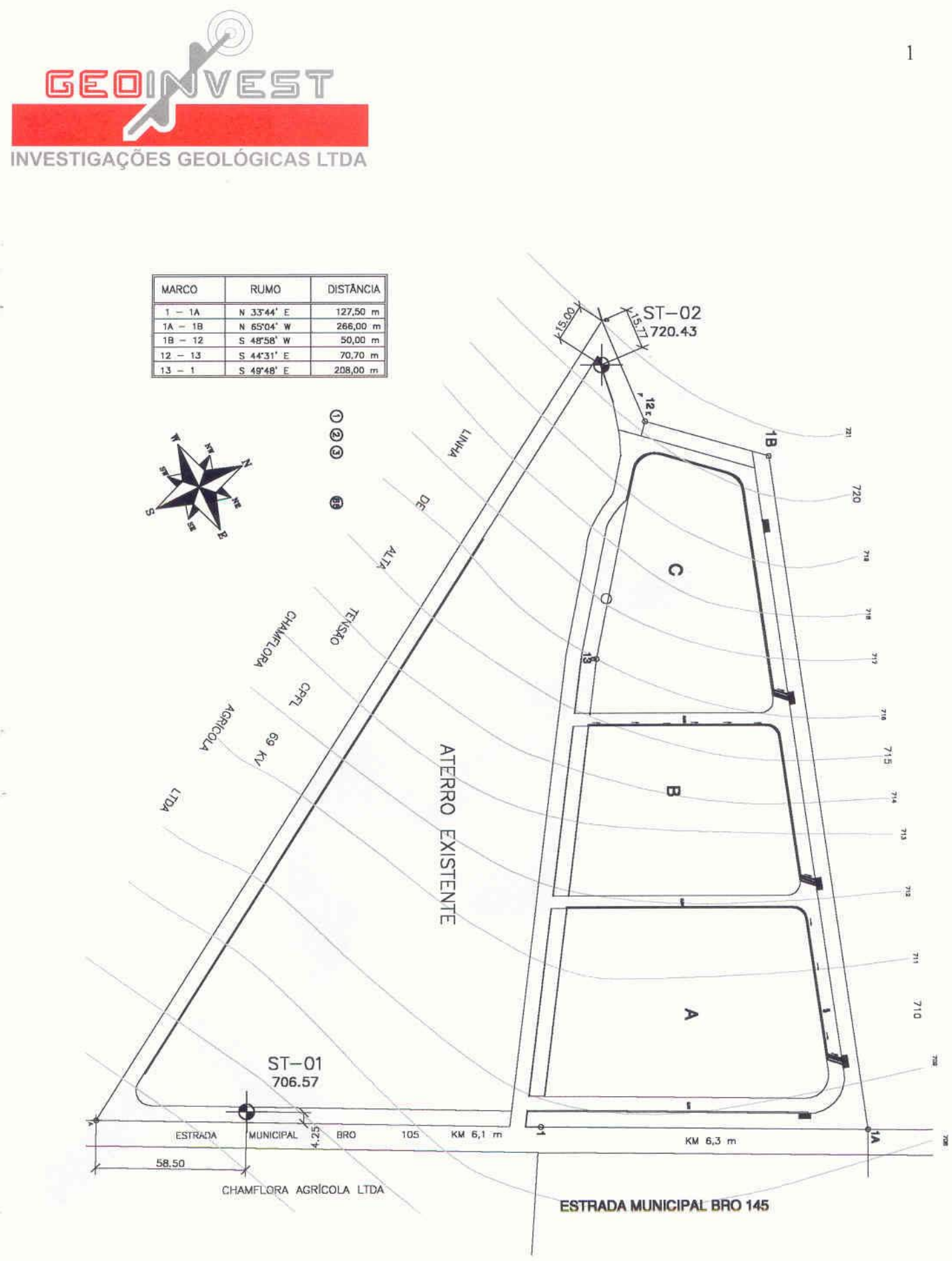

Locação dos furos de sondagem (Escala 1:2.000).

Rua General Osório n ${ }^{\circ} 1630$ - Vila Seixas - CEP: 14.015-030 - Ribeirão Preto - SP Fonefax: (16)3941-4616 - Email: geoinvest@uol.com.br 


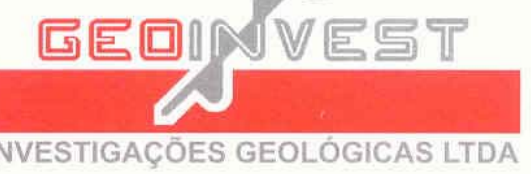

\begin{tabular}{|c|}
\hline FURO \\
"ST-01" \\
\hline
\end{tabular}

PERFIL GEOLÓGICO

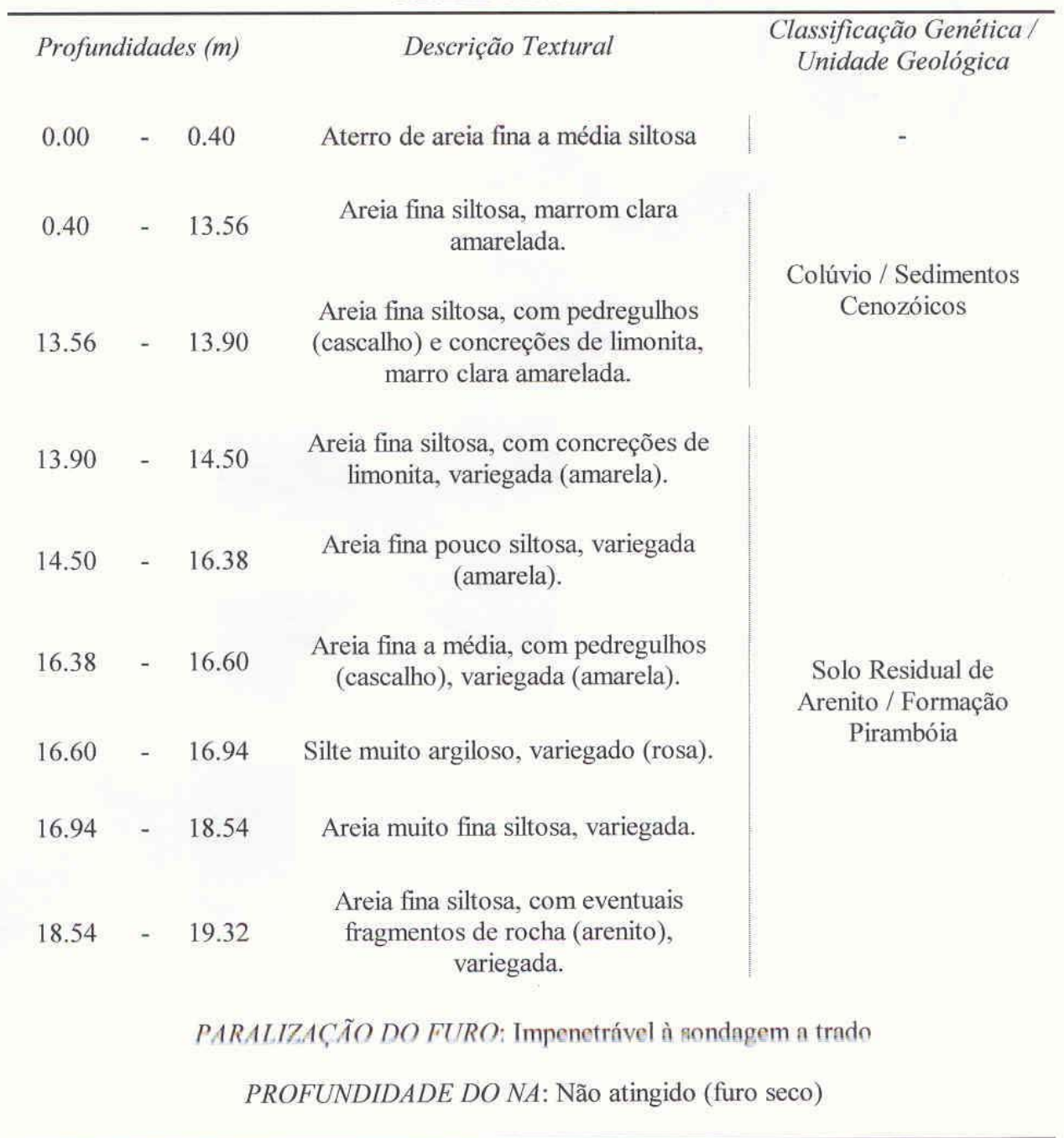

Rua General Osório nº 1630 - Vila Seixas - CEP: 14.015-030 - Ribeirão Preto - SP Fonefax: (16)3941-4616 - Email: geoinvest@uol.com.br 


\section{PERFIL GEOLÓGICO}

\begin{tabular}{|c|c|c|c|}
\hline \multicolumn{2}{|c|}{ Profundidades (m) } & Descrição Textural & $\begin{array}{c}\text { Classificação Genética } \\
\text { Unidade Geológica }\end{array}$ \\
\hline 0.00 & $-\quad 1.21$ & $\begin{array}{l}\text { Aterro de areia fina a média siltosa, com } \\
\text { lixo, variegado (marrom escuro). }\end{array}$ & \multirow[b]{2}{*}{$\begin{array}{l}\text { Colúvio / Sedimentos } \\
\text { Cenozóicos }\end{array}$} \\
\hline 1.21 & - 8.92 & $\begin{array}{l}\text { Areia fina siltosa, marrom clara } \\
\text { amarelada. }\end{array}$ & \\
\hline 8.92 & $-\quad 13.74$ & $\begin{array}{l}\text { Areia fina siltosa, marrom clara } \\
\text { amarelada com manchas variegadas. }\end{array}$ & \multirow{3}{*}{$\begin{array}{l}\text { Solo Residual de } \\
\text { Arenito / Formação } \\
\text { Pirambóia }\end{array}$} \\
\hline 13.74 & - $\quad 16.50$ & Areia fina siltosa, variegada. & \\
\hline 16.50 & $-\quad 18.18$ & $\begin{array}{c}\text { Areia fina a média siltosa, com } \\
\text { eventuais pedregulhos (cascalho), } \\
\text { variegada. }\end{array}$ & \\
\hline \multicolumn{4}{|c|}{ PARALIZACCAOO DO FURO: Impenetrável à sondagem a trado } \\
\hline \multicolumn{4}{|c|}{ PROFUNDIDADE DO NA: Não atingido (furo seco) } \\
\hline
\end{tabular}


Anexo 2 - Relatório de sondagem e construção de poços no lixão de Jaú

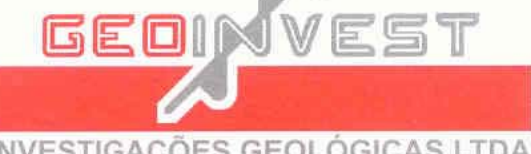

INVESTIGACŌES GEOLÓGICAS LTDA

\section{VALDIR SCHALCH}

POÇOS DE MONITORAMENTO DO LENÇOL FREÁTICO

ATERRO SANITÁRIO MUNICIPAL

Jáú - SP

Agosto/2004 


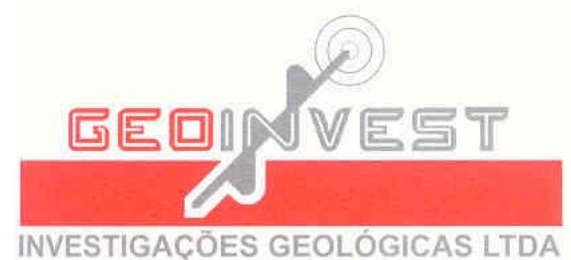

INVESTIGAÇÕES GEOLÓGICAS LTDA

\section{INTRODUÇÃO}

-A Geoinvest Investigações Geológicas Ltda apresenta os resultados dos serviços de sondagens a trado e construção de poços de monitoramento do lençol freático, realizados no Aterro Sanitário Municipal de Jaú, com acesso pela rodovia SP 225 km $165+700$, no município de Jaú, SP.

No local foram construídos quatro poços de monitoramento, sendo um a montante (PM-1) e três a jusante (PJ-2, PJ-3 e PJ-4) e realizado um furo de sondagem a trado (ST-01), para obtenção de informações complementares da profundidade do lençol freático e tipo de subsolo local (figura 1). Para a locação dos poços foi levada em consideração a posição dos depósitos de lixo existentes na área em relação ao provável sentido do fluxo d'água subterrâneo (figura 1), o qual baseou-se nas feições topográficas do local e de seu entorno e que acabou sendo confirmado pelas informações da profundidade do lençol freático obtidas durante a execução dos poços.

Nos anexos encontram-se todos os procedimentos adotados na construção dos poços bem como o perfil do subsolo de cada ponto perfurado, incluindo o tipo de formação geológica no qual estão inseridos. Devido ao significante do teor de silte e argila do solo local, toda a coluna filtrante de cada poço foi envolta por uma manta de geotextil, objetivando, com isso, uma diminuição da entrada desses materiais dentro do revestimento resultando, com isso, uma melhor filtragem da água a ser coletada.

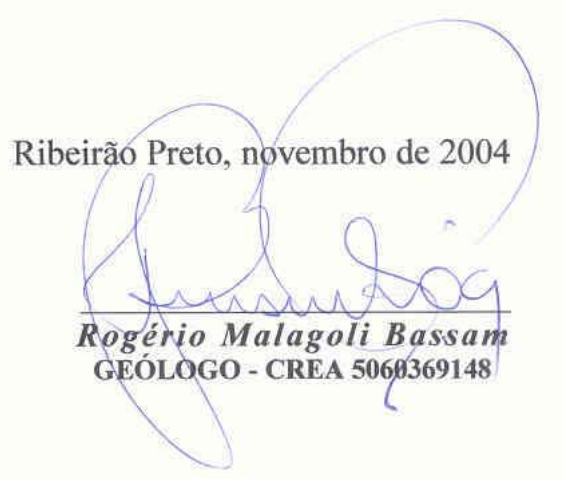

Rua General Osório n 1630 - Vila Seixas - CEP: 14.015-030 - Ribeirão Preto - SP Fonefax: (16)3941-4616 - Email: geoinvest@uol.com.br 


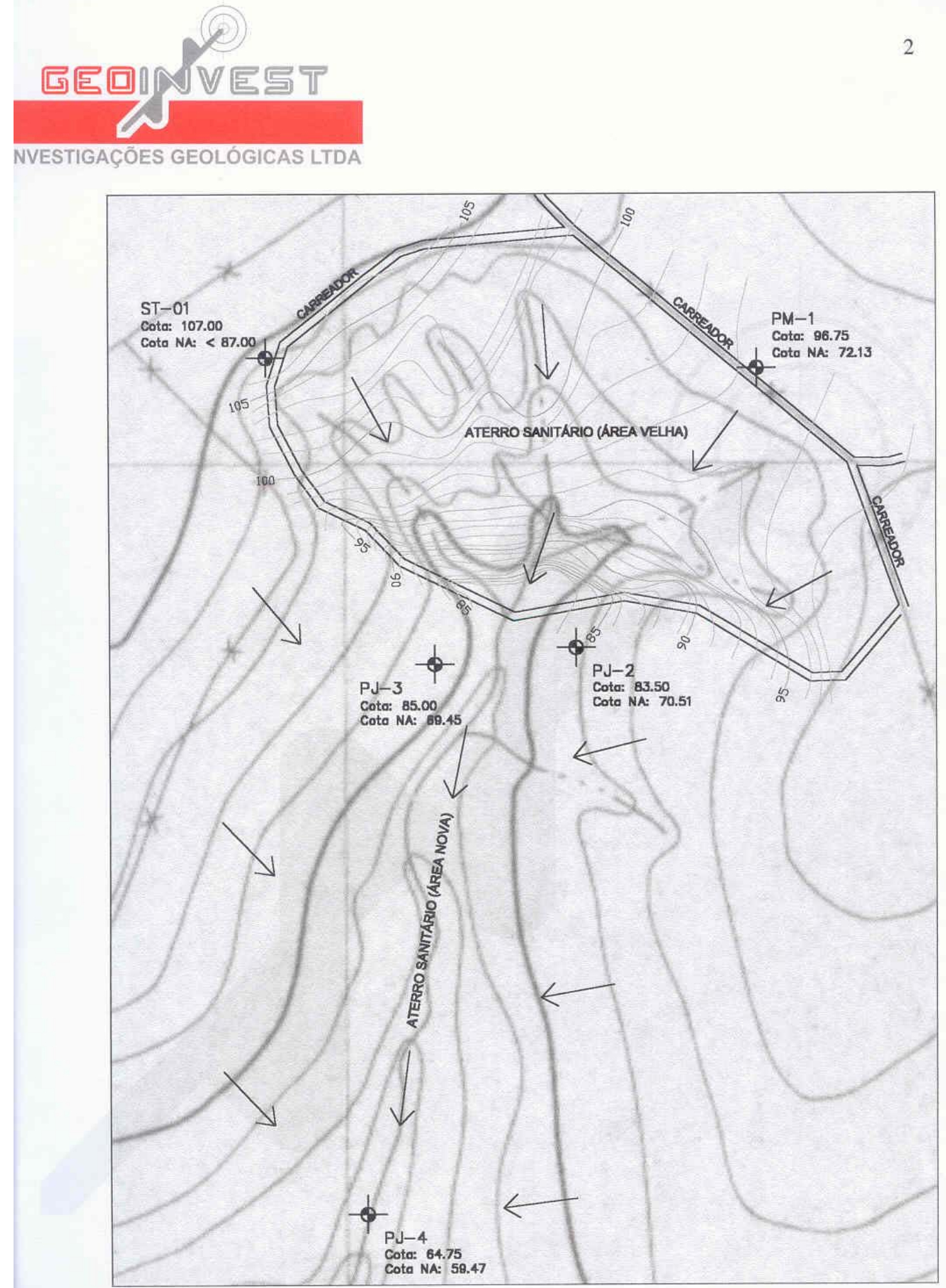

Figura 1: Localização dos Poços de Monitoramento e furo de sondagem na área do Aterro Sanitário Municipal de Jaú, com as setas indicando o sentido do fluxo do lençol freático (Escala 1:2.500).

Rua General Osório n ${ }^{\circ} 1630$ - Vila Seixas - CEP: 14.015-030 - Ribeirão Preto - SP Fonefax: (16)3941-4616 - Email: geoinvest@uol.com.br 


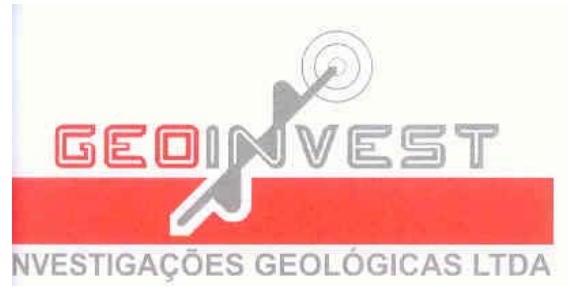

\section{POÇOS DE MONITORAMENTO}

Aqui estão incluídos em detalhe todos os procedimentos adotados na execução do poço, os quais foram baseados na norma CETESB 6410 "Amostragem e Monitoramento das Águas Subterrâneas - Construção de Poços de Monitoramento de Aquífero Freático", de abril de 1988 (atualizada em novembro de 1999). As perfurações foram realizadas com trado helicoidal de 4" e 5" de diâmetro (DN 100 e 125) e a instalação dos poços feitas em 2" (DN 50) com utilização de tubos de PVC Geomecânicos (Linha Piezométrica). A profundidade e a montagem da coluna de revestimento foram determinadas pela Geoinvest Investigações Geológicas Ltda, sendo baseadas na profundidade do lençol freático obtidas durante o processo de perfuração. 


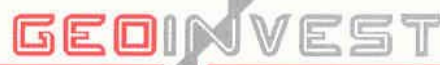

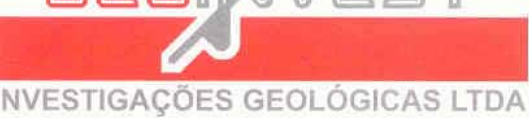

\section{POÇO DE MONITORAMENTO}

"PM-1"

\begin{tabular}{lrlr}
\multicolumn{4}{c}{ DADOS GERAIS } \\
\hline Localização & & Figura 1 \\
Cota do Nivel do Terreno & $96.75 \mathrm{~m}$ & Posição do Revestimento & $-0.50 \mathrm{~m}$ \\
Profundidade Perfurada & $29.00 \mathrm{~m}$ & Profundidade Revestida & $28.50 \mathrm{~m}$ \\
Diâmetro da Perfuração & $4 "$ & Diâmetro do Revestimento & $2 "$ \\
Nível Estático & $24.62 \mathrm{~m}(27$ Ago. 2004) & Volume de Agua no Revestimento & $7.6 \ell$ \\
\hline
\end{tabular}

\section{DATAS PRINCIPAIS}

\begin{tabular}{|c|c|c|}
\hline Etapas & Datas & Equipamento \\
\hline Perfuração & $24-26$ Ago. 2004 & Trado Mecanizado \\
\hline Revestimento & - & Não utilizado \\
\hline Pré-Filtro & 26 Ago. 2004 & \\
\hline Selo de Bentonita & 26 Ago. 2004 & \\
\hline Laje de Proteção & 27 Ago. 2004 & \\
\hline Desinfecção & 27 Ago. 2004 & \\
\hline \multirow[t]{2}{*}{ Desenvolvimento } & 31 Ago. 2004 & Bailers descartáveis \\
\hline & \multicolumn{2}{|l|}{ PERFURAÇÃO } \\
\hline Intervalo & \multicolumn{2}{|l|}{0.00 a $29.00 \mathrm{~m}$} \\
\hline Método & \multicolumn{2}{|c|}{ Trado Mecanizado a Seco } \\
\hline Equipamentos (Perfuratriz) & \multicolumn{2}{|c|}{01 Trado Helicoidal Mecanizado DN 4" } \\
\hline
\end{tabular}

Rua General Osório nº 1630 - Vila Seixas - CEP: 14.015-030 - Ribeirão Preto - SP Fonefax: (16)3941-4616 - Email: geoinvest@uol.com.br 


\section{回區回UN區写T}
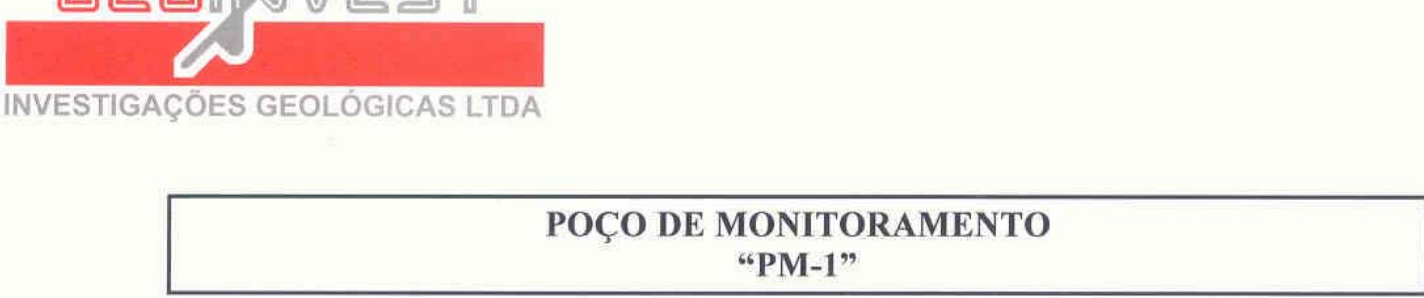

\section{REVESTIMENTO}

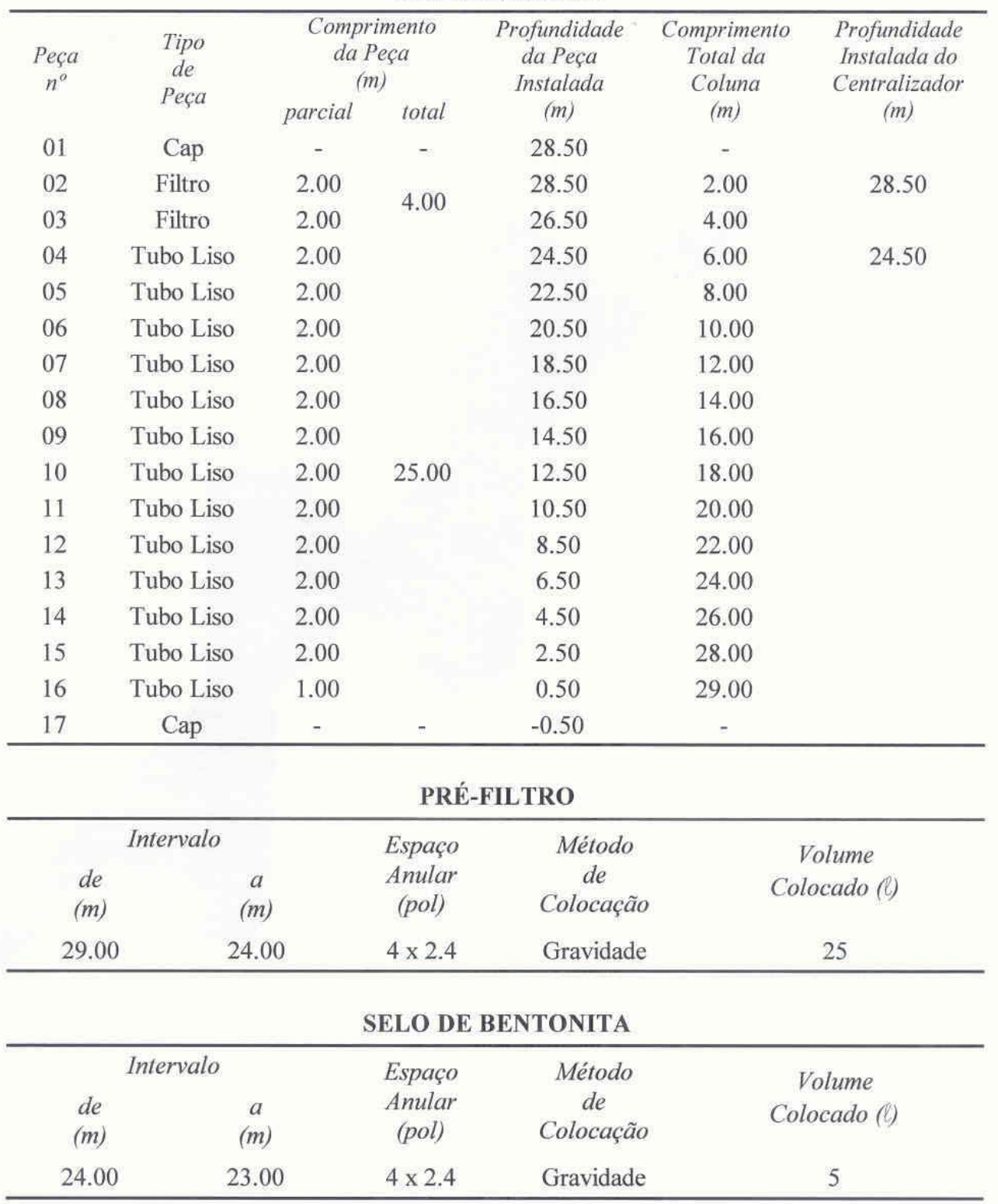

Rua General Osório n ${ }^{\circ} 1630$ - Vila Seixas - CEP: 14.015-030 - Ribeirão Preto - SP Fonefax: (16)3941-4616 - Email: geoinvest@uol.com.br 


\section{POÇO DE MONITORAMENTO}

"PM-1"

\begin{tabular}{|c|c|c|c|c|}
\hline \multicolumn{5}{|c|}{ PREENCHIMENTO - SOLO } \\
\hline & & Espaço & Método & Volume \\
\hline $\begin{array}{l}\text { de } \\
(m)\end{array}$ & $\begin{array}{c}a \\
(m)\end{array}$ & $\begin{array}{c}\text { Anular } \\
\text { (pol) }\end{array}$ & $\begin{array}{c}\text { de } \\
\text { Colocação }\end{array}$ & $\begin{array}{c}\text { Calculado } \\
\text { (l) }\end{array}$ \\
\hline 23.00 & 0.50 & $4 \times 2.4$ & Gravidade & 111 \\
\hline
\end{tabular}

\section{SELO DE PROTEÇ̃̃O SANITÁRIA}

\begin{tabular}{|c|c|c|c|c|c|c|}
\hline \multicolumn{2}{|c|}{ Intervalo } & \multirow{2}{*}{$\begin{array}{l}\text { Espaço } \\
\text { Anular } \\
\text { (pol) }\end{array}$} & \multirow[b]{2}{*}{ Material } & \multirow{2}{*}{$\begin{array}{c}\text { Traço } \\
\text { da } \\
\text { Mistura }\end{array}$} & \multirow{2}{*}{$\begin{array}{c}\text { Método } \\
\text { de } \\
\text { Colocação }\end{array}$} & \multirow{2}{*}{$\begin{array}{c}\text { Volume } \\
\text { Calculado } \\
\text { (l) }\end{array}$} \\
\hline $\begin{array}{l}d e \\
(m)\end{array}$ & $\begin{array}{c}a \\
(m)\end{array}$ & & & & & \\
\hline 0.50 & 0.00 & $6 \times 2.5$ & Concreto & $1: 2: 3$ & Gravidade & 9 \\
\hline
\end{tabular}

\section{TUBO DE PROTEÇ̃̃O}

\begin{tabular}{llcc}
\hline Especificação & $N^{o}$ de Peças & Comprimento Total $(\mathrm{m})$ \\
Tubo de Proteção DN 6" de Alumínio & 1 & 0.60 \\
\hline & \multicolumn{2}{c}{ LAJE DE PROTEÇÃO } \\
\hline Dimensões & Comprimento & $0.65 \mathrm{~m} \times 0.65 \mathrm{~m}$ \\
Material & Espessura & $0.15 \mathrm{~m}$ \\
\hline
\end{tabular}




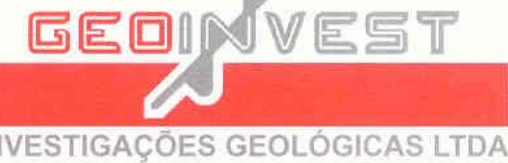

INVESTIGAÇŌES GEOLÓGICAS LTDA

\begin{tabular}{|c|c|c|c|}
\hline \multicolumn{4}{|c|}{$\begin{array}{l}\text { POÇO DE MONITORAMENTO } \\
\text { "PM-1" }\end{array}$} \\
\hline \multicolumn{4}{|c|}{ PERFIL GEOLÓGICO } \\
\hline Profunc & dades (m) & Descrição Textural & $\begin{array}{c}\text { Classificação Genética I } \\
\text { Unidade Geológica }\end{array}$ \\
\hline 0.00 & $-\quad 11.47$ & Areia fina silto-argilosa, vermelha. & $\begin{array}{l}\text { Colúvio / Coberturas } \\
\text { Cenozóicas }\end{array}$ \\
\hline 11.47 & - $\quad 17.20$ & $\begin{array}{c}\text { Areia fina siltosa, vermelha clara com } \\
\text { manchas variegadas. }\end{array}$ & \\
\hline 17.20 & - $\quad 24.20$ & $\begin{array}{l}\text { Areia fina a média silto-argilosa, } \\
\text { variegada (vermelha clara). }\end{array}$ & $\begin{array}{l}\text { Solo Residual de } \\
\text { Arenito / Formação } \\
\text { Itaqueri }\end{array}$ \\
\hline 24.20 & $-\quad 29.00$ & $\begin{array}{c}\text { Areia fina a média silto-argilosa, } \\
\text { variegada }\end{array}$ & \\
\hline
\end{tabular}

\section{CLASSIFICAÇÃO HIDROGEOLÓGICA}

Unidade Geológica Solo Residual de Arenito - Formação Itaqueri

Unidade Hidrogeológica Aquitardo Solo Residual

Rua General Osório n ${ }^{\circ} 1630$ - Vila Seixas - CEP: 14.015-030 - Ribeirão Preto - SP Fonefax: (16)3941-4616 - Email: geoinvest@uol.com.br 


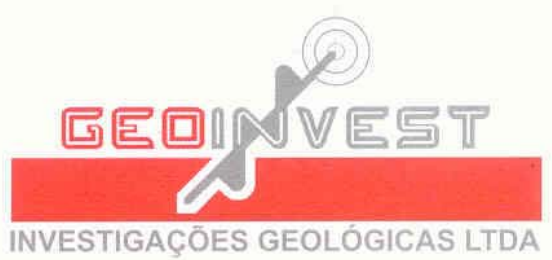

\section{POÇO DE MONITORAMENTO}

"PM-1"

\section{PERFIL ESQUEMÁTICO}

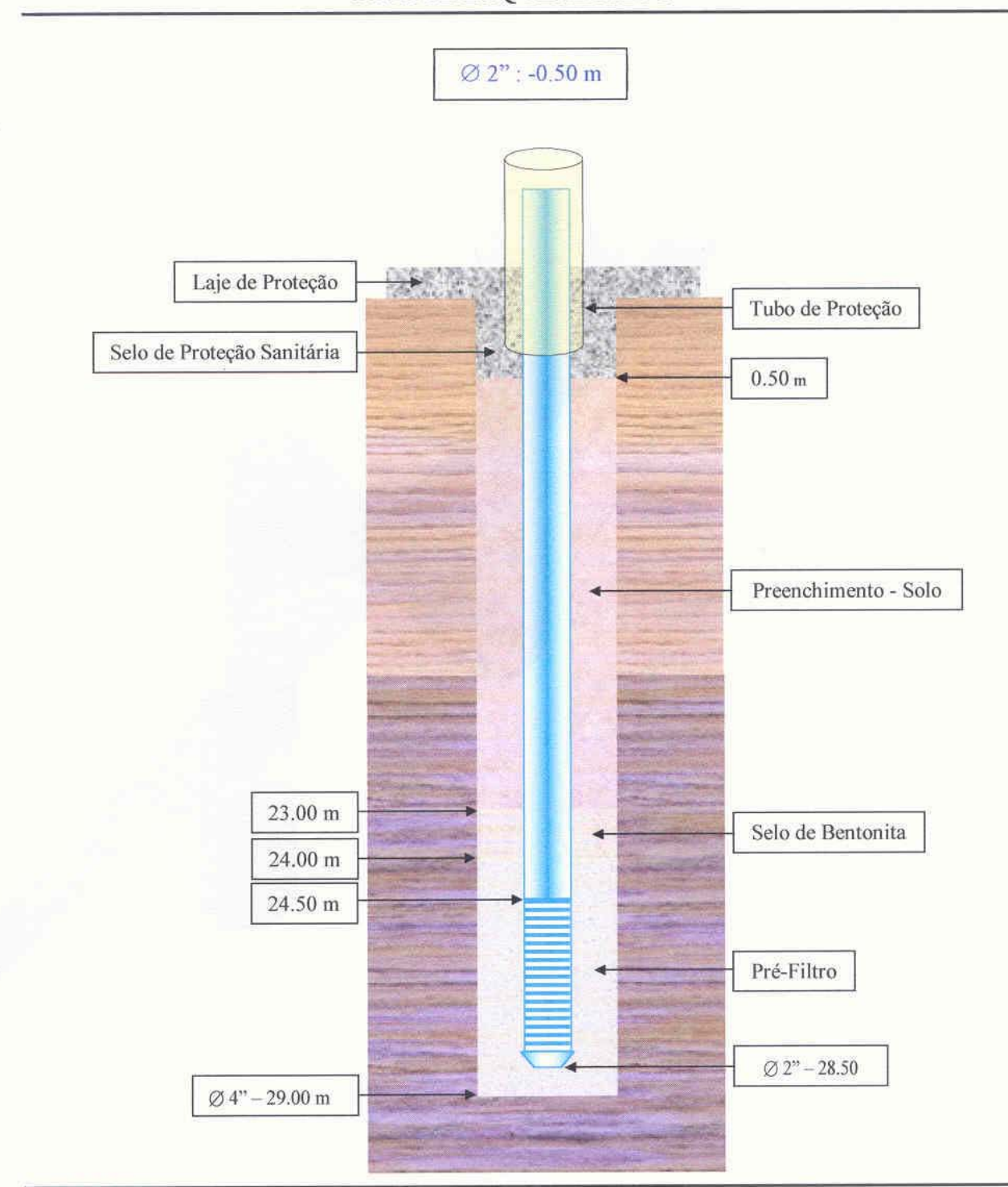

Rua General Osório no 1630 - Vila Seixas - CEP: 14.015-030 - Ribeirão Preto - SP Fonefax: (16)3941-4616 - Email: geoinvest@uol.com.br 


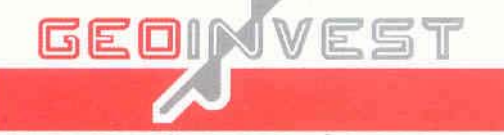

\section{POÇO DE MONITORAMENTO}

"PJ-2"

\section{DADOS GERAIS}

\begin{tabular}{lrlr}
\hline Localização & & Figura 1 & \\
Cota do Nível do Terreno & $83.50 \mathrm{~m}$ & Posição do Revestimento & $-0.50 \mathrm{~m}$ \\
Profundidade Perfurada & $17.50 \mathrm{~m}$ & Profundidade Revestida & $17.00 \mathrm{~m}$ \\
Diâmetro da Perfuração & $5 "$ & Diâmetro do Revestimento & $2 "$ \\
Nível Estático & $12.99 \mathrm{~m}$ (11 Ago. 2004) & Volume de Água no Revestimento & $6.9 \ell$ \\
\hline
\end{tabular}

\section{DATAS PRINCIPAIS}

\begin{tabular}{|c|c|c|}
\hline Etapas & Datas & Equipamento \\
\hline Perfuração & $09-10$ Ago. 2004 & Trado Mecanizado \\
\hline Revestimento & - & Não utilizado \\
\hline Pré-Filtro & 23 Ago. 2004 & \\
\hline Selo de Bentonita & 23 Ago. 2004 & \\
\hline Laje de Proteção & 24 Ago. 2004 & \\
\hline Desinfecção & 27 Ago. 2004 & \\
\hline \multirow[t]{2}{*}{ Desenvolvimento } & 31 Ago. 2004 & Bailers Descartáveis \\
\hline & \multicolumn{2}{|l|}{ PERFURAÇÃO } \\
\hline Intervalo & \multicolumn{2}{|l|}{$0.00 \mathrm{a} 17.50 \mathrm{~m}$} \\
\hline Método & \multicolumn{2}{|c|}{ Trado Mecanizado a Seco } \\
\hline Equipamentos (Perfuratriz) & \multicolumn{2}{|c|}{01 Trado Helicoidal Mecanizado DN 5" } \\
\hline
\end{tabular}

Rua General Osório n ${ }^{\circ} 1630$ - Vila Seixas - CEP: 14.015-030 - Ribeirão Preto - SP Fonefax: (16)3941-4616 - Email: geoinvest@uol.com.br 


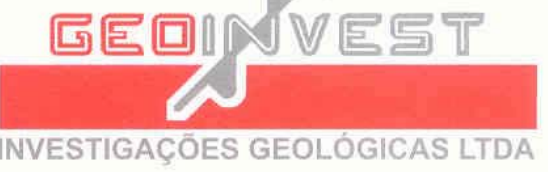

\section{POÇO DE MONITORAMENTO}

"PJ-2"

\section{REVESTIMENTO}

\begin{tabular}{|c|c|c|c|c|c|c|}
\hline \multirow[t]{2}{*}{$\begin{array}{c}\text { Peça } \\
n^{\circ}\end{array}$} & \multirow[t]{2}{*}{$\begin{array}{l}\text { Tipo } \\
\text { de } \\
\text { Peça }\end{array}$} & \multicolumn{2}{|c|}{$\begin{array}{c}\text { Comprimento } \\
\text { da Peça } \\
\text { (m) }\end{array}$} & \multirow{2}{*}{$\begin{array}{l}\text { Profundidade } \\
\text { da Peça } \\
\text { Instalada } \\
\text { (m) }\end{array}$} & \multirow{2}{*}{$\begin{array}{l}\text { Comprimento } \\
\text { Total da } \\
\text { Coluna } \\
\text { (m) }\end{array}$} & \multirow{2}{*}{$\begin{array}{l}\text { Profundidade } \\
\text { Instalada do } \\
\text { Centralizador } \\
\text { (m) }\end{array}$} \\
\hline & & parcial & total & & & \\
\hline 01 & Cap & - & - & 17.00 & - & \\
\hline 02 & Filtro & 2.00 & & 17.00 & 2.00 & 17.00 \\
\hline 03 & Filtro & 2.00 & 5.00 & 15.00 & 4.00 & \\
\hline 04 & Filtro & 1.00 & & 13.00 & 5.00 & \\
\hline 05 & Tubo Liso & 2.00 & & 12.00 & 7.00 & 12.00 \\
\hline 06 & Tubo Liso & 2.00 & & 10.00 & 9.00 & \\
\hline 07 & Tubo Liso & 2.00 & & 8.00 & 11.00 & \\
\hline 08 & Tubo Liso & 2.00 & 12.50 & 6.00 & 13.00 & \\
\hline 09 & Tubo Liso & 2.00 & & 4.00 & 15.00 & \\
\hline 10 & Tubo Liso & 2.00 & & 2.00 & 17.00 & \\
\hline 11 & Tubo Liso & 0.50 & & 0.00 & 17.50 & \\
\hline 12 & Cap & - & - & -0.50 & - & \\
\hline
\end{tabular}

PRÉ-FILTRO

\begin{tabular}{|c|c|c|c|c|}
\hline \multicolumn{2}{|c|}{ Intervalo } & Espaço & Método & Volume \\
\hline $\begin{array}{l}d e \\
(m)\end{array}$ & $\begin{array}{c}a \\
(m)\end{array}$ & $\begin{array}{c}\text { Anular } \\
\text { (pol) }\end{array}$ & $\begin{array}{c}\text { de } \\
\text { Colocação }\end{array}$ & Colocado (l) \\
\hline 17.50 & 11.50 & $5 \times 2.4$ & Gravidade & 60 \\
\hline \multicolumn{5}{|c|}{ SELO DE BENTONITA } \\
\hline \multicolumn{2}{|c|}{ Intervalo } & Espaço & Método & Volume \\
\hline $\begin{array}{l}\text { de } \\
\text { (m) }\end{array}$ & $\begin{array}{c}a \\
(m)\end{array}$ & $\begin{array}{l}\text { Anular } \\
\text { (pol) }\end{array}$ & $\begin{array}{c}\text { de } \\
\text { Colocação }\end{array}$ & Colocado (l) \\
\hline 11.50 & 10.50 & $5 \times 2.4$ & Gravidade & 10 \\
\hline
\end{tabular}

Rua General Osório n 1630 - Vila Seixas - CEP: 14.015-030 - Ribeirão Preto - SP Fonefax: (16)3941-4616 - Email: geoinvest@uol.com.br 


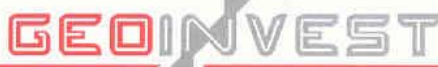 \\ INVESTIGAÇÖES GEOLÓGICAS LTDA}

\begin{tabular}{|c|}
\hline POÇO DE MONITORAMENTO \\
"PJ-2" \\
\hline
\end{tabular}

\section{PREENCHIMENTO - SOLO}

\begin{tabular}{|c|c|c|c|c|}
\hline \multicolumn{2}{|c|}{ Intervalo } & \multirow{2}{*}{$\begin{array}{c}\text { Espaço } \\
\text { Anular } \\
\text { (pol) }\end{array}$} & \multirow{2}{*}{$\begin{array}{c}\text { Método } \\
\text { de } \\
\text { Colocação }\end{array}$} & \multirow{2}{*}{$\begin{array}{c}\text { Volume } \\
\text { Calculado } \\
\text { (l) }\end{array}$} \\
\hline $\begin{array}{l}d e \\
(m)\end{array}$ & $\begin{array}{c}a \\
(m)\end{array}$ & & & \\
\hline 10.50 & 0.50 & $5 \times 2.4$ & Gravidade & 98 \\
\hline
\end{tabular}

\section{SELO DE PROTEÇÃO SANITÁRIA}

\begin{tabular}{|c|c|c|c|c|c|c|}
\hline \multicolumn{2}{|c|}{ Intervalo } & \multirow{2}{*}{$\begin{array}{c}\text { Espaço } \\
\text { Anular } \\
\text { (pol) }\end{array}$} & \multirow[b]{2}{*}{ Material } & \multirow{2}{*}{$\begin{array}{c}\text { Traço } \\
d a \\
\text { Mistura }\end{array}$} & \multirow{2}{*}{$\begin{array}{c}\text { Método } \\
\text { de } \\
\text { Colocação }\end{array}$} & \multirow{2}{*}{$\begin{array}{c}\text { Volume } \\
\text { Calculado } \\
\text { (l) }\end{array}$} \\
\hline $\begin{array}{l}d e \\
(m)\end{array}$ & $\begin{array}{c}a \\
(m)\end{array}$ & & & & & \\
\hline 0.50 & 0.00 & $6 \times 2.5$ & Concreto & $1: 2: 3$ & Gravidade & 9 \\
\hline
\end{tabular}

TUBO DE PROTEÇÃO

\begin{tabular}{llcc}
\hline Especificação & $N^{o}$ de Peças & Comprimento Total $(\mathrm{m})$ \\
Tubo de Proteção DN 6" de Alumínio & 1 & 0.60 \\
\hline & \multicolumn{3}{c}{ LAJE DE PROTEÇÃO } \\
\hline Dimensões & Comprimento & $0.65 \mathrm{~m} \times 0.65 \mathrm{~m}$ \\
Material & Espessura & $0.15 \mathrm{~m}$ \\
\hline
\end{tabular}

Rua General Osório no 1630 - Vila Seixas - CEP: 14.015-030 - Ribeirão Preto - SP Fonefax: (16)3941-4616 - Email: geoinvest@uol.com.br 


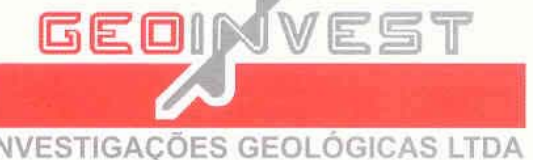

\section{POÇO DE MONITORAMENTO \\ "PJ-2"}

\section{PERFIL GEOLÓGICO}

\begin{tabular}{|c|c|c|c|}
\hline \multicolumn{2}{|c|}{ Profundidades (m) } & Descrição Textural & \multirow{2}{*}{$\begin{array}{l}\text { Classificação Genética } \\
\text { Unidade Geológica } \\
\text { Colúvio / Coberturas } \\
\text { Cenozóicas }\end{array}$} \\
\hline 0.00 & $-\quad 2.60$ & Areia fina silto-argilosa, vermelha clara. & \\
\hline 2.60 & 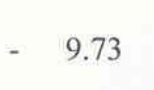 & $\begin{array}{l}\text { Areia fina siltosa, vermelha clara com } \\
\text { manchas variegadas. }\end{array}$ & \\
\hline 9.73 & - $\quad 13.12$ & $\begin{array}{l}\text { Areia fina a média argilo-siltosa, com } \\
\text { eventuais nódutos de argila (basalto } \\
\text { alterado), variegada. }\end{array}$ & $\begin{array}{l}\text { Solo Residual de } \\
\text { Arenito / Formação } \\
\text { Itaqueri }\end{array}$ \\
\hline 13.12 & - $\quad 17.50$ & $\begin{array}{c}\text { Areia fina a média silto-argilosa, } \\
\text { vermelha clara com manchas } \\
\text { variegadas. }\end{array}$ & \\
\hline
\end{tabular}

\section{CLASSIFICAČ̃̃O HIDROGEOLÓGICA}

\begin{tabular}{ll}
\hline Unidade Geológica & Solo Residual de Arenito - Formação Itaqueri \\
Unidade Hidrogeológica & Aquitardo Solo Residual
\end{tabular}

Rua General Osório n 1630 - Vila Seixas - CEP: 14.015-030 - Ribeirão Preto - SP Fonefax: (16)3941-4616 - Email: geoinvest@uol.com.br 

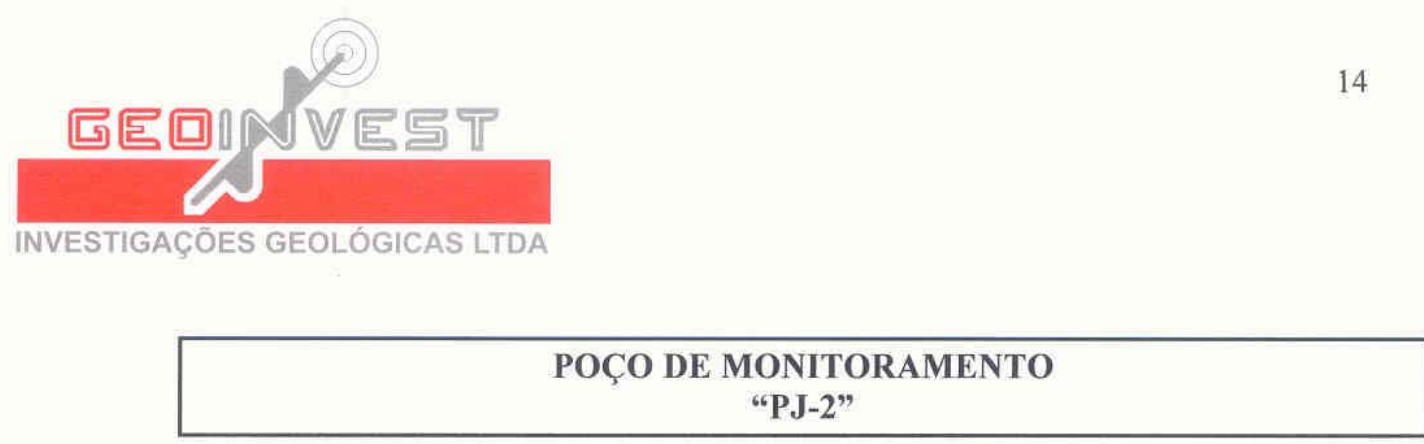

\section{PERFIL ESQUEMÁTICO}

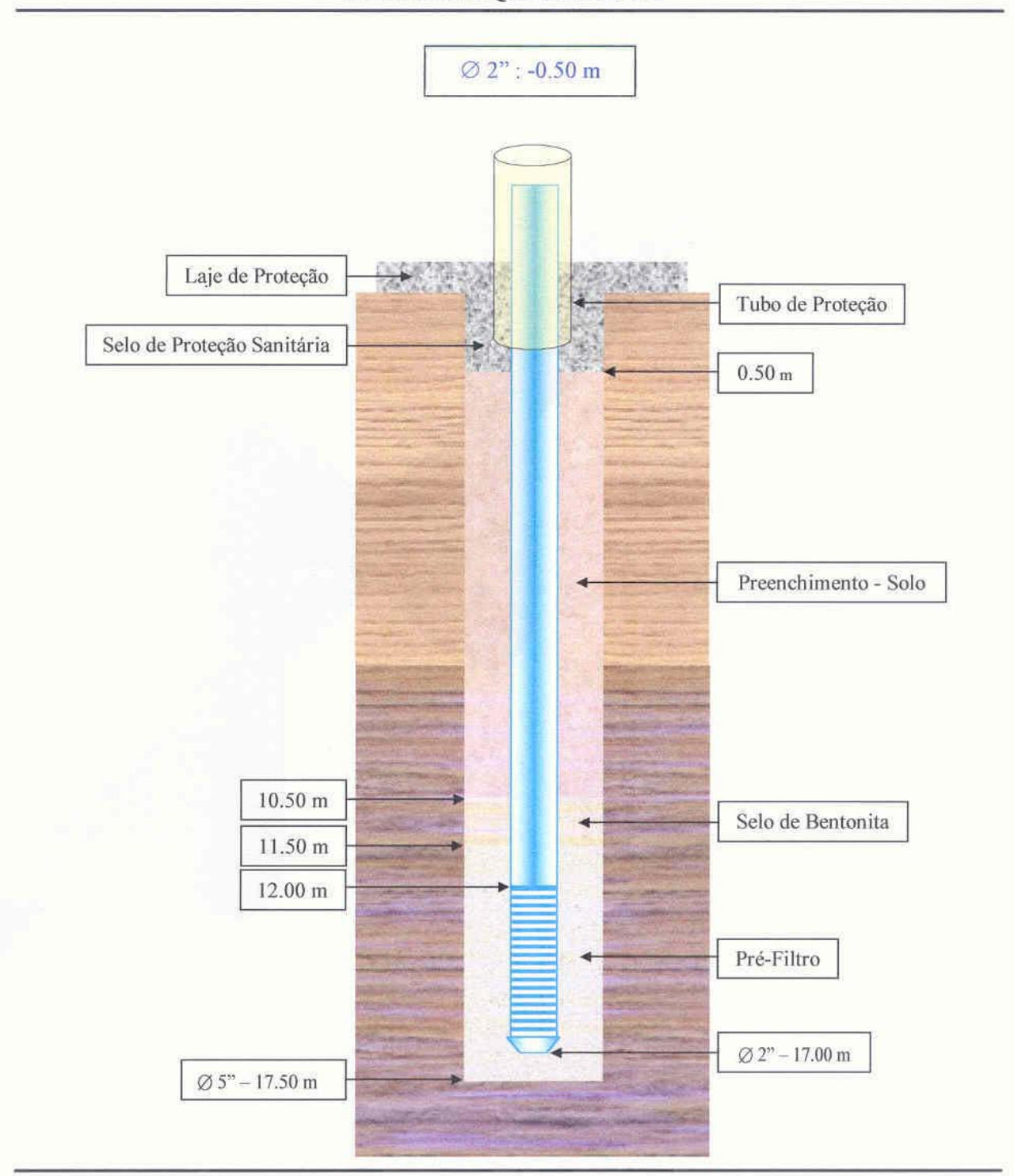

Rua General Osório n 1630 - Vila Seixas - CEP: 14.015-030 - Ribeirão Preto - SP

Fonefax: (16)3941-4616 - Email: geoinvest@uol.com.br 


\section{POÇO DE MONITORAMENTO}

"PJ-3"

\section{DADOS GERAIS}

\begin{tabular}{lrlr}
\hline Localização & & Figura 1 & \\
Cota do Nivel do Terreno & $85.00 \mathrm{~m}$ & Posição do Revestimento & $-0.50 \mathrm{~m}$ \\
Profundidade Perfurada & $18.00 \mathrm{~m}$ & Profundidade Revestida & $17.50 \mathrm{~m}$ \\
Diâmetro da Perfuração & $4 "$ & Diâmetro do Revestimento & $2 "$ \\
Nível Estático & $15.50 \mathrm{~m}$ (26 Ago. 2004) & Volume de Água no Revestimento & $3.9 \ell$ \\
\hline
\end{tabular}

\section{DATAS PRINCIPAIS}

\begin{tabular}{|c|c|c|}
\hline Etapas & $\underline{\text { Datas }}$ & Equipamento \\
\hline Perfuração & 26 Ago. 2004 & Trado Mecanizado \\
\hline Revestimento & - & Não utilizado \\
\hline Pré-Filtro & 26 Ago. 2004 & \\
\hline Selo de Bentonita & 26 Ago. 2004 & \\
\hline Laje de Proteção & 26 Ago. 2004 & \\
\hline Desinfecção & 27 Ago. 2004 & \\
\hline Desenvolvimento & 31 Ago. 2004 & Bailers Descartáveis \\
\hline \multicolumn{3}{|c|}{ PERFURAÇÃO } \\
\hline Intervalo & \multicolumn{2}{|l|}{0.00 a $18.00 \mathrm{~m}$} \\
\hline Método & \multicolumn{2}{|c|}{ Trado Mecanizado a Seco } \\
\hline Equipamentos (Perfuratriz) & \multicolumn{2}{|c|}{01 Trado Helicoidal Mecanizado DN 4" } \\
\hline
\end{tabular}

Rua General Osório n 1630 - Vila Seixas - CEP: 14.015-030 - Ribeirão Preto - SP Fonefax: (16) 3941-4616 - Email: geoinvest@uol.com.br 


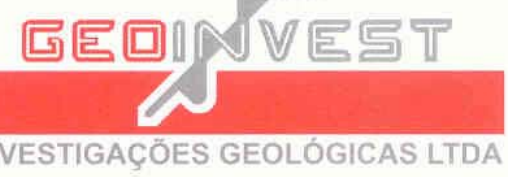

\begin{tabular}{|c|}
\hline POÇO DE MONITORAMENTO \\
"PJ-3" \\
\hline
\end{tabular}

\section{REVESTIMENTO}

\begin{tabular}{|c|c|c|c|c|c|c|}
\hline \multirow[t]{2}{*}{$\begin{array}{c}\text { Peça } \\
n^{\circ}\end{array}$} & \multirow[t]{2}{*}{$\begin{array}{l}\text { Tipo } \\
\text { de } \\
\text { Peça }\end{array}$} & \multicolumn{2}{|c|}{$\begin{array}{c}\text { Comprimento } \\
\text { da Peça } \\
\text { (m) }\end{array}$} & \multirow{2}{*}{$\begin{array}{c}\text { Profundidade } \\
\text { da Peça } \\
\text { Instalada } \\
\text { (m) }\end{array}$} & \multirow{2}{*}{$\begin{array}{c}\text { Comprimento } \\
\text { Total da } \\
\text { Coluna } \\
\text { (m) }\end{array}$} & \multirow{2}{*}{$\begin{array}{c}\text { Profundidade } \\
\text { Instalada do } \\
\text { Centralizador } \\
\text { (m) }\end{array}$} \\
\hline & & parcial & total & & & \\
\hline 01 & Cap & - & - & 17.50 & - & \multirow{3}{*}{17.50} \\
\hline 02 & Filtro & 2.00 & \multirow{2}{*}{4.00} & 17.50 & 2.00 & \\
\hline 03 & Filtro & 2.00 & & 15.50 & 4.00 & \\
\hline 04 & Tubo Liso & 2.00 & \multirow{7}{*}{14.00} & 13.50 & 6.00 & \multirow[t]{7}{*}{13.50} \\
\hline 05 & Tubo Liso & 2.00 & & 11.50 & 8.00 & \\
\hline 06 & Tubo Liso & 2.00 & & 9.50 & 10.00 & \\
\hline 07 & Tubo Liso & 2.00 & & 7.50 & 12.00 & \\
\hline 08 & Tubo Liso & 2.00 & & 5.50 & 14.00 & \\
\hline 09 & Tubo Liso & 2.00 & & 3.50 & 16.00 & \\
\hline 06 & Tubo Liso & 2.00 & & 1.50 & 18.00 & \\
\hline 08 & Cap & - & - & -0.50 & - & \\
\hline
\end{tabular}

\section{PRÉ-FILTRO}

\begin{tabular}{|c|c|c|c|c|}
\hline \multicolumn{2}{|c|}{ Intervalo } & \multirow{2}{*}{$\begin{array}{c}\text { Espaço } \\
\text { Anular } \\
\text { (pol) }\end{array}$} & \multirow{2}{*}{$\begin{array}{c}\text { Método } \\
\text { de } \\
\text { Colocação }\end{array}$} & \multirow{2}{*}{$\begin{array}{c}\text { Volume } \\
\text { Colocado }(\ell)\end{array}$} \\
\hline $\begin{array}{l}d e \\
\text { (m) }\end{array}$ & $\begin{array}{c}a \\
(m)\end{array}$ & & & \\
\hline 17.50 & 13.00 & $4 \times 2.4$ & Gravidade & 24 \\
\hline
\end{tabular}

SELO DE BENTONITA

\begin{tabular}{ccccc}
\hline & Intervalo & Espaço & Método & Volume \\
de & $a$ & $\begin{array}{c}\text { Anular } \\
(\text { pol })\end{array}$ & $\begin{array}{c}\text { de } \\
\text { Colocação }\end{array}$ & Colocado ()$)$ \\
$(\mathrm{m})$ & $(\mathrm{m})$ & $4 \times 2.4$ & Gravidade & 5 \\
\hline
\end{tabular}

Rua General Osório nº 1630 - Vila Seixas - CEP: 14.015-030 - Ribeirão Preto - SP Fonefax: (16)3941-4616 - Email: geoinvest@uol.com.br 


\section{POÇO DE MONITORAMENTO}

"PJ-3"

\begin{tabular}{ccccc}
\multicolumn{5}{c}{ PREENCHIMENTO - SOLO } \\
\hline \multirow{2}{*}{ Intervalo } & Espaço & Método & Volume \\
de & $a$ & Anular & de & Calculado \\
$(\mathrm{m})$ & $(\mathrm{m})$ & $($ pol $)$ & Colocação & () \\
12.00 & 0.50 & $4 \times 2.4$ & Gravidade & 57 \\
\hline
\end{tabular}

SELO DE PROTEÇÃO SANITÁRIA

\begin{tabular}{|c|c|c|c|c|c|c|}
\hline \multicolumn{2}{|c|}{ Intervalo } & \multirow{2}{*}{$\begin{array}{l}\text { Espaço } \\
\text { Anular } \\
\text { (pol) }\end{array}$} & \multirow[b]{2}{*}{ Material } & \multirow{2}{*}{$\begin{array}{c}\text { Traço } \\
\text { da } \\
\text { Mistura }\end{array}$} & \multirow{2}{*}{$\begin{array}{c}\text { Método } \\
\text { de } \\
\text { Colocação }\end{array}$} & \multirow{2}{*}{$\begin{array}{c}\text { Volume } \\
\text { Calculado } \\
\text { (l) }\end{array}$} \\
\hline $\begin{array}{l}d e \\
(m)\end{array}$ & $\begin{array}{c}a \\
(m)\end{array}$ & & & & & \\
\hline 0.50 & 0.00 & $6 \times 2.5$ & Concreto & $1: 2: 3$ & Gravidade & 9 \\
\hline
\end{tabular}

TUBO DE PROTEÇÃO

\begin{tabular}{cccc}
\hline Especificação & $N^{o}$ de Peças & Comprimento Total $(\mathrm{m})$ \\
Tubo de Proteção DN 6" de Alumínio & 1 & 0.60 \\
\hline & & \\
\multicolumn{3}{c}{ LAJE DE PROTEÇÃO } \\
\hline Dimensões & Comprimento & $0.65 \mathrm{~m} \mathrm{x} 0.65 \mathrm{~m}$ \\
Material & Espessura & $0.15 \mathrm{~m}$ \\
\hline
\end{tabular}




\section{POÇO DE MONITORAMENTO}

"PJ-3"

\section{PERFIL GEOLÓGICO}

\begin{tabular}{|c|c|c|c|}
\hline \multicolumn{2}{|c|}{ Profundidades (m) } & Descrição Textural & \multirow{2}{*}{$\begin{array}{l}\text { Classificação Genética / } \\
\text { Unidade Geológica } \\
\text { Colúvio / Coberturas } \\
\text { Cenozóicas }\end{array}$} \\
\hline 0.00 & - $\quad 4.97$ & Areia fina silto-argilosa, vermelha clara. & \\
\hline 4.97 & $\begin{array}{l}-\quad 7.80 \\
-1\end{array}$ & $\begin{array}{l}\text { Areia fina siltosa, vermelha com } \\
\text { manchas variegadas. }\end{array}$ & \\
\hline 7.80 & $-\quad 14.70$ & $\begin{array}{c}\text { Areia fina a média silto-argilosa, } \\
\text { variegada. }\end{array}$ & $\begin{array}{l}\text { Solo Residual de } \\
\text { Arenito / Formação } \\
\text { Itaqueri }\end{array}$ \\
\hline 14.70 & - $\quad 18.00$ & $\begin{array}{l}\text { Areia fina a média argilo-siltosa, } \\
\text { vermelha clara amarelada com manchas } \\
\text { variegadas. }\end{array}$ & \\
\hline \multicolumn{4}{|c|}{ CLASSIFICAÇÃO HIDROGEOLÓGICA } \\
\hline \multirow{2}{*}{\multicolumn{2}{|c|}{$\begin{array}{l}\text { Unidade Geológica } \\
\text { Unidade Hidrogeológica }\end{array}$}} & \multicolumn{2}{|c|}{ Solo Residual de Arenito - Formação Itaqueri } \\
\hline & & Aquitardo Solo Residual & \\
\hline
\end{tabular}

Rua General Osório n 1630 - Vila Seixas - CEP: 14.015-030 - Ribeirão Preto - SP Fonefax: (16)3941-4616 - Email: geoinvest@uol.com.br 


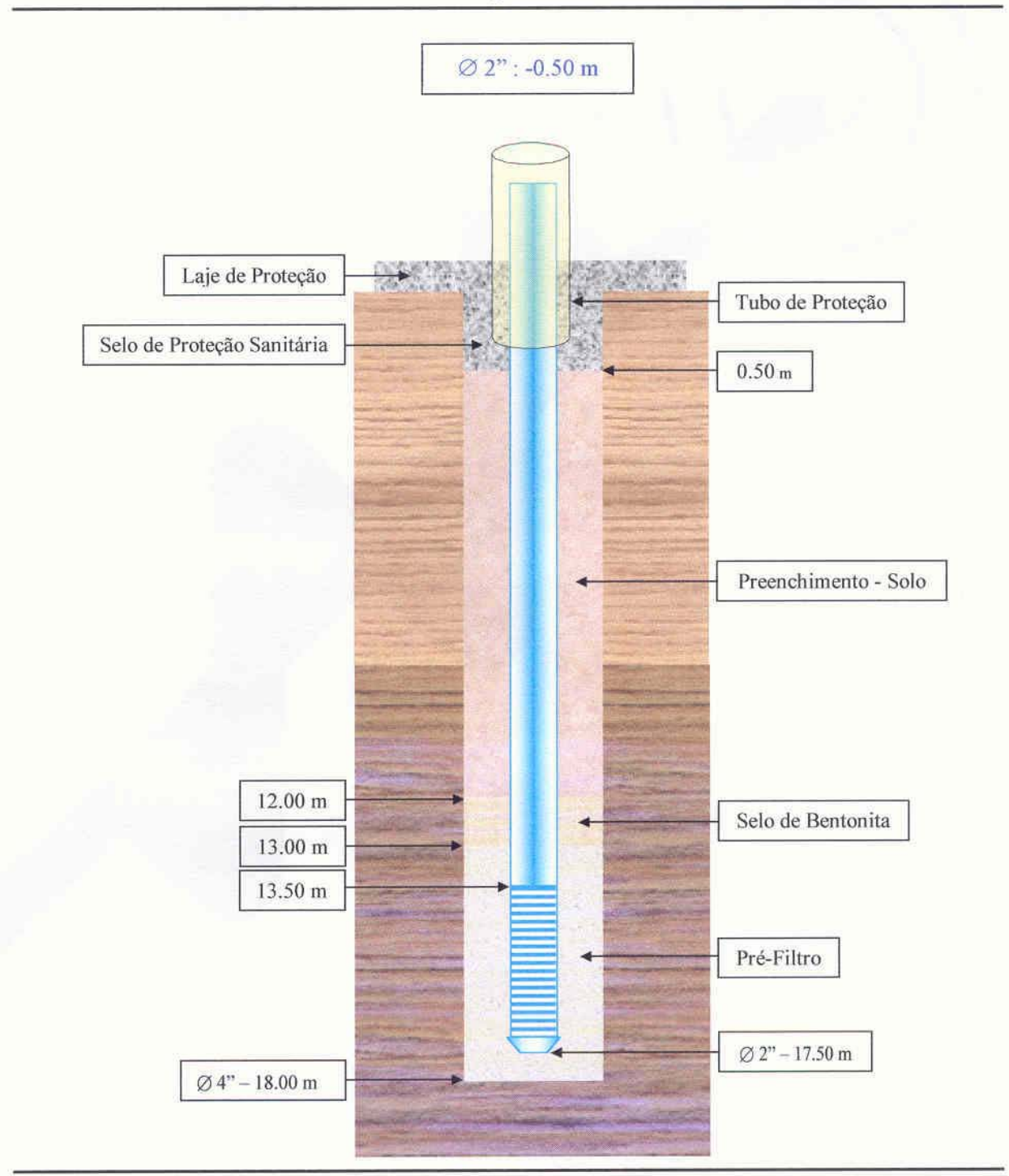

Rua General Osório n ${ }^{\circ} 1630$ - Vila Seixas - CEP: 14.015-030 - Ribeirão Preto - SP Fonefax: (16)3941-4616 - Email: geoinvest@uol.com.br 


\section{POÇO DE MONITORAMENTO \\ "PJ-4"}

\section{DADOS GERAIS}

\begin{tabular}{lrlr}
\hline Localização & & Figura 1 & \\
Cota do Nivel do Terreno & $64.75 \mathrm{~m}$ & Posição do Revestimento & $-0.50 \mathrm{~m}$ \\
Profundidade Perfurada & $9.50 \mathrm{~m}$ & Profundidade Revestida & $9.00 \mathrm{~m}$ \\
Diâmetro da Perfuração & $5 "$ & Diâmetro do Revestimento & $2 "$ \\
Nível Estático & $5.28 \mathrm{~m}$ (23 Ago. 2004) & Volume de Água no Revestimento & $7.3 \ell$ \\
\hline
\end{tabular}

\section{DATAS PRINCIPAIS}

\begin{tabular}{|c|c|c|}
\hline Etapas & $\underline{\text { Datas }}$ & Equipamento \\
\hline Perfuração & 23 Ago. 2004 & Trado Mecanizado \\
\hline Revestimento & - & Não utilizado \\
\hline Pré-Filtro & 24 Ago. 2004 & \\
\hline Selo de Bentonita & 24 Ago. 2004 & \\
\hline Laje de Proteção & 24 Ago. 2004 & \\
\hline Desinfecção & 26 Ago. 2004 & \\
\hline Desenvolvimento & 31 Ago. 2004 & Bailers Descartáveis \\
\hline \multicolumn{3}{|c|}{ PERFURAÇÃO } \\
\hline Intervalo & \multicolumn{2}{|l|}{0.00 a $9.50 \mathrm{~m}$} \\
\hline Método & \multicolumn{2}{|c|}{ Trado Mecanizado a Seco } \\
\hline Equipamentos (Perfuratriz) & \multicolumn{2}{|c|}{01 Trado Helicoidal Mecanizado DN 5" } \\
\hline
\end{tabular}

Rua General Osório no 1630 - Vila Seixas - CEP: 14.015-030 - Ribeirão Preto - SP Fonefax: (16)3941-4616 - Email: geoinvest@uol.com.br 


\section{POÇO DE MONITORAMENTO}

"PJ-4"

\section{REVESTIMENTO}

\begin{tabular}{|c|c|c|c|c|c|c|}
\hline \multirow[t]{2}{*}{$\begin{array}{c}\text { Peça } \\
n^{\circ}\end{array}$} & \multirow{2}{*}{$\begin{array}{l}\text { Tipo } \\
\text { de } \\
\text { Peça }\end{array}$} & \multicolumn{2}{|c|}{$\begin{array}{l}\text { Comprimento } \\
\text { da Peça } \\
\text { (m) }\end{array}$} & \multirow{2}{*}{$\begin{array}{l}\text { Profundidade } \\
\text { da Peça } \\
\text { Instalada } \\
\text { (m) }\end{array}$} & \multirow{2}{*}{$\begin{array}{l}\text { Comprimento } \\
\text { Total da } \\
\text { Coluna } \\
\text { (m) }\end{array}$} & \multirow{2}{*}{$\begin{array}{l}\text { Profundidade } \\
\text { Instalada do } \\
\text { Centralizador } \\
\text { (m) }\end{array}$} \\
\hline & & parcial & total & & & \\
\hline 01 & Cap & - & - & 9.00 & - & \multirow{7}{*}{9.00} \\
\hline 02 & Filtro & 2.00 & \multirow{2}{*}{4.00} & 9.00 & 2.00 & \\
\hline 03 & Filtro & 2.00 & & 7.00 & 4.00 & \\
\hline 04 & Tubo Liso & 2.00 & \multirow{4}{*}{5.50} & 5.00 & 6.00 & \\
\hline 05 & Tubo Liso & 2.00 & & 3.00 & 8.00 & \\
\hline 06 & Tubo Liso & 1.00 & & 1.00 & 9.00 & \\
\hline 07 & Tubo Liso & 0.50 & & 0.00 & 9.50 & \\
\hline 08 & Cap & - & - & -0.50 & - & \\
\hline
\end{tabular}

\section{PRÉ-FILTRO}

\begin{tabular}{|c|c|c|c|c|}
\hline \multicolumn{2}{|c|}{ Intervalo } & Espaço & Método & Volume \\
\hline $\begin{array}{l}d e \\
(m)\end{array}$ & $\begin{array}{c}a \\
(m)\end{array}$ & $\begin{array}{c}\text { Anular } \\
\text { (pol) }\end{array}$ & $\begin{array}{c}d e \\
\text { Colocação }\end{array}$ & Colocado (l) \\
\hline 9.00 & 4.50 & $5 \times 2.4$ & Gravidade & 45 \\
\hline
\end{tabular}

SELO DE BENTONITA

\begin{tabular}{ccccc}
\hline & Intervalo & Espaço & Método & Volume \\
de & $a$ & Anular & de & Colocado $(\mathrm{l})$ \\
$(\mathrm{m})$ & $(\mathrm{mol})$ & $5 \times 2.4$ & Gravidade & 10 \\
4.50 & 3.50 & $5 \times 2.4$ & \\
\hline
\end{tabular}

Rua General Osório no 1630 - Vila Seixas - CEP: 14.015-030 - Ribeirão Preto - SP Fonefax: (16)3941-4616 - Email: geoinvest@uol.com.br 


\section{POÇO DE MONITORAMENTO}

"PJ-4"

\begin{tabular}{|c|c|c|c|c|}
\hline \multicolumn{5}{|c|}{ PREENCHIMENTO - SOLO } \\
\hline & & Espaço & Método & Volume \\
\hline $\begin{array}{l}d e \\
\text { (m) }\end{array}$ & $\begin{array}{c}a \\
(m)\end{array}$ & $\begin{array}{c}\text { Anular } \\
\text { (pol) }\end{array}$ & $\begin{array}{c}\text { de } \\
\text { Colocação }\end{array}$ & $\begin{array}{c}\text { Calculado } \\
\text { (l) }\end{array}$ \\
\hline 3.50 & 0.50 & $5 \times 2.4$ & Gravidade & 29 \\
\hline
\end{tabular}

SELO DE PROTEÇÃO SANITÁRIA

\begin{tabular}{|c|c|c|c|c|c|c|}
\hline \multicolumn{2}{|c|}{ Intervalo } & \multirow{2}{*}{$\begin{array}{c}\text { Espaço } \\
\text { Anular } \\
\text { (pol) }\end{array}$} & \multirow[b]{2}{*}{ Material } & \multirow{2}{*}{$\begin{array}{c}\text { Traço } \\
\text { da } \\
\text { Mistura }\end{array}$} & \multirow{2}{*}{$\begin{array}{c}\text { Método } \\
\text { de } \\
\text { Colocação }\end{array}$} & \multirow{2}{*}{$\begin{array}{c}\text { Volume } \\
\text { Calculado } \\
\text { (l) }\end{array}$} \\
\hline $\begin{array}{l}d e \\
(m)\end{array}$ & $\begin{array}{c}a \\
(m)\end{array}$ & & & & & \\
\hline 0.50 & 0.00 & $6 \times 2.5$ & Concreto & $1: 2: 3$ & Gravidade & 9 \\
\hline
\end{tabular}

TUBO DE PROTEÇÃO

\begin{tabular}{|c|c|c|c|}
\hline \multicolumn{2}{|c|}{ Especificação } & $N^{o}$ de Peças & Comprimento Total $(\mathrm{m})$ \\
\hline \multicolumn{2}{|c|}{ Tubo de Proteção DN 6" de Alumínio } & 1 & 0.60 \\
\hline \multicolumn{4}{|c|}{ LAJE DE PROTEÇÃO } \\
\hline \multirow{2}{*}{$\underline{\text { Dimensões }}$} & Comprimento & $0.65 \mathrm{~m} \times 0.65 \mathrm{~m}$ & \\
\hline & Espessura & $0.15 \mathrm{~m}$ & \\
\hline Material & Concreto & & \\
\hline
\end{tabular}

Rua General Osório n ${ }^{\circ} 1630$ - Vila Seixas - CEP: 14.015-030 - Ribeirão Preto - SP Fonefax: (16)3941-4616 - Email: geoinvest@uol.com.br 
POÇO DE MONITORAMENTO

"PJ-4"

\section{PERFIL GEOLÓGICO}

\begin{tabular}{|c|c|c|c|}
\hline \multicolumn{2}{|c|}{ Profundidades (m) } & Descrição Textural & $\begin{array}{l}\text { Classificação Genétical } \\
\text { Unidade Geológica }\end{array}$ \\
\hline 0.00 & -1.83 & $\begin{array}{l}\text { Aterro de areia fina siltosa, vermelha } \\
\text { clara amarelada }\end{array}$ & - \\
\hline 1.83 & $-\quad 5.20$ & $\begin{array}{c}\text { Areia fina silto-argilosa, vermelha clara } \\
\text { amarelada. }\end{array}$ & $\begin{array}{l}\text { Colúvio / Coberturas } \\
\text { Cenozóicas }\end{array}$ \\
\hline 5.20 & -7.08 & Areia fina siltosa, variegada (amarela). & \\
\hline 7.08 & -9.14 & $\begin{array}{l}\text { Argila siltosa, pouco arenosa, cinza com } \\
\text { manchas variegadas. }\end{array}$ & $\begin{array}{c}\text { Paleoaluvião / } \\
\text { Sedimentos Cenozóicos }\end{array}$ \\
\hline 9.14 & -9.50 & $\begin{array}{l}\text { Areia fina muito siltosa, cinza clara e } \\
\text { branca }\end{array}$ & \\
\hline
\end{tabular}

\section{CLASSIFICAÇÃO HIDROGEOLÓGICA}

\begin{tabular}{ll}
\hline Unidade Geológica & Sedimentos Aluvionares \\
Unidade Hidrogeológica & Aquitardo Sedimentos Aluvionares \\
\hline
\end{tabular}

Rua General Osório nº 1630 - Vila Seixas - CEP: 14.015-030 - Ribeirão Preto - SP Fonefax: (16)3941-4616 - Email: geoinvest@uol.com.br 


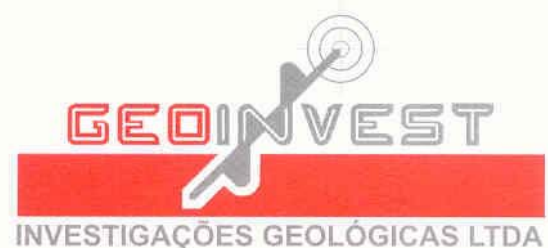

POÇO DE MONITORAMENTO

"PJ-4"

\section{PERFIL ESQUEMÁTICO}

$\varnothing 2 ":-0.50 \mathrm{~m}$

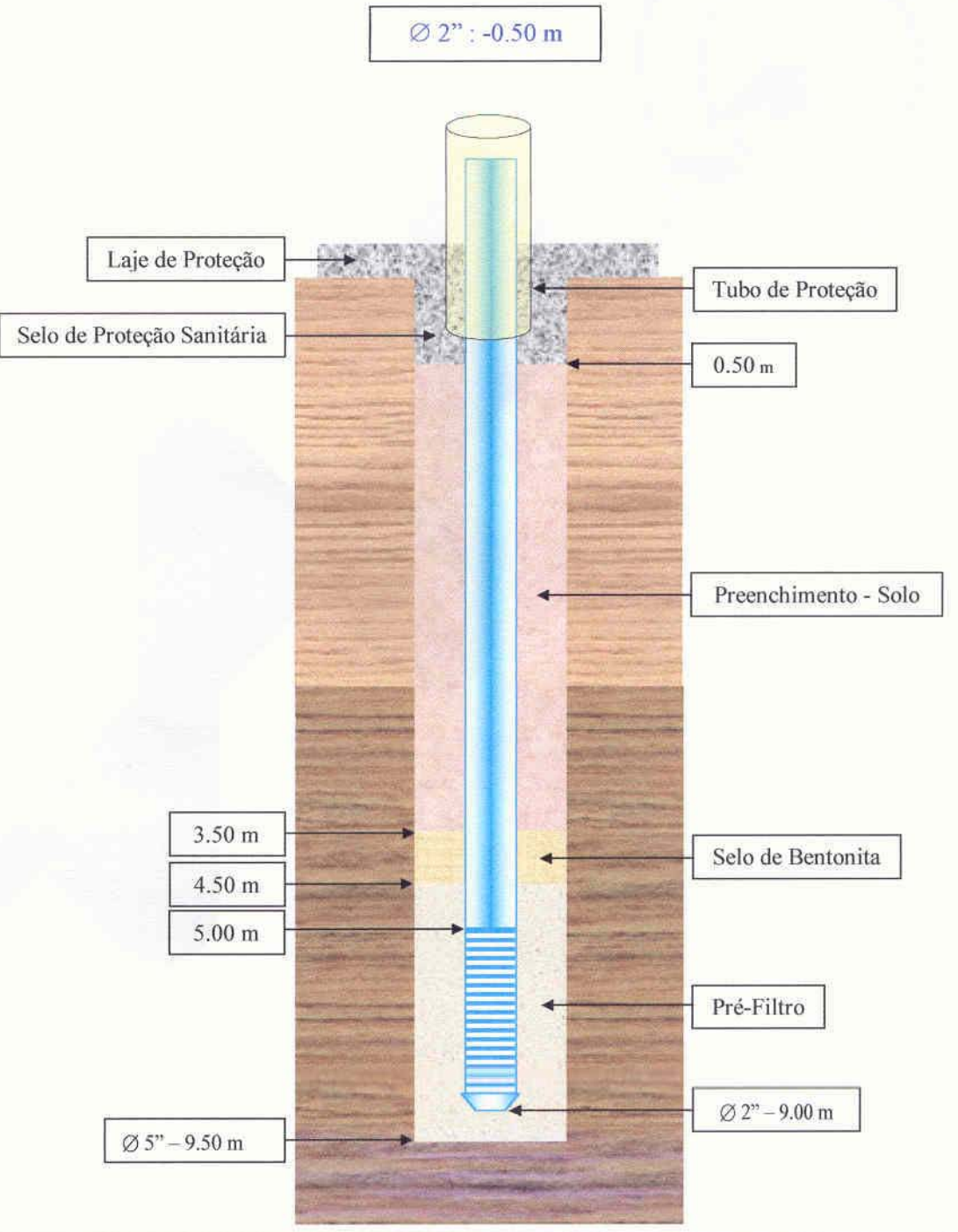

Rua General Osório n ${ }^{\circ} 1630$ - Vila Seixas - CEP: 14.015-030 - Ribeirão Preto - SP

Fonefax: (16)3941-4616 - Email: geoinvest@uol.com.br 


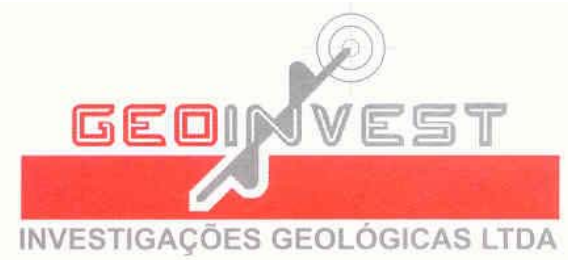

A sondagem a trado é realizada por meio de um trado helicoidal de diâmetro 2.5 " e também através da cravação de um amostrador padrão (tipo S.P.T.) possibilitando, dessa forma, a coleta de amostras deformadas, as quais, em laboratório, são submetidas à análise tátil-visual para classificação das mesmas e montagem do perfil do subsolo de cada ponto sondado.

Rua General Osório n 1630 - Vila Seixas - CEP: 14.015-030 - Ribeirão Preto - SP Fonefax: (16)3941-4616 - Email: geoinvest@uol.com.br 


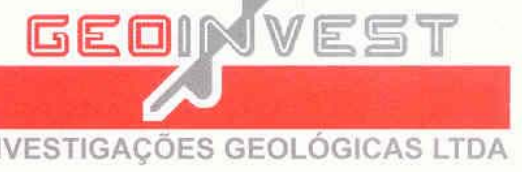

\begin{tabular}{|c|}
\hline SONDAGEM A TRADO \\
"ST-01" \\
\hline
\end{tabular}

\section{PERFIL GEOLÓGICO}

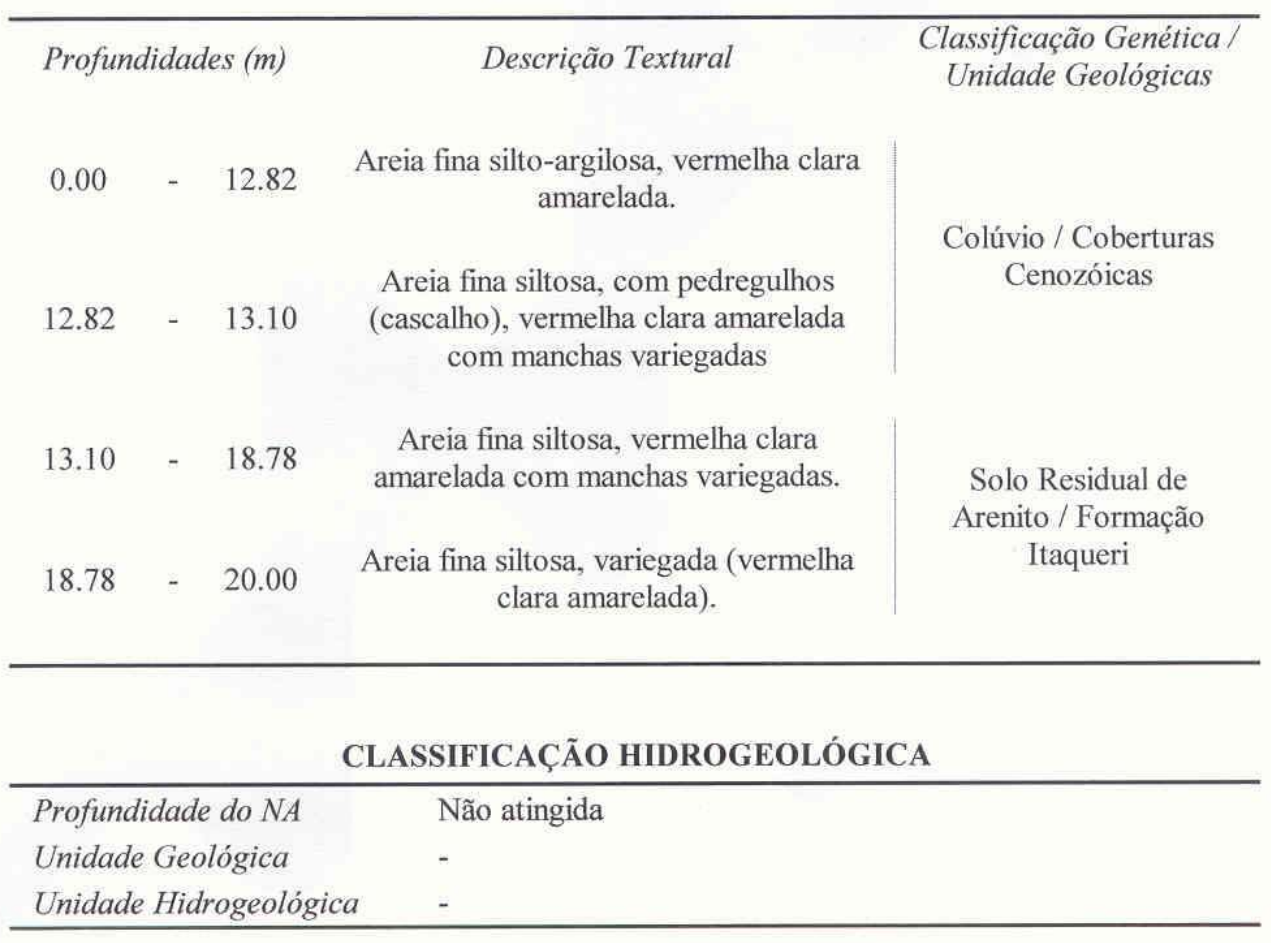

Rua General Osório n 1630 - Vila Seixas - CEP: 14.015-030 - Ribeirão Preto - SP Fonefax: (16)3941-4616 - Email: geoinvest@uol.com.br 


\section{Anexo 3 - Relatório de sondagem no aterro de Ribeirão Bonito}

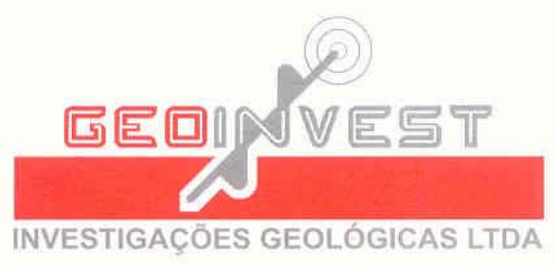

$\mathrm{AO}$

PROF. VALDIR SCHALCH

Av. Trabalhador São-carlense $\mathrm{n}^{\circ} 400$

São Carlos - SP

Ref.: RELATÓRIO DE SONDAGEM

Prezado Senhor

A Geoinvest Investigações Geológicas apresenta o resultados dos serviços de sondagem a trado, para caracterização das camadas do subsolo, realizadas no Aterro Sanitário Municipal de Ribeirão Bonito, no município de Ribeirão Bonito, SP.

\section{DADOS DA OBRA}

Tipo de serviço: Sondagem a trado

A sondagem a trado é executada por meio da cravação no solo, por meio de rotação, de um trado do tipo helicoidal que, após ser retirado, Descrição: $\quad$ possibilita a coleta de amostras deformadas sobre as quais são realizadas análises tátil-visuais para sua classificação textural possibilitando a montagem do perfil do subsolo no ponto perfurado.

Quantidade de furos:

02

Total de metros perfurados:

39.45

Amostras coletadas:

40

Diâmetro da perfuração (pol.) 4 (até 13.00 metros) e 2.5 (restante)

Data do início:

$28 / 07 / 04$

Data do término:

$30 / 07 / 04$

Anexos:

- Planta com a locação dos furos de sondagem (página 1)

- Perfil individual do subsolo dos furos executados (páginas 2 e 3)

Rua General Osório no 1630 - Vila Seixas - CEP: 14.015-030 - Ribeirão Preto - SP

Ribeirãø Preto, 05 de Outubro de 2004

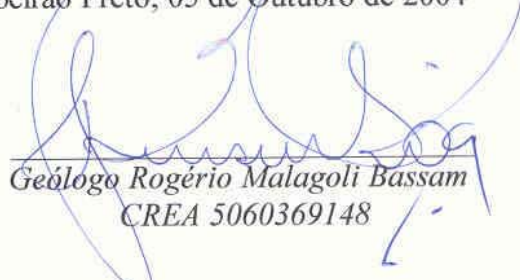

\footnotetext{
Fonefax: (16) 3941-4616 - Email: geoinvest@uol.com.br
} 

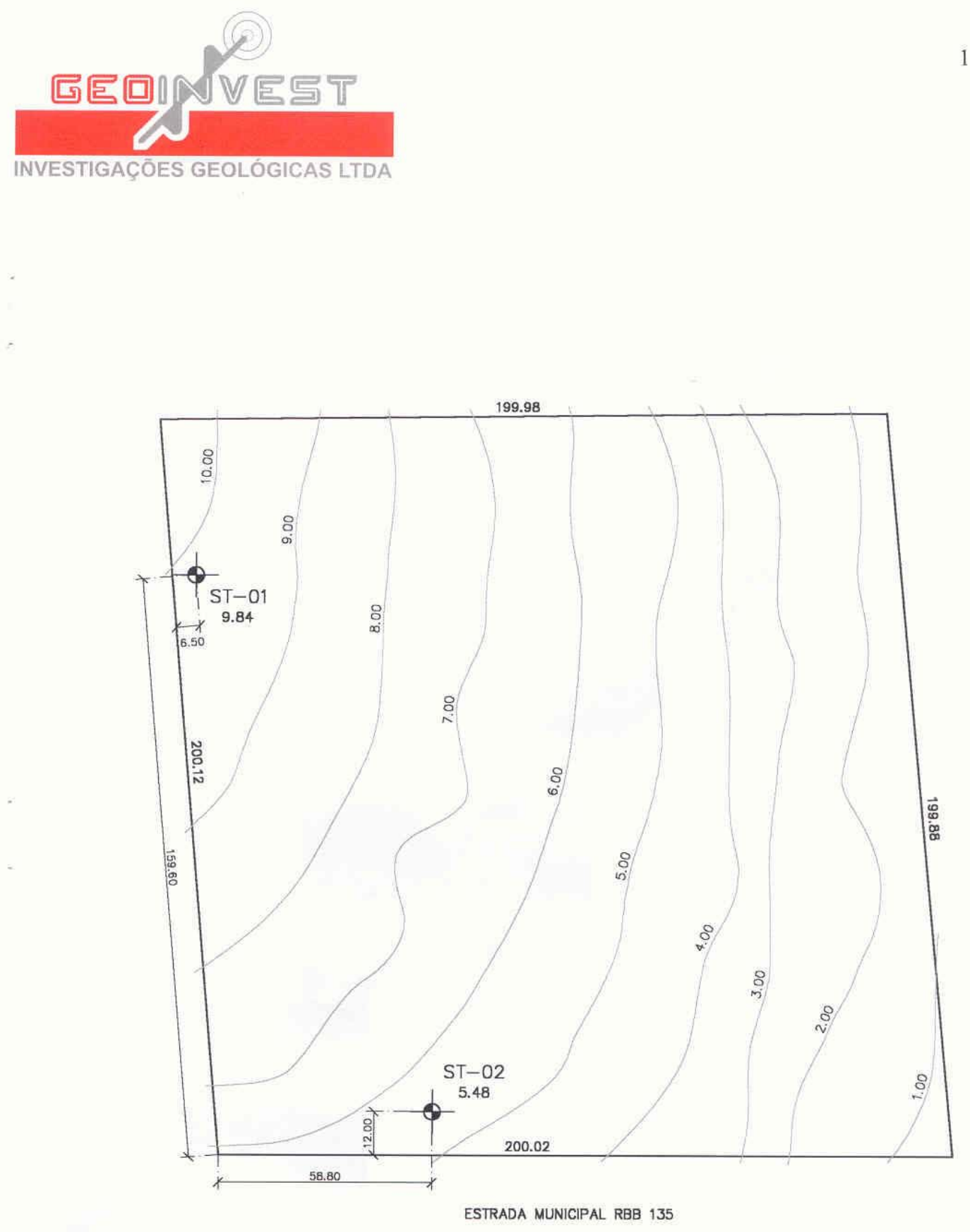

Locação dos furos de sondagem (Escala 1:1.500).

Rua General Osório nº 1630 - Vila Seixas - CEP: 14.015-030 - Ribeirão Preto - SP Fonefax: (16)3941-4616 -Email: geoinvest@uol.com.br 


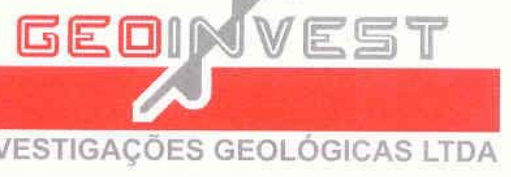

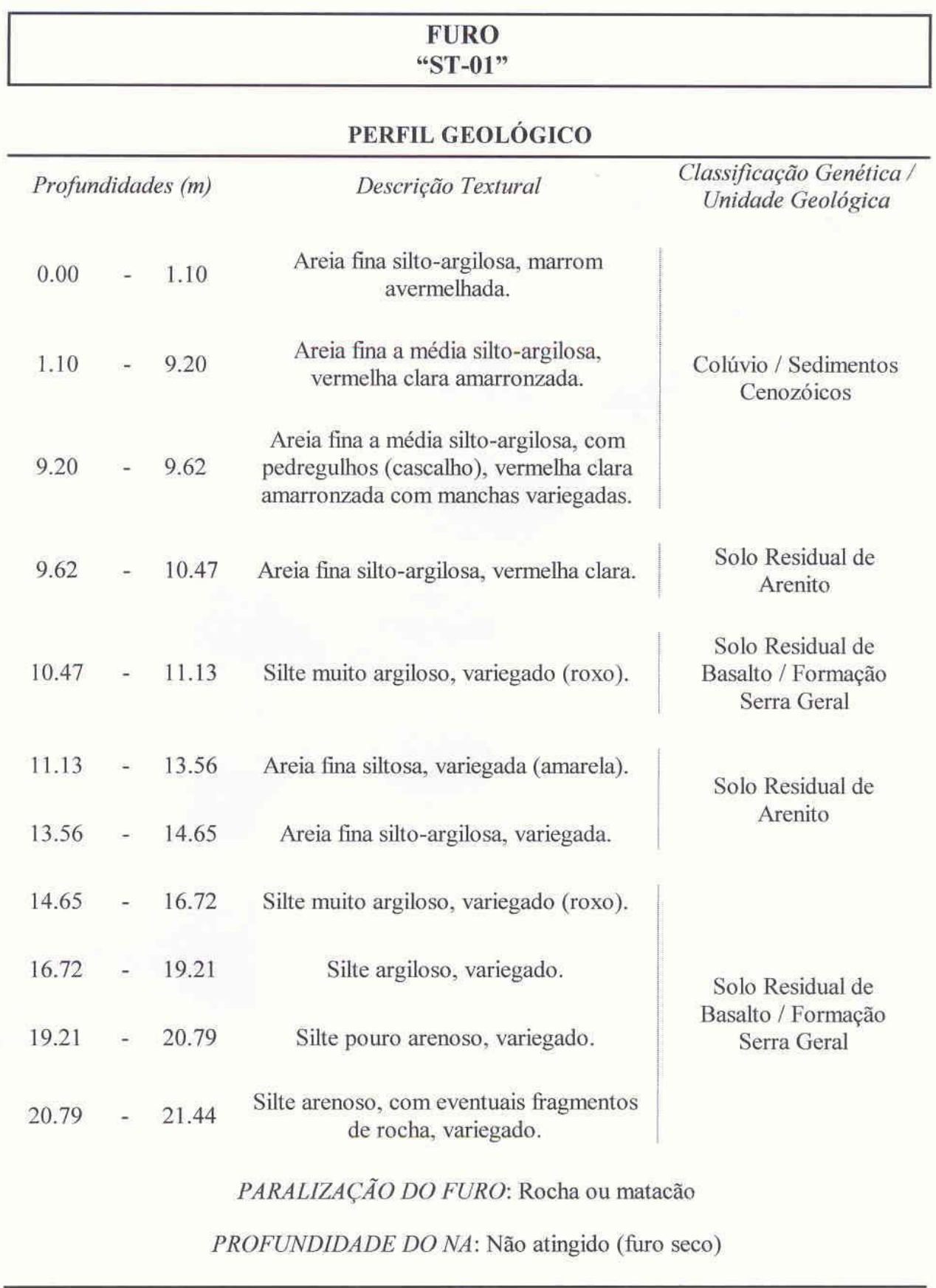

Rua General Osório n 1630 - Vila Seixas - CEP: 14.015-030 - Ribeirão Preto - SP Fonefax: (16)3941-4616 - Email: geoinvest@uol.com.br 


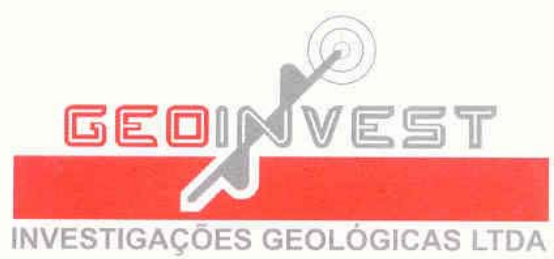

\begin{tabular}{|c|c|c|c|}
\hline \multicolumn{4}{|c|}{$\begin{array}{l}\text { FURO } \\
\text { "ST-02" }\end{array}$} \\
\hline \multicolumn{4}{|c|}{ PERFIL GEOLÓGICO } \\
\hline \multicolumn{2}{|c|}{ Profundidades (m) } & Descrição Textural & $\begin{array}{c}\text { Classificação Genétical } \\
\text { Unidade Geológica }\end{array}$ \\
\hline 0.00 & -4.40 & $\begin{array}{c}\text { Areia fina a média silto-argilosa, } \\
\text { marrom avermelhada. }\end{array}$ & - \\
\hline 4.40 & -6.58 & $\begin{array}{c}\text { Areia fina a média silto-argilosa, } \\
\text { vermelha amarronzada. }\end{array}$ & \\
\hline 6.58 & $-\quad 10.42$ & $\begin{array}{c}\text { Areia fina a média silto-argilosa, com } \\
\text { eventuais pedregulhos (cascalho), } \\
\text { vermelha clara com manchas } \\
\text { variegadas. }\end{array}$ & $\begin{array}{l}\text { Colúvio / Sedimentos } \\
\text { Cenozóicos }\end{array}$ \\
\hline 10.42 & -11.43 & Areia fina a média siltosa, variegada. & \\
\hline 11.43 & $-\quad 13.11$ & Areia fina siltosa, variegada. & \\
\hline 13.11 & $-\quad 14.70$ & Areia fina siltosa, variegada (amarela). & $\begin{array}{c}\text { Arenito / Formação } \\
\text { Botucatu }\end{array}$ \\
\hline 14.70 & $-\quad 18.01$ & Areia fina pouco siltosa, variegada. & \\
\hline \multicolumn{4}{|c|}{ PARALIZAÇÃO DO FURO: Impenetrável à sondagem a trado } \\
\hline & & FUNDIDADE DO NA: Não atingido (f & seco) \\
\hline
\end{tabular}

Rua General Osório n 1630 - Vila Seixas - CEP: 14.015-030 - Ribeirão Preto - SP Fonefax: (16)3941-4616 - Email: geoinvest@uol.com.br 